\title{
Environmental Aspects of the
}

\author{
Transuranics
}

A Selected, Annotated Billiagraphy

\author{
sponsored by \\ Nevada Applied Ecology Group \\ Nevada Operations Office
}

\section{OAK RIDGE NATIONAL LABORATORY}


This report was prepared as an account of work sponsored by the United States Government. Neither the United States nor the Energy Research and Development Administration, nor any of their employees, nor any of their contractors, subcontractors, or their employees, makes any warranty, express or implied, or assumes any legal liability or responsibility for the accuracy, completeness or usefulness of any information, apparatus, product or process disclosed, or represents that its use would not infringe privately owned rights. 


\section{DISCLAIMER}

This report was prepared as an account of work sponsored by an agency of the United States Government. Neither the United States Government nor any agency Thereof, nor any of their employees, makes any warranty, express or implied, or assumes any legal liability or responsibility for the accuracy, completeness, or usefulness of any information, apparatus, product, or process disclosed, or represents that its use would not infringe privately owned rights. Reference herein to any specific commercial product, process, or service by trade name, trademark, manufacturer, or otherwise does not necessarily constitute or imply its endorsement, recommendation, or favoring by the United States Government or any agency thereof. The views and opinions of authors expressed herein do not necessarily state or reflect those of the United States Government or any agency thereof. 


\section{DISCLAIMER}

Portions of this document may be illegible in electronic image products. Images are produced from the best available original document. 
ORNL-EIS-75-2I-NO. 5

NVO-AEIC-75-1

\title{
ENVIRONMENTAL ASPECTS OF THE TRANSURANICS A SELECTED, ANNOTATED BIBLIOGRAPHY
}

\author{
Compiled and Edited by \\ R. A. Faust \\ F. M. Martin \\ C. T. Sanders \\ S. S. Talmage \\ Information Center Complex \\ Information Division \\ OAK RIDGE NATIONAL LABORATORY \\ operated by \\ UNION CARBIDE CORPORATION \\ Oak Rldge, Tennessee 37830 \\ for
}

U. S. EITERGY RESEARCH AND DEVELOPNEIT ADMINISTRATION

Contract $W-7405$ eng 26

June 1975

Prepared for

Nevada Applied Ecology Group

Nevada Operations office

of the

U. S. ENERGY RESEARCH AND DEVELORMENT ADMINISTRATION 


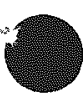

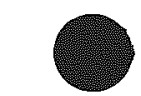




\begin{abstract}
$\underline{\text { Page }}$
ABSTRACT. . . . . . . . . . . . . . V

PREFACE . . . . . . . . . . . . . . Vii-Viii

SAMPLE REFERENCE. . . . . . . . . . . . . IX

BIBLIOGRAPHIC REFERENCES. . . . . . . 1-146

INDEXES

Author ............. 147-152

Keyword............ 153-164

Geographic Location. . . . . . . 165-166

Permuted Title......... 167-204

Taxon............. 205

Publication Description. . . . . . 207-219

DISTRIBUTION. . . . . . . . . . 221-226
\end{abstract}



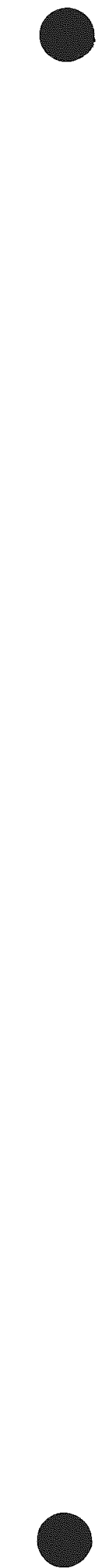
ABSTRACT

This fifth published bibliography of 594 references is from the computer file built to provide information support to the Nevada Applied Ecology Group (NAEG) of ERDA's Nevada Operations Office. The general scope is environmental aspects of uranium and the transuranic elements, with a preponderance of material on plutonium. In addition, supporting materials involving basic ecology or general reviews on other nuclides are entered at the request of the NAEG. Tables containing significant numeric data are referred to in the comment field. The references are arranged by subject category with first authors arranged alphabetically within the category. Indexes are given for author, keywords, geographic location, permuted title, taxons, and publication description. 


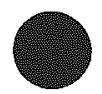

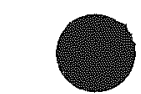


Vi̊

PREFACE

This publication of 594 references is the fith in a series of published bibliographies from the Applied Ecology Information Center of ERDA's Nevada Operations Office. The identifying report numbers in this series of bibliographies, ORNI-EIS-21 (SuppIs. 1-3), have been changed to add NVO-AEIC.

The scope is centered on the environmental aspects of plutonium, but has been expanded to include uranium and the transuranics. Studies on the ecology of the Nevada Test Site, redistribution and resuspension, low-level radiation effects, technetium, and reviews and bibliographies on other radionuclides have been added to scope at the Nevada Applied Ecology Group (NAEG) request. The current domestic and foreign literature is actively sought. As an example, WASH-1359,

"Plutonium and Other Transuranium Elements; Sources, Environmental Distribution and Biomedical Effects" from the December 10, 1974 U. S. Environmental Protection Agency hearings is included in this bibliography. Because of the interest in energy from nuclear power and the concern about safety aspects, 25 references cited in the report, WASH-1259, "Environmental Monitoring at Major U. S. Atomic Energy Commission Contractor Sites," are also included.

AlI the published literature references are contained in a dynamic computerized information fille that is avaliable for search upon submission of specific requests.

Citation Form

The references are arranged by subject category, with authors listed alphabetically within each category.

As a result of computer limitations in indicating superscripts and subscripts in the standard manner, certain conventions have been established in the bibliography:

1) $X$ sub $t$ ( $X$ being a variable) means $X_{t}$ or $X$ subscript $t$.

2) In chemical compounds and elements, $\mathrm{NaIO} 3$ (for example) means $\mathrm{NaIO}_{3}$.

3) $10(E+3)$ or $X(E-3)$ ( $E$ denoting exponent) means $10^{3}$ or $\mathrm{X}^{-3}$, respectively. 
Viำi

4) For units of measurement, such as centimeters, meters, feet, etc., $\mathrm{X} 3$ means $\mathrm{x} 3$.

\section{Indexes}

Indexes are provided for: 1) author, 2) keyword, 3) geographic location, 4) permuted titie, 5) taxon, and 6) publication description.

\section{ACKNOWLEDGEMENTS}

P. B. Dunaway, Manager of the Nevada Applied Ecology Group, Nevada Operations office, has closely guided this NAEG Information center in selection of material for this project.

Beth McMullin has assisted in the literature scanning and selection for this bibliography.

Dr. G. R. Eisele of the Comparative Animal Research Laboratory has contributed documents on the biomedical aspects of plutonium, and the Nevada Operations Office Technlcal Library staff have been helpful in alerting us to relevant materials.

Ruth Slusher of the Computer Sciences Division, ORNL, and Faye Fletcher of the Information Center Complex have managed the computer production of this document.

Ecological Sciences Information Center Oak Ridge National Laboratory

Building 2029

P. O. Box X

Oak Ridge, Tennessee 37830

or Te1. 615/483-8611, Ext. $3-6524$ or $3-6915$ (FTS) 615/483-6524 or 483-6915 


\section{SAMPLE REFERENCE}

This is an example of the format of the descriptive foields used in this bibliography:

$\begin{array}{cc}1 \text { - Subject Category } & 6 \text { - Document Title } \\ 2 \text { - Record Number } & 9 \text { - Publication Description } \\ \text { (Sequential Number } & 8 \text { - Abstract } \\ 3 \text { - Author } & 9 \text { - Abstractor's Initials } \\ 4 \text { - Corporate Author } & 10 \text { - Comments } \\ 5 \text { - Publication Date } & \begin{array}{c}\text { (Pertinent Numerical } \\ \text { Data) }\end{array}\end{array}$

1 CHEMICAL ASPECTS

3 (260)

4 Clanet, F., J. Ballada, J. Lucas, and C. GII,

Faculte de Pharmacie, Laboratoire de Chimie

Mineral et d'Hydrologie, 37-Tours, France;

Commissariat a I'Energie Atomique, Department de

Protection, Fontenay-aux-Roses, France. ${ }^{5} 1973$,

JuIy: 1972

6

Determination of Urinary PIutonium by

7 Radiochemical Analysis on Ion Exchange Filters.

IA-tr-73-39; 6 p.; Health Physics, 23, 245-247

${ }^{8}$ A new method for determination of urinary plutonium is described. Known amounts of Pu $239(+4)$ were added to human urine collected in concentrated hydrochloric acid. The plutonium was purified and fixed on Amberlite SB-2 filters. Following elution and evaporation the radioactivity of the residue was measured. The detection limit was 1 pCi Pu 239/1 of urine. The average recovery yield was $80 \%$. This method reduced analysis time by one-half when compared to the classic method using columns of ion exchange resins.

10 Translated by Kanner Associates, Redwood City, California for Los Alamos Scientific Laboratory, Los Alamos, New Mexico. 
《1

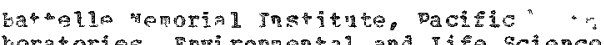

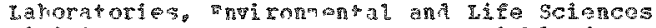

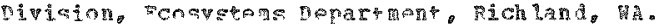
1074. Janisary

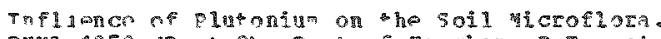
Fin 1, 1950 (Part 2):

The efrect of 30 is plutonilu congersation on

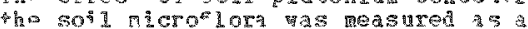

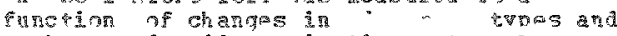
zan

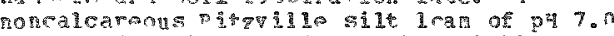
was anomed rith on 39 as the solube

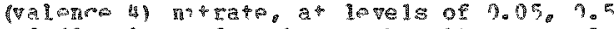

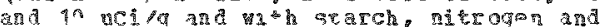
water to provide oo 1 al microbjal activity. absamplos of ooj meso perodicaliy temoved to deternine the changs in tor

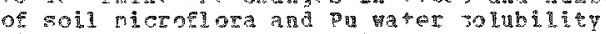
Hith he. Soil respiration ratem Tonitorer by contsingus collection of

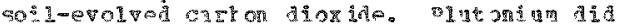
pot aenerally affect the rate of noosth bit flecreased to otal numer of 11 classes of marontanis. The fund here the excepon, direoring from the controls onlv

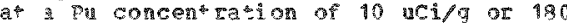
umpt. The accurnitive carbon dionde curvo geperallw corresporfan to the grnth curve of the fungi. In the case of the of her clisses

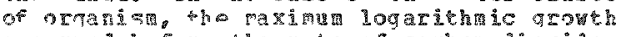

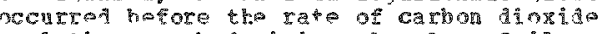

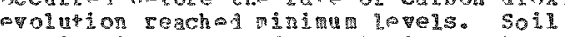

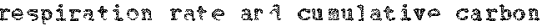
dioxide over he incubat lon pariol vers

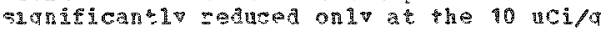
level of on ame ginent, lthough sumbers of all alasses or orgatisis except the fungi mere dopressed bolow his level (Auth) (ตA

$<2$

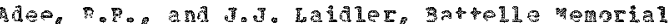

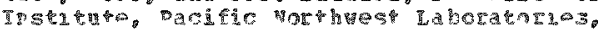

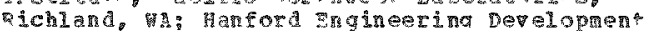
takoratory. Appied pesearch Derartme Richland. 月. 9073 , tgverber

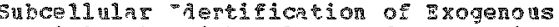
Particles bv high-voltage f lectron picrascop

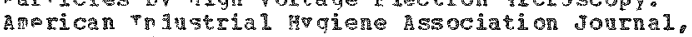
$34(11), 507-511$

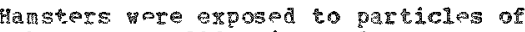
ashestos, Cr 203 , Nio, and wats to Pa 230 pun2 be oither aerosol inhla jon or

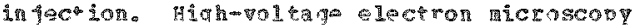

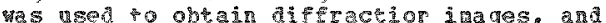

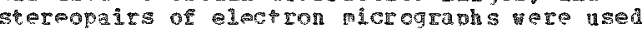

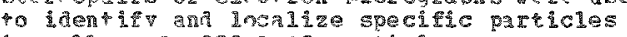

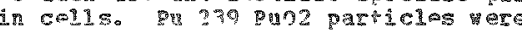
saspentes in setine and in jected intram

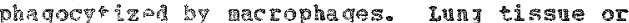

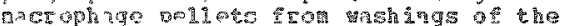

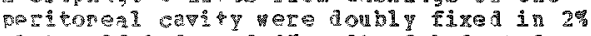
ght through a araded series of a 1 coliol and

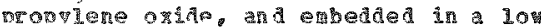
vํㅡㄹ

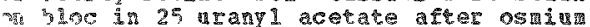

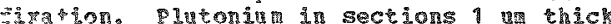
Wa too dronse to get a clear aiffraction pacters, hut accopt bo patceras corld be obn ined in 0.3 un sections. The sections

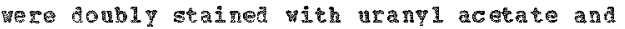
leat cibre and exaned in a JEOL 1000-ky

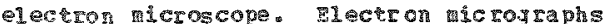
vere taker at initi l agnifications of 5000

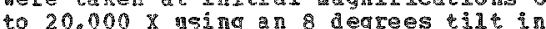
obtaiding stereopairs. Difreacton paterns mere obtained from particulate aberials by selecter area diffration. Pary

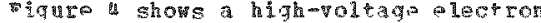
wicrentaoh of a Pu 239 puoz particis

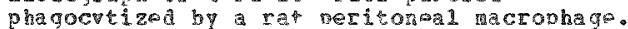

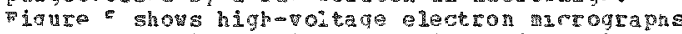

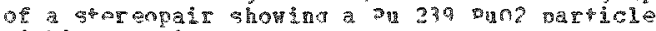

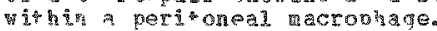

43

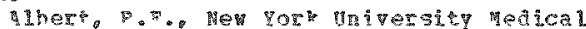

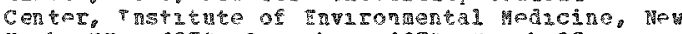

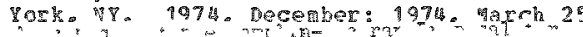
fe

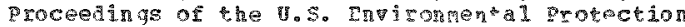

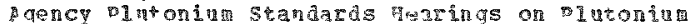

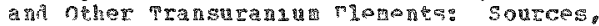
ryor ropental Distribution and iomedicm Effrets held in washington, D.C. Decetion $19-1 \%, 1974,10.311-326 \%, 32 \%$.

Lergel

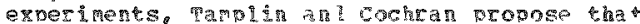
a sirale radianche partiche in the lug which dolipges a local dose of tore than 1090

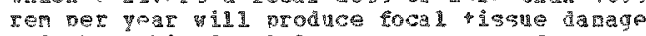
and that fis fock dange ner se confers a rish os ling cancer of one in two housand. Fhe Taplin-Cochra aporoach to the riste

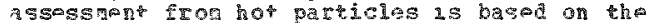

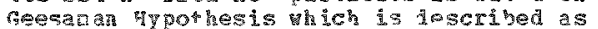
follows: Wher a erithcal archatectural unat

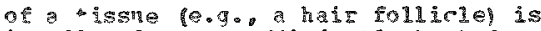
irraniated at a sufficientiv high fosage, the charce of it beconarg cancerous 25

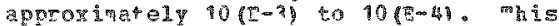

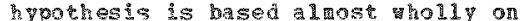
ratiaton skin experinents nth rats bo Albert. The Tatrolin cochraga provosal is evalua hed here from tro stan 100 ints: if does tossin damare, per se, cans cancer? 21 vould antense tradiation of a certed

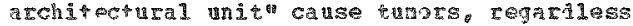

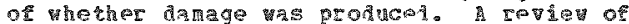

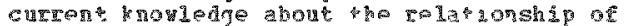

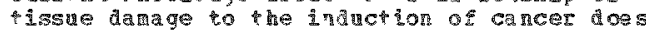
not support the contertion that tissue danade is a proxidate casto of carcer: rather than tissue famge represents a paralel toric action of careinogens which, to some exten

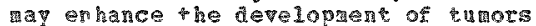
aroduced by carcingurens. since the Tarplin-Cochran proposa 2 is based anos wholly on radiation tuar seudies of the rat shin follicles. the decisive argumentalnst this proposal is the evidence that focal Q lphe irtadnation of localized regions on the hair follicle, in a patern

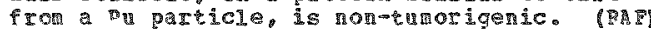

\&4

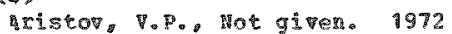

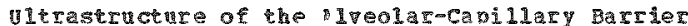

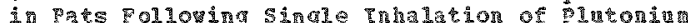
239 Citrate. RC-er-7457: Part of yoskalew.

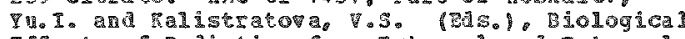

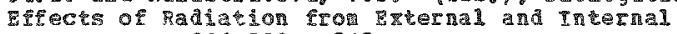
Sonrces, (p. 391-390), $515 \%$.

Male vistar rats weling 110-130 g yere nsed in the experisent solution of 239 vas nsed for the ingation (activity 292 aci/2. cistar $2 \%$ aispersion aproximati

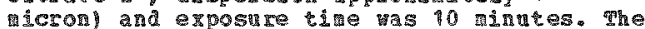
a minals vere sacrificed ingeriately after cerminating he inhalation, then efer 30

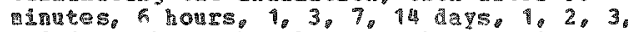
and 6 month. Fhe electron nicroscopic Einkings ace described. irradiation, destretive changes in the 
(4) CO $\mathrm{FT}$.

a veolar-aplilary al1 are usua 11 y observed before 1 tonth. degenerative chages are observed at 11 eanination times. These changes lead to an in parred exchange of gases. The greatest develonment of destructive processes in the 1. referable to the isth day ater inhalion. At this tide, wost capillaries shov extevelp narticed vacuolization and lanination of the

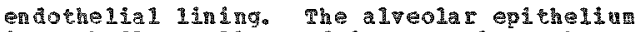
is marisedi" swo 12en and its cytoplasm shor: dil inished electron denstry. There are rany destroped cells, ba re nuclei, as all as macrophages and axyhrocytes, which are not infrequent $1 y$ hemolyed in the alvolar lumen. Fhire days after inhalation the changes included focal swelling in the endotheling and epithelium. wan mitochondria, auch larger than those or control anzals are otten seen in the crtoplas of the alreolar epitheling. The substantial distinction of the effects of in haled $P$ is also the relatively smal d cunlative ionization dosage absorbed by the lungs (42 rads), ith which tarked destructive changes a ce observed in the alveolar-capiliary barrer. In all probability, this is ave to the lagge local doses created at the site or deposition of Pu。 (PM)

$<5>$

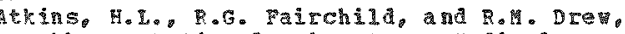
grookhaen Hation 1 Laboratory. Hedical Departient upeon, iong I sland, HY. 1973, farch

Biological properties of Caformin 252. part of proceedings of the sth innul A paring society Symposin held in Boca Reton. Forida, Map 14-49, 1972, $(7 \mathrm{po})$ : Merican Journal of poentqenology. paiu Ther ap and puclear pedicine, $147(3), 704-710$

There is qood biological evidence for a enhanced effect of califorman 252 on tumors becanso of a re duced necessity for the presence of oxyen during the period of irradiation. This is the primary reason for consideration of its use in interstitial and Intracaptary cancer the rap . Balanced againgt this is the corplexity of dosage calculation and the variability of PE depenaing on dose rate. A table of $R \mathrm{BR}$ values of cf 252 in systens is qiven. In a study on spleen

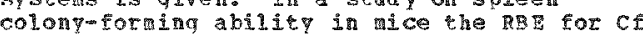
neutrons was 2.44 colparea to gama

irradiation. Experinents with chinese hamser cells mere performed to measure 1 is and or

cor cf 252. Survival curves for warious dose rates of $\mathrm{CE} 252$ and $\mathrm{Cs} 137$ a ge givan and the RBE of CE 252 as calculated to be 3.94 . Heasurement of the ots of $C$ F 252 a re also reported in tabular fort for several biological 5ystems including vrCIA PAB and HEIA cells. The measurements shou gool arreement, ith values generally ranging fron 1.4 to 4.75 . The airficulties in storgoe and handing of Ce 252 due to special hazards must also be considered. Because of these problems a careful evaluation of californium 252 must be cartied out prior to its routine clintcal yse. (FMM)

$26>$

Atkins, h. H., R.G. Fairchila, ana J.S. Doberson. arookhaven veional Laboratory. Madical Pesearch Center. Upton long Island, W. $19^{-5} 2$, paq

Dose-pate Frects on 3 of californin and palut pactions of big skin. Radiology.
$103(2) \cdot 439-482$

Experionts on the skin of pigs showed a marked dose rate dependerce of the bjological erfect of Cs 137 or Re 226 gata rays ofer the cinically useful range. The siope of a 1ire relating duration of exposinge to dose w 0.296 in a series of experinents. On the other hand, exposure to nixed neutron and gaxa ray Ce 252 radiation resulted $1 \mathrm{n}$ effects which were wch less dependert on dose reate. The relative biologlcal efrect varied warkedly ith dose Eate Fon about 5 at acute exposures to over 7 at prolonged low dose rate axposeres. It is suggested to ba se the radiation dose of ce 252 on a given dose of nenterons with slight correction for the additional gama dose obtained vith the cF. (a ash) (RAF)

<7)

Bair, H.J., satelle memorial Institute, Pacific morthrest Laboratories, Richland, MA. 1974. Decenber

The Blological ERfects of Transuranin Elerents in zxperinental Ani Iiverman, J.L. et al, proceedings of the v.S. Environmental grotection Agency Plutoni un Standards Hearings on Plutonim and other Transuranin lements : sources, Fnvironental Distribution and Bonedical Effects held in lashington. D.C. December 10-11, 1974, (p. $(71-229), 327 \mathrm{p}$.

A reviev is presented of the absorption of the eransuraic elerents into the body, and the aistribution ithin the organist

colloving ingestion, deposition on skin and inhalarion. Experiaents show that wost + ransuranic element compounds are notreadily absorbed from the gastrointestinal tract. In rats. Mp nitrate as most readily absorbed. near $171 \%$. The least absorbed as Puo2. $0.0009 \%$. The effect of the physical

properties of the inhaled particles on retention of pu in the 1 ung is discussed and retention half-lives of several pu compounds are sumarized for various animal species. the translocation fron 1 ung to other tissues is described. A11 of the transuranics tend to transiocate fron lung to bone and 1 iver and to a lesser extent to spleen and kidney. however the rat depends mostiy on the in however, the atepends mostiy on the in
vivo solubility of the conpound inhaled. The biological effects hich occur depend on the raidion exposure and the relative radiation sensitivity of the tissue into mhich the Fadionuclide is deposited. Inimal

experiments have identified neoplasia as the most sensitive response to the long-term effects of transuranic elements deposited in the body. The rost consistent hematologic response seen after infection and inhalion of the transuranics is 1. ostoogenic sarconas appear to be the most senst itwe effect following the skeletal deposition of $\mathrm{Cu}, \mathrm{Rm} \mathrm{Cm}$ and $\mathrm{Fs}$ in mice, rats and dogs. Lung cancer has been observed in laboratory animals following inhalation of relatively soluble pu conpounds and the relationshio between cancer incidence and radition dose has been described

mathematical1y. The hot particle issue is Aiscussed at length and it is believed from the results of some experiments that

particulate alpha emitting transuranics in the lung do not represent a higher risk of lung cancer than the equivalent quantity of relatioly non-particulate transuraniua - lements aistributed throughout the lung. The dose levels at which rajor biologicas affects have been obserped in experitental animals are shown relative to the maxim 
(7) conts.

peraissible lung burden of 0.016 uci for occupational exposures. lung cancer has been observed dos levels equivient to about 100 times the axirur 1ug burden. Fesearch is in progress to exanine the late effects of lov levels of transuranic elements and to develop beter understanding of the mechanis by which alpha eniters induce cancer. (Fin)

Figure 1 shows retention of $P u$ in pul monary region of lung for waions anial species. Figure 3 shows retention of tramsuraniur elements in rat lungs (Pu 238, Pu 239. An 24. Ca 242 , Fs 2531. Figures 11-12 show distribution of PII in dogs after in ha lation of Pu 239 (po3) 4 and 239 puoz. Fign 2 . 19 shoss pu-induced lumg camcer in experitontal animals. Pigure 24 shows obseraed biological effects of inhaled Pu.

$<8>$

BaiI. W.J., Battelle lemorial Institute, Pacific Horthwest iaboratories. Biology Department, RichIand, Wh. 1974

Toxicology of Plutonin. Part of dett. J.T.e et al (2as.). Advaces in Radiation Biolog\%, vol. 4. Acadenic ress. Inc. Wev york, ( $\mathrm{\beta} .255-315) \cdot 435$.

This reviev describes the current status of our knowledige of the toxicology of plutonium. The subject is consiaered in respect to the 3 most conmon romtes by wich plutoniun ingt enter the body: The gastrointestinal tracto the respiratory tract and pounds in the skin. the respiratory tract and roula in the

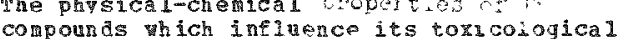
properties in addition to the route of entry. are given. bsorption, retention and translocation of pu in the 3 routes as well as the fate of systen ic $p$ in in 11 ver, bone and other tissues and its excretion are

discussed. Other subjects revieved are: The biological fiects of pu on blood, bone. liver. Ings, and lyph nodes vith a brier discussion of conter measures of Pu contamination. (Auth) (RA

c9>

Bair, H.J., and 7.H. Hillara, General Rectric Compan. Hanford I abosatories, Biolog

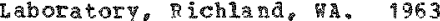

Plitonin Thalation 5 turies. 3. Ffect of Particle size on Total Dose Deposition. Retention and panslocation. Health Physics, 9. $253-266$

Forty-eight beagle dogs vere exposed to plutonium dioxide aerosols of three particle size ajstributions. The arosol

concentrations ranged from $10(E-7)$ to $10(E-3)$ ne per cris air and ho total amoun of plutonin a opositen in the dogs varied form 0.01 to 100 uc auring exposure periods that ranged from to to 30 min. Total deposition in degs exposed to aexosols with count hedian Dianeters of $0.08 \%, 0.43$, and 0.60 u werager 4. 30, and 60 per cent, respectivelp, of the total amount of pluton in inhaled. por all particle sizes tho percentage of plutonilu apparentiv deposited in the alveoil of the lugd increased with Aecreasing microcuries of deposited plutonint For a ginen anont of plutchin heposited, the percentara abosited in the alveoli was greatest for the aerosol ith particles of the largest rentan

diameter. The cates of pulwonar clearance. cranslocation and excretion in both urine and feces were areatest for the aerosol with particles of the stallest median a iageters.
In comparing the three aerosols it concluder that all processes furored pulmonary deposition and retention of pu 230 Puo2 inhaled as an aerosol with he largest count Mediar Dianter, 0.60 a. (ath

$\langle 10\rangle$

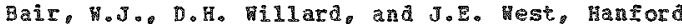
Atoric Broducts operation. Biology Laboratory. Rchland. 1961. January 10

Plutoniur Inhalation stuaies. How-69500; Part of

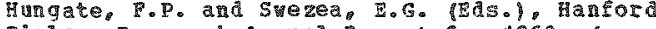
biology Research Anntual Report for 1960.10

$67-761.195 \mathrm{p}$.

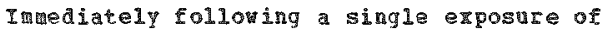
beagle a ogs to Pu 239 P102, 40 ro 85 per cent of the total Pu 239 deposited was recovered Fron lungs. Deposition and retention of pluton iam in lungs was less for particles vith a geonetric toa dianerer by vight of 1.7 marons than for 4.3 midron particles. but a larger percentage was excreted in the but a larger percentage was excreted in urine, Petention was also less fhen the
amount deposited as increased. For 4.3 micron particles the half-tine for pulaonary retention vas about 2.000 days. phere was arked accumulation of plutonin in bronchial 1 yeph nodes bit only trace amounts yere translocated to other tissues. In other dogs death occurred at times up to more than one year following deposition of more than 0.1 uci/g of lung. Histopathologic effects vere confined to lungs and bronchial lyph nodes. (suth)

Table 1 shows the distribution of en 239 in logs iratiatedy after enposure.

(1)

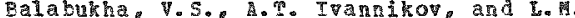
Razbitraya, vot given. 1972, Septerber

The Efect of Aminoalkylphosphonic Acids on the

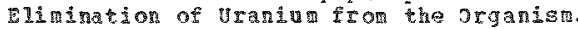

Gigiena Truda i professional nye oboleranya.

9. $29-32$

nata on the stuy of complex-forming

properties of a in oalkylohosphonic acids vith respect to iramil and their effectiveness in eliminating utaniul from the organism of rats are presented. Seven different

aninoalky phosphonic acils were studien. Al

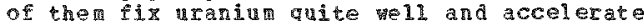
its ellination fIca the organism. regaras their efficacy they are superior to apinocarboxylic acids. Jranyl complexes vith amoalkylphosphonic acids are shown to be characterized by a consideraba strength and a comperatively 10y solubility. Sone features peculiar to their effact depending

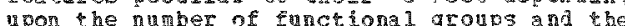
presence of the hetero-ator $N^{2}, 5$ and 0 in she carbon ring were revealea.

Apinoakyl phosphonic actds hola out proxíge

in accelerating elimination of araing (Auth)

<12>

Ballou, J.E. Haford tonic products pperation, piologv Laboratory. Rchland, Wh. 1962, January 15

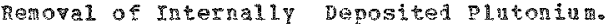

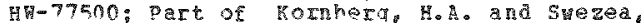
E.G. (Pas.). Hanfor Biolory Research snnul. peport for 1951, (0.77-80), $180 \%$.

Fvaluation of the efrectiveress of chelating agents shosing promise in plutoni therapentics yas continued in rass burdened 
MOLOG TCA. ASPECTS

$\langle 12\rangle$ cont.

with plutoniuf. prelime ary tests indicate the complexing agent triethylenetraram hehexa cetic acid (mpral is as effective as aiethy lenetriaminepentacetic acia (DTBa? when oiven intraperitoneally an are effective than DTPA when administered orally. The range of tosici sty and therapentic effectiveness of Trith has not yet been clearly defined. (atuth

(13)

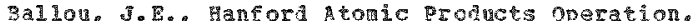
Biolog Iaboratory, fich

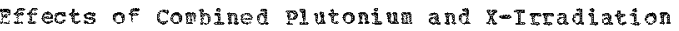
in the Rat. Hith-6950; Part of Hungte, F.P. and Snezea. E.G. (Eds.) flanfor Biology Research Annual geport for 1960 (p. 134-137), 195 p.

Rats adinistered 32 uCi Pu/kg anl 400 p tota l-body s ray were not protected by delaying the $x$ ray exposure $1 / 4$ or 28 ays. Plutonin adrinistered

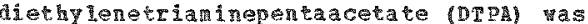

less toxic in conbination with $x$ irradiation

than equivalent plutonin citrate solutions.

Aporoximatel o oer cent of the olutonin

adringtered vith a 12 tines nolar axcess of

DIPA vas excreted in tho days. (Ruth)

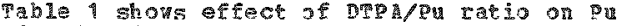

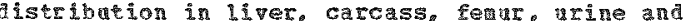
seces 48 hours after in jection.

<4 43

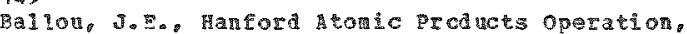

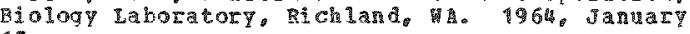

Marenal Distribution of vepturitu 237 and

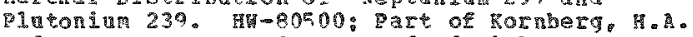
and 3 mezed.

research Annal Repore for 1983, (p. 70-72), 242

Neptring 237 , folloving intravenoms

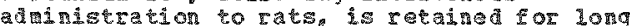
beriods of tile in the adrenal cortex associated prinarily ith cells in the

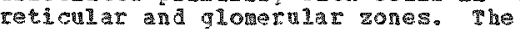
Alstrinveion patern of pu 239 in the adrenal

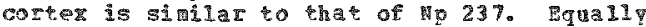
peolonged retention was observed in the adrenel and ferus. plutoniu a

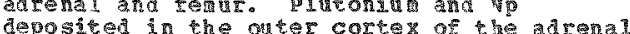

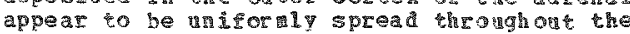

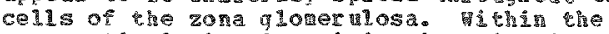

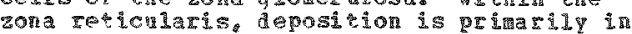
cells of the reticuloendothe $1121 \mathrm{sgst}$. 91 yth the extractable lipid Fraction or with cell nuclei. The rraction of Pu derosited in

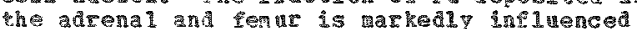
bo he nass of radionucline injected. (1)

<15>

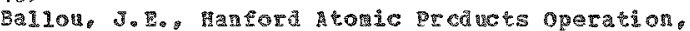

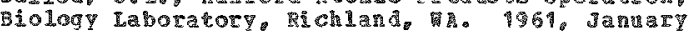
10

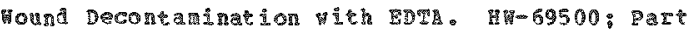

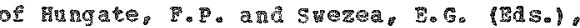

lanford Biology pesearch annal tepor for 1960. (0. $111-113) .195$ o.

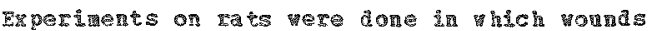
comeaninated wh the

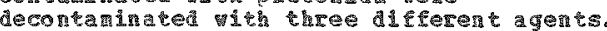

The plucon

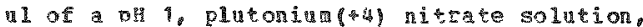
and allowed to dry 15 ainutes before zecontarination procedures were commenced.

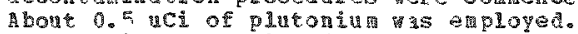
Decontaninants enployed vers: water. a to percent solntion of household detergent. and a 10 percent solution of household detergent with $7 \mathrm{q}$ of the tetrasodiun salt of DDF wded per 100 m. The results suggest ehat

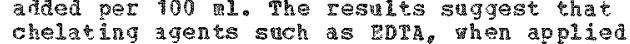

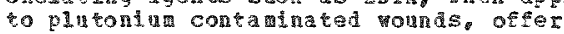
Iithle advantage in renoval of the plutoniun and ne significanty jncrease its aborption into the body. (uth) (rim)

(16)

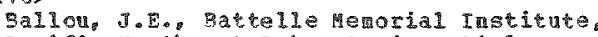
Pacific Morth west laboratories, Biology

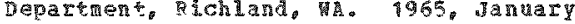

Erfect of solenectomy on actite glutenim Toxicity. Bind-122; Part of Thorason, R.C. ant

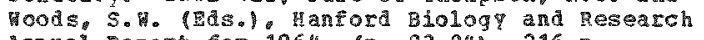
m mel pepotr for 1964, (10. $83-84), 216$ p.

Sthales have indicated that the greater toxicity of Pu 239 mas probably related to the greater mass of Pu 239 involved 11 uCi of Pu 239 the abs abou 270 thes as ach as 1 uci of Pa 2389 . but probably a not involve any factor of intect chenical toxicity. It seened post linely the the different toricities vere $\mathrm{spl}$ andable in term of diferent Aistributions of the tho isotopes atong body organs, the distribition bejng influenced by the ass of 3 terial involved. Pt as observed the initial deposition of $q u$ 239 in the spleen was seval tives greater than that of Pu 236 (as percent of infected dosel and that histopathologic damage to the spleen tas greater in the case or Pu 239. Bxperiments vere done on res spienectomige three week prior to intravenous injechion of Pu 238 or an 239 as citrate solitions. It was show that the survinal tive of rats infected ith either par 239 or pal 239 mas not aterea by grior splenectom. Thing yould seew to elininate spleen darage as a critscal fector in arvining the greater action

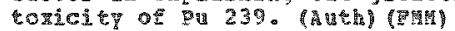

<17)

Ballow, J.E. E. Eusch, and G. Eagle, Battelle morial Institute, Pacizic Forthest Taboratories, Biology Departments ichland attelle henorial Institute Pacific Norkhnest

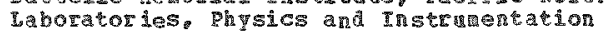
Departient, ichian, wh: Batcelle gerorial

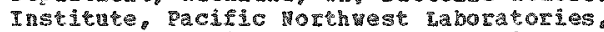
Radiologice sciences Departant, hichlard, 7974, angest

yistopathologic Erect of Intratracheany Instiled gintesning 253 chlorife in Rats.

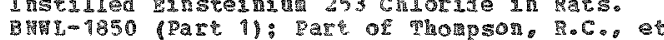

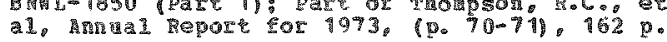

4aLe mats vere ada intratracheal instillation. The biological etrects vere followed for 80 dats as gat of studies in progress on Iong-torn bolontca

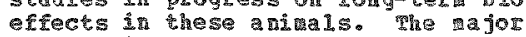
pathologic les ions procumed by

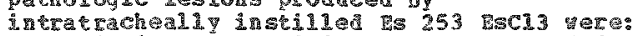

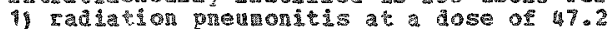
tCi/pa. 2 osteosarcomas at a dose of 10.7

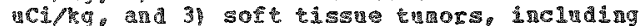

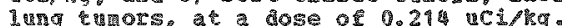
(A)

<18

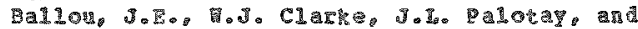


<18> cons.

A.S. Vou है anford Btomic products operation. Biologw Laboratory, Richland, HA. 9964, Januay

Toxicity of Plutonim 239 and plutoni 238 in

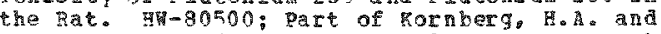
Stezed. E.G. (Eds.). Hanford $830 \mathrm{log}$ i Research Annul Report for $963,(0.67-69), 242$ p.

The significance of the tissue aistribution of acutely toric amounts of plutonium is considered in relation to the heratolodical and histopathological changes observed. citrate solutions of pu 239 and pu 239 of comparable physical and chenical state vere ingected intravenous? in $\mathrm{rats}$ at a ase level of a proximately $75 \mathrm{HCi} / \mathrm{kg}$. Anirals were sacriclcod at intervals arter injection. median survival tiae for the pu 239 injected rats was 15 days; for the Pu 238 rats. 75 days. Comparison of the histopathological and hematological changes preceding death indicates dama to spleen nay contribute to the earlier death 238 was preceded by a decrease in rarrow capacity a tue to the marked increase in trabecular bone ill the rarrom spaces. Peripheral blood values aid not reflect the progressive decrease in marrow volume. The indications are that Pu 239 is more toric than pu 238 because large doses of pu 239 more effectively irradia te both bone marrow and sensitive soft tissues. Pu 239 deposited in sort tissues tends to accurulate in cells of the reticuloendothelial systen resulting In combined $\mathrm{I}$ adiation to both the rator reticulcendothe lial and hematopoietic tissues. (A mth) (F)

Table 1 shous ajstribution of Pu 238 and Pu 239 in tat tissues liver, fema. spleen and total rat).

<19>

Ballow, J.E. and H.G. Morrow, Batelle terorial Institure. Dacific Northest waboratorles, viology bevartment, wichland,

The Long-Term Biological Effects of Intratracheal1 Instil led Einsteing 253 chloride in ats. F倠l-1750 part part of Thompson, R.C. (EA.). Annual Report for 1972. (p. $32-33$ ) $103 \%$.

Male rats were anainistered 0.5 of Es 253 Es C1 3 in llel solution (pt 2) at 47.2 . 10.7

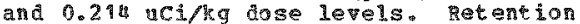
curves vere deternined rom ats admistered

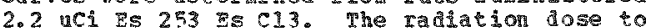
lung. kidre\%, liver and skelecon as calculated using parameters determined from the short-tern retention curves. The long-term effects of intratracheal Fs 253 Rscl 3 vere characterizied by: (il a depresser rate of grovth which vas dose related; (2) eariy death due to tadiation prevanitis in the 47.2 uci/sg group: (3) death due to neoplastic lesions in bone and soft tissues, a nd leukera in the $10.7 \mathrm{uCi} / \mathrm{hg}$ group: and (4) essentidityo effect at the lowe st level of $0.214 \mathrm{uCi} / \mathrm{kg}$. (Auth) (RAP)

$<20>$

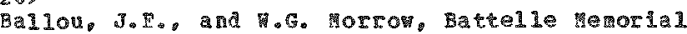
Institute, Pacific Northyest laboratories Bology Department, september

In Vitro Binding of Platondu 239 by Calciu Sodiu DTPA. Z Thompson. R.c. (20.). Anual Report for 1971. (p. $276-278), 313 \mathrm{p}$.
DTPA enharced the ultrafilterability of Pu 239 in blood serum ard in a singlated lung F1uid. The Dipt effect jecrassed rapidi ater Pu 239 âdition denonserating the inportance of pronpt chelate therapy. These in vitro studies demonstrated a decrease in the availability of Pa 239 for chelation by DTP in dog blood serun at a rate of $0.45 \% /$ min between ard 129 ain after Pu addition. In a sinulated lung fluid on third as wuch of the pal 239 vas a vallable for chelation after 5 min, buth the subsequent rate of decreased availability was approximately the sate as for serum during the first hour feer gu addition. It is suggested that hodrolygis may be the primay action which interferes with the forkation of the Bu-DTP chelate. (Auth) (RAF)

Table 1 shows the composition of solutions emploper in pu 239 in uleratilterability staly. Figure 1 shows cile course of pur availability for chelation in hum plasma, dog serum and Gamble"s Solution.

$<21>$

8a1lou, J.E., and J.I. Paloray, hanfora Acoric Products operation. Blology Laboratory.

Richlamd,

Removal of Internall Deposited plutoniu

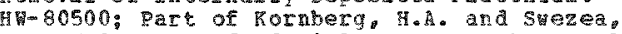
E.G. (Eds.), Hanford 9 iology Research Annul Report for 1963 . (p. 113-119), $242 \mathrm{p}$.

Comparative tests indicate prompt oral treatant acia is more effective and less toxic than equivalent treatment wh DT or the pentachtester of Dipa in rats tremted ome hour arer pu 239 injection.

histopathological change in the iner.

conounced in the DPR andis.

(A) Ba?

\&2>

Ballon, 3.8., and J.P. Park. Battelle levorial Instithte Pacific Northrest taboratories. Biology Departient, Richland, 1972 September

The Disposition of Ingested, Irjected, and Inhaled Plutoniu 239 citrate and plutoniun 239

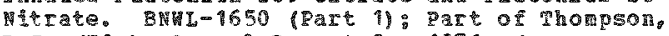

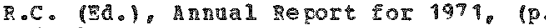
$146-1521.313 \mathrm{p}=$

Dogs a tainistered oral intravenous or inhaled Pu 239 cirrate or nitrate vere sacrificed from 1 to 100 days after exposire to compare distribucion and cetention Wnetics. Approxinacely $0.09 \%$ of the citrate and 0.095 of the mitrate oral ase was retained after 3 days, alstributed manily berver sheleton $150 \%$ and $26 \%$ and $13 v e r$ (25\%

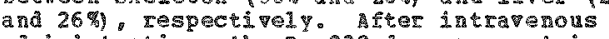
adañ stration, the Pu 239 dose vas retainea principal1y in the liver $(32-46 \%$ citrate and $29-62 \%$ nitrate and skeleton $(29-46 \%$ citrate and $13-56 \%$ nitratel during the 100-day postinfection period. Inhaled pu 239 citrate and nitrate vere cleared from the blood and excreted th kinetics singiar to those described by ohers for aogs and humans adrin stered intravenots pu 239 citrate. The Inng, skeleton. 11ver blood, and inkestines retained tost of the

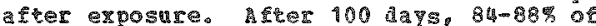
the initial luno burden vas retained. principalin in the lung, skeleton. agd 1iver. plutonin wa concentreted by lyophatc tissue following all aethods of 
BTOLOGTCAI ASPECW

<2) corf?

aำ Although the concentration in specific 17roh nodes thepatic splenic, tediastinal, and tracheobronchiail was wong the hasest of any tissue analyzed the total anourt deposited in a selection of 12 1Yu pod

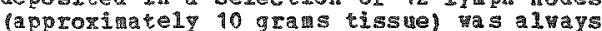
loss than $0.6 \%$ of the body burden. (Auth)

(23)

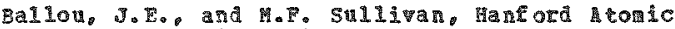
Products Operation, Biolog" Laboratory.

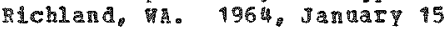

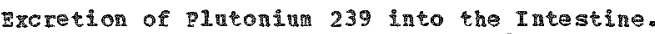
Ho-80500: Part of Rornberg. H. A. and Suezea. E.(G. (E).), Hanford 3 lologY Re search Annul Repore for 1963. (p. 196-1191. 242 。

Studies with gut-perfused and bile duct-cannulated rats inplicate the bile as a major route of plutonlu excrepion into the intestine. plutoniu collected fron the cannulated bile duct accounted for about half of the intestinalip excreted radionuclide innediately acter injection and accounced for 75 to $90 \%$ subsequent to DTP adinistration. Biliary pletonin levels increased $12-$ fold subsequent to DTPA reatment and renarined higher than pretreatment levels for at least fonr ays. (Auth)

$<248$

Beatley, J.C., mituersity of California Laboratory of "vucl ear edicine and Radiation Biology, Los angeles, CA. 1970, April

Perennation in ASPAGAIUS HEHTGIMOSUS and

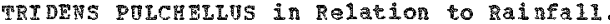
Marano, $20(6), 326-332$

The fate of ASTRAIAtis seedings on five sites, and TRTDES on one site, as a contribution to the understanding of the anntal-biennial-perential habit in relation to precipitaton. is recorded. Fonr of the sites mere located on the upper bajada of eastern Jackass Flats. Tegetation was typical of the high mojatre Desert region. Soils more oredominativ sand a essentialiy without oredominativ sand and essent dily whout 500 desert paverent. The altitude was around north of Jackass Flats. Desere pavement of the soil surface vas in a disturbed condition. The sigth site was of the bafada below the Ranger monntains with a trell developed desere paverent typical of that below izmestone monntain ranges of the region. Data of growth were recorded in lata hay or early june of consecutive pears. Painfil 1 vas recorted year-round on each Site. Tn ASTRALGUS UETTST pulcherits it appears the large and itportane I reproducing popalations in the northern porave resert are biemials or annuls, which germinate following unusual1y heay raintall in the spring or atuma only a linited number sincessfulip peremate vhere precipitation is irreqular and variable from season to season. In these environments, those that do becone perennial plats flover and fruit during the years between large gerwintions and give coneinuty to the presence of the species in the cormanity. The large perential populations of ASTRABGUS are confined to he higher valley floors and mountains, where there is relative constancy of precipitation above a minim mecessary

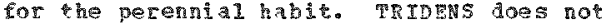
occur at he higher elevations in this reqion, and the perenial populations are those hich survive the vagaries of precin ic (A) BCh) (RAB )

$<25>$

BeIyaev, Yu. Hot given. 1960

The vse of Ion-menange Resins After the vatrance of 21 itoniu into the Gastrointestinal Tract. JPRS-5124: Rare of medical Radologr. $\left(p_{0} 110-116\right) \cdot 253$ po: tedical Radiologr, $5(3)$.

Ion erchange-resin Ieducea bi geveral times the absorption of Pu from the intestine and the pu content in the skeleton and $11 v e r$ of
rats. The efrectiveness of these resins

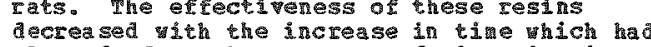
elapsed after the entrance of plutonitu into the bod\%, which is directip assoclated ith the rate of Pa absorption from the gastrointestinal tract. The nature of distribution of plutoniu in treated rats in the prineipal organs in which it is retalned (skeleton and liver) is unchanged by this procedure. (Anth)

$<28\rangle$

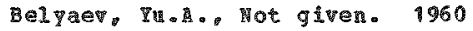

The Influence of the Calciul-Disodiug Salt of Diam nocyclohexanetetraacetic Acid on the

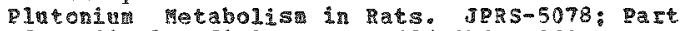
of gedical Rediologi, (9. 131-141), 260 P.: yedical gajolog, $5(2), 54-50$

The intraperitoneal a dinistration of $\mathrm{Na} 2 \mathrm{Ca}$ bCF (aíarnocycloheranetetracetic acid) to rats (fron the fourth through the loth day) in doses of 10,40 and 100 in reduced the 8 il 239 content in the liver wich anounted cespectively. to 72,69 and 48 percent of the contro1. A reduction in the Pu 239

deposition in the sheleton occurred on fiter doses of DCTA of 40 and 100 wa and anounted to $80-32$ percent of the control. A reduction in the content of pu 239 in the liver by to times was observed even in the late adrinistration of DCT at 30 days. The combined intraperitoneal intection of DCTA (40 mal and zirconing cicrate (10 wg) from the fourth thromgh the $18 \mathrm{ch}$ da lowered the Dis 239 content in the skeleton a lone to 68 percent of the control. whe oral administration of DCTA $(100$ aq $)$ was not very effective elther wh the adiltional administration of soliu bicarbonate or vithout it. The concent of Pu 239 in the liver anounted to $83-79 \%$ of the control: in the skeleton it yas unchanged. The combined oral adninistration of DCT (40 ngl and zirconiu citrace $(15 \mathrm{mg})$ zeduced the pu 239 content in the $11 \mathrm{ver}$ to $66 \%$ of the control. (anth)

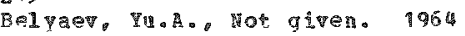

Relative eficiency of cercain complex componds in the Remaval of 1 utoniun 239 from the organise. AEC-tr-6408: Part of Radiobiolog. (p. $125-128)$

The effichency of several conplex-forming

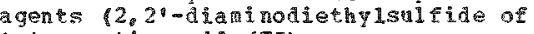
tetraceric acid (TS).

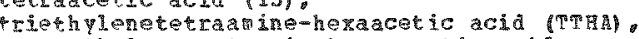

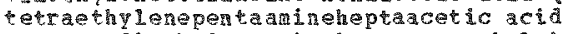
(TPHA), aieth ienetriamine pentatethylphosphin c acia (DPpPA) for removal of plutoniu from rats as investigated. The strongest effect at early stages as shoun hy Trith. This compond mas several times more eficicient 
<27> confr.

than DTPA which was taken as the stancerd for the efficiency of the other complez-forming agens. The effect of TPH was sorinat veaker than that of wh than DTPA. The least effective DrPp Was effective for the remova of pu DrPp tas effective for the renova of 1 u the whole its efriciency was less than that

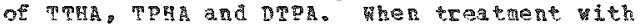
complex-forning agens vas stared 30 da after the infection of $\mathrm{Pu}$, the efficiency of TTMA dia not anfer from that of TPHA and

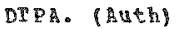

Tables show $P u$ content in tat organs after IV or IP injection of coaplex-foraing agents at various intorvals after bu adrionistrion.

(28)

Gerlin. J.D. ana D.D. Wahlum, Batelle Memorial Institute, Iacific porthest iaboratories, Biolog Departient, Richland, H. $9967, \mathrm{Ju} 2 \mathrm{Y}$

Meptunim-Indured Fatp livers in Rats: Jiectron Hicroscopic and 32 ochenical studies. Bryl-480

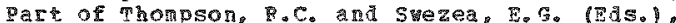
Annal Report for 1966.(P. 43-46).207 p.

The effects of $\mathrm{yp} 237$ on the fine structure of rat hepatocttes and on protein synthesis were studied. The earliest observed

norphological a terations in developing fatry

1ivers inaced by 237 were dilatations in

the rough endoplastic resiculut. The se

dilatations appeared to give rise to the

iipid bodies characteristic of pip $237-$ induced fatty 1ivers. Morphological and biochemical evidence suggests that protein synthesis may be less natked? inbjusted atter 1923

adninistration than arer cc14, purowein or ethionine adininistration. A

<29>

Gerliner, Dol., M. Lo Bertiner, and T.

Doughery, vinersty of tha college of

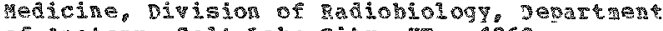
of Anatory, Salt Lake city. WT. 1962

Whe effects of chronic Trradiation by Thernally Deposited adionuclides on Corticosteroid giosynthesis. pare of poughery. g. (Eds.) Proceedings os a S7rposiun on Some Asperts of Internal Irradiation held at The monestead, Heber, utah, Mat 8-11, 195 l. Eerganon pess, oxford, England, (0.179-186). 529

The influences of various ithermal enters (Fr 90, th 228, Ra 226 , and 239 ) on the biosprothete capabilities of the areal

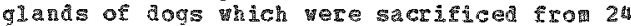
hr to 6 years ater in jection were stulided. The effech on adrenal sterotiogetest

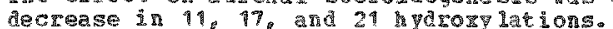

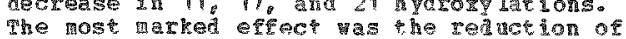

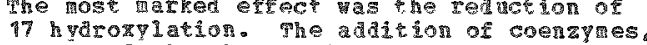

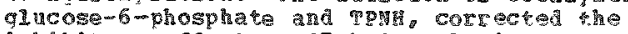
indibiory efect on 17 hyisozylabion. Chronicali irradited aogs stima ated Sr 24 hr prior to sacrifice responded with increased corticosterone synthesis. The site of 7 hydrorylation in the arenal is the reviculoevdothe Hal cells. (ST)

$<30>$

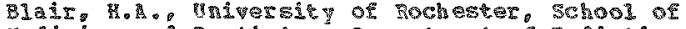

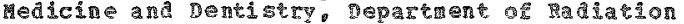
B10106y, Rochester, Wr. 196

The shortening of life span by angle

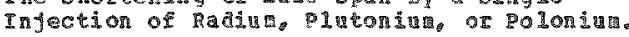

Padiation Research, Supplement, 5, 215-22\%

It is shown that the 1ife-span rolationship cor polonium poisoning in the rat can be cepresented hy equations appicd previoush to data on penetrating ionizing radiation. These equations are based on the hypothesis that saliation produces injury thich is reversible in part ad irreversible in part and that life shortening is a reasure of the toral infury, unrepasted plus irreparable existing at the tine of death. Seniempirical equations derived from the mane hyothesis for radiu and glutonitu poisoning permit easy handing of data on the rat and rouse and easy comparison of these elements vith poloniu. The long-tern toxicities of poloniur and plutomin are each about 5 compared to that of radin in the rat. (Auth)

$\langle 31\rangle$

Bloom, 年, (Ed.), University of chicaqo. Institute of Radiobiology and Biophysics,

Histopatholog of Irradiation Fron External

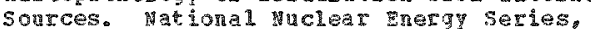

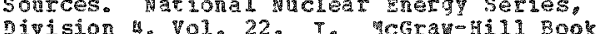
Compary. The. The pork. mer york: $808 \mathrm{p}$.

The volume is one of a series thich has been prepared as a record of the research por done und the wahtctan Profect and the Atonic Energy Comission.a report is given of three years of intensive research undertaken to compare the histological changes that result from varions types of radiations orianacing externaly ara internally. Frternal radiation as obtained using $x$ rays beta Eays enitter by 32. gana rays released by radiur and fast and slow nentrons. Internal raidion vas obtainea from several radionucides, narely, alpa particles from pa. Pa and po: beta

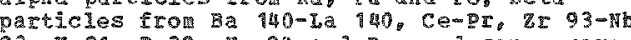

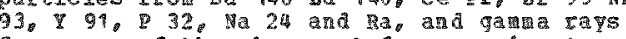

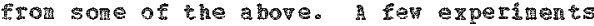

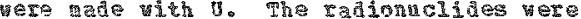
a d. intracardal1 or incrapericonealiy, also by

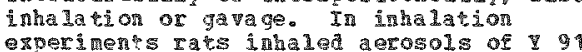

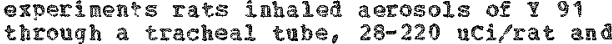
Ru, 1.5-31.5 vcifrat. plotonim nitrate or citrate as adningered It to nice 10.08

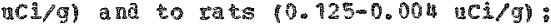
intranuscular injections inco the hind leg of

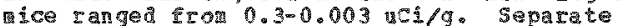
chapters cover the histopathology of the cell, shing bore, bore rarcot, spleen, 1 yoph

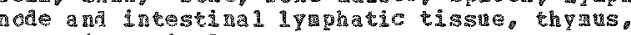
gastrointestinal ract, testes, ovarip

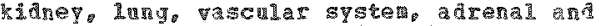

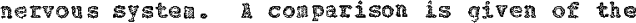
several radidetom and radosenstury a nd

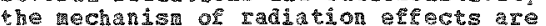
di

$<32>$

Bopger, B. B. Lovelace Foundator for medical Bducetion ant Research Inta

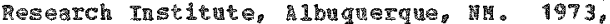
Decenber

Cholce of the Bagle 109 as a laboratory Aastal. LT-46: Part of leclellat,

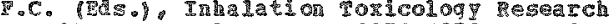
Inst to 34280

The advatages of ming beagle dogs in studas of the lorgtrer jological effects of znternaly depositad sadionucides are 
RTOLOG ICA ASPECS

<32> CORT.

revieved. General characteristics which favor the use of the beagle dog as an experinental anial include its intermediate lifespan, wediu body size, short hali coat. Iriendiy temperament, ease of handing and Iriendi\% terperatent, ease of handin
good litter sizes. It has been wall characterized in nuber of laboratories. patal discases in the beagle dog are abrerse and not orershadond by one predolnane cause as is seen in sore species. In inhalation toxicology studies, aecosol deposition patterns have been shom $n$ to be sinilar to those seen in huans. Mlso. particle size differences in the deep lung and subsequent retention in the lang differ from those seen in roden species. The dog forms an important link in the extrapolation of results fron laboratory anials to nan. It is a Iso large enough that possible therapeutic procedures for min such as bronchopul anar 12 age can be exa tested in detali. (Auth)

<33>

Brooks, A.L. D.R. Mead, and R.F. Peters, Lovelace Foundation for fedical Education and Resea rch. Inhalation Toxicology Research Instutute, Albuquerque. Wh. 9973, Decenber

Distribution and Retention of Monomeric plutonium 239 citrate in the chinese Hatster and Its cytogenic Efrect on the Testes. ZF-46: Part of reclellan. R.0. and Rupprecht, F.C. (EAs.). Inhalation Toxicology Research Institure tanal Report. 1972-1973, (p. 240-243), 342 p.

chinese hasters were injected fich pu 239 citrate to characterize the retention and distribution of this chemical form of the isotope. These data vere used to make an estinate of the radiation dose to the testes which vas celated to the chrcmosome damage recoried in vitotic metaphase cells.

Injected pu 239 citrate in the monomeric for was retained in the chinese haster with a long effective half-11fe. It day zero, the liter and bone each contaned $40 \%$ of the sacrifice hody burden, increased ith time whereas the bone renined alost constant. This long effective hate-life in the liver is sinilar to that seen in doo and an and indicates that the chinese haster ay be a useful small animal model for stulying the retention, clearance and biological effects of $D$ is 239 in the liver. There as no significant increase in the frequency of cliromosome aberrations in the testes at 64 days after injection. indicating that the genetic risks from ou 239 citrate are small compared to the risk for 1 ife shortening and cancer induction. (Auth)

344

Brooks. A.L.. and J.A. Mewhine\%, Lorelace Foundation for hedical Education and esearch. Inhalation Toxicology Research Institute, Albuguerque, $\mathrm{q}_{\text {r. }}$ 1973, Decerber

The Frequency of chronosome Aberrations in the Blood iymphocytes of the chinese Hanster Following Inhalation of plutonina 238 Dioxide particles. IN 46 ; part of peclellan. R.O. and puppreche, FoC. (Edso). Inhalation Toxicology Pesearch Institute Annual Report, 1972-1973, (p. $230-232) .342 \mathrm{p}$.

To evaluate the extent to which chromosoa aberrations are produced in blood lyaphocytes by inhaled plutoniu, chinese hawsers vere exposed via inhalation to pla 238 p 102 and the chromosome of the hlood lwaphocytes examined for danage 25 days later. Andrals vith injtial lung burdens of 650 to 920 nci died with a reaian survival tile of 16 days. Inimals 1 th initial lung burdens of 60 to 80 nCi had $50 \%$ reduction in 1yaphocyte count at 25 days post-inhlation. These anals also bat as berration frequencp of 0.014 aberrationsfcell wile pooled controls showed a frequency of 0.004 berrations/cell. Further experinentation is needed on this syster to make it useful as a rodel for studying the effect of inhaled toxicants in producing early biological changes in the blood lypphocytes. (Auth)

$<35$

Brooks, A.L. J.C. Retherfora, and R.O. ucclellan, Lovelace Foundation for Nedical Eacuction and Research. Inhalation Toxicology Research Institute, Albuquerque, Wh. 1973, Decerber

The Effect of plutoniun 239 Dionide particle puber and size on the Frequency and Distribution of Chromosone aberations in the diver of the Chinese manster. IF-46: Part of teclellan, R.O. and Ruppecht, F.C. (Eds.). Thalation Toxicology Reseacch Institute Innalineport, $9972-1973,(\mathrm{p} \cdot 233-239), 342 \mathrm{p}$

chinese hamters were infected intratrously with Pu 239 citrate or pa 239 PuO2 particles. There mere four particle sizes injected, $0.17,0.30,0.44$ and 0.80 wial wh would var the local radiation dose rate to the surrounding cells. Aditional hasters yere injected inth graded levels of activity from $5 \times 10(\mathrm{E}-5)$ to $6 \& 10(\mathrm{E}-3)$ uCi/g using 0.30 u pu 239 puo2 particles. This changes the particle nuber and the average dose rate. An experiment was also conducted to deter the retention and distribution of the particles using $\mathrm{Cr} 51$ to trace the Pu 239 Puo2 particles. The particles were concentrated in the reticuloendothelial systen ith $90 \%$ of the injected activity in the liver, $3 \%$ in the spleen and the rewainder associated yith bone and bone marrow. There vas particle clumping causing high local doses in all particle sizes studied. The pu 239 citrate produced a Iinear inctease in the chromosome aberration freduency ith a slope of $4.8 \times 10(\varepsilon-3)$ aberrations/cell/rad. The aberration frequency increased with

increasing average dose following injection of the $\mathrm{Pu} 239$ Pro2 particles ith little evidence of an effect or particle size on the aberation frequen. This increase in response plateaued at higher average doses. when local dose as related to aberration frequency, the smaller the particles the greater the effectiveness in producing chromosome darge. Following injection of all particle siges, there tas anoun ifor distribution of chromosome damge in the cell population vith some individual cells containing as high as 13 aberrations. The nonouniform dose distribution is thus reflected in mon-unifora distribution of biological darage at the cellular level. The number of cells at risk following particulate deposition is much less than from uniforn distribution of the same total activity. This ay indicate that long-ter risks from pu 239 Puo 2 particles would be less than that eroa uiformly istributed pu 239 citrate. (Antin)

<36>

Bruenger, F。 ... Stevens, D.R. Atherton, and B.J. Stoper. University of vtah, college of Medicine. Radiobiology Division, Department of Anatom, Salt lake City, UT, 1972, march 31 
<36〉 conp.

The pfect of the Physical-chen ical state of

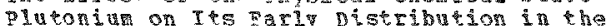
iver. Co0-119-246: pare of pougherty. pesearch in adiobiology. Hnual peoort of hork in progress in the Internal Irradiation Program, (p. $148-160)$, 380 p.

The early neposition ara subcellular distribution of $239(4)$ in cantre 1 in 230 following admintection of either stricti monomeric $\mathrm{pu}(\mathrm{m})$ as a transfercin complex $(0 u-7 f)$, Pu(b) in citrate buffer pll 3.5

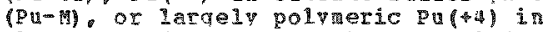
nitrate ofl 6 (pin-D) has been stuaied. Large differences in the onatities deposited and the intraorgan aistribution patten in the 1iver mere observed. Inver deposistons ranged from 25 of total dose for the strictiy vonomeric (Pu-Tif) an averate of $32 \%$ for Pu- to approritately $70 \%$ for the largely polvmeric aterial. Autoradiographs shower thet initially pur vas deposited wh. form 1 and diffusely in hepats cel1s whereas $P u-p$ vas found large ly in randon clusters in reticuloendothial cells. cellular distribution patterns of puwf and pu-m injecten dogs were quite similar. Iiver homogenates from a dog infected vith pum an the aninal injected wth pu-P also vere studied by differential and sopycric sucrose density oradient procedures. Monowezic plutonin soluble liver ocoteins (ferritin) and found at later times wh subelinlar fractions tich in mitochondria and also with Iysosomes. Tn these organelles. wost of the nuclide was either nenbrane bound or possibly

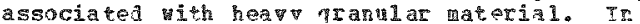
liver homogentes obtained from loas injected with pu-p most of the nuclide sed mented vith nuclei or a cochondra. To association of Pul $\rightarrow$ it soluble oroteins could be deronstrated at perp shor times atter

injection. (anth)

<37

Brumer, H. D. J.S. Atomic Energy Comission, Division of biolog and DC. 1971

Distribution of Pritiun getreen the lyarosphere and Invertebrates. con-710909: part of moghissi, A. and Carter。 M. H. (Eds.)

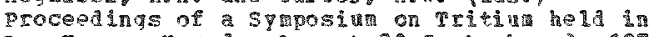
Jas Vegas, vevada, Argust 30-3eptember 2, 1971. Messenger araphics. Publi Shers, Las Vegas. hevala, (P. 303-314), 809 P.

The literarure tas reviewed in order to establis thether he lover form of life. and esoecially phose invertebrat es eaten by higher orders, exhbit evidence of entichnent of tritin in the organic corround of their tissues. The data seviened hith one

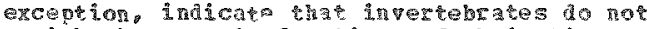
enrich the organic fractions of the ir tissues

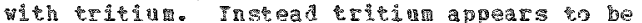

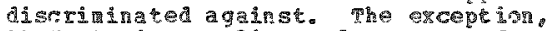

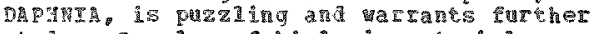
serdi. Samples of biologic materials oriqinating between abon 1954 to 1963 are Guite likely to have elavated specific

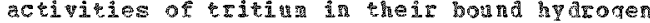
or vacer of conbustion. The envitonent levels of triti un a d ing these vearswere

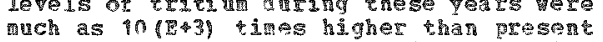
levels and samples or biologlcal aterials

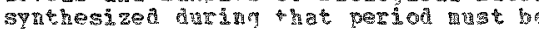
incerpeted accortingl\%. Th the pentix.a tale is given of the specific activity tritin in Dhtoplank

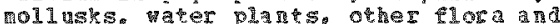
insects, relative to the speciple activity of the mediug in which they live. frogn

$<39\rangle$

Buldakov, L.A. M.P. Mifatot, R.A. Perokhin, and L.G. Filippova, tot given. 1971

Biological Tefect of Dlatoniul 239 with cutaneous and Intracutaneous injection.

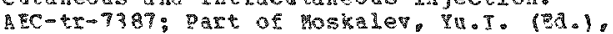

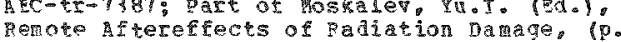
$331-387)$. 574 .

Tats of the wistar line were injected with $P$ 239 in a solina citrate solution of yith

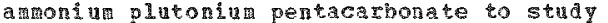
the effect of plntoning athe injection site and resorbed plutoniu on the rat bod Injected doses Iangea from $0.09 n$ to 1 uci/rat. one halt of the rats were injected subcutaneously, the ot her half

intractaneonsit. All of the rats were subjected to a pathologic anatonical a utopsy. cerputations of the raditan aros in the bones fere aade on the hasis of airect measurerents of the plutoniag content in $1 \mathrm{~g}$ of bone tissue. Folloving ingection of 1 uCi the average lifetine as rednced from approximately 515 àvs to approminately 427

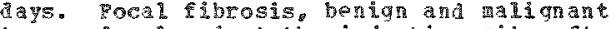
turos developed at the injection site after both tpes of injection of soluble plutoniut componits. The frequency of orcintence of scar changes (sclerosis) in the skin and in suhcuteneo's cellular tissue as dependent on the quanticy of injected pintoniun and cangea fron 8.2 to $30 \%$. Bentgrs tursts of the gkin and subcutareons cellu lar thssue in fron 2.3 to $3.8 \%$ of the cases rese detected after the infoction of 0.0001 to 0 . 1 uci and ralingat tumors arter the injecrion of $0.001,0.005$. and 0.1 aci in 2.48, 1.3 , and 2 of theses. respectively. ostersargomas in $3 / 4$ and $25 \%$ of the rats were discovered vith the infection of 0.1 and 1 nci when the ratiation doses in the bone tissue vere $40-79$ and 400-513 rad raspectively. An estimated $40 \%$ of the isotope tas lost aring injection. Changes following sablutaneous and

intracutaneons injection are sion lar. (ST)

$<39>$

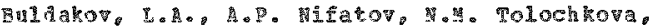
and I.T. Burov, Institure of Diophysics, Hoscow. 8SER。 9967

Aborption of Pluconiun 239 Through the skin and tron the subcutaneous tigsue of toung Pas. AC-tr-5989: Part of Radiobiology, (p. 157-182)。 253 po: Radiobiolotge, 7(4), 591-609

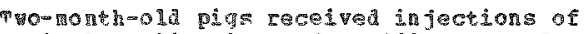
topical applications of 2 i⿺ 239 componds to

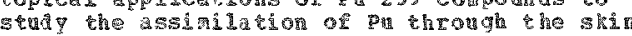

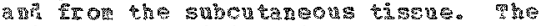
anima

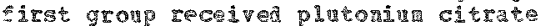
intratenomsly at a tose of 9 wi the second

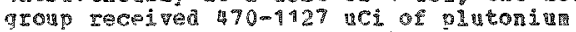
citrate ac a 34 of 6.5 apglied on shaver and tegreased skin near the spine, a

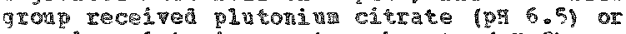
a subcutaneoris at a dose of 1 uci. Rt

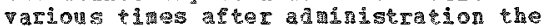
anitals there sacrifice for histrological. redionetric. abd histoaucoradiographic scudies. The tognt showed that $0.347 \%$ of the appised plutonin citrate was aborbea in six days: $0.183 \%$ vas a sorbed the first day.

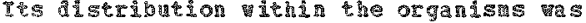
simidar to that ater internel

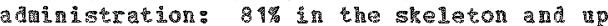
to $18.5 \%$ in the lipe. During the first 24 
<39> $\cos 9$.

hours the isotope accumiated in the epidermis, hair follicles, and sweat and sebaceous glands. After subcutanous injection the plutoniu citrate content in the soft tissues was higher than the content of amoniu plutoniu pentacarbonate, while in the skeleton the relation ship was the reverse. The microdistribution at the site of injection and in the regional 1 yaph nodes al so differea between the tro compounds. The assiailation of $P u$ from the site of injection occurred along the blood and 1 ymph pathways. (Auth) (ST)

<40

Buldakov, I. A., A.P. Nifatov, a nd R. Terokhin, mot given. 1971

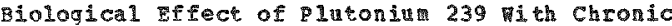
Perorgl adrinistration. ABC-tr-7387: Pert of moskalev Yu.I. (Ed.). perote Atereffects of Radiation Damage, (po $388-398), 574$ p.

Three hundred and eighty-five male and female anials of the wistar line vith an initial weight of 152 plus or minus $0.7-205$ ples or and 1.8 g were used in the experinent. Six times a meek the experimental animals were

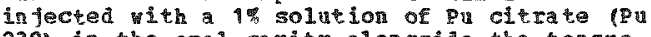
239 in the oral cavity alongside the tongue in volume of 0.2 al. The activity of the Pu was 0.01 uci-10 uci for the various groups. The experioental and control rats were periodically veighed, and the

composition of their peripheral bl ood was studied. The organs were in westiquted radiometrically and histoautoradiographically. The ID 50 values for different times ith peroral adinistration ame given. It was noted that ID 50/90-240 values in the large intestine $(236-3 h 9$ rad vera $1.4-2.2$ tines lower than in the steleton $(112-242$ rad and the us $50 / 480$ values in the lare incestine the LD $50 \% 480$ values in the large intestine rad. The mean iffetine of the experimental rats decreased little wth the daily adrinistration of 0.5 uci and decreased considerab1Y in adinistration of $0.1-10$ uCi/dav" phe data show that using the criteria of lifetime and weight protracted peroral adinistration of Puismore tokic peroral admistidion of Puls inore to than single adainistration. among the
pathological changes noted were peritonitis. anemia. leukopenia osteosarcomas 17.4 in rats daily receiving 0.5 uci pu 239 and tumors in the soft tissues. (r)

〈4 is

Busch, R.H. Batelle Memorial Institute. Pacific lorth west Laboratories. Biology Department. Bichland. H. 1972, September

Exfoliative Iung Cytology of Beagle Dogs Brposed to Padon Dawhters. Draniug ore Dust, and Ciqarette snoke. But -1650 (Qart 1): part of thompson, C. (EC). Annua 1 Report for 1971 . (p. $246-251), 313$ p.

Samples of deep lung cellular waterial vere obtained by pulmonary lavage frot beagle dogs exposed to radon alughters ith or ore alust plus cigarette smoke, radon daugters with ore dust, cigarette sinolse only, and control dogs. The samples were obtained for the purposes of technique evaluation and cellular detail studies. Comparisons of cell-counting techniaues For deteraining absolute and differental counts were made. Influences on these counts due to methol of preparation vere studied. nifferential cell connts obtained by the nothods reqarded as most accurate indicated that dogs that vere exposed to to ore dust had chronically inclared lungs thile those exposed to only cligarette smoke shomed slight evidence of inflas ation. (nith)

$<42>$

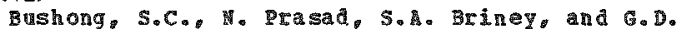
$011 \mathrm{ver}$ J. By lor college of gedicime and Veterans adinistretion Hospital. Departanen of Radiologi. Houston. Ty: Anderson hospltal. rouston. Tx. 1973

Rad copogenetic studies with Califormin 252. International Journal of Radiation Biology. $23(2), 105-112$

Chromosomal analyis of chinese haster opary cells was conducted ater irradiation with either radiun or Cf 252. Irradiations perior med at tho different dose rates with each radiation source and under aerobic and rnaerobic conditions. Iow and high dose cates for radiu vere 79 and 327 rads/m. bow and high dose rates for ct 252 were 167 and $06-522 \mathrm{rads} / \mathrm{hr}$. The oxygen enhancenent ratio vas apporinately 2.3 for radiu and 1.8 for Cf 252 and as independent of dose rate. The relative biological effectiveness of C 252 compred ilth radiu ranged from 1.7 to 4.3 depending on radiation conditions. The number of single-and alti-hit aberations per cell are given in tabular form. (Ath) (ST)

<43

Casarete. A.P. Cornell Unifersity. New York state Veterinary College, Department of Physical Biology, Ithaca, NQ 1958

Radiation Genetics. Part of Radiation Biology. Chapter 6. Prentice-Hall, Inc. Englatood Cliffs, wev Jersey. (p. $178-135), 368 \mathrm{p}$.

This chapter is ligited to those radiation induced changes (mutations) in the cell that are not physically isible but hich are recognized by a change in phenotype or survital of the progeny. mutation studies in Drosopnr. $\mathrm{A}$ and the gouse are revieked. The rate of atation production is examined using different dose rates, fractionation patterns. and cell stages. Somatic mutions and the effect of background and costic radition on evolutionary processes are briefly mentioned. (ST)

<4 48

Casarett, 2. . Cornell uiversity, New Tork state veterinary college, Departient of physical Biology. Ithaca. WT. 1968

Radiation Biology. Prentice-Hall. Inc. Fng lewood Cliffs, ver Jersey: $368 \mathrm{p}$.

Radiation biology is concerned with the description and explanation of the rany changes thich radiation produces in biological aterial. The bok is intended for use as an introductory textbook on the graduate or undergradute level, as suppleaentary reading a the high school or early college level, and as a source of general information for those vith a majo general information for those ith a mor book begins vith a brief historical introduction to the field with an account of the contributions of early radobiologists. The next chaters describe the principles of radiation physics, the major characteristics of various types of radiation and their jetection and measurement. Typical experinental facilities for exposure of 
$\langle 44\rangle \cos m$.

different biological waterials and problems of dosimetry and dosage calculation are include. Chapter is contains a general description of radiation chemistr and outines the effects of radition on chenical systems of parving complexity. The remainder Systems of varving complexity. The ren radiation on biological material starting with siople systers and progressing in order of increasing biological complexity. Enphasis is on the effects on wanalian systems and mants, but other biological forms are considered whenever pertinent. The final chapter aiscusses radiation in ou environment-sources, nses, exposure levels and possible risks to the human popnlation. It stresses the relationship of the

experimental effects described in preceding chapters to the effects that no occur in humans as a result of the expanding of of radioactivity. To a id the reader in understanding the thanges which are aescribed in the various systers, basic biological back ground information is given. Specific and general references are included at the end of each chapter and at the end of the book. The experimental mature of the field is stressed by the inclusion of than illustrative studies. (ST)

Radiation Biology by Aison P. Casarett is a broad, unified coverage of the effects of ionizing radiation in biological spstens at the molecular, cellular, organ, organism. and com nity levels. Inciuding introductor material on radiation physics, dosimetry. an general biology. the book gives special attention to manalian radiobiology. Dossibly the rost ontstanding feature of this fully ill ustrated book is its broad coverage in ihout over exphasis on specific areas. worthe of note is the coverage of the acute radiation sundrome in mamals description of effects and possible mechanises). radiation dosimetry including techniques commonly used for radiating biological specinens, and certain aspects of applied radition biologi giving the exposures to be expected and estivates of the probable effects on present and future generations fro current Bedical, jndustrial and nititary applications of ionizing radition. Reviemer"s com ments)

<45>

Casaret, A. B. Cornell in iversity, Nat Tork state veterinary college, Departhent of Physical Biology, Ithace, HY. 1968

Efrects of Radition on Higher plants and plant Conmuties. Part of Radation Biology. Chapter

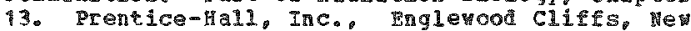
Jersey, (P. 284-314), 368p。

The first two parts of the chapter consider the effects of externa 1 radition sources on is given to the effects of radiation on pollen, developing plant abryos, seeds. growing plants, growth, porphology, tur incidence, and plant hormones. The radiosensitivit of certain species is Tadiosensitivit of certain spect

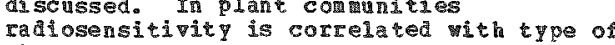
plant (herbaceous vs woody). grovth stage, and interphase chromosone polume. Inplications of radiation induced alteration in plant comunitudes are considered. studies of natural clant comanities erposed to chronic gam radiation at Brookhwen

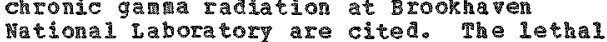
pationa 1 Iboratory are cited. Ihe letbl 1,000 and $150,000 \mathrm{R}$. The last part of the chapter is genera 1 iscussion of radionuclide cycling vithin a comunity. adionuclide aistribution within the components of a fool chair is governed by metabolic behavior, concentration factors. and utilization celative to a similar elenent. The complexities of food chains are illustrated. (ST)

$\langle 46\rangle$

Casarett, A.E., Cormell university, New Tork State veterinary College, Department of Physical Blology, Ithaca, 壮。 1968

Effects of Radiation on the cell. Part of

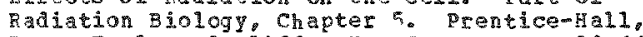
InC.. Englemood Cliffs, New Jersey, (P. 90-117)。 368 p.

The effects of radietion on the najor structures and sunctions of a typical cell ith reference, when possible to the underlying rolecular a terations are described. The discussion first revievs current concepts of the structure and function of the cel1, with erphasis on those characteristics of the cell which are related to rafiation anage. Cell irradiation leads to changes in membrane permeability, rate of ATT and DHA \$Ynthesis, enzwe levels, chromosone structure, cell division eycles, and to cell death. Experimental evidence suggests that the nucleus is the prinary site of radiation darage leading to cell death. (ST)

<47》

Casareth, A.P.. Cornell Jniversity, ner York State Veterinary College. Departhent of Dhqsical 8 iology. Ithaca, Wr, 1958

Acute Ratiation pfects in hhole Animals. Part of Radiation Biology. Chaper 10. prentice-Ha11. Inc. Englewood cliffs. Nev sersey, (p. 247-235), 368 p.

phis chapeer deals with the syndropes which occur within one to two months arter irradiation. The procedure for estimating lethal dose is outined and a table of typica 1 ID 50 values for several species of animals is included. The acute radiation syndro in described and the relationship between dose. time of death, and specific organ styten darage is given. Three organ systems appear to be most inportant in the acute radiation symarome. The central nervous syster is rost involved wh exposures of severa 1 thousand rads or more. Betveen 500 and 2000 rads the gastrointestinal syster is of rafor

inportance. Exposures of less than 500 rads produce changes wich are prifarily associated with the heratopoletic systen. piscus sions of radiation effects on prenatal levelopent and regeneration are included in the chapter. (sक)

<48>

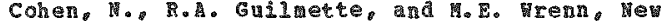
York yniversity edical center. Institute of Evironental hedicine, gev Hork, 政, 1974

Chelation of Anericina 241 for the Liver and skeleton of the Adult Baboon. Radiation Research, $58,439-4,47$

Investiqations were performed to evaluate DFph effectiveness in the remotal of An 249 frol the adul baboor. By adninistering therapl at long as vell as at shorter times after single IV injections of a 241 , it as possible to study the efficacy of bepr 
(48) cons.

therapy as a function of the site of its deposition in the prinate. i.e.. the skeleton and/or the liver. Heasurenents of concentration changes effected in the bone and liver were performed by ponitaring 241 in tigsue biopsy specimens, in scintillation counting and routine ratiocherical analysis of excreta. In a arial with an established bone burden of am 241 , a total of 8 of of the body burden was renoved due to DFPA administered over a 3-wh period, at a treatment reginen duplicating that presentip used for gan. Appromimatel 15 की of the body burden yas renoved during a similar time period from an animal still having a significant fraction of its burden in the 1iver. Partition of activity excreted as a result of chelation therapy zas monitored by daily a nalysis of urine and ceces. (Anth)

$<40>$

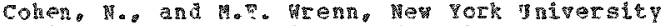
medical center, Institute of andronatid Medicine, 7ev York, 羽. 1972

The saboon as an raperinental atral for Metabolic studies of Bone-seeking Radionuclides in Man. Covf-7206103 part 31: Fare of Goldspith, E.T. (E.J). medical Prigatology. Proceading of the $3 r d$ symposint on zperimetal

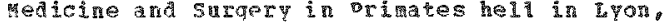
Frane, June, 1972. Farger. Gasel, ver tork, Nev yor. (P. 226-235)

The adult female baboon vas chosen as the experimentel aninal for the study of the retention and astribution of $\mathrm{Pb} 210$ and $\mathrm{A}$ 24 for several reasors including its size and netabolic sinilarity to ma studies in proaress. including netabolic characteristics

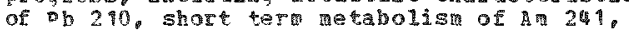
and lead toricity, were reviemed. (ST)

$<50\rangle$

Cole, R.S. and c.u. orosser, iniversity of Chisag, chictgo, TL. 9945

Biological Re search section. Ch-2786: Part of Health Droblers selatirg to product for sonth of Hach 1945. (D. 8-12), 35. p.

The effects of valence state and complexing agents on rates of absorption and subsequent distrinution of plutorith compound were studiet following solution intalation by

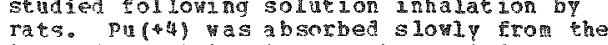
Iung oith a half-tide of about is dats.

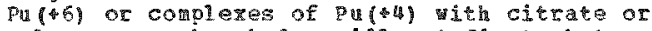
calgon were absorbed rapidly at eirst, but sloned to the rate of absorption of pu(t) within one day. phere was no difference in rate of absorption between the (t) and (tf) citrates. pu(t4) was deposited lin liver and sheleton at a very slos rate: Pu(t6) vas considerably faster, and the citrates reached very high concentrations in both of these orqans vithin a dav, is decreased following cessation or rapia absorption from the lung. A siailar phenomenon vas observed vith the skeleton. There as no difference in the metabolisin of freshl prepared solutions and solutions that were several hours olz. Plutonium

administerad inctanscularly to the as the citrate $(5)$ was nore toxic than the nitrate. (Auth) (ST)

$<51>$

Conar, Col Cornell thiversity, New Tork state vetarinary College. Departhent of Physical
Blology, Thaca, No. 1972

10logical prects of Taplanted fuclear Energy

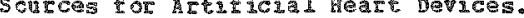

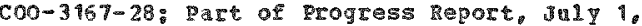
1971 to la $31,19 \% 2$, ehase $4,(p, 223-24 \%), 256$ P.

progress if reported on studies of the biological efects of rafition from nuclear pover somrces inglanted in the rlank of Lahrador Retriever dogs. During the past Year fourth group of anials as inglanted. This group consisted of \& blaths 4 togs

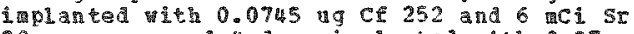
90 sources, and 4 dogs inplanted with 0.37 ug cef 252 and 30 aci $5 E 90$ sources. A sulary of all dogs implanted to date and ther current status is given in tabula form. Clinhal tests shoved a relative lyaphoperia. beginning about one month after surgery in begining about one tonth arter surgery in
the large source $(500$ het sr $90 * 0.37 \mathrm{Cr}$ 2 2) dogs. Wales in this gronp also showed a conplete lack of spermatozon. The clinical thstort. pathological changes, and postorted eranination results of one relale lith a larqe Doker source are described in the fext and desended in the appendices. Abrorkal ities were sinilitet to those of other dogs in this Troup previousiy described. The ovary nearest the source was severell atrophied. Exanin ation of the aputated humerus of one of het offspring irredided in itro and imediately postutally revealed chronic osteonelitis of unkomn etiology.

Tyternal ly observable changes have not occurred in any of the inplanted anima excent for a loss of hair and

itverpigmentation of the skin over the source of the large source animas. These ands also apear to be aging fister. (ST)

$<52\rangle$

Craig, D. Cart, "and Park J. T. Batedie penorizl Institute. Pachic porthest Laboratones. Biology Departmente Fichland, fa. 1972, Senteraber

Relationships 3ethen pespiration pareters of wnanesthetized Adule Beagle bogs During Training and During Plutoubu 239 punz Aerosol inhalation Exposures. B Thomeson. R.C. (EA.). Arnual Renort for 1971, (1). $209-211), 313 \mathrm{p}$.

Prior to sublection of dogs to aerosol irhalation exposures, they are trained daily for 2 weeks to falidiarize then with the axposure procedures. Respirtion rate and volno are measured and used to estimate the volne of air inhaled by each dog during its - roostre to aecosols. An instrulent for continuous montroring of tidal volume (Fin

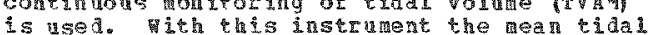
volue (TV). the rean respiration rate (15y).

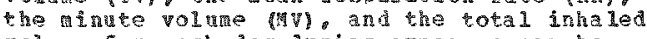
plua for each dog during aposure can be aetertined. Complete respiration data aring both training and exposire have been gathered for 98 dogs and compared in order to

letermine the reliability of the estimates of inhaled volude of dogs in those instances vere the data were not obta ined during serosol exposure. The cesults showed that, despite the apparentiy significant differences between the means of the respiration data gathered during training and

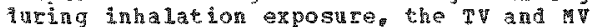
data were both significant ly correlated the $99 \%$ lovel. This vas not conststenty true for the data. Therefore equations vere derived to enabie $\mathrm{z}$ and asting ted from the taining dat when 
TOLOBTEI ASPTCTS

<52> Comp

necessary. (Buth)

<53)

Decker, J. Battelle lemonal ristitute, Pacific horthwest Iraboratories, Biology Department, Richland, 1972 , Septeaber

An Instrument for contanuous montorino of Tial Voluge of the Beagle Dog During Exposure by Inhalation of Ratioactive Aetosols. ghm 1550 (Pare 1): Part of porloson, R.C. (EA.). Mnnel peport for $1971,(p, 223-230), 313 \mathrm{p}$.

A data acquisition syste for continansy nonitoring and recording the tidal volume of beagle dog during indation exposure to ragloactive aerosols has been constructo and

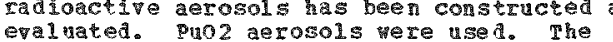
syster consists of a dog inhalation mast. penturi air velocity meter, two differental oressure transducers vith associated carrier

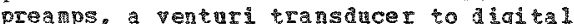
it tegrator interface signal conditioning systen, analog strip chat recorder, poltage to frequency converter, digital el ock and a digital. integrator and printer. The velocity profile which is useful is analyzing variations in breathing paterns is recorded by the and log strip chart recorder. Thal volume, as well as elapsed time fron the beginning of exposil re. is autolintically printed out in aigital form at the end of each breath. The syster is capable of weasuring tidal yoluses ranging erom $30 \mathrm{cc}$ to 33 cc and total inspired air volume ap to 1000 liters with ats ercor less a (a)

$<54>$

Decker, J.P., and D.K. craiq, Battelle Menorial Institute, Pacific morthrest Laboratories, Blology Devartment. Richlard, 1972 , Septeaber

An Instrumert for gapia Deterination of Concentration of Alpha- Stitting Aerosols for vse in Mnimal Tnhalation studies. BWw -1650 part 1): Par of Thompsos, R.C. (Pe.). Annal Teport for 1971, (0. 212-222), 313

studies to determine the $b^{1} 010 \mathrm{~g}$ ical effects and netabolism of inhalea 20233 puo 2 in beagle dogs require alveolar burdens over a $1500-f o l d$ range from 2 nci to 10 i to be feonsited in an anesthetized dogs by aerosol inhatation. Aerosols ith concentrations ranging srom 0.1 ni $1 /$ to 5 uci $/ 1$ here generated by nebulizing nater suspensions of Pu 239 puo2. To facilitate control of alveolat deposition, an aerosol concentration nontor. vhich is capable of rapialy determining a pha radionctive aerosol concentratons imediately precealng agy hiting dog exposures. vas josingel aril fahricated. successive aerosol samies of 0.5 to $4 . n$ liters aro aran through a absolute filter by a remote controller. automatically timed solenoid in a vacuan line. phe filter cemains in its original position wile, immetiately following sapiling. alpha particles are counted by a systen conorising a zinc sulfide scintillator and a hotomuliolier. The detector is separated from the filter paper which is contalned in a plastic finter holder bi an air tight wylar cower. Several samples can be accumated on single filter paper. The monitor is capale of measuring the concentration of sampling with an error not exceeding plus or mines $20 \%$. $(\mathrm{s})+\mathrm{h})$
$<55>$

Dijley, J.V. Battelle remorial Instate Qacific Northest laboratorim biology Departrent Tichland, ys. 1967, July

Tautine Ruction in Beagle Dogs after

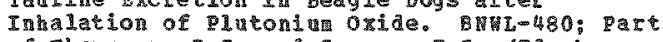
of Thowpon, R.C. and Swezea, B.G. (Eds.). Mrnal Report for $1966,(0,73-74), 207$ p.

Pre-erposure Iyphocyte levels vere deter ined in beagle dogs acclinated to tabolist cages. The anials vere then

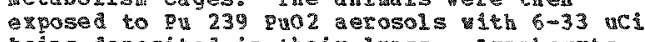
being deposited in their lungs. Lyphocyte counts and 24-hro urine samples vere taken periodically over the following 3 -month period. The results stow that the dogs period. The results stow that the dogs with the $3-$ mon period following the inhation. It is suggested that the increased urinary tarine levels are associated with the destruction of circulating Iyphocotes. (Auth) (FMa)

$\langle 56\rangle$

Dety. 5.B., C. Risecleski, and . T. Thage, Rice iniversity. 3ological Laboratories. Houston, Fi Argonne Vationa Laboratory, Biology Division, argonte II: J.S. Atomic znergy Comission, Division of Blology an pedicine, ashington oc. 1965. May-septes ber

Esfect of Short-Tern Alpha Irrad etion on Parathyroia Activity and osteoclast Nubers. procedings of the Society for Broerimental Biology and medicine, 119, 77-81

A study of the distribution of plutonia 239 in bone, and its effects on bone cells was presented and correlated uth enagenous parathyroid activity. ahe Pu in the rori of the nitrate (1 uci) was injected intraperitoneally into rats mej 9. There as no neasureable effect on the function of existing osteoblasts or osteoclasts during this short torn (5 day) experinent. Also. incorporation of plutoniug into osteoclasts aid not aispupt the ability of parathyroid hor wone to matain norval caleiul levels. Honever, it could be deronstrated that plutoniug for he first 48 hours after adoinistration affectea certain of the undiferentidted bone cells, vhich in turn prevented the increased osteoclast prorvetion norwall seen follouring endogenous parathyroid stinulation. (Auth)

Table 3 shows effect of PQ 239 on Thymidne-H and Proline-t 3 uptake.

<57

Dorgherty. J.H. Whitersity of "yth college of Medicine, Padiobiolog Division, Department of Antorv, Salt Iake city, UT. 1972, March 31

moxichty to Blood Cells of Aturiciun 2 an compared to other Transuraniur vicides. cco-199-245; Part of Dougherty. T.P. Pesearch in Rabioblology, annual peport of work in Progress in the Internal Irradiation progra (c. $272-281), 380$ e.

A comparison of the effects of the bone surface seekers pu 239 , A 241 and $\mathrm{Th} 228$ and the bone walume seeker Ta 225 on leupocytes of logs has been tade for the first year rollowing infection using the technic of probit analosis. Henatological responses for total white lood cells, polymorohonuclear 
(5) COV T

lenkocktes, Ifrohocytes and monocter thro oval uated at sig atie periods trom $30-360$ favs postinject Don. The prohit of the percentage depression of the various cells when plotted adinst the log of the intecter activit yiolied apporinately straight lines

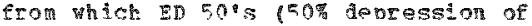
leupocytes) were calculated. Usiny 226 as a standart nuclide foxicaty indices pa 226 a standard nuclide, foxicity indices depression vere deterined. Frow these data

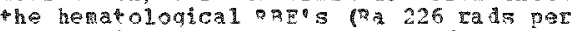
dav/ruclite rats per diy for $50 \%$ depression) were computed for the vations leukocytes over the first year. mhe surface seekers, pul 239 An 241 and Th 22 shomed considerably greater toxicity than a 226. The pattern of

depression and recovery of 1 earocytes is most siluilar for an 244 and Pu 239 as shoun by the probit nethod. $(n+h)$

Dorgherty, J. W. University of veah, college of dedicine, Rafiobiology Division gepartment of

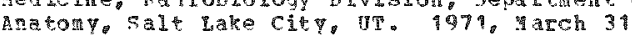

Parly yentologic Effects of Californ in the Beagle. Cno-19-2 bi Part of Doughert. Fo. in Erogress in the Intermal Irtaditan orogramo (0. $117-125$, \&24 0 .

The henatoloqic changes following intravonous infection of $C E$ 2u of CE 252 into 11 yound adult beacles are reported for the first 8 peels nost-infection. Three dog which received 2.9 uci/ka of cf 240 developed a severe deoression of granular lenk ocytes and blatelets which was aarithel 2 to 3 veeks following intection with approxinately little recovery by 8 meeks. The lymohytes were decreased below nor al by 2 weeks and continued to fall thereafter to on ethird of pre-infection alus. Changes in granilar leukocve values of 4 hogrs injected ith atoroxinatel $40.29 \mathrm{nCi} / \mathrm{s}$ of $\mathrm{CF} 249$ mere conparen to those of a dog intected th 0.28 ucifka of cr 252 . There vas a preater and more prolonged depression in the of 252 injected logs probaly due to the adad bone dose rate from fission fragments on bone surfaces which mould callse a greater irradiation of bone rarror. There have been no changes thas far in red cells. platelets or 1 ymphocytes in 1 ogs receiving $0.28 \mathrm{nci} / \mathrm{kg}$ of either ce 249 of Cf $2 \mathrm{~s} 2$. (AITH)

<59)

nougherty, T. F, University of thah, College of medicine, padiobiology Division Depatrane of Anatom, 3 al Lake city. UT. 1972, March 31

Pesearch in alobiology, Anual Report of work in Progress in the Internal Irradition Progran. $\cos -19-246: 380$.

Progress is reported on the university of vtah beagle dog studies compating the relative tosicities of $\mathrm{p}^{\mathrm{a}} 226$,

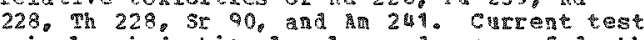
animals, injection levels, and cau se of aeath are listed. studies on $5 t$. Bermard dogs and nice are included. The report concentrites on three principle radionulides: plutoniug.

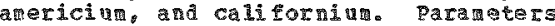
studied mere effects of ohisical an chencal state: offects of $t$ tre of compond administered: tissue and cellular concentration. retention, and distribution: tissue dose rate as a function of dose level. toxicity: tumor incidence: genetics: effects of lov asses of radiation: and pla she steroid lovels. The tissues stulied vere bones, foeth blood, liver and severnl soet tissues. Tnel phes are notes on harium 133 and rubidium 9 half-life deterinations. Trenty articles mere selected and abstractei separately for the ata base. (5\%

26

nougherty, T.F., Bniversity of ptak, college of mertcine, Panobioloq Disision, Departiont of Anatomy, salt Lake City. 0T. 1972, March 31

Injection tables. Coo-119-246; Part of Doughert. T.F.. Research in Raliobiolog?. Anula peport of pork in progress in the Tnternal. Trradiation progran, (1.9-105), 380 o.

Poxicity--those ainals thet vill be mantaned until sacricice becomes a clinical necossity--and test aninals-those animals that nay be sactificed as needed for special stuales-are listed in tabular form. The number ing syster for the infection levels of the six rationulides studiel is explained. the tables include the calcalated dose in rads to the skeleton at jeath and contrents on the ractors that had the most prominent effect on the clinical sratis of the aninal. (ST)

$661\rangle$

pougherty, T. P. vingersity of wtah, college of Hedicine, Padiobiology Division Department of

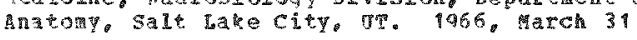

Research in Radiobiology. Rnnul Report of work in Progress in the Internal Irradation progran. $c 0-119-234 ; 326 p$

Prontess is reporter on studies at the Tniversity of thah using beagle dogs to study the toricity of a 226, Pu 239, Re 229, Th 228, a nd $5 \%$ 90. The current injection ororram is ligated to $\mathrm{Ra} 226$ and Pu 239 at ioxer ase levels. Fhere are five retained dose levels for each radionuclide except sr 90. in which case they are greater by a faccor of 10 . Dose level 1 is the basis of the schere and is 10 times the maximation pertissible dose of Ra 225 in tan. Tncluted are injection tables which present the lestons or suctors that had the nose provinent effect on the clinical status of the anial. Three papers on 239 vere abtracted separateip for the data base:

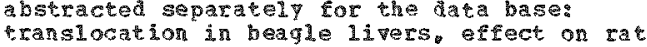
bones, and effect on serum transainase levels and other serum constituents in the dog. (ST)

$652>$

Doughare T. T. (E.). T.S.S. Jee (Ed.), C. A. vays (ra. and Boj. stover (Edo), university of flah, colleqe of kedicine salt dake city pr. 1962

Sone Aspeces of Internal Irradiation. Proceenings of a 5yposinu held at The Homestead, Reber, Tha, May 8-11, $1961,529 \mathrm{p}$.

Thite-tro papers concerning the pathological changes induced by internal irradiation vere presented. The problets or metabolis and dosinetry and visiets of pathological endpoines mere considered. dose-response relationship vas observad for wang heratological and biochenical alterations bone pathology, dterations in the central nervous spter and epes. and to the general orerall change in rate of the agling process. Two of the gavers presented aterial ained at

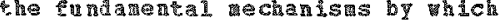


(62) con?.

iraniaton might induce malignancy: entocrine neataten carcinogenesis and ital carcinogenesis. Some indiract nechanisms by which pathological charges of a wide variety ma be intucea were hiscussed. Beagle dogs. rats, monkeqs, minture stine, rabbits, and man mere ased to $\mathrm{s}^{+} \mathrm{udy}$ the effect of radian.

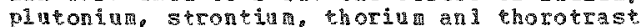
on bores, carcinogenesis, the nervous syster. heratolog, agina, steroid biospmesis, hlood forming tissues. 1 ung, and fetuses. Wifteen papers were selected for separate abstracts in the dat a base. (ST)

$\langle 63\rangle$

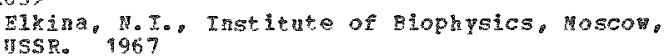

Calciu and ohosphoras latabolisa in tabbit Bone Tnder the Exect of Plutoniu 239. A SC-tr-6986: Pare of Padiobiology (p.53-72). 255 P.: Raciobiologiva, 7(1), 42-47

In a study of normat rabbits, it as established that the ca and in the diaphyis of tubular bones yas 10-34\% higher than in the porous part of the bones, whe the rate of inclusi on of $\mathrm{Ca}$ and $\mathrm{P}_{\mathrm{s}}$ as indicated by erperiments 32. mas $2.3-2.8$ times lover in the dimphys than ir the porous part. Between the ages of 90 and 35 days, the rate of uptake of $C$ a and p into the bones decreased by factor of 2-6. while the content of these elements in the bones aid not change sienificativ. on aldinistration, (by a single intraterous injection) of Pu 239 (as Pu nitrate at pu 2 ) in a cose of 2 or 7 uci/kg to rabbits, the ca ind dose of 2 or 7 ver/kg to raboits

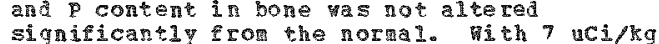
dose. the tiste of upiake of ca 45 and $\mathrm{p} 32$ in bone decreased: 30 days ater andistration of 2439 to the rabbits. the $\mathrm{Ca}_{4} 4 \mathrm{~s}$ ctivity vas $66 \%$ in the aiaohysis and vertenrae and $52 \%$ in the spiphysis vs controls, while the 52 in the spiphysis vs controls, while the $67.5 \%$ in the porous part of tubular bones and of vertebrae ys. controls. Between the $30 \mathrm{ch}$ and 180 th lay arter Pu adinistration the retes of uptake of Ca and showed a tendency to rerurn to normal. on adringerseion of $\mathrm{Pu}$ 239 at a dose of 2 vci/kg. changes in the uptake rate of ca 4 and 32 took pace at a later tine than after administration of the lasger dose. Fhe rate of uptake of $\mathrm{ca}$ as and p 32 in osteosarcomas that deteloged after atwintration of 239 at a dose of 2 uci/kg vas higher by a factor of $9-15$ and 2-16. respectively. as compared uth the non-tumorous bone tissue of the raboits vith turors. (Anth) (PMn)

<64)

Dlkina, N.T., not giver. 1962

M100d Seru proteins of Rabbits and Dogs

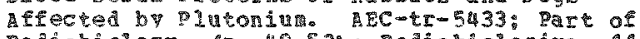
Radiobiolog\%, (p. 48-53): Radioblologiya, 11(6). $834-837$

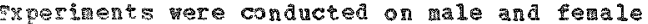

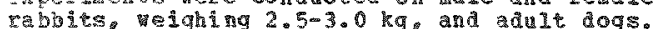

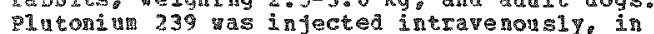
a solution of the nitrate (pth 2 ) in doses of a solution of the nitrate (pt 2) in doses of
7 ucikg (Eabits) and 2 uci/kg (dogs). At fixed tives after the injection of the pu 239 the protein fractions of the bloa gerun vere investigated by paper electrophorasis. It was shown that the in lection of platoniu into the nimas led to zeduction of total proteln in the blood serum. The reduction is due mainly tc a decrease in the albuln content. A calculation of the ionization dosas receiged by the liver of the rabbits and dogs shoned that the reduction in total protein and albugins did not ocenr until the cumlative dose vas very hioh. For instarce. in rabits these changes occurred at doses above 3748 rad, and in dogs doses a bove 796 rad. These data indicate that the 1ivar of toas is raxe sensitive than that of rabsits to the action of plutoniu alpha rays. (P)

<6.

Pairchild, R.G., H. Lo Atkins, T. M. Drev, and 3.5. Robertson, Brookhaven National Laboratory. medical Research center, pton, Iong Island, 1973

Biolodical tfects of Calisornin 252 seutrons. Conf $-731030 ;$ Part of procedings of the 2 nd symposin on Fundamental and practical ispects of the Apolication of Past pientrons in clinical Pacicherapy hela a the Rague, Netherlands. ockober 3, 1973, 114 P.

The biogical efects of cr 252 netrons have bee stadied wh cultured cells, and with intagt tissues. Measurements available to date, of the relative biological effect (RBz) and of the oxygen enhareenent ratio (oph are sun mation and discussed. An increase in RE vith decreasing dose rates vas de monstrated. However, a comparison of zesults was complicated by the fact that FBEs can oe quite sensitive to the gamma standard dose rate used. Biological evidence is presented for an enhanced effect on turors because of reduced necessity for the presence of oxtgen during the period of irradiation. Blological considerations suggest caution in the use of CF 252 in a hospital environgent. The lack of recovery from cellular dange dae to meutrons results in high values for PBE, particularly for lov doses and low dose rates. (Aath) (RAF)

Tables and 2 present $R B E$ and $0 \mathrm{R}$ data in blological systers.

<66.

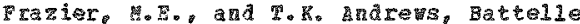
Henotial Institute Pacific Morthest Laboratories. Biology bepartrent, ichland, 1973. Aril

Detection of cytotoric Lyphocytes in geagles yith 21 lon in 238-I duced Bone Turors.

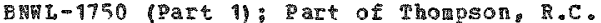

(EQ.). Annual feport for 1972, (9.37-38), $103 \mathrm{p}$.

The experiment was designed to investigate the transtissibility of Pu 238-induced canine bone tumors. Bone tur cells from beale that had been exposed to Pu 238 by inhalation mere injected intraperitoneally into neonatal opies. These anials at 9 month of aue showed po evidence of turars, but they vere producing 1. 1 iphocytes that rere cytotoric to caltured Pu 23 -induced canine bone turor cells. Prelininiry experiments suggest that cell Iines prepared from calline bone turors have at least one antigen which is conan to bone unors found in other dog that inhale Pi 238 . Dogs yith these bone tumors a 150 possess 17pphocytes that are cytotonic to cultured bone thor cells from heterologous andals. Culturea cells from a sportaneous 国积ary tunor and Pu 239-indnced can ine lung turar cells vere not killed by these lymphocytes, implying a degree of specificity bsed on tuor type. In adition, spectic seru-blocking factor, capable of preventing the cytotoric effect of 1 prohocytes alrected 
$\langle 65\rangle$ CONT. against canine bone tutor celis, has been found in one dog dying trom such a bone eumor. (Auth) (RAF)

<67>

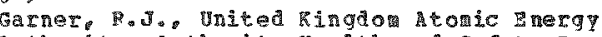
Authory. Authority Health and Safecy Branch. Tadiological rofection Division. Farell. Didcot, Berkshire, Endand. 1965

Natural Uraning and Geazing Anals. Health Physics. 11. 323

With the advent of nev inforation on the behavior of $v$ in large animals and of revised recommendations from the Intermational comission of adological protection the author recognizes the necessity of a reviek of the situation. Findings show that considerably moze of the daily intake labout

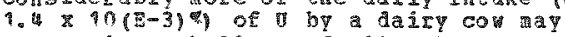
appear in each liter of vik than was ordinaliv supposed but that the aount of v excreted in the urine and ill together is consistent with the assurion that $1 \%$ of ingested is absorbed frob the gut. The aximu per ij in drinking ater currenti recongended by TcRp, in relation o indididuls in the population, is $6 \times 10(5-7)$ act. equivalert to a daly intake by an adult, of $9.3 \mathrm{x}$ $10(E-3)$ uc or $4 \times 10(E-3)$ a The perissible daily incake by chila can thus be assured to be $4 \times 10(4)$ (4) The peratsible concentration or natural of in meat is then 2 $x 10 \mathrm{E}-5) 9 / 9$ lassuning a chid to drink 0.71 ailk dalil. The peraissible concentration in anton and beef gould be attained if the daily intake of the sheep or cow vare 1 and $7 \mathrm{~g}$ Eespectivel permissible concentration in milk, the daily intake of a con rould have to be about a These anounts are greacer than the daily intales which pere astinated to produce sI ing malaise in sheen and a transient deptession of nilk yield in 10.05 and 0.49 respectively). (Auth) (RAF)

\section{〈क्रे}

Gillis, W. J. J Decker, J.

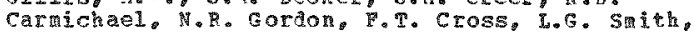
and J. Beaner, Batelie menorial Institute, Pacific Northest waboratories, Radiological Sciences Departient, Richland, perorial Institute. Pacific Northest

Laboratories, physics and Instrmentaton Departaent. Vichland, 茲. 1973, February

Biological Effects of Intracorporeal Radiolsotope Heat Sonrces. Bn $1-1850$ (Part 4) part of Nielsen, J.H., Annal Report for 1973 . (0. $85-88$ ), 1170 .

A 50-wate intrathoracic Pu 239 Puo 2 heat soturce in a miniture swine produced no clinical sions of untoward errect over a periof of alnost 10 months, in spite of areic occlusion and burnup some time prior to sacrifice. Retroperitomeal abaminal inplant experiments indicate surface heat thux tolerance 12uits of less than 0.01

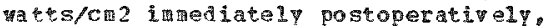
increasing to nearly 0.04 patts/ch 2 vithin one anth, ezploiting surace tissue ingrowh techniques. A riniature swine continues on

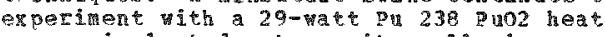
solrce inplanted recroperitoreally in a aiscoid alumina container ith velour fabric coat. (Auth) $<69\rangle$

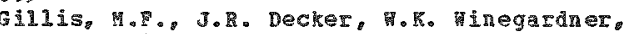

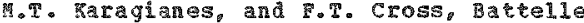
Herorial Institute, pacicic horth Laboratories, Biology bepartent, Richland, 牾。 $1973, \mathrm{Apri1}$

Bjological Effects of Intracorporeal Radiolsotope Heat Sources. Buth-1750 (Pate 11 : Part of Thompson. R.C. (Rd.). Anat Beport for 1972, (p. $57-69), 103$.

A past of study on the long-tertafects of radiation from an abdomally located radioisotope (plutoniul 239) heat source, a 5 in diameter silastic sphere weighing 2 lib tras covered with niton violor fabeic and

idplanted retroperitonea11\% in the abdomen of a pinture swine. mealing was rapid ans zithout incident acept for a single sment peritoneal ahesion. The implant did not tarate or produce deleterious effects. heat exchanger device has been perfected vhich cools the source by capid transfer of hat to the thoracic aorta. To surgical control animas isere implanted vith thoracic lat exchangers in thelr descending aorta and are being observed. In the event that intravasculax heat exchangers are necessary. arous, surface-passivated titania allow ube implanted in the thoracic aorta of a miniare suine was tested. There was no -vidence of thromi a month later. (ST)

$\langle 70\rangle$

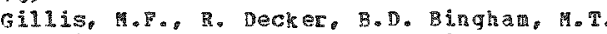

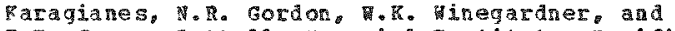
P.T. Cross, Batelle tenorial Institute, pacific vorthest Iaboratories, Biology Degartment ichland, 7月. 1972, Septerber

Biologic Effects of Intracorporeal Radoisotope Heat Sources. But Thompon, R.C. (2do). Rnut Report for 1971. (p. $296-301), 313$ p.

Thoracic intcaaortic iplantation of heat exchangers containing 50 wate, medical gradepu 238 puoz heat sources for long-term stulies of the effects of added endogenous heat and radiation in iniature swine presents a nubber of bioengineering problems. Through the inplantation and 3 ronth evaluation of three shat devices and by vabsequent dress rehearsal inplantation of subsequent dress rehearsal dontrol exchangers ost of these problens have been solved. Development of techlniques for intrababoinal inplantation of heat sources is in progress. (Auth)

$\langle 71\rangle$

Gomez, L. S. Colorado state University. Devartant of Radiation and Radiation Biology. Forf Collins, co. 1973,

Lyph phansport of Plutonin 239 Puo2 in Dogs. con-1787-17: Ph, D. Thesis, Colorado state Iniversity; 76 p.

The translocation of high-fired plutoniun 239 Quo2 $v$ ia the I.ymphatic syster from sirulated puncture wound in a dog's pay was stuided with two objectives in tha. The first was to study the effect of 1 ympadenectony on puo translocation, and the second was to determine the mode by which Puo2 is rapidly translocated from wound site to lymph node. Iy yph node excisions vere carried out on the day of the Pu inplant, as vell as 14 days after implant. Comparisons were made between dogs ith and 1 thout excision of the left superficial cervical

ipaph note. Higher levels of pu pere found 
(7) COR

in the liver, spleen and hepacic lyoph nodes of I dogs. Implications of the dats to

therapeutic Iyn ph node removal from vorkers contaninated with pu are discussei.

Chelation therapv and/or wound site excision may increase the therapeutic value of exciston of Pu-contaminated lyaph nodes. Data suggest that puo2 is primarily 4ransported by the cellular fraction of the 1ynph. The Pro2 transported in the cellular fraction was mainly associated vith the betalohulin orcesin eraction, which includes transferrin, the rajor pu-transport protein in plasma. The data also suggest that the rapil guo2 transport was associated with the orotein-bound Pu; the slower trassport of la rae puo2 particles vas via the Collular fraction of the 1yaph. (Auth) (MAY)

$672>$

Hahn, $F_{0} F_{0}$ and B.A. quggenburg, Lovelace Foundation for medical rducation and pesearch, Trhalation Toxicology Research Ingtitute, Al kury ueque, 1979, Decenber

In Viero Maration of Alveolar Macroohages Prom ongs that Inhaled cerian 144 Fused clay particles or Plutoniun 239 oxide. E-45; Part

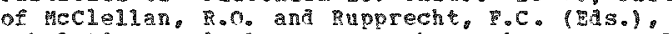
Tnhalation Toxicology Research Institute Annul Peport, 1972-1973, (0. 219-222), 342 p.

Aveolar macrophages are an ingortant constivunt of pulmonary deferse nechanism and anp decrease in their function such as 任 $q$ he be produced by radiation tay be detrigental to the integrity of the lung. The effect of alpha and beta irradion fror inhaled radiojsotopes or the in vitro migration of levegen cells vas exalined. Cells obtained from lavage of the lungs of dogs exposed to either ce 144 fused clay

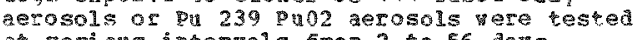
at various intervals from 2 to 56 days post-inhatation exposinge. Trhalation of $\mathrm{Ce}$ 144 fused clay did not significant 18 afect the in vitro aigration of lavaged cells at any time tested from to 56 daps

post-exposure. quoner. inhalation of pu 239 Pro2 did significantly depress migration at 312 times tested, $2,7,10,13,21,28,36$, 42 nd 49 days pose-weposure. A possible mechanish relates to alpha radation-induced cell death, and release of inhibitory factor from dead or dying cells. (Muthe)

(7)

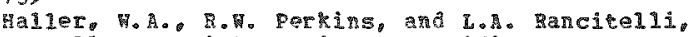
Battel1e memorial Institute, acific vorthest Haboratories. Environment and Radiolonical Sciences Department. Padiological sciences section, ichlant, 1368 , October

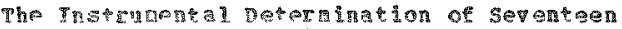
iements in traniu wi mers Tissue by veutron

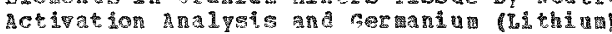

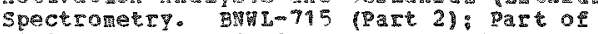

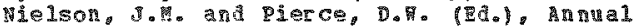
Report for $1967,(0.124-12 \%), 230 \mathrm{p}$.

Thstrumental neutron activation andysis has been enployed to deternine 17 elements in lung tissue. In adijtion to the lenents

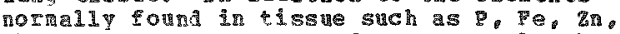
Rh, $\mathrm{Na}, \mathrm{R}, \mathrm{Br}, \mathrm{Se}, \mathrm{Co}$ and $\mathrm{Rg}$, several other Qlevents vere atected. Abnormaliy high

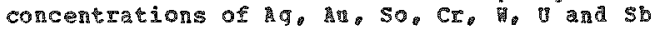
vere obserped. The uratu comtert $c$ m be fere observed. The wandu comtent can be or the (Ba-La) T40 fission product. (Auth) $\langle 74\rangle$

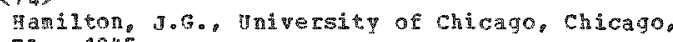
II. 1945

Technical Progress Report on the netabolic Strilies of Draduct. CH-2786. Part of Heal th problems pelating to product for month of masch $1945,(2,29-35), 35 \mathrm{p}$.

Studes of bone radioautographs and their coresponing stained sections revealed that the andosten and cancellous bone are the privalfie sites for the deposition of Distoning in the rat skeleton following ineran ucular injection. There vere no significan aifferences in the deposition pater for the three valence states studida The inhalation of ruor (noy) 2 sprays resulted in the initial Ietention of allost hele of the inhaled product by the lungs. At the end of 17 alas a most 20 of the aterial inbaled vas deposited in the stepetono in

exanination of the size of both pura smoke and pu2(no3) 2 spray particles bith the aid of the lectron alcroscope inatcater that the particles inhaled by the animals were fairly honogetous in size $10.90-0.30$ u in didgeterl. A prelininaty study of the long terk excris following insation of puor smoke indicated that the rate of licination at the end of six months was of the order of is per day of the retained material. This rate renained relatively constant frow the second to the sixth ronth atter exposure. (Auth) (St)

$<798$

Hodne, H.C., university of Callforna Departrent of ohareacology. San pancisco. CA. \97\}

A History of veandu polsong $(1824-1942)$.

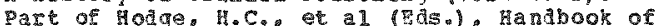

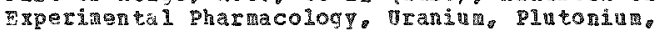
the Transolutondc Elesents. chapter 1. springer-verlag, ver York, vev York, (p. 5-68) $995 \mathrm{po}$

2arly experinents done on the effects of ij on

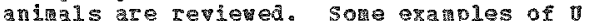

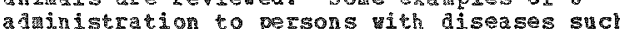
a diabetes are noted. selected data on the toricity of 0 compounds in andis are presented in rabular form. Erperinents are described of the use of o to induce experinental nephriths. Certain changes in the glorerular loops indicated a gossible vilue rabitity of the glomerula in regara to i. thus experinents to differentiate glomer 1 ar infury versus tablar injary are given ruch attention. Experimertal nephritis in relation to urinary gincose and the means by poisoning is reported as are studies of albuninuria, urinary acetone, organic acias, phenols, sodiu, potassiur, chioride and phosphate. The affects of on the cardiovascular syster. blood chenistry. liper, anscle, nervous syster, enzymes, protein and ijpid netabolis are aiscussed. several therapeutic measures are aescribed for treatrent of poisoning and the protection by sodi en blcarbonate against pidrey injucy crom nitrate in dogs is described. described. some of the analytic methods are described. There is an extensive bibliography. (pron)

$<968$

Hollins, J.G. A. Durakovic, and H.C.Storr Hational Research council of canada. Division of 
BIOLOGTCAI ASPECTS

<76) CONT.

Biological sciences, ottawa, ontario, Canada.

The Retention of Americiul and Calciu by the Sheleton of Growing and freture Ferale Rats. Calcified rissue Research, 12(3), 239-246: NRCC $-13241: 8 \%$

The retention of $\mathrm{Ca} 47$ and an 241 by 10 parts of the skeleton of groving and mature fena 10 Eats 7 days after injection has been measured. The various parts of the skeleton possessed videly differing abilities to concentrate both these elements. The bones of the younger rats had a significanty greater ability to concentrate A 2 hil but not Ca 47. Americiun concentrated auch rore on resorbing surfeces than on actively ealcifying surfaces. Results indicate that the long bones are nost at risk. The inplications of these results for the radiation aosimetry of internal contamination

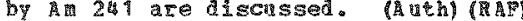

$\langle 77\rangle$

Horstan, T.G. R. L. Persing, and L.R. Bustad, Hanford Atomic products operation, Biology Laborator, , Riehland, YA. 1969, January 10

Effects of Intradermal Inqection of plutonium in swine. HH-69500: Raxt of Hungate, F. D. and Syerea, E.G. (EAS.) Han Eord Biology Research Snezua Report Eor 1960, (p.64-65), $195 \mathrm{p}$.

In study designed to derine the acute and long-tern effects of plutoniun in the skin of minature blond swine. 24 to 30 sit as in the lateral thoracico-3bolotinal region of each of two animas were injected intradermali with $0.0016,0.008,0.04,0.2$, and 5 uci of nitrate. Erythera, sweliling and foci of nitrate. Erythenas stelling, and foci of nectosis were evident after 24 hours. 40

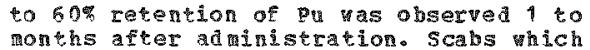
foraed at these sites containea over $80 \%$ of the retained dose. Injected areas showed a aiscoloration that still remained after 6 ponths. Swelling was observed in some of the

nonth. Sweling was observed in some injection. (Auth) (as

$<78$

Hsieh, J.J.C., F.P. Hungate, and S.A. Hison, Battelie memorial Institute, pacific morthest Laboratorles, Biol ogy Department, Richland, 1965. Jenuary

w1trahigh-speed Gross 1pha lutoradiography.

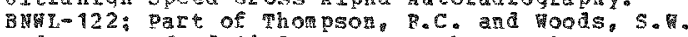
(2ds.) Hanford Bology Research Anmul Report

for 195, (p. $180-112), 116$ o.

High-speed gross alpha a utoradiograms can be obtained using zns: Ag as an intengifier in conjuetion wh high-sped film. The conjuction with hal-speed rilm. The technique requires aproximatelv $1 / 1000$ o
the exposure time needed by conventonal the exposure tine needed by conventional
methods of using Rodak's WTs plates (nuclea track enulsion for beta particles)

Experiments are described demonstrating the use uiness of the technique. Autoratiography Was done on rat fen ar sections with deposited pu 239. Both the contrentional and the high-sped technigues ve ce comparas. The critical level of $\mathrm{p}$ in urine samples was critical level of plin urine samples was determined from autoradiographs made fro
electrolttically deposited saphes. For detecting Pu sliver in or on the skin an pqoosure time of 40 sec. was required using the high-speed autoradiographic technigue.

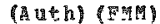

<9>

Iungte, T. E. and D. 月. Dater, Batelle Merojial Institute. Pacific morthest Laborator Les, Btology Departent, RIChland, 1972 , september

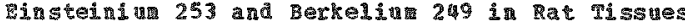
Following Intragastic and Intravenous

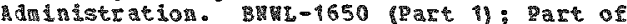
Thospsong.C. (Ed.) Aamal Repore for $197 \%$ (p. $88-92), 313 \mathrm{p}$.

Tissue distributions of 253 (1) 25 in 2 al

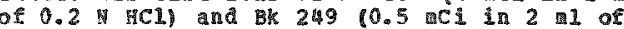
$0.2 \mathrm{HCl}$ were measurea folloning intravenous and intragatric admintstation of the chloride in poung adult shale rats veighing aproximately uoog. Aproxidately $4710(\mathrm{E}-3)$ percent of each lelent vas recorered in body tissues 21 days collowing intragastric intubation. Folloning intravenous infections, gross tissue distributions of to radionuclides wer genera 11y sinilar wth highest persistent concentrations in bone, followed by spleen. idney and liver. The biological half-lifo of 249 in bone appears to be less than 100 of 249 in bone appears to be less $t$ ittie loss of 253 from bone vas observed. suggesting a behavior typical of nost actinides. Urinary excretion of as 253 mas initidily very high with nearly $40 \%$ of the ingested fose excreted during the first day postinfection. (nuth

$<80>$

Hungate. F.P., B.I. GrifEn, JoH, Jarrete, and M. Fo Gills, Bttelle Hemorial Institute. Pacific orthest Laboratories, Biology

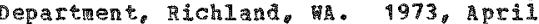

Development and valuation of Blood Irradiators.

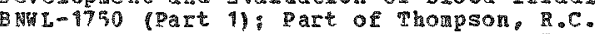
(Fa.). Annul Report for 1972, (0.69-70), 103 ?

A nex type of irradiatior consisting of 2-inch stainless steel ofre coated in its id segmen tith Pu 238 covered by thin 1arer of $p$ t. mas inplanted in the aort of $a$ dog $b$ insersing the wire diagonally throngh the vessei and suturing the ire in place at both ends. The dose ras designed to be in the range of 50 to 100 rads/day. Some loss of radion uclide has occurred as evidenced by pu 238 in the urine and feces. This irradiator has been in place for 6 months. vo change has been observed in 1 ymphocyte levels nor in the robility of peripheral cells challenged by antigen in vitro. nor as there any effect by antigen in vitro, nor as there any efi on time of llograft rejection. principal portable extracororeal irradiators adaptable to asteriovenous shunts, such as are

tyoicalle installed is renal transplant

atients. (Auth) (RR)

(81)

Twannikor, A.T. Not given. 1965

on the sianificance of the pabsorption of Bicarbonates in the Injurious Effect of Jranim Upon the fidneys and Its Elimation Fros the organism. ABC-tr-6603: Part of Radiobiology. (p. $136-145), 238$ p.: Radioblologita, $5(6)$. $869-872$

The intuence of diacarb, (e sulfarilatide preparation/s on the excrecion of uranium was studied in 132 white fenale rats, weighing 150-220 9. iranyl nitrate yas injected subcutaneonsly in a dose of 5 and $10 \mathrm{mg} / \mathrm{kg}$ of body weight in the for of $20.25 \%$ aqueous 
$\langle 81\rangle \operatorname{cov} T$.

solution. Fonut, which was infected intragastrically in the form of ainely pulverized porder in a $0.5 \%$ starch solution. $200 \mathrm{mg} / \mathrm{kg}$ of bony meight loptimum dose for urinary erfect) was used as the carboanhyrase inhibitor. parallel experiments pere conaucted ith the intraperitoneal injection of sodin bicarbonate in the form of $25 \%$ solution in a dose of $200 \mathrm{mq} / \mathrm{kg}$ of body weight, after adninistering urany nitrate at interpals of 3.5-4 hours. The results show that the administration of diacarb gives rise to an administration of alacarb gives ris bicarbonates, which promotes acceleration of the excretion of uraniun wh $^{2}$ the urine and reduces the kidney injury. The administration of diacarb in con jurction ith sollu biocarbonate is ore effective in accelerating the excretion of u than eithar of ther used indivianaliy. death rate was observed hen sodiu bicarbonate poisoning, and the clinical course of severe i poisoning developed when alacarb was administered, when they vere conbined all the rats experienced on Iv a slight sichness vithout signs of pronounced depression and tremors. The foint adinistration of diacarb and sodin bicarbonate is also nse ful in that the deposition of in the steleton is substantially reduced. (FH)

$\langle 82\rangle$

Ivanikov A.T., Not qiven. 1966

Dffect of 2-Acetylatino-1, 3 ,

4-Thia iozole-5-Sulfonatide on the S1 inination of Jranium from the organism and or the course of scute yraniun Poisoning. ACof loskalev, Yu.I. Distribution and Biological iffects of Badioactive Isotopes, (p. 678-687) 718 .

Uraniu elingan can be accelerated and injury to the organisu prevented by suppressing the reabsorption of bi ocaronates frot renal canaliculi g the the of diacarb-ma chemical acting a carboanyarase inhibitor. Diacarb is erfective in the early stages of acute urain poisoning. The

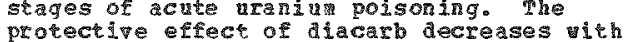
protective effect of diacarb aecreases ith the time elapsed since the administation of that dose. Treatrent with diacarb in late stages of uraniu poisoning actravates the course of the poisoning. The effectiveness of diacarb is agnified by a dinistering it in a combination with sodiu bicarbonate. ith reapect to both accelerating the elimination of uraniur and increasing the surpival rate of the exporimental animals. The most distinct procective efrect was produced by prophylactic $(1-3$ hours prior to polsoningl administration of diacarb in contination conbination with sodiul bicarbonate. together with sodiu bicarbonate prevents th together ith sodiu bicarbonate prevents th death of the animals following the intection of arany 1 nicrate in a dose causing $100 \%$ mortality of vite rats. (A uth)

Table 2 shows the uraning content in kidneys and sieleton of rats in percent of admin istered dosel on the 6 th day following poisoning vith rany 1 nitrate in a dose of 5 ng/kg and following ereatient with diacarb and sodiu bicarbonate.

$<83>$

James, A.C., Royal free Hospital, School of
Medicine, Physics Department, London, England. 1972

Dose to osteogenic cells from plutonin 239 Depositea in Rat Bone. Radiation Research. $51(3), 654-673$

Six to eight-week-old rarshall-k agust rats were giver a single Iv injection of 4.5 nCi/kg solukle gu (m) th a dose-1epel expected to give ar approximately $80 \%$ pield of osteosarconas. Localized dose-rates mere measured at fixed reference distances between 5 and 20 un from bone surfaces by counting alpha-russ entering small cylindrical targets located in a thin nuclear emulsion in contact with bone section. Dose-rates 1 day atter the injection ranged frol 22-57, 12-37 and $7-25$ rads/day at distances of $5,12.5$ and 20 wi, respectively, rrom a number of different endostea 1 surfaces selected for measurement. These local a ose-rates changed with time by factors of the order of 2, in either direction. depending on the prevailing conditions of remodeling. histological evidence of preferrea sites for the developant of osteosarconas is discussed in relation to local alpha-dose. A cumatitye alpha-dose of about 2000 rads delivered to prinitive cells at trabecular surfaces over a period of $36 \mathrm{wk}$ lay be associated vith a $10 \%$ probability of developing $a$ turor in an individual Eenoral epiphysis. (Auth)

<24)

James, A.C., and W.F. Herber, Royal Free Hospital, School of hedicine, pepartment of Hedical phyics. fondon. ngland. 1970

Apha Particle Incidence in Sall gargets. Physics in wedicine and Ejology, $15(1), 39-46$

A gethod for the direct reasurenent of the frequency distribution of alpha-particle incidence in targets of silitar divensions to incidence in targets of sinilat distision yielding the value of the rean dose in rads. these weasureaents enable the variation of dose in small targets to be erpressed as percentages of cell nuclei receiving zero. single of wltiple incidences in a stated tine interval. The relevance of this particle incidence concept of dose is discissed in relation to carcinogenesis and illustrated by actual measuretents in bones containing pa 239. (A

$<85\rangle$

Iee. H.S.5., and J.S. Arnold thiversity of itah. College of Hedicine Division of Radiobiology. Department of Anetory. Salt iahe city. एक. 1960 . August

Radioisotopes in the Teeth of Dogs. 1. The Distribution of lutonin Rading Radiothoriu. Hesothoriu and Strontiu and the seruence of Histopathologic changes in Teeth containing Platonit. Archives of oral lology, $2,215-238$

Jans and teoth containing radioisotopes from adult beagles mere studied to determine the location of the activity ana the sequence of histopathologic changes. Radionatography after a single intravenons injection of bone-seeking radiolsotopes (plutonim. radin strontiul in young adult beagles yielded the sare aistribution patern in dental tissur. The sequence of changes observed in dogs ingected whth plutoniu iserially sacrificed aogs and aogs alloned to live uni 1 moribin involved the formation of second ary dentue. alsturbance in cementu 
<85〉 COR

formation. resorption of cementu and dentine with metaplastic bone formation, damag to periodontal menbrane, ankylosis of teeth and loss of teeth. There as a direct relationship between the sites of plutoniu deposits and locations of dental lesions. Mo tunor arose from dental tissue, but a fer osteogenic sarconas occurred in the jays. (Auth)

$\langle 86\rangle$

Jee. W.S.S., and J.S. Artrolla gniversity of Ttal, college of Hedicine, Ratiobiology Division, Department of Anatom, Salt lake city. ขึ. 9959

Structural Changes in Dog skeleton Containing Plutonium. Coo-218; Part of stover, C.H.. Ir. (Ed.). Annual Progress Report, (D. 214-215), 229 D.: Part of Proceedings of the 5 th Annal Heeting of the orthopedic Research society held
in chicago. I1linols. Januery 23-24, 1959, (2 p.)

Eone changes vere observed in 30 young adult beagles containing body burdens of $2.5,0.89$ or 0.27 ucifkg of plutonitum 239 , bone seeking alpha etitter, using celloidin. radiographic, microradiographic and au toradiographic techniques. The impairment of vascular supply as also studied by India inc injection of the hinalimb at a atopsy. The sequence of bone changes was studied in 13 serially sacriticed dogs contrining 2.5 uci/feg of plutonium. Plutonium deposited on calcified bone surfaces and produced bone chanqes by direct and indirect nechanisms. Darly bone changes occurred in trabeculat bone. while late changes generally occurred in cortical bone. The earip efrect was observed in formation of acellular marrow cavities, peritrabecular fibrosos, trabecular resorption and endosteal bone grom th. The continuous effect was observed in plugging of haversian canals resulting in osteocptes death followed by disturbance in bone remodeling producing excessive nubers and irregular shaped resorption cavitîs, itregular shaped, hypercalcified and hypocalcified haversian syster, eroded periosteal surfaces with fibroses and fractures. The translocation of plutonin as a function of bone remodelling, correlation of sites of bone chanqe and plutonium localization, and comparative toricity of various dose levels will also be discussed. (Complete text) (anth)

<के

Jee.

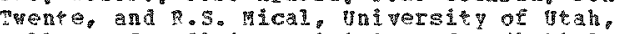
College of medicine nivision of padiobiology 1962

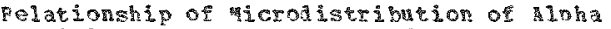
particles to Damae. Part of Dotgherty. T. F.

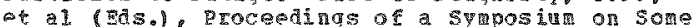
Aspects of Internal Irradiation held at The homestea, Heber, utah, my $9-11,1961$. perganon press. oxford, England, (p. 27-45), 329 P.

studies by attoradiography of the distribution of plutonathe radiume mesothoring and ratothorin relationshi of aistribution to daga, and the consideration of dose parameters in

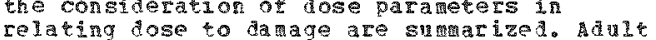
beagles ware used to stuly the histological chinges and inciaence of turors over a vide range of tadiation doses. The patern of disgreibution of Th 228 and $\mathrm{Pu} 239$ was

singlar. The ingitial deposits mere on hineralized bone surfaces and in the reticuloendotholial sytem. Bone temodeling atered the initial surace deposits bi bone resorption ard apposition. Radiation injor to the bone vasular syster is reviewed and the groblens involved in calculatiag local doses due to differentil uptake of isotopes. bone remodeling. and change in cells at rist are discussed. $\mathrm{Ra} 226$ and 228 degosited in high concentration in rapid ly calcing ing bone atrix beneath osteoblastic surfaces and hroughout the pre-existing old bone in areas of more uniform concentration. The deposition of the four radionuclides in teeth was sindia. In gereral, there was high concentration on nevi\% formed dentina surfaces of the puip chaber, an intermediate concentration in the cenentur and alveolar bone enveloping the peridontal mabrane, an a weh lower concentration in the enatel. most of the initial deposition persisted. In soft tissues generalized vascular changes, nechrosclerosis and regenerative 1iver nodules occurred in ligh level radiothorin ags. Concentrations of alpha particles occurted ithin the artic nedia. (ST)

<88>

Jee, HoS., P. Ottosen, R. Hical, and Mowe Universicy of itah college of hedicine Radiobiology Division, salt lake city. WY.
1957, gareh 31

Bone: Histopathologic and Autoradiographic Findings. ACCy-3522; part of Arrual Progress Report. (p. $86-114), 177$ p.

This preinginary report beals with the histologic survey of 47 beagles reaching a rops to ade this includes 43 toriciti and \& noral dogs. brief sumary and

discussion of the important histopathologic

rindings are praserted. The findings show

that the four alpha enters, plutonitu, meso

and radiothoriving and radiu produce

identical types of histopathologic bone

changes. These detectable chandes are fisturbaces in norna bone wetabolisa which alter the normal microscopic architecture of bone. They fall under four wa for categories: 1) response to alpha enitters by endosteal na bone arrov cells 2$)$ diseurbance in normal bone grom 3 ilisturbance in formal bone remodeling or reconstruction and i) foration of osteogenic sarcona. The detail a toradiographic studies are in progress and vill be sumarized in the negt report. (IC)

Table qives the positive histopathological findings in autopsied beaqles for Pu, Ra, msh and $\mathrm{dTh}$. Tabie 2 gives the numer of fractures, teeth lose and nictoscopic identification of osteogenic sarcomata found as altopy in beagles hich survived more than six

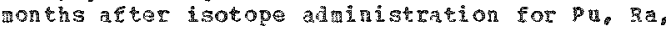

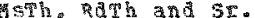

89

Jones, D.C.l., and J.S. Krebs, scancorh Research Instituce, Menlo tark, CA. 1972, kugust

Radiobiology of Large Animals. DT-8150; AD-752049; Annual peport for 1972 ; $43 \mathrm{p}$

A revien has been completed of a 11

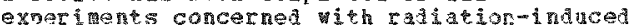
iethaifey in sheep and conductel by the of val Radiological pefense Laboratory andpor the stanfora Research Institute under the auspices of the Defense civil Preparedness Agency. Acter consideration of a series of Qxperiments in molving shear exposed to co 50 a ana raciation at vacious continuons. 
<89> conT.

intermitent, or combined irtadiation schedules at dose rates of is $\mathrm{P} / \mathrm{hr}$ or less, it appears that the ma for factor determining mortality in such exoerinents is the average dose per day over the entire exposure period. and not the specific dose rate during the

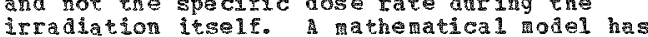

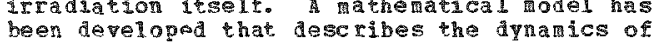
injury and repir as a function of dajiy werage dose rate. Studies of cell kinetics in the bone marrow of mice have revealed that differences in mortality following

irradiation at difierent dose rates nay be relater to corresponding differences in repopulation rates in this critical time rather than with differences in eell

destruction at the two dose rates. (Auth)

Sixty-day mortality in sheep following yeekly exposure to co 50 gama rays at difcerent rates is given i 1 ables 103 . Tables 4 and 5 contain the nuber of colony forming cells an total nuber of bone maxton cells in ice after irradiation with co 60 .

<9०।

Jones, D.C.L. and 3.S. Krebs, stanford Besear h

Institute, dife sciences Division, Menlo Park.

CA: Civil Defense Teparedness Mgency washington. DC. 1973 , gugust

Raciobiology of Large Anira 1s. AD-770131: $28 \mathrm{p}$.

Hematologic changes occurring during and after complex sequences of 1 ow-dose-rate egposure of sheep to gas radiation fComal exposure of sheep to gala radiation (Cowalt depressed early in the irradiation sequence. 1 i further gradul depression after cessation of exposure. Leukocptic values decreased in a stepuise fashion dinting the irradiation sequence, with the patterns of decrease na post-irradiation recovery dependent on the particular varameter of ratidion exposure. Studies of bonewarrop cell finetics in mice receiving single exposures showed that post-irradiation changes in total cellularity deperd on ase rate. Further studies or lethality in sheep irradiated at low dose rates indicated that a previonsly developed nathematical 1 on 1 relating paraters to lethelit to regure modicication when the exposure dose rate is of the order i/hr or higher. (Auth)

<913

Jones, T.M. P.O. Jackson, and Battelle Gemorial Institute, Eacific Northest Laboratories. Envi conental and Radiological Sciences Department. Radiological sciences section. pichland. 1968 , october

The Deternination of Plutoniul to Ratcian patios in Blological specidens. BNm-715 (Pare

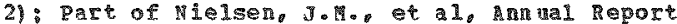
cor 105\%, (10. 140-141). 230 p.

go atd in the evaluaton of tolotolcal translocation of $\mathrm{pu}$ and $\mathrm{n}$. two precise measurement techngines ver developed to determine the pu to $\mathrm{A}$ Itrios in organs of anitals which had inhaled anted pu- an oxide. In one nethod, ater wet asing, the actinias in the samie vere electroplated and alpha pulse height anasis was used to and alpha pulse hejght analysing tused to
detertine the ratio. In the other. the ashed saples as precisely pounted and photon spectronetry (At
<92>

Jcshina, H. O. Matsuoka, and Mashio yational Institute of Radological sciences. Chiba, Japan. 1970, october I

The rffects of Calcin DPPA on the thole body Retertion and the Thsae Distribution of monoric plutoniu and polymeric plutonium. MIPS-Du-7: part of Reswarch geport on Interral Exposure to glutoniua in April 1969-4atch 1970 . (p. $57-61) .91 \mathrm{p}$.

The effects of Ca DTPA on tissue distribution ith regards to the whole bony retention of moneric and polyneric pu vere investigated. sinole intravenous infection of 1 uci (about 0.03 uci/g body weight of mopomeric pu or polymeric pu was given to forty-six male ace. on the day after infection of pu. sig wice which were given monomeric pl vere sacrificed to deternine the tissue

distribution as controls, and the first of 12 intraperitoneal injection of Ca DTPA or of saline, spaced 3 days apart, was given to the other forty ice. The individual dose of Ca DTP was 100 makg body weight. During the erperimental period the whole body activity was determined using three thin vaI(T) crystals. Trinediately before the - ice died the liver spleen and salivary land vere removed and analyad for puby gind were removed and analyed por pu results of whole bod retention. monomeric pus is are readily excreted than polytaric $\mathrm{F} u$ and the effect of Ca Drpa on the excretion of polyeric pu is staller than that on monomeric Pu. It seened the effect of $\mathrm{Ca}$ DTPA on the excrection of $\mathrm{Pu}$, both in mononeric and polymeric $2 u$, gradualy decreased sis passed. The tissue distribution data indicate that the so-called ' mononeric Pu' contain consinerable anounts of polyoric pu. In the liver and salivary gan. gonomeric pu which mainiz exists in the extracellalar fraction is easily chelated by Ca DTPA. On the other hand polymeric pol which is engulfed by the soleanic

reticuloendothelial cell is not chelated becase the cell nembrane is relatively inperveable to ca DTP. But even if Ca DTPA can permeate the cell mebrane, engulfed polygeric pil ill not be chelated because of its physiocherical property. A nes concept

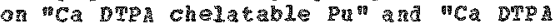
unchelatable Pry as roposed. Because 11 of the chelatable Pu as excreted, the later Ca DTPA treatnents had little effect on the whole body getention of Pu. (Auth)

<3)

Ra1mysova, Z.I., Hot given. 1969

on Certain Changes in the Red Hlood and Hemodynasics vrder the Tradation Injury of by a citsate of 21 utonita 239. A EC-tr-7195: part of hoskatev. Yu.I. (Bdo), Radioactive Isotopes and the Body, (p. 354-363), $458 \mathrm{p}$.

Rats of the wistac strain, weighing 140-170 ore or tocted to inhalat or 230 citrate vith $a$ prof 6.5 in a special chaber. The animals vere divided into three groups: the first and 2nd gronps were treated to single inhalation ith an initial conten in the 1 ings of 0.648 and $0.106 \mathrm{ac}$ of pu and the 3 ra group chronic inhalation for 160 days with dajiy deposition of 0.004 uci of 21 in the 10 ing. There were also two conerol groups. It was abserped that under alngle inhalation of $\mathrm{Pu}$ 239 witrate vith prelingna concentration in the lungs of 0.648 ucis, different shifts on the part of the Ied blood and the

henot mandes occurred depending on the 
〈93〉 colfT.

pertods of lingury. For example, or the first day after inhalation, the followiag changes were seen: macrospheroctersis of erythrocytes, a shift in the exythrogran to the left, a arop in the saturation of artería blood vith oxpen, sharp increase in the rass of cireulating blood and an acceleration of maturation of reticulocytes. In subsequent periods (8-64th day) there appeared a tendency toward normalization of saturation of the blood with oxygen and the mass of blood, fiacrospherocytosis of erythrocytes was replaced by normo- and microplanocitosis, the eryehrogra shifted to the right of aid not change erom that in the control. and the rate of blood flow and maturation of reticalocytes slowed down. On the 128 th day spherocytosis of erythrocytes and a shift of the erpthrogra to the lext were again observeh. hyporen ia was depressed and a disturbance of the elastic force of the iungs appeared ore clearly and inturation of reticulocytes again accelerated. Jnder sing le inhatation of Pu 239 citrate yth an initial concentration in the Iungs of 0.106 uci all these changes vere less sharply expressed than in rats of the first group. for 160 days gith a daily de position in the lungs of 0.004 uCi, mecrocytosis w ith spherocytosis of the erythrocytes was noted on the uth day of dosage, macro ant pianocytosis inmediatel after stopping inhalation, and at the end of the observations (by the 40 th day the airensions of the erythrocytes were not afferent from the control. The erpthrogra during the period of macrospherocytosis shifted to the left and coincided with the control in the period of micro- and nor woctesis. (Auth) (FMm)

〈94>

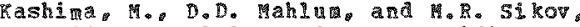
Battelle Hemorial Institute, Pacific morthest Laboratories, Biology Department. Ri chland, RA. 1972. Septeaber

plutonium and the Litver of the Irmature mat. BNGL-1650 (Pare 1): Dare of Thompson, R.C.

(Bd.). Anval Report for $19 \%$, (p. $77-81), 313 \mathrm{p}$.

Both rarenchyma 1 ce 11 Enction and ret iculoendothelial function of the Iiver were studied 3 wels $\mathrm{m}$ fter intracardial of intraverous injection of monomeric 660 uci/kg) or polymeric (30 uci/kg) pu 239 to newhorn, peek-old, veanling. or adult rass. The adult and reanling groups ahoved little effect of the pul 239 on these parameters. Harked impaiment of both parench mal cell and reticuloendothelial eunction was found in those infected at birth or a 1 teek of age especially after treatient with the (A⿱ $)$ ith)

$<99\rangle$

Kember. N.F. Erookhaven palonal Laboratory. ipton Lon Tsiank, wY. 1962

kinetics of population of Bone-Formin cells in the porma and Irradiated Rat. Part of

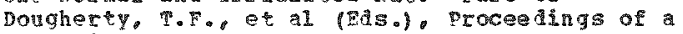
Symposium on Sore Aspects of rnternal. rreadition held to The Howested. Heber. Jeh. May $8-11,1961$. Perganon ress, oxtord. England. (9. 309-316).529 p。

pritiated thyldine was hored as a tracer for Dut surthesis in hone cells in nornal rats and following hind lib tradiation 1750 and

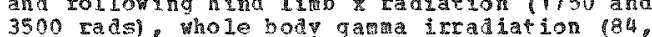
176. and 15 radstay, and 82 injection delivering wore tha 300 rads to the cells of the priary spongiosa in the rist day following injection. nutoradiographs used to rake labeled cell counts. Labeled cells of hind limb itradiated tats inithaly fell 1 I nuber followed by abortive recovery. and at 16 deys 1411 recovery the lower dose. At the higher dose there vere fer labeled cells after 28 days. In the contiluous1y irradiated zats the nuber of labeled celis fel1 rapial: hat at sis rads the cells contined to divide at reduced rate. Following infection of 932 there an inatate drop in nubers of labeled cells colloved by cecovery. Fhese results vere confir med in one stud using a 241.

chthough nabers of labelea cells returned to the noxal value fairly rapidly in the 232 erperiments, differential cell counts showed that 80-100\% of the labeled cells were spind le cells wich normally comprise only 25-30\% of the labeled cell population. (5

<95)

Rhodyreva. M.A., thot giveñ. 1966

Absogption of PIutoni un 239 Through the Skin of Aninals and Its Distribution in the organist. ABC-tr-6944: Part of Moskalev, Ya. To Distribetion and Bological tefects of Radioactive sotopes. (p. 99-105).718 p.

The results of experiments on rabbits established the possibility of the aborption of pu nitrate through the skin into the organdsm. On the fith day following the application of a solution of nitrate salt of Pa 239 to the skin in anounts of 0.4 and 4 acuries/cal 2 the body of the animals contained acurias/ch 2 the body of the animas conta iuth al a tere the application of a single Aose of plutoritu nitrate to the skin of the rabit the bulk of the absorbed dose was detected in the skeleton, liver and muscles. (A)

2978 Khodyreva, N.A., R.Y. Sitko, G. H. Parkhomenko, and H. Sarycheva, wot qiven. 1972

The Desactivation (Decontamination) of stin from the Transuranit Fiements. Gigiena Sanitariya, 37(12), 57-61 fussian, English

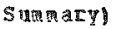

A relative accumition of the isotope was found to take place in the skin layers depending on the type of containation and the mode of decontanation. on the basis of the investigations performed the most efficient chelates for the decontanination of skin ron 2 an 2 vere elaborated and certain neasures vere suggested for completo

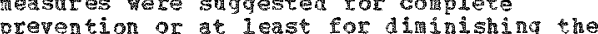
pravention or de least for ain inishing he substances. (Auth)

<98>

Rlepper, B., add D.R. Craig, hattelie Memorial Institute pacific porthast daboratories. ny ronental and ife sciances Diwision cosystems Department, Richiand, 1974, Januen?

Deposition chracteristics of herosnl Particlas

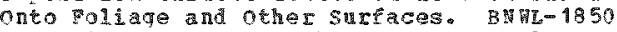
(Pact 2): Part of Vaughan, B. Report For 1973, (0, $5(-54), 200 \mathrm{D}$.

An zerosol exposure ind tunnel has been constructed and calibreted for use in studies concerned wh interetions betveen foliage 
<98> cons.

and airborne pu particles. The vind tunnel is 9 ft long and is enclosed in alexiglass glovebor comprising 3 sections: a transer hatch, an experinental section where material is put into and removed from the ind tunel. and an aerosol generation section. The glovebox is continully exhasted at a rete of about 40 cfin through an absolute filter. plants are grown in pin ice crean cartoms in plants are grotn in pint ice crean cartons in seedings with unifoliate leaves fuly expanded vere used in experiments were a An 198-labelled colloidal gold aerosol vas generated and depositea at several wid speeds. The short hal-1ire 164.8 h and easily nea sured gan decar energy $(400 \mathrm{keV})$ make Mu 198 a convenient isotope to nse. Plants pere oriented in varions airections. Also. 1 in. wide strips of asking tape were exposed at different orientations to the wind an air velocity of $0.42 \mathrm{~cm} / \mathrm{sec}$ about 0.7\% of the total activity passing through the test section was deposited on the above ground surfaces of 2 bean seedings. The zerosols had an $A$ of about 0.8 and and a GSD of 1.65 . Fhe deposition velocity for

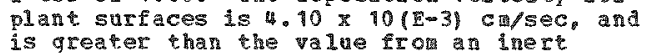
horizontal surface. (Ruth) (RAR)

Figure 2.10 shovs transverse section of a qlovebor and aerosol exposure ind tunne. Table 2.17 gives 3 eposition of arcosols on horizontal surfaces. pable 2.18 gives deposition of aerosols unto bean plast ts ander constant conditions in a dra tunel.

\section{<99>}

glepper, B. and D.F. Crajg. Battelle rerorial Institute. vacific vorhest Iaboratories. Environtental and life Sciences Division. Ecosystems Departrent, gichland,

Interactions of Pluconiut a tosols th plant Foliage. R⿴囗十 - 9750 (Part 2): Part of Vaughan。

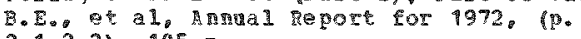

$2.1-2.2), 105 \mathrm{P}$.

The preliminary design 1 s shown of the glove bor and aerosol expostre chapher in which interactions between pu particles and plan foliage can be intestigated. In the first. erperinents, tro-week-ola bean seenidnos be exposed to pu 239 nit wate arosol particles in the sige range of $\mathrm{m}$. 1-3 um. G.S.D. equal to 1.5-3, at a vid sweed of 50 ft/nin. Later experitents ill involve ou 238 particles, chencal forms other than the nitrats, shower ina speeds and plant species other than bean. (rian)

\section{<100>}

Ronstantinova, V.V.,

physicochemical Champs in Deoxyribon ucleic aci.

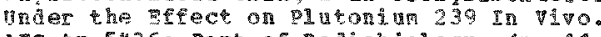
AEC-tr-5436; Part of adiobiology, (P. 19-97): gadioblologiva, $(3), 11-17$

Pabits weighing $2 .-3.2 \mathrm{~kg}$ were incravenously aninistered a single dose of 7 uci/g of pu 239 nitrate. After $3-6$ months the animals vere kiled and DNA preparations were obtained aro the liver. The results showed that the nat of the oxperiantal anifals hal a lower nolecular veathe 31. $5-19$ or less thas the control. The yida of Don estinated per 10 of vet tissine vas distincty decreased at al poriol of investigation. upon study of the nucieotine composition of Din it as found the bonth

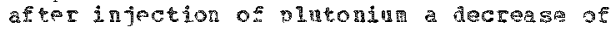

cytosine content (by 13\%) ccarrea.

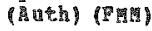

$\langle 101\rangle$

Konstantinova, T. V., and P.E. Gibinson, Mot given. 1958

The content and Synthesis of hucleic Acids in hiver Inder subacture Intorication yth

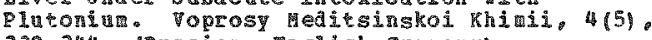
$339-344$ (Rusian, onglish Sumary)

Data are presented relating to the efrect of Pu on the content and synthesis of nucleic acids in rat liver. Plutoring nitrate was injecter intra peritoneally in toses equivalent to 0.02 uCi/g body weight. Investigations were carried ont 8 and 2 weeks and 1 and 2 month collowing injection: Four hours before belng sacrificed, the ani were injected with radioactive phosphate (P

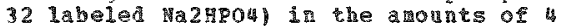
uci/100 9 body feight. Bstivetions rere ade of the nucleic acid content of the livers and of the rates of 932 incorporation into in and DHA. One or 2 months follwoing the

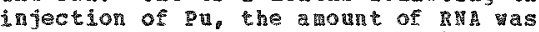
increaser an aøerage of $25 \%$ vilie the arount of DNA as an average of $25 \%$ lomer than norma 2 veess arter injection and

thereafter. The rates of PNA and DNA synthesis vere increased more than two cold aring the whole periol of investigation. The perreability of liver tissue for radioactive 2 is increased under conditions of Pul intorication. (sush)

$<102>$

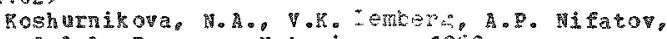
and A. Pozprev, hot gituen. 1968

Pnevmosclerosis in Rats ater Intratracheal Adinistration of soluble Plutoni un 239 conpounts. Gigiena Truda i professionel lnye zabolevaniqa. $27-32$ prussing Brglish

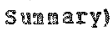

The frequency and severtity of prougosclerosis in rats following incratcrachea 1

alninistration of Pu 239 nitrate in doses of 0.00042 to 1.0 uCi/5at and sodium platony trincetate in a dose of 1.0 uci/tat pre stullef. penumelerosis was as frowent in rats following adinistration of a 0 .01 Folution of nitric acia as in rats receiving the Lowest dose of pu nitrate. Following d] in the freruepct on prinosclerosis occurres. it remote intervals atrez adainistration of hoth conponds. lungs vas characterized by nonuniformity. Injury to the sfructar 1 elements of the

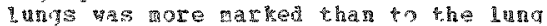

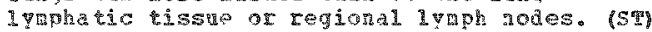

<103

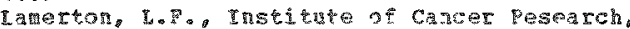
Royal Cacer Hospital Phsics paparment. London, England. 1962

The Relationship setwer Alpha and geta Dosimetry. Part of Dougherty, z. E.. at al (Fas.). Proceedings of a syposing on some Aspects of Internal Irradiation held at The

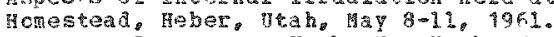
Waratar Prass, gev York, Wev York, le. $307-407), 5290$

The extent to which datailed investigtion of sadiation dose aistributor are practical and worththle in stulites with bon-seking rationuclides is sumarized. problens 
<103) cons?

encountered are a reflection of the essential complexity of the action of bone-seekers. Without sone knowledge of the distriution of cadiation doses in an giten case, it is too easy to wake false deductions or liss an irportat conclusion. Dose distribution studies lacking a close correlation ith histological factors are of little use, and investigators in the field are presented $u$ ith major problews. Mutoradography, the only technique avajiable at the tive is a laborious method for alpha evitters such as plutoniu and the short range beta emitters, and full ase âstribution is generally an Irpractical ain. Heasuring doses recelped by prixative osteogenic cells in bone requires knouleage of radiation dose distribution in bones and the aistribution of the cells themselves. por alpha and shore range beta enitters, any useful estinate ay be inpossible. If tuar production is affected by general tissue disorganization or is the result of induced cytological abnormalities, dose rate independence will not apply. Statistical problems involving the interaction bet een radiation and attar arise in considering radiation dose distribution at low levels of dose. (8B)

$\langle 10$ a $\rangle$

Langhan Scientifjc Laboratory, Los Alaros. M. 1951. Noyember 15

Excretion and Deposition of Aericina and Plutoniug. BA-1709: Patt of The Relative Physiological and Poxicological Properties of Anericiu and Plutoning $(0,43-15), 61 \mathrm{p}$ (Beclassified November 21,1955 )

Fifteen rats vere intected in the tail vein with 0.03 uci of arericiu per gra of body weight. Dally rine and feces collections were wede. Animals vere sacrificed at 4,16, 32. and 48 davs for tisste deposition scudies. Curves indicating a comparison of urinary and fecal excretion rates of americind (administered as $\mathrm{A}$ (C13) and plutonitu (administered as pu(mo3) 4) vere graphed. Data on plutoniu vas obtal ned from a previous stridy. Data shov that at the end of 32 days 9.91 of the injected dose of Ac1 3 was excreted in urine compared to $1.46 \%$

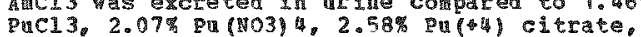
and 10.04 pucl $3.2 .07 \%$ Pul (No3) $4.2 .58 \%$ Eut

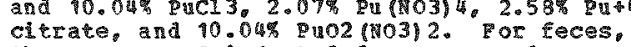
the percent of infected dose excre ted as $24.3 \% \mathrm{ACl} 3,39.74 \%$ PuCl $3,32.8 \% \%$ Pu $(103) 4$.

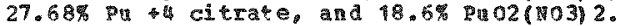
(BB⿵冂)

$\langle 105\rangle$

Langhan. and R. E. Carter. Los Mas Sciertific Laboratory。 Ios Alamos, Wh. 1951. Hoveaber 15

Relative Erfects of Anericiu a nd Rutoniun on the Pexiphera1 Blood. IA-1309: Part of The Relative Physological and Toricological Properties of A $22-23$. 61 p. (Declassified Hovember 21. 1955)

Hewatological observations yere conducted on serviving rats used for the ecute lethal studes conducted in the laboratory. Parying anounts of MCL 3 and Pust citrate vere infected into the animals. 1 lood counts vere taken over 300 day period post injection. Granlortes and 17 phoctes vere equal19 depressed ined iate $1 \%$ folloring in jection. The proporsion of granulocytes and lquphocytes zea inea esseritily uchangea despite the wide variations in the total wite counts. Morphological changes in white blood cells were the sare as those noted in other types of ionizing radiation dama and ccrisisted of bizarre nuclear forms and increased cytoplasuic basophilia in the iymphoctes. (6⿴囗十)

Data is included in Figures 7 and 8 comparing the effects of areiciur and plutoniu on red and wite blood cell counts.

<106>

Langhat, wa. and R. E. Carter, Los 1 lamos Scientific Laboratory, Los Alamos, HH. 1951. Novenber 95

Reletire Effects of mericium and plutoniu on General Health and ife Span. In-1309; Part of The Relative physiologica 1 and

Toxicological Properties of Americiun and plutoniu $(p, 26-27), 61$ p. (Declassified movenber 21,1955 )

Rats pere injected intravens iy with varying amounts of plutonium and anerciun, and the iffe history and general health sere followed for a year. In general, And pu given in equivalent icrocurie anounts seen to wa comparable effects on the survival of rats. Nearly all animals injected with $0.032 \mathrm{uci} / \mathrm{g}$ of body weight or greater appeared in poor health. high percentage failed to gain weight, sustained ultiple fractures and suffered from chronic uper respiratory infection some time prior to death. occasional aniwals surviting beyond 300 days gained veight norkall and appeared to be in good general health. Survival curyes are graphea.

<107>

Langhan. Ha R. E. Carter, Los Alamos

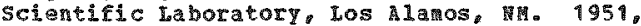
翟overaber 15

Relative Refects of thericiur and plutonim on Skeletal Structures. LA-1309; Bart of The Rel tive Rhysiological and poxicological

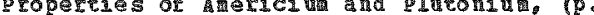
$24-25,61$ p. Declassified vove ber $21 \% 9955$

Eight weeks after injections of aericius and ilutonin. rats developed linb deformities. Radiological indings noted vere: pathological fracturas of the long bones of the litas; osteoporosis; densities along epiphyseal growth lines: bone necrosis: and rarked thin ing of the cortex of long bones Hith occasional psendo fibrocystic changes. There were no atferences between groups

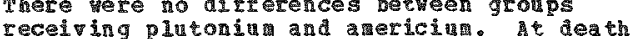

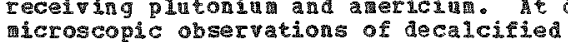
sections showed extensive areas of bone nectosis. (BBM

<108>

Lngban. and R. Carter Ios Mlamos Sclentific taboratory. Hos Alayos. Mt. $195 \%$ move

Melatipe Production of Bone sarcoma by mericlum

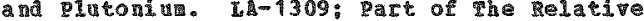
Physiological and Toxigological Proverties of

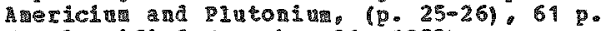
(Declassified toverber 21,1955 )

Four osteosarcomas tere seen in rats injected vith plutoniu and mericiun. The tumos vere alscovered at the tila of death or shortly before. Metastases. pretominaty pularary, occurred in four of the ten 
〈108> COHT.

anilats with osteos mecoms. Two fibrosarconas vere seen in animals injected

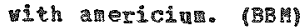

<109)

Gatghan

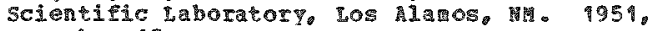
Novenber 15

Relative Effects of Anericlu and Platomin on

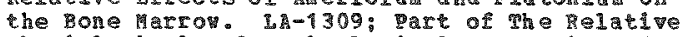
physiological and Tori cological properties of

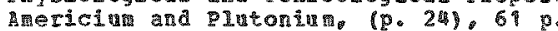

(Declassified November 23,1955 )

Rats that had been injected with plutoring and merici um vere sacrificed and femoral bone marrow was obcained. Examation showed no significant devition in the relative mubers of the various arrow cells. There vas a firlp marked increase in the general cellularity of the femoral narrov. (sam)

<110>

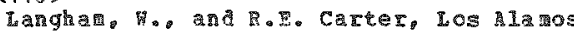
Scientific Laboratory. Los Aamos, H. 1959 Novertor 15

The Relative physiological and Tozicological

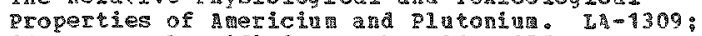
bl $\mathrm{p}_{0}$ (Declassified

The relative physological and toxicological properties of a mericin and plutong been studied following their intratenous adinistraton to rats. The arinery ard fecal excretion of arerich thas similar to that of plutoni a d in istered as pu(to3) 4. The deposition of americiun in the tissues and organs of the rat vas also silutir to that observea for plutoniu. The liver and the skeleton were the mafor wites of deposition. zirconiur citrate adinistered 15 mintes after in jection of amer jcin

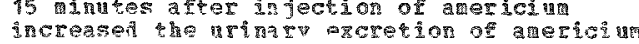
and derreased the arou found in the liver and the streleton at 4 and 16 dars. I0 $50 / 30$

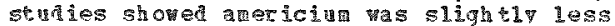

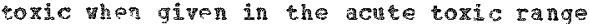

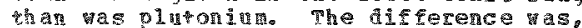

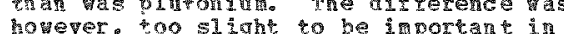
hovever, 00 slinh to be inportat in

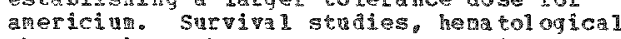
observations, bone merow observition

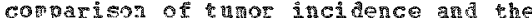

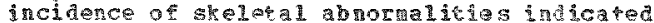

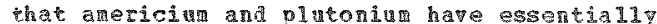
the same chronic toxicity when given on an equal uc basis. These stunies sipport the conclusion that the tolerance values Fot

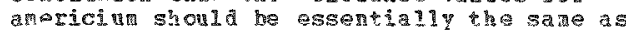
thrae ror olutonin. sepnate section of the report have her entered into the data

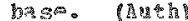

prot from the othites.

$\langle 11\rangle$

Langhan, Californa, Bos Alamos scientific laboratory

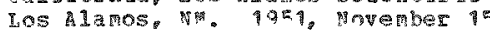

Relative Toxicolorical and physological efrects of Aveticin a the pelative Phviolonical, and Toricoloaical

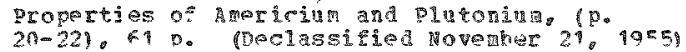

wive groups of 20 rats were in incter with solutions of a th eitrate of varting strengths, and seven groups of 20 rats pere

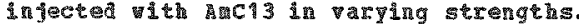
Data Fom the test shon that the nealan Iathal dose of olutonin a a marion

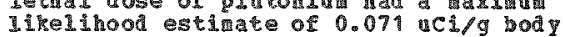
veight ith elducial probability of $95 \%$ that the medan letral dose migh be expected to lie between 0.056 and 0.086 uci/g. For americiul the median lethal aose had a

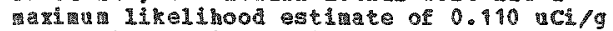

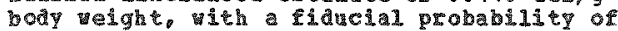
95 that the rea ian dose ray be expected to is between 0.090 and 0.130 aci/g. The ratio of the ost likely $\mathrm{HD} 50 / 30$ doses of americiu and plutoniu is $0.11090 .071=1.6$ and there is a 99 to $99.9 \%$ chance that the two are different. (BBm)

Table 6 gives the vci of vateral injected and the 30 ay artalit of each group of animals.

$<112\rangle$

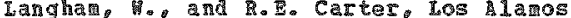
Scientific laboratory. 105 A 1 a povember I5

Effect of zirconiun citrate of treretion and Deposition of Anericiur. IA-1309: Part of the Relative Physiological and Toricological Droperties of Aaericiur and Lutonium, $17-20) .61$ p. Declassified Hovemer 21.1955

raelve rats mere injected intravenously $y$ 0.03 uci/g bod weight of anericiut as arc13. ther 15 quates 6 os the rats vers

injocted intraperitoneally vith 40 at of

girconitu citrate. The total excretion of atericiu in teces and urine during the first 2 4 horrs was $37.7 \%$ of the injected dose for aimals receiving zirconin and $6.9 \%$ for the control group. The single dose of zitrconin had essentialy no effect on urinary and fecal arcretion of aericin after the first 24 hour meriod. Total excretion for the 16 1avs of the experinent was 48.9 for treated animals ard 27.4\% for conctol animals. The effoct of zirconin on the deposiclon of anericiulin in various tissues and organs at 4 and 16 ays vas investigated. At 4 days after treatment, zirconing had ateriaill affected the deposition of arericiun. phe Iivers os control aninals contained an average of $39.3 \%$ of the infected dose compared to $17.9 \%$ for treated animals. shalet ons of the untreated aroup contained 30.75 compared to $22.5 \%$ for the treated group. The 16 dar results aro relatively in important because the zitconilu treathent is effective only ditring the fist $24 \mathrm{hr}$. (매)

Data from the stuly is indicated in Tables 4 and 5 of the repost.

113

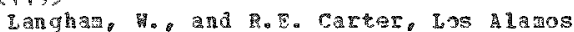

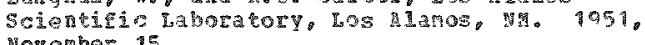
noverber

Congarison of Tissue Deposition of Americiun and

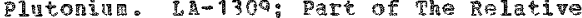
Physiolonical and Toxicolonical properties of

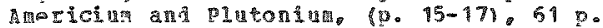
beclassitied Noverber 21, 1455p

Tats mere intected ulth 0.03 uci of acl3 per qrar of body meight. Tissue deposition tas

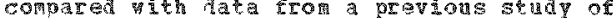

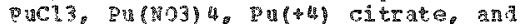

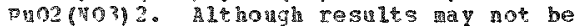
competely comparakle. data suov hat anericiug, lise plutonium in its various valence states, deposics primariv in the 


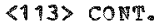

liver and skeleton. Amclis is conparable to Pu (No3) 4 and puc13 with 38.3\% of a mericiang and $39.7 \%$ of pu (no3) 4 located in the liyer and $30.7 \%$ of americium and 29 . 4 \% of $\mathrm{pu}(\mathrm{No})$ ) 4 located in the skeleton. Comparison of other tissues and organs is of little significance because of the small fractions of the total doses which they contain, al thongh values for americi ur and piutonium are roughly comarable. The qualitative similarity of the mode of deposition of americian and plutoniula was denon strated by

autoradiography. These autoradiog raphs show the great selectivity of both americiur and plutonium for the epiphyseal line and for the endosting and their complete exclusion from cartilage and dense bone. (BBM)

Table 3 presents data hich detail the deposition of the radionuclides.

<14

Leach, I.J., C.I. Yuile, H.C. Hodge, G.E. SYlvester, and R.B. Hilson, oniversite of Rochester, School of edicine and Dentistry. Departhent of Radiation Biology and Biophysics. Rochester, NT, 1973, september

A Five-Tear Inhalation 5 tudy y th vatural Vraniun Dioxide (002) Dust. 2. Postexposure petention and Biologic effects in the monkey. Dog and Rat. Health Physics, 25, 239-258

Inhatation studies show that dogs, monkeys and rats can breathe a natural uraming dioride (yo2) a exosol of approxidately y mass median particle diameter (fin). at a mean concentration of 5 mg $0 / 03 / 25 \times$ threshold linit value (TH or $28 \mathrm{~g}$ llpea). for periods as long as 5 ve ith little evidence of serious infury. Sone of these animals vere observed for protracted postexposure periods auring which pulmonary neoplasia developed in $a$ high percentage of the dogs exanined $2-6$ yr after exposure. Pullonary and tracheobronchial ly ph node fibrosis, consistent wh radiation effects, apoarently dose dependent, and mor marked in monkeys than in dogs was alse noted. evidence of uranium toxicity tas found in records of body weights, wortalitt. various hematologic paraneters or the histologic condition of the kidneys. (Auth)

Tables 3,4 and 5 show uraniu concentrations in dog, monkey and ret tisines. Table 9 shows canine lung turor incidence associated with inhaled $\mathrm{Pu} 238$ Puo2, $20239 \mathrm{PuO} 2$ or natural 002 aerosol.

\section{<115>}

Eebeinshil, A. V. (Ea.), and Hu.I. Moskalev (Bd.). Wot given. $196^{\circ}$

Distribution, Biological Effects, and igration of Radoactive Ilements. ACC-tr-7512: 409 p.

The report contains fortyme papers on the aistribution, ccel rated excretion biological effects and aigration in the biosphere of severa 1 rafonuclides inclading cesiu 137, strontiu 89, strontilu 90. bariug 190, ceriun 144 , Ianthanu 140 , ruthenit 106, plutonitu 239 , and ptrtion 91. The report is aivided into three parts. The first part subwits data that characterize the distinctive features of distribution of

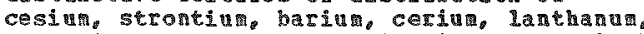
rathening, and phosphorus in ifferent ainal species as related to route of access.

phystological state of the organist. for of compound a dinistered, ph of the initir solution, and quantity of isotope carrier. aistribution whin the organist. Particular attention as given to the distribution and coefficients of accuaration of cesium 137 and strontiun 90 following prolonged intake through the gastrointestinal and respiratory tract. The possibility of aborption through the sin in as studied. In the second part Aata is presented which establishes the levels of acule. subacute, and chronic effectite doses of several radionuclides including pluconium 239. The effect of 5 a 11 doses, optima and inimu blastomogenic doses, and the effects of temerature, complexing agents, and solenectomy on the course of radiation sickness induced by strontiun 89 and strontiun 90 are included. The third part discusses the igration of strontiug 90 and other radioisotopes in biological chalns. lovenent with ground weer, effects on licroflora and fist. and accumulation in fish ere studied. To articles tere selected and abstacted separatelp for the data base. (ST)

$\langle 116\rangle$

I, erberg, V.K.. N.A. Koshurnikova, A,P. Nifatov, z. Bukhtoqa cova, and N.P. Kudasheva, not given. 1966

Effect of Adational Pathological Factors on the Lonq-Term consequences of plutoniug 239

poisoning. AfC-tr-694t: Part of Moskaler. Tu. I. Distribution and Biological Bffects of Radioactive Isotopes. (p. 484-492), $718 \mathrm{p}$.

Pu 239 as adninistered to rats in single doses of $0.63 \times 10(\bar{B}-3)$ and $2 \times 10(\mathrm{~s}-3) \mathrm{uCi} / \mathrm{g}$ is the for of the nitrate salt. Aditional pathological factors were applied incluang a septic inflamation, produced by introducing turpentine under the sking altiple repeated blood lettings, pone fractures and injection of carbon tetrachloride. It as foud that the combined effect of $\mathrm{p}$ and the additional factors caused a decrease in the average life span of rats of all series conpared with the controls, except for the female rats wich received " $p_{u}$ in combination with repeated blood lettings. The total nuber of turors occurring in the animals wheh seceived $R u$ in occurring in the aninds wheh zeceived $R 4$ in higher than in control anils and in andals receiving Pu above. sirilar pattern vas observed for 1 lo rats receiving pul in 2 combination ith repeatea bone fractures. a epeated injection of cclu in a combination ith incorporation of pa intersitied degenerative processes in the liver.

(1F)

\section{<17\%}

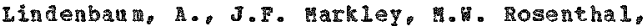
7. Mest fall, and $\mathrm{E}$. S. Morett. Argonne National laboratory, Rrgonne, IIs 1963, way

Progress geport: Plutonin Removal. 5. uitrafilterability and Disappearance of

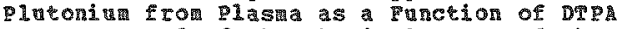
Treatrent and of the physical state of the giutorian, $14-6723$; part of Biological and Plutorium A $1-6723$; part of Bological and January through Jume 1962, (p. 146-148), 259 p.

Two plutonin injection solutions vere prepared. The onomeric contained 9.7 uci Pu per 1 : citrate: Qu ratio equal $60:$ pof oquals 6.0. The polpuetic solution contained 7.8 nCi gu per 1: citrate:pu ratio equals 2 ; pH equals 7.1. Minety Spragne-Danle fewale rats, veighing about 250 g. were injected intravenously ith the plutoni solutions in ather for at 7.2 or $10.6 \mathrm{mcl} / \mathrm{kg}$. The 
<117> corr.

treated rats received Ca DpH at 500 [ $\mathrm{G} / \mathrm{kg}$ intraperitoneally $1 / 2$ hr after plutonila adinistration. plutoninanalyses pere performed on vhole blood, plasma and plasma performed on vhole blood, plasma and plas results showed that the plutonill content of the total plasa yas about equal to that of the total b100d, indicating that there is no significant fraction of the plutoniun contained in the celinlar components of the blood. Although the plasta levels of the two Forms of plutonium in the untreated cats were about the same at the beginning (itos at $1 / 2$ hr) and at the end $(9-10 \%$ at $24 \mathrm{hr})$ of the period exanined, the rate of disappearance vas raster for the polyneric form than for the nonomeric fat 2 hr polyneric equals $21 \%$ and monomeric equals $32 \%$. DTp therapy increased the rate of aisapearance of both forms markediy; for example, at 2 hr after plutoniun intection, the pu levels in the plasma of the treated tas were 4 for the monomeric and $9 \%$ for the polymeric. The percentage of the plasma plutonila that was utrafilterable as very low for both forms $(<0.01 \%)$ in the absence of DTPA therap. wreatment increased this considerabl\%, and ererted a more pronounced and sustained effect on the monomeric form. For exaple. at 3 hr, the monomeric plasma Pu as about $37 \%$ ultrafliterable as compared with about on for the polymeric plasia Pug corresponating values at 12 hr were about $10 \%$ and $1 \%$. (F)

61983

Lloyd, R.D., D.R. therton, S.S. Gaufin, C. ays and $G$. college of searcine. Radioblology Division. Department of Anatomy. Salt lake city. VT. 1972 . $\operatorname{arch} 31$

Americium 241 skeletal Distribution in geales. coo-119-246: Part of Dougherty. Th. Rearch

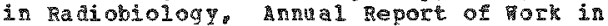
Prograss in the Internal Irradition progran. (P. $263-265), 380 \mathrm{p}$.

Data on the skeletal aistribution of 241 in beagle aogs is given in tabular form. It is concluded that retention patterns ar determined by dose level. A transcribing error in $a$ earlier report $(609-119-244)$ is cor acted and the corrected percents of in scted $\mathrm{am} 24$ in the total skeleton are given in tabular fort. (ST)

See 1so feport coo-119-244, (P. 151-158), 1971

<193

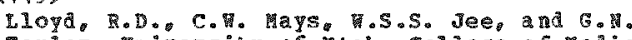
Taylor. Unipersity of tah. College of medicine, Radiobiology Division, Department of Anatony. salt lake city. vit. 1972, March 31

Skeletal Distribution of Americin 241 and Plutonin 239 in Beagles: Can They Be Compared?. Coo-119-24: Part of Doughert. T.F. Research in Radiobiology Anral peport of work in progress in the Internal Irradiation Prograt. (P. 249-262), 380 p.

Mo statistical justicication หas found for refecting data of 200 sacrificed 1 day after the infection of $\mathrm{pu} 239$ from the vean after the infection of $\mathrm{Pu} 239$ from the mea included data from 19 other dogs sucrificed 5 to 769 days after Pu 239 injection. An equivalent conclusi on va aravir fon corresponding data for dogs injected 241 and sacriteced 9 and 7 to 7535 days later. Comparison of the mean strietal distribution of Ietained pu vith retained all eaphasizes situlitities more than differences. Whereas the relative distribution of $p_{1}$ in the skeleton was not generalli dependent upon tiae after injection, a highly significat relationship betreen relative skeletal distribution and burden tiae was revealed for $A$, with

vertebras, tail. and starnum, which have much trabecular bone, exhibiting a decreasing Fraction of retained $\mathrm{kn}$ with increasing time. (Auth)

Table 1 shows distribution of injected Pu 239 in the beagle skeleton.

$<120\rangle$

Hovd, R.D., C. H. Hays, D.R. Rtherton, G.N. Taylor, S.S. McFarland, and a.to villia as, university of Jtak, College of Medicine. padiobiology Division pepartment of maton. salt lake city. 10. 1973, March 31

Californius Retention in Beagles During the First wo Years after Injection. coo-119-248: Part of Dougherty. T.P. Research in Radiobiology. Annial Report of pork in Rrogress in the Internal Irradiation Progtar $(\mathrm{p}$. $156-1621.400 \mathrm{p}$.

Retention of ef in the total body and in the liver of 21 beagles in jected ith $\mathrm{cf} 249 \mathrm{a}$ ad 19 beales injected with Cf 252 has been determined by cotal bod and partial body counting techniques for burden times of more than 2 years. Total body retention tas as if 23.8\% of the injected ce as retained with biological half-life of about 1.6 days and $76.2 \%$ with a half-1ife of about 3129 ays equal to 8.6 years. inver retention was as if $9.6 \%$ of the $3 n j e c t e d$ cr was retained ith a half-1ife of 2.5 days and 18.5 with half-life of 1992 days equal to 3.3 years. It appeared that there vas $n o$ inportant differences between these two $\mathrm{Cf}$ isotopes in either total boay or Iiver getention. (Auth)

$<121\rangle$

Lloyd, R.D.g G. Gafin, University of Jtah. College of thedicine adiobiology Division, Department of Anatom, Salt lake city, UT. 9972 , march 31

Californiul Recention in Beagles During the Pist rear After Injection. Coo-119-246: Part of Dougherty. T. F.. Besearch in adiobiology. Anual Report of Work in progress in the Internal Irradiation Progran, (p. 289-298). 380 p.

Measurements of the retention of citrate conplexed. intravenoust injected cf 249 and cf 252 in the total-body and liver of beagles have been extended to one year after injectlon. The biological hallotime of cf in the total body ppears to be in the order of 6 tars. Sacrifice of 2 additional dogs for distribition studies contrin an earier conclusion that liver, skeleton, thyrold and kday were the tsanes th highest CE concentration. Wission product lodine isotopes vere found in the throid glands of Cf 252 injected dogs. (A ath)

Table 1 shovs alstribution and concentration of injected $c$ 249 and $C$ f 252 in the tissues of beagles.

<122》

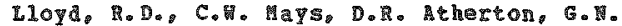

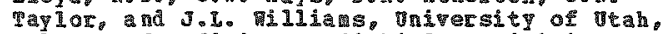
coligge of Hedicine Ratobiologr pivision. 
$\langle$ 22> coms.

Departant of Anatong, salt Lake City, Ug. 1971. $\operatorname{arch} 31$

Californiu Retention, Erretion and Distribution in Bemges Soor Bfter Infecton. coo-119-244: Pare or Dougherty. T.F. Research in Radiobiology. Annual Report of hork in Progress in the Incernal Treadiation Progran. (p. $(92-196), 424 p$.

The merabolisw of californit studied in 11 beagles frot to 82 days after intrapenous injection ith Ce 249 or CE 252 as $C f(+3)$ in cierate bufer. Toral excretion auring the firse 21 days after injection tas mainly urinary. of the $C$ elininated in this 3 week period, about $3 / 5$ appeared in the rirst day's collection. Mearly tou as auch californin injection as has heen observed reth beales qiven Aa 241 or Pu 239. A conbination of total-body and partial-bod 7 gana counting of the liting dogs indicated that at 4 week abont $20 \%$ of the injected ct tas deposited in the liver and that nearly $50 \%$ rewained in non-1iver tissue maju $2 y$ sheleton. This tetention pettern persisted until at least 82 ays after injection. In contrast, the retention of an 241 during corresponding period averaged abolt $50 \%$ of the injected activity in liver and $40 \%$ in

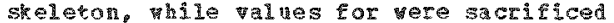
for distribution studies $\rightarrow 2 n$ and 21 after the infect on of $c$ 249. Tissues exhititing relatively hidh ce concentrators nere liver. skeleton, kidney, aura, connective tissue, and. in the 7 day dog, the thyroil. Although ilver concentration of cf as lower relative to that of Du 230 or especiall $\mathrm{Am} 241$. kianey concentration of ch was significantly hiaher. Skeletal ce concentration as sinilar to that for $P$ a 239 but was about double thet for $A$ m 241 at corresponding burden times. a or these 3 elewerts were highest tor a ericium and california but lovest for plutoniun. Fissues at risk from incorparated californiu appear to be liver, sheleton. kidney, and throla. (nuth

Tablea 2-7 show the excretion, biologice 1 retention and distribution of ci 249 , cf 252 , Pa 239 and 241 .

《127\%

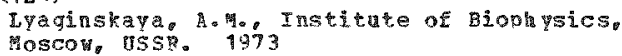

Estimation of pertissible Radiation Doses Erom Iodine 13\%. Strontiu 90 . HFo, and to the Gonats. Contr-720503: Part of Bafdoso. E. (EA.). Health Physics Problems of Internal Contaninaton. Proceenings of the IRPA $2 \mathrm{nd}$ European Congress on Radiation Protection held

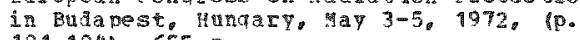
$189-484), 655 \mathrm{p}$.

Experiments were performad on cats that tere subjected to a single administration of Sr 90 in a dose range of $0.004-20 \mathrm{uCi} / 9$. RTO-Eron 6 to 300 aci $/ 9$ or An $241-$ frot 0.0005 to 0.92 aci, 9 . Functonal and seructural changes were studied in the gonads at various tive periods after aministration of the radionuclides and the aborbed doses in the whole body and in the gonds were estimated. The results showed that 2 an 241 cansed $a$ loosening of tubule structures while 3599 caused a tightening and reduction in size. HTo and oxterna 1 radition induces

progressive develop ment of degenerative changes and I 131 caused excess proliferation of initial sparmatogenesis cells. The data on developien of cotases and progeny rrom daraged males showed that such progeny vas characterized by hioher ortality Th concluded that the genetical risk associated bth the radionulides ras pincipally detertined by the dose long asorbed in the testes and did not depend on radionuclide ajstribution and the dose absorbed in the vhole body. Sensitivity comparison of the ale and fenale gonads showed that female gonds vere more sensitive to the action of the given radonuclides. This may be

probably explained by increased radionuclide affinity to the ovaries as compared to the testes. As evidenced by the recent data if the arainu pernisible concentrations recomended by ICR to the gonads as the critical organ are taken into account. it should be reviered towards their decrease: for the ovaries by 2.7 times for the testes bw 3.6 tines ( 131 ): fot the ovaries by 3 tires, for the testes by 1.5 tines (Ru 105): cor the cestes by 14-45 tiaes (A 2411 : fron the data of the author for the testes by $3-5$ times (atol: and by $1.5-2$ times (I 111).

(하에

《124)

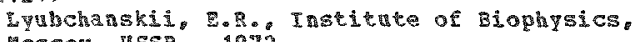
Moscov, ISSR. 1972

Behavior and wature of the microdistribution of Plutcriug 230 in the sete organist after chronic Taha lation of Its soluble corpounds.

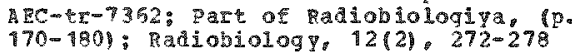

The behavior and icrodistribution of

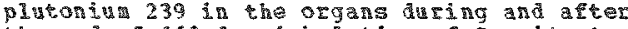
the ent of 160-day dntation of pu citrate and a studied in experiaents on 205 rats. Good correlation as established between the actual and celculated accurations of the isotope in the lungs and steleton during the process of inhalaton. B nomunitorta

distribution of platon in in the langs was revaled by the rethod of

histouteradontaphy. Anth

The content of Pu 239 in the organs of rats following inhalation of soluble $\mathrm{pu}$ conpounds is given in a table.

$\langle 125\rangle$

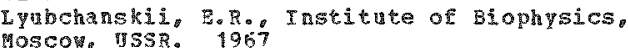

Fhe Behatior of Plutonin 239 in Rats After a single trinalation of some of Its cherical

Compounds. AgC-t-5889; Pazt of Radiobiology.

$(3.84-96), 253 \mathrm{p}:$ : Radiobiologiya, 7 (4), 547-547

Aerosols of $P$ 作 conponds differing in solubility and valence state tere inhaled for 20 thin by 591 cass of the vistar line veighing $140-200 \mathrm{~g}$.o The compounds were platen in citrate (4). sodila

alinton y triacetate $(* 6)$, a rmoniu glutoniu centacarborate (t4), plutoniur chloride (4)

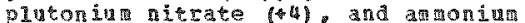
ploton in pentacarbonate (4h). The aninals were sacrificed inadiatedy after inhalation and after $7,8,32,64,128$, a nd $230-256$ deys. Pu content was deterinined in the lungs, hifurcated lyph nodes fentu, liver, spleen, and idneys. Iritial deposition of Pa 239 28.6\% of the intakel did not depend on chemical form and concentration in the inspired air. In all sibsequen periods the level of $P_{u}$ in the lungs depended substantially aon the inhaled Form. The soluble compounds rere deposited ainly in 
<125) cONT.

the lungs and skeleton. Pu 239 mas excreted fror the langs in 1 to 255 a a ys with tro half-1ives, 75.5 days $(34-65 \%$ and 175 days $(8.76-23.5 \%)$. original deposition in the lungs yas uniform: 32 days iater accumiation was present in the form of stars. Most of the translocated pu vas deposited in the skeleton there it aid not exceed $9-30 \%$ and in the liver $(4-7 \%)$. The effect of cherical for on accunulation, ranslocation. and elitination are aiscassed. (Auth) (ST)

\section{$\langle 26\rangle$}

Mahiun, D.D., Bat elle menorial Institute. Paciejc Northest iahoratories, Biology Department, Richland, WA. 1972 , September

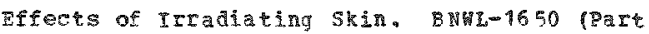
1); Part of Thompson, R.C. (TA.), Annal Report for 1971, (0. 10-11), 313 p.

$$
\begin{aligned}
& \text { observation of pigs, thich vere exposed to } \\
& 1-40 \text { kras of beta radiation from } 204 \\
& \text { plaques approximatel } 3 \text { years } 390 \text { continues. } \\
& \text { Areas that were exposed to } 6.15 \text { or } 49 \mathrm{krad} \\
& \text { when the animal was an abut appear as thin } \\
& \text { whitened circles uith an area on } 1 \mathrm{y} \text { ightiy } \\
& \text { larger than thet originally exposed. Hreas } \\
& \text { which received } 1 \text { or } 2.5 \text { krad are not grossly } \\
& \text { wisible. In contrast. in animals axposed as }
\end{aligned}
$$

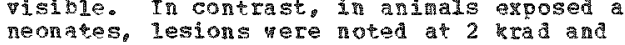

$$
\begin{aligned}
& \text { the affected area as several times that } \\
& \text { orioinially irradiated. Adat iona } 1 \text { analyses } \\
& \text { have been obtained fron tissues from pigs } \\
& \text { wich received pu } 239 \text { intradermall } 8-10 \\
& \text { vears aco No so } \\
& \text { found. The concentration of pu } 239 \text { in liver } \\
& \text { tound. The concentraton of greater than that in bone. }
\end{aligned}
$$

\section{(127)}

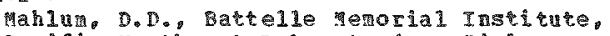
Qacific North vest laboratories, Biology

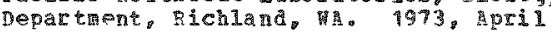

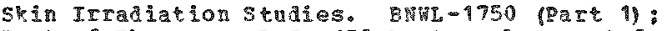

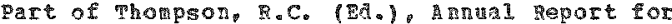
$1972,(0,15-16), 103 \mathrm{p}$.

During the past year no changes hare ocurred in the shin of manford inilure swine exposed four years ago to graded radiation doses forf i 1204 plagues. Ares of $0.5 \mathrm{cr} 2$ and greater, exposed to doses of 6.25 hrad and hioher, appear as thin whiten ed areas. aninals exposed at eight days of a ge show extensive enlargenent of the exposed area. extensive enlargenent of the exposed a r accompanied by considerable scar tissu
formaton. Dama in adult and nevborn rats exposed to as much as 50,000 rads from pu 239 plaques is linited to a slight outline of the exposed areas in a fer anin.

<128>

Panluw, D.D.. Batelle memorial Institure, gacifle North vest Laboratories. Blologr Departhent, Richland, 1973 , April

Q1 2 ton 1 มี 11 : Part of Tholpson. R.C. (P.). Anmul Repor for 1972. (0. 11). 103 p.

The last of the iniature plgs injectea incradermally ith 0.0016 to 5 uci of Pu 239 approrimatel 11 Tr ago was nectopsied, and tissues taken por histologic exam nation and radiochenical a halyses. Is vith previous animals, there vere minal skin lesions-ostall depressions of h scar tissue built up around the depression. Home of these aninals showad gross evidence of steletal turors. The radiocherical data fron these andinals his been ued to calculate radiation doses, particularly to the Iiver and to the sleleton. Doses to bone have exceeded those which resulted in a substantial incidence of osteogenic sarcoma in the intversity of utah iogs. These da deripea from only six oigs, strongly inarcate the need for additomal long-ter studies in a Iarge aninal other than the dog. muber of liver lesions, including tumars, were noter in these pigs; and attempts are being rade to determine inether these are in excess of those normaliy expected. (Auth) fcomolete text)

$\langle 129\rangle$

gahlur, D.D., and 尚a. Clarke, Hanford Btomic Products Operation, Biology Laboratory. ichland,

Iniluence of Interial sitters on cherical carcinogenesis. Ho-30500: Part of Rorrberg. H. A. and Stezea, F.G. (Ea.) , Hanford Biology pesearch Annul Report for 1963, (p. 123). $242 \mathrm{p}$.

Fenale rats were infected intravenonsly yth the radionuclide $(2$ nCi pu 238 or 2 or 20 aci ce 144-Dr 1449 and then fed a dies containing 0.06 divethylaminoazobenzene (D)h 1 ). It received both radionuclide and DAAB terded to have slightly bover incidence of tum formation than those that received DhA alone. The types of neoplasms observed appeared to be predoninanty of the biliary adenocarcinoma tipe. (F) (P)

$\langle 130\rangle$

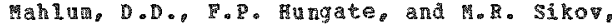
Batelle gemorial Institute, pacific horthuest Laboratories, BIolog Departient Richland UA. 1973. Apri1

Einsteiniu and Barkeitu Toricity and Metabolis in eats. Bry-1350 (Pare 1): Part of Thompson, R.C. (19d.), annal Report for 1992, (p. $12-13), 403$ p.

Rats injected intravenously with Es 253 as adults showed greater nortality and osteosarcona incidence than did rats injected as weandings. The incidence of a anary turors vas increased in nales infected as adults. Absorption, of $\mathrm{E}$ or $\mathrm{ES}$ given in $\mathrm{HCl}$ Eron the gastrointestinal tract inas increased mearly 100 fold then the normality of the acia vas increased from 0.01 to 0.5 . (A uth (ST)

<13)

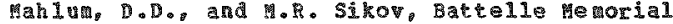
Institute, Pacific Northyest Laboratories.

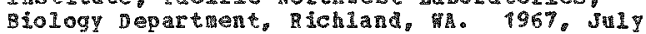

Effect of Age on Aborption of plutoniun from the Gastrointestinal Tract of Rats. Bhl 480 ;

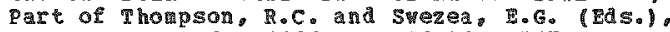

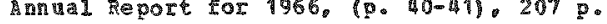

Pluton gavage to gromps of rats of 1.20 (1 daY before meaning) 21 (imediately postweaningl. or 35 days of age. hinals from these groups were sacriticed at serial thes ranging fro: 1 hI to 20 daps

postad

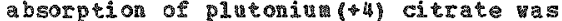
substantaly greater in the ay-old rats 


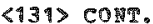

that in the rats of 20,21 , or 35 days of age. Petention was higher in the preveaning $(1$ and 20 day) rats than in the ol der andals and there as $^{2}$ an evident teadency for translocation of Pu to bone in the

preveanling rats th ich as less evident ith increasing age. (2m

<132>

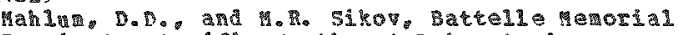
Institute, paejicle Northest waboratories. Biology Departrent Ri chland, 1972 . September

Influence of Age on the late Efrects of

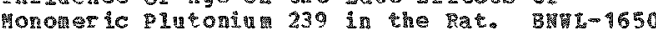
(Part 1): part of Thompson. Report Eor $1971,(9.75-76), 313$.

The protocol for a study of the influence of age on the late effects and on the evertual tusor response of ats to ply 239 is described. Adult, peanling, nevorn, and 19 da fetuses vere exposed to monomeric $p_{4} 239$ by a single ineravenous or intracardiac injection or by intravenous infection of the da. Dose levels vere selected to give the sane arage radiation doses 17,23 , and 70 rads) to the femur in the first 10 da postexposure. The doses were: prenat dose to dam, 6.0 to 60 uci/kg: nemborn, 3.0 to 30 uci/kg; and weaning and edult, 0.3 so 3 ucilkg. No resules are yet avaliable.

<133\%

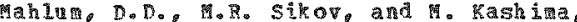
Batelie porial Institure Pacific Morthest Iaboratories. Biol og Department. Fichland, 1972. September

Distribution and subacute Toricity of Ensteinin 253 in

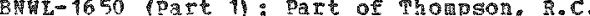
(Ed.). Annua1 Report for 1971, (0.82-85), 313 p.

The highest concentration of 253 was found in the skeleton of the rat wether it was administered to newbrns, meanlings or adiles: substantial concentrations were also foun in the liver. spleen and kidney. For wh 50 to 150 acilkg doses of Es 253 but stelotal defects re more prevalent and severe anong an mal treated 25 weanlings. marked effects on dentition pere noted in both veanlings and adults treated ith $\mathrm{ES}$ 253. This nay be related to an early localization of the nuclide in or near the tooth had. (huth) (Pap)

〈134〉

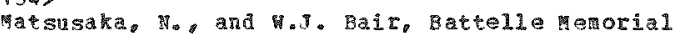
Tnstitute, paific wor these Laboratories. Biologt Departient, Richland, H. 1968, hay

Biliary Ercretion of Pltoniun after Pulmonary

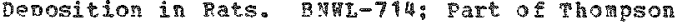

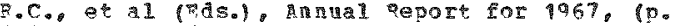
$3.20-3,221,2530$.

Billatv acretion of plutonium mas neasured in wats after intratracheal injection and inhalation of severa platonita componds. faximu biliary exeretion occurted arer inhalation of Pu(NO3) 4. This anon nead to about $35 \%$ of the tot 1 o intoning excreted betueen the seventh and thirty-eighth day after exposute. (Auth)
<135:

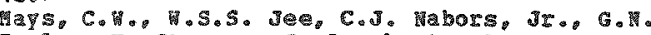

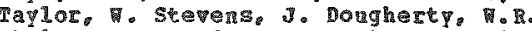

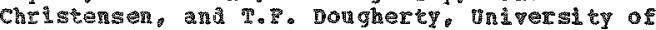
vtah college of vedicine, Radobiologi Division, Departient of Anatory, Salt lake cleyo vis. 1973, $\operatorname{macch} 31$

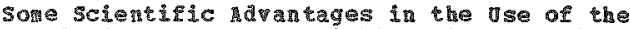
Beagle in Long terr fadoblological studies. Coo-119-248: Rar of Dougherty. T. F. Research in Radiobjology Annal tepore or pork in Progress In the Internel Iriadiation Erogra

(p. 110-140), 400 D.

The beagle was originally chasen as an experidenta aninel in radjobiology pinarif becass of its relatrely long lifespen and metabolic similarity to ma some obvions scienticto advantages in wsing the beagle are: skeletal sichiarit to gan, importat Jay sydrome induced in mand beagles, but not rodents, relevant radiographic information. osteosarcona location, possible difference in shape of doseresponge:

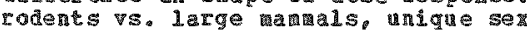
afference in bone sarcolla induction: nice w. homs and beagles, growth drnames of osteosarcomas, liver retention of Pu 239. advente in obtaining seguential blood samies in beagles, corticosterold production sinilarity between man and beagle. transanisase and allinaline phosphatase similarities between man and beagle, and a partage of larger organ sjze in radionuclide aistributon studies. (Auth)

《136\%

Mays. C. H. and R.D. Llota, universtey of Utaho College of tedicine Radiobiology Division. Depactrent of Anatony. Salt Iake city, uTH. 1973.

Dose-Response Relationships for the Ind vetion of Bone Sartomas by Beta and Mlph-B hitters and the Fffect of Dose-Rate on Delayed somatic Esects from Lop det and Alpha-Eadation (A sumary prevared for the HAS-vic Low Dose-study Group peeting of JuIY 25, 19731. C00-119-248: Part of Dougherty. F. F. Fesearch in Ratiobiologr. Anntal peport of tork in progress in the

Internal Trtadiation Progra (p.370-377), 400 v.

The dose-response telationship for the induction of bone sarcola by long-lived beta-e inters is strongly sighold. For 1pha-emitters such as pu 239 , Th 228 , Re 228 and $R$ a 226 . the relationship apears linear for rodents, but man and dog. In 10 interconparisons of life shortening and the induction of neoplesis fron 10n IBT radiation. the effect per rad at low dose-rates ayeraged 0.2 of that a high dose-rates. In contrast, for a lisa irradition frot $\mathrm{Ra} 224$ " the incidence of bone sarcomas from a given dose increased as the dosa-rate was lowered. (Ruth)

$\langle 137\rangle$

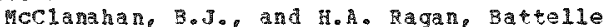
Meroril Institute gacific Vorthest Loboratories. Biology Departwent. Richland, $\mathrm{A}$. $1967.501 \%$

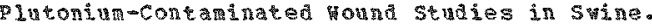

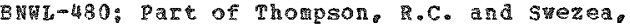
E.G. (Eds.). Annal Report for 1966 , (po $101-1031,207 \mathrm{p}$.

vour years after intratermal infection of olutoniu niterate in suine, liver and stelat busdens ere $11 \%$ and $13 \%$ 
$\langle 137\rangle$ CONT.

respectivel $\gamma$, of the dinistered dose.

plutonium also present in iyph nodes. Tourniquet application appeared to realuce the absorption of subcutaneously implanted plutoniun in the foreleg of swine. Chilling the contaminated foreleg aid not reduce absorption. (Auth)

rable 1 shows retention of Pu in suine 4 years after intradermal injection.

《139>

Meclanahan, B.J., D.H. wood, V.Go Hor geman, H.A.

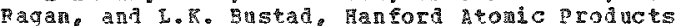
operation, Biology Laboratory, Richland, ta.

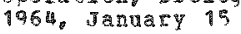

Effects of plutonium in Sing skin and Its Revova 1. Hil-80500; Part of Rornberg, K. A. and Swezea, Fog. (Eds.) phanford Biolody Research Annua 1 Report for $1963,(p \cdot 120-122), 242 \mathrm{p}$.

Blond niniature swine were in nected on each foreleg pith 5 uCi of $\mathrm{Pu} 239$ (t4) nitrate in 0.04 af 0.2 Hinos solution. Pour hours later the first of four consecutipe daily injections of the trisodiun calcin salt of diethylenetrianinepentacetic aci (na $3 \mathrm{Ca}$ DTPA) was adrinistered intravenous IY. It vas cound that increasing the quantity of $\mathrm{Ha} 3 \mathrm{Ca}$ DTPA adinistered intratenously following subcutaneous injection appeared to further reduce the amount of Pu 239 retanned. Suffusing the injection site vith chpotrypsin aid not increase po 239 translocation, while acplication of a tourniguet of cold pack did not ceduce translocetion. Four hunered and eighty stin sites on nine mantord iniature swine injected intrader $11 \%$ with 0.0016 to 5.0 uCi Dn 239 nitrate per site, 22 to 30 ro: ths ago. were ezanined. ond 250 sites ver detectable as denressed andor thichent Reratinizea areas, and they vere limited to sites inlected with $0.008 \mathrm{uci}$ or tore: hovever, no level vere all sittes

detectable. (suth) (gang)

Table 1 shows effect of VacadTPA (ng/kg) on retertion of 8139 in liver sheletom and regional lyph nodes.

<1398

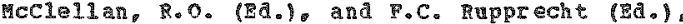
rovel ace Fondation for hedica zacation and Research. Inhalation Toxicology Resea tch Institute. I buguerque, Nh. 1973. Decenber

Inhalation Toxicology Research Instituto Anaul Repore, 9972-1973. IF-46: $342 \mathrm{P}$.

Pifty-five papers are included in the $1972-1073$ prual report reported on studies conducted to evaluate factors inflinencing the tomitit of inhaled radionucidas incluaing plutoniu. several

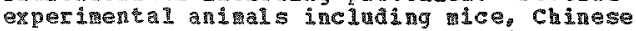
hasters, syrian hasters, rats, and beagle dogs are being roucinely used. Sections one throngh seven a concerned with research in rected tovard aneloping an 3 inpoved understanding of the nature of ratioactive aerosols, including their prod ueth and characterization for use in anial exposers: obtaining an uderstanaing of the radiation dose pattern resulting from inhataton of radioactive aerosols of diverse character: establishing the celationship between exposure to various levels and types of aerosols and the resulting biological erfects: developing an inproved on derstanding of the pathogenesis of radiation induced 1isease, especial1y as produced by internally deposited Eadionuclides thet enter the body va inhalation; developing effective therapeutic procedures for treating individuals accidentaliz exposed to radioactive arosols: developing respiratory tract deposition models: and finding the retention pattern and effects of repeated exposures to radioactive aerosols. Appendix - contains date on the strets of longevity and sacrifice experiments in beagle dogs. Data a re presented on selected paraneters relative to total body and lung content of radionuclides and the resultant radiation dose recei ved by indivial dogs. Information is provided on the current interpretation of the ast prominent cinico-pathological features associated ith death of the anials. Thiteen papers vere selected and abstracted separately for the data base. (ST)

\section{$\langle 140\rangle$}

meclellan, P.0.. W.J. Clarke, V.G. Horst国ar, J.R. Hekenney, M. E. Kerr, and L.R. Bustad Manford ktomic Products operation, Biology
Laboratory, Richland, 1961 . Jamary 10

Ccmparative Toxicity of Strontiun 90, Radiul 226 and Plutoniu 239 in Miniature Swine. How -69500 : part of Hugate, F. 2. and Stezea, E.G. (Eds.). ranford Biology pesearch Annal Report Por 1960. (p. $(3-15), 195 \mathrm{p}$.

Hale initure stine of three different ages injected intravenows 1 with Sf 90164 acifkg). Ta $226(6.4 \mathrm{Hi} / \mathrm{kg}$ or $\mathrm{Pu} 239 \%$ u $\mathrm{Ci} / \mathrm{kg})$ have exhibited only wini nimal pathological darage in nine to fifteen months Hematological and blood biochenistry deternations vere wade pounely on all a nials. The right bind and fore limb of each animal were radiographed every three wonth for detection of possible skeletal pathology. Although darage has been ininal to date changes noted have included thickening of the cortical bone, ontarowth of cortical bone into the meduliary canal, loss of definitive wedulary canal and increased trabeculation of spongiosa. The changes noted do not appear to be aistinctive for any of the radiorulides injected. (Pस) (HP)

$\langle 4 \mid>\rangle$

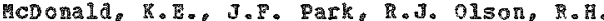
busch and c.l. Sanders, battelle memorial Institute, pacific rorthest caboratories, B lology Departient, Richland, september

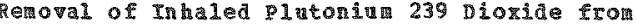
Beagle Dogs. BHrit-1650 (Part 1): Part of Thotgson R.C. (Bd.), Annuel Report for $197 \%$ (p. $157-163), 313 \mathrm{~g}$.

Beagle dogs were exposed to plutoniu 239 puo2 acrosols and treated vith DTP

Phenergan fpromethazine hyaroch1oridel. DTPA plus Phemergan or pul onary 1282 ge to deterine the efricacy or these treatnents in remoring inhaled pu. Lavage was acconplisheo by using a double lanen carlen's bronchospironetry catheter lavagiag the

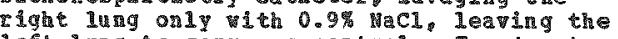
left lung to serve as control. Treatment continued on 11 groups for appromitately 20 vecks. The artg-treated groups retained essentially the sare arount of Pu as the concrol group, hile the lavage anials had reduct ton of $50 \%$ in the lavaged lung. The Elmal burden of the 1a vaged Troup was $67 \%$ of the inteial alveolar buraen comparea to 93 留 for the controls and 9 s\% for the other 


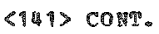

treated andals. At the present the pulanary lavag is the nost effective nethod

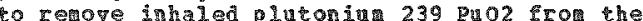
Iung. (kuth) (RA)

<142>

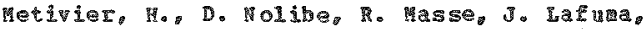
and A. Horvath Translatorl. Comissarlat a

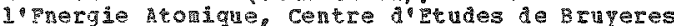

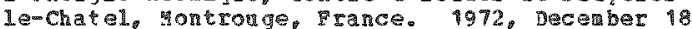

Neoplasas Induced in Baboon Apes (REPO PALIO) by the Irhalation of plutoniur axide. Comptos Rendus Acader of Sciance. Series D. $275(25)$. 3069-3071; 2 F-ter-80; 6 o

Young baboon apes (PAPRO PADIO) axposea to 239 oride vere found to exhibit lung cancer three ronth after inhalation of the toxic substance. The types of tucts ohserved. epideral carcinomas and adenocarcinoma are conparable to those observed in man and the prospect of extrapolating these results to ma

\section{<143>}

merhiney, J.A. A.I. Brooks, and Lovelace Fondation for Medical Education and Researeh, Trhalation Poxcology Resea rch

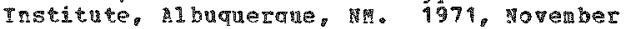

Petention and Distribution of Intected Californiu 252 In Pats and chinese 1 arsters. LF -44 ; Part of meclellan, $\mathrm{B} .0$. and pipprecht. F.C. (IdS.). Inhalation Toxicology pesearch Institute Anual Report, 1970-197\%, (p.96-101). 3930 .

The retention of califor chinese hasters was observed for 64 dats collowing intraperitonea 1 injection of $a$ citrate conplex of californi u 252. organ distribution tas deterined by serial sacrifice of groups of six animals at 1.2 4.8 .16 .32 and 54 a 15 post injection for each species. comparison of the wole-body retenton wetern of ct 252 in the rat and chinese hamster revealed significant differences. A liough whole-body clearance was rearly equal at comparable tives post-iniection through 64 days, differences were reflected in he nuber of exponential componerts needed to adequately describe the data and in the effective halition of the data and in the effective hall-tiaes of the For rats the long-term component as clearly a function of avid sheleral retention whereas the long-tern component for chinese inaster retention as a function of combined liver and sheletil retention. pro greater contrasts between the tuo species vere noted in orgar distribution and retention. The rat initially deposited much lower guntities in the liver and kianey. vilinination fron these organs was characterized by half-tines of approxi patel $^{2}$, davs. In the chinese haster. initial deposition in the tidney and liser

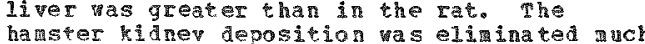
like the rat with short effective hall-tide. mowever. the liver of the havter ret ined the initial burden mon longer than ata the ra* IIver. (ath)

〈14 is

Hewhinney. J.A. A.t. Brooks, and R.0. Hcclellan, Lovelace Foundation for Elucation and Fesearch, Inhalatich Toxicology

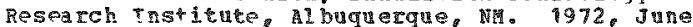

Comparison of the petention and Distribution of
Injected Californiu 252 in 2 ats and Chinese Hansters, Cohy-710919: Rart of Thompon, R.C. Tanfort

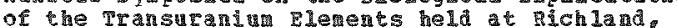
vashingn, Seotenber $27-29,1971$. Publishei in ashington, Segtenber $27-29,1971$
yealeh Physics, 22(6), 695-700

The retentions of Cf 252 in the rat and Chinese haster vere compared for 64 days colloring intraperitoneal infection of the citrate compler. organ distribution was deterninea by serial sacrifice of grongs of 6 anials at $1,2,4,8,16,32$ and 64 days postin jection for each species. comprison in the rat and chinese hamster revealed. significant differences. Al hough whole-body clearance nearly equal at comparable times postinlection through bu days. aifferences vere reflected in the numer of erponemtial components needed to adequately describe the ata and in the erective half-tires of the long-ter conponents of the two equations. For cats, the long-ter componen vas clearly a function of a via sheletal tetention wereas the long-term component for chinese hasser retention was a function of colbined liver and skeletal Ietention. The greater contrats between the two species vere noted in organ aj. stribution and retention. The rat initiaili deposited moh loger gum ntites in the liver and kidney. Elitination fron these organs was characterized by half-tines of pproxintoly 5 days. In the chinese haster, initial deposition in the kidney and liver was greater than in he rat. The haster kidmey deposition was elininated wuch like the rat tith shore effective hal-tive. However, the liver of the hanser retained the initial burden auch longer than did the rat liver. (Auth)

<145>

Miller, S.C. and .S.S. Jee, gniversity of otah college of wedicine Radioblology

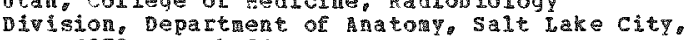
UT. 1973, March 31

The tefects of Disodium Ethane-1-Hydroxp-1. 1-Diphosphonate (EHDP) and Disodiul Dichloromethanediphosphonate (CM2MDg) on Bone of the Proxima I ibia of the Groving Rat. coo-119-248: Part of Dougherty. T. F. Research in Radiobiology, Annual Report of work in Progress in the Internal Irradiation erogra. (p. 27is-287), 400 p.

In rats treated for 10 days with supo and c12mop, observations from past studies, such s endochonar 1 grouth inhibition, bone

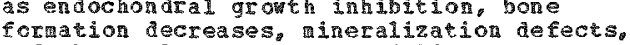
and abnormal metaphyseal fodeling pere confirmed. The current studies also found the labeling inder of ostooprogenitor cells was depressed by higher doses 1.0 and $5.0 \mathrm{ma}$ $\mathrm{p} / \mathrm{kg}$ davl of both corpounds. whe muber of osteoblast as lower for all doses and fucther ovidence of docreased bone formation. onlip $2.5 \mathrm{lg} P / \mathrm{kg}$ and 5.0 ng P/kg iowered appositiona bone formation rates. The numer of osteoclasts along with the nuber of nuclei/osteoclast, was higher at al doses. Inderstanding of the iphosphonates is i portant becnase of the possibility that they ay afect the skeletal binding a nd metabolisa of bone-seeking radionucildes such as 239 . (HP)

(146)

Hoghissi. A.A. and M. Harter (Fas.) National Environtent 1 Research Center, das Vegas, HV. 
<146> Com.

1971

Fxith

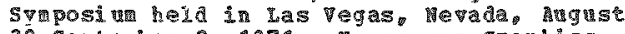
30-Septenber 2, 1971 . Messenger Graphics.

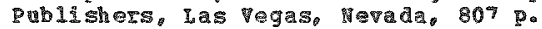

The book is preprad trom parers presented at

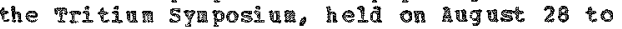
septemer 3,9971 in the pronter potel. Ias Yeqas, Fevada. Pigh ty-four papers are included. thirty-four of hich have been abstracted soparatel for the pata Base. The

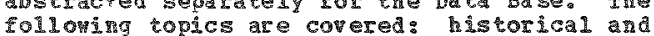
current perspectives of trithu int protuction in reactors and by nuel weapons, dececion and measurement of tritid的, chemical and biolog leal effects of trieiun, kigetics of triteiu in biological sy stems such as 1 to behavior in $1 \mathrm{sh}$ excretion and in naturnover in amals. envicontental aspects of trithur. such as its behavior in the soil, environaenta 1 aonitoring techniques as data including tritu releases from nuclem porer strions, applications of tritu in biological. wedical and hyarological studî́ a health physics relatad studies. (pry)

$\langle 147\rangle$

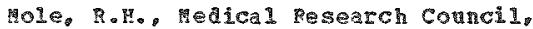

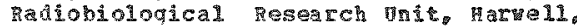
Esqund. 1962

Problems of Low-level Irradiation. Dart 0 Dougherty. T.F. et al (Bds.) Frocedings of a Sprposium on some Aspects of Internal irradiation hela at The Homestead. Ma 8-11. 19k1. Derganon Press, Her Tork, New York, (0.207-232), 529).

If this revien paver. low-1evel ra defined as a level of radiation which proluces a lon level of effect rather than a spectic dose or 10 se rate. Hon-specific Ife shorening is not a consemence of raditaton erposure, and mose of the

presentation concerns carcinogenesis. Sowe hem evidence points to the idea that tur induction by radiation is a multiplication of a natural process rather than an independent and aditive phenomenom. The gengral principles of extracting information fron data are the wame hatever level of effect is being looked for or becanse it is 30 much pore laborious to look for low level extects. there is a strong teaptation to lower the standards of experinenta 1 pannis and of interpretation belon the scientifically permissible. The ratiobiological aspects of low level reatiotion and cancer as a rare effect are aiscussed tith respect to different studies. swyeral involving

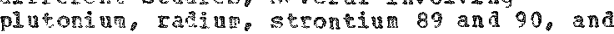

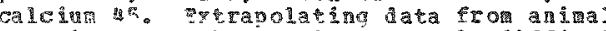
oxpetigents to hums is extremelp difficult and can be alsleating. Portyone papers are

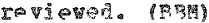

$\langle 448\rangle$

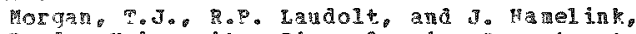
purdue vidisersti, Bionucleonics pepartment. mast Iafagete. Th. 1971

Qehavior of Tritho in Fish Fol Toring chronic

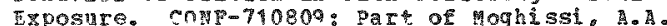
and Carter H. H. (Eds.). Proceedings of

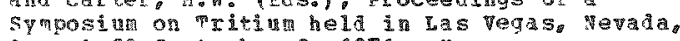
Auqust $30-$ seppenber 2 . $197 \%$. pessenger Graphics, Publishers, las Vegas, Nevada, fp. 378-3911, 807 p.
4 preliainary epatution of the ptake ard eling trituated vater is presented. The tritum

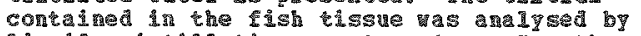
1 Iqu uptake gendies blueglils and chandel cats vere erposed to tritiated water

concentrations of $40 \mathrm{~m} \mathrm{CM/vol} \mathrm{at} \mathrm{a} \mathrm{varer}$ terperature of 23 c. ph 7.5 and

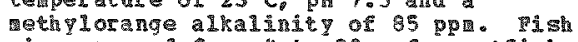
simes ranged from 4 to $20 \mathrm{~g}$ for catish and 10 to $65 \mathrm{~g}$ for bluegilis. For elipintion strdies catfish vere exposed to tritiated vater at a concentration of 20 h $\mathrm{CH} / \mathrm{M}$ for 20 days. then transerred to ancontainated vater. The rate of uptake of tritiun rapid and reached maxinu values whth approxinately cour hours. channel catish exhibiting a nore rapid rate than plagilis. The 圂a species yas aporoxinately 75 留 of that of the media. channei cateish rhinted a rapid release of trit tiu trisin being elininater in hours after rewoval ston trithated vater. The rate of

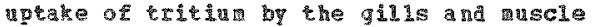

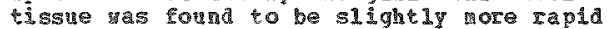
than for the out and kidneys. (RAF)

《ा 49

Hoskalev, Tum. Institute of Biophrgics Moscon。 USSR. 1973

Sone Inportant Problen of Bological Action of Transuraning plements. Con

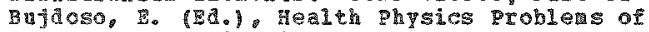
Internal contanination, Proceedings of the IRPA 2nd Buropean Congress on Padiation protection

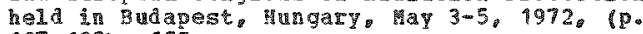
$(87-795), 655 \mathrm{p}$

Results obtained on the problems of

biological action of 2 v 239 and other

transuranim elenents are presented.

Biological action of various conpounds of

hese tadionilides is considered as a

function of the dose an pouce of intake inco

the body. Including inhalation, intravenous

and introeritoneal adninistration of the

isotopes. Wuch attertion is given to the

andys of late effects deviloping in the

boly as a result of ingry by Py 239 . An 24

and Hp $^{237}$. dose-effect curves for bone and

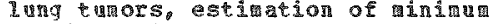

carcinogentc dose levels and doses not

aftecting the natural iffe-span.

comarative analyis of the data on the

biological effect of P 239. A 24 241, c 244

ard p 237 reveals that the are all highly

toxic. The acuer (LD 50/30 and subacute (ID

$50 / 120$ ) efrective doses for pu 239 are

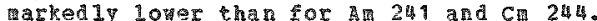

The chronically effective doses (LD $50 / 360$ )

for Pu 239 and 241 are the sal but

Ch 242 they are considerably lower. The ID $50 / 30$ values for 1023 are 20 to 38 times. and the Lo $50 / 350$ values 3 to 8 times lover than for Ru 239. An 241 , and cri 244. comparison of data on Pu 239 toxicity. as related to the entry pathway indicates tha inhaled $p_{1} 239$ is far more toxic than

pluton in introduced intraperitonealiy. Thus, when comparing the doses causing a aninu reaction of rat life expectancy. pa 239 in far more toxic than plutoniu

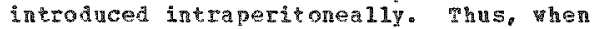
comparing the doses causing $z$ ming covaring the doses causing $z$ hing (citrate or plutonium-amoniun pentacatoonatel when sahabed $(0.00073$ uci/g) proved to be about seven times as toxtc as when adinistered intraperitonea $11 \%(0.0050$ uci/g). When comparing the votential hazards

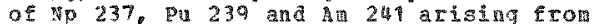


<149> CONT.

alpha irradiation by these isotopes, it is revealed that in inducing osteosarconas and Iung cancers vp 237 exhibits the bighest efficiency. Pu 239 occupies second place, and in 24 is the least effective of the three radicelerents. (Auth) (FM)

able 1 shows LD 50 values following intravenous adanistration of transuratc elements to rats.

২१९०े

moskalev, Yu.I., and V.S. Ralistratova. Not given. 1972

Bioloaical sffects of Radiation from External and Internal sources. Asc-tr-7457:515 o.

The book contains investiqations by sereral anthors of the biological effects of ionizing radiation from both external and internal sources. Twent $y-t i v e$ papers have been abstracted separately for the data base. Data are mresented on the biological effects of fission mentrons, as vell as hil ted qua and neutron radiation. The results of these stales show conclusipely that the biological effect of irratiation is related to the aistribution of aborbed energy in the organisa and radiation conditions (instantaneous, brief, long-tera). Studies on netabolis and biologleal effects of the followina radionuclides, $6 \mathrm{~d} 153$, g 235 , pu 239. and Am 241 are reported. Also included are data on distribution of radioactive isotopes, on kinetics of matabolis of transuranic (4p 237. A $24 \%$, C 242 , Pu 239$)$ and rare-erth elements (Gd 153, ba $140, \mathrm{Ce}$ 144, PM 147. Eu 152, Tb 1601, the quatitative relation betreen sone paraters of tetabolisw of radioactive substances and theit physicocherical properties, the effects of external irtadiation on the behaphor of

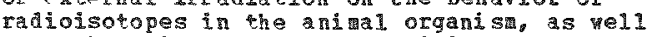
as matheratical methods describind the

characteristics of radionclide metabolist in the organism, atat on the role of the geonetric factor, and coefficient of nonuniformity of ase a istribution in expression of the biological effect. Data are reported on the biological effects of transuranic elements and specifically, data on the kinetics of metabolis and biologica? effects folloning inhalation thereor: some experimental data are given on the functional changes in the resplratory. cardiovascular. and other systems, as well as information about norphological changes in organs at short and long terms of observation, as related to different routes of adrinistration. The longuter effects of exposure to external and internal ionizing radiation. the high carcinogenic activtr of incorporated radiolsotopes, ad the optinu incorporated radioisotopes, and the opti different radoisolopes are discussed.

(F)

<151>

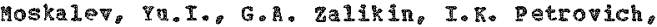
and V.P. Panova. Not giten. 1971

characterisitcs of the 8 iological Effect of Americiun 24\%. AEC-tr-7387: part of poskaler. Yu.T. (BC.). Remote Afterefects of Raiation Darage, (p.434-44 0), 574 p.

241 in the form of a chroride solution was administered to 450 white rats and 20 comon dogs. The rats received single doses from 0.0025 to 0.2 uCi/g vith a total of 8 doses. The dogs were adninistered dosas of 0.001 to 0.06 aci/g ith a total of 6 doses. The life time of the ami nals, morphological composition of sternum bone punctuates. periphereal blood, changes in weight, blood distribution of the isotope in the organs and tissues, and kinetics of its elinination fron the animal body was studied. Results were compared with ariler collected ato on the A 241 distribution in racs. vith intravenous administration of a 241 to dogs the isotope vas distributed for the most part the same as in the bodies of rats, other than for a somevhat higher content in the skeleton, but it as eliminated considerably more slowly than from the bodies of cats. For 11 methods of admistration, An 241 was selectively deposited in liver and bone tissue. The acute 1 p toxic doses for dogs $(0.01-0.06 \mathrm{uci} / \mathrm{g})$ were $10 \mathrm{uer}$ than for rats $(0.11-0.2 \mathrm{uCi} / 9)$. This fact indicates a greater ra diosensitivity of dogs than Iats. Both tats and dogs exhibited a slowing of veight gain with all doses used.

Heratological tests showed that ith large aoses of $241(0.01-0.06$ aci/g) the dogs developed acute radiation sickness. herorrhaging, and blood formation aplasia. Radiation darage as are pronounced in dogs than in rats. farked iapairment of bone marrov formaton in dogs was deronstrated. her 345 days of observation the rats developed osteosarcomas vith doses of 0.025 to $0.0025 \mathrm{aci} / \mathrm{g}$ A 241 . (Auth) (RAP)

The results of experi ments for the study of the A 244 distribation in the body of rats have been published in Radiobiologiya, $3(1), 55,1968$

$\langle 152\rangle$

Mcskalev, Ru.I., G.A. Zalikin, I.K. Petrovich, E.I. Rudnitskaia, and $\mathbb{R}$. A. Veselovskaid. Institute of Biophysics, Moscon, ISSR. 1972

Radioresistance and Radosensitivity of nimals to Eposure to Transuranium tements. vCR $I_{0}-$ rans-1462;3 p.: Translated erom Radiatsia i organiza. Sbornik Material ov Ronferentsil. Obinsk, i, 76-78, 1967

Dogs, rats, and rabbits have been used.in studing the biological action and toxicology of At 241 and thp 237. The 50 id 50 nd the longevity of anima species sensitivity. and causes of death of the animals were studied, along wh changes in peripheral blood and spinal cord punctures, isotope aistribution investigated by historadiography, pathomorphological changes in organs and tissues, and the functional status of the cardiovascular syster. upor intravenous adrinistration to rats of hydrochloride solition of a $241,57 \%$ accinulated in the liver and up to $30 \%$ in the skeleton. The distribution of a 241 in the

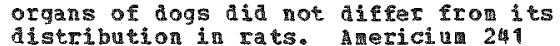
clearance frot the liver of dogs was somer than in rats: by the eighth day ret liver contained $33.3 \%$ of the a aunt adinistered. as colpared to 32 in ings. After 32 days. $4.2 \%$ vas found in tat liver and $33 \%$ in dog 137er. When 241 was given

intratracheal1y. it 2 s sion 1 sorbed from

the Iung with an effective period of 66 the Iung with an effective period of gastrointestinal tract does not exceed $0.03 \%$, and when the citrate complen was

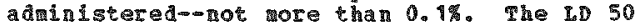
values for rats then the hydrochloride solution of 24 tas given intravenous 1 vere as follows: LD $50 / 15-0$. 14 uC1/O: ID $50 / 30-0.41$ aCI/9: LD $50 / 60-0.06 \mathrm{uCi} / 9$ : and ID $50 / 120=-0.043 \mathrm{uCl} / 9$. In dogs, pronounced signs of herorrhagic diathesis were striking. and aplasia of the hematopoletic organs vas found. Hutohistoradiography shoged that the 
<152> CON⿴囗十.

substance in organs and issues during these periods is in the finely disperse state and is distributed uniformy exept for the kidneys here a large amount is found in the cortical layer. I ise in neutrophil and lyphocyte counts of 30 to $60 \%$ or more noted after $\mathrm{Am} 241$ doses that caused death in 7 to 14 days. By day 5 to 7 , the nuclear element count in the spinal tap as vell as the leukoctute count in the perioheral blood was reduced by 80 to $90 \%$. Beginning fronday 3. a trend toward bradycardia and hypotonia was noted in animals receiving $A$ a 24 in the amount of 10 tillicuries/kg and 2.5 milicuries/kg. The thermoregulat ory mechanisn and respiratory systems yere not changed during the month of the

investigation. at aiferent times after investigation a diferent times after carcinogenic effect as noted isolated osteosarconas with wetastasizing in the lungs and the bones of other regions of the body and tunors in the warkary glands intuced ag ainst a background of fibro-osteal mastopathy. Which indicates dyshor ${ }^{2}$ ind mastopathy, which inaleates dyshorinonal significant species aifferences in animal sensitivity to 8 m 241 : dogs > rabbits $>$ rats. Doses casing $50 \%$ fatality in animals during the first months after An 2 is ad inistration are in the ratio $1: 3: 15$ (IDD $50 / 30$ as alopted as the unit in the case of dogs). The high cherical activity of the thp 237 is most important in rats given the isotope intravenously as a nitrate solution. ID 50 was 0.003 uci/g; however, this a ount of isotope causes death of andis during da 3 to 4. while a reduction in the dose causes death 6 months after allinistration. The distribution of 237 when given intravenously as a pH 3 nitrate solution proceeds with the predorinant accunulation in the sheleton up to $35 \%$. wp to $6 \%$ in the kidneys, and ap to 9 of in the liper for the atount of isotope adinistered). Aipose aystrophy of the liver and lesions of the epltheling of the convoluted tubul es ore found soon after isotope adninistration. changes in the liver vere similar to changes during acte jaundicial dystrophy. Lesions of the liper and the heropoietic organs vere noted, wich can be explained by the redistribution of the isotope, its deposition in bone tissue and therefore, constant irradiation of the spinal cord. (MP)

\section{<953>}

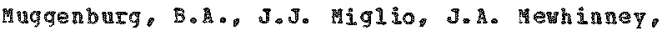
D.0. Slansong and 0 . HCCLILn. Lovelace Fonndation for Medical wucation and Research. Inhalation roxicology Research Institute. A buquerque, 1973. Decenber

Browchopul wonar Lavage and DTPA Treatine for

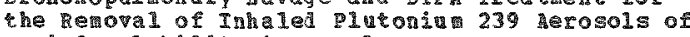
varied Solubility in Beagle Dogso le-th: Part

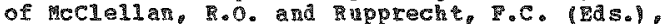
Inhalation Toxicolog Research Institute Anatal Report, 1972-1973, (P. 255-250), 342 .

This work vas initiated to determne the efficacy of bronchopulanary lavage ama chelation therapy for cenoving pu 239 following inhalation of pu 239 aerosols of differing in vivo solubilit chacter in Beagle dogs. phe four aerosols used wero Beagle dogs. The four a resols $39 \mathrm{cl}$. neat treated at terperatures of 325.600 .900 and $1150 \mathrm{C}$. Six beagle togs tere exposed to each of the four aerosols and subsequentit 3 dogs in each group intravenous DTp and 3 arogserwed as controls. The treated and is received 10 unilateral bronchopul monary lavages during the period $2-40$ days post-exposure and 18 intrapenous in pections of the chelating agent diethy lenetriainepentacetic acid (DTPA) ower the experimental period of 56 days. Complete resules are available for tissue distribution of Pu 239 on all dogs in the study and complete excreta cesults are avalable for one treated and one control log exposed to aerosols treated at 325 and $1150 \mathrm{c}$.

ronchopulanary lavage removed 37 and 54 of the initial lung burden of pu 239 for the 325 and $1150 \mathrm{c}$ ereated asrosols, respectively. vrinary excretion of $\mathrm{Pu} 239$ mas increased by DTPA therapy at both aerosol treatment tenpertures. Deposition of Pu 239 in 1 iver and bone following solubilizat jon in the 1 ung was signiticantly depressed by DTPA therapy in the dog exposed to the $325 \mathrm{C}$ aerosol: at an aerosol creatment of $1150 \mathrm{c}$ only minte quantities of gu 239 were solubilized in the Iung and hence the effect of DTPM therapy on aeposition in liver and hone as difficult to assess. (Auth)

<154)

Mushacheva, G.S.. Ministry of Health, Tnstitute of Biophysics, Moscon, USSR. 1972

Activity of Heleases in Rabbit Iungs after Inhalation of Plutoniun. Topros Heditsinskoi

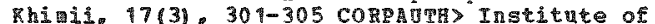
Biophysics, Moscot, USSR

Activities of acia DNase and both acid and alkaline Mwases after a single plutoniu inkalation ( 1.5 nCi) into rabbit lung vere stualed vithin 4 months. An increase (up to 139\% in the acid Drase activity per $1 \mathrm{~g}$ of the fresh tissme during the first two veeks ater inhalation as noted. An increase in the total activity of acia pNase took place within the period of investigation, the manima increase (185\% of the control) being with the first month after inhalation. The total activity of acid $\mathrm{n}$ ne was increased $(106-173$ 然) within the perion of investination. The activity of alkaline Rase wincreased $(183 \%$ only ithin a month after inhalation. The problew of the 1 portance of mulesses activition under irca đa postirradition recovery is discussed.

(Roth)

《५ 55)

habors, C.J. JE. Oniversity of whan, College of Hedicine Radiobjology Division. Departient of Matom. Salt Lake city. OT. 1972, tateh 31

Biochemical Changes Produced by low Dose of Radiation. Coo-119-246: Part of pougherty. T.F. Research in Radiobiology. andal peport of Work in Progress in the Interma Irradiation progra. (p.

Long ter studies on lor aose level nuclide-bearing an inals are reported. Beagles bearig arted a iterations in seru aikaline phosphatase and serm glutaic oraloacetic

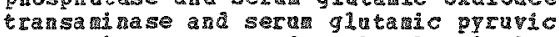
transalnases. Iow aose 1 evel anila is appear to have a ruch longer laterit period prior to the apparance of altered ser biocheristry than do arilals ith higher dose levas. (ateh)

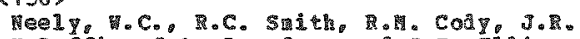

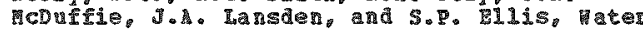
Resources Research Institute, hubrin viversity。 School of trts and Sciences, Departant of 
$\langle 156\rangle$ Copr.

Chemistrof Aburn. AL: Water Resources gesearch Institute, aburn thiversity, School of Agriculture and Agricultural Experinent Station, Departient of Animal and Dairy Seiences, Aubur.

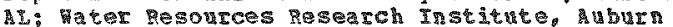
tniversite. School of Agriculerure and Griculcural Erperiment station, Depertment of Botany and February

Ciological and Thotobiological Action of pollutants on quatic icroorgensma. MRRI-BOLL-9; 1240 .

The varions aspects of the biolodical and photobiological action of pollutants on aquatic wicroorganisms ha been exploted in a series of seudies covering a vide range of chenical species and two classes of acuatic microorganis has been shown that certain etal ions. insectcides, polycyclic am an and aycotoxins are capale of drastic alteration of the life grocesses in test strains of either bacteria or paralecia or both. In some cases concurrent exposure to light and the pollutants was necessari and in others the toxic and/or muctanic reactions vere independent of light exposure. In paticular the urany ion beta raphehyl anine and alfatoxin 5 sub 1 mere found he bhototoxic while the insecticide phyon, was found to be strongly dark-toxic. All agens arfected

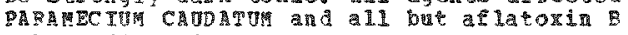
sub 1 affected ESCR ERICHIA COLI. IR addition. the mant lon cassed morphologhcal mutations in 8 . COL $\mathrm{T}$. The public health hazard connected with such alterations in 1ife cycles resulting from vater-borne pollutants is difficult to assess rom laboracory data bue the possibility should be ruther investigated. (tuth)

$<15 \%\rangle$

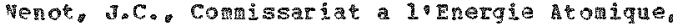

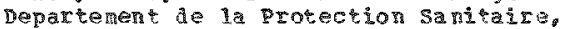
Fontenay-a un-Roses. France. 1970

Study of the gffect of Irradition on Iung cleatance. CONF-700971; part of Walton. (Ed.). Broceedings of the 3 ra Interntional Sympsiur on Tnhaled Particles held in london, England. Septemer 14-23, 1970, 701. 1. Jnitin Brothers Iithed The Gresham press, old wokina surrey, Equand (p. $239-246) .1090 \%$.

The infuence of radiation exposure on lung clearance in rats as studied fros a functional point of vier. Exposure was delivered in tho ways: wher extrornd exposure at I. 50 or internal exposure with Dis 230 aerosols at ifferent concentrations. Three levels of alveolar contanination in aluh emiters bere studied: 1.0 .1 and 0.007 acina ent 1 ung. Inng clearance

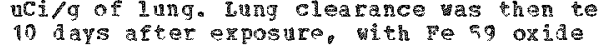
insoluble particles adinistered to the anials by inhalation. Futernal exposure did not notify either retenton or clearance rate, hereas incernal exposure to alpha particles large 1y odiciea clearance

kimetics. qhis study vill be carried or with kinetics. phis stud inil be carried on (anting

<158>

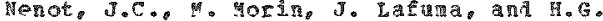

Parker (Translatorl. Comissariat a lonergie

Atomine, Deparmen de la protection santaire.

Fontana-aur-poses, Fance. 1972, June

Fixperimental Fud of Decomtamination of the
Sheleton After Inhalation of mericiu nitrate.

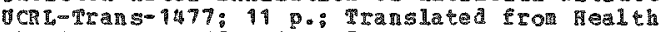
2hysics, $21,3950400,1971$

Sprague-Dawley rats were injected

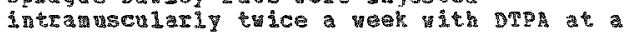

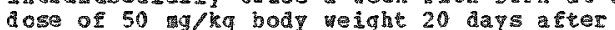

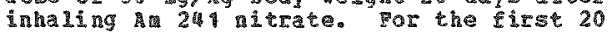
days, $20 \%$ of the 341 activity traniocated from the lugs to bones. He the ternimation of the experiment, sonths atter lnhalation, the DFPA-treated tats had a bone burder reduced by factor of 1/3. For the first 20 day posttratment, the urinar elinination by the treated anials as prom both lungs and bone, but later the eling ing ion was and bone, but later the eliningrion was lobth day of treatwent the decrease in osseous aceivity is $4.1 \%$, in pul monary activity is $5.8 \%$ and the increase in urinary activity is 10.7 (MP)

<159>

Hewcolbe, H.H. Acomic nergy of Canada Linited, Biolog" and Health Ditision. Chalk Miper, ontario. Canada. 1973. Angust

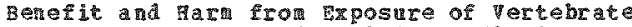
Spert to Low Doses of Tonizing Radition. Hea 1th Physles, 25, 105-107

Exposures of trout spera to 25 and 50 rad of ionizing radition are shown to have both hatmin and beneficial effects. Although more of the evbryos from the lrradited sper are ma 2 or survival are both enhanced by the treatrent. hith higher doses to the sperm, however. the affects are consistently harful. Hough indiced genetic changes are presumed to be involved in the production of the observed differences in enbryo mortality. the dose-response curve is unifue in the it is not on non-inear but actualy changes inrection at its low-dose end. The results have bearing or the estination of genetic risks to man. In reed for catron is indicated in aterots to equate small radiation exposures of human ger cells ith apparent increases in cetal and infant mortality. (nath)

《960)

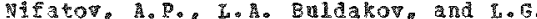
Filigpota, Rot giver. 1971

Comprative poxicisy of ariciun 241 Nitrate and Citrate. AEC-tr-7387: Part of Moskalev. Pu. I. (2d.). Rerote Afterefiects of Fadiation Damage, $(\mathrm{P}, 425-433), 574 \mathrm{D}$.

Rats of the thitar line vere injected intraperitonea 11 y of th the nitrate or citrats form of 241 a single lose to stid the relative toxicity of these tro componds and relative toricity op these tho compo

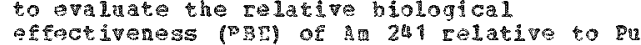
239. Doses ranged from 939 to 418 ucis/ag (nitratel and 2.56 to 275 wei/kg feitratel. pollowing adninistration of the isotope aysteratic study of the seripheral blood. change in sight time of onset of death and change in deight time of onset of death and notphological changes in the princion as vere ade. Damage symptom appering during the first seven days uere similar to the cliateal picture of other radioactive substances and vere dose dependent. Farliest changes there detected in the peripheral blood and vere narifesta by a lenkopena and

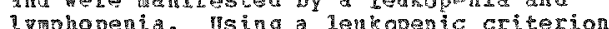
the RBP of aneticin relative to pu 239 os 0.15 to 0.25 . The PSE increased th 
<160\$ coNT.

decreasing dose. Comparable quantitis of eitrate and nitrate produced Identical dalage to the blood syster. OnI acute doses of anericium nitrate mere more toric than the citrate in shortening the mean lifetime of the rats. ase rate of 0.26 rad/ay coula be regarded as safe using the criterion of shortening of lifespan. Bone morphological changes vere sidilar to those observet following $P Q 239$ injection. Liver da rage was greater in rats that received the isotope in the nitrate form and as caused by dissinilar the nitrate for and as caused by diss norphological changes in rats dama ged by $A$ m 249 are sinilar to the changes caused by the adinistration of a plutoniu citrate complex in lesser quantities. Degenerative processes leading to death at different dose rates are disc ussed. (ST)

$\langle 161\rangle$

Mifatov, A.P., and IoA. Buldakov, not given. 1971

Microlistribution of Plutonin 239 in the Bone Tissue of Rats During Chronic Peroral Administration of the Isotope. AEC-tr-7387; Part of goskalev, qu.I. (Ed.), Remote Aftereffects of Madiation Danage, (p. $399-405), 574 \mathrm{p}$.

The aicrodistribution of plutoniug 239 in the hil bones of wister rats dying from 32 to 663 days after chronic peroral administration of the isotope was studied using the technique of histoautoradiography. The rats were given a 1 citrate solution siz times a veek: activities ranged from 0.01 to 10 uCs. During all observation periods up to the 600 th day there vas a nonuniformity of isotope distribution wh greatest concentration is the exdosteun and beriosteum, primarily of the epinetaphyseal patt of the hip. The maxinu nusber of osteosarcomas $(7.4 \%)$ was fou nd in rats receiving 0.5 nci dail\%. Repeaced irradiation of the cambrial elements in bone rere responsible for the development of malignant growth. (ST)

<162>

Not given, D.S. Atomi= Energy Comission, Technical Information center, oak Riage, Tho 1967

Radiobiology。 Asc-tr-6889: $253 \mathrm{po}$

The scope of the 25 articles in this volume is wide covering the effects of raliation and administered rationuclides in plants. animals, aicroorganisms, and cell cultures in a variety of laboratory situations. A large percent of the articles covered the effects of external radiation (prinarily $x$ ) on piants seeds, seedlings, and compounds: hith molecular welaht molecul og incluaing qucose polymers, DNA, and enzymes; cultured cells in various media; body cells and organ systers: and electroretinograms. The remainder of the articles covered the behavior, thetabolism, physiology, tzansport, aistribution, absorption, and effects of radionnciales absorptions and etrects of radionuchias po 210, and ce 14t in various laboratory animals. In adaition the modifying effects of media nutrients and ion content.

radiprotective substances, and various doses on recovery were studied. one article concerned the construction of a rathematical nodel for calculating effective dase. Two articles on $P u 239$ hohavior and ab corption were selected and abstracted separ ately for the data base.

$(S 2)$

<163>

wot given, university of chicago, Chicago, It. 196

mealth Problems Relating to Product, ponth of

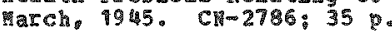

2rogress is ceported on studies concernith the tabolism, toricity. and ercretion of

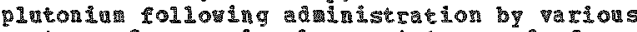
routes of several valence states and of different conpounds to the rat and ag In one study clinical observations, including onset of nadiachon slckness. excretion b100d levels, protein binding, hemerologe and blook cheristry, are reported in the dog. Bubiding, equipment, and personnel alphe exposire surveys are reported and thods of luton in detectio in urine a na feces are

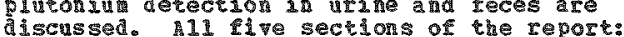
clinical pedicine ard medical research. biological research, medical and industral

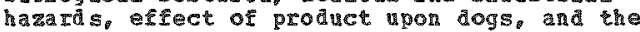
technical progress report on metabolic studies vere abstracted separately for the data base. (5T)

<154

wot giver, Brookhaven lational Laboratory, pton, Long Is13nd, Mo 1971, Januar

Cell culture studies. Californin 252 grogress, 6. $1-52$

A Brookharen Hational Laboratory the continuing evaluation of $\mathrm{Cf} 252$ in railation therap has included cell culture studies on chinese haster cells to deterthe the dose rate effect, the relative biological - ffectipenegs pRB and the ozygen

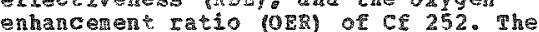
progress of these studies is reported in several issues of the journal. coll starival crryes mere obtained wh chinese naster cells at ci 252 dose rates of 18.6 and 13.5 rads per hour to observe the effects of a faster cell doubling time fappronigaty 10 hours for haster cells vs approximati 20 hours for Hela cellsh. SHrvival curves for the hanster cells were also obtained ith cesium 137 t 37.3 rads per hour. whe Do s. $^{\circ}$ that is. the absorbed lose requited to reduce survival by a factor of l/e or the aean lethal dose. for ci 252 tose rates of 18.5 and 13.5 rads per hour tere 160 and 210 rads, respectively. Whon compared to the DO of 500 raÄs for cesiun 137 at 37.3 rads per honr, pBes of 3.13 and 2.39 were obtained. SUIVival curve as also obtained for cestu $137 \mathrm{at} 15$ rals per houc. Cell recovery and proliferation alnost nilify the effects of irradiation at this dose rate. (MUM)

0165

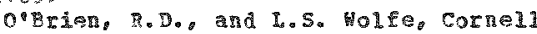
Iniversity. Department of Bntorology. Ithaca. M: Nontreal yeurological Institute, Departinent of wenrochemistry, Montreal, quebec, canada. 1956

adiation, Radioactivity, and Insects. Academic Press, pev lork, Hev York; $211 \mathrm{p}$.

This mograph. one of a series, was reten to direct attention to biologists" increasing utilization of radiation and

radiolsotopes. The hook is intended for the entorologist and blogist and For those

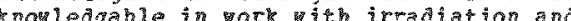
radioisocopes. chapter vis vitten as an 
$\langle 155\rangle$

<165〉 CONT.

introduction to the structural, functional, and behavioral features of insects. succeding chapters show how research ith radiation and tadiolsotopes has ad vanced understanding of insects and for wat kinds of problems the insect is a sutable organism. An appendix gives a brief introduction to concepts, techniques, and units of neasure. Genetic effects of rabition upon insects are not aiscussed. whe book is intented to give a con prehensive account of acadentc and utilitarian radiation work that has been applied to insects and also of the diverse uses of ralioilsotopes in entomology. for labelling and control of insects and for elucidation of biocheaical. ohysiological. and toricological inechanis (ST)

$\langle 166\rangle$

Palmer. R.F., and B.0. Stuart, Battelle vemorial Institute, Pacific Northest daboratories, Biology Department, Richland, A. 1973, April

Comparative pfects in Hamsters, Rats, and Hice of Exposure to simulated Uraniul Mine a mospheres. Bhi-1750 (Part 1): Past of Thompson, F.C. (Ed.). Annul Report for 1972. (p. 50$), 103$.

Progress is reported on studies involving 90 hr/vk exposures of SPF tats, harsters, and mice to atospheres containing $\mathrm{Rn}$ daughter levels ranging from 3000 to 6000 vi with or without $18 \mathrm{~g} / \mathrm{g} 3 \mathrm{v}$ are dust. The purpose of the experiments is to provide interspecies comarison of the effects of these uraniu mine inhalation hazards. The three species are exposed silultaneousit in the same chanbers. A nila is are sacrificed when noribund and ti ssues are retained for histopathologte exanination. Hortality is nearly complete and histopathology on sacrificed animals is in progress. (ST)

$\langle 167\rangle$

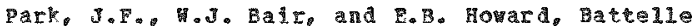
herorial Institute, Pacific Morthwest

laboratories, Blology Departant, Richland, ma. 1968 , 粮

scute Toricity of Inhaled Plutonim 239 mitrate in Beagles. Bur et al (ras.). Annul Report for 1967, (p. $3.22-3.269 .253$

Beagle dogs died of pulanary insufficiency 3-10 months after inhalation of 9 u 239 (No3) th. Bod $Y$ burden at death ranged from $5-65$ aci. of which approxime ly half was present in the lungs. The lung lesions vere silliar to those seen in dogs dying within a pear after inhalation of $\mathrm{Pu} 239$ puor and the lathal dose on aci/g of lung an death basis was also sinilar. About $50 \%$ of the plutonitin translocated to the Iiver and skeleton casing lesions in trabecular bone and a leucopenic response. Inha lea pu 239 (no2) is is considerabit rore torte on uci/kg basis than intravenousiy in ilected pluton in (Auth) (F) (Fig)

<168>

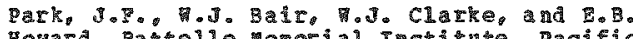
Homard, Battelle Merorial Institute, Pacific Morthest Iaboratories, Bology Departane

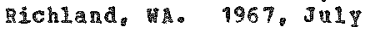

Chronic affects of Inhaled glutoniu Dioride in Dogs. BlWI -480 : part of Thompon, R.C. and Sverea. F.G. (Eas.) Anmal keport for 1966 , (P.
$57-611.207 \%$

The present status of experinets inyolvi ng Eorty beagle dogs given a single 10-30 minute oxposure to pu 239 Quo 2 arosols por 7 pars ago for study of long-ter translocation and biological effects is sumarized. prenty dogs have died or were sacrificed when death was inminent 29-79 months post exposure. The plutonisu buraen at death teanged from 0.3-3

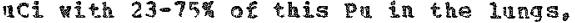
16-44\% in the tracheobronchil iw wh nodes. $-32 \%$ in the Rediastinal lyaph nodes, $2-26 \%$ in the 1iver and $1-7 \%$ in the bone. The calculated radiation dose to the lungs ranged up to $13,600 \mathrm{rad}$. Respiratory insuficiency and 1yphopenia vere the prinary clinical signs associated ith severe fibrosis of the tracheobronchial and tedistinal 1 piph nodes. Trelve of the dogs showed primary pularary nooplasia. one dog had a lyphanglosarcoma in aediastinal lyph node and two dogs showed neoplastic changes in the vasculature of the lung. (Auth) (ST)

〈१69〉

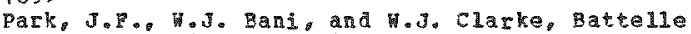
Merorial Institute, Dacicic North west Laboratories, Biology Departaent, Richland, 1966. Jan uar?

Chronic Effects of Inhaled Plutonita Dioxide in Dogs. Bly

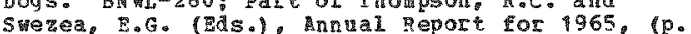
$45-47 \%, 139 \mathrm{p}$.

Forty beagle dogs, given single 10 to 30 min exposure to $\mathrm{Pu} 239$ PuO2 aerosols 3 to 6 years ago. are being held for study of long-cerm transiocation of Qu 239 and for observation of biological effects. of the 40 dogs exposed. 13 died a fer 29 to 66 months. The bodw buten at death ranged from 0.5 to 3 uci with 0 to $75 \%$ of the body burden in the lungs, 20 to $50 \%$ in the bronktial and nediastinal 1 lqph nodes, 2 to $24 \%$ in 1 iver, and to $7 \%$ in skeleton. Cause of death was bulmary insufficlency resulting fron the severe pul torary ibrosis. Seven aninals severe pul mory rbrosis. Seven anina (I):

\section{$<170\rangle$}

Park, 3.P. W.J. Clarke and Menorial Institute. Pacific Morthest

Laboratories, Biology Departrent, Richland, 角. 1968, gay

Chronic Effects of In haled plutoniu 239 puoz in

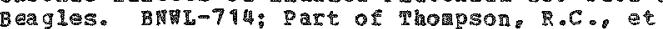
a (EdS.), Annual Report for 1967, (P. 3.3-3.4). 253 p.

A Long-ter study of the biological effects of inhaled pu 239 vuo2 in dogs is in its ninth year and the results of this study hate been reported andulip. of 40 dogs exposed, 20 have died or were sacrificed when death vas ininent, whic rine vere sacrificed to obta in tissue disteribution data. Trelve of the 20 dogs have had primary pul on ary turors. several of the 14 puritionary dogs shov radographic evidence of 1ung wors. Wost show 1 yphopent. has been a consistent finding in the study. All of the mortality and twor data obtained te date from 5everal oxperiments wh dogs which indied pu 239 puro 2 are sumariged. Data the far evaliable indicate that a level

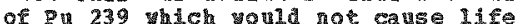
shot toning in dogs is that aoun thich mould result in a lung weder of less than about 2 $n C I / 9$ lug 15 pear a a fer expostre. 
<170) CONT.

(Auth) (Prom)

\section{<171>}

Park, J.F., and w.J. Elarke, Hantord Atomic products operation. Biology Iaborator $\%$. Fichland, 1月. 9963, January 15

Chronic Toxicity of Inhaled plutoniu in Dogs. H.7.76000: Part of Rornberg, H. A. and Swezea E.fi. (EdSa), hanford 3 iology Research gnnul Peport for 1952, (p. 118-125), 269 p.

Eeagle dogs were given a single exposure to Pu 239 oside aerosols. Two dogs di ed 855 and 933 days after deposition of 6 uci in the lung. average ratiation dose to the lung tissue as 12,000 rads. Dyspnea and

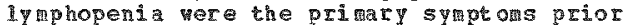
to beeth. Gross and wicroscopic histopathologica 1 changes occurred in the lungs and associated lyph nodes hich contained 80 to $95 \%$ of the pu content of the dogs.

rajioactivity associated orth

histopathological changes. Increa sed respiraton rates and lyphopenia are the primary olinical sw 1 ptoms in dogs that are alipe three years post-exposure. (Auth)

\section{<172>}

Pating S.A.P. Pechkurenkov, and T. Shakhanova, M1-Union Resemrch Institute of sea Fisheries and oceanography. Woscon, 55 . 1971

Kinetics and gechamise of Acculatation of

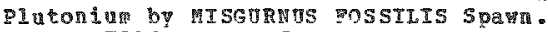
AEC-tr-7306: Part of RDIOBIOLOgYl (p. 153-159): Radiobiologiya, 11 $(5), 742-746$

A series of experinents was perfortied to study the accum lation of platonila 239 by

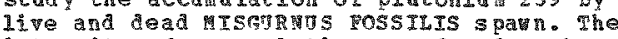
intensity of accum lation mas foum to be related to the phase of extryogenesis because

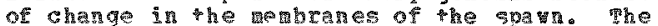
buIt of the plutonin was atsorbed on the nempane of live shan. In kead span, the adsorption of plutoritu vas vaction irreversible. Phys cochenical and cherical forms of 9 in solution affected its uperio by developing spawn. (Auth) (RAP)

<173)

Pechkurenkov, V.T. I. I. Shekharova, and I.G Telysheva. Ali-ini on iesearch Institute of sea

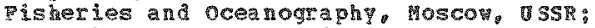

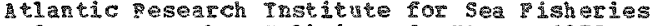
and oceanograph. Kaliningrad,

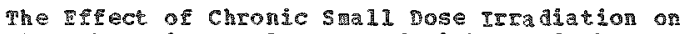
the Eabronic Development of ishes and the valdity of Varous Assessment hethods. Journal of Ichthyology. 1.71-79

A 5tud was made of the eprect of four

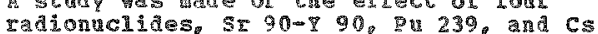
$13 \%$ on the emryonic develogere of loach sa lon, and pike fish and an asessinent was tade of the use of various tests for comparison os experimental and control variants. Engs of the loach obtained tolloring pitaitary infection

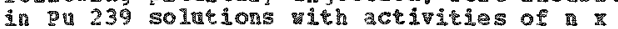
$10(\mathrm{E}-11)$. I $810(\mathrm{E}-10)$. and $\mathrm{x} 10(\mathrm{E}-\mathrm{B}) \mathrm{Ci} / 1$. garameters strafed ware eq wortal ity and larval defortaties. The coefricisents of reproduceability of the characteristics invescigated varied ridely. Comparison of

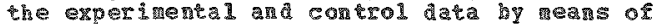
a nonparametrie test of colparison shoved that in most instaces there vere no significant aifferences between the experimental and control fish with respect to al of the characteristics investigated. (s\%)

<1?

Popoleme1 1. D. S. Atomic meapons Research Establishtent, Berkshire, Eigland. 1973, october

Plutonim uptake by coll cultures in presence of some chelating agents. Health Physics, 25. $413-420$

A study has been made of the uptake of pluton 1 in and raioiron into MeL $a^{-S 3}$ and Chang liver cells. The influence of various chelating agents on this uptake has been extmed, the object being to set up a method of assessment of the value of potentil therapentic agents for the renoval of accidentally ingested plutonim from humas. Hthough it has been shown that chelating agents hich alter the Alstribution of ingested plutoniug $i n$ animals are capable of influencing the rate of uptase of plutoniun into cutured cells. there are variations in results between afferent cell species. This means that the cell culture epaluation method for chelating agents can only be used to supplement rather than replace animal experiments. (Buth)

《175》

Brice, 唯, Batelle Heworid Institute. Pachic irorthest Iaboratories, Bcosystens Department。 Richland, H. 1973, May

Tumbleved and Cheatgrass uptake of Transuraniu E le rents Applied to soid as organic Acid Complezes. BN

Part uptake of radioctive paste materials is a biological interaction inoortant to the enviromental magenent of aste storage sites. This staly on the uptake of cransurani u elewerts from soll by plants demonstrates that shoot uptate is clearly incluenced by the chemical form of the transuranic. It is unclear at this tiac whether soil andfor plant pechanisis are responsible. Future studies are planed to inveseigate these aspects. The observaton that sone organic acids suppress plant mptake of a merici futcher to evaluate the use of soll additives to suppress plant uptake of transuranics. Test results indicate that organic acid complexes of pleteni such as osalate or citrate can increase plant uptak when added to soil as conpared to uptake from dilute nitric acid solutions. (Anth

<176>

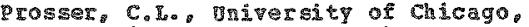

ietaliurgical Laboratory. Chicago, If. 1947s Septeraber

The Clingl sequence of Plistological pffects of Tonizing Radichion in

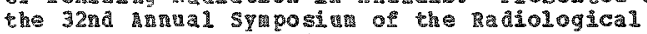
sociert of North herica heli in Chicago.

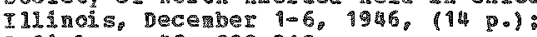
Badiology. 49. 299-313

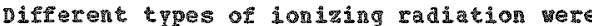
aduinstered â aifferent gose rates to

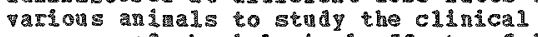
sequence of physiological effects of ioniging radicion. mesults yere smanamed and

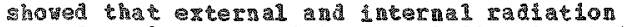
from deposited waterial rere similar in their cinical action: nearly every organs syster was affected letha doses of werp type of 
<176> coms.

ra dation: no single elinical reaction was peculiarly specific for irraliation datage: and the clinical picture and the conditions resulting in death varied vith the dose rate and the duration of exposure for both erternal and internal radiction. A series of elinical patterns leading to death after irradiation were identifled: inamediate death at very high doses and high dose rates with general cellular destruction: injtial shock-like death within $48 \mathrm{hr}$ after irradiation in some animals; early deaths at high doses in dogs and rats; acute deaths with all types of radiation, except beta. within nine to 21 days after treatment; subacute pathological changes, pri warily anerias, ilver degeneration, and bone lesions: chronic irradiation deaths from turors anc prenature aging. (ST)

<177?

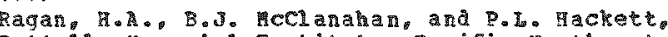
Bat te lie morial Institute pacific vorthest Laboratories, Biology Department, Richland, th. 1973. April.

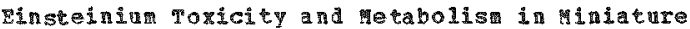
suine. BNy,-1750 (Pare 1): Part of Thompson. R.C. (Ed.). Annual Report for 1972 , (p. $93-15)$. $103 \mathrm{p}$.

Heanling iniature sine were infected intravenously $\mathrm{kith} 3$ uci/kg of $\mathrm{BS} 253$ citrate to study the toxicity and wetabolisn of this

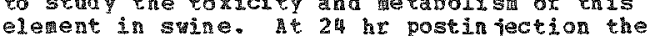
liver containea the largest amount (15\%) of liver concainea he largest amount $(15 \%)$ of
the injected dose. about 5 was excreted in 7 days.

Granlocytes and platelets vere initial1 denressed but returned to control levels with in months postinjection. Total lactic dehyarogenase (LDki values showed an inthedate decrease but had recovered within 42 days, although LDH iscenzye patterns differed from those of controls at 235 diys. (Avth) (Sg)

$\langle 178\rangle$

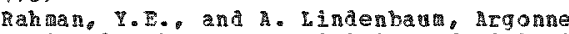
Nationa 1 laborktory. Division of Biological and hedical Pesearch, Argonne. IL. 1964

Itsosone particles and subcellular Distributions of Polyeric Tetravalent Plutonin 239.

Padiation Research. 21(4). 575-583

Tissue factionation studies vere made of 1ivers of Iats 1 an, 8 days, and 28 days after they received singie intratrous injection of 0.5 uci of polyeric plutonius Qu $239(+4)$. The subcellular diste ibution of the $p$ as foun to be nearly identical with the distribution of the acia phosphatase. the aistribution of the acid phosphat

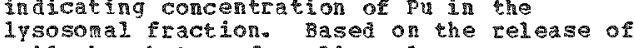
acid phosphatase from litver 1ysosomes. no diference in sensitivity to nonionic detergent, Igenal-530, was found between the methranes of 1 wosomes of rats receiving plutoning and of uninjected controls for at least 4 days atter blutonin injection. (a) $1 \mathrm{~A}, \mathrm{~h})$

\section{<179>}

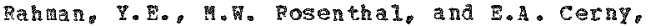
Argonte vational l lobatory, Division of Biological and hedical pesearch Argone, IL. 1973. B prit. 20: 1972. December

IntracelluIar gluteona: peroral by - iposome-
A $125-126), 246 \mathrm{p}$ : CIEUCEI $180(4083), 300-302$

chelating agents, such as

eshylenediaminetetraacetic acid (EDTh) and

diethylenetrianinepentacetic acia (DTPE)

vero successfully encapsulated ichin 11 pia

spherules (that is, 1 posotes). Encapsulated

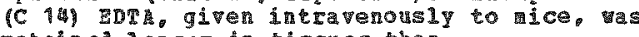
retained longer in tissues than

nonercapsulated (C 14$)$ EDTA. Emcapsulated

DTE, given to 国ice 3 days arter piutonium

injection, removed an additional fractlon of

plutonin in the liver, presuably

intracellular, not a vajlable to

nonencapsulated DTPa. It also further

increased urinary excretion of plutoniu.

Introduction of chelating agents into ceils

by liposomal encapsulation is a propising nev approach to the treatment of retal poisoning. (At)

$<180>$

Rehfeld, C. E. Jadrersity of ttah, Radiobiology Laboratory. Salt Lake City. 10T. 1959, Harch 31

Toxicological Aspects of Ionizing Radiation Due to Bone-seeking Radioisotopes, coo-219: part or stover, C.N.. Jr. (Fa.) Annal Progress report. (1. 293$), 229 \mathrm{p}$.

Studies are being ade of the effects on beagle dogs of intravenous adrinistration of 5 bone-seeking xadionuclides, the beta eaitter Sr 90 and alpha entters $R 226$, Ra 229. Th 228, and Pu 239. When these radion ucliaes are incorporated into the body structare they introduce extra energy which the body is unable to dissipate haralessly. The toxic effect of this ionizing radiation is to break chelical bonds, create highly reactive substances such as 102 and 202 and to inactivate enz res. poxicity is explessed in this study by formation of bone turors. destruction of bone resulting in spontaneous fractures, aplastic anelia lesions of the eye, renal changes, liver pathology, and preature loss of teeth. Each isotope produces its individual pattern. (BBM)

$\langle 181\rangle$

EehFeld,C.E.. B.J. Stover, G.1. Taylor, and C. Mays, Wniversity of vtah, college of Medicine, Division of Radiobiolog Departant of Amatom, Salt lake city, wi. 1962

Fracture Incidence In Beagles peceiving single Injections of Radiug or plutonium. Part of Dougherty. T.F.o et 1 (EdS.). proceedirgs of a Symposiug on sone Aspects of Internal

rrrafition held at The Homestead. Heber, Jtah, May 8-11, 1961. Pergamon Press, Oxford. England, (p. 131-143), $529 \mathrm{p}$.

Pure bred beales vere given either Ra 226 or $\mathrm{Pu} 239$ by intravenous injection. A complete radiographic recora was ade of the sicletor at sufficientl frequent intervals so that any gross bone changes could be tabulated chronologically. The sesults show the the fracture rate i highest in the highest dose levels. There is a good correlation for fracture incidence and the dose rate the dogs were injected vith Ra 226 but such correlation is less obvious fractures vere wore numerous in the dogs given Ra 226 and rate of repait uas ruch greater than vith PU 239 , oniy Ra 226 treated ags ha long bone fractures and only Pal 239 treated dogs had pelipic fractures. Approximately equal nubers of botb gtoups had fractures of icreathlar bores but the zyerage nuber per dog was greater for pu 


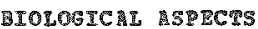

<1813 coner.

treated andsals. (1) (19)

$<182\rangle$

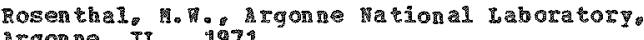

1971

Quatutitative comparison of lonoveric and

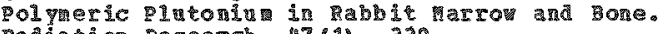
iadiatoin Research.

Tibia of young adult fertale Dutch Belted rabbits vere used to conrare the uptake of two different physical-chencel forns of plutonin in matron and bone separately. The and intravenous injection of approxingtely 0.33

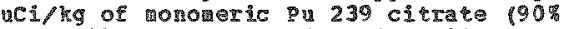
ul tratiterablel or of graded mid-range poly taeric Pu 239 nitrate (15\%

vitrafilterable The Rerron pushed out of the tibias after wabling cross cut 1 ca from each end of the bone. The ratron

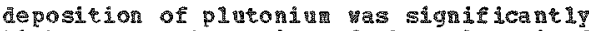
higher after injection of the poltweric forl. The aran contalned $40 \%$ of the total tibial radioactivity after polyneric injecton as compared to $3 \%$ following nononeric injection. The average concentration ot the polymeric form was 0.254 as compared to $0.015 \%$ for the monomeric form of the injected dose per gran wet meinht. parrom concentration ar both forms the spatial distribution of the red

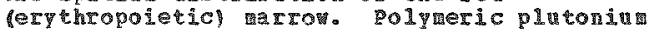
has up to 30 ti

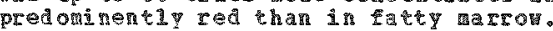

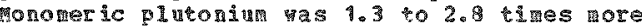
concentrated in red marrov. This preferential aeposit tion of pluteniu especially the polyeric cor in the especialit the polveric por

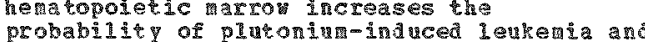
anemia. (A uth ( 5 T)

\section{$\langle 193\rangle$}

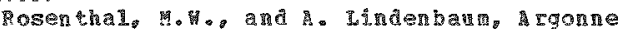
ational iaboratory. Division of giological and medical Research, Hgone, In. 1969

Osteosarconas As Relatea to pas

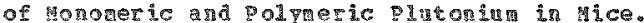
covit-67ness: Part of Proceedings of a $S$ yposin an belaped refects of

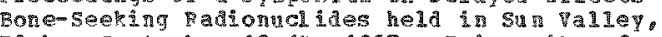

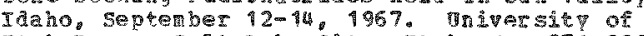

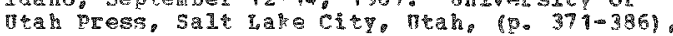
5190.

The long-tern effects of intravenously

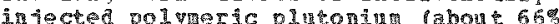

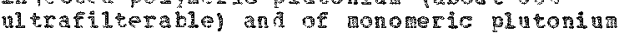

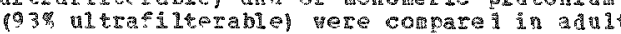
cFis forat

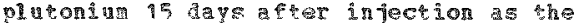
hasis of reference. Tro levels of polveric

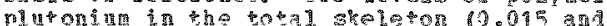

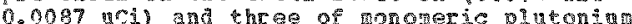
$0.025,0.012$ and 000 art the lower levels in each case resilter from Drga therapt. Interpolation of the resluts. to enable comparison of the efrects of equal ancunte of plutonin in the hone, showed that mice in jected to contarea to those wh polveric plutoning began ayng earliner vich osteosiscomas and had aboth thes as high a

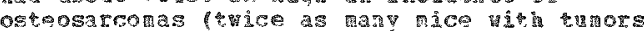

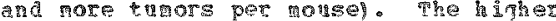

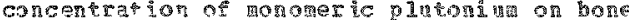

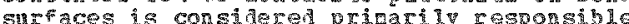
sur those alfferences. other fosshle factors are also àsmased. (A
Table 2 Fhow setention of polyertc or monomeric Pu in bose and iser of lce after intravenous infecton, wh the and cheragy.

$<184$

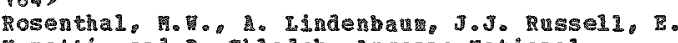
Horetti. and D. Chladek, Argonne a lonal Labotaror. DH pesearch, gonne, II. 1972, Angust

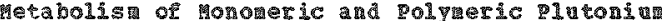
in the Rabift: Corparison th the Moase. tea th Phyics, $23,231-238$

Toung adut ferale Datch $\mathrm{Del}$ ted rabbits Given a single intravenous ingecton of

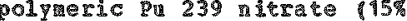

pl Itraf il terabiei or of montoret is Pu 239

cistrate (90\% Itratilerale) and silled at 3

days. Ine platoniut content of the intact fear (bone plus arcov) a polymeric form. physideal removal of arrow frok bone in the tibia shomed the platorin concent of the bone to be slighty lon and of the maston to be 17-501d higher after polyneric than after nonomeric olutoni Dolyoerc plutonituas a 150 more concentrated in spleen ovaries, satestines (with contents). \$holetal Juscle and urine but less concentrated in liver. About the same levels of the to for 1 of plutoniu yere found in blood, ile and Ing. For the first 30 min afor injectron, the poly meric oluton 1 vas cleared tron the circulation more rapidi than the monomerie. Atrex abont 60 min the two fors were cleared at

genera 11 y comparable, decreasing rates.

polvteric plutonin tires (erpthropoletic) ararov shan in fatty rarrow. monomeric plutoniu was $1.3-2.8$ ines wore concentrated in the red arrop. Mice injecta with se same plitonin solutions as the rabits shoved in comparisong a higher per cent of the injected mononeric plutomiu in the fenures and lower per cont in the 11ver; thep shoved a horer uptae of

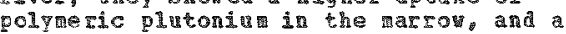
bigher untake of bot rorms in the spleen and

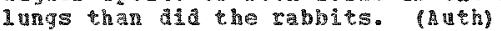

Table 1 and 3 give the afstribution of polvaeric and three days after intravenous injection.

$\langle 195\rangle$

asenthal Mo

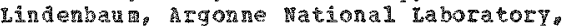
Araonine The 1963. pctober

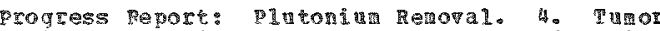

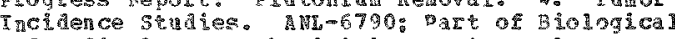

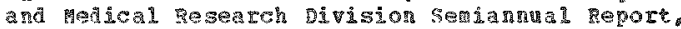
Jul throrah pecener $1962,(0,87-91), 236$.

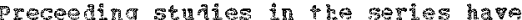
aternine survipal ara bone thor incidence

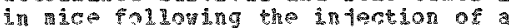
polyteric form of plutoniug. phese vere correlated this the agree of remoral of skelotally deposited plutonu by therapy

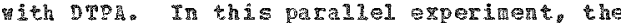
moromeric form of to compare tanor incidence following the tro forms of olutonis. therapy and also to determine the effect of

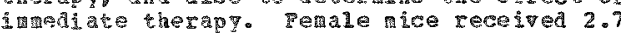

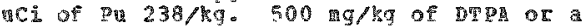
saline control as given either 1 hout or 3 Iavs atroryares and once per ay for 12 Aays. Anhals vere sacrificed at intervals and 


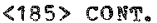

excretion data mere comiled. In controls. the plutoniun was about equally aivided between bone and lifer at time when uptake was at a maximum level (between 1 and 6 days after infection. The level of platonim in bone at 6 days remained constant for 90 days. However, it had aropped about one thitd by 300 days. When DTP therapy was begun 3 days after plutomiun injection, loss of plutonium fron liver wa accelerated so that allost all was removed after 3 days, and the level in bone was reduced by about one half after 12 days. When initiated after 1 hour, the same course of therapy again removed one half of the deposited plutoniun from bone and nearly all from ilver. In addition, it prevented all deposition in bone after 1 hour, so that the total retention in bone in the se treated mice was less than one quarter of that of the saline controls. The amount of plutoniu lost from the liver is the same as that in the feces, and that removed from bone is equal to the amount appearing in the urine. Data showed that 12 days of therapy was sufficient and further daily injections of DTPA would have promoted little or no increaser effect. only a preliainary survey of bone turor incidence can be made at the present time. Data suggest that after administration of monomeric plutoniut, bone tumors appeared earlier and there was a higher proportion of mice with a bone turor at death than fter adinistration of the groun receiring therapy at 1 hour, the latent proup receiving therapy at 1 hour, the lat lower than in the 3 day treated group.

\section{$<186>$}

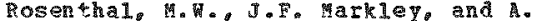

Iindenbaun, Argonne National taboratory,

Argonne. It. 4963 , Wa

Progress feport: plutoniu Revoval. 3. Tumor Incidence studies. Mul-6723: part of Biological and Medical Research pipision semiannal teport.

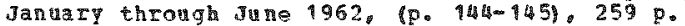

The effects of 2 and 12 days of DTPA therap following a single intra wenous lnjection of 2.6 uci/ha pu 239 on bone tumor incidence are sumarized. DTP w injected

intraperitoneally at a concentration of 500 mg/kg 3 days after Pu admini stration: controls received saline injections. The inder of radiation effect has the oroportion of aice that had at least one ralignant bone timor at death. DTP treatment given for 12 days removed $43.2 \%$ of the pIutoniu deposited in the bone and reduced the fraction of aice with bone tumors by 42.5 at the time the last untreated mouse died (515 days). Treatrent for 2 days had less effect on removal and tumor incidence. and the tro indices of effecer were not as closely correlated. Tumor rate increased ith tine in all grongs and as reduced by DTPA therapy. (ST)

$\langle 987\rangle$

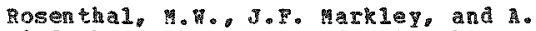
Iindenbau. Argonne Mational taboratory. Arg onte. II. 1963 , october

Progress Report: Rlutoni Reroval. 6. Chemical Removal of marrow and IEs Plutonilu from Bone. ANL-6790. Part of Biological and Hedical Research Division Semianual Report, JuI through Decerber 1962. (p. $92-93$ ) 236 p.

In the estination of radiation dose absorbed by bone after skeletal deposition of a bone-seeking radionuclide, it is essential to distinguish quantitatively between the radionuclide located in the bone itself and that deposited in the marrom A chencal techngiue using the protein solvent Hyarine has been developed by which 211 exposed orqanic raterial including arrov can be alssolved from bone. The removal of the organic portion of the bone with its associated plutoniun does not remove the radionucilae. that is deposited in the hat bone. Hice vere in jected with 2.7 or 1.6 uci/kg of $\mathrm{Pu} 238$ and sacrificed after three days. Marrow fron a segment of the shaft of the thia tas extracted by saline irrigations and a sililar segment as extracted using three changes of Hyauine over a period of 2 velks. Since tianine solutions cannot be easily ashed, the plutoniun extracted must be measured indirectly by subtracting the amount of radioactioty in a bone sample treated ith Hyane fron that in a comparable untreated sample. Results ith Haline extraction did not differ significantly for those th saline irrigation. This should be a valuable technique in the quantitative differentiation between the plutonjun in marrow and that in cortical bone or on trabecular and other bone surfaces.
especialy in skeletal areas in whin physical regoval of the parrow is not possible. (BB)

(188)

Russe11, E. R. H. Delaney, E. Wotta, J. Huntz, E.S.G. Barron. E.E. Painter. R. Edwards. 0 France, C. Hagen, and S. Schvart, oniversity of Chicago, Chicago, IJ. 1945

Fffects of Product Upon Dogs. CN-2786: Part of Health Problems Relating to Proluct for Month of farc 1945 (p. $18-28) \cdot 35$ p.

Dogs yere injected intravenous1 10.286 mgkg) and intratuscularl (0.404 ag/kg) with plutoniu (\$) citrate and the excretion and blood levels of plutomiun tere studied. Total excretions at two veeks vere $15.3 \%$ of the in jected dose in the intramusculariy injected dog and $24.4 \%$ in the intravenously injected dog. These alues re compared with those of a previous study in which a dog was injected ith the nitrate. Equilibri blood levels rere about 0.01 ing $\mathrm{Pu} / \mathrm{i}$. B $100 \mathrm{~d}$. most of the pluton ium in the blood as attached to beta globulins. Both dogs shomed tariked reduction in cellular conponents of the blood. Fhite blood cell count as ini 1 on the 13 th da postinjection, but the neutrophil count showed sole recovery after that tive. The intravenousit infected dog suffered for radiation sickness frok 10 to 15 days arter injection: the distribution of lism proteins was altered and there vas an increase in urine urobilinogen. Both dogs an increase in urine urobilinogen Both dogs injected dog. (Auth) (ST)

$\langle 189\rangle$

Rysina, T. Wot given. 1972

Biocherical and Horphological changes in the Lungs of Rats Accompany ing fulple Inhalation of Rlutoniu citrate serosol. aEc-tr-7387: Part of Moskalev, Tr.I. (Zd.). Remote Atereffects of Radation Dalage, (10.364-370), 574 .

Peale rats of the 1star line vere a dini stered a solution of Pu 239 citrate

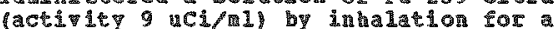


<99 copra.

period of 10 minutes three tines a trek for 30 days to study the latent effect and biochenical and ror phological changes produced in the lungs. nuber of inhalations, there was an average acculntation of 0.0727 uci of pu 239 in the lughs. Animals vere sacrificed during the inhalation period and up to the tenth onth after inhalation ha ended. Moisture. total nitrogen, lipid, nuclelc acid.

by lungs vere deternined. Irtadiaty following inhalation aloha tracks were distributed relatively uniformit in the lungs. By the twentieth dav and up to the sixth ronth. dense stars corresponding to wacrophages and alveolar cells ere evident. 84 8-10 months a moderatel expressed pneumosclerosis vas present. Early mormhological indicators of danae vere the mobilization and destruction of a lveolar nacrophages and an increase in the nuber of mast cells. Hfer 40-80 days there was an increase in the rubar of cells in the alveolar septa at the expense of alveolar cells and histo-1y phocytic

elemerts fith an alnixture of seguentonuclear lewhoctes. Beginging vith six gonths there were indicators of an intensification of fibrilogenesis. An increase in the total content of protein and hexosatine were the earliest and most clearly expressed biochenical changes in the iungs. an increase in the tuatio of nucleic acids was observed durimg the period of collagen Formation. The level of lipids increased to a lesser degree than the contert of the other studied compounds. (sT)

\section{<190s}

Sanders, C. Pacific northest loboratories, Biology Departuent, Richland, 1972, September

Metabolism of soluble plutonil 238 fron crushed

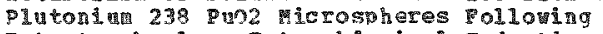
Intratracheal or Intrabaoninal Tnjection.

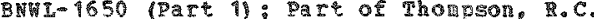
Ba.). Annual Repore sor $1971,(0.254-262), 313$ p.

Soluble Pu 283, prepared by crashing plutonin 238 PuO2 wicrosphwes, adningsterea to cats by intrabadomal intection $(1980$ mCi) or intratracheal instillation $(720$ ci). A large fraction of pu 238 was excreted in the urine: urinary excretion of PI 283 was warkedig increased

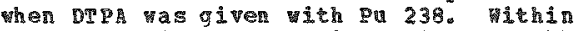
hours, 238 as trasiocated to the blood and concentrated in the skeleton. About $20 \%$ of intrabdominal in injected gu 238 was in 1 thally deposited in the 1 iver a nosty cleared during the first 40 days. Pecal excretion of PU 238 was predorinant following intrabaorinal injection vhereas trinary excretion vas greater following intratracheal instillation. a bout $70 \%$ or 1 intratracheally instilled Pu 238 sas cleared erow the lung during the risst day and an aditional $20 \%$ during the next 40 days atter insti11ation. (A) un)

\section{<199}

Suders. C.l. Batelle fiemorial Institute. pacific northest Lahoratories Biologr Department, Richland, 1972, Septemer

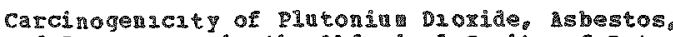
and Benzpyrene in the Abdoninal cavity of Rats. BNWL-1650 (Part 1): Part of Thongson. R.C.

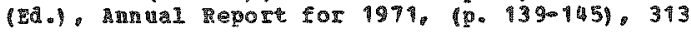

शu 238 PaO2 chrysotile asbestos, and benzyprene vere effective in inducing a large muber of abdoninal sarconas and pesotheliomas. The pu 233 PuO2 incuced tumors originated mostly in the omental region in ase-apendent manner at radiation doses of fros 34,000 rads $165 \%$ incidencel, 6,3000 rads (32\% incidence) and 770 rads (17\% incidence) delivered to onental tissues. Pu 238 puO2 did not induce any resotheinomas and only $15 \%$ and 4 s incidence of sarconas at radiaton doses of 31.000 rads and 10,000 rads, cespectively, delivered to orenta t tissues. Eu 238 guod 2 as spread more even 1 throughout the omentu whereas pu 239 Quo2 as concentrated ithin a fev thot spots of intense alpha activity in onental tissue. Both asbestos and benzyprene actea in an additive maner when injected with pu 239 Puo2 the conbination of agents inducing as many sarconas or mesothellomas as uas obtained by adding tomor incidence fros the agents given singly. (athe

<192\$

Samders, C.ls., Battelle ferorial Institute pacific Morthest Laboratories, Blology Departuent, Richland, 1. 1972, Septemer

Carcinogenicity of Inted plutoniu 239 from Crushed picrospheres. BNH -1650 part li: Part of Thompson. R.C. (Ea.). Annal Report for 1971. (p. $262-271), 313$ o.

An estinated $99 \%$ of inhaled "Solusle" Pu 239 Aerived fron erished microspheres cleared frow the lungs of rats by 200-300 days after inluatation. bout $50 \%$ of terainal pu 238 sas Found in the skeleton. The highy toric nature of pu 238 pas show by increased

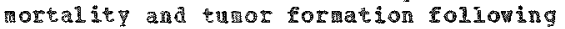
intial lung deposichons of 5,18 or 207 nCi. To date 13-23\% of animals exposed to $\mathrm{gu}$ 238 and 19 of controls have developed normak nornamary tumors were found in the lug following estimated cumlative ratation doses to the lung of 10 to 375 rads. Further interpretation atyits antopsy of remaining

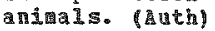

Table 1 gipes the tissue and organ distribution or inhaled Pu 238 in rats.

$493\rangle$

Sanders, C.I. Eatre11e Herorial Institute. Pacific bepartaent, Dichland, 1973 , April

Carcinogenicity of Inhajed luctonit 238 from Crushea microspheres. BHI-1750 (Part 11: Part of Thorpsor, R.C. (Ed.) Rnnal Report for 1972. (p. $28-31$ ) $103 \mathrm{p}$.

Three groups of 70-day-old fenale rats mere exposed to an arerosol of soluble

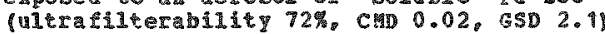
derived sto crushed 20238 PuoL microspheres suspended in phisiologleal saline for 2 to 3 ponths prior to the ani 1 exposures. Following inhalation, 12 to $25 \%$ of the Initial alveolar luag burden remained in the body 1 to 2 \%r after erposure: 0.3 to ir of this vas in the lungs and 50 in the skelet orl. phe ling turos incidence was 6.6 , 23.3, and 25\% for intital lung deposition of 5. 18. and $230 \mathrm{mCl}$. and average radiation doses of 9.32 , and 375 ras. respectively. toses or 9.32, and 375 rads. controls. The ineldence of 11 thors other thar man controls and 1 in the 238 -erposed rats. 
《193〉 cons.

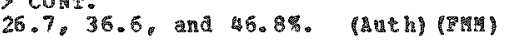

〈194\$

Sarders, C.t., Jr. Bettelle merial Institute, Pacific porthest iaboratories. Blology Departrene. Pichland, WA. $1973^{3}$. Deceaber

Carcinogenicity of Inhaled Plutoniua 238 in the Hat. Radiation Research, 56(3), 540-553

Three groups of fenal albino rats were exposed to an aerosol of solubie $\mathrm{P}$ un 233 derived frov crusled pu 238 Puor nicrospheres suspended in physiological saline. Initial alveolar burdens of $\mathrm{Pu} 238$ were 5 nci fGroup 1). 18 nCi (Gronp 2), and 207 nci (Group 3 ). only trof of the initial alveolar long burden retained in the lung at 1 year, aecressing to $0.3 \%$ by 600 days after mposure. The $\mathrm{Pu} 238$ boat burden was $25 \%$ of initial alveolar burden at 1 year, decreasing to $12 \% \mathrm{by} 1000$ days after exposure: aboug hale of the body burten was found in the skeleton at these times. The cumiative radiation loses to the lung at 2 years after exposure were 9 rads (1), 32 rads (2) and 375 rads (3): unexposed controls exhibited a median survitral time of 825 days as compared to experimental sureival times of 650 days (1). 675 days (2). and 550 days (3). The incidence of lung tumors in controls was 1.1\% as compared to incidences in po 238 exposed rats of $6.6 \%(1) .20 .0 \%$ (2). and $25.0 \%$ (3). The incidence of ali tomors, other than manary tumors, yas $4.3 \%$ in unexposed controls, and in Pu 238 exposed rats, $26.7 \%(1) .36 .6 \%$ (2). and $46.8 \%$ (3). (Aath)

$\langle 195\rangle$

Sedina, NoS., wot given. 1991

Effect of Uraniun wission products on the Functional state of the Central Nerpous system. AEC-tr-7387; Part of loskalev, Tu. I. [Bd.l. Rerote Aftereffects of Radiation Na ge, p. $246-252), 574 \mathrm{p}$.

changes in the functional state of the central nervous systen of rats were studied following administration of uranin fission products. Doses vere 2 and 20 mei $/ \mathrm{kg}$

introduces by stomach probe and from 0.08

plus or thinus 0.01 to 1.17 plus or ainus 0.08 mi/kg adninistered by inhalation.

Conditioned reflex activity was investigated by the motor reaction-food method. Chronaxie of the tibial nerve vas measured to study shifts in subcortical nerve centers.

Fegardiess of dose and administration aethod. the observed changes conld be divided into

tho distinct phases. The first phase lasted to days an in the latent period of the reflex, a decrease in the degree of the conditioned reflexes, and a marked weakening of the conditioned inlaibition. The second phase lasted five or six months arring which there were no marked deviations from nor alcy in animal behavior, but impairment in the conditioned inhibitation process was
conibited. goth phases transpired differenty for the different meth ods of contaminetion. almost all of the animais died by the twelvth month. Dystrophic changes in both groups preceding death are discussed. Trpairment of higher nervous activity accompaning internal. radiation was - progressive reakening of conditioned inhibition and an intensification of unconditioned inhibition during the entire course of the diseise. (ST)
<1968

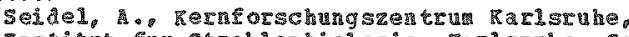
Insticut fur Strahlenbiologie, Karstuhe, Gerar Federal Repricic. 1972

Distribetion of Plutonin 239 pelated to bifferent reshods of areparation of a citrate Injecton Solution. Internation 1 journa 1 of Applied adiation and Isotopes, 23, 195-196

Citrate solutions of pu 239 prepared by three different tato ferale albino rats of the melligenberg strain. The ratgere sacripiced by axsang uination seven days arter injection of

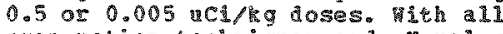
preparation techiques and pH values tested. the resule cortesponded to that asmribed to monoric Pu 219. With one exception, all preparation procedures applied yielded identical zestlts tor the distribution of 239 soon after its intravenous injection into the rat. Solution preparation methods are described. (IT)

<197>

Seidel. A. Rernforschungsentra gardsruhe

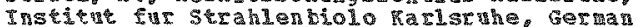
pederal Repulic. 1973

Wetention of Americiun 241 by Some mdocrime orgath of the re and Its Response to DFE Treatrent. International Joutral of Radiation Biology. 23(4), 415-4 16

Pale albino sats vere injected

incravenol with $0.3-0.6$ wei a 241 citrate

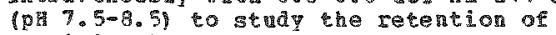
a

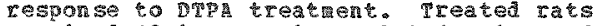
cecelved 12 intraperitoneal injections of Ca or Zn DTPA $(30$ ula $/ \mathrm{kg})$ Fron 1.5 mingtes to 71 days or from is to 81 ays folloning anericiu adainistraion. There yas no signaticant 1irination of arericing sron the thyroid. ovaries. or adrenals of the control anials after the ifteenth day. Both chelates vere equall effective in reducing the $\mathrm{g}$ (4) content of the oxans and their effectiveness depended on the tiae of adinistration. The mobilization of 241 from the thryoid was higher than from the ovaries. The concentrations of th 241 in the andocrine organs vere compared with those of the ijver and skeleton and the effect on the ovaries a ve to its long time retention, nonmifor distribution, and poor response to treatuent is a iscussed. (ST)

$\langle 198\rangle$

Selcel. A. pernorschugsentruk karlstahe. Institut ru Strahlenbiologie, Ralsurhe, German Federal Republic. 1973, tay

Comparison of the Effectiveness of Calcium DTP

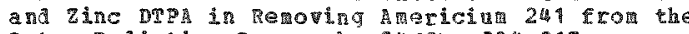
at. Radiation Research, $54(2), 394-315$

Fente albino rats vere injected

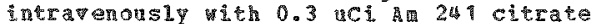
Followed intrapertoneal injection of 2 to 200 用 cromoles of calciun DTPA or zIIIC DTPA to study the mobilization of internal1y deposited $\mathrm{A} 24 \mathrm{~T}$ as dependent on time and dosage of the chelates. The efrect of both chelates as sustained over several days and decrea sed wh increas sing tire interval betreen injection of $\mathrm{A}$ (n) 4 and chelete. The removal of 241 from the liver 205 makedy higher than from other organs. In case of

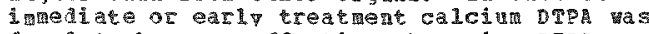
found to be more effective than zinc DTPA. 
<1983 COF

There of delaped treatrent. Al dosemerect curves mere linear. phe thooreched and practical impications of the results are disc sased. (th

〈999>

Seide1. A. Rernforsch ungzentru Rarlsruhe Institut fur serahlenbiologie, RarIsr pederal Repubic. 9973

Qistribution of Americiu 241 in the Rat as Influenced by Dose and the phl of the Injection Solution. Intergational Journal of $\mathrm{pplied}$ Radiation and Isocopes. 24, $362-363$

Aat at teale rats of the meiligenberg strain vere infected intrivenously with 0.03 to 3.0 uci/kg \& 241 in citrate solution to

deterane vhether ase influences

distribution and retention $i$ in the skeleton.

1iver, and kianeys. The effect of pll 12.7 .

7. 4. and 9.4) on distribution was also

studied. The al pha actiply of the tissue

sa

counting. There was no systematic and

statistica11 signeficant influence of the $\mathrm{pH}$

on the distribution patern. An increase of

dose from 0.03 to $3.0 \mathrm{uCi} / \mathrm{k}$ had no in

on $A$ m 24 retention by the i iver and

skeleton. A slight 1 h hghex a content in the kidneys was present yth the higher dose. (S)

200

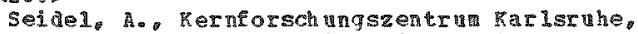
Institut fur strahlenbiologie, harlsruhe Geran Federal Republic. g97

A Hutivariate Analysis of Calcium DTPA Ecrectiveness in resoving aericiun 241 from the

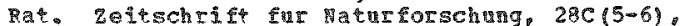
$316-318$

The dependence on ine of the dose-erect relationship has stidied for the Femoval of m 241 from the skeleton and 1 itver of the rat by Ca DTPE. Due to the linearitrit of the dose-effect-curpes (in a $109-100$ scale) as vell as to the inear depenterce of the slope on the logarith of ine simpig equatons were derived thich describe he nobilization

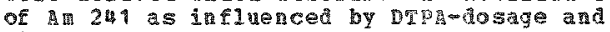
time of treatrent. (Anth)

$6201\rangle$

Seidel. A., and $\eta_{\text {. Wolf }}$ Rernforschungzentrum Rarisruhe, Institut fur strahbonbiologie. Karisruhe, German Federal Repubile. 1972. Decerber

Dffect of DTP or the Americiun 2 th Concent of

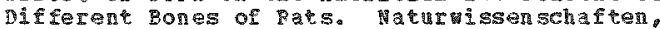
$59(12), 652$ (German)

hericion citrate yas in jected intravenously into serale rats folloved by the njection of Ca DIPA or Zn Diph aftar 90 ma or \& days. 1 Dha activity of the bones has determined? days after DTos injection. Americium 247 concentration in the femur, parietal os. mandibles, teet and ribs vere not un form bu it was concluded that the an 2 is actiplty of the ferur presented a reasonably accurate picture of its aistribution in the steleton. There as no significan difterence in elther

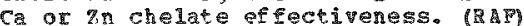

Insticute, Bacific horthmest Laboratories,

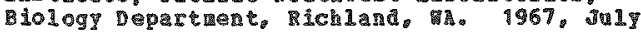

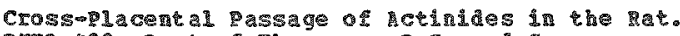
B

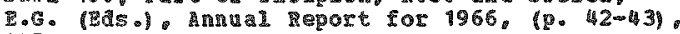
207 .

Pregant rats were intravenous in infected vith a oses of approzinatel y 50 uci of Pu 230

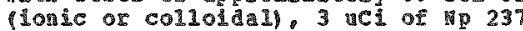
(ionic) or aci of 233 (ionic) Infection of each solution mas ade ater 15 or 19 days of gestation and the rats killed 24 hr later. ondi sall arounts or actionty vere found in the fetus folloning the

adui istration of the radionuclides although sustantial concentrathons were measured in the placenta and fetal perbranes. The partition of these aterials mong the fetal tissues tas otten dissinilar to that found in the corresponding watermal tissues. (Auth) (F) (F)

2able 1 shous the distribution of actinides in tissmes. $24 \mathrm{hr}$ after injection in pregnamt rats.

$\langle 203\rangle$

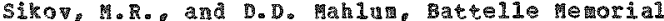
Institute. Pacific Rorthest laboratories,

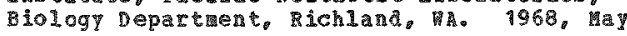

Effect of $\mathrm{sge}$ and Ehysicocherical por on Plutonis Toricity and letabolism in the Rat. BNy -714: part of Thompson, R.C., et al (2as.) Annal Report for 1967, (p. 5.8-5.14), 253 o.

The Aistribution and tonic effects of monomeric and golyeric pluton in in neonati. veaning, and adult rats injectod ineravenously in a dose of $6-90 \mathrm{nci} / \mathrm{kg}$ hod we ight in citrace or nitrate solntion vere compared. Fhe parareters studied included radonuclide distribution and retention growth, acute and chronic toxicity. and daraing effects on several specific organs. The polyer was more torac to pearlings and a duts than was the monomer, but there vas litele aifference betveen the tvo forng in newborn rats. Veight galns were suppressed in animals of all age groups. honoweric plutoniun greater extent than in the liver; vin the polyer, liver deposition predominated. fross and histological tamage ras noted in the livers, particularly in and receiving the polyoer. phe changes pere rost severe in those exposed as weanings. There vas a general tend ency tomard a dose depenate increase in the susceptibility to audiogeric seizures after exposure of the veaniling to the nonorer. The reights of several organs, in relation to total body veight vere altered by exposure to

pluton in In $I$ was concluded that disferences in acute lethait relared to marked age dependen differences in distribution of the two form, which also led to age dependent a terations in organs such as ijver, spleen. and sheleton. (Auth) (ST)

Table 1 Tipes the acute lethal efrect of pu 239 adrinistered as monomer or polymer to rats of different ages.

<204s

Sikov, M.R. and D.D. mahlu, Batelle Memorial Institute, pacific Northest Iaboratories, Biolocy Departrent, Richland, kA. 1972, septerabex

Distribution of Einsteiniu 253 in the Fetoplacemtal Unit of the pat. B 1 wh-1550 part 
<204>

BJOLOG ICAL ASPECTS

204〉 COkT.

1): Part of mhompon, R.C. (Pd.). Anmul peport for $1971,(0.85-87), 313 \mathrm{p}$.

The cross-piacental transter and istribution of Es 253 in the fetoplacental uni of the rat was determined 24 hr after injection at 15 or 19 days of gestation. The fraction entering the fetus was nch lower than that observed yth other heav retals previously studied. The concentration in the mempanes relative to that in the placente as likevise quch lower although the distribution ithin the membranes vas similar to that previously cound vith Pu 239 . (Auth)

\section{<205>}

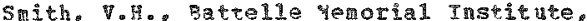
Pacific worthest Laboratories. Biologr Department, Richland, พh. 1972, Septerner

The sioloqical. Disposition of Insteinitin Nitrate in Rats After Intravenouse Intratusculac, Subcutaneous, and rrascutameous

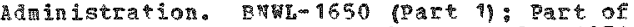
rhompson. F.C. (Ed.). Annual Report for $197 \%$ (0. $279-282), 313$ p.

pegardless of the injection roupe. Bs (ho3) 3 tas retained preponderantiy in the sheleton up to 24 days after intravenous (TV).

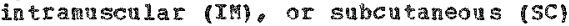
adnistristion. The liver burden decreased Erom $26 \%$ of the initial Bs a drinistered IV at 4 hours to 1 to at 1 day and $<2 \%$ at 24 days. The skeletal content increased to about $70 \%$ on ay 7 and decreased to about 56 by da 24. The 11ver and sheleton retention at 24 days from the $\mathrm{SC}$ and In infections slightlo less than rrom the IT route. Injection site retantion as greater for the sc route, $16 \%$, than for the In route, $8 \%$ stin absorption was very high, about of of the available $5 \mathrm{~s}(2.5 \mathrm{uci} / \mathrm{cm} 2 \mathrm{pH} 2 \mathrm{mitrate}$ solution boing absobed in 30 mintios.

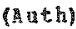

\section{$\langle 205\rangle$}

smith. V.H., Hanford Atomic Products operation. Biology taboratory. Richiand, HA. 1964, Jankary 15

Interactions in the metabolisw of Plutonim 239

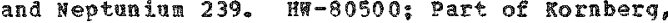
H.A. and 5 wezea, E.G. (Eds.) Macord Rology Research Annal peport for $1963,(0.73-75), 242$ p.

Ferale rats weighing approxinately $250 \mathrm{~g}$ each were injected via the tali wain th $P$ $239(4)$ and ip $239(+4)$ as the phl citrate complex. They received 0.03 moles $(118$ mg)

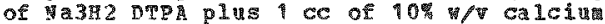
gincohe ptonate intraperitoreally one hour ater he isotope a dinintration. The whol tisswes vere counted in a 256 -channel gama andizer to obtain the vp 239 content. and then. after w 239 decay, vere wet combusted ทi.th tho3, plated, and the 239 content measured in proportional folog conters. The results show that deposition of $1 \mathrm{p} 239$ in the

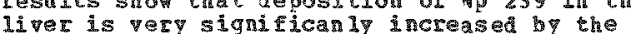

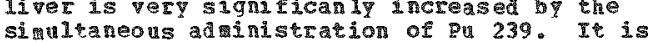
simulaneous adinistration of Pu 239 . rel tively wh greater mass. tends to

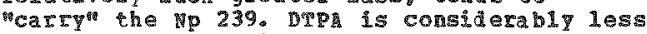
effective in reaving 239 fror the liver than in removing Pu 239 from the 12 ver: and is totall inerfective in removing 239

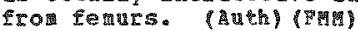

Table 2 shous percent of $\mathrm{Hp} 239$ and 239 doses remaining in tissues a excretion five ars ater adinistration.

〈207>

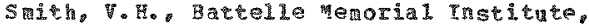

Pacific Morthest Laboratories, Bolog

Departaent, Richland, WA. 1972, September

Prompt and Delared Chelation pherapy for the Decorporation of Binsteinin 253 fron Rats Ising

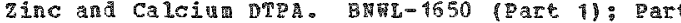

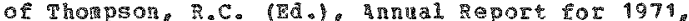
(p. $284-296), 313$ p.

when chelation therapy as comenced 7 day atter the intravanous adminstration of einste inilu $253 \mathrm{Es}$ (NO3) 3 , the soft tissue retantion vas 2 to 5 times greater than when treat ent has given azter 1 hr. sheletal retenion as doubled fron $35 \%$ to $77 \%$ of that zetained by the control rats by delayidg the treatment. The relatively short physical half-lite and the prearonate deposition in skeleton rakes prompt treatment imperative if itradiation of the skeleton is to be arfectively zeduced, Directy injecting $\mathrm{z} n$ DPP. near the site of intramscular deposits of $\mathrm{Es}$ reduced $106 \mathrm{~d}$ Is retention sore than * wofola compared to treatments remote from the deposte. zn DTPA appears to be as efrective in decorporating is from rats as ca DTR and, since it is less toxic, is recomended for that purpose. fenerally. Es is ror susceptible so DFPA therapy than pul (aveh

$<208>$

Selth. H. H. 3atelle werorid Institute. Pacific rorthest Laboratories, Biologr Departaent, Bichland,

Interaction of plutoniut and Cesion Durino Chelation Therapy in tacs. Bump 1650 (Part 1): Part of rhomson. R.C. (Ed.). Annual Report for 1971. (p. $274-276) \cdot 313$.

In rats, during the early ghases of deposition and decorporacion by chelate therap. an excess of stabe cerium citrate had iftele efrect on pu 238 retertion or removal by $\mathrm{in}$ DPR. on the other hand, an

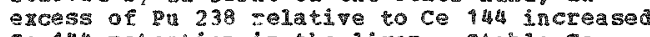
Ce 1 hl retention in the 1iver. Stable ce athinistered as the Drga chelate caused increased retention of ce 144 in the sott tissues and as less erfective in the revoval of Qu 238 or Ce 144 than 25 DTPA. (Auth)

$<209>$

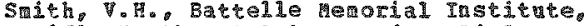
pacific torthest Laboratories, siology

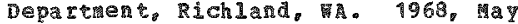

The Solubilit of Plutonita 238 Dioxide Microspheres in Sinulated Gastric Juice.

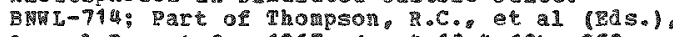
Anal Report for $1967,(\mathrm{p} .4 .18-4.19), 253 \mathrm{p}$.

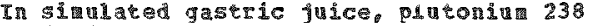

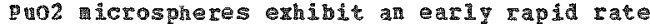
of dissolution fol lovel atrer $1-2$ h5 b 2 constar and relatively slomer rate. sswing the stomen vould norma11y engty

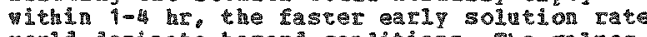
would doninate hara condithoms. Fhe velues repored are alid only for the particular icrospheres anloyed and shon 1 id not be considered to represent the solubility of an average \$HP ral particle. Solubility may especed to ary ldel depending on the production conditions, surface ariation. cleang procedure, and the general past istor of the icrosphere. (ath) (Rh) 
$<210>$

Smith. V.t., Battelle meroxal Institute. Eacific morthest Laborator jes, Biology

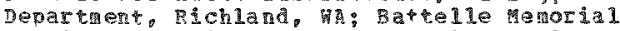
Institate. Pacific porthest laboratories. Physics and Instruentation Departiento PChland, MA; Batelle vemotal Institre. Pacific horth Sciences pepartment. Fichlarô, 1974. August

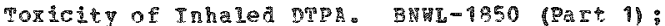

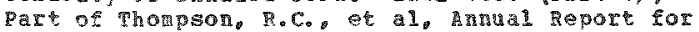
$1973,(0,111-112), 162$ p.

Mo significant gastrointestinal patholog was seen in rets, alring or following inkala bion of Ca Dra at dajle dose levels uo to 20 thines those nox mall taken by man and for up to 20 consecutive atas. Fyen at these high levels the inh lation route seems unable to ma intan sistenic lovel of DTPA sufficienty high to produce the gastrointestinal syarome seen following continuons infusion. A transient vesicular enph sena tas produced that genera1liz vas not present 3 veeks atter cessation of treatnent. yone of the filcotic changes observed weh zotratracheally injected $\mathrm{Ca} D \mathrm{DP}$ at high dose levels vere noted. (Ath) (RE)

<211>

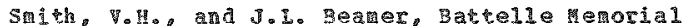
Instivte vacific worthest Laboratories,

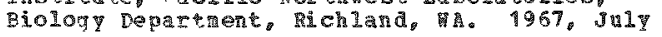

Absorption of Q1utonita 238 PuO2 from the Gastrointestinal Tract of Sulne. Buth-480: Part of thompson, R.C. and serea, $\mathrm{E} . \mathrm{G}$, (t)ds.)

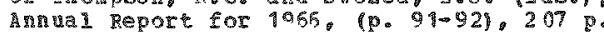

wine zanford minature swne vere given large

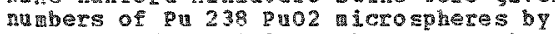
gavage. After 14 bys the a mont aborbed to tissues and urine vas less than 19 (s-6) of the dose. sin ref ace area of the nicrospheres vas less than 2 mci/p2. (Âuth)

Tabie 1 shong pu 238 conter in tissues of sine dainistred pu 23 guo2 microspheres by gavage.

$\langle 212\rangle$

Salh. T. Institute, pacific morthest labaratories. Biology Departrent. Hichlat, 1967, July

chelates as Contrast Hedia: tranin-DTPA. BWFI-480: part of Thorson.

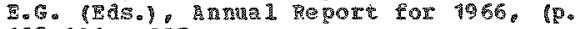
$105-106) .207 \mathrm{p}$.

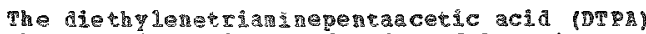
chelate of uratin produced useful angiogras when tage in sed

waicsted cardac arrest, contraindeates its ves in a mog

$<213>$

Sath, ํ. Battelle Taboracories, Sology Departaent, ichland, M. 1967.3019

Bessage Tíne and Pathology Following peeding of

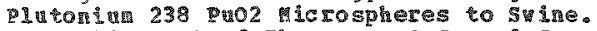

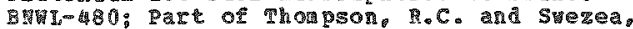
2.G. (Eds.). Annat Report for $1966,(0.88-90)$. 207 p.

The passage time of Qu 230 puoz ceranc

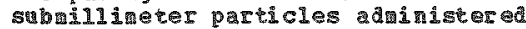

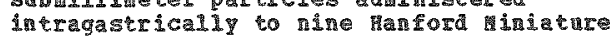

Suine averaged 10.5 anys for the egcretion of $99 \%$ of the dose and 5. days for of of the dose. The passage of 0.10 to $1.1 \mathrm{ci}$ of pu 238 elicited only mid, inflamatory response. Tro cases of particle retention at the ileo-cecal junction produced lacal inflamation and small regions of necrotic tissue surgounding the pateicles. (Auth)

《214>

Stevens, W.. D. R. Atherton, B.J. Stover, and F. Bruenger. Unipersity of ytah coliege of medicine, Madiobiology division, Departrent of

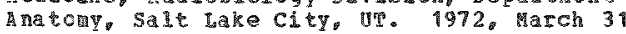

The Effect of the ghysical-Cherical state of Plutomin 239 on Its Farly Retention in Plasia and Selected soft Tissues of geagles.

con-119-246: Part of Dougherty. T. P. Research II Radiobiology. annual peport of work in progress in the Internal Irradiat ion Progra. (5. 137-147), $380 \mathrm{p}$.

The earit aistribution and retention of Pu $230(4)$ in plasma kidney, spleen, and other selected so th tissues vas studied in beales after injection of the stricti monomeric

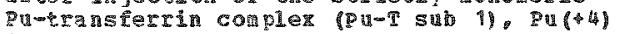
in chtrate buffer ef $\mathrm{pH} 3.5$ (Pu-m) and polvaeric plutoriun (2u-P) prepared by differential precipitation from a puritied solution of plutonium nitrate. It vas given ata pH of appozinately 6. Bu-T sub 1 was renoved fron the circulation at a rate slowex

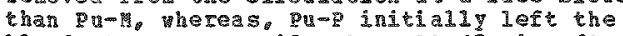
blood at a very rapid rate. At 15 hin after injection $87 \%$, 64\% and $<2 \%$ of the three forms of plutondu ware circulating in plasma respectivley: $100 \%$ of $\mathrm{p}$ um $\mathrm{sub} 1$ and the larger fraction of Pan was protein bound. No protein binding fo pu- $\mathrm{P}$ vas seen. he tro weeks after injection the concentration or pl thon in in nost soft tissies as guite similar for Pu-T sub 2 and gu- Compared to Puof 20 . preas, soleen retenk by a factor of 10 in the Pu- injected anisal. Fise concentration of Prin in the spleen as 1.6 tios greater than the concentration in the Iiver. Following differertial centrifugation of tissue horogenates frol $20 \mathrm{P}$ injected and als, the precencage of plutoniu in the soluble Fracion yas greaty reduced in spleen bus not in sidilar fractions of tidney hen compared to Pu-T sub I and Pu-h injected dogs. Most of the muclide ir the kidney was found in the fraction rich in thochondria. In the case of $\mathrm{Pu}-\mathrm{D}$, a large concentration of pluton in also was found in the nucles traction of soleen howogenates. The concentration of plutondu in thyroid.

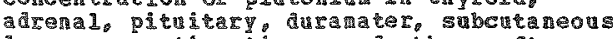
loose connestive tissue and other soft trissues are corpared. (Auth

<215>

Stover, B.J.p D. A. Atherton, F. Brunger, ad

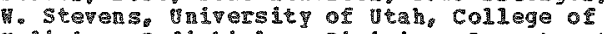
Hedicine, Radiobiology Division, Deparement of Anatory, Salt Lake City, th. 1972, Hach 31

CCR pron LItonin 239 in the Beagle as a zuction of Dose tevel. coo-119-246: Part of Dowgherty.

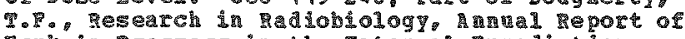
cris in PIg

Progras, (p. 167-192), 380 .

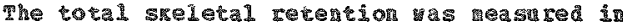
four bagles the vere injected intrapenously

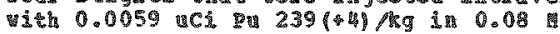
citrate bufer. ph 3.5. mhe alog vere youmg 
<215> COHT.

aduts at the tiae of injection an they tere secrificed at 1648 to 2546 days after injection at hich thes the removal of plutoni fro trabecular surfaces by remodeling hal decreased significantly. retention of plutonim in 8 humer ad third lubar vertobrae was neasured ja dogs

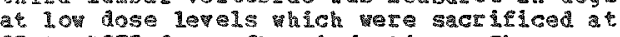
35 to 375 ars arter in jection. These results are conblined leh previous data on car1y deposition and retention in the skeleton, and early and long tern tat on retentor in the husus and thisd lubar vertebra, to obtain a set of four sieletal retentirn equations applicable to at least seven dose levels. Frow measurements of the defleshed skeletons of 18 beagles. the ind cated vet skeleta 1 weigh pas 7.5 plus or minus 0.9 of of the reight of the dog at intection, value lover the the previongly assumed 10\% o 31 ing the sec of skeletal equations. and the measured skeletal veight. the cumlative rads doses to the akeleton and the liver are compred. The average dose to the 1iver exceds that to the steleton except at che 2.8 ucifig tose level after 1300 deys. (A) a h

Table 5 shons average values of some measurenents of velght and $\mathrm{P}$ (3) 239 retention on beagle sheletons.

$<216>$

Stover, B. I., and D.R. A thercon, Intersity of thah college of nedicine, Radiobiology oifysion, separthent of Antomy. Salt lake city. up. $1972, \mathrm{karch} 3$ ?

Concentration of Pluton 239 (4) in the Blood Dissma of the seagle. coo-119-216: Rart of Dougherty. T.F. Peserch in thadiobiology. Annul peport of hork in progress in the Internal Irradiation Prograto $(p .|6|-166) \cdot 380$ 9.

The concentration of plutonu in plasa has been neasured fron 1 linute to 12.5 years following injection of the young alut beagle with Pu 230 (si) in 0.08 M citrate butfer. 3.5. The folloving sur of exponentials has been fit to the data: $\mathrm{B}=0.196(\mathrm{E}-1.05 \mathrm{~s})$. $0.017(E-0.47 t)+0.0015(\mathrm{E}-0.080 t)$ $+0.00016(\bar{s}-0.00089 \mathrm{~A})$ where is the percent of injected pu $239 / 9$ of plasia and is days. samples vere obtained from dogs at 5 ase levels, and fron ve11, ill, ha terminal dogs. Thus becanse of the know effect of dogs level on hepatic and sheletal retention dose level on hepatic and skeletal recention of the anital metabolic interpretation of the equation aust be linted to the observation that, on the average, there is a continuous decrease in the concentration of Pi 239 in plasta vith tine. An effect on the fourth ter of pas observed at he highest dose level only. (Anth)

$<217\rangle$

stover, B.J., and Horing, Iniversity of Utah, tadiobiology Division, Departhent of Anatony. salt lake city, Tr: iniversity of veah, radiobiology Division Departhent of chemistry Salt lake city. VT. 1970, JuIY

The Dytratics of life. 3. Mechanists of Honsurvival and the Relation of Dose size. proceedings of the vational Acadeny of Sciences. $6(3), 672-676$

Prom the steady state theory or mution rates, we have the probability, of the rccurrence of a critical change at some site
In $a$ cell that leads to genetic alteration. and the probability. equals log. that the site either is not changed or that it has been repaixed. In this paper, the for theor is reended to inclede survipal of bological systers in particular. the surviti curves of Deagle dogs hose deatil resulted con aging cancer epilepsy and

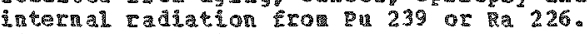
Single and itiple mechanisis of nonsurvival, and nltiple factors acting on a single nechansin, are considered. The nuber ot sites that ast be litered to lead to nonsurvival is examned and found to be nonsurvilis is examed and found to be action on separate sets of sites and the relationsip between dose size and surpital tala a ge aven. (Auth) (RAP)

<2183

Stover. B.J.. G. H. Tayor, and D.R. Atherton, Universict of btah, college of medicine. Radiobiology Division. Departient of matory. Salt Lake city. ir. 1963. September 30

Conpletion of the Injection Thase of the Basic Toxicit Experiment. Coo-228: Part of Dougher $y_{f}$. T. F.e Research in Radioblology. Semiamual Report of pork in zrogress on the

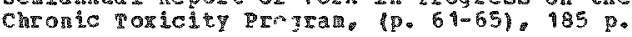

The 444 young adult bealles planned cor the long-ter stedy of the effects of Ra 226. Pu 239. Ra 228, Th 228 , and $S 590$ have received their single intravenous injections. Injection of the toricity dogs began in Decerber 1952 and tas concluded in Jul 1963. Thus searly 11 vears tere regulred to ineroluce this nuber of aogs into the experiment. As of septenber 30 , 1963 . there are 258 of the 444 dogs $(60.5 \%)$ still living. osteos arcomas have been found in 112 of the 176 dead dogs $(63.7 \%)$. of the 176 dead dogs. 9 lived 10.0 years or vore. (Auth) (PMl)

(219)

Stuarc, 3.0., Battelle lecorial Institute. Pacific morthest Ioratories, Biology Department. Richland. WA. 1967, July

Acute Lethality of Inhed Led Ptoniu 238 Puo2 and plutoniu 239 puO2 in Rets. BNmL-480: Part of Thompson. R.C. and Swezea, E.G. (EdS.). Annul Repore for $1966,10.661,207 \mathrm{p}$

The oxides of Pu 238 and $2 u 239$ Fere calcined t 350 deqrees $c$ and ground to a particle size of 0.1 u fcount redian diameter). Groups of $12 \mathrm{cats}$ were exposed to one of Groups of 12 cats pere exposed to one of each of the two isotopes. Acute mortality curres vere dram using estinates of the quantity of plutoniug in itially deposited in the 1 veoli as etermined frot whole-body counts and analyses of lung tissue.

Prelininary resil it 3 suggest that inhaled pu 239 puoz is somedhat nore erfective thin pu 238 PuO2 in causing acute nortality in rats. (Auth) (F 陆却)

Table 1 hows in 50 for inhaled 5 a 2 in rats.

<220》

Strare, B.0., B.8. Homard, D.L. Clary, and D.R. Craig. Batelle Merorial Institute, Pacific vorthuest Laboratories. Blolog Departant. Richland, 羿 1970, Mugust

Chronic Exposute of Hanters to 31 mulased

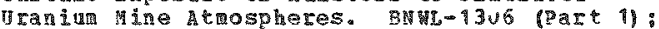
part of thompon. R.C. (Pa.) Annal, Report for $1969,(p \cdot 58-60), 90$ p. 
$\langle 220\rangle$ com?

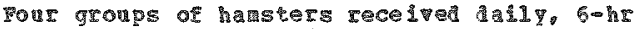
exposures to 30 m $\mathrm{m}$.

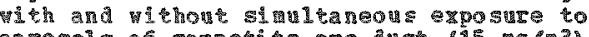

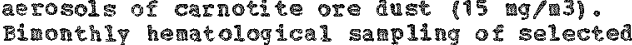

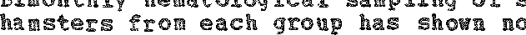
significan disferences in periphera blood parameters. Hter the tirst 6 months of

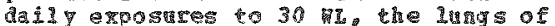

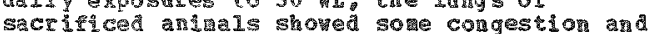
oder. vith stight thithening and oari

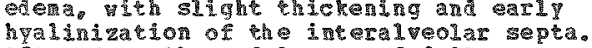

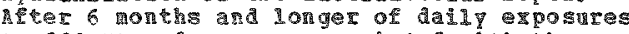
to 500 m, edena vas zssociated vin the livolar septa: areas of peripheral emphysena

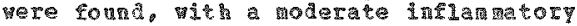
reaction 17volvigh polymorphonnclear cells. Lungs of andman exposea to $600 \mathrm{VL}$ plus carrotite ore dust showed areas of alveolar septal breakow vith enposen plus dilation and congestion of the pulnonary vasulature. A severe

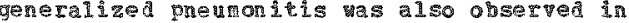

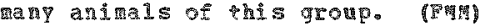

<22난

Stuar. B.0.0.5. Pas

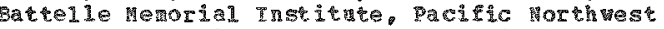
Laboratories, BI010gy Departrent, Pichland, $19 \% 2$. september

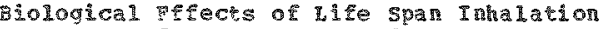

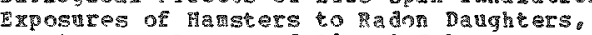

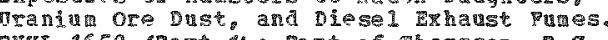

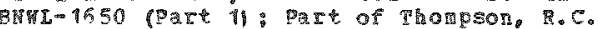
(Ed.). Amual seport for 1971, (p. 232-235).313 p.

Siz growps, each onsisting of 102 male

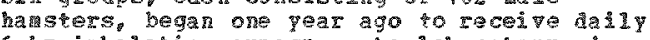
6-hr inhalacion exposuris to laboratory air

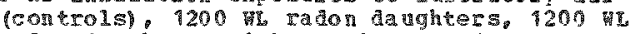

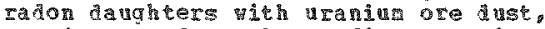
uraniut ore fust alone, diesel engine exhaust (50 pros cnl. of 1200 vL radon daughers

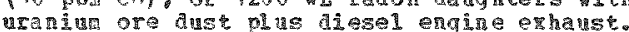
sacrificed hasters have shown respiratory tract lesions covering a spectrum tanging from norwal lugas in control hambers to netaplasia of bronchiolat-alveolar epithelin (cubiodal detaplasia or bronchiolization in hasters in the exoerine

Accugulation of proticulate-laden acrophages about \$na 11 bronchioles at vessels appearea wh th a fer months in almost 21 of the harsters exposed to diesel enoine axhaust

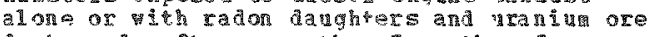
Aust: and arter more than 5 month of exposure, in about $50 \%$ of the hampers

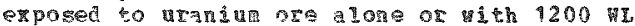
rador a deposits ver heaviest, they pere frequenty acompant her setal cell hperplasia. Cases of metablasia in groups receiving 1200

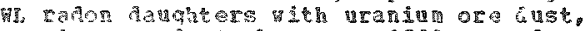
uta denghers whanet heran to apper after 5 to 6 monehs

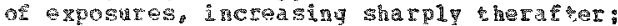

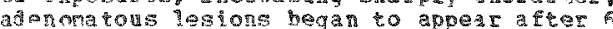
non

2.22)

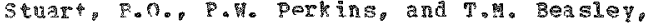

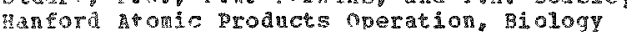
Lahoratory. Richland, WA. 1964 , January

Prelinisary Studies of Inhaled Uraning

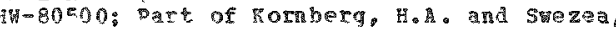

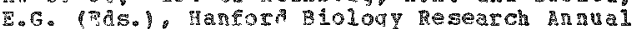
Peport for $1963,(0.50-59), 242 \mathrm{p}$.

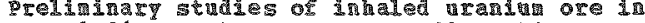

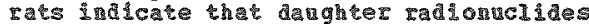

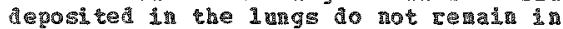
secular 1 qu ratios increased irow 1.0 to more end 2 or 3

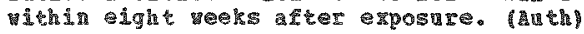

《223》

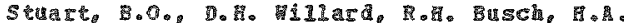

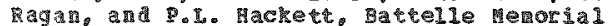

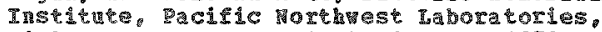
Bjology Departaent. Richland, Septengex

Biological Hecter of ISfe-Span Inhalation Erpostres of Beagle Dogs to Radon Dalghters. Uraning ore Duste and cigarette Sake.

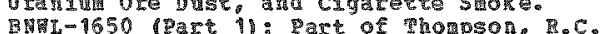

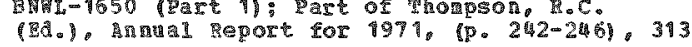
p.

sixty beagle logs are continuing to rective

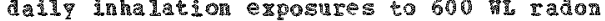

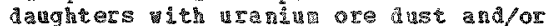
cigarete sinoking 110 cigarectes/day. 7

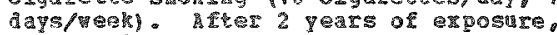
resciration rates and polumes and hody wejght have shown betheen the exposuge groups and controls. toral white blood cell connts and segmented ventrophil levels rose significately deing the last ${ }^{2}$ onths lin the group receiving 600 WI rafor danghters th oxe plus cigarette smoking. Lutig lavage saples srom dogs in this groug and in the group receiving $600 \mathrm{~mL}$ radon dathoters itio ore dust shov large nacrophages ith incresased nubers of nentrophils and occasional 17mphocptes. Whe lungs of fone aogs lone per gron of sacrificed

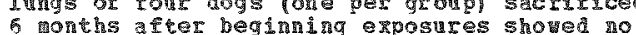
abromalities in the control a jog but perîvasentar and peribronchiolas acculat lations of acrophages in the dog inhaling cigarete smoke. The ags receiving 600 WL radon daghters ath ore alst. with and vitholt cigarete sroking, showed peribronchiolitis, perivasculits. fibrosis. vesicninar enphysena, and hyperplastic and retaglastc lesions of the bronchiolar

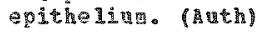

<224>

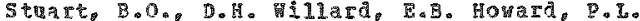
Clary and D. K. Caig. Batelie Memoríl Ingeltute pacific Northest laboratories. Bioloqy Departinent, Pichland, HA. 1970, Angust

Chronic Raposure of Dogs to simulated Uraniu Hine temospheres. Bith-1306 part if: pare of Thonosol, R.C. (Pa.), Anzual peport fot 1069. (F. $60-67), 90 \mathrm{p}$.

rพexty beagle dogs were exposed dast to 600 it of radon darghters gins carnotite ore तust. An additional 20 dons mere sindary exposed, but in adation smoted 10 cigarettes

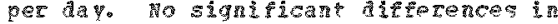
resoiratory rate. minute volume, tidal volue thoracic padiographs. hatology or clingal cheastr, have been observed betaen groups at 2 months after beginning taily exposures. Two dogs were sacrificed 15 month a forer conclusion of $1 / 2 \mathrm{hr}$, trice aaily exposures to pitchblende ore ast 10.1 g/11terl. Radiochenical analysis revealed nonedis librin ratios of 234 . Th 230, Ph 210, and Po 210 in the lungs fracheobromohil lyph nodes, kidney itwer. spleen, rad weletor, wh th $230 / 023$ $x$ atos Eangind frov 2 to 10 . po $210 / 0234$ ratios in the lungs and tracheobronchial Lymen notes paried fror 5 to 29 . The highest concen trations of Th 230 vere found in the 
S224> 60 政

1uga, steleton, and tracheobronch lal lyph noges. (F)

$225\rangle$

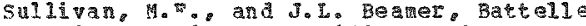
penorial Institute. Pacific Northest

raboratories, Biol ogy peparment, ichland, w 1972. september

The tanfor hiniature swine as an Animal godel for Intracavitary Irradiation by Madiul 226 and californiur 252 . $9 \mathrm{NH}_{0}-1650$ (2art 1): Pat of Thoapson。 $\left(p_{a} 32-35\right) \cdot 313 \mathrm{p}$.

Technicues have been developed using thera miniture suine that vili al1ow comparison of the effects of 226 capsules inplanted in the otherine cervix the those resulting from inplanted cf 252 after loading capsules. These methods stould a 110 w calculation of radiobiological effectiveness (RBE) for this neutron enitrer. The organs evidencing post severe damage from intracervical placement For either ga 226 ox Cf 252 after loading capules vere the rectu, bladder, and the uterine cervit. Results suggest that the stine is a useful asidal rodel for evaluating the effects of an intracertical treatrent

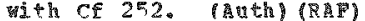

$<226\rangle$

Sulling, 特, J.L.Beamer, and A.C. Case, Battelle memorial Institute, pacific horthrest Iaboratories. Biology Department, Richland, HA. 1977. Apri]

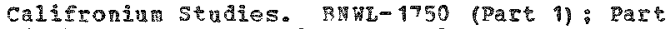
of Thompson. R.C. (E., Annul Report for 1972 (p. $11-92), 103 \mathrm{p}$.

Hantord inidure stine, exposed to cf 252 irradition. vere studied to deteraine the a thet a 2 maxtm of 2 nCi per tol was excreted in the urine following sposures that delivered from 2500 to 4000 rads to a point 2 cr lateral to tanden applicators containing four 12 ug ce 252 sources. The a doun excreted mas ratired in health of the anima 1 ; an aninal in poor healh retained va regardiess of the length of exposure to nevtron source. (Auth) (RA

$<227>$

Taylor, D.M., and A.R. Chipperield, Institute of Cancer Research, Departient of Biophyies. Sutton, surrey. Fnglana. 1970

The mode of ixation of Plutoniu 239 and Anericin 241 in Bone: A Possible Ezplanation of Their Different carcinogenicity. com -680435 ; Dare of sellifie. A. and Strickland. B. (Eds.). Proceedings of the ossiun Syposin keld in London England April $4-6$. $1968,(0,219-217), 340$.

The results of some studies on the comparative binding of $\mathrm{p}$ lotorth americi by bone inera and by the

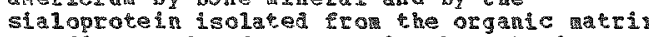
are discussed and tentative hypothesis to explain the different careinogenicity of the two lements is pronosed. The rel atro affinty of bone mineral for plutonin and arericiur was compared by asuring the upte of $\mathrm{P} 239$ or a 241 on she borine cortical bone as a runction of the concentration of citrate in the suspending mediug. The resulis showed that its increasing citrate concentration o to two handred times that found under biologieal conditions, the oroportion of plitoning bound by the bone ash decreased, bat a mericiun was hound firml over a wide range of concentrations. 2esults of gel filtration studies of the binding of anericinat and blutoniug to bone sialoprotein and halan transferrin in vitro suggested that plutoniun is bound much more strongly than americiun by sialoprotein and that both elements are bound ore strongly by sialoprotein than by transererin. The following adninistration of equal microcurie amounts of pu 239 and 241 , both nuclides are deposited in bone wanly bu surface absorption on the wineral phase, but preferential cellular binding of Pu $23^{3}$ to sialoprotein would result in a areater taliation dose being delivered to bone cells those producing a greater risk of carcinogenic transformation. (ST)

<228>

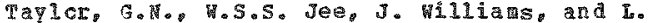
shabestari, University of teh, college of medicine, Radiobiology Division, Department of natoly. Salt lake Gity. UT. 1972. Harch 31

Anatonic Distribution of noneric and Polygeric Plutoni u 239. Coo-119-246: part of Dougherty. P. P. iesearch in Radiobiology, Annul Report of werk in Progress in the Internal Irradition proqrate (p. $105-125) 390$ p.

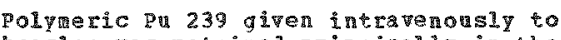
beagles mas retained principall in the reticuloendothelial cells (RE) of the liver and the spleen. Qetention in the skeletor was limited to the RE cells of the bone arron with very little, if any, uptake in the bone proper. Excepe in the lung. Where sole mechanical filtration or laxger sone mechanical filtration or latger polyraric pul 239 mas principally governed by ohagocytie factors hich not the case ith onomextc Pu 239. Fonoweric Pu in the initial deposition was orincipal 1 in the hevatic epithelium with little, if ant retention in the $\mathrm{RE}$ cel1s. pproximately $0.5 \%$ of the injected dose was initialiy retained in the kidney. Petention of monoueric vu in the spleen wa nore uniformy distributed. like the polpreric for it appeared principally in the RE cells. The retention of rononeric Pu 239 in the 1 ymph noles was Lowe Retertion ithin the skeletal tissues

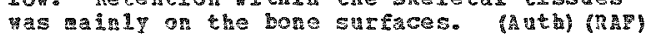

Figures 1-12 show electron lorographs and atcoradiograns of pu-containing tissues of beales.

220

Tay Lor, G.M., M.S.S. Jee, R.B.Dell, C. J.I. Hilias, and I. Shabestari, University of or his. College of redici Re Radiobiology Ditision, Departient of Anatomy, Salt lake city。 UT. 1971 March 31

Distribution of Californitu 249 and Berke11u 249 in the sott Tissues of Beatles.

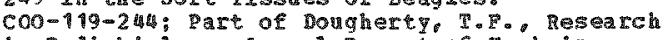
in adioblology Annal Report of work in Progress in the Internal Irradition Progra, (0. $126-146), 424 \mathrm{p}$.

The micescopic distribution pattern of Cf 249 and $5 k$ in in the sort tissues of beagles. at one to three peeks following a single intravenow injection of a citrate solution, vas ver sililar to A $24 \%$. helativel high concentrations occurred in the hepatic colls of the liver, the glomeruli of the kidney, the interfolitcular region of 
<229> cont.

the thy roid, the catilaginous tissues of the Ing, and nedia of the smaller arterioles of most orcans. Very intense, but sparsely scattered "hot spots vere also present in the renal papillae and in the subucosi of the bronchioles. wesser sites of localization were the endocarilua of the heart valves fof the atrioventricular valves, the glassy membranes of the larger hairs of the coat, the zone puliucida of the ratatin follicles and the zona arcuata of the adrena? cortex. With the exception of the liver. where the radionuclide as principally ithin the hepatic cells, most of the deposition sites vere extracellular, ithin or a dacent to connective tissile which gave a positive periodic actidoschif reaction. (A ath)

Thirteen autoradiograms of soft tissues following $C$ f 249 or $B$ K 249 injections are presented.

230>

Tay Ior, G. H., C. Re Refeld, W. Christensen, and flicine, Department of Anatomy. Salt lake City, UT. 1969. Septerber-october

Influence of Raditin 226 and PIutoniti 239 on the Dental Root Canal of the Dog. Journal of Dental pesearch, $48(5), 924-927$

Sixteen ronth old beagle dogs vere given a single intravenous injection of plutoniu 239 ( 3 uci/kg) radiur 225 (10 uci/kg), or sadiu $224(10 \mathrm{nCi} / \mathrm{kg})$ in a citrate buffer solution and the infuence of these radionuclides on the rate of narroning of the dental poot can al mas studied by periodic radiograns. Ho significast change in the rate of decrease in alaneter of the pulp chabers occurred as the result of irradiation. The influence of age on the findings was discussea. (5T)

<231>

Taysun, D.t. and G. T. Taylor, university of beah, college of Rajeine. Radoblology Division, Departient of Anatom. Salt dake city.

Californium 252, Californio 249, plutoniu 239 and Radiu 226 Toxichty studies in ice. coo-119-245: Bart of Dougherty. T.F. Tesearch

in Padobiology, Anul Beport of hork in grogress in the Intermal IrIadition Program. (P. $284-286)$. 380 p.

a proposal for a pilot study to propide experimental evidence for cancer induction by cf 252 is oresented. The objectives atre to - stablish the toricity of fission pragment entiting cf 252 relative to the al pha eritting $c$ i 249 . Pu 239 . and 225 , and to exalne the shape of the dose response curve for each of thase nuclides. The rperinental design calls for 24 tosicity ice (ale and feral at each aose level (6) for each ruclide (4). Radionuclides in a citrate solution vill be injected intraperitonea11 into young adrits about 10 plus or ras weeks of age. This pilot sevay sur oud require about 5 years to complete.

(Auth) (

$\langle 232>$

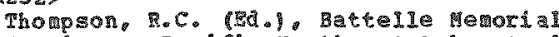
Institute, Pacific horthest laboratories. B10 logy Department. Richland

Antral Report for 1972 to the USAEC Division of
Biological and Fnvirontental Research, Volume ? Life Sciences, Part 1: Biological Sciences. B N⿴囗十 1750 (Gart 1): $103 p$.

This report covers mork in the biological sciences during calendar year 1972 . Sublect categories researched ware the toxicity of ingested, finjected inhaled, and topically applied radionuclides including plutoniug and the transplutonics: inhalaton hazards to

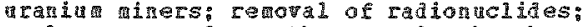
nuclear-powered prostheses and other hum aplications: and mechanisas of radiation afects parameters studied inchuded toricity. metabolism, age effects, dose-effect. long-terin afects. carcinogenicity. cocarcinogenicity. detection, inhalation hazaras, and chelate effects. Also studied were the effects of intracorporeal ralioisotope heat sources. develoment of blood irradiators and the tevelopment of blood irradiators, and th thagnancies. Iaboratory anima used in the studies were rats, mice, dogs, hasters, and miniarure smine. (ST)

$\langle 233\rangle$

Thompon. R.C. (Rd.). Batrelle nenorial Institute, Pacicic Northese daboratories. Bology Departuent, Rchland, $7 \mathrm{H} .1972$. september

Anul Report for 1971 to the USEE Ditision of Biologv and hedicine, volune 1: uife $\$$ ciences. part is Biological sciences. Bhy -1650 (Pare 1): $313 \mathrm{p}$.

This part of the progress report covers work in the biological sciences. Reports are groupen into sections covering a ride range of topics incluaing radiation effects. cellular regulator mechals radionacilas, carcinogenesis,

decontanination, temerature effects. evaluation of blood irradiators. and biological efects of internal radioisotope heat sources. Laboratory and ice, rats, hasters, beagle dogs, and pigs vere used to study the offects of $\mathrm{Ra} 226, \mathrm{Cr}$

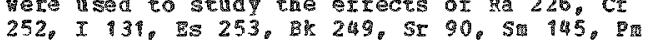

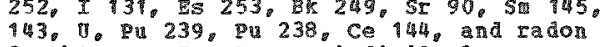
daughters. Tyenty-one individual papers. priparily colverning Pu 239, Du 02 , and rador daghters and uraniu ore dusts. vere a stracted separately for the data base. These papers inolved studes of absorption an retention. skin irradiation age factors. carcinogenesis, adninistration Foutes, decontamination, instrutentation, deposition following inhalation effects of chelates. and internal heat sources. (ST)

《234

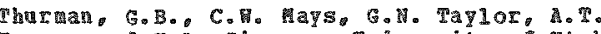
Reane, and 1 . \$issons, priversity of brah, Radiobiolog Division. Aatom Department. Salt Lake City. IlT: Agonne rational Laboratory. Radiologica 1 Physics Dílion Argone. IL: Institute hf orthopedics. Devarturnt of Forbia snatory, Lordor, Englata. 1973, Jul

Skeletal Location of Radiation Induced and Iaturally occurring osteosarcomas in Han and Dog. Cancer Research. $33,1604-1607$

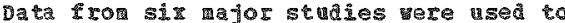
compare the type and distribution of

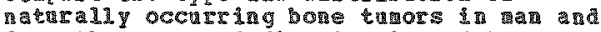
dog, the tipe and aistribution of bone turors indreed in and and og by bone-seening Falon of osteosarconas. Osteosarcon was the rost irequent type of bone sarcora observad. Fhe 
<234> cont.

akeletal aistribution of osteosarcomas induced by bome-seeking cadionuclides $1 R$ 226. Pu 239. Fुh 228 , 223, Sr 90, nd 224) In aistribetion of Hatura11y occureing osteosarconas. The jar skeletal site of aturally occurting osteosarcoms in hums is neare the kae (appromiatel $50 \%$; dogs have an extremely high frequency of these tumors in the radius (28\%) and min (6) osteosirconas induced in humans an beagle dogs differed anl in the fact that beagles had $a$ high frequency of vers ebral twors (26\%) phereas wan had a high Erequency in the ferur $(21-24 \%)$ an pelvis $(20-29 \%)$. (ST)

\section{$\langle 235\rangle$}

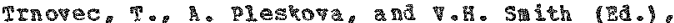
Battelle Hetorial Institute. Pacific Morthwest Laboratories, Richland, 1971

mechanisms of nepatic vptake of hepatotropic

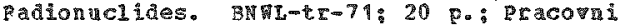
Lekarstvi, 23(5), 175-181

A survey concerning the mechanisn of the uptake of radionuclides in the lipar has beer
presented. The mechanis of heptic uptabe of polynerizable ra donuclides aepend markedy on the physicochencal condition in which they exist in the blood. 30 th principal types of 1 iver cel1s. barenchyal and Roper cells take part during unge of the padionuclides of rare difing uphe of the cadionclides of care earths and transuraniun elentits into the
liver. Date concerning pu aptake in the 1.ver of various animals has been obtaned by weans of the autoradiographic nethod and ace discussed. Further investigarion of the wechanist of hepatic uptake ci polymerizable radionclides ant begin with the latese discoveries conceming the morphology and physiology of the liver tissue. Such discoveries, fron $\mathrm{s}$ point of viev of association between bhese radionclides and plasta proteins are. por exanle, findings concerning the netabolisin of isologols proteins in the liver cells. Also. the woverent of these radionuclides in the 1 iser tissue should be investigated uth respect to the cytosis process and the mechan is of utilization of exogenous substances in the iver cells making use of the lysosome concept. (Auth)

\section{<236>}

Tsarakin. S.R.and Z.G. Sych, wot piven. 1961

gefects of Plutoni un 23 and strontin 89.90 ort Abino Pat marzo\%, AEC-tr-7512; pat of Lobedinskì. R.V. and moska lev, Yu.I. Bistribution, Biological effects, and hiotion of Padoactive Tsotopes: (P. $332-338)$, $408 \mathrm{P}$.

trperimegts were done on albino rats ranging in age from 2. to tonths and veighing 85 to 129 grams. A misture of strontim 90 and

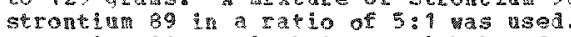
strontiu 90 vas in ha lance with its daghes

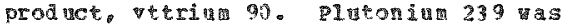
adninistered in the for of a citrate complex, Both isotopes vere itrected ineraperitonealit in doses of 1.5 uCi/gran for strontiul 89 , a and 0.0035 uci/an for plutonim 239. phese doses constitute the subacute effec ive level (uD stopl. The resules show cercal teatres in colron in bone marrow reactions to equieffective

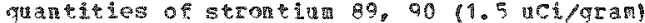
and plutonin $239(0.0035 \mathrm{uci} / \mathrm{g})$, navely: greater sensitivity of cells of the ervthropotetic class, as comparea to the granulopoieric class, presence of an initial hyporegenerative phase, increased muber of degenerative cells and pathological mitoses. Unlite strontun, the reaction of bone arrow to plutoni in is characterized by supression of the hyperregenerative phase and infury to reticuloemdothelial and histiocytio cellso (Ad

<237>

pseveleva, I.A.g and R. Yerokhing Hot givan. 1969

Behavior of Afericiu 241 in the $30 d$ of of Rats Under Intraperitoneal and Intratracheal Adrinistration. AEC-tr-7195: Part of ploskalov Yu.I. (EA.), Radioactive Isotopes and the Body. (p. $161-167), 458$.

Eperiments vere conducted on rats of the

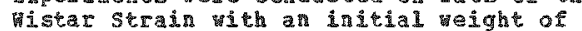
$160-180 \mathrm{~g}$. Amertein as adinistered in the form of a nitric acid solution at pH 3.8 ith

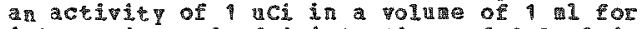
intraperitoneal admistration and 0.3 min the case of intratracheal administration. Ater sacriflce, the $\mathrm{A}$ content was deterined in the liver, thigh, kidreys. spleen, and langs of the rats. phe results show that vith intraperitoneal adanistration of $A$ nitrate, the liver and skeleton are the basic organis of deposition. The ma

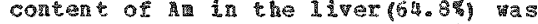
observed after 1 day and after 30 day in the sheleton $14.6 \%$ of the aninistered dosel. inety-ive and sig tenths percent of his Q1iminted th the $1 / 2=14.4$ days from the iiver. The contert in the skeleton acceases irh $^{\mathrm{T}} 1 / 2=406$ daps. one hour after intratrachea ad difistration of An nitrate about $70 \%$ of the radios lement is observed in the luggs, Ilimination of ha from this organ occarred ulth 3 effective talf-lives: 22 . hours (log of the radioeleaent. 5.9 days (55\% and 195 days (3\%). Dithe 15th ay a cher intratracheal arinisteation a considerable quanety of a vas deposited in the liver (19\%) and sheleton (26.5\%). vinety-hree percent of the issotope

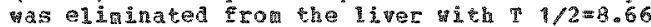
ays. The neriod for the elinindion of $\mathrm{A}$ from the sheleton was equal to 298 days. A comparison was aade of tissu doses in odgan of rats collowing adinistration of pu nitrate at the same levels of adtitury as the An used in the experinerts. It was sean that under intraperitoneal administration or the jonization dose if the skeleton i.e. in the critical organ for this method of adainistration, was lover than the dose projuced by Pu by a factor of $2-21 / 2$. under entry of $\mathrm{n}$ into the rempiratory treks the 1urgs recelve a ase that is $21 / 2-31 / 2$

times lower as compared wh the dose which this organ receiver in the case of Pu aumistration. mon

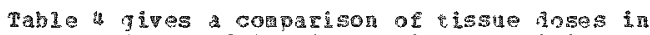

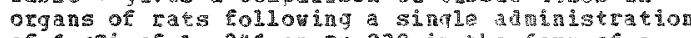
of 1 uCi of $A$ a 24 or 94239 in the EOr of a nitrate.

$<238\rangle$

Van cleave, C.0. un inersie of horth carolina.

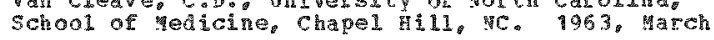

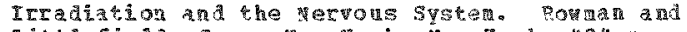

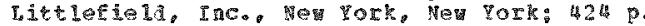

This hook atents to give comprehensty survey of the efrects of ionutin radiation on the fanctional, behavioral, and rocphological responses of the central 
<238> CORT.

nervous systea, large amount of inforation is covered. The bibliograph includes work done in the united stakes and also other contries, including the vsst. most of the chapters are devoted to morphologic inforation, but complation of physiological and psqehological stual es relating to the effects of lonizing rallation is also presented. Por example, the effects of ionizing ratiation on learning in wide range of animal spectes, especially monters, are sumarized. chapters on the effects of radition on sensory receptors and behavioral response are included. (ST)

<239?

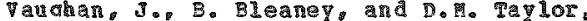
Churchili hospital. Bone Re search Laboratory. oxford. England: Institute or cancer Researeh. Royal cancer Hospital. Suteon. Surrey. England. 1973

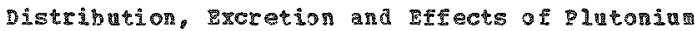
as ane-Seeker. Part of todge, pl.c. et al (Fas.) Fandbook of Erperimental Prar

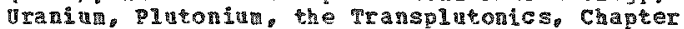
10. Springer-Verlag, rev rork, Hev Vork, IP. 349-5021.995 p.

The biological behavior of plutonitu in wa and varlous laboratory animas is revievea under the rollowing headings: The wetabolism of $\mathrm{g} 239$ with spesal reference to the skeleton, other pluton in isotopes, the patern of $q u 23$ a istribution in the steleton, the binding of plutonits in bone theory and techidque of alpha dosinetry with particular reference to the skeleton. radlation dose measurements irron deposition of Pu 239 in the steleton. effects of $p_{1} 239$ deposition in he skeletor, and removal of internal1y deposited $\mathrm{B}$ from the skeleton. aspects of plutoniu netabolis studiad were species and ace differences: effect of route of entry on skeletal metabolisio effects of chelating agents; ilfermces in the behavior of Pu 239, 238, and $23 \%$; tut origenesis: plasna transport and clearance; excretion: plasma transpor and clearance; excretion: in bone and bone marrov: binding in bone: theory and teck niques of theasuring ratiation from alpa particles: dose rates to the sirelecon; and radiation efrects. (ST)

$240>$

Volf, V. Hernforschugszentrun Rarlstue. Tnstitut fuer strahlenbiologie, Rarlstuhe. Gerra Federal Pepubic. 1974, July

Combnet grfect of DTP and cistate on an Intranuscular 210 tonin 239 Deposit in bts. fea leh physics, $27,152-153$

male rats vere infected intrammcularally wth 0.5 uci Pu $23 \%$ in 10 目 3 \%

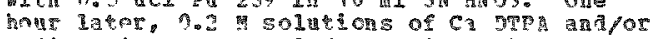
sodi un citrate were injected into the pu

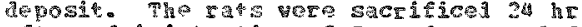

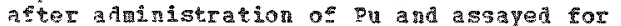
al phe activity. Regnles show that absorption of a from the injection site is increased by DIDA to a nathediq higher estent than citrate. The comined admintration of the hat doses of ach agent, however, is elearly nore effective than DTPA alone, althoulg the uptake of $\mathrm{Pu}$ by bone and liver is reduced by Dos irrespective her given alone or wh ctrate. citrate, on the ot her hat produces a strithin increased getention of Pu. The stnerdistic action of $\mathrm{DPPA}$ and citrate miat be explained by the formetion of a miget ternary conplex. (RAm
$<248$

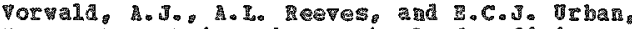

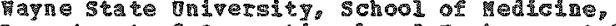

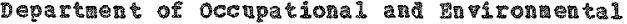
Hea Ith. Dotrost. 1966

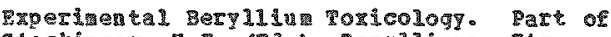

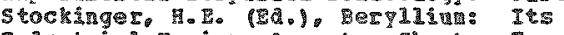

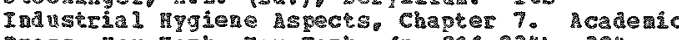
ress, ver Tork, Met Tork (2. 201-234), 394 p.

Egperantal studis concerning the coxteity of parous berplitu compounds following utilizing variety of labor $a$ tory animas are revieved. Efforts to produce erperimentali acate berylling pnearonis met success. In adition it was round that certain berplitu conpouds have an affingty for bone and produce osteosarcoma. Pri - wnarg cancer mas produced in rats and monkey

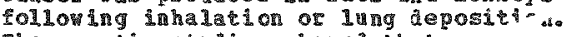
Therapeutic studies shoved that

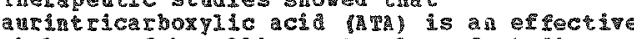
chilet or of bert11iug. Results of studies on the bological activity. transort, storage.

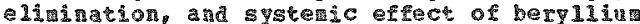
are also riefi revieved. (st)

\section{<2, 2 >}

Hallage, H. University of California, Soll Science and Agricultural Engineering. Riverside, CA. 1972, 15

Effect of stean sterilization of soll on Hesponse of Tyo Desert lant species. tCLA-34-P-51-35: Part of Behavior of Certan synthetic chelating Agent in Biological soll 5ysters. Anual Progress Report, $(0,27-30) .99$

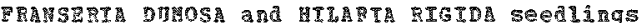
sere grow in potted soil which was collecten at the tevada Test ste near mercury Revada. The soil represented areas nât shrub and also areas betreen shrubs. Soll was ither stea sterilized or not stoan sterilized. The sterilization areaty decreased yidals ocssible because of induced phosphorus heficiency. It va sugaester that symbiotic prorrbiza necessary for absorption for the species involved ight have been Q13irated. There as an interaction in that

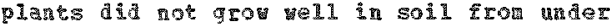
shrubs regardles of steaning indicating possible allelopathic etrects. sterilization incressed both hrond an in plants. (nuth)

\section{$\langle 293\rangle$}

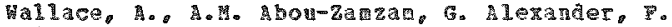
Brinkerhoff, C. Frolich, V. T. Hale, G. Jovan, Hol, Young,

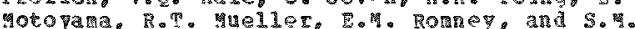
suffi fyndersity of Calitornia, fos nngeles, C\&. 197 औ

Fegnlation of the 1 icrondicient status or plants by ohelating tomes and other pactors.

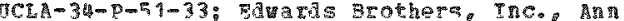
Arbor, gichigan: 300 p

The a for part of the book conta ins progress reports of the use of chelating agents in plant rutrition and of the ricromutritut status of plants. The est of the book contan a list af reports on chalating

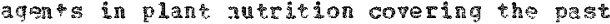
Aocnde (up to 1971 ) and partial reviem of

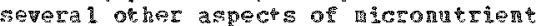

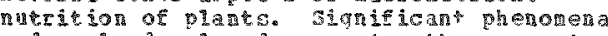
and 
(2) 3) COMm.

statrs of the 3 se of metal chelates in nlan atrition met chelution and nerhaniss of metal function in biological systers, the status of general cules comeerning plant. nutrients ano general conclusions concerning chelating aqents in plant nutrition ars discussed. whree articlesthat discuss the uptake of $\mathrm{A}$ m 24 in olants enteres in the tata base. (RAF) (CTS)

<24 \&र

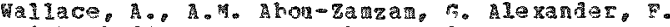
Brinkerhoff, C.P. Carkack, A. EIGazzaI, ${ }^{2}$. Frolich, V.2. Hale, C. Jowen, H. Tound, E.

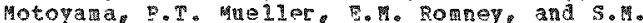
Suffl, Unimarsty of alifornia. Los Angeles, CA 93024.091

Efrect of citsus Rootstock and chelating Agent on Specife Activity of Iron and zinc in Shooss of Gratted plants and on Iron 59 , zimc 65 Lead 210 , and Americina 241 contents in the shoots.

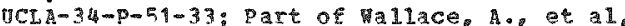
pegulation of the micronutrient status of Plants hy chelating agents and neher Factors. wards

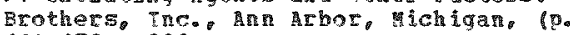

$168-1721,309 \mathrm{p}$.

Valencia orange scions mere grafted to rough lemon or trifoliage orange rootstocks and grown for 140 days ith and vithou chelating agents in calcareous laciend 102 soll to which high specific activity 59 , zn 65 , ph 215 or h 241 had been nixed. Minera analyses ere deternined after 5 days in beaves and stens of sucters grouino from the root stock and also in nev ana old leaves and sters of the scions after 119 davs. The chelating agents had little effect on Fe
content of the plants but they increased considerably the specitic activity of the ce in the shoots. 2 h 157 increased it vore than DwPA did and the effects were ruch more pronounced the rough lewon rootstock than with trifolite orange DTPA increased the In 65 contents but ith rough lexon rore 30 than with trifoliate orange. It dia not consistentig increase $z$ content. Ho eftects were noted for contents of 210 in shoots: virtully none vas present. DTP did increase the contents of 241 in shoots of both rootstock-scion combinations. (Auth)

<245>

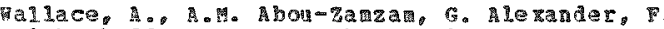
Brinkerhoff, C. H. Carnack, A. BLazzar, B.F. Trolich, Y.2. Male, C. Joven, H. Youth,

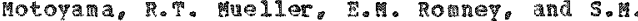
Suffi CA. 1991

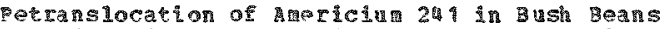
BCLA-34-P-51-33: Dare of 1212Ce. A. ot 1 Pegelation of the hicronutrient Status of plants by Chelating Agents and neprer actors. garmats Brothers, Inco, Ann arbor, Hohigang (D. 96-97). 309

Since the chelating agent DF has been shown to increase ge 24 uptake by plants, this study was nade to detertine if Dga had any was accnoulat in lants. Tants mere

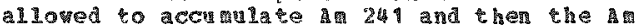
241 vas renowed and plants rere lomed to grow to maturity 241 inderily atter absorption tas largedy located in leates of plants. During stbsequent grouth period sone of the A 2 is vas transported fror the old leavas to the nev leatres and to nev roots. The che

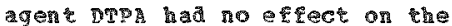

retranslocation. (ARth) (RAg)

$\langle 245\rangle$

Ma11ace, A. A.n. Aboumzaran, G. Alezander, F. Brinherhoff, Con. Carmack, A. Blazzar, E. F. Frolich, V.Q. Hale, Ca Joven, H. Ho Tongo $\mathbb{B}_{0}$ Sufti. Iniparsity of Califorria, Los Angeles. CA. 1971

Effects of Hicrontcient and TTPA ApPI 1cakions on aericiu 24 and PT 4 619-5-1 sopbeans Grow in calcareons

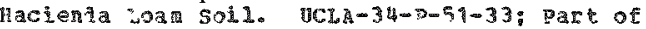
Mallace. A. ot al, Pegulation of the picrontrient status of plantis by chelating dents and other Factors. Edvaras Brothers.

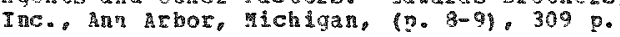

PI54619-5-1 sopbeans whici are susceptible to lime-induced chlorosis were gron in calcareons lacienda loa soll wth micronutrient and chelate additions. Ar 241 which had been aixed with the soil was greiti increased in plants to hich iron DTPA had been added to the soil. Applications of high lavels of $\mathrm{z}$ or in aecreased 241 content of plants onIY silgti\%. Fhe Fe DTP was of slight value only in correcting the line-indicen chiorosis. The pounds per acre of ee as Dip increased zn contents of leaves as auch as did 100 pounds per cre of added $2 n$. Mnganese increased nu contents of leaves: 200 pounds in per acre doubled the vn concent. (10uth

2437

พildung. R.E. and T. R. Garland, Battelle 4emorial Tistitute pacific morthest Laboratories. Envi ronmental and life sciences Dipision Ecosysteas Departwent, Richland, if 1973, qarch

Deve lovent of rethods for mearurenent of Plutonium complexation in soil and verake by plants. Broto-1750 (Part 2): Part of Varghan. E. E. at al, Annul Report for $1972 \mathrm{~s}$ lP.

$2.7-2.91 .905$ p.

Basic procedures tor the assessment of the potential entrance or Pu into the bood chain at the soil-olant level are resented. Stulies vere undertaken to determine is the effects of $p_{11}$ on the sol 1 microbial

population and on soil ricrabial processes. 2) the potential for forration of Du complexes in soli and the role of the soil microflora in this process, 3) the extent of plant uptake and translocation of pu or its compleges, and un the bond types and chemical forms of actabolites in lceobial and plant tissies ard soils. PRA?

\section{<248>}

illung, 2.8., T.R. Garland, and fl, Drucker

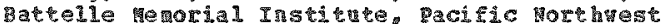

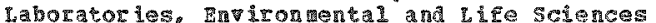
Division, Dosystems Department, Ridhland, 1974. January

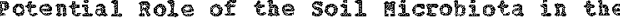

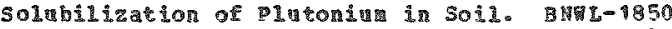
Pate 2): Part of Report ror 1973, (0. 21-22), 200 .

To provide a prelin potential for acrobial alteration of Pu

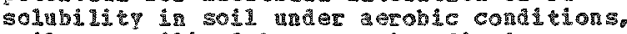

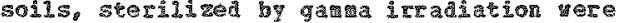

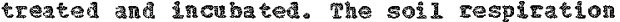

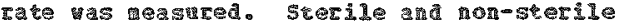
solis auring a 30-day incubaton porjod 
248> cont.

containing 19 ucifg of scil, ver subsampled and suspended in 1 liter of distidled uater and filtered after a hr equilibration period through $5,0.5$ and 0.05 u 111 ipore filters. The $\mathrm{gu}$ in the 0.5 and 0.1 u fil trates vas designated water gol uble. plutonian solubility in the non-sterile soil. While initially lower, increased bv a factor of 3 with incubation time to 14 asys and renained significant 19 higher than the gererife solil aluring the incubaton periot. The increase genera $11 y$ folloved the accumuletion carbon disoride curve, an 1 masinum solubility occurred at the end of logarithmic arouth for all classes of orqanisms. (A⿱

(24)

Hildun, P.F.。 and T.F. Garland, Battelle yesorial Institute, Pacific Northmest taboratories. Evironment and Life seiences Division。 Ecosỵters Departuent。 Richland, 1974 \% January

Inflance of soil yicrobial hesitity on the yptake and Di stribution of plutoning in the Shoots and Roots of Barlev. BNWL-1850 (Part 2): Dart of Paughan, B.Fo, et a 1 , Annal Report for $1973,(0.22-28), 200$ p.

In order to determine the aistribution of pu in the structural components of plants grown on Pu contajning soil and to deter aine if the increased Pu solunility on incubation

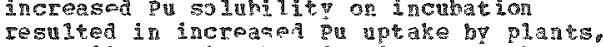
the soil were incubated, planter to barley and culturea using a split-root technique which allowed measurement of the uptake. sites of deposition and chemical corr of pu in slant shoots an roots. The results were compared to the results of similar plant studies an which the soils had not been incubated. The concentreton of $P$ in in barley shoots and roots decreased $w$ isth decreased soil Pu concentration regardless of the culture athod employed. The Provels in

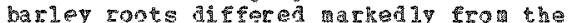
shnots uith levels of pu exceeding the shoots by factors of 3 to 8 . aependine on soll $P$ in concentration. In the shoots pu vas concentrated near the crom: in the roots Fis ras distributed over the entire lemgth of the root. Findings suggest that the $\mathrm{g}$ a in the roots originated from the soil and translocated downard from the soid in the root systen. Inplications of these eindings In terms of evaluat lon of pu hazards in the envitroncent ase discussed, (Auth) (RAB)

$250 \%$

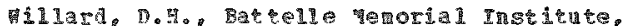
pacif noreh mest Laboratories. Biology

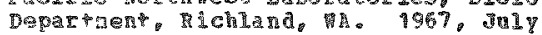

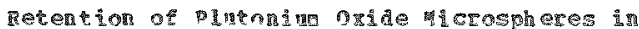

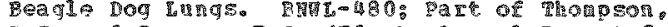

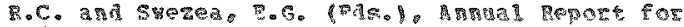
1966, 10. $97-891,207 \%$

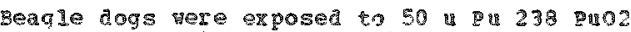
mi crospheres dispersed th air or given single 120 a $\mathrm{Pu} 23$ ? Pro2 nicrospheres by pul

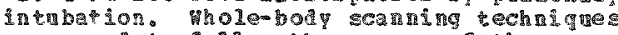
vere usera to follow the course of the

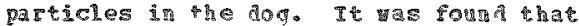
alveolar hespalt

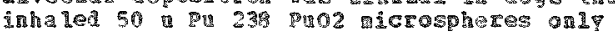

onf prticle being fond in the lung of a dog sacrifice dimediately after prposure. Tho

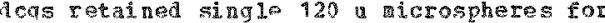
more than 6 months. The only biological effrct observed in dogs which retained partictes for 6 montlis as a possible reduction of circularing lyphocytes. (Auth) (F)

$251>$

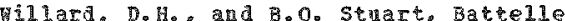
penorial Trstitute, Pacific Northest Laboratories, Biology Departaent. Richland, 1959 . खै:

Pulnonary Deposition and Retention of Plutonidr

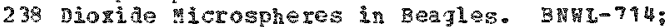

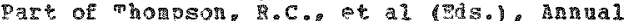
Report for 1967, (p. $0.3-4.5), 253$ p.

Two series of experiments were gerformed. The Eirge involved intalation of 50 is Pn 238 pon2 icrospheres dispersed in air; the secont intolver pilmonary intubation of 50 . 120, or 300 microspheres under wodium pert hal longlt unal scanning techniques fere used to follow the course of the particles in the dogs. The results shon that none of the 50 u

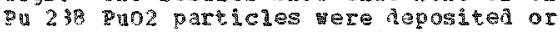
retained in the lover respirator tract of the dogs. To thogs have retained sing le 120

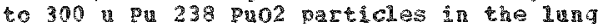
งve: 1 year after deposition by pudonary intubathon. Such deposited nicrospheres are mu less effective in produing reduction in circulating lymocytes than whon be an eguivalent quantity of 2u distributed more

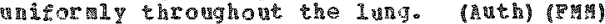

$\langle 252\rangle$

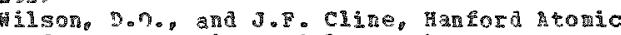

Prolucts operation. 9 jology laboratory.

pichland,

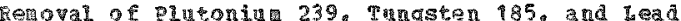
210 frop Soil by Plants and Ion Extracting 210 fros Sol1 by Plants and Ion Rtracting
5olutions.

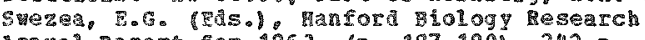

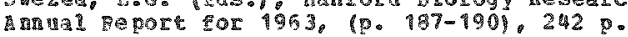

The uptace of DS 210 by barley vas strated using a roditied menbarer technigne. The wptake of 185 and ou 239 vas studied by groung bens and barlen in met cans contalning 1600 of soli. The lsotopes ere added to the soli as 2 \%ol, gbel 2 , and

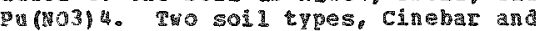
Ephrata. these, combined fich a thira soli type.

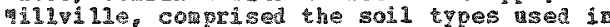

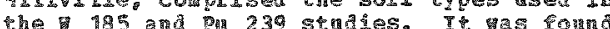

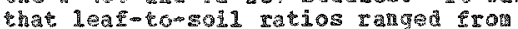
$<0.710015$ to 0.00026 for Du 239 . Fron 0.002 to 0.005 for $2 b 210$ and for 0.009 to 0.28 for 795.211 atraceirg agents ravera grearer quanties of Du 239 and 195 than

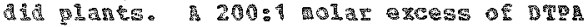
carsed 28 of the एu 239 to remain in the equilibrin 30 lation of the cinebar soll.

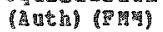

Table 2 shows upake of 185 and pu 239 by plants aroton in cans containing three differemt

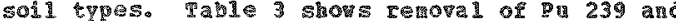

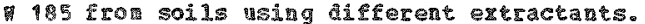


<253>

Balabuha, V.S. L.T. TIthonowa, Lo H.

Razbitnaya, D.D. S

0. L. Torchinskava, Tot given. 1966

Physicochenical Approach to the selection of Organic Compound Designed to Elidonate Padioactive Substances from the organist. EC-tI-6944 (Pev.): Rart of Moskalev. Yu.I. Distributon and 8 lological 1 iffects of madioactive Isotopes, (1. 581-591). 718 p.

A phistocherical approach to finding effective organic compler forming agents that can elinate radioactive isotopes from the organism as enphasized. The dependence of complex formation of bine chelating compounds

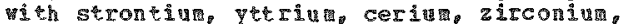
uraniug and ruthen in on the physiocherical properties of the lexent concerned, the selectivity of the isotope ith respect to specifle atom of the organic conples former. and the formaton of highly stable complezes is discussed. $\mathrm{ST}$

〈2,4

Benck, R.F. C. Crisco,A. Runguise, and E.P.

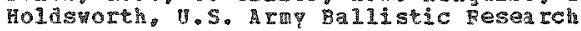
iaboratories. Aberdeen proving Groun. Aberdeen.

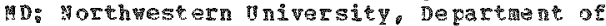

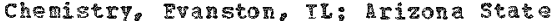
In 1973. August

Charactergation of Fallou Particles frog

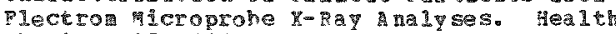
Bhysics, 25, 188019

The association of raloactivity of fallont paticle with specific elenent istribution with the particle as studied. Salulas of this stud originated from 5 H.S. nuclear detorations $(2$ in the pacific, 3 in vevade). galitative conpositions of 33 varticles mere deternined by electron icroprole analysis of

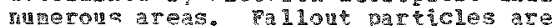
generall a heterojempous elemencs indigenons to the detonation location. In gereral, watrices of particles formed in the pacific vere ach in fald a matices of provad formen particles vere generaly an luming silicate vith traces of Fo Ca and $\mathrm{k}$. In and ton to these

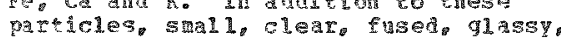

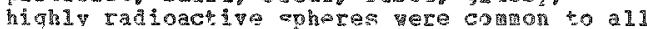
detonations. Such spheres vere losulip pused

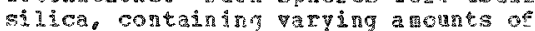

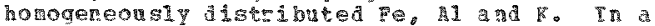
ma fority of fallont particles seud Ied, radionucildes vere concentrater hin spectric areas rich in Fe relative to the bul in marticie. phe onl fallout particles that were homognous in elemental conposition and raliogetivity a istribution vere from tho

ger

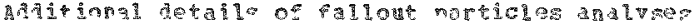

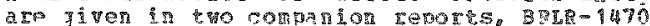

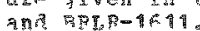

$<255>$

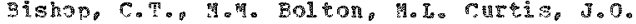

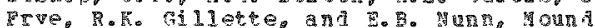

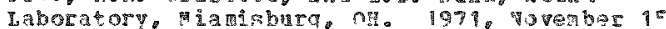

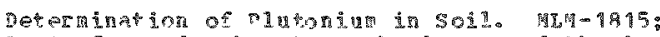

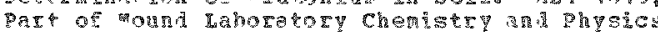

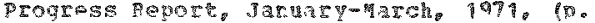
$18-29) \cdot 230$

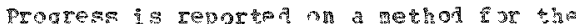
detarmanation of ol

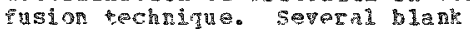

deternation possibility of contarination of the cagents or glassuare. A plutonu 236 tracer was added to all the blanks and carried through the entire procedure as a chech on percent recovery. Pon soil saliples and tro standara plitonit sanpes were analyzed. (ST)

$\langle 256\rangle$

Bojanouski.R. H.D. Bitingston, D.I. Schnelder。

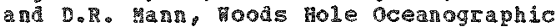
Instituton,

A Procedure for inalysis of A Eviritonenta2. Samples. coo-3563-8; part of IREA Fechnica Report Series on Reference hethods for

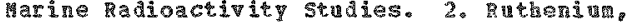
Icine, silver and the Transuranio Elements, 19 5.)

A method is aescribed for the beasutement of

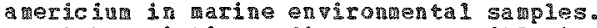
An alpha-emitting radiotracer, a 243 , is used to heasure the ratiochenda 241 separated fron sample. A lanthaide carrier is used in preilinary concentration cartier is used in preilinar concentrat

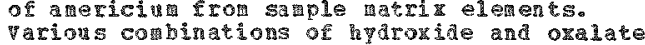
precipitan íns are used Atror the

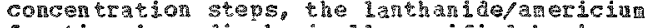
fraction is ratochealed ly prisied by lon exchange frot alpha-enitring isotoges of the natura ladioactive series. Folionthy purification the $\mathrm{A}$ is lectroplated for alpha-spectrometry. The actipity of am 241 and of the 243 yield-nantor are measurea vising a high resolution sureface barrier latector. Some data are presented to shov tha rethod is capable of acceptable accuract an prepision n exrensive series of tores aiscusses the rationale tor parious steps in the procedure. (huth) (7)

259

5 al

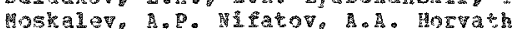
(Translator), and R.G. Monas (EA.). Lovelace

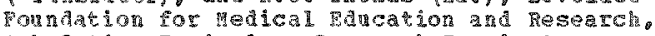

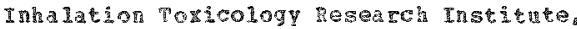

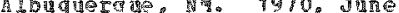

Qhysical ard cherical properties of plutonin

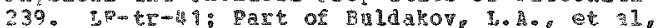

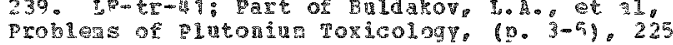
p.

The cherical and physen pronertes of

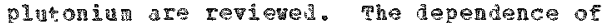
distribution of grutonin in the human hody

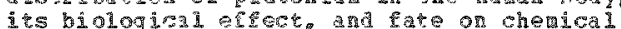
properties is discussed.

$<259 \%$

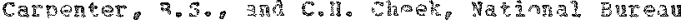
ô

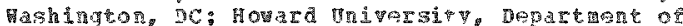

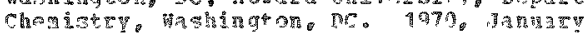

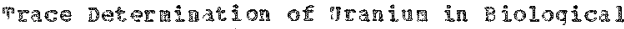

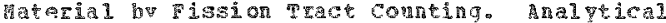
Chemistry, (1) $121-12$

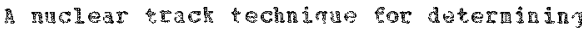

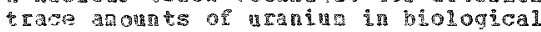
raterials is described. Saples of human whole blood and plasn were placed on teran

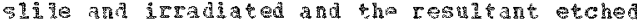

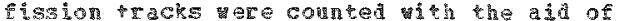

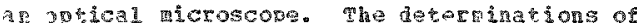

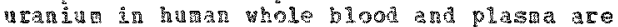
gaven in tabala cora. (ST) 
<259>

Casaret. A.P., Cornel1 university, pev state yeterinary college. Departent of physical Biology. Ithace, H. 9988

Radiation Cheistry. Part of Radiation Biology. Chapter 4. Prentice-flal1, Inc., Englewood C1irts, Hev Jersey, (p.57-89), $368 \mathrm{p}$.

The principles of general radiation chenistry are reviewed and in particular the chapter deals with the ionization of rolecules. changes produced in then and the changes they produce, secondarily in other atom and molecules. The effects of radiation on water (ionization and production of free radicals) and simple agueous inorganic and organic solutions are discussed. The last part of the chapter considers the radiation induced changes in the wolecules which are of particalar imporance to the structure and Eunction of a living cell. Effects on proteins, enztres, rucleic acids, lipids, and carbohydrates are discussed. (ST)

\section{$\langle 260\rangle$}

Clanet, F., J. Ballada, J. Iucas, and C. Gil, Faculte de pharmacie. Iaboratoire de chimie Minerale et a'pyarologie, 3\%-Tours, France: Comissariat a l'Energie Atolique, Department de Protection, Fontenay-aur-Roses, France. 1973, July: 9972

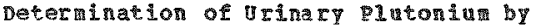
Radiochenical Analysis on Ion gehange Filters. in-tr-73-39; 6 p.: Fealth physics, $23,245-247$

A nev method for determination of urinary plutoninis is described. Knovn anounts of Pu $239(+4)$ were added to human urine collected in concentrated hydrochlcric acid. The plutoni um vas purified and fired on Amberlite 5B-2 filters. Polloring elution and evaporation the radioactivity of the residue was measured. The detection limit vas 1 pci pu $239 / 1$ of urine. The average recovery piela was $80 \%$. This method reduced anal ysis tive by one-half when conpared to the classic method using colunns of ion ezchange resins. (ST)

Translated by Kanner Associates, Reduood City. California for Los Alamos Scientific Laboratory. LOS Iamos, New rexico.

<261>

Cole, H., D.J. Simans, H, Cumins, F.J. Congel, and J. Rastener, Argonne Ration a Laboratory. Radiological physics Division, Rrgonae. IL. 1970. Jul

Application of Cellulose Nitrate Filas Eor Alpha antoradiography of Bone. Health Physics. 19, $55-56$

High resolution autoradiographs of bone containing 24239 were prepared by coating sections yith cellulose nitrate detector films that are selectively sensitive to al pha particles. The radiation alanged sites in the polyner were developed by etching with WoH. The cellulose nitrate method propides an aiternative to a utoradiography with nuclear enulsions. It does not require darkroon facilities. The filus are vert stable and vill not fog during long exposures at roon temperature. (Auth) (ST)

$\langle 262\rangle$

Darrall, R.G., G.C.1H. Ha mond, and J.F. TYler, Laboratory of the Government Chemist. Department of Trade and Industry, London, England. 1973.
ไมบ

The Deter Andyst, $98,358-363$

H sethod is described for the sindtaneous

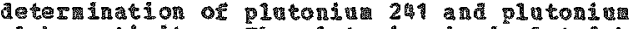

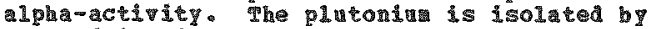

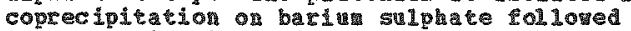
by extraction Into al (2-ethlinezril)-phosphorle acid Hich Is licorporated in a Iiquid scintillator for counting in 1 iguid scintiliation spectropeter. Interferences

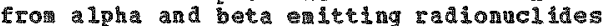
are studied together non-radioactive eleaents. The lover linit of detect son is in the region or 1 pci. (nath)

$<253\rangle$

Gind1ex, J.E, SIgonme Hational Laboratory. Argonge. II. 1973

phrsical and chenjcal Properties of uranin. Part of Hodge, H.C. et a 1 (Eds.). Hamabook of

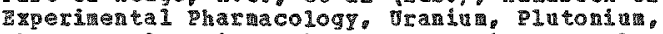
the Transplutonics, Chapter 2. Springer-veriag. Hev Pork, Hev York, (p. 69-164), 995 p.

The physical and cherical properties of viniulare reviewed. Physical properties are alscussed under the headings ertra-nuclear properties and nuclear (isotopes and nuclear fission) propertis. The cheristry of a ranin is aiscussed under the headings: getallic uraniul conpounds of uranium and non-metallic elesents: uraniu sats, hydrated oxides, wrinates, and peruranates: and usaniu in solution. The preparation and properties of retalic uranium, chemical preparation and reactions of prinarily blnary and a fevinged uraniu componds, and the preparation ma properties of a rev uraniul (to) and $(+5)$ sales important to uraniu technology are discussed. (ST)

$<264>$

Higgins, G. H. Latrence Radiation Laboratory, Inivermore, CA. 1950, october 25

The Radiochenistry of the Transcuriu Flements.

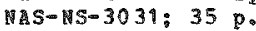

The volume deals ith the radiochemistrit of the transcuriun elenents and is of use to the radiochemist a mesearch workers in the
fields of phylcs, bochemisty or medict Included is reviev of the nuclear and chemical features of particulat interest to the radochemist, a discussion of problems of aissolition of a sample and connting

techniques, and a collection of radiocherical procedures for the element as cound in the literature. (ST)

\section{<265>}

Jackson, D.D. J.2. Rein, and G.R. Waterburye Los Alanos Scientific Iaboratory, Ios Alamos. 滕. 9973

Cheaical assa of plutonia for safeguards. L $A-0 R-73-1585:$ Confo-731101: Part of Proceedings of the Joint heeting of the Aerican Huclear societr and the homic Industrial Forba and Nuclear gergy thabition held in san pancisco.

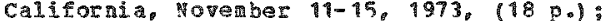
ransactions of the American puclear society. $17,303-308$

An anatyical nethodology used for Pu assay for various nuclear fuel cycle aterials ith epphas is on $L$ su practices is presented. 
<265> COHT.

Wher selecting whalpical merhod, the interplay of desired precision and accuracy levels, selectivity, and tire consunption ust be considred. Por the assay of relatively pure product pateris. generally bith high pu content, very reliable nethods are required. For pure product materisols. highly selective the thods are not required. General1\%, titcinetric wethods are favored using techificues of potentiometr? visual-indicator end-poin detection. ar perometry, conlonetry, and calorifetry. As these hichly precise methods are complex. time consulng, and reguire highly shilled analysts, atromation is needed. Less reliable methods are acceptable for beterogenerous scra-type materials of 10 h Pu contents. An alternate type of assay for scra $p-y$ pe materials is heing deve loper. This assay involves high-temperature, high pressure acid attack to solubilize $90 \%$ or more of the Pu, analysis of the lon-Du residue by a gana-ray assay, and analysis of the Pu-rich soluble fraction with an automated spectrophotometer. The gama-ray assay systen emphasizes sinpliei oresation and lowmost apparatus ith an operational goal of 10 precsion for the and 1 yis of $10 \%$ or less of the total Pu. The

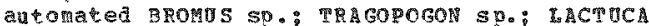

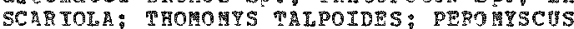
nethod for measuring 0.5 to 12 ag of pull $a$ sample volume of 0.5 ar or less. whe relative standara deviation is ip or less for measuring tore than 1 wg of Pu. The instrament takes wo to 24 samples with a througheut cate of $5 \mathrm{~min} / \mathrm{sa}$ ole. For pu isotopic abundance neasurement, bhermal Lonization ass spectrometers are used almost miversally. Samples are subjected to chenical separation procedures to obtain a pure Pu Fraction which then is placed in the mass spectroneter here the relative abundances of the 238 through 242 mases are peasured. The status of Pu ongsical standerds is discussed. (Auth) (RAF)

$\langle 266\rangle$

Rahn B. National Sny irontent Fesearch Center, Radiochemistry and ruclear Engineering Research Division, cincinati, oH, 1973

Deternination of adioactive ruclides in mater. Part of Ciaccio, I.L. (Ma.), Watar an Pol1ution Handook, Voluge 4, Chaperr 25. garcel Dekier, Inc. Ner York, Mek York, ID. $1357-9388\}$

This chapter sumarizes the technting of

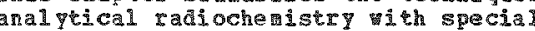
consideration ofver to the analysis of wer

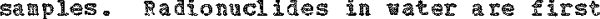
discussed in terms of permissible and actid concentrations. The tro componerts of analyeical radi ocherist $y-c h e$ ical

sevaration and radiation detection-are then described, ata a tpical araysis is presented step brtep. stin aly.

instranental calloration, sove 1 mortant pariant procedintes, and specienc analytical problens are considered. (ST)

$\langle 267\rangle$

Reenan R.G. T.S. Public Health Service, Division of occupational Heal h. Physical and chemical analyis section. Cimcinget. OH. 1966

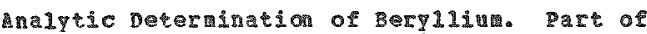
Stokinger, H. E. (EA.), Berylidua: Its

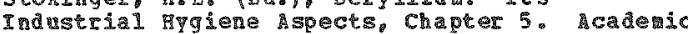

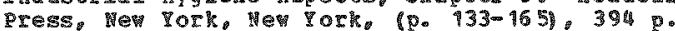

Analytical aethods for the deter rination of subnicrogran quatities of baryl1im in atmospheric samples and biologic substances are revieved. A critical exalnation of the ashing procedures for biologic materials, the cusion nethols for the decomposition of berplitum ares and refractory forts of bexylitun oxide the physical and chemical separation procedures, and the chemical, fuorometric, and spectrographic nethods for the determination of berpilium is presented. 型he special vrecautions peculiar to each preparatory and aeterminative type of method are enphasized. tabulation of the cherical methots along rith their individual applications is provided as a guide to the cherist or techrician who rust use these rroced ures. Tro spectrographic methods. highly sensitive and specific fluorometric aethot for all types of sampies. and a siplified aorin method for air samples are recomended. In adition, to rapia and direct spectrograpilc methods for the analysis of bervlizu in air sames are included. (ST)

<268>

Reough, Institate. Pacific Northest Laboratories.

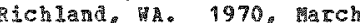

Deternination of Plutoniug in Biological

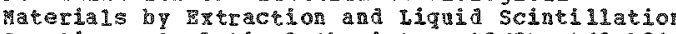

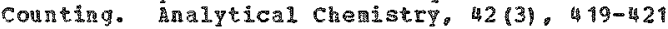

4. Thed for the determination of pluton 1 in in biological marerials is described. The method utilizes the direct ertraction of plutonin from the acjalc solution of saple ash into a tollene solution of

di (2-ethylhexpl phosphoric acid (D2 En scintillators. Extraction is carried out in the counting vidi. Liquid scintillation counting is bone ith both phases present in the vil. Counting efficiencies of 100 were obtained in scintillator solutions containing

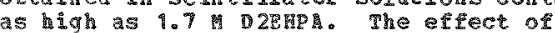
various ions on recovery of plutoni un from nitric acid are listed. Detection 1inte decends on a nutuer of factors but one a isintegration/min-gram of wet sample can be measured ith a five minute count. The techin que can be extended to the detersination of other alpha and beta enitters by the proper selection of rtractaris, solvents, and aqueous phases. (ST)

$<269\rangle$

Roide. H. and Z.D. Goldberg. Seripps Institution of oceanography. Ha Jolla, CA. 1965

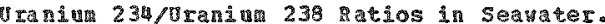
part of progress in oceamography. pol. 3 pergavon press. oxtord, England, (0. 173-177)

The ingortance of radioactive disegullibriug within the natural uranin 238 series in varions natural spocens, has steally galned I geocherical studies Recenty. Russian vorfers hav shom that the parent 238 , and the daughter. 234 in groundwats do not exist in radioactive equalitibriat concentrations. It has been postulated that hile 238 erists in crystal rocks primaril In the su 5 tate, as a Iesult of the Tadoactiva decays producing the dangher 234, electrons are lost for the nucleas such that a part of the 023 ends u in the 6 state. The lattor cor is preferentiliy bros ght into solution by weathering aters

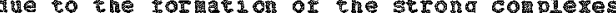


<269> cont?

formed between uranyl and carbonate ions.

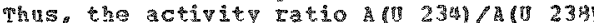
often exceeds one in surface waters. Experimentall deteraneil values of the activity ratio in surface and deep seaters from the Atlantice and pacific deeans and the nediterranean sea are uniform vith a value of 1.14 plus or minus 0.014. The error arises from the courting statistics in the

radioactive assay of the alpha particles emitted by these tro isotopes of uranium. This constancy in the ratio is consistent with the long rasidence tize of aranian and relative lack of reactivity in seraters. (A) the

$6270>$

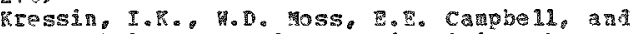

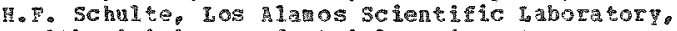

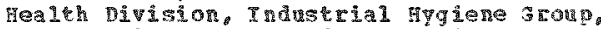
Bioanal prical and chencal Section. los Alamos.

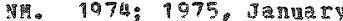

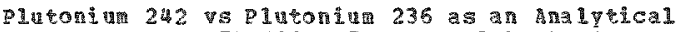

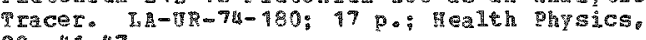
$28.41-47$

Plutonin 242 was conpared to Pu 236 as a tracer isotope in the andilysig of very low levels of Pu 238 and Pu 239 . and 1 thas fourd levels of Pu 238 an Pu 239 , and it a alaqhters, contributes to the bach ground leve 1 for pu 238 . or is increased background becomes intolerable at he higher levels of the Pa 236 tracer becalse of the large variation in the background values. In contrast, the backgrona values for Qu 238 and Pu 239 remain constant hen the 2424 used as a tracer isotope in the analysis. plutomin 242 solutions shom no ingrowth of daughers vhereas u 236 solutions require periodic purification and stendarization to renove the 232 and 228 anghers interfere in the alpha spectometry. (Auth)

Q27)

Tevine, Mo and A. Lamana. T.5. Department of Health, Fducation and welfate Public mealth SErvice, Division of Raliological Hea lth. Radiochentstry Supore Iaboratory. Ma shington, DC. 9965 , march

Radiocherical Deternination of Urandu in Environental Hedia by dectrodeposicion. PHS-999-Tा $-11: 21$ p.

mranin is isolated by erther of tyo techyigues: ad sorb th on strongly bas ion-exchenge resin pretreated uath bil washing with 94 HCl to renove interfering

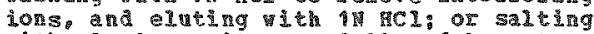

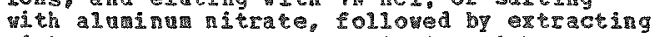
with ethyl acetare and stripping ver water. If is then electrodeposited on vickel-plated copper aisc trom al alute amonjar oxalate solution. Electroplating efriciencies are about 55 to 95 percent. A regulated porter soarce connected in parallel perrits several electroplating oneralons to proced sinultaneouslig. The procedure has been DPLIed to a series of spined solutions

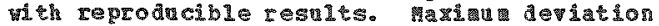
is less than 5 percent cor ay one
determination. Beer's La is followed over a

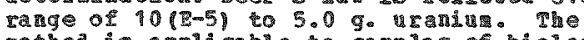
athod is appleable to samples of bialogical

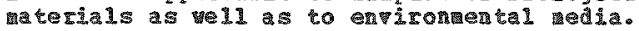
(atath)

<272

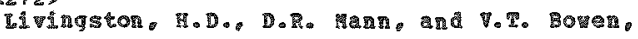

moods thol oceanogeaphic Institution, Woods घcles 생. 1972

Domble Tracer stuates to optinize conditons for the patiochenical separation of plutoniti from Large volume Seavater Sarples. coo-3563-12;

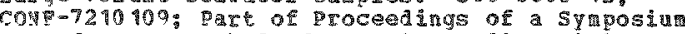
on Reference "hethods for warine Radioactivity studies: Deternination of Trangramic mlements.

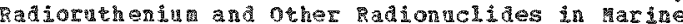

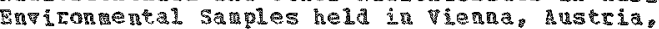
october 30-Hoverber 3. 1972, $111 \mathrm{p.}$

3y using two tracers of a single eleinent as yield-montors, adding one at late steps in sequental procedure. it is possible

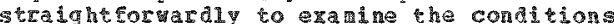
affecting exiciency at each step. In the analyses described Qu 242 paokt 2 distutegrations per hinutel was added to seavater sarples ( 50 to 60 liters), al ong ith various carriers, and yas used to deterane the overall recovery of platonia separated frow the saple. Then recover of (1) 242 a any chosen point in the procednee vas asured by the adation of a sillar amount of $\mathrm{Pu} 236$ at hat point and the percentage of $\mathrm{gu} 236$ inaly fecovered vas pised to calloula the $\mathrm{Pu} 242$ Fecovery at the trae of Qu 236 adeition. The experience

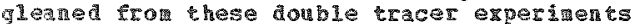
has pernited inorovements in the abilitp to recover plutolua fron 50 liter seater samples for I-spectrotertic analysis of Pe

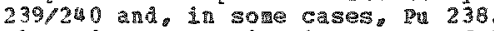

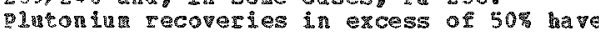
been recenty routhe, rather than erceptions as vas the case grior to this study of the sources of losses during concentration and

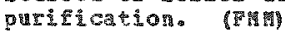

\section{$<273>$}

LOH-Heer, A. deG. Iatrence diver iaboratory. Io iperare, CA. 1973

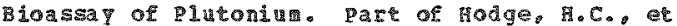

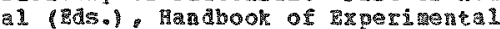
pharmacology Grandu, Plutondu, the Transplutoing chaper 13. springer-verlag, Hew

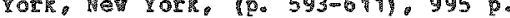

The principles on thich bioassay protgras are based vere revieved and related to reconandions of the Internationad Cotaission for Radological protection ICRPI. The general consideretons that

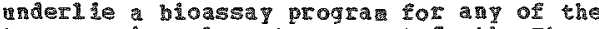
transigra includ protocols for routine rontoring and for accirental erposires sethols of preparation of satoles for radiocherical aciysis and instrumention for decection of a ph radioactivity nd low energi photons. Padochenlcal procedures desingned to

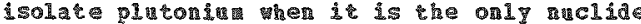
of interest but not wen it is one

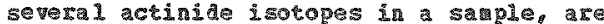

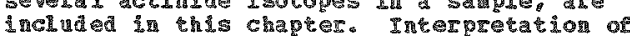
houssa results is discussed and equations relating excretion retes to hody buger are preserted. (ST)

274

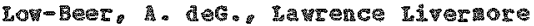

Iaboratory. Itiermore, CA. 1973

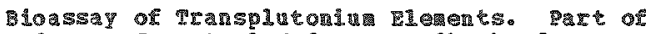

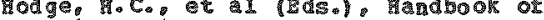

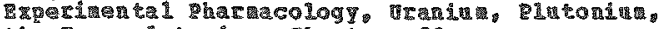
the Transol

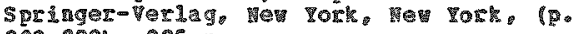
$909-3281,955$ ? 
274> COVT.

The chapter is concerned with radiochenical and detection methods that ho been designed to take advantage of the chemical and physical properties of the tramsplutonin elenents that differ from those of plutoniun. These relate to the predominati trivalent state of the transplutoning elements and to the exission of abusdanthigh energy gan tays by many of thet. Chembal procedures used for the separation of transpl utoniut elements are reviened and wodilied verbods designed to overcone the problems emcountered in dealing with biological materials are presented. Characteristic alpha energies in addition to ganma erissions of characteristic energy and 1 on energy photon spectre are used for detection and identification of individual radionuclides. Presently the interpretation of bionssay results depends on aodels that have been developed to describe the metabolic behavior of platconiu a. Hover, dat from recent investigations indicate that the transplutoniun lewents a have greater mobility and are excreted ore rapidiy than plutonis u. (ST)

<275>

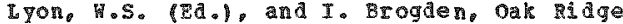
Mational Laboratory. Oak sidge. Th. 1974 January

Radioamalysis of Environmental yaterials.

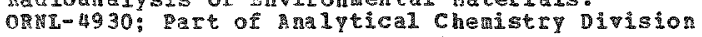
An nal Progress Report For Period Pnding septerber 30, 1973, (p. 39-40), 87 p.

Analytical and general radiochemical studes

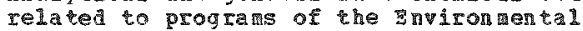
Sciences Division are in progress. An investigation of rethodology for

determination of actinides in envi ron tental aterials such as soil, vater, a nd bilogical matter has begun. plutoniu is the element of primary interest at this tine becasue of its radiologieal significance in the lorpa and radioi sotope-sotrce program. It was suggested that the vational Fin reau of Standards smpoly calibrated solutions of pu 236 to be usea for 51 multaneous evaluation of recovery and counting efriciency in pluconin analvsis. Honever, Hs and the $\mathrm{A}$. Health and sefety laboratory (HAs h) ho chosen to use Pu 242 for this purpose. 25.13 and vegetabie table atter of kou plutoniu content are being obtained fram the

International Atomic Energy Agency (TAR) and Erom C.H. \$III (AEC, Tahol, and STH D-19 is planning a round cobinn on pluton iun in water. It was desíned to have a 3 mbstitute for piutonia to permit exploratory work outside containment. A reviev of the radiochenical behap or of simiar elements led to the suggestion that thorium voma probably be best, and Th 23 is a satisfactory cracer. Putonin 237 is a use 1 isotoplc tracer and exits $x$ and gand raditions, thus apoi ding complexities of alpha counting and permitting in situ measurements. Tts properties and methods of production have been revieved in a ntînacion of obtainino a supply. (Fin)

$\langle 276\rangle$

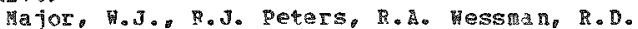

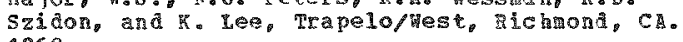
1968

Derermintion of Anericium 241 in vrine by Curin 244 Tracer. Tht $-6099 ;$ CCH of Proceedirgs of the 13 th Annual Health Physics societ symposium held in perver. colorado. Iune $16-20,1968,(16 \mathrm{pa})$
A rethod has been developed for tracing a

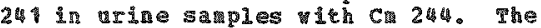
chenical procedure consists of: net ashing

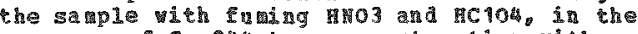
presence of cin 244 tracer, extraction with HDQHP, purification and isolation yith ion-exchange resing. and iectrodepositeilon of platinu. The A 241 content is measured by isotope dilution using alpha pulse-height andysis. birits of detection are

pproxirately $0.05 \mathrm{ais/min.} \mathrm{Sor} \mathrm{a} \mathrm{thousand}$ minute count. A typlcal chercal recovery is 65 and conding precision is ithin 3 per cent. Experinents to determine the ceasibility of using $\mathrm{C}$ 24 4 sor tracing 241 in urine sarbles showed statistically

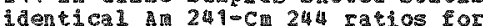

electrodeposited standards and processed sampis. indicating fractionation of $A-C$ ald mot occur. The advantages of the method are: a high degree of sensitivity: accuracy and freedom frow other alpha eniturs is obtained: no measurable residual activity fron the tracer ever appears in spectra of the 241 energy region las sometimes happens when 243 is used for tracing) and recoveries re precise and estinated $p$ ields are avoided. (Auth)

<277>

Martell, C.J., Los Alaros Scientifie Iaboratory.

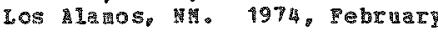

The effect of particle size on the Carrier Distillation analysis of Plutoniu Dioxide. ZA-5454: 6 p.

Sample particle size is one of the parameter that ust be controlied to ensure the sinilarity of salples and standards necessary for reliable spectrochenical analysis. In g pectroche vical carrier-aistillation analysis of Puo2. significanty greater intensities are obtained frol the inpurity elements when the particle size of the pun2 is 45 un or less. Iarge Puoz particles when present. reduce the intensites of the irpurities and of cobalto the interral standard. Because these intensity changes are not the same for each element, accurate spectrochenical yalues camnt be obtained wen large puo2 particles te present. Proper preparation of the puoz can be done easily by mortar grinding and aechanical ixing. (Auth)

$<278>$

MCDomell. Cak pidge Hathol Laboratory, Chenical Techrology Division, Dak Ridge, Tw; Tennessee pechnological vniversity, Department of cheistry. Cookevile. Th. 1974

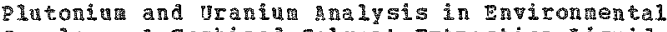
Samples: A Combined Solvent sitcaction-higuid Scintilation tethod. Talanta, $21,1231-1245$

- Reth od for the analytical determination of manilu andor plutoniun by conbined high-resolution ligud scintiliation-solvent extraction method is presenter. nssuing a sample count equal to backaround cont to be the detection linit the lover detection iint for these and other alpha-enitting muclides is 1.0 dp with a prex saple tube. 0.3 and with a gerartz saple tube using present detector shielding or 0.02 dpa with pulse-shape aiscrimination. lohe counting efficiency is $100 \%$. Identification and quantitative deter ination of a specific a I pha ent iter independent of che rical separation are possible in this method. The separation procedure al10 greater than $98 \%$ 
2278> CONT

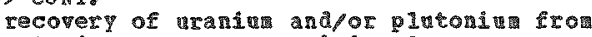
solution samples containing large amouts of iron and other interfering substances. In most cases uraniu even wen present in

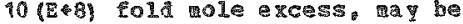
guantitativel semated com plut oni

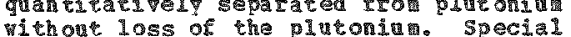

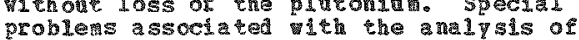

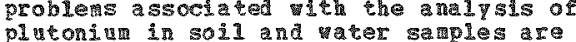

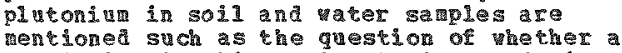
particular leaching. dissolution on fuston procedure laces all of the Pu in a sele in solution. The a valabillty of plutonidu the enfironment ro milder leaching agents such as carbonic or acetic acids is such as carbonic or acetic achds is a pertinent question relevant to the hacard and biota, and that the technidges presented are easily adapted to the assa of plutoning (OF other a 1 phe enithers) in such solvtions. (A 1 th) (F)

<279s

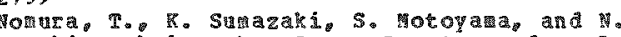
Stquki. Tokai orks pover Reactor a d uclear Fuel Development Corporation. Tokal. Tharaki. Japan. 1973, December

Rapid Deterination of plutonin in ios say Sasples. PVCT-831-73-02: Part of Toka morks,

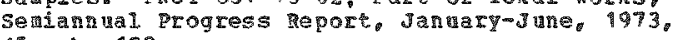
$(5) .12,.2 \%$.

A new wodified procedure is describel for the rapid deternination of gu in bioassay semples. The procedure has two

characteristic points: the adoption of solvent extraction technique asing tri-noctyl amine (TOA) as the organic phase. and the use of $P(236$ tracer to correct the recovery of plutonin. Following separation. the puritied pu is electrodeposited ito stainless steel discs and the pu is determined by aloha spectrometry. Thirten fecal samples and four arinary saples pere tested using the procedure aentioned above. The average recoveries of plutoniu vere 82. 4 and $70.9 \%$ for feces and urine. respectivel\%. The recoveries range rom $76.0 \%$ to $94.7 \%$ for feces. from $67.5 \%$ to $74.1 \%$ for urine. (Fhis)

\section{<280>}

Wot given, Philippine Atomic Energy Conission, classification and Infornation Branch, gerran. Manila, Philippines. 1972, January

Cobelt 60: A Literature Search. PREC $(M)-727:$ 249 .

This bibliography of 1.411 entries was prepared for $\mathrm{sc}$ ientists and resedrchers interested in the stud of co 50 . Fntries are listed under the following headings: chenistry, earth sciences: engineering: instrumentation: 1ife sciences: metals ceraics an other terials: phys ics (generall: physics (hidh eneray): physics (generai): physics high energy): phisics

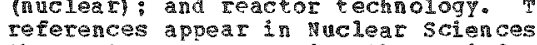
Abstracts (NSA) conering the periol July 1955 to JuI 1970. The entries are arranged alphaberically by titles under the respective subject headiags. Personal author and corporate author indexes are provided to facilitate cronpt retrieval of the vaticular research information. (5T)

$\langle 281\rangle$

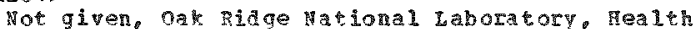

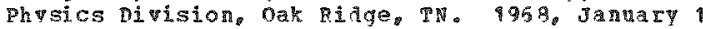

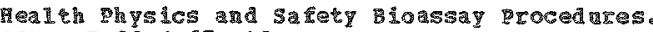

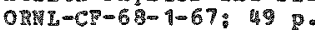

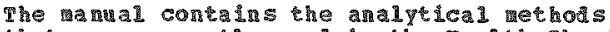

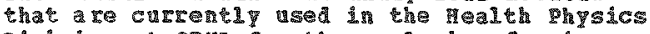

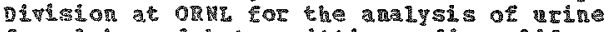

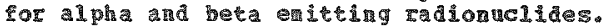
The ga urine ma tecal saples ace deteratned hy counting the savie with the crystal and a gara spectrin analyzer. OnII proced ares for the most hamatous

radion uclides are included in the report. Arong these are $\mathrm{Pa}$, actindes, $233, \mathrm{~Pa} 24 \%$ a

radiostrontiu Co tritu and cosiu. Since the rate of ercretion of some of the ore hazardows todilonuclides is 50 low, it is necessary that a large wol phe of grine be taker so that a reliable rad Lockerical ateraination can be nade. In practice, the analy ical procedures are designed for a

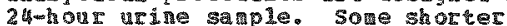
radiocherical procedures are also included

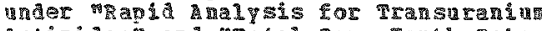

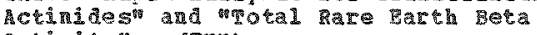

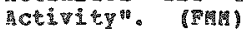

<282>

Penneran R.A. and T.R. Keenan, Los Alamos

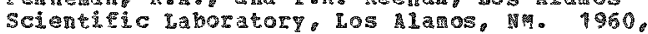
santary

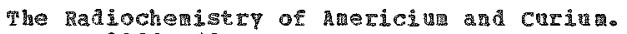
ทีS- ก-3006: 62 p.

The volue deds ith the radiocheristry of arericin of wonographs on radiochenistry of the elenents. There is included a review of the nuclear and chemical features of particular interest to the radiochentse a discussion of problens of dissolation of a saple and counting techniques, and a collection of radocherical procedures for the elements as foumd in the literatme. (ST)

<283>

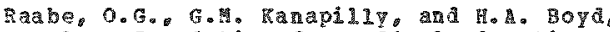
tovelace Foundation for medical Education and Research, Inhalation Toricology Research Institute, Albugneqque, H. 1973, Decerber

Stadies of the In vitro solubility of Respirable Particles of lutoni 238 and Rlutonat 239 oxides and an Aceidentaliy Released Aerosal containing plutonitin 239.

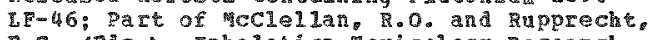
F.C. (zds.). Inhalation oricolog Research rnstitute anul teport, $1972-1973$, (p. 2k-30)。 342 .

The ob jectives of this study pre to meastre

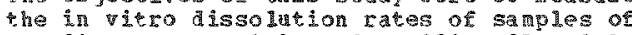
monodi sperse particies of 238 pu2 and pr

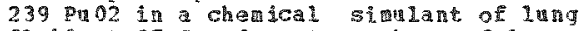
flud at $37 \mathrm{C}$ and to tese the useringess of the in vitro aissolution spsten in predicting the in vivo aissolution of inhaled aerosols containing glutosiu. In the systom a continuoush flowing strea of a chenical simulant of bloon serula passes a sample of particles wich are sealed hetween aembrane filters. Dissolved plutorian is carried off in the strean and measured to deterine the aissolution rate and the rate constant of svecific solubility. Monodisperse particles of both oxides were found to be relatively insoluble: hotever bu 238 proz vas observed to fissolve about tro orders of nagnitude faster than Pu 239 Puo2. At $37 \mathrm{C}$ the average

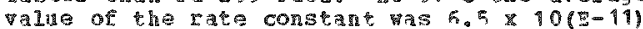


$\langle 283\rangle$ comp

a/ch 2 ay for Du 239 Fuo2 and $1.2 \times 10(\mathrm{~B}-8)$ 9/c⿴囗十 2 a for pu 238 pu02. To demonstrate the potent in dissolution studies for hazard evalution, a sample containino pu 239 aerosol aceidentally released another laboratory and involvea in ham exposures zas strided using the sare dissolution svster oplacations of in vitro dissolation data in the evaluation of lung burden frow urinary excretion data and on the efficacy of DTPA therapy are alscissed.

(स)

<294?

Silker. H. Fate Pacisic Vorthest Laboratories, Tnironental and Life Sciences Division Bcosystens

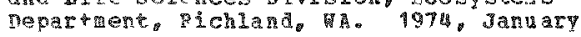

Measurements of plutonin in seatater.

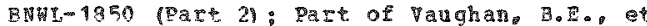
a1. Annal peport for 1973, (p. 114-119), $200 \mathrm{p}$.

Analytical efforts in the oceanographic fiel. were extended to include measmrements of plutonin isotopes concentrated by the laminu oxide and filters equoped in fiela semoling. Recovery rates ranged fron 50 to 80\%. Plutonin analysis of samples previously analyzed for other radionuclides re given in tabujar form. Soluble Pu 239 concentrations in he Sacoasso Sea verions deoths vere peasured and measurements of pu 239 and $p u$ 238 in surface vater collected in the south Pacific tore also made. Dlutomum concentrators in the Atlatic ocean were consisten with those of other investigators. Pq $238 / 239$ ratios are qiven for the northern and southern he isoteres. Staller ratios at and southern herispheres. Staller ratios hemispheres suggested that the plitonin was injected orior to the interhemispheric transer to the northern latitudes of Pu 238 from the failure of the SNBP-9A device in 1964 . (5)

<285:

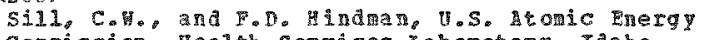
conmission, Healn services taborator. Idaho Falls, ID. 1974, Jamuary

2reparation and Testing of standar soins

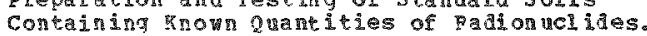
Analytical cheister. $46(1), 113-118$

A general procedure for preparation of standard soils containing a prom grantity of any given radionucida is describea. Pour separate standads have been orepared from three different soils ienonstrate the reproducib l o deronstrate the repoducibility ara analyses using Pu 23 tracer shou that the standard contain the aract concentration calculasen to have been added. that they are no decectable frhonogeneors on samples as stall as 1 arat and that horogene ons standards of lover concentrations can be prepared exacty poight dilutions with the insplifed SPIS. of a total of 56

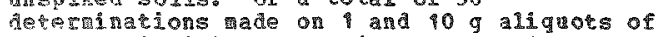
the rom individially soiked standard and to others ade by dilution. only four decermintions shom a d stinct signg of inhorogeneity ith the particalar method of preparation and sample size enoyed, of the re raing 52 measurenents, 11 agreed ith the calculated value ithin three standard deviatons of the determinaton, nat 42 ve whin tho standari deviations. whe dramate effect of heat treatrent on the leachability of the plutonilu is dewonstrated. Also, an alternative method for prepartion of solid standars for menbers of the natrial uraniun and thoriu series is suggested. (Auth)

$<2863$

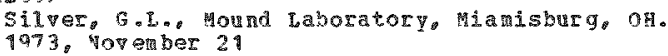

Plutoniun in Buvitongental Waters. PLl 2099 ; part of Mound Iaboratory isotopic power vuels prograts, Jilli-september, $1973,(21-23), 40$.

A theoretical discussion of how theh putonina an dissolve in natural wates and in what fort it aht be is presented. At on 5 the concentration of pentay plutoriu in equijibriu pluton 3 ur orides my have a value of almost $10(\mathrm{E}-5)$ \%. Factors that Hag $^{2}$ increase or decrease this palue in natural waters-the solution potential and corplexing aqents-are iscussed。 (sip)

$<2879$

Tay 1or, D.4. Institute of Cancer Desearch, Royal Cancer Hospital, Suton, Surtey, England.

Cherical and ohysical properties of the

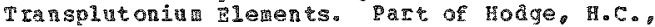
et a 1 (Eds.). Handbool of Experimental

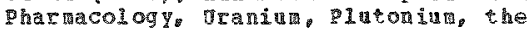
mansplatonics, cha pter 17. Springer-Verlag. New Fork, Nev Pork (p.717-738).995 p.

The chemistry of a mericiut curiug berkeling, and calltorniu is ferieved vith scecial reference to those properties which nay be important in deter ining heir bioloaical behaviot. The elements

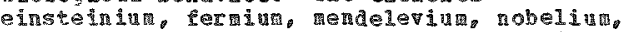
and lavenciur are includer, although little is known about their cheaisery. Conpound and colplex formation and solution chemistri of the transplutonin elements are discussed in

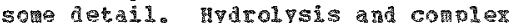

format lon play important roles in determing the tabolic behavor of americiun and curiug. and rap be expected to be similarly inportant in relation to the higher transplutonic elenents. The interactions of aericiur and curiug ytu plasta proteins. and bining to perritn, bone proteins, and other substances is discusse. (ST)

289>

Tay or . Toyal Cameer Hospital, sutton, Surrey, Ingland. 1973

Cherical and Physical properties or Plutonitu

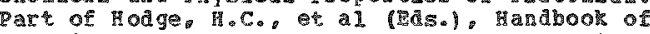
Experinental pharacology, tranind, Plutondur. the Transpiconics, chapter springer-Veriag.

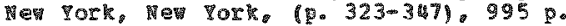

The chapter reviews chose aspects of platonu chemistry rhich are per vaderstanding of the biological behavior and toxicit of plutoniun. Metallargleal chealstry of plutoniug receives bries attention: solution chesistry and compler forration are discussed in sore detail. The pluton in conpounds discussed are those uhich have inortant technologleal uses elther as reactor fuels or in the chenical processing of plutoniur. Fese compounds together i th a fev comples conpounds i iscussed sepresent the range of comounds hich are nose like 19 to be encountered in cases of accidental

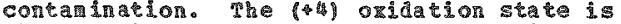
the nost ingortant in conpound formation. 


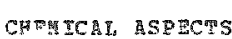

<288> comp.

Firally, the interaction of Flutoniug ith

proteins and other sibstances of biological

ingortance is reviewed. (ST)

\begin{abstract}
$<289$ >

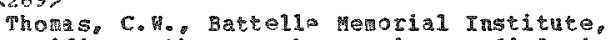
Pacific porthest waboratories, Raliologica1 Sciences Department. Bichland. WA: Batelio memorial Institues Pacific Morehwest laboratories, Atmospheric sciences rogram Rchland, A. 1973, Aoril
\end{abstract}

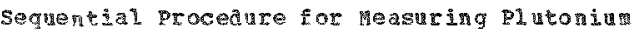
230. Putonin 23\%. Americium 2u1. Strontiu 90

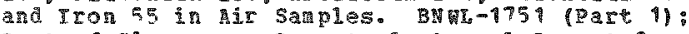
Part of sinpson, $C$. Ino et al, Annual Report for

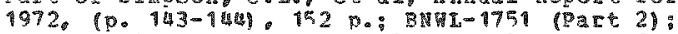

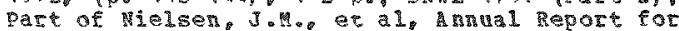
1972, (0. $66-67), 116$ o.

Tethol as developed for the sejuential

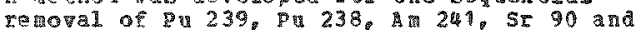
Fe 35 from a large neabrane iliter. The rileer speciner. after additian of Qu 236.5

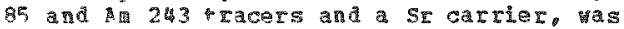
evaporated to drvness Hin acenthe charrea and zused at $900^{\circ} \mathrm{C}$. The melt was dissolved

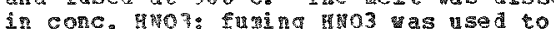
trecipitate SE as he insoluble mitrate. The filtrate is passed through a Dower $1-\mathrm{H}_{0}, \mathrm{cl}$ form that has been equilibrated it th 7.7 Nino 3. The resulting eluate contains an and

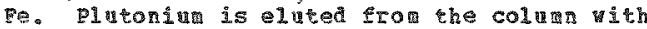

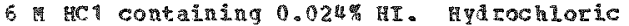
acid and iodic acid are removed from the

\begin{abstract}
Alute containing Pu by evaporating to near dryness vith conc. Huas. The restane is is acia end point of thyol hlue. plutonium is electrodeposited onto stainless steel or $\mathrm{P}$ dises from this solution at 1.1 aps for 2 hours. phe pu isotopes are then toasured hours. alpha energy analysis. Analptical ising a pha energy analysis. Analptical 241 measured on 70 saples vere 77 plus or

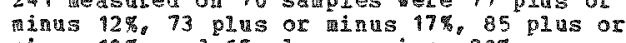
目意保 $10 \%$, and 65 plus or ${ }^{2}$ inus $20 \%$,

respectivel\%。 (RA)
\end{abstract}

<2a0〉

Thomson, G.ll. Savanah River plant, Miken, SC. 1973. June 10

Ion Frchange Separation of curdum 2 th 2 from

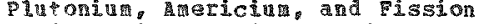

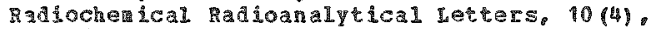
$223-230$

Curiu 242 vas separater from Pu by anion ezchange at from and fission products by bressurized cation exchange in a high flow syster. It was demonstrated th excellent anion exchange separation of pu fron $1 \mathrm{ci} / \mathrm{m}$ solutions can be obtained, if radiolytically formed $102-$-is eli 1 mated prior to and during

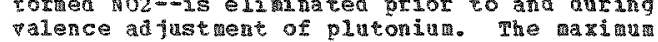
a woun of ca 242 processed in a single cation exchange process rum was $0.6 \mathrm{~g}$. (Auth) (RAF) 
42913

Beater. H.C. Urlversity of Califorma, school of hedicine, Laboratory of Hot Radiat

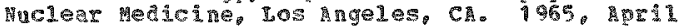

Ecology of the nevata past site. 1. Geographe

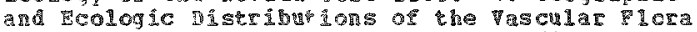

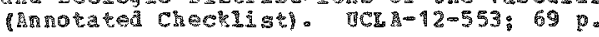

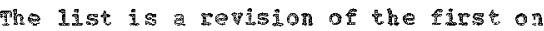
vascilar plants or the Nevara Test $\$$ inte and an expanded opfort to bring togeth what 28 hor records, or the oconrence and aistributions of the vascular species of the large reservation. Tncluded in the itst are 526 tax (of sub-generte rankl belonging to 5 ? fantises, 239 gener, and 88 specis. Pelative a bra nce vegetation types with which he taga are associated, geogra pha

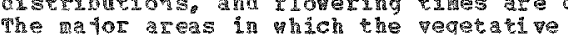
types are represented are indicat on map. (P)ing

2292>

Beatlev, J.C. University of Caiditoria

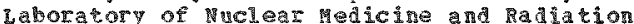
B

Efects of Finfall and penperature on the

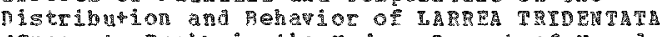
(Creosote gush) in the lohave Desert of Hevada. scolog $, 55(2), 245-261$

The efrects of cainfall am terperatire on the distribution and certain behavioral characteristios of LAREEA TrTDENTIS (Creosote-bush at and Rear ies norehern i. sonthern prata. ware ingestigated at 30 sites with I IRF

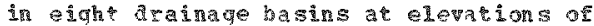

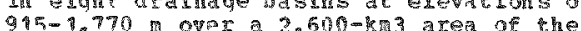

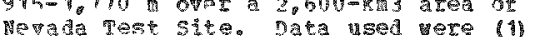
rainfal1 records for 9 yr $19963-91$ for each

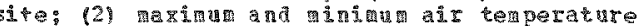
recorts for each site povenher $1952-$ pebruary 1972: (3) percentage cover by 211 shrub

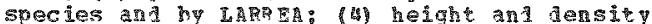
date for $\mathrm{I}$ ARPR: an (5) percentage of geres populations for hree seasons $(1963-65)$ in relation to the seasonal rajtill for each site. potal percentage cover by 11 shrub species is high raince?. less moll correlated with

elevation. Th genero io

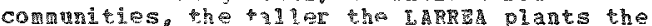
pewer here are of ther bue the relatonshis is not strictiv 1 iner. Jsing height as an

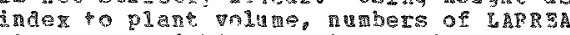

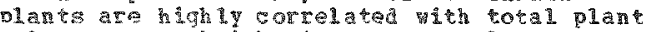

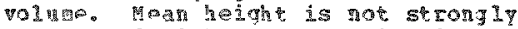
corpol zor

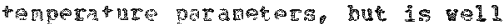
correla 0 a nTecipication pean teroerature. phe

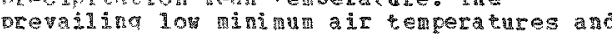
thai extrenes in the loviands of anclosed trajulare basins are inferred to be the

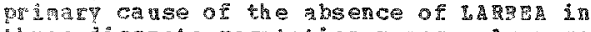
three diserep pequtarion zones. Average ertrome nin

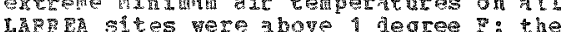
absolute ininum

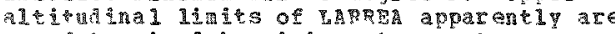

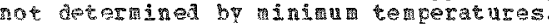
There is no patern of rela ionship between

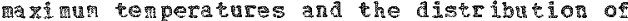
IAPrin a though the highest extrem ration

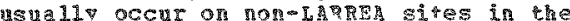

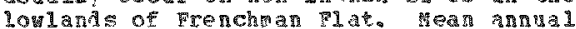

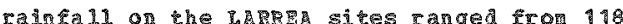

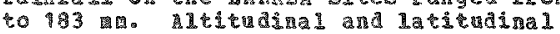
Ii

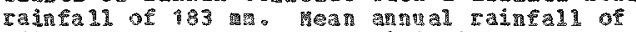
$160-183$ appears to exicked to the behavior of LARER. Germinaton trials subert the inferemes of a deleterions eftect of throngh tive: there vere high cotrelation coefficients hegative or positive. depenting on the real betreen the raineal of the arfective rainfall season and the percencage or germinable seeds: vercertages $20 \%-60 \%$ occurred

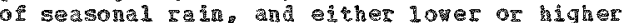
samanal rainfall resulted in lower

percertages of gerininabe seeds (0\% (Aute

2293

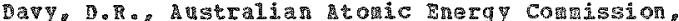

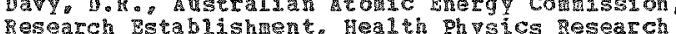

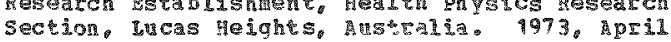

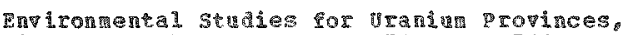

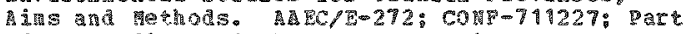
of Proceedings of the ARE SYlaposilu gnv con

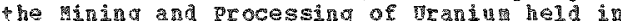
Lucas Heights, Decebuer $9-10,197 \%, 123 \mathrm{p} .1$

The general approach to the environental studies for the torthers Territory uranibs province is given. The enticonental

cheracteristics are described such as the black soll plains. sedge adowo freshrater systeras, grass growth the wet seasoll. The

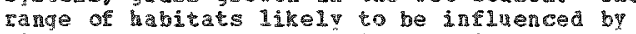
ming operations and their rebative sensitipities to the range of potential pollubants are investigated. The tolerance of significant habitars to heav metal, chencal or radiolonjcal pollution is geasured and an investigation is made on the significance of

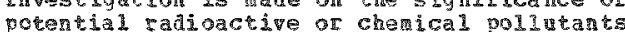
potential adionctive or cherical pol wth erphisis on items of food or iood ban both in relation to food collection by a horigines and pesent ater usage and in celation to the develovaent of wining toms. (5)

* able 8 gives the content of 7, cu, $P$ and 60 in bialogical samples. Fable 6 gives apprent concentration factors for V. Ra, Pb and Cu in grazing animals. otger tables give elements found for soil and vater andyses.

<294\$

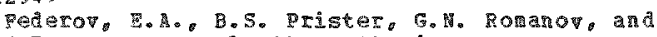
H.I. Burov, et al. State holle Bnergy corititee. uSSR. 1972

The Biological Bffect atd Eenation of Radioactie Fission products in âricultural Chains. CoH -710901: 5TT/PHB/300:

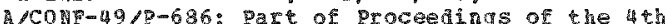
International symposiut on the peaceral toses of A tonic ganergy heli in geneva, switzerland. septemer $5-16,1971$, Vol, 11, (p.663-674) (Fussian, molish Abstract)

d discussion is presented of the aricultural aspects of the ratiation situation that can arise through contanination of the environgent by a risture of nuclear rission products or different ages a na products resulting from neutron activation or the soil. Trostinental ata obtained in or carried out inder natural contitions on experimental plots are quoted. Felactonships are established betreen the density of the radioactive contanintion 
<294> conT.

prodaced on agraculeted lard by

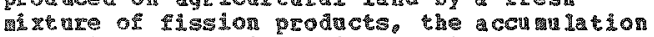
of radonclides in agriculcural crop: contamated at afferent stages of their grovth the gar a doses and comtact beta. doses to plants and the resulting radition ind 15 to the later. coesticients of proportionality are established betreen the intensity of precipitation (simgle event or continuous) of radioacinge pisston production continuous) of radioactive risson pro fanction of the conposition of the

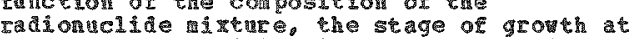
the time of precipitation and the period alaping after the plants are contanimat.

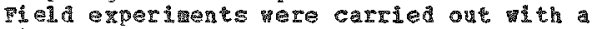
vien to deriving coerficlents of proportionality relating the density of soil contamation by radioactive ission products, neutron activation products and fissine materials to their degree of accumilation, as a funcion of the soil properties and the biological natire of the plants. The pare played by soll and follar aptake of $r$ afonclides in the contanination of croos by radioactive fission products and nevtron activation products is aiscusseu. In other experiments, in wheh a fresh mixture of uranum 235 fission products introduced into nilich coms, a study as rade of the aceutation and elimation of

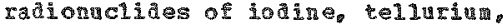

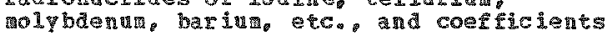
mere obeained or the proportionality between the uptake of the mixture by the animal and the radionuclide cortent of the anital products. A relationship yas escablished between the uptake of a 1 irture of fision products by cors vila the teed. the dose burdens to the critical organs and the degree of radiation injury. phe results obtajned ore nsed to calculate the lowest abnsty of radioactive contanination of agricultiral crops, peadows and pastures by radioactive fission products of differen ages the till case radiacion intury to pasture minals and plants. (Auth)

$\langle 295\rangle$

Koval'sily, V. V., and I.Te. Vorotnitskava, V.I. Fernadskiy Institute of Geocheristry and Analytical cheristry, Moscon, USSR. 1966

Regularities in the Biogenic higration of Bokhinichni zhernal, 4, 49-424

Biogenic migration of chemical elenents in the biosphere depenas not only on their concentration in the environment, but also on the denand for ther, and on the mature of the organisms. 1.e. it is determined by the character of the biogeocherical rood chains. The article deals isth study of the ti biogeochenical provinces of Rirgiz SSR, and a partial comparison of them ith regions uth normal content. The iogenic migration of y under dzy-land conditons was studied in

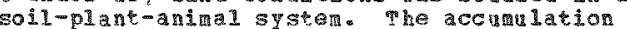
of by plants grounc on soils whel eleved 0 content was on the average of $5-85$ times

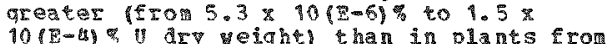
unentiched regions. pianes from the Kurskiy chernozen reservation contain frol 1.0 $10(\mathrm{E}-6) \%$ to $4.0 \mathrm{~g} 10(\mathrm{z}-6) \%$ o dry is shown that a non-niform arount of $v$ enters sheep (through the food chain) from the different zones studied. The daily ration of sheep raised in the v provinces of the Isspk-kul basin contains on the average

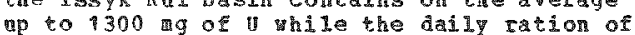
sheep Erom the Tala oblast contains from

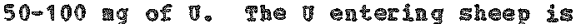
deposi ted prinerily in bones. W001. hooves 部

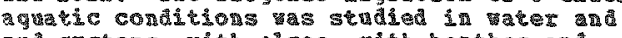

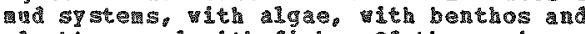
planktong and with fish. of the arine -

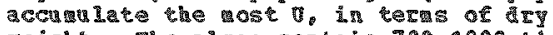
wight. The algae concain 700-1000 thas gore than $\mathrm{L}$ in the underlying a ds. Bentho

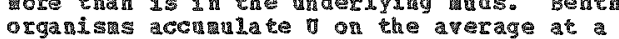
rate less than lgae by factor of six and fish accialua it to an even lesser degree than benthich organiss. its accuration gtadient vater are seduced cas passes through the food chant. It is thought that the blogenic argation of in take Isspr-Ral occurs wainly in the form or uranyl carbonate

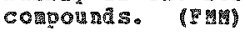

<296>

Lea vitt, V.D. Wational Entromental Reseach Center. Monitoring ST stems Research and Developaent Laboratory. Las Tegas, NV. 1974. March

Soil Survers or Pive Plutoniu contanatad Area on the Test Range Complex in Hevada. V

Soils in fire areas located on the test Range comple $x_{\theta}$ ye count $\%$. Metada, are discussed. All of the areas have at one time been sites of above-ground nuclear safety tests. The treas are contaninted th pu and are. therefore, the object of investigations regarding the woreate of $\mathrm{Pu}$ in the environate. post of the surface soils in the five areas have a gravelly texture ind are topicalip classified as gravelly sandy loan. The nafority of the surveyed land is either food-plain or alluvial fan ith deep soils having vell-developed profiles and platy structure. III of the solis are alkaline ranging in pll Irom 7.0 to 9.0 . The vegetation is clasified in tho seneral categories, low and high desert shrub. The lov deset shrubs are predonianty

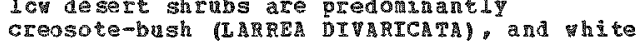
bursage (FRANSER DUMOSA). The high desert shrubs are mostly fonrting saltbush (ATRIDIE

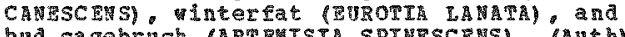
bud sagebrush (ARE PHISIA SPINBSCENS) (nth)

$<297>$

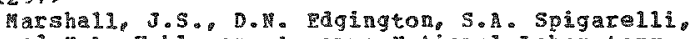
and 4. A. Tahlgren, Argonne Hational waboratory. argonis. IL. 1972

Great Hakes $^{2}$ adioecology: Introduction and

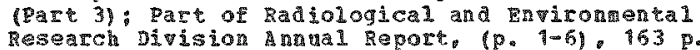

The ultimate objective of the Great lakes Radioecology zogran is an understanding of the biogeochemical behavior and pathways to man of radionuclides and toxic trace elements in the Great Lakes, and the capability of predicting the transport and Eate of artificia raAion aldes introduced the the creat Lakes fron a source. Cycling of the radionuclides pu $239, \mathrm{Cs} 137$, and $\mathrm{Sr} 90$ within the take hichigan ecosystem is being studied through representative sampling of trophic syster organism, sediment, and water from various locations, inclading existing nd known future tuclear sites. vater. sedinent, and plambton sames for radioncilde analyis were taken at 25 stations throughout iake lichigan during the 
<297> CoNT.

June 1972 cruise of the university of michigan's M/V Inland Seas. viological sa ples consisted of representative ish species (appropriate size ranges). MYIS REICTA. POW Three hundred and eighty fish samples (alewife, sqelt, sculpin, hiterish, coho salaon chinook salthong cainbow trout, lake erout, perch and other species) have been obtained rom sampling seations. Bq measuring the vertical distributons of $p u$ $239 . \mathrm{Cs} 137$, and $3 \mathrm{r} 90$ in selected areas or Lake tichian. it is possible to improve estimates of the inventory of these long-lived radionuelides in the lake. comparisons of inshore and offshor concentrations, and those of the southern and nothern reqions of ike wichigan, can $\gamma$ iela useful information on vertical mixing. vater mass residence times, ana sedimentation characteristics of various lake regions. (Fing

$\langle 298>$

Medica. D.A.g F.B. wurner, and D.D. Snith. unipersity of cailfornia. Iaboratory of vuclear medicine and Ralation Biology. Los a neles, ca. 1972: 1973

Effects of Radiation on anced Population of Horned Lizards (PRRY Sowthern Nevada. vChA-12-885;21 p.: Journal of Herpetologi, $7(2), 79-85$

Between 1964 and 1966 minimu spring densities of homed lizards ranged from $1.0-2.5 /$ hectare (ha) in 3 aha enclosures in Rock Valley, Hevada. Mininal survival of hatchling hornea lizards to the age of 8 hatchling horned lizards to the age or months vas about $26-38$ per cent. Ana per cent. Ferale hormed lizards usualiy $1 \mathrm{a}$ id one clutch of eqgs per year, nultiple clutehes mere observed in 1969. Conversely. no repraduction tas observed in 1970. The - $x^{\circ}$ ming life span of horned izards is at least 94 months. Ine of the nelosures was subfected to continuous gav a irradiation from a centrally located source of cs 137.

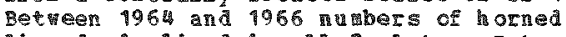
lizaras declined in al1 3 plots. Bet 1967 and 1970 numbers of horned hizards increased in the tro control areas bit continued to deciline in the irradiated plot. Fenale sterility ouling to regression of ovaries is fudged to be the cause of the pories is judged to be the calas or the

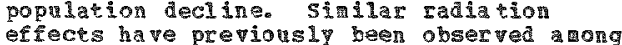

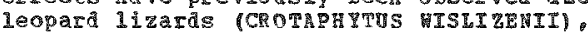
Whiptail lizards (CHEMTDOpHORUS ITGRIS), and

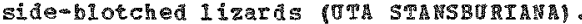
(t) uth

$299>$

Hot given, Internatonal Atome Energy Agency. vienna. Austia. 1973

Badioactive Contanation of the laringe Environise. conp-720708: proceedings of a Symposium on the Tnteraction of Radioactive

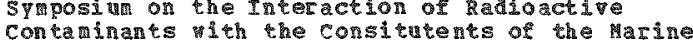
Environeat held in seatte, washingt on, July 10-14, $1972,786 \mathrm{p}$.

At the spy posiun forty-eight papers tere presented, five of which have been abstracted separately for the data base. The gecing
covered four anin topics: physical and

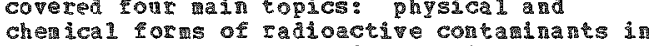
the rane environment interaction of radionaldes of hards to the health and safety of man: and study of radologically labeled enviponments. The vapers give results of recent research on many aspects of the tootes nentinned and should serve as a guide not only for those interested in narine radicactivit studies but also in the wholo subfect of oceanograph. (P.M)

$\langle 300\rangle$

vet given. university or callfornla, Iaboratory of nuclear hedicine and Radiation Biology, ios Angeles, CA. 1973

Annul progress Report for the period Ending June 30, 1973. VCLA-12-919; 142 .

Research activities of the sir divisions of the laboratory for the par June 1972-June 1973 are reported. Actiplies enconpass the discigline areas of health, envi ronpental. biological and physical and analytical studies: but are focused primarily on medical and envrontertal problems. Research in biological systemsill contribute to an understanding of radiation effects on understanding of tadiation effects biological processes. Enpiron antal stuiles at the Hevala Test site are characterized by research in phystologica 1 ecology and studies on the uptake and transport of radionculides. Sore of the inditidul studies are:

analysis and modeling of a desert ecosystem:

behavior, diet and reproduction in a desert

izard: partitioning of photosyntheicicaly tized $c 74$ in perenial plants of the northern hojave Desert: plant root and stem relationshipa: rertical root profiles of perental plants: comparative photosynthetic production in shrubs: contribution of salts to the water potentil of mood shoots: revegetation in areas daraged by close-in fallout rrom ruclear detonations: some characteristics of soll and perenila vegetarion: 70 correlations cetwen soil characteristics and plant ecology: effect of shrabs on native fertility and sodidu relations in desert plants. The progran in radich ion measurement attacks the problems of

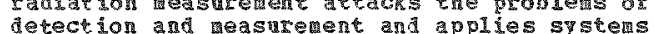
to the solution of environental wedical. and $1010 g$ ical probleas. Progress is reported on fabication and use of an esophageal probe to easure (i vivol deposits of par translocated to 1 ymph nodes. Tests with a 1 aT (w1) crystal coupled to a low poise photonutiolier in a human thoraz phanto indicate a detection lingt of about T. (ST)

<301\%

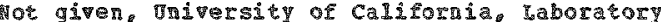
of viclear hedicine and ad Angeles, Ca. 1992

and 2 Fogress Report for the period Fualng Ju民 30 . 1972. TCI

Progress is reported on the for jor projects of the several divisions of the dabotatory. studies of nutrent and radionucinde cyeling and plant ecology were conducted primanily at the hevada west Site. Som of these studies included revegatation problem: creosote-bush

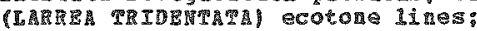
persigtence of radionclides il soils. plants, and secll mals; increased notake of A 241 by plants calsed by the chelating agent DTPA: ecologher 1 aspects of platon dissemation on in terestrial envicoments: vegetatipe propagation of moody shrub species: density of biogas of plants in the Rock Valley Sit. and of theratre on the behavior atd alstributhon of creosote-bush. Transplanting of shrubs 
(301) contr.

appears to be practical means of shortening the veretative recovery time of aisturbed areas. (ST)

$<3028$

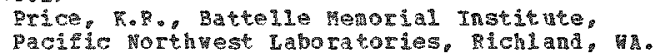
1973 , January-

A Reviev of Iransuranic Tlements in soils, plants and andals. Journal of tnviromental 2ualit?. $2(1) \cdot 52-66$

Published information concerning the atseribution and fate of mextrniur

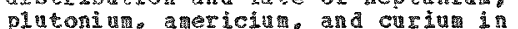
terrestriel ecosysters is revieved, and areas needing further sed dp are ideneified. In the fina 1 analysis of enviromental qualist. radionuclides with very long half lives 111 become increasingly importane to an as they continually constitute a gearer ropotion of nvis ronmental raciloactivit th. The transuranic elements have bern lientifed as the nost hazardous radionuclide by-products of andear reactor operations. The relativelv fer stadies condacted ind cate that exansuranje elements a not cemain in solution in solls, plants, or anirals, but organic conjeres and chelator greati en hace mobility. The elucidation of navural organic compleres and chelating arents has not been atternted oxidation state also influences moblity. but possible biological

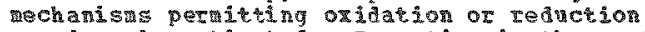
remain uningestigated. Ingestion is the most it porkat transer mechanist in ecospstens. but assi inition of transuranics frotionatural food sources is nostly unkover. Evidence in the iltarature suggeses three possible mechanisns leading to the observed increase in plart uptake ith tire: the for tation of organje complexes or chelates a builum of radionucide concentration at root surface. or the slow but continul uptake by perennial plants. Sach of these mechanisus deserwes Erther studi? (tuth)

<303>

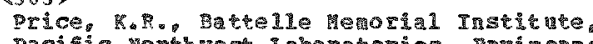
Paciple Morthest laboratories, Invironger

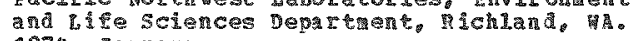
1974 . Janutp

The Behavior of 留aste nalonuclides in Soli-Plant 5ysters.

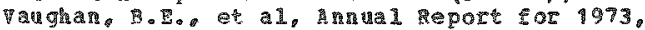
(P. $38-411.200$.

Soil-plant interaction under fiela and laboracory condicions for plants and solis characteristic of waste storage sites were investirated. Special atrention and fate of long-iviea radionuclides.

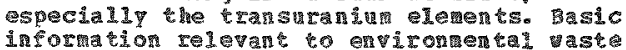
informa ton relevan to environerat mangement has been provided srow th

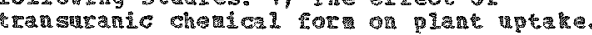

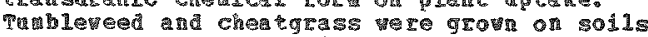

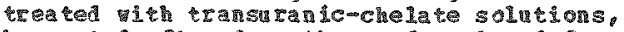
herestra after 2 moths and and

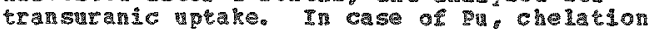
apparenty not only increased plan

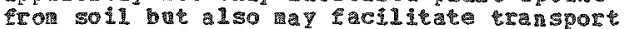
from soot to shoot. 21 the influenco of degtio of aste burial on plate upeate and

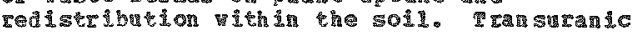

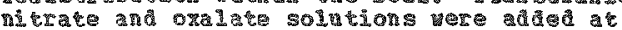

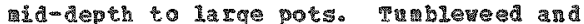
cheargrass shoot and root tusses were harvesten ateer a 2 month grovth period. Roots were harvested separately frol soil abote and belon the placement zome. In all cases, ercept Mp 237 , uptake into coot tissue vas detected only below the radioactive layer and not above it. 3 the relationship betreen plant age and uptere of transuraniu elements rom soll. Trubleves and

cheregrass plants were harpested periodically for 16 veeks. Initial plane uptake was very high but decreased ith titne though about 6 to 10 weeks and than levelled off.

pertilizers, such as amoniu sulxate can result in increased pu uptake by wore than a factor of tho. lthout complextion or chelation, transuran

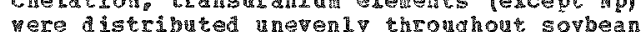
plagts wh hithest concentrations occurring plats wh hithest concentrations oct envimonental waste nagementivicatons of these results: are (1) anvironmtal pontoring sapples should consist of seading or older tissues collected near the base of the plant, (2) roung and succulent plants atractive to toraging anirals ifirely bil contain the greatest concentrations per gram of tissue and would coster mation

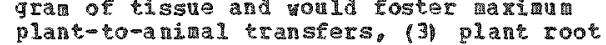
systems prowlde a nechanis whereby cadioactivit can be spread from a laper buried beneath the soil surface and wa atend several neters deep under field conditions. complering or chelating agents present in enticon aental vaste storage sites

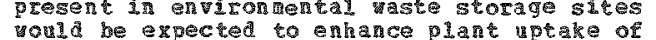

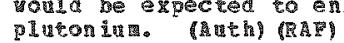

$<3048$

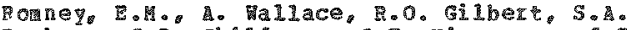
Bamberq, J. Childrass, JoE。 Kinnear, and T.L. nckernan, ynipersity of californa, Laboratory of Wuclear heaicine and Radiation Biology hos

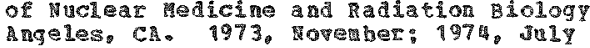

Sone Ecological Actributes and plutonin Contents of Perennial Vegetation in ires 13.

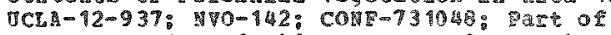

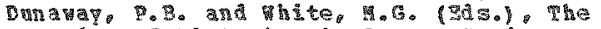

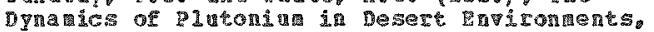

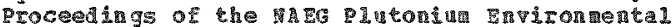
studies Prograr syoposu held in tas vegas vevad, october $2-3,1973,(p .9-106), 369$.

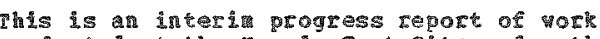
conducted at the mevada Test 3 ite under the

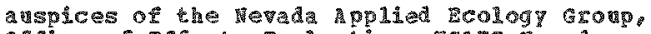
office of Effects Evaluaton, ThI

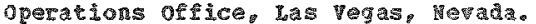
Included are data on some ecolog $1 \mathrm{ca}$

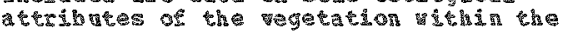
ferced porcion of the Brolect 57 fallo 10 pattern in Area 13. A 130 incl aded a re some prelininary date on the pu 239-240 and 24 in sanples of vegetation collected in conjuction vith the soil sapting progran. Provila en

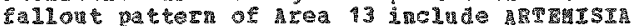

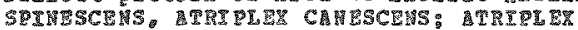
COXVESEY

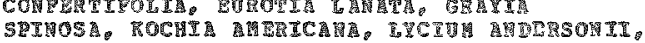

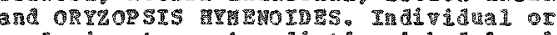
Comda

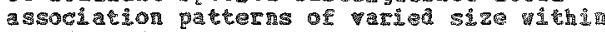
the fenced sendy rea. vegetstion cover

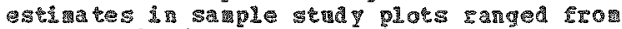
12.8 to $28.3 \%$. Shrth

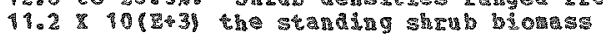

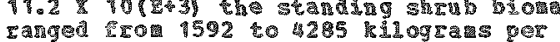
hectar 10.7 to 1.9 tom peras dere

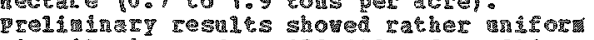
A

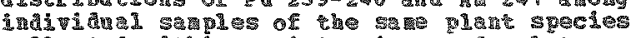

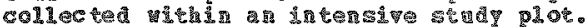

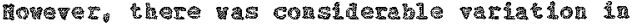


《304) COHT.

the contanination levels between different species, presuably foro supericial entraphent of resuspended particulate

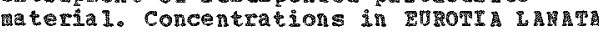
were three to five times higher than in other species sampled from the sale study ste. The pu $239-240$ and 241 generall 24 terded to decrease in samples of vegetation collected at increasing distaces frov ground zero, but there were poor correlations between

vegetation and soll pu 239-240 concentrations

in sopleth strata ithin the fenced grazing area. Pesults showed inconsistencies in the Pu/A ratios for vegetation and soil. Lover ratios found in veretation samples indicate that preferential uptahe and concentration of An 249 through plant roots ight have occurred in the protect 57 fallout area. (A) 는

$<305\rangle$

Rombey. E. E. A. hlace, and J.D.Childress. yniterste of calliforna, Laboratory of viclear Medirine and Radiation Biology, Los Angeles, CA. 1971

Revegetation problems Following puclear pesting activities at the Neva da pest Site.

conf-710501: part of Nelson. D.J. (EA.). Radionuclides in ICosystems. Proceedings of the 3ra vational symposiut on Radioecology held in

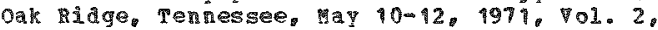

(p. $1015-1022) \cdot 1268 \mathrm{p}$

Wh rever vegetation has been destroved at the nevada pest site as the result of nuchear activities, the SALsol, species and native annul species and grasses have grown abundantiy in subse quent years on those areas. Experience indicaces. hovever, that decades of time are necessary for the perennial shrub wegetation on a disturbed site to return to its original state. In disturbed areas on Paht mesa, the disturbed areas on Pahute resa, the germination and survival of native shrub years and sufficient to return that portion of the southern Great Basin Desert to its original condition. After severe drough periods many new seedling have disappeared not airect ly because of drought but because of browsing animal activity. In the notave Desert portions of the mevada inest site the Desert portions of the revada Test sites the gertination and survival of shrmb seedings of a ahute tesa. Ani in have destroyed vid nalif all shrubs which have transplanted into disturbed areas. Newertheless, transplanting has been successful when protected rrom broving aninals, and this appears to be a practical means of shortening the vegetational recovery time for these disturbed areas. (Buth)

<306>

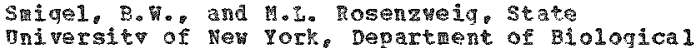

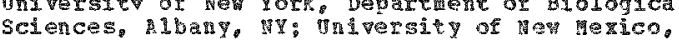

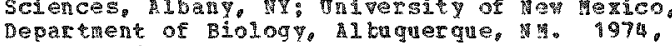
Rariy spring

Seed selection in DTPSDOHY PEROGHATHOS PENICILLATUS. ECOL CgY. $55(2)$ $329-339$

Theories of resonrces allocation in sypatric heteromyids have often been based on the idea that body size is a ket factor an deterining the size of resource packages an animal takes. Consinerable fiela ata have supported this idea. In this study, hovever, two coexisting heteronyid species of aifferent sfices are shown to be selecting the sare set of sed sizes. These findings and other conflictng da sa theoretical basis for the correlation of body size vith seed size in heteronylas. Both species tested take a lore specialized diet at high seed densities than low. This supports the hypothesis that these 3 eed eaters are in sone serse adaptively flexply selective. It also supports the rotion shat the selectivit is inversely proportion to the tire regalred to find sed. (Auth)

<307》

Stith, D.D. Hational Environental Researeh Center, Monitoring systers hesearch and Develope the haborary. Investigation Branch, Cas Vegas, NV. 1973. october

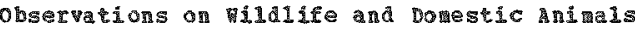
Exposed to the cround hotion refrects of underground roclear Detonations

G $R C-I V-539-24:$ iी

Since 1963, several hundred cots, horses. deer, and elk have been stationed or observed in close proxinte to surice Ground zero at

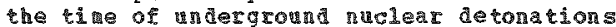
at the merada gest stre and at other test locations rithin the contiguous vaited states. This peport gives subjective sumaries of large animal involvement with spectic nuclear events. Detoration size and seismic ata peak upara groud motionsl for each vent are included. Wo physical dame was noted from the ground notion the anima is experienced. experimental verification of these subjective observations. (Auth) (Sw)

$\langle 308\rangle$

Folchok H.I. Health and Safet Laboratory. Hew York. H4. 1974, Decewber

Transaranic lements in the flarine Enviroment. MSH-7359: art of I. Broceedings of the J. S. Environdental Brotection gency Plutonian standards hearings on 21 atoniu a nd Other Trasurantur lements: Sources. Environgental Distribution an Bionedical

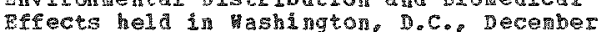

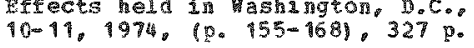

In arine envigronents, transuranic elements have been introduced, in ingersed form, in fout nuclear explosives testing, vorlatide fallout fron nuclear explosives testing atmos pheric butrup of $\mathrm{Bu}$ power supplies. and fluid wastes butrug of $\mathrm{Pa}$ power supplics, and flada from chemical reprocessing and reactor
operations. profiles of pu concentration as a function of depth in coean water colums have been measured, and the relationship between pu 239 in sedirent and the overlying water has beed studied. The accidental

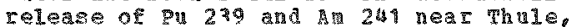
freenland showed that of the pu beastred uptards of 95 \%ent to the sediments: uptards of 95 vent to the sedinents found in the vater colums was ine
partictes. pu 239 and An 241 from fallout particles. pu 239 and A 241 from fallout variet of places in both hemis $y$ heres, for example, ca 242 has been found in Fucas fror the Irish sea and to 237 in a vaty of samples from newetak concentration factors samples crow newetak. Concentrator factors in marine plants and this level orten exceeded by marine benthos. zooplankton and the Helante Dcean species of pelagic Sargassum. In genesal it appear that marine invertebrates exhibit highor concentration of fallout w tha do fish. The data shov 
<308>

BCOU TETCAL ASPECTS

〈309> COHT.

Iitt le evidence for trophic level erhancenent of Pu 239 accumulation. although in one case studied. Starfish shoued consistently higher Pu 239 (fallout than did the aussels on

which they vere feeding. A residence

half-time of 3.5 yr was qiven for Pu $23^{\circ}$ in albacore liver frow the results of a study.

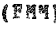


$<309 \$$

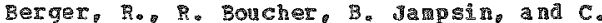
Devillers, Comissariat a I trergie gromigue

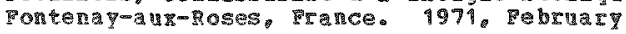

Plutonum 238 sources for Cardiac Pacenders. cons-700930;

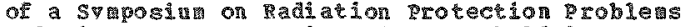

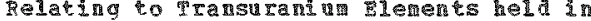
Rarliruhe, Garthany, Septepher $24-25,1970$, (p. $915-1491.560 \mathrm{p}$.

The radiation protection and sarety concepts Por platorin 236 capsules for cardice pacenakers are described according to the following: dose rate equivants.

therno-mechanical stresses, chemicat

corrosion. This surqu is supplemented by experinental results obtained when carrying out the progras undertapen under se sponsorship of the Delegation tererale a la Fecherche scientifique et ซgechnique. (anth)

<310>

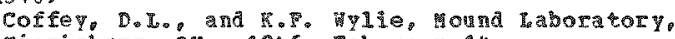

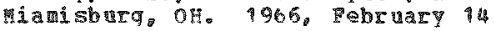

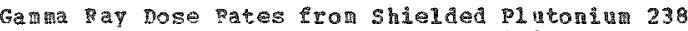
Sources. HL, 1267 : 10 po (Declassified october 22. 19711

mpeoretical gama ray dose rates from stielded cyindrical plutonit 238 sonrces were computed and compared to measured dose rates. The measured and theoretical gama ray tose rates agreed when sultable instrugemtation and procedures ver used and when certain theoretical etrects vere taken into consideration. whe agreenent betwean
the values indicated that the mal ished mass attenuation coefficionts for plutomin ana the elements used is the shieldin naterials are sufficienty accurate for compung dose races. The arreerent 150 validisted self-absor ption corrections which assumed a solherical1v astributed sonrce: the cotrection

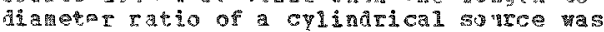
three or less. mbis methol of conputing fose

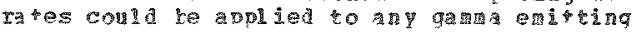
sontee. A A

$\langle 319\rangle$

Crandal. J.L., Savanah iver Laboratory

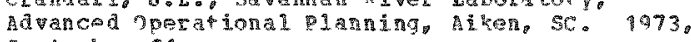
septenber 21

Applica DP-

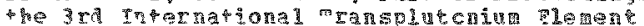

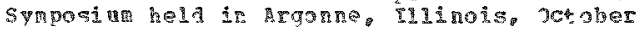

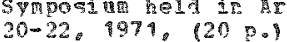

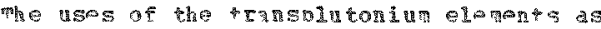

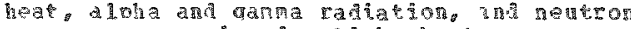
sourres at reviever. Alph her burcese

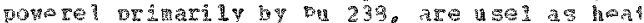

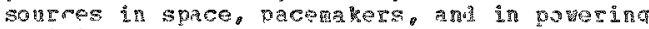
aet

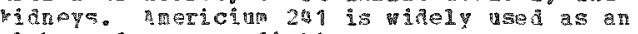
al pha ard olmariation source.

spplica ions includ use in transtission

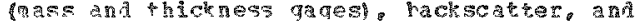

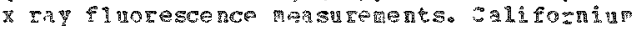

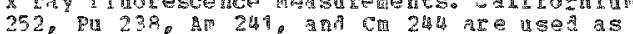

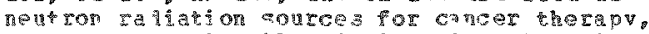

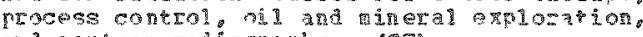

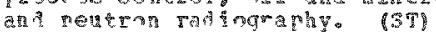

$<193$

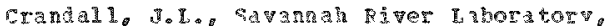
Aiten, Sr. 1959, Jantary
Surrey oI conp-681032: Part of sarker. J.3. (th.). Proceed

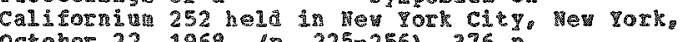
october $22,1968,(0.225-256), 376$ ?.

Troposed uses of Cf 252 that steriz rom its unigue properties are discussed. Ce 252 il1 a 1was bo relatvely expensing: but becanse of its high average neutron pleld per radioactive disintegration, it produces nentrons less expensively than any comparable radioisotope somice and comperitively ith small nelear reactors and accelerators. It thus has ofor potential in providing conpact, oorable, and reproducible neutron sources at intensities ranging fron a fer neutrons/second us to $10 \mathrm{~g}(\mathrm{P}) \mathrm{l}$ )

nertronsf secomd. Such sources have unique applications as tissue ilplants for carcer therapy, as poite sources for nevtron radiography, and as portable tools for

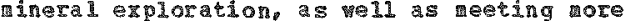
specialized purposes such as reactor physics measirements. other wes of the cf 252 sources are expected in such fields as

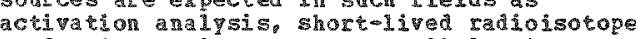
productong moisture gages. vell logging, in-line process instruatentaton; were the

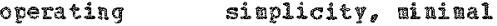

Minterange, and full preaictable output of these soures should oren gan apolications which are currenty closed to the wore convertional accelerator and reactor sources. Darticular eaphasis is being placed on industrial was of the ce 252 sources for thing process control. reli of possible cr 252 applications indicates

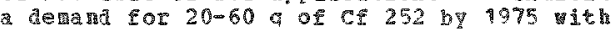
the probability of an exponetially increasing derand for sone time thereater.

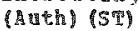

<313>

IfutE

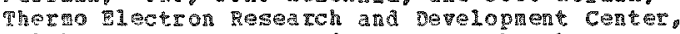

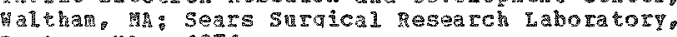
sosten, म19. 1971

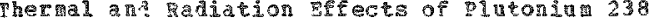
Pue 1 Capsules on Dogs and printes. covpo 711009 . part of proccedings of the A derican

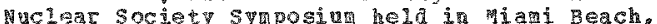
For la, October 19. 1971. Dubished in Prarsactions of the anorican Puctedr society. 14 $(2) .511-511$

Heat an $r a$ ation effects of taplanted radioi sotope hear. emchangers fueled with $p$ 238 HFe orchanger and ics insereron into dogs and

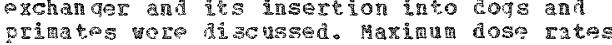

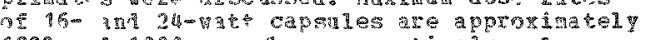

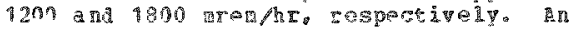

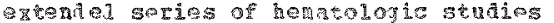

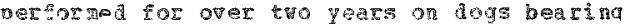
capsules a other than possible lymphocyte dinorialities

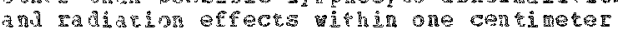
of he sources. It appears that aninals adjust their temperature regulation

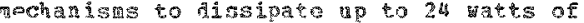

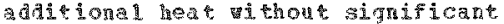
elevation in core tenerateres. The rost sitrificant cesults of these studies are the

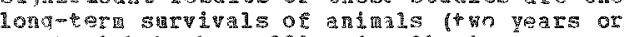

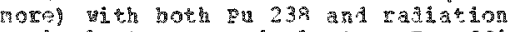
equivalent sonree implants. Tr adiltional

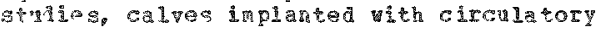

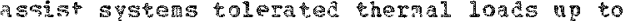
36 vatts. Those levels or hox and tantion

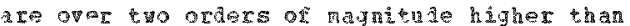


(313) CONT.

those associated with nuclear powered vacenters.

<314〉

Pot giver, U. S. Atonic Energy Comission. Division of Civilian Aplication, hashington. DC. 1957. Harch

Theoretical possibilities and Consequences of Wior ccilents in lar ge vuclear power plants. A Study of Possible consequences if certalin Assumed Accidents. Theoretically possible but Hiohly Itiprobable, tere to pccur in $\mathbb{f}_{e}$ arge Nuclear power lants. ทม

The stuay analyzes possible consequences of pajor peactor accidents and the likelihood of occurrence of such ator accidents. The conseguences of theoretical accidents started Consequences of theoretical acciddents
with the assumption of a typical power wth the assmption of a typleal power
reactor. of 500,000 kilowites ther mal pover. in characteristic power reactor location. Accidents vere postulated to occur after 180 days of operation. hen essentiall y full ilssion product invertorles had been built up. Three types of accidents which could cause serious public datages were assured. Pessinistic (ifiger harat) values vere chosen for numerical estimates of man of the nucertain factors influencing the final 西a gn itude of the estipated damages. For the three tupes of assumed accidents, the

theoretical estivares indicated that personal theoretical estivates indicated that personal infurea or kilied to a upper iimit in the horst case of about $3400 \mathrm{killed}$ and about 43.000 iniured. Theoretical property da 1 iges ranged from a lower 11 it of about one half pillion allars o an aper linit in the Worst case of about seven billiog dollars. This latter figure is 1 argely due to assuted contarination of land th fission products. onder adverse combinations of the conditions considered. it as estivated that people could be killed at distances up to 15 niles. and injured at distances of about 45 miles. Land conta ingtion conda extend for greater distances. In the large majority of

theoretical reactor accidents considered, the total assumed losses moula not exceed a fen bundred hilion dollars. Hstivations of the probability of reactor accidents taving for effects on the pubitic ranged from a chance of one in 100.000 to one in billion per pear for each large reactor. However. whether nuerical1. expressed or not, there as no disagreerent in the oninion thet he probability of afor reactor acciaents is exceedingly low. The grendices include articles on the nature and atent of a fission product release from a porr seactor. a method for calculating the naber of people that conld be affected by a fission product Ielease and the efrects of fission prodnct relase on humana and land use. Values aro Ieloase on humana land use. Yalues are ô.

\section{<315े}

fot qiven, International Atoic Energ Agency. vienna. Auseria. 1974

Environment aspects of uclear poner stations. CONF-700810: STI/PED/251: proceedings of a

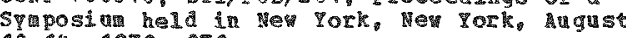
$10-14,1970,970 \%$.

At the squposin actirities in the production of nuclear power that wight have a inpact on the environtent were ascusised cond comped. about 350 participars frow 25 countries a 9 International organizations hear 58 papers and took part in two panel discussions. The crogran started with corecasting of the future needs for electrical pomer on a world-wide and nationd basis. phe standards for control of effluents vere aiscussed and. apart from the new $1 Y$ energing theral standards, the very wide acceptance internationally of the rcrp Recomendations vas enphasized. The siting of pover stations was also discussed in a muber of papers. The effects of fuel transportation, aesthetic requirements, wate heat discharge, smoke and other non-nuclear pollutant exissions, and radioactivity enissions in connection with both nuclear and cossil-fuel power stations vere compared. The part to be played by the public in participating in pouer plant siting studies or regulatory practices uas enphasized. Finall it as suggested that the real problen facing arkind vas that of reconciling inordinate growh of population with a 1inited quatity of resources. It was recognized that, if the standard of iiving in the vorld ras to continue to rise, cheap energy mist be wade available and the conclusion was reached that nuclear power was the on iy feasible answer to vorld

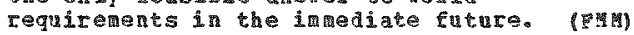

$\langle 316\rangle$

Prosser, D.C., and D.P. Kell\%, Gound Laboratory,

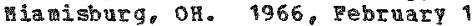

Fabrication, Testing and Rvalution of SNBp-15A capsules. Hel $-1258 ;$ M -3679 (49th EA.): 36 p. peclassitied notemer 2, 197 )

wound laboratory fabricated and evaluated heat source capsules for the $\$$ in

illitat generator developed by the General

Aonic Division of the General Dymanics

corporation. pach capsule contained

sufficient plutoniu 238 metal to provide approximately 1.5 watts of heat. Pabrication procedures and hazards avaluation including effects of high temperature burst. pibration. mechanical shock, terperature shock.

corrosion tasts, and shock overpressure for

the sources are presented together ith fuel

properties ad rabricated capsule parameters. Data for a simulated fire test at 1800 : performed with two fueled units are givan. The evaluation progra used for the $5 \mathrm{AAP}-15 \mathrm{~A}$ project has shown that the reproducibility of integral relas and fuel content can be achieved even wen large nubers of capsules are involved. It is strggested that this inspection procedure be considered in inspection procedure be considered in (Auth)

$\langle 317\rangle$

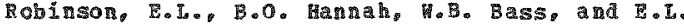

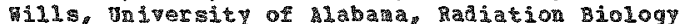
Laboratory, Physucs Departient, Bir ingha, al. 1974. Apri.1

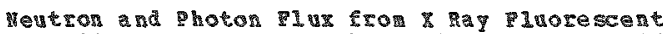
Thyroid Scanners. Healch Thysics 26,30 y-306

Systens using 8 rap fluorescence for in ivo organ studies especially thyroid scanning. are mow in use a several institutions. The most con monit used sources of gama tadiation for stimulating fluorescent I $x$-rays for thyroid seans are mulenterie sonrees of 24\%. Mlpha particles from the decay of $\mathrm{Am}$ produce nuclear reactions in the source matrix and give rise to a fist rentron fizz and garian rays. The neutron dose rate delipered to b heyes of patient during scan is less than y source nowted inside a $1 / 2$ in thich tungster 
ร2:

\$317> CORT.

alloy source-colingetor assethit and the

gara-ray dose rate dellvered to the

patient $s$ eves excon this source during a scan

Is less than 0.1 mR /hr. t typical

Eluorescent scan requires $20-30$ min. (nuth)

$\langle 318\rangle$

harner. F. F. McDonnell Douglas Corporation. McDonnell Douglas Astronatics Comany. Donala T. Douglas Laboratories. Richland, 1972

conparison of plutonin and Promethiu Contain reter for Medical Applications. Colp-720519; Part of Proceedings of the 2ta International Symposium on Power from Radioisotopes hela in 1. 1972, (p. 875-891), $986 \mathrm{p}$

Safety criteria developed for plutonin ay require modification for betamemting

isotopes such as promething beanse of the absence of heliu generation aifferences in radiation characteristics, and relative biological hazads. Design aptroaches for plutoniu capsules are compared vith those for a promethiu-fueled nuclear battery illustrating technigues wich meet the critical cremation and mechanical loats Safety test results are presented to devonserate that both plutonion and promethin devices are suitable cor widespread inplantable nedical applications. (Ad ath

<319>

Cross, F.T. and J.C. Sheppard. Battelle Metorial Institute, Pacific morthwest Laboratories. Richiand, 1973

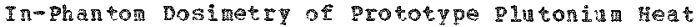
Sources for Circulation Suppor. Systers. COPF-720411: 59I/PUB/311: I of procedings of a spaposiun on posinetry Technigues Applied to Agriculture. Industry.

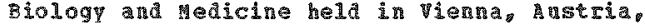
AETi2 17-21, 1972, (p. 497-506i, 685 p.

The dose cates frot various inolanted Pu 238 heat sonrces have been measured and calculated. Fe source aterial was encapulated wedical grade $\mathrm{pu}$ retal and $\mathrm{P}$ dioxide of molatial 30 wtrength. The later aterial was placed in a prototype circulation-support subsyster. The tissue eguinalent phantons vere a large bonogencous right-circular cylinder and a man-sinelating RERA phantol. Dose rates vere calculated using a roditied point-kernal code QAD-D 5 . The calculations vere in gool agrestent wh the seasurements, at least in the regions where the phot ons and meutrons make thej5 grestest dose contribution for a source enclosed in citculation-siaport syster. Dose rates to various organg and regions. both internal and external to a

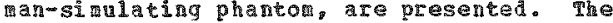
values are derived from mesurements and cllculations. verticon dose rates were measured hith sall tissue-eyinalent proportional counters biased to exclude the photon contribation. host of the nentron values vere derived rirol neasureterts on $\mathrm{ct}$ 252 Hhich was used as a substiture for the pu sources. Photon dose rates tere measured with small thermolumescent cosimeters (TID-700) hown to be insensitive to the reutrons fron cf and $\mathrm{zu}$. Integrated and average body dose rates yers derived from the Beasurements in the large logogeneous

tissue-equivalent phanton. These values are presented for an articicinl heart power sonrce with a ten wear aission life and therefore include the "groving-in" of the dose rates crod the heat somrce 1 mpurities. these palues vill be compared vith past radiolonic experience and conclusions vili be presented on the acceptability of an artiricial heart device incorporating medical grade pu heat source. (ath) 
$<320\rangle$

Augier, J.A. D.J. Cheistian, T.D.Jones, G.D.

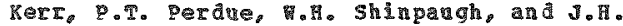

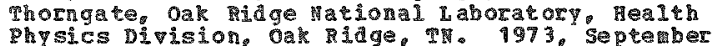

Contribution of tatural Terrestrial sources to

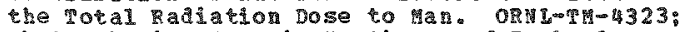
gh.D. Thesis, Geogia Imstitute of Technology: $160 \mathrm{p}$.

Investigations vere done to deterine the inportant paranerers affecting rador enanaton from radionclides for typical concentrations in soilo to determine the possibility and practicability of using high resolution spectrometers to peasure 1ow levels of radioactie contambation ane to han activities. a to evaluate najor sources of extermal and internal han exposure dae to the natura radiation envi ronnent. It vas demonstrated that the most important paraeter in controling the enarion of radon frop concrete is the free moisture contern of the concrete. Hadon concentrations in diellings constructed of uranian bearing pateinis are orten in the rang 1-5 pci/1 of atr. These concentrations result in the irradiation of the basal cells of the lung bromchial epithelin near the first ive bifurcations by the alpha enitting da ughters of radon that orten exceeds. sonetines by a large cactor, the averge thole body absorbed dose due to the garina rays from the natural radiation environdent. Further, the doses to these basal cells over

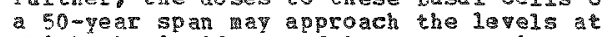
whoh the inciance of 1 ang cancer in uranin miners is increased by a factor of two over the normal incidence in wer of the same age.

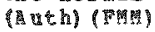

Table 3 shows average concentration of 0 and Th in geologic fortations. Table 4 shovs geogranhical ares having soll concentrations of 15 andor thorin to produce the dose increvents indicated.

<321>

Cook. C.S. U.S. Naval Radiological Defense Laborztory, San Francisco, CA. 9968

Basic characteristics of Nuclear padiasion from Ballout. Covp-680507. Part of proseenings of Symposium on Radiological Protection of the Pubic in a vuclear Mass pisaster held in Interiaken. Switzerland. Wa 26-June t, 1968. (1. $65-83), 688$ p.

Th is discussion provides a brief surary of currentiv a ailable information abont lonizing radiation frotallout. Pifty-eigh ceferences are attached to provide a basis for alditional search of the literature. The review considers the following topics:

Ionizing radiation resulting from a nuelear meapons detonation conparison of fallout and fission product gana ray spectra.

aerodynaic effects, detonation conditions neezed o forn local fallont, rectionation. neutron induced activities in surrounding meterials, gama rajation from jistributed sources, calculate radation rielas ana esperiments usina sitalatel sources and using real fallow tields. (8B)

$<322>$

Dole, S.H. and T.A. papeti, Fand, Santa Monica, CA. 1973, January

Environtental Pactors in the production and ve of Energ\%. $R-992-$ at: 770 .
The afor undesirable environantal ofects of energy production and ge, the avalable control technigres, ant the costs of control.

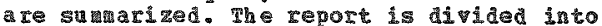
sections dealing the the ais, the ater, and the land--each division indicating the sphere of man"s natrical envíconer hat is most affected by ham activities associated vith energy groduction or use. The section on a is inclues discussions of as poldutants fron or incidental to the combuston of trels, ait pollutats E⿱艹 theria 1 inputs into the ilr gaseors resources and acoustical noise. The section on water is concerned wh cherical-physical factors such as oil splils and acid tine drainage, radialogical factors such as critila and other radionctivit crom liquja efriverts, ureniul niling zastes and ther 1 inputs into ater. The section on land deals in ach a fallout from the air. rineral fallout from cooling towers. solid wates. high-1evel radioactive astes land subsidence dive to underground wining of cost. strip-rining of coal. land use in pover production and trangrission atd hydroelectric

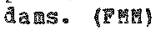

Table 5 gives a surary of releases of aำ 焦sicn and corrosion products frot porer reactors in 1 iquid effuents in 1969

<323>

Fey. L.. Jr., Las tamos Sciemticic Laboratory. LOS Mlamos, H. 1967 , June 16

Health Physics Suxyey of Trinity Site.

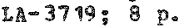

More han 20 years after the first nuclear veapon test, a health phics survey of the Trinity site as nade to deter a ne wether it ould se rajologicalit safe for the public to visit. The survey ineluded monttoring of the ontire site for whole-body erposure rates, monitoring of samples of trincite carried awa from the sjote for gammaresposure rates, measurenent of surface epposure rate for 1 ndividual pieces of erinitite. calculation of deposition of radioactivity in the body from injested trinitite, amalysis of soil samples. and analysis of air samples taken in the area. The whole-body ganas-exposure rate at Trinity site varied from a high of 3 nolh near ground zero to 10 of 0.03 ag/h. Fe be wole-bod exposure rate received by a person visiting Trinity site onld avarage less than 1 in $/ \mathrm{h}$.

Trintite also contained sone unfissioned $\mathrm{pu}$ 239 but the deposition of radioactivity in the body due to ingestion of trinitite cannot be considered a problen oning to the large a mount $i$ to voll be necessary to consume in order to deposit a maxida permissible body burden. Soil and air samples taken at Trinity site revea led that all the activity is contalled in pieces of trinitite. There appeared to be no activity associated vith particles of respirable size. From the cesults, it does not appear that anyone coulc Feceive any radiation influry through a visit to Trinity site. Gama radiation at the Trinity site comes from fission and

activation products sand to for a green glossy substance called trinitite. Most of the gama activity is caused by $\mathrm{Cs} 137$. Eu 152 and 5060 . (FHM)

<324s

Erigerio, N.A., K... Eckersan, and R.S. Stome Argonne lational Laboratory, Rnvironemtal statement Profect. Argonne. II. 1973, september 
<324〉 COHP.

The Argonne Radiological Tpact progran (ARTE).

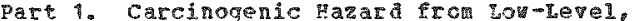
Low-Rate Radiation. AML/ES-26 (Part 1): 35 .

The entire Argonne Radiological Tact Program is briefly outlined, and part of the prograr dealing wth ratation hazards from nuclear powe planes is ajscussed in detail. Various models and predictions of carcinogenic hatari are examined and conpared wth actulal experience in ${ }^{\prime} \xi_{\text {a }}$ a foreign populations. 11 of the podels ptadict significant inctement in walgnan mortality with increasing background. Observation of the actual populations at risk stows not only no increment, but an actual aecrenthe so that these prefictions are left quite rithout observational support. It is concluded that extrapolation of high-rate and usuld high dose-level studies to lov rates an lov levels is probably invalid, and the ratiation at sich levels and ates does not constitute an environmenta 1 catcinogen of significance. (Auth)

$\langle 325\rangle$

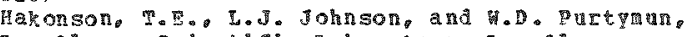
Los lamos scienticic daboratort. Los Alaros. vos 1993

The Distribution of Plutoniu in Liquid hate

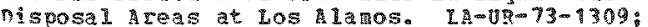
contr-730907: part of poceedites of he 3ra Ing International congress hela in washington D.C.e september $9-14,1973,(6 \mathrm{po}$

An ecological investigation of plistonin in the Ios Alaros Scismeific I aboratory environs is aescribed. Data are presented on the distribution of plutoniu in the llupial sediments, water. vegetation and roderts from Mortandad canyon, an area which has been usea for 11 quid aste disposal for 10 years. It was concluded that strea channel sedinents we the mar reservar of the waste Pu. Levels of pu 238 and pu 239 increased Erom less than $0.5 \mathrm{pci} / \mathrm{a}$ ary at the premolitil stations to over 370 pci/g in post-outell stations to over 390 pci/g in post-outell
saples. Data on 10 growing grass species showed that the plutonin concentration ratios for plant/sediment are on the order of $3 \approx 10(E-2)$ to $8 \times 10(2-2)$, which was goout an order of angitude higher than that reported by others for root uptake of plutoni un fron soils. Where appeared to be relationship between growh for and the plutoniug contest of the plant. Lower grouth Forms contained higher plutonilit concentrations than higher groth for $\mathrm{as}_{\text {. }}$ The wighest rean Pu 238 and Pu 239 concentrations in the lung and hide of codents from the canyon stuggested that resuspension of sedimert-bound plutonin ay

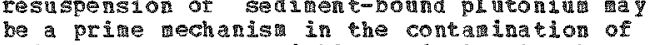
rodents. The apreciable paration in the plutoniur data for rodent tissmes indicated that the contanination of the small aral populations living near the strean chanel is

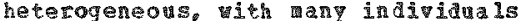

receiving inute quaties of plutonin and others receiting rellatively large arousts. The pu $238 /$ Pu 239 catios calculated from the date provided assessient of the vertical and horizontal movement of the

effluentassociated pletonin. (Auth) (PMH)

Table 2 shows the Pu $238 /$ Pu 239 racios in water, sediment vegetation and rodents from ortandad canyon in october 1972 .

\section{$<325\rangle$}

Hardy, E.P., Jr.. Health and Sacty Laboratorp
A

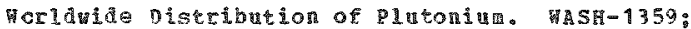
Part of Iiverman. J.L. et ad Proceedings of the U.S. Ervirontental protection Mency Plutonin standards Hearings on plueoniug and pther Transuraniu lements: Sources. Qnvironmental Distribution as Biomedical effects held in washingeon, D.C., December $10-11,1974,(p, 115-128), 32 \%$ po

Plutoniur conearination of the ervirongent on * global basis is priarily the result of atrostheric nuclear veapons testing. There arelocalized areas were pu contination has occurred through accidents or inadvertent releases fron nuclear facilities. The total anounts released are on the order of curtes as conpared ith hundreds of thousands of curies ron nuclear tests. Pbout 320 silocuries of Pu 239 have deposited and abous 4 kiocuries reatinitu in the stratosphere will reach the earth" surface. Measurenents are being wade of air concentrations at ground level and of the deposition tate. It is agreed tha hum exposure to pu is privar ily chrough inhalation. ve assess the inhataton hazard the fraction of the total concentrotion which ay deposit in the nonciliated portion of the lung, nust be knotn. Measurements of deposited gu have rade it possible to estidate the total anount on the earth surace and to deternine its distribution. A 241 , with a 25\% activity level of that of $\mathrm{gu} 239$. shows a depth distribution in soil sililar to pa 239 . futher stuies in this area are indicated. (RAR)

Figures $1-7$ show stratospheric ingentorp of Pu 239. stratospheric intentory of $S$ NAP-9A Du 238 Qu $239 \mathrm{in}$ sur cace ais (Hew Yorkt. distribution or deposited Pu 239 and 238 in the northern and southern hemisphere cumiative deposic of $P$ o 239 in $\mathrm{CA} / \mathrm{Km}(\overline{\mathrm{E}}+2)$ in the United states. and Pu 239 deposition rate in Wew Yark.

$\langle 327\rangle$

4c13ing sworth, R.E. U.S. A tomic Energy

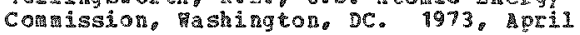

Envi ronmental statement, inderground fidclear resting Prograt Hevada Test site. WAspu-1526: $60 \mathrm{p}$.

This environartal starement covers all undergroumd ruclear tests and preparations for tests of one agaton or less at the vevad Test site during iscal years 1974 and 1975. The probable inpact on the environgent due to continued anderground nuclear testing at the envi ronental inpacts translate to costs in terns of subsidence craters. pockets of underg round ratioactivity. and a irect ground ncton. The subsidence craters are depressions in the gromind surface that occur as anifestations of ground settling above the detontion cartit. once Foraed the subsidence eraters do mot constiture a particular hazarid. Most of the radiozctive paterias which are created as a tesplt of the nuclear explosion become trapped in wolten rock as lt solidifies, nedr the detonation polnt so that noble gases and tritida are the ondy jor untraped radioactive trerias which are potentially avaliable to igrate very slowly fron the cavity. These do fot reach the environgen in letras or possible haztat. Practions of the rajonuclides gtrontiu 90 and cosiu 137 are poe traper in the solidified melt: these are deposited on $r$ ock sureaces some di stance up the explosion produced chingy. The 
$\langle 327\rangle$ Congra

direce grond otons fron larger tests can be felt but these are not large enough to damae the seructural integrity of buildings offside. (Bgm

<328>

Kaplan. I. . University of California. Los Angeles. CA. 1972

Biological cycling of tenents and stable Isotopes in

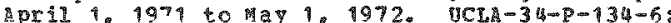
$208 \mathrm{p}$.

1. sumary of projects in progress is given. The following studies are described: 23 m 238 in recent corals and related carbonates: trace elements uptake by corais an sealments from hev caledonia: distribution of uraniur in near shore narine sediment: sedinent squeeger for removal of pore oters 1 ithout air contact: and mechanisms for marine iron salide formation. (auth)

\section{<329〉}

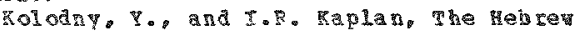
un versitw, Departwent of Geolog\%, Jerusalem. Israel; University of california. Institue of Geophysics and planetary Physics. Ios hineles. C. 1972

Deposition of uraning in the sediment and Therseltial water of an Anoxic Frora con-700965: Part of proceedings of an International 5 yposiun on Hydrogeocheristip and Biogeochenistry held in pokpo, Japan. Septenber

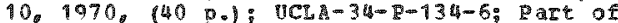
Kanlan. I.P. Biological Cycling of Elements and Stable Isotopes in Harine snvironnents. Progress Report cor April 1,1994 to MaY 1. 1972.40 P.). $200 \%$.

The aistribution of uranior in the sediments of Samich Inlet tas determing as ing cheralcal fractiontion Bethods to separate authigenic urania from detrital an $234 / 13238$ activit ratios rere for da to be good indicators for deceraing ing the efficiency of the separation. Traging concentration in the sedinent shons significant encichment relative to deap sea

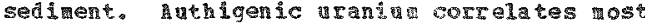
strongly ith the organic carion content of the seaiment and is probably bound as

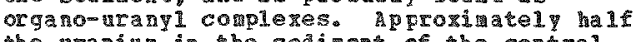
the maniu in the sedirent of the central fjord is organically complezed and the reminder is distributed anong detrital aincrals, auth gente tetravalent uranitu and uraniu adsorbed on organic ater. vrantin is highly enriched in incerstihial both oxidizing and reducing maters vith an th range of +380 ny to - 140 mVl redative to its concentration in nornal searater. Its concentration apears to depent on the oxidation state and the organic content of the sedinent. Concentration of uranin by the sediments vas found to be pery efficieac il this envisonment. The reslatence tide of uraniur in the veter colum was found to be 3 or 4 orders of magnitude less than estimated for the open ocean. (Fnm

<330?

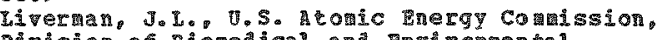
DI Is ion of Bionedical and Environertal Research, pashington, DC. 1974, Decenber

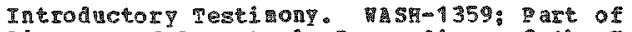
Ijvernan. J.L. et al proceedings of the 0. miviron wental Protection Agency PIuto nim
Stanaras Hearings on Plutoniut and other Transuranium Lerents: Sources, Environmental Distribution and Bomedical fifects held in vashigton, D.6. Decenber 10-11, 1974, 90 $1-101,327 \mathrm{p}$.

public concern regarding the manufacture and use of transuraniun elements is based on several facts. Increasing quantities of the transuranics are being produced. and the rate of production 111 increase substantial1. Several radiaisotopes of pu and other transuric alements have excedingly long ilfe-1ives and, once released wil persist and accumulate in the environment for tiae periods extending over nany han generations. These naturally occurring a pha-enitting radioisotopes are known to produce cancer of the lunge bone and liver in hrans as vell as 1 n experimental andis. Meaningul judquents on the adequacy of current standats and guidelines nust be
based in part on the nom ledge and

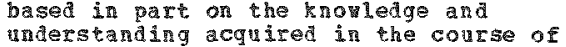
nuclear jevelopment incliding the research in the life scierces. phere are several anestic and forelgn organizations.

independene of government that have plaped a role in the aevelopant of stanaris. criteria and gudelines. It is essential to he alequte intoriation on the biowedical and ancontintal chatior of $\mathrm{Pu}$ and other transuranics in order to assure safety in current and futhre activities ard to identify secific areas where increased understanding is likel to have the greacest inpact on is likel to have the greacest inpact on
sqecific atevelophental, operational, and specific developmental, operational, and cocussed on these areas. The najor research programs of the AIC on the bionedical and environemeal aspects of the transuranics

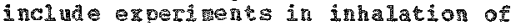
aerosolized transuranics, effects of not particles" the Transurandu Registry and behavior of transurante elements dispersed globally by veapon testing. Increasingly. In anticipation of RRDA, cesearch activities sthe area of the transuranics is being integrated vith research on the enviromenta? behavior and patential halth consequences of poll bants from alternative energy sources so that a better assesstent of the

bioen Ironmental aspects of alternative enemgl technologies can be mala, so as to help orchestrate thelr development and to provide sound basis for operating and regulating these technologies as they are installed. (Fin)

<331?

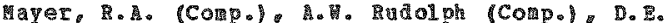
Bell (Conp.) and R.S. Davidson (Comp.).

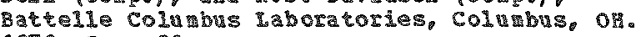
1972. Iune 30

Bioenvironental iffects Associated with meiear porer Plants: Selectea Bibliograph. PID-26164: 292 .

There are 45 abstracts contalned in the bibliography. Fhe sources used for the selection of references were uclear science tbstracts, special biblographies and reviev papers. The references contain athors. corporate athors, fitle, pablicatiog description, abstracts (in dost cases) and

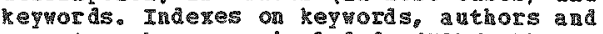
regort nubers are included. (葆) (LCh)

<332〉

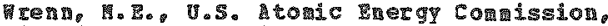

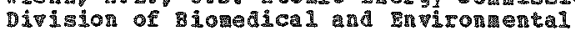
Research, Hashington, DC. 1974, Decerber 
<332> comp.

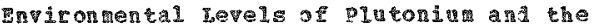

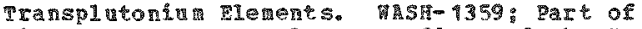
Herman. J.L. et al, procedings of she v.s vavironental Protection homey Plutonin standards Hearings on Plutonid and the Transuranin Ferents: Sorrces, Environental Distribution and somedical Eefects pid in ashington, D.C. Decenber 10-11, 1974, 1p.

89-112), $327 \mathrm{p}$.

Information about the locations, nounts, otigins. and distribtions of Fu na transplutonitu elements present in the envi rongent, available for environ mental transport, and not readily anemale ror retrieval is sumarized. Envicongental gu is described in two gener Tloball or locally aistributed Pa. Globally distributed Pu emates from tho sources-riclear weapons testing and space nuclear application. Fhe qlobal inventory is

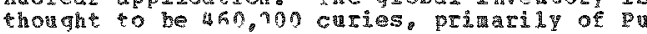
239 and Pu 240. Local sources fall in five yeneral categories: nuclear veapons testing. ruclear ne apons acoidents,

production and test wites, A IC contractor

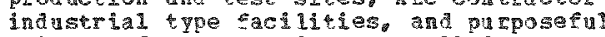
release of wastes under controlled

conditions. It was concluded that the nafor transuranic actiply in the environent is conposed of Pu and trom apons esting and that thes waterial is detectable in surface solis around the vorda, although their presence rasses the alph background in

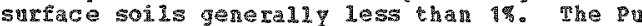
and activity per gran near the suriace wil decrease slowly ith tive. Finally.

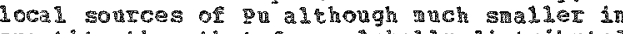

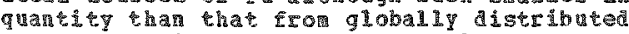
veapons testing rallont can result in concentrations of min soll erceeding the concentrations of the global level from meapons testing. (RAE)

Figures 1-7 show the yearly deposition of Pu 239 in mev York since 195 and Its cumulative deposition, he distribution of pir 239 between ncrthern and southern henisphere of of

$1970 / 1971$, Pu 238 and Pu 239 in surece air 45 degrees roth the distribution of $\mathrm{Sr} 90$ wh latitude, 239 accumation in

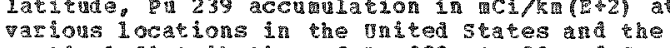
vertical distribution of gu 239 , St 90 and $\mathrm{Cs}$ 137 in sand loam soil sanples fron Ner England. Table $1-5$ shou estimates of lobally

distribured Pu, actinde concentrations is United states soil representive

concentration of gu 239 in variols mediti (circa 19711. preli inary estinates of local sources or Pu ig the environent and concentrations of Pu i. scil. 
2333

gerton,

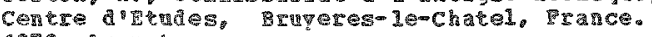
1972 .

Peaceful 1 ppications of

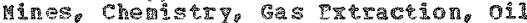

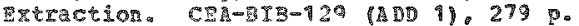

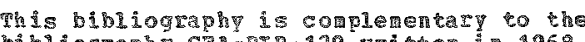

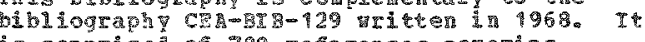
is compased of $78 \mathrm{~g}$ raterences covering

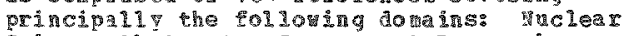
Science abstract, $60 \mathrm{~V}$ er Abstracto, Scientific Technical Ae rospace

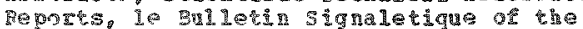

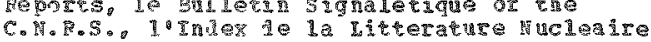

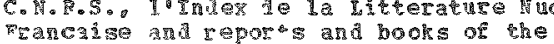
central Iol hrery of saclay. The dochents are presented in a surber of chafrers indicatod

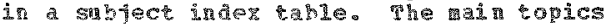
coverea are: 3 ivects of underground aritosins uneroroun water. enviromental efocts ano

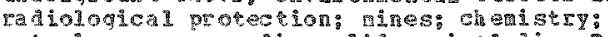

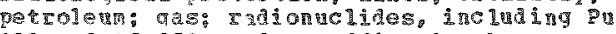
239 and $C$ 2 24 ; and specific plosshare profects. Several inderes a prear at the ent of the bibliographt: athors indes, index of reporss inder of repiev articles, inders of congresses. 1mater of books and a patents index. (Anth) (T)

(3) 34

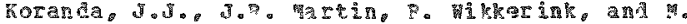

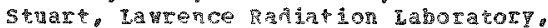

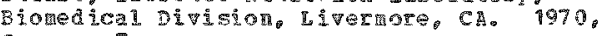
Jaำ

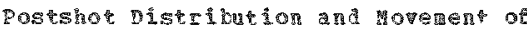

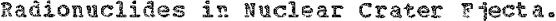

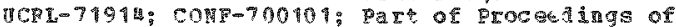

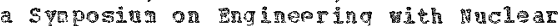

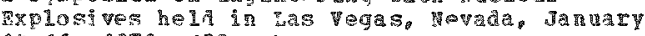
14-16, 1970, (33 p.)

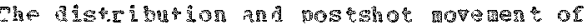

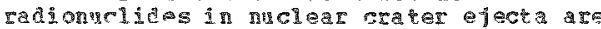

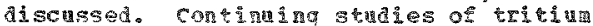
novenens in ejecta sedan crater

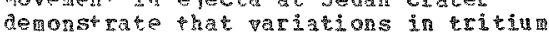
deronstrat that variatons in tritith

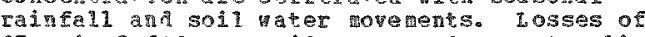

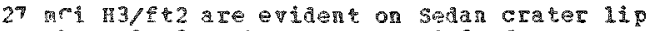
at the ent of a the ver period of measurenents in which an unguly large flu of rain as recerved, The disteribution of

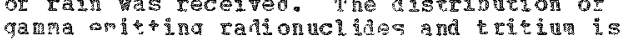

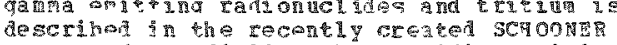
crater ejoct fiela. The specific activity of radinnclines if the scioong a fecta contignt is shown for e jegt a coll ect ed From the crest lin to 7 miles frombround zero

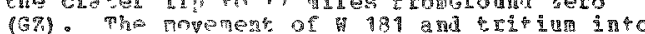

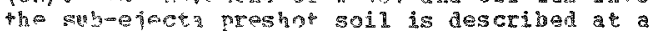
site 3 min

$\langle 335\rangle$

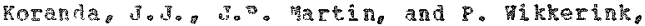

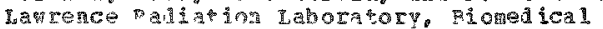
Uivisis, Iivernore, CA. 196\%, Jecenber 7

Fo

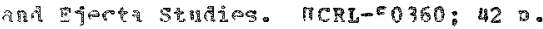

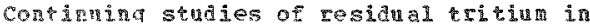
soil or ejecta deposited on the landscape arond the sedan crater, wevat Test site,

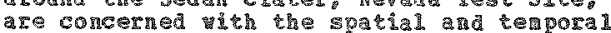
aistribution or

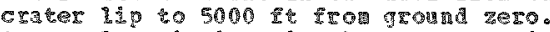
seasonal variation in the concentrations of

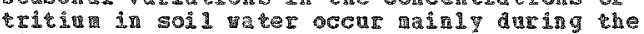

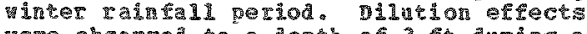
vre observed to a depth of 3 if during an

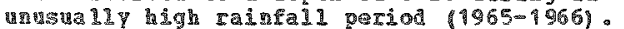
1) strata of sol 16 in. to $3 \mathrm{Et}$ ) increase to

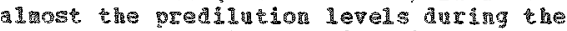

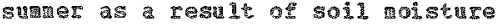

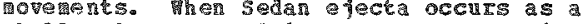
sha 10 layer over lying the preshot soll,

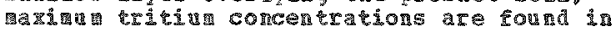

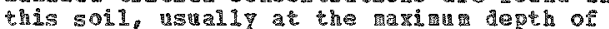

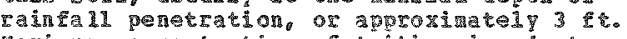

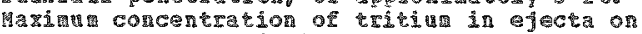

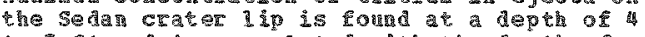

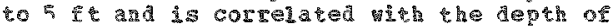
ejecta materials found aroun the crater lip. An ingencory of trith in the seran etecta field tas calculater, based mar collections of sol 1 saples along transeces of the

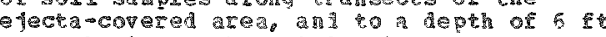
at each site. The tritiul inventory measmenants are essentily of b avalable tace it the solit syser.

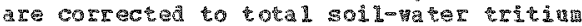

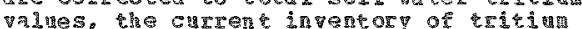
ouside the sedan crater in 1967 . Five years postsmot, is 5 to $6 \%$ of the estidated inventory of the residual tritura in the efecta at shot tide. (Auth)

$\langle 336\rangle$

Not jituen, gevala operations of fice, Ias Vegas. ง. 1973. Jancary

peports a ilabie in the Alaskn InFormetion grogram.

g bibliography has bee职 coppled listing all locuments avatiable in the oper fill

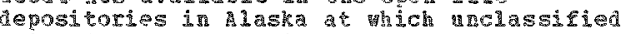

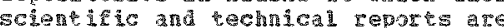
a vailable relating to the USAEC's Anchith Tolated hot ivities. These reports provite facts of the test prograr and deta 11 nea sures bein ther to assire the satey of the qublic and test participants as mell as potection of the environnert- -163 reports are cited. (PBu)

<37?

Hot giver. Fevada operations office. was vegas. NV. $1933, J 15$

Peports a valable in plowshare open File. WVO-A6 (ReV. 3): 35 o.

A biblographic 1 isting of all open file publications concerning project Gasbuggt.

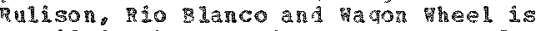
crovidel. These protects are part of the

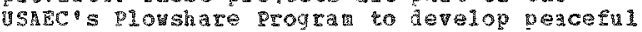
uses for nuclear explosives and use the suergy of deeoly buried nuciear explosives to increase the permeatility and porosing of rock thereby stilutating the flow of natural gis. Reports include production testing data on and offite a a-safery ata, and gacel laneous data. 240 reforences are citer. (BB⿴囗十) 
-

○ 
<38>

Bayer, R.C. vationa 1 nceanic a mo hasoheric Adinistration, Rarti Sciences daboratories, das

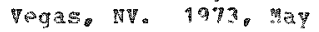

1 Preliminary seismicity study of the souther.

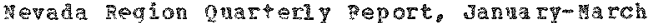

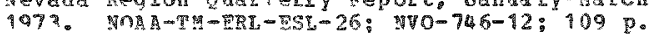

A cooperapive pFst, Sandia saboratories, and USGS network of 24 seismic velocity sensitive stations is operated in the southern vevada area: the stations are

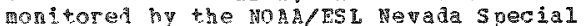
propects Party, located in uas vegas, frevada. The rost active area during ahis period as in the anger lountains/Frenchan lake area or and arjacent to the weval Fest site (pTs). Six monthly seismicity aps are inclinad three of the southern vevada region and throe of the seismicity on and atjacent to the rewad Test site. This is the initial to the revada pest site. This is the int southern vevada reaion. as chitored by the las Veqas, levala-based special projects party. Tho sel shic data ouput is listed in the Hyporenter Suanates and the station data is tabluter in the seisalogical Sulletins. The andises are the resulf of dac scaled only from the local cooperative networt and

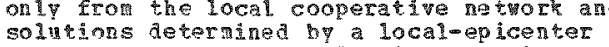
proyran. A total of 365 epicenter is isted, over two-thiras associated vith the 整ager mountains sequence. (muth)

$\langle 339\rangle$

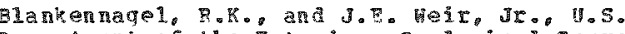
Departart of the interior, Goological survey. vashrigtor. DC. 1973

Geohydrology of the Bastern Das of Pahute

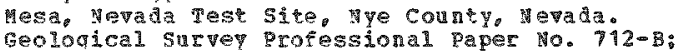
35 D.

a Hepo structura nenression the sinent Canyon caldera, anderiss che easern part of Pahute mesa, gre connty. Mer. The caldera is elliptical in plan and neasares about 11 in 14 jiles: the yreater axis trends in north-northeasters direction. Ezploratory drilling peveal ed a Tertiar volcance section of $a s h-10$ and ash-fall tuls and rhyolitic lawa tlows which artained thicknesses in encess of 13,686 feet. Hyaraulic tests mate in deep arili holes indicated that these in deep arid holes indicated that the se volcanic rocks are capable or transmiting
water and that measurable permeability occurs $a^{*}$ depths greater than 3,500 teet below the top of the saturat at zone. most woverent of groundwater beneath the pasa ocurs through interconnecting fan 1 and to in systers. The

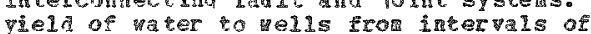
ash-fall and monvelded ah-flon tuffs. particiarly those that are zeolitized or ardilizen, is low. Hence hese rook are considered the best peat a for underground chabers in the saturated zone. In the silent cayon caldera, depth to vater ranos fron about 1.952 feat ale. 4.154 ft in the vestern pare to 2,350 feet falt. 4,685 fich in the eastern part. In the extrene northestern part of the Hevada pest site. outsde the caldera the depth to rater is about sto feet (alt. 4.700 te). puping tegts indicate that transissivities ramge fron 400 to 140,000 gallons per day per

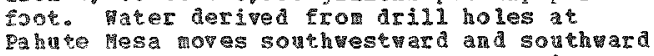

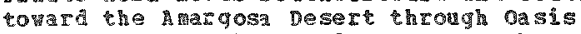
valley, crater Fat, and western 3 ackass Flats. Fhe tlow, across a 15-mile underton strio vich extends from the hqdealic barrier on the vest to the ground
Aiviae on the east is estinated to be 8.000 acre-feet per year. Tstimates of ground wter velocity vary as much as tho

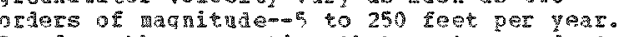
based on the assungejon that nost groundzer moverent occurs a long interconnected cractures and that some rovement occurs throlin interstices a reasonable estivte of velocity is less then 15 feot per war. thuth

<30 30

Cherdytsey, V.V., and J. Schmovak (Translator) Geological Institute of the Academy of sciences of the USS, Dating Laboratory, Moscon, USSR: Razak University, AIna-Ata, USSR. 1971

vraniu 234. Teter Press, Jerusalem, Israel: 234 c.

R spsteratic account of the experinent 1 ata avalable on uranium 234 in nature is presented. The ieeds of specialists in the Field of uraniug readers zutorested in science in general, nd Iesearchers in the fielas of geology. physics, archeoloap ceeanology, and soli seience are considerea. moerithental dat and literature references incluing foreign publications are exhastive uo to 1966. Chater i den 15 with the physical principles of nuclear geochemistry. succeeding chapters are devotod to cractionation of heavy radioactive elements in thatue, fractionation of radioactive isotopes, y 234 in nuclear geochemistry, u 234 in uraniu minerals, y 234 in continental waters and in gutcemary hegosits, and 234 in the ocean. Dating with 234 , particularly auring the quatertary. is extensively aiscussed. Atrention is called to its use in the future as a tool of todern aclear geocheristry. (Si)

This is a translation of HRAN-234.

<3⿻1

Claassen, H.C.. V.S. bepartent of the Interior, Geological Surver, Federal Center, Iakevood, co. 1973. Jan ura

Whar guality and Pbysical characteristics of Hevada Test site vacer-Supplip ขSGS-474- $958 ;$ ขTS-242: 152 \%。

Chenical, radiochemical, and hraraulic data obtained by the t. S. Geological Survey from the mater-supily vells at the Mevada Test the ater-suply vells a the vevada Test paraneters are discussed and evaluated. Ajagra matic representation of vell construction and lithology penetrated is included for each vell. Inth

<342》

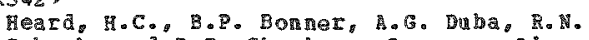
Schock, ma D. Stephens, darence ivermore Zaboratory. II vergoce. CA. 1973, Hay 22

High Pressure mechancal properties of ht. Helen, tevada, TufE. UCID-1626\%: $41 \%$.

Dessure-volume, unaxial stross, failure enveloge, uniagial gtraln, and acoustic velocity reasurements have been mate on the Dorovs, fine grained ht. Melen tuff. por ech type of measurement. three levels of seturation vere investigated: 0.50 and

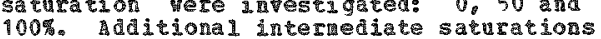

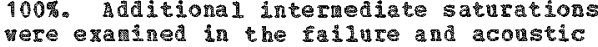
velocity deter compression to $40 \mathrm{kbar}$. 1 idd conpactins tanging from $27 \%$ for $0 \%$ saturation to $23 \%$ for $100 \%$ saturatsogs. Bulk noduli (R) as 
BYOLOGTCA ASPECTS

<342〉 CORT.

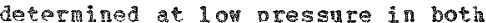

pressure-volume and undal stress loading

Yola values of approtiately $30 \mathrm{kbar}$ for

both the dry and saturated tuff. The

corresponding range of shear noduli (micro)

froll the uniarial. stress tests are

approxinateli 15 to $30 \mathrm{kbar}$. Porh and a

defermined for the 50 \% saturated tuff give

anomalous resules 9 argesting chemid

interacton bet ween the pater and component

mirerals. pestits from the acoustic velocity

measurement $\$$ liso suggest cherical

interactions. Shear strengths (pi) of the

wh. helen tuff depend strongly on water content at all pressures. values for pi in dry tuef range fron 0.2 to $3.0 \mathrm{kbar}$ oter the pressure range of 1 bar to $7 \mathrm{kbar}$. In the

Eq1LY saturated aterial. pi. ranges from 0.1 to 0.35 kbar over the sare pressure range.

buctile behavior is ubiquitous for all

saturations at pressures less than 0.5 to 1.0

kbar. The path in uniaral strain loading

rises airectiv to the vicinity of the cailure anvelope and then closely parallels it to the highest pressures. independent of ater content. (Anth) 
$<3443$

Becker, K. and D.R. Johnson, Oak Riage Hationa Laboratorp. Health phsics Division, Oak Riage, IH. 1970, march a

Won photogravhic Alpha A utoradiography and Neutron-Induced autoradjography. Science, 167, $1370-1372$

Hith a nev combination of tro technigues. (1) al phas article or fission fragment

registration in thin polyger foils by etching and (2) antonatic counting and agnification of the atched perforations by local evaporation of a thin getal layer vith an electric spark, the sensitivity of conventional photogradic methods for deternining guanticy and spatial distribution of a lpha enitters. fisile wherials, and of elenents undergoing $(n$, alpha) reactions can be drastically inproved, whout a eed for darkroon processing and icroscopic evaluation. (Auth)

$\langle 345\rangle$

Casarett, A.P. Cornel 1 uni versity, hew State veterinar college, Department of physical Biology, Ithaca, gig. 1968

Padarion Detection and Dosigetry. past of Padiation piology. Chapeer 3. Erentice-Hall. Inc. Tnglewoor ciffs, New Jersey, (p. 31-56). $368 \%$.

This chapter deals with radiation letection measurement, and dosimetry and with general
technitues of irradiation. Radiation detection nethods are reviewed and several types of dositeters are described. Enphasis is placed on those derectors hat are ased in radioblology for greasuring radiation distribution and exposure. Techniques of measuring internal dose to tissues and factors mich influnce tissue dose aro discussed. Descriptions of several experimont 1 oxposite set-ups are included in this section. [SF]

$\langle 345\rangle$

Clemente, G. Fo Comitato pazionale por l "Energia wacleare, mirongental kadoactivity saboratory. Dome, Italy. 1973

In Vipo Measurements of plutonium 239 in man. CONF-720503; Part of Buroso, E. (Bd.), Health physics Prohlens of Internal contamination. procedings of the IRPA 2 nd surcpeas Confress on Radiation protection held in Badapest, Tugary. a $3-5,1972,(0,503-507), 655$ p.

Throe different sets of equipment here tested for use in raking in vivo lung weasurenents of plutoniun 239 of personsel at the Casaccia Wuclear centre, pome. It aly, where plutonium cuel elements are prepared. 11 measurements were made inside the shielded rool of the whole Body Counter of the laboratory. A thin Gristal composed of a 125 m $x \quad 0.5$ an crystal optically soupled to a 125 m 250 贸 csirva) crystal used together vith a puse shape discrimation system yialded the necessary sensitivity of 4 nci. Results obtained from the three sets of counting eguipien are reporteit. (ST)

<347\}

Davis, Wo, JI. Oak Pifoe vational laboratory,

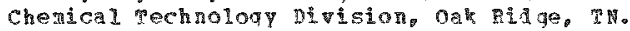
1974, Apri].

Hich-Efficiency Daticulate Air pilters: Stato of the are Sumary pertaining to Plutoni

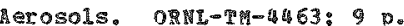

High-eficiciency particulare air (HEDA) filters now being mafactured comarcialy routinely exceed the specification of removing $99.97 \%$ of 0.3 in-d lameter particles of anodisperse diocty 1 phthalate (Dop) arosol. Laboratory tests indicate that when such filters are properiy installed in series, at least up to three, each ill perfor at this same ievel with plonia aerosols, leading to decontanination factors in excess of $3 \times 10(2+10)$. Filter mediz shat are resistat to serious degradation by hydronen luoride and fluorine are now in the process of asserbly into fiter units for testing. (Auth)

<348>

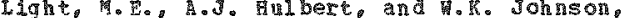
iovelace poundation for medical Education as Peseareh, Inhalation poricology geseareh Institute, Abuquerque, NM. 1973, Decenber

An Instrument for Realtine Determination of Concentrations of Aerosols of Alpha-Eititing Padionucliase for gye in Animal Inhalation Studies. IMP 46 ; part of McClel1an, R.0. and Suporecht, F.C. (SAS.). Tnhalation Toricology Research Institute sanual Report, 1972-1973, (p. $21-231$. 342 .

A aerosol concentration anitor has been designed and fabricated for the purpose of masuring aerosol concentretions of alph-ereting radionuclides jurino exposures of experimental animals. herosol samples are draw at flow rates of $200-500 \mathrm{cc} / \mathrm{a}$ in from the exposure chamber and throigh a filter wh is separated fron alifused-junction gilicon radition detector by approxinately c. The face of the detector is covered by a light tight las cover. Alified pulses from the detector are routed through a atscrimititor so that only particles above a threshold energy are connted. The counting cidcuitry computes and inplays accumbated activity and the zate of acounulation. (Auth)

<349

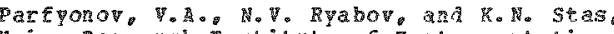
union Research Institute of Instrumentation. state comitte for vtilization of stomic Energy, 国oscon, USSR, 497

Pergonnel Mondtoring of sespiratory pract overirradiation Razard pue to Radon Dacay Products. Conf-720503: Part of Baldoso. E. (EA.) Healeh physics problems of Irternal Containgtion, procedings of the IRPA 2nd Europear Congress on Eadiation protection held

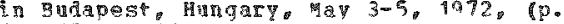
$149-152), 655 \%$

The trokn personnel aonitoring techniegues of radon short-lived decay proiucts are cevieved and their advantages and isadvanages are discussed. Aspects of furthor development of monitoring apparấs aro discussen. (A) uth

$<350 \%$

Postone J.H., Oak Ridge Narional daboratort. Health physics Division aak Ridge. TH. 1971

A Detector for the masurenont of Dose

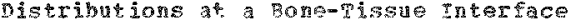
CONF-701412: STT/PUB/269: Dart of Proceedings of

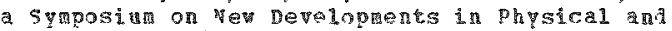
Biological Radiation Detectors held in Vienda. ustria. Foverber, $23-27,1970,(0,299-319)$. 7 虹 20 


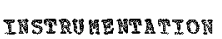

$<350\rangle$ cowe

Radiation detectors ace described which facilitate the measurement of dose distributions at bonetissue interface. These small extrapolation-ionization chatabs allog the reasuretents of dose distributions

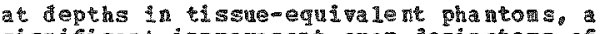

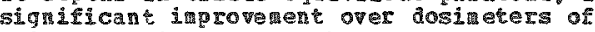
this gerieral type. Stch reasurements allov a more accurate assessinent of the inportance of this interiface in the establishent of external radiation exposure standards. Detectors characteristics, such as saturation voltage as a function of electrode spacing. directional response of the chanders, and effects of change in collecting electrode area. are discussed. 1 methcd for measuring ionization corrents prod isced in these chabers at large distances frolu the point of measurenent is presented. Results of measurents in tissue-ertivalen phaston are presented tor neutrons from several isotopic sources, i.e., Am, anse, and pure. Dose distribution fron a 14 MeV neutron source are given al so. The significance or these results in relation to theoretical studies and the present exposure standaras is di sc assed. (Auth)

\section{$8351 \%$}

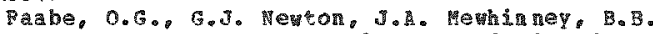
Boecker, L. E. Woven, Lovelace Fund a jon for

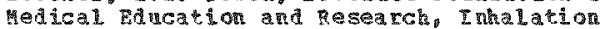
Toxicology Research Institute. Albuquerque, wo 1973

An Irproved system for Exposure of seagle Dogs to Radioactive Aerosols. IF-46: Part of Hcclellan. R. O. and Ruppreche. P.C. (Eds.). Inhalation Toxicology Research Thattute haval Beport. 1971-1973, (p. 10-15, 342 po

A rev apparatus is described for individually exposing beagle dogs to radioactive arosols for periods an to two hours. The systen whilizes wholembly plethysmognaph for reasuring the dog's respiratory activity during the exposute. Fhe dog is restralned In the lethys arposed to the radioachive aerosol.

provision is ade for aerosal generation cor heat reathent of the aerosol if necassary anctor sa pling for arosol haracterization ith a cascade ipactor, a filter and electrostatic precipitator. The prinary inproverents over grevions equip ient include: (1) ise of stainless steel glove boses ith safery-glass vion a cosol equipher. (2) sinplified aerosol

chaber and aerosol dilution syster. (3) isolation of the bigh temperatrie hearing colum used for heat treatment of aerosols. (4) provision for obtaining aplicate and (ritiple aerosol satples, and (5) renote control and monicoring from a single concrol panel of 11 noral operations jncluaing panel or ang. Successive tests with nonodisperse

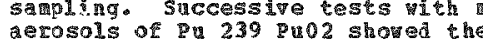
aerosols of Pu 239 Pu02 showed the
reproducibility of aerosol concentrations and particle size ajstributions as measured pith altiple sagles. (Auth)

$<352\rangle$

Watson, C.R. Battelle Menorial Institute. Pacific worthest iaboratories, Blology Departrent, Richland,

Radiondide Seanning Faciley for Dogs

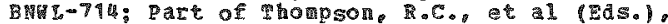
Anval Report Eor 196\% (p. 315-317), 253 p.

dog scaming aparatus, first operated in 1960 , has been refined so that it allow simitaneous scanding for Pu 239 and A 241. Beagle dogs vere scanned following inhalation of An 241-emriched pu 239, to deternine whether these inhaled radionuclides follow the sate path with in the bod 
(353)

Atkins, H.L. Brookhaven mational aboratory, Hedical Research Center, Upton, long Island, WY. 1969. Januar

The redical yse of Californiun 252. BuL-12919: CONF-681032; Part of Barker. J.J. (Bd.) proceedings of a symosiun on cilifornim 252 heli in Hey York City, Hev York, October 22. 1968. (p. 285-302), 376 p.

Nethods of treating raijoresistant anosic tunor cells are reviewed. The use of californiu isotopes as implantable fission neutron sources, a viety of high linear energy transter radiations, has been suggested. The advantages of using this and its lipltations are discussed. Results of studies with human tumor cells in culture showed that the relative hological effectiveness of californiu hith respect to protracted irradiation by radu is approximatelv 2.9 . Studies are in progress to determine the oxygen enhamcenent ratio of californiug. IS

3543

Bair, h. J and R.C.Thompson, Battelle meworial Institute. pacific Morthest Laboratories. Biology Departient. Richland, $\mathrm{A}$. 1974, February

plutoniut: Biomedical tesearch, Science, 183 $715-722$

The bionedical itterature on plutonim mas reviewed in an effort to sualurige the known toric effects of this lement and to evaluate the hazards to man. Because of the future role of plutoniu in the production of power and in fueling bres det reactors ore information is needed on other radionuclides with wich the toxicity of plutonium can be compared. phe chentical and onysical properties of plutoniur are briefly sumarized and $a$ brief historical survey of bionedical studies in the vnitea states is

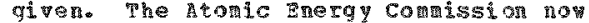
spends appropiratel $\$ 6$ wilion on research on plutoniu and the tramsuranic elements. Inhalation is the nost probable route of entry into nan during occupational exposure. pluton un reaching an by way of environmental routes is more likel to be by uptake of resuspended particles than through food chains. From 0.3 to 0.5 million curies of plutonin have been released as a regurt of atmospheric veanons tests. Autopsy results in the Boston area suggest that each human ma acculate 10 (5-17) of this total amont. pesuls of beagle aog straies suggest that inhaled soluble plutonim ar bo

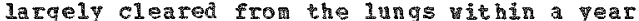
and transpocated to bone and liver. Insoluble particles are $r$ atined in the lungs longer and are translocated prinarily to regional lynoh nodes. The influenere of physical and chemical form and couts of administration on speed of remava from the blood and pranslocation is discussed. Deposition sites with in the liver and bone and wetabolis and retention ithin these a nd other tissues is reviewed. Excretion studies by Langha revieved Excretion studies by Langha 1956 cite the slow removal of injectad
plutoniu. Aninal stuides show that the

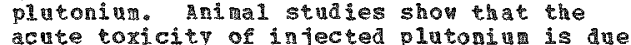
to its destructive efrects on the

heratopoietic syster. The wost sensitive inder of olutoniut toxicity in bone is the induction of oseosarcona. Searle dog studies induction or osceosarcona. Seagle dog stude

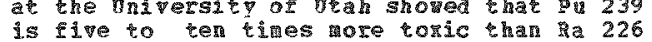
(thays.1972). other and stuats showed that the earijest response to inha led ol atoning is 1 ymphopenia, but the rost sensitive index is lung cancer. The safest and nost efrective decontaination aeasures used on man are discussed. Problems enconntered in attenpting to evaluate the hazaraus effects of plutonim in man and to establish exposure litits are aiscussed. resent accopted ICRP pertissible body burden for occupational exposure is $40 \mathrm{nci}$. It is suggested that mon more information on plutoniug toxicity is needed so that reliable predictions call be rade. (5is)

$\langle 35 \%\rangle$

Barron, S.S.G., and J. Muntz, pniversity of chicago. Chicago, TH. 1945

Clinical medicine and Medical Research: Studies on the Hechanist of Plutoniun Intoxication. CH-2786: Part of yealth Problems Relating to Produce for wonth of arch $1945,(p \cdot 4-7) .35 \mathrm{p}$.

Plutonium nitrate 10.0001 la aded to huan blood seru and subjected to electrophoresis migrated dith the beta-gama globulin fraction. Upon ulerafiteration of plutonin serura and plutonin plasma ixtures, 24 and 15\% of the plutoniun as found in the 1itrafilerto. phere was no difference betren dilyzed and unialyzed saples. an inaication that plutonin aia not forn fir complex compound with the and ons of blood plasiata (Anth) (ST)

$\langle 356\rangle$

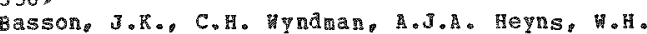
Keeley, I. Hebster, C.P.5. Barnard, M. Hanro, and 1. Hebster, National vuclear Research center, Pelindaba, South Africa; Chather of Hines of south Africa Johannesburg South Africa: Rational sesearch Instithte for occupatona 1 Diseases. Johamesburg. Sout a

Siostatistical Investigation of lung cancer

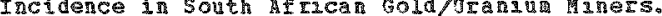
CONF-710901; A/CONF-49/2-659; STI/PUB/300: Part of Droceedings of the 4 th International $S$ y posiun on the peaceful uses of Atomic Energy held in Gereva. Sutzeriand. Septerber 6-15. 1971, V01. 11, (p. 13-29)

The incidence of lung cancer anong South African gol miners as ingestigated to deter ine yhether, as a result of erposure to radon ianghters, arising frron the presence in the ore as mined of loy concentrations 10.015 to $0.075 \%$ vo 308 of uraniug it is greater than for the nle population as whole. A randon sample of 1100 wen as dran fron the total of 227,000 white iners registered by the Chamer of Mines u to the end of 1967 and the cumative exposure for each wan was calculated as the product of the shifts calculated as the product of the shif concentration of radon dathiters. on the concentration of radon daturers. on mines, estitates of radon concentrations expressed in "horking levels" were assing to each of the 119 olnes concerrad. The averave culling ive sposure over the period

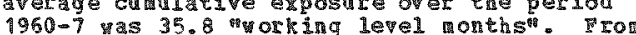
the nuber of deaths due to brochogenic cascinona and the extilated population at risk fusing an expansion factor $(227,000 / 1100$ equals 206 ) the crude death rates pere calculated. rhe averge annul death rate due to Iung eancer arong white gold miners in south africa uas found to be 2.06 per 10.000 for 3.70 then cortected for al1 possible orissions) as compared with 3.12 for the general population of white somen levican males for 3.67 when corrected for age aistribution). It is concluaed that the 


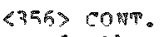

death rate fron Iung cancer among thite south artican winers has not been increased by the jow radon exposure ocenring in south ifrican golafuramin aines. Furthernore, athough this investiqutor was unertaker as a pilot stuin it apdears that no incrovel re sules

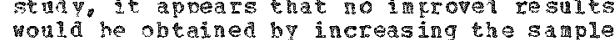
size as the estivates of cur ulative exposure of individualig are nocessari ly very crude ane

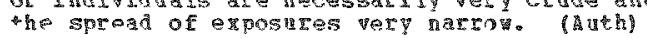

\section{Q3 3573}

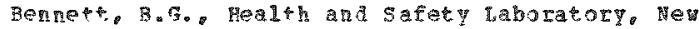
Pork, Ni. 1974 , Decerher

Environment patinays of Transuranic Elements. Hafl-1359: Part of Liverman, Jol.o et 21 . procedings of the

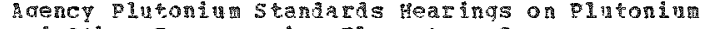
and other Transuraniu Benent Sources, 3nvitontent 1 bistribution and Bomedical

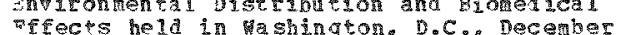

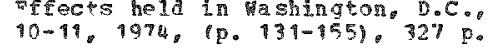

Fyposure of ran to transure ic element contanintion a occur by the inhalation or ingestion pathways A discussion is given of the specific aspects of these pathays such as resuspension of demosited actitity. platet uptar. and physical and biologica 1 transfers in terpesteial and aquatic environents. In adation, the geasurements of fallout $\mathrm{v}$. tracing the course of this waterial in air and diet to man, provide some of bue most. directy appropriate late regarding the

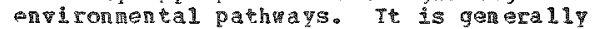
Iecoqnized that for an initilly a irborne release, the indelaton pathwa is the dominat contributo to the low burden in man. The 10 wolubility of the tramsuranic elraents inkibits blan uptake and absorption from the gastrointertinal tract and a inj the importance of the ingestion pathry. Fo contanination which originates on the ground surtace, such as leakages or spilis respisperso could bo an i porfagt resaspersion could be an inporiat
consideration. It is reconnized thata nuber of paraneters are involved in descrining the resuspension process, icluding soil

conditions, moisture, wind, vegetition cover and mechaical isturbances such as digging or traftico The Eactors intuencing plant uotake of transuranic alenents are chenical form. Solubility, oxidation state of the radioactipe alenent conositivan an of the soil ant plant species. Pro she data avalable, the uptase of pu vas assigred as

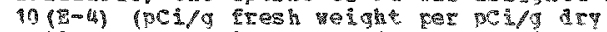
sol1 plus or anve an order of mand

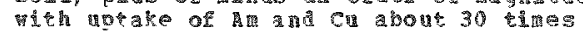
areater. The ingestion and inhatation pathays of fallow $\mathbb{P}$ to ton are constaered

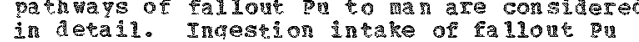
has been detern net frol concentration resules and food consurgtion esth tes. The

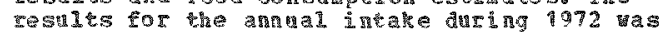
1.6 pci die $35 \%$ to gran procucts 20 each

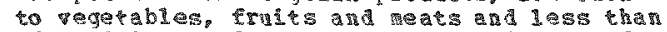
ur to dast prodicts. Inhalation intak of

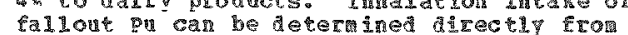

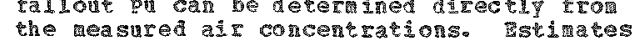
the reasured ai concentrations Escinates organ a istributions are obtained sing the TCRP Tash Group ing worel. The a easured inhalation inteke of fallout Qu and the conputed organ hurans are shom graphically. min culative doses throvgh 1973 to an ind vidual exposed throunon the ertire fa11. out perjod since 195 have been 15 meer to lung, 8 mrer to bone and 4 mren to liver. (7)

Figure 2 shows inhation intake and burden in

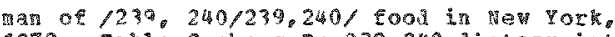
1972. Table 2 shows Pa 239.2 ta 1 ictery intake in Nev York, 1972. Table 3 shows fallout Da 279,240 inhalation intake and computed body burdens. Pable 4 shows follont 2 il 239.240 in añ

\section{$\langle 358\rangle$}

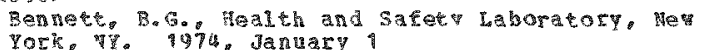

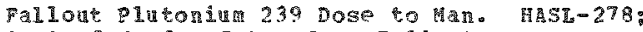

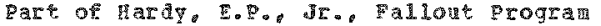
gurterly Sumary Repore. Septenber l. 1973

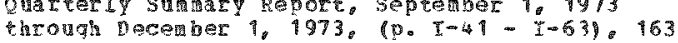
P.

The dose to man through the year 1972 due to Pu 239 srom reapons testing is estinated to be 15 mren to lang, 7 mrea to bone and 4 mrea to liver. The dose comlitwents through the pear 2000 are somerhat 2 arget than the doses plicady delivered due to the continat

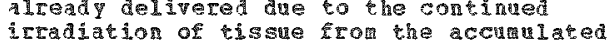
organ buraens. Fhe dose estinates are based on the predorinant inhalation pathray. considering the Qu 239 concentrations in air in Nev York and thilizing the TCRP Task groug

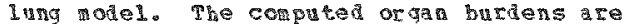

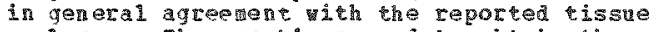
analyses. The equations usad to obtain the organ burdens and doses are presented and esaraples of acise and chronic intake

situations are also given. (Ath

Table 1 show Sr 90 and Do 239 measurements a

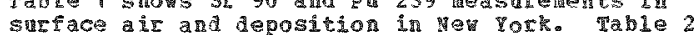
show fallout Pu 239 det for yev rork including shopositiong indalotion incake. and content in tissues of man. Table a shon pu 239 in man. Her pors 1968. Table 5 shoms Pil 239 in an. colorado and vem texico, $1970-1979$.

\section{<359>}

Burr. H. Tiviston of Biomedical an Environental Research,

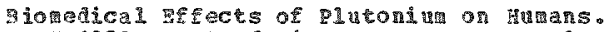

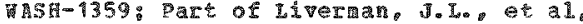
Procoedings of the U.S. Rgvironmental protection

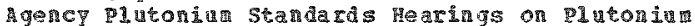
and other Transuraniu laments: Sonrces. and other Transuratib Laments: Sources icects hel in ashingtong.C. December $10-11,1974,(0,231-234), 327$.

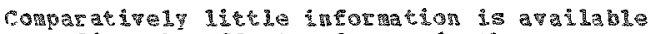
regarding the effects of pu and other

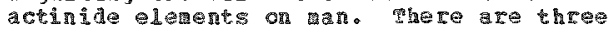
troups of indigiduds who have been exposed toups or individua wo have been axposed

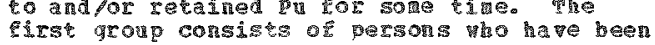
occupa tiona 1 y expose 30 Pil a some time in

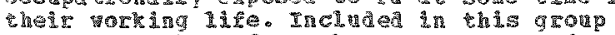

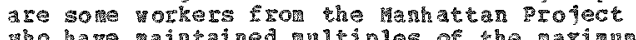

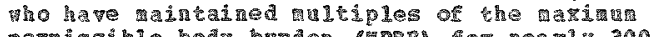

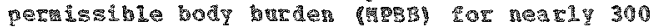
T. H.

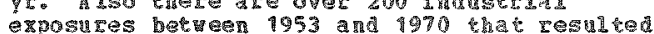
in burdens of pu excedyn $25 \%$ or the ris. The secomi group consists of 18 people thought to be hopelemiy ill wo mere jnjected wh $\mathrm{Pa}$ auring and the daps of the rahatean profect to stuly excretion and distributon patterns in

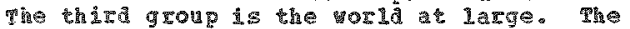

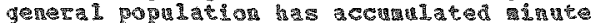
quatities ot pu frow the fallow debris that resulted from thelear teroting in the

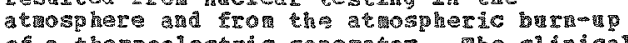
of a thergoelectric generator. The clifical follow-a of persond 
<359> ConT.

reassuring, but any conclusions with respect to late effects of Pu in man must reain trontative for solle tine. It can be gtated. hovever, that available data dose not support the viewpoint that the current raliation protection standaras and guidelines wich have been followed for many years

undereseinate by many orders of manteve the rist due to gu deposition is man. (FM)

$\langle 360\rangle$

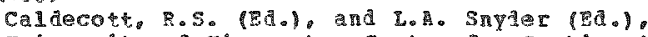
onipersity of minnesota. Center for continuation study of the General zxtension vivision, minneapolis, mo

padioisotopes in the piosphere. Proceedings of a Swmposium held at tire University of minnesota

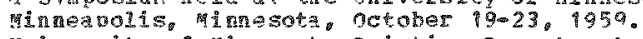
university of minnesota printing Department. minneapolis,

whe sqposiun yas concernea with a discussion of the facts and deficiencies in knowledge rolating to the nathrgy of radioisotopes fror the tine they enter soils until they are excroted frot living systems. papers vere To ported under the folloving sections: ranioisotones in soils and olants: radiossotoves and heir relation to the gentetic mechanism and ohysiologica 1 procosses: 5adioi sofones and envir onental cirenstances: radiol socenes in the spaleton: raAioisotope toxicity: and ranloi sotope absorveion and gothols of elimination. Particular erphasis was rilacel on the uptape of radisisotopes by plants, amimals, and gan ani the renetic conserquences of their ingestion. phinty-sewen gapers vere presenter: seven fere abstracted separatel for the deta base. (ST)

<3दार

Casaret $\mathrm{A}_{0} \mathrm{P}$, Cornol 1 hn

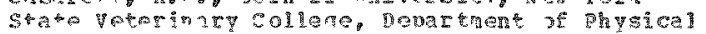

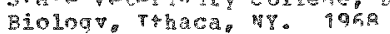

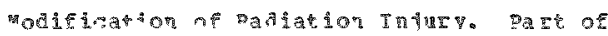

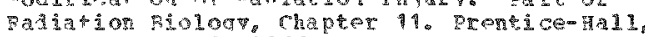

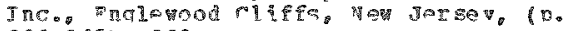
$235-265 y, 3 h 8 p$.

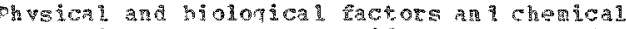
protective arents re considere some of the current conpobes of the treatom of

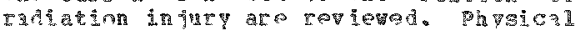

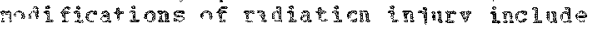
prtid holy IA

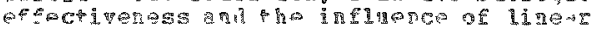
areveranfer. dose rata ant chron

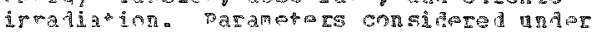

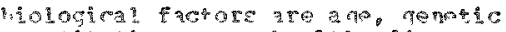
constiphion, ser.

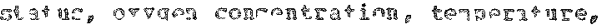

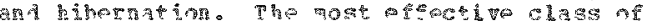

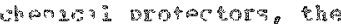

A M ing

D $2-7$.

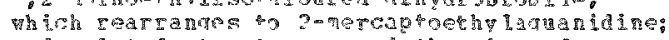
An

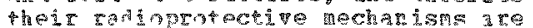

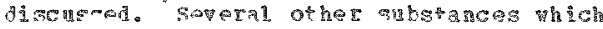

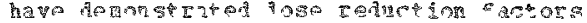

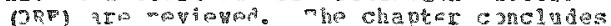

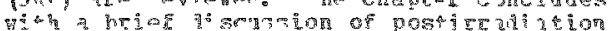

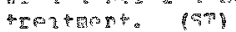

$6720^{\circ}$

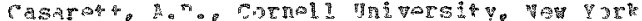

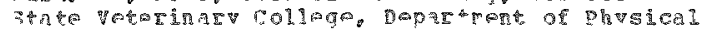

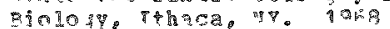

Ratiation frects on Microorganisus and Tudepentert Cell Systems. part of padition

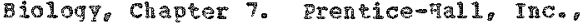

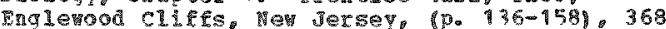
.

Targot heories are reviewed and the interpretation of experinentil results in teris of the earget theories is discissed. studies of radiation effects on

icroorganisms and barkatian cells in tissue

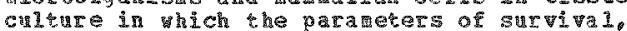
ability to carry on metabolic processes. ablity to repalr and divide. and growth vere studied are reviever. Radiation sensitivity of in vivo and in vitro mamalian cells is

compared. Inditect efects trom the

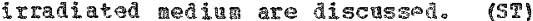

(36)

Casarete, A.P. Cornell university. Mev York state Veterinary college, Departient of physical Siology, Ithaca, H装, 1968

Differential Cell Sensitivty. Part of

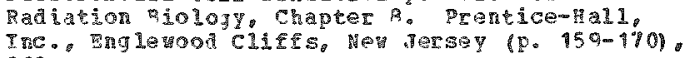
3580

7arioks cellat oharacteristics ohich have

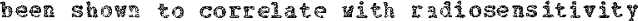
ate a

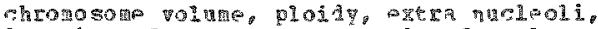

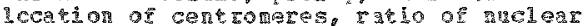

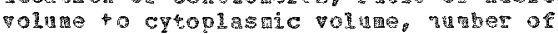

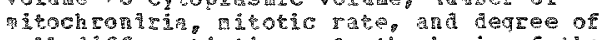
coll tisterentiation. on the basis of these characteristics and histologic observations

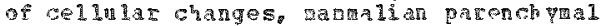
cells vere aivided into fonr general

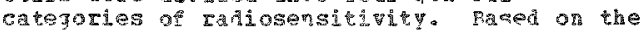
criterion of early cell death as fudar by

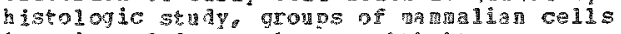

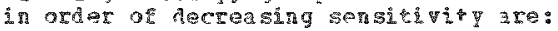

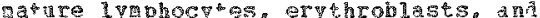
certin ovarian Golicles.

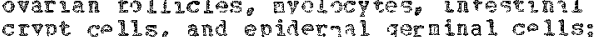

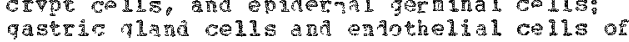

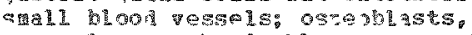

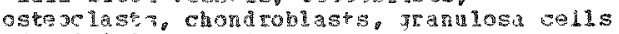
of Dri

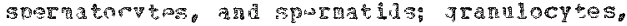

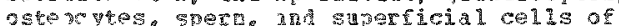
the auc cells of glands, furoblasts.

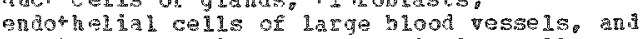

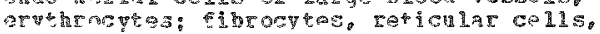

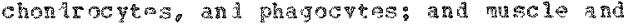
terve colls. (SI)

<3⿻

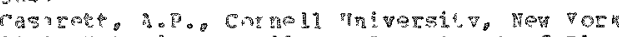

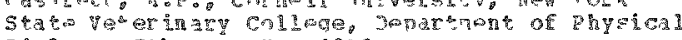

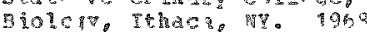

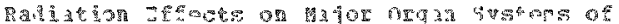

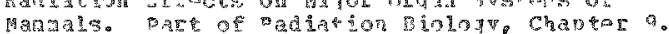
Franalson

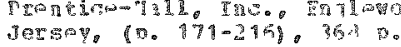

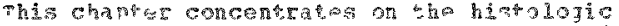

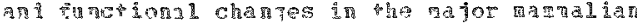

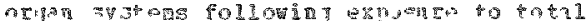

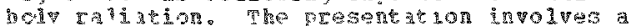

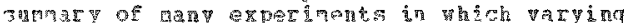

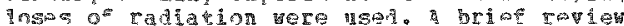

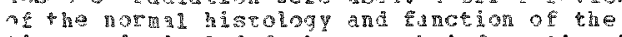

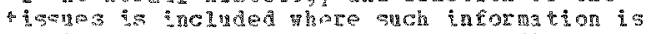

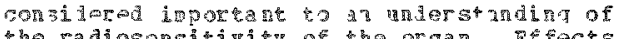

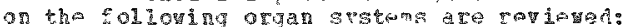


GEDTCA ASOECT

$\langle 364\rangle$ CON?

blood and heartopoietic tissue, di gestive

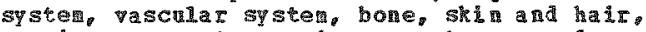

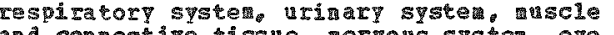
and connective tissue, merpous syster, eye,

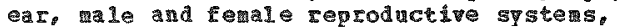
and endocrine systel. The stress and imune masponses to rajation are brieri discussed. Tesponses to rajation are bricly discussed. and histologic sections. (ST)

(365)

Casaret, A.P. Cornel I Un versity state Teterinary College. Department of phisical Biology. Ithaca.

Applied Radition Blology. Part of adation Blology, Chapter 14, Prentice-Hall, Inc.

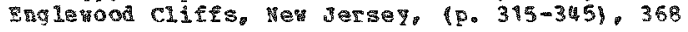
p.

Some of the practical applications of ionizing radiation are described. These include medical, industrial, and research uss. The effects of beckground, nedical. fallout, and industrial and research radiation exposures on the human population are considered. Fisk to individuals is assessed in tine of dettimental solatic and genetics ffects and genetic effects on later generations. (ST)

6366>

Casarett, A.P., Cornell vniversity, Hev Tork State Veterinary College, Department of Physical Biology, Ithaca, W. 1968

Late sffects of Radiation. Part of Radition Biology. Chapter 12. Prentice-Rall. Inc. Englewood clifs, Hew Jersey, (p. $265-283), 368$ D.

This chanter deals with long-ter radiation effects, apparent inths or years after recovery from initial radiation syuromes. These effects inclide ife-shortening. These efrects inclide life-shortening radiation carcinogeresis are discussed in terms of somatic mution. viruses, tissue lesions, threshold dose, direct versus indirect irradiation, and the tose-response relationship. Thresholds of carcinogenesis and dose-response effects are cited from ras experiments. Radiation carcinogenesis studies in wan--turar inciaence ju banese bomb survivors, cadiation therapt patients, ra di dia dil painters and laborator vorkers. and following dignostic radation, and lenkenia in radiologistsmare revieved. other late effects of radiation, effects on fertility and bone and radiation cataracts. are mertioned. (ST)

$<367$

Conar, C.L. (Chair man, Nationa 1 Acadeny of Sciences, National Fesearch Council, Division of medical Sciences, Fashington, DC. 1972, Novebor

The Pffects of populations of Exposire to Low Levels of Tonizing padition. Feport of the Advisory Conittee on the Biological Bffects of Ionizing Rations: $217 \mathrm{p}$.

s sumary and analysis of current kmoviedge relating to risks from exposure to ionking radiation is presented. Fhe report deals radation is presentedo The report establishment of raliation protection establishment of radiation protection standards and enconpasses a reviev and
reevalution of exísting sciencific knowledge concerning radiation exposure of uman populations. The following generd principles are recomended consideration of cost-benefit. upperlinits for non-medical exposure cor personnel and the general pubile. restrictions on medical radil ion exposire, gulance for nulear pover industry and considaraton of uncontrolled releases. occupational and exergercy exposure Ii htis. ore environtental zaliation studies, and accurete stinates and preatchions of radiation equivalent dosages ror all planned and existiag sources. Carrent inforat ton reported uder the following chapter titles: needs of the tires. sonrces of ionizing radiation and population exposures, enviromental transport and effects of radionuclides, genetic efrects or lonizing radiation, effects of lonizing raldion on groweh and development, and somate effects of ioniging radiation. (5T)

The appendices contain tables of basis of rish estitates and incidence or risk of levkewia. thyroid, bone, skin, breast, and lung cancer. and other neoglas

\section{$<368>$}

Cooper, J.A., Gattelle terorial Institate, Pacific Northest I aboratories, Radiologica I sciences Departrent, Richland, Wa. 1973, April

Eerental characterization of sin ine Atospheres. Brtho-1751 (Part 2): Part of Helson. J.H. et a. Anual Report for 1972

10. $1-2 \%, 1160$.

The correlation of the high incidence of Iung cancers and other resplratory ailients in uraniu hiners vith lung exposure reguires uranit accurate characterigation of the of the uranim ine atmosphere. Simulad uraniun chabers are being characterized and conpared to the acrosols found in operating uration mines. (at ath)

<369\%

Dean. P. Blomedical Research Group, Los Mlanos, No 1973. Apri1

Estination of Chest hall wickness in tung couning for plutonium. Health physics, 24, $439-440$

Direct measurements ith an ultrasonic analyzer vere made to estinate the thickness of soft tissue in the chest wall over1ying the lungs. More than one point was measured since thickness in individula varies considerably. Also. the right chest wald is considerably Also, the right chest

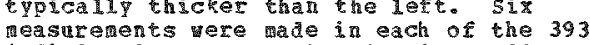
individuals between the ribs in a 120 ma diameter circle on each side of the chest. All of the measurements vere made mith the sabjects standing. phe effective thickmess for both sides of the chest was calculated. The average effective tissue thichness for this proup of smbjects tas 22.6 . standard deviation of 3.9 mand a range of 14-33 ar. The effective tissue thickness a lso as calculuted from mesurements of various bodiv paraleters such as wejoht. helght and chest circulerence. (RAp)

<370\%

Dolqirev, E.I., G.N. Raidanovsky, and V.P.

Shatov. Instisute of Radiation Leningrad, TSSR. $\$ 973$

In Vivo Couting of Transuraniul Isotopes in the 
$<370>$ comp.

Human Body. CoN -720503: Part of Bujaso, E. (Fa.). Hea th physics problens of Internal Contamination. proceedings of the IREA 2 n European congress on Radiat jon protection held

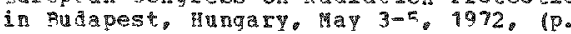
$497-502) .655 \mathrm{p}$.

The method of the determination of pu and $\mathrm{m}$ deposited in hullan lungs. liver and skeleton is described, Calibration of a scintillation

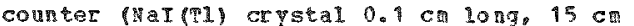
diameter and a proportional counter (AR-CMu. window area of $300 \mathrm{~cm} 2$ and gas layer thickness of $7.5 \mathrm{ct}$ is providing variabe thickness of tissue absorber. Activity distribution in three subjects is presented. organ contents aro qiver as a porcentage of the total bony content. The skeleton contains wore than a hal of the total incorporated activity. This suggests that the conta ination occured many years ago. Considerable variation is observed in isotope a istributions betreen lung, liver and skeleton in different subjects, that can be atributed to different chemical forms and modes of entering of transuranin isopopes ineo the hunan body.

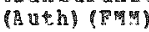

\section{$\langle 371\rangle$}

Dolphin, 6. . and S. Jackson, Arowic snergy pesearch Establishment, Health physics and Medical oivision. Hareli, Berkshire, England. 196 actober

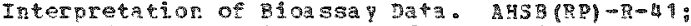

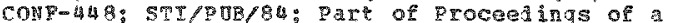
5 ymposing on the ssessment of pationctive pody Burdens in man held in peidelberg, Germay, gay $11-16,1964,(0.329-354)$

In order to estimate the radiaton dose to the critical organ a ve to internal contratistion ith a radionucliae it is mecessary to measure the aroun of ranonaclide in the botw. yhen the radionvelide entes gama or ratation or beta radiation giving rise the suitable brenstrahiug, direct measurenents of the body cortent can be 5 ge in a hole body

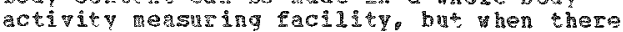
is no suitable emission of radiation it is mecessary to resort to estimation of the body contert from reasurenents of the atont of

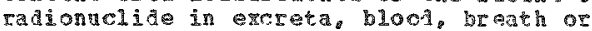
suab taken from the nose or mowh. There has been solle study of the excretion at

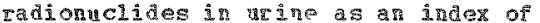

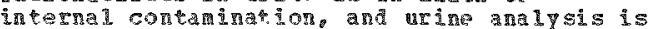
the wost extensivel y practised for of buossay. In the reviev three broa categories have been used in classirvigg the different wodes of petabolis of pardans radionnclides. The first group includes those ration onch ines distributed ohrongliout the body. The second

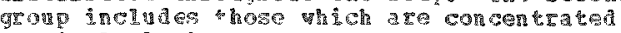
particulariy in one or wore organ of the bod in portant sabgronp of the second, corprises the bone sebers. The pattern of ats excretion and particularly in selation to the radiation dose fielivered to the critica 1 issues, is atstincty different for these different groups. It is eapasized that folloning the recogition of as

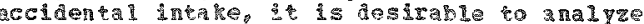

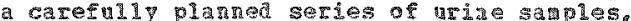
to provide measure of the rarinary excretion

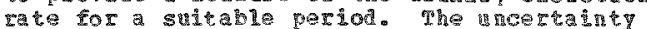

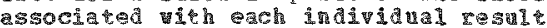
vecause or finctuation in excretion rate can

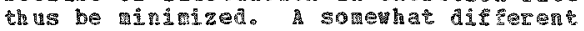

approach is suggested in the case of urine 5 ming for routine surveilinance of a group of personnel. The data avallable about getabolism of the radionelite are used to evaluate an investigation bevel, namely, the urinary ezeretion rate corresponaing to a chosen level of body content. A sumaty is presented of the human data available on setabolism and urinery excrection of tritiun,

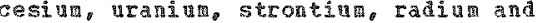
p latron

Figure is a sinplisied compartant model 11lustrating metabolic pathwats for inhaled or ingested radionuclides. Figure 5 shors the excretion of saluble uras y following a single intake. Figure 8 shows urinary excretion of pa following an jntake of 0.04 uci.

<32?

Donoghue, J.K.. E.D. DYson, J.S. Hislop. A. H.

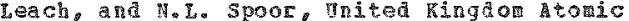

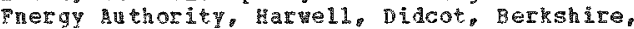
Fingland. 1972

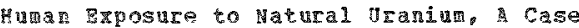
listory and alyeical nesults ix or some postrorter pissues. gritish fournal ot Industrial hedicine, $29(31), 01-8$

3 fter the collapse and sudden death of an

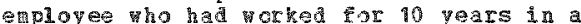
natura 1 urantu porkshop. in which the

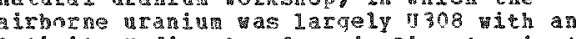

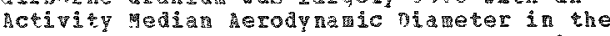
range 3.5-6.0 an and a verage concentration 300 u/3. his intertal organs vere analyzed For uraning. The tissues exatnod included

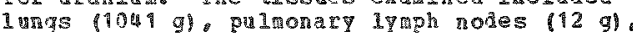

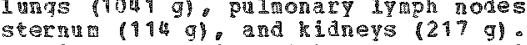
stertu (1) glo and ansiysis, using irradiated tissue ash, and countion the del aped neutrons from uraniug 235. The concentrations of aranda ve tissuel in the lungs, lyph nodes, sternum, kidnevs are $1.2,1.8,0.09$ and 0. Ah respectively. The vetghts deposited in the lungs and lyaph noles are less than the arouts calculated from the entironuental data thish the paraters currentiy applied in radiological protection. whe relation herren these results, the evvironent ezposute data and biological conitoring data is discussed th the contert of current views on the petabolis of inhaled insoluble

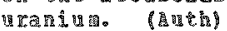

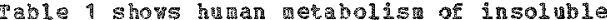
va halum uranus in poseromentissues.

4373

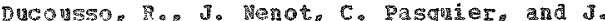

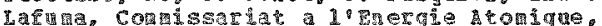
Certro a'

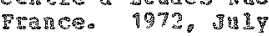

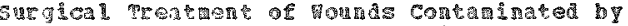

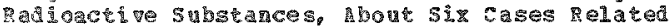

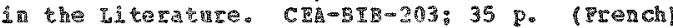

The book let is designed to be an aid to surgeoms likely to be faced vith the fine cenovi of caijoactive substances from vounds. Basic ata are presented in the first part: notion of transferability, anjo used for internel containaton, properties of $p_{18} 239$, waracteristics of $\mathrm{x}-\mathrm{ray}$

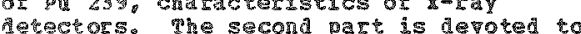
both a agcourt of six cases published in recerp years and aricical reviev sin ordex to bring out that \$rould be tone and aboye 
〈373> COHT.

al1 what should not be done in such cases. The third part gives a sumary of the surgical handling of a wound contaminated by plutoni uala (Auth)

$\langle 374\rangle$

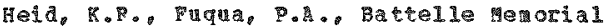
Institute Pacific Northust Laboratories.

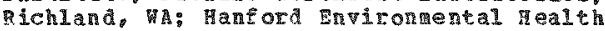
Foundation, Rehlana, 1 . 1974, MaY

Reviev of yranium Inhalation case. mealth Physics, 25, 399-403

s case involving chronic exposure to natural

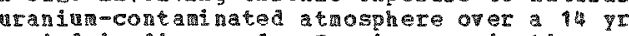
period is aiscussed. In vivo exaninaton data, including sone obtained collowing an extended abserce from work. are used, along with other supporting data, to evaluate the resulting lung dose. In vivo chest

exanination data are conpared to resints of four samples of lung tissue and throe lyoph notes which were analyzed for uraniat content using hoth neutron activation and fluorometry technigues. As a result of the study conducted, the zoutine surveillance program for uranitu workers was changed. (huth)

<375>

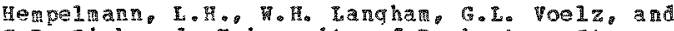
C.R. Richnond Oniversit of Rochester, Strong Memorial Hospital, Rochester, scientific Laboratory, Health Division, tos Aamos, N. 1973

Biomedical Follow-7p of the Manhaten Project

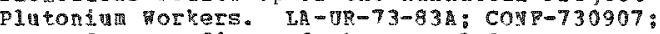
Part of proceedings of the IREA 3 ra Buropen Conqress held in tashington. D.C. Se ptember 9-14, $1973,(7 \mathrm{po})$

Long-tern studies have been performed on 25 nen tho were exposed to pu during horld hat II at what is now the Los hlamos scientific Iaboratorv. Al most all of the subjects had body hrtens of pu ranging from $9.1-1.3$ ug or $6-80$ nci of relatipel pure $\mathrm{P}$ in 239 as estimated from the urine assay nethol for pu used los Mlatos priar to 1950. The paper zeconstructs the har-tine exposute conditions, discusses the estimates of body ard lung burdens hased primarily on urine assay for plutonitur and recapitulates the todical strates that have continued during the intervening vex c\$. (Auth)

Table I shows gu bod burden estimates in man based on urine assay a ta.

$\langle 376\rangle$

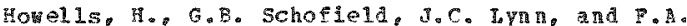
hard, British vuclear Puels. Iimted. Seascale. cumberand, nind. 1973

Assessment and mandgentent of a putoniun Contaninated vound Case. Conp-720503: Part of sutroso, E. (Fd.), Heal h Physics problems of Intergal contamination, Droceedings of the IRP 2nd Europen congress on Radition protection held $n$ Budapest. Hungary, Mav $3-5,1972$, (p. 201-503), दूर p.

A plutoniun contaringted vound case is described. Intially 14.2 uci tere present at the wound site. Afrer tho excisions about 1. uci renained. veasurements of the activity vere also wate along the lize of the 1ymohatic irainage and in the livar region. DTPA was adrinistered intravenously. trinary excretion data indicated a systemtic uotake of 1.2 uCi. (ututh)

<37》

Hursh, J.B., and N.L. Spoor, university of Rochester, Rochester, NT. 1973

Deta on man. Part of rodge, H. Co, et al (Dds.) Hanabol of Experimental pharacology Uranitu. lutonin, the Transplutonics, Chapter t. springer-Verlag, Nek Hork. We Fork, lp. 197-239), 995 p.

Tuan data on uranin expostre is revieved in three sections: il planned experinents organized according to ronte of a ainistration: 2) data from industrial exposure: and 3) data from background studies. Sore of the problems involved in the collection ard use of data from these sources and the extrapolation of animal data tc man are discussed. The experiments and ata reviered range in tire from $185 \%_{0}$ wen uranyl nitrate as used as a treatrent for diabetes mel1itus, to 1972. There possible, the affects of the alence state. physico-chemical form. solubility. dose rate, and biological half-1ife are included. The three sets of intravenous injection experiments shov good agreement where comparisons are possible--ercretion rate. vinimal dose to produce kidnez injury, and tissue distribution of uranium The reported results of the oral expetinerit $\$-$ gastrointesti nal disturbances, urine analysis, and kidney influry-are critically evaluated, The build-up of tolerance to uraniu toxicity

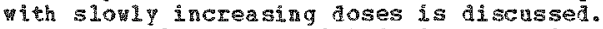
Interpretation of the inhalation experiment is discussed in term of deposition of uranin dust in the apper resoiratory tract. arcretion, chemical ford, tissue deposition. and loss from the nostrils. Data has been obtained from occupational exposures to urania by biological monitoring following kown exposures and from postmorten data. Rate of wetabolis correlated with cherical form. For the pcstrorter data it is concluded that a though there is no tendency for traniug to accumalate in the body. most of the uraniul absotbed into the body from the lungs and
gestrointestinal tract is deposited on

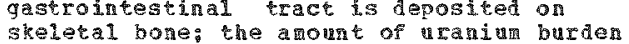
in the lungs of workers exposed to insoluble uran is considerably less than that calculated using the parameters for inhalation from the evaluated air concentration ata: and the concentrations of uraniu in the tracheobronchial lyaph nodes are not greati different from those in the lungs. Mornal and chronic level exposure to nraniu compound appears to produce no vernanent damage to the hum body. Values. taken from numerous sources, are given for

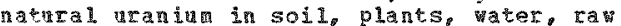

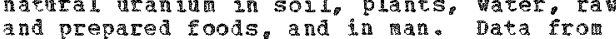
and preparea coods, and in tan Data fron natural uram ina in man and his gastrointestinal ract and the rate constant for loss of taniug from the total body.

(St)

This reviev includes bibllography of 121 references on uraniu dation an.

\section{《378>}

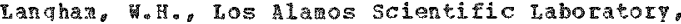
Los Alamos, NM. 1959

Physiology and parcology of glutonim 239 . part of proceedings of the 7 th Hot iaboratories ans Equigment symposid hela in cleveland, ohio. A PTi $7-9,1959,(p, 256-275)$ 
$\langle 378\rangle$ conts

The phviological and toxscologica properties of $\mathrm{Pu} 230$ are sermatized to

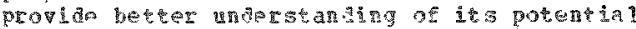
as an industrial hazard and to exolain the necessity for rigorous industrial hygiene an engineering cogtrol over al1 plutonis processing. Tn pareicular the radiotogica 1 properties; absorption deposition an 1 excretion; toxicological and radiztion efrects on body systens and organs: marimu peraissible and estinated body burdens; accelerabed excreting; and human experiences with pri 239 exposure are revieved. (3T)

$<3703$

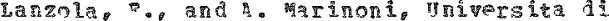
Pavia, Ististute di I

Conprison of the Radionctive contan nation of the rotal Dier of halescents in the com 3. Basisis of pood consun ction in the Institutional piet progra. EVh-3945-e (Part 3): $31 \mathrm{p}$.

As part of an investigation into the fentoe of galozetive containaton of the diet of

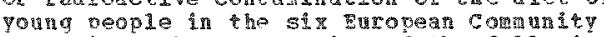
contries, the constrintion of the following food group was eqaluated: nilk, cheese cereals and cerea 1 products, potatoes. veqeables, fruit, neat, and fisho The intake of calories, proteins, lipias, and calciur ere calculated. Appliceton of statistical technigues resulted in bridence of significant differences betheen areas in irdividual comtries. The foods aisolaying the areatest frequency of siqnificant difference petueen the various olices vere cereals cheese an a vegetables.

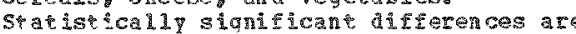
present at intoriational level for some principal foodstuff betneon various places in Eapoperobals inolying considerable Hiferences in eating hat Pestige from a previons investigation carried

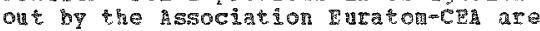
constant? lorer than those ret the present senuty. (sT)

$\langle 380\rangle$

Iister, B.A.3.A. Aorgan and R.J. Sher wood,

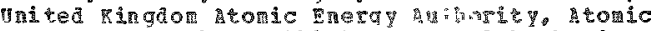

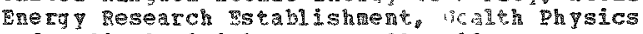
and Hedical Division, garte 11, Diacot

serkshise, 3ngland. 1962, Mat; 1973

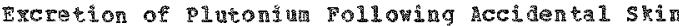
Contannation. AERE- $-4064 ; 27 \mathrm{p}$ : PHysics, $9,803-815$

An extensive study was ade of the fecal and uringey plutonin excretion from two subitaces who shstained hich levels of contanination on the uncut sin of the hand from accidental contact ith acia plutoniun solutions. In one case, where the contaninat Plutoniu isotopes in aça rea act the thesurenes reported covered 150 days. In the other case, excretin after contamination ith solution of plutonitu in allute hydrochloric acid contalning DTA and a detergent was followed for 110 digis. The ezcretion patterns show marked dif ferences from the hum experinental dat published by Langhang particnlarip ir the high ard variable amonnt of olutonin excreted in feces relative to urine. The excretion date are supplemented in one case by a series of measuretents on the leve 1 is or shi contannation, by erploratory body ratioactivity measurenerts a nd by inconclusive blood plutonin and
Atrempts vere made to estimate the hod y buriens in various tows The wide vaxition of these estatiates indichtes the

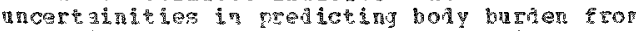
excration data. The present study gives no indication as to the rajor site of leposition of the pintonin. (1)

<381>

Lushbugh, C.C.g and J. Langhar, tos Hamos

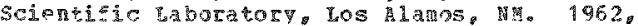
nctober

Dermal Lesion fron Taplanted pritonim. Archines of Dermatology, $86(4), 461-454$

Histologic and autoradiographic examation of a piece of palvar human skin sald to have been contaninater by a penerating viece of plutonilu revealed incense alpharrack concentration in a ninute focms of subacute and chronic radioderatis. Athough the penetration of the alpha-particles yas

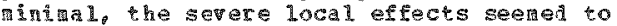
indicate that a rasive arese of

aloha-rajiation had been delivered to the area in the g pears the contarination had been resent. (Auth

《392》

Mays, $c$. Division, Salt Late city, Dr. 1973 , March 31 1973. Decenber

Cancer Induction in Radioactivit. Co0-119-248: part of Dowgherty

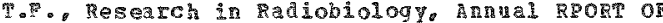
work in promress in the Internal Irradietion Progran, (p. 378-400) 400 p.; Health Physics. $25,595-592$

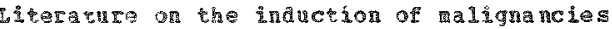
in uranin aipers by in 222 , dial painters by

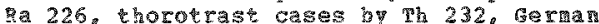
patients by a 224, polycythemia patients by

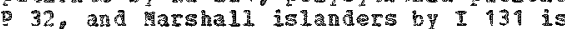
reviever. Host a 11 of the induced

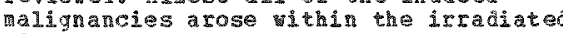
tissue. (5)

$<338$

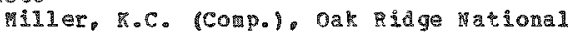
Laboretory, Tozicolog Infornation pesponse

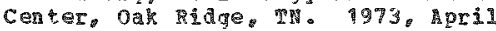

Diannosis, Treatrent and occurrences of 7adonclide Contamination of pounds: Bibliography. ORLE-TRC-73-18; 16 P

The bibliography contains 164 selected Ieferences, which are divided into primart and seconary rererences: each section is arranged by pear and alphenetically by first a ther with each year. The sources searched a twenty-7ear tio span, from 1952 through Hatch 1973. The bibliography contains citations about both acciaental and experi nental incidences of mount Contar

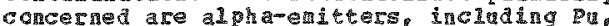
pith fer peferences to bet an gama eriteing elements. (A the

《384⿻

mel son, I.C. and

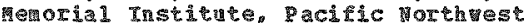
Laboratories, Bichland

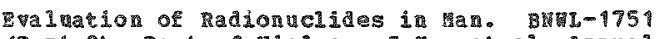
(Part 2): part of report for 1972, $(0,95-96), 116$. 
〈384 CONT.

Erortese is reportat on evaluating post norter tissue samples of individuals tesiding or formerly residing in the vicinity of the Hatord complex. Trentp-tro postrorem tissue and blood sandes gom the 1.5. Transuraniu Registry and 44 environdental samples vere processed in 1972. (ST)

$\langle 385\rangle$

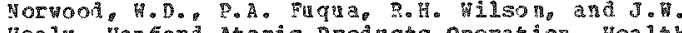
Healip vamord htomic prodncts noeration health and Safoty operation, Pichlan, VA. 1958

Treatgent of PIutoniu Inhalation: Caso studies. A/con $-15 / 9-765:$ part of procedings of the 2nd Internation $5 y$ mosiun on the Peaceful IIses of Atonic Energy held in Geneva,

Switzerland, Septerser 1-13, 1958, Vol. $23,1 \mathrm{P}$ 434-838)

After 13 vears of operation at the mancord Atouid products operation an accidant occurred which released an unreported anount of plutoni un thoughout a vorking area and resulted in the exposire of rerson nel. The orocedures are reported for band1 ing this accidont in which he maxtua peratissible arount of plutonium deposited in the bod? $(0.6$ u. 0.04 uci) was great Iy exceeded in one operator, with ruch less exposire reporter in other personnel. Analpsis of rose swab revea led a laost $1,000,001$ dpa. Al urine analysed during the 12 hours after the accident conteined a total of 310 apr indicating that a sinificant asount of plutonit had enter ed the blood strea almost ingediately. Ca por was admistered ineravenously for 11 days and oral Ca EDT was adninistered for 21 days. Freatront continued for 7 months. ora 1 doses of $\mathrm{Ca}$ EDTA were determined to be of no pactical value because of the sall increase in elinination of plutonium. zirconiu citrate พas giver intratenously on three occasions. the curve for excretion data assurad by sample results indicated a half life of $30-40$ deys in the lungs and an initial deposit of approxinatelp 0.35 nCl. The cotal plutenitu excretion reasured during the 220 days of observation indicated the 0.037 uei vas aliminated in urine, weh 0.033 uci eling inat during $c a$ GoT therapy and 0.004 uCi during no treatrent. Total elimination in feces 0.35 uci. Extended treatent increased urinary 1 inination by a ractor of 10 but resulted in only $10 \%$ of the estivated body deposit being elininated by this route. The study indicates the need for continued research to obtain an effective rethon of treatment. The nost exhaustive contro methods gust be usea to prevent plutonim deposition. (BB)

$\langle 386\rangle$

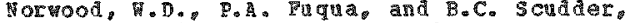
Hanfor tomic prodncts operation. Health a safety section, Richland,

Treatrent of Acute Plutoniu Poisoning. Industril vedicine and Surgert. 25(1). 135-139

A pethod is out lined for the tratgent of individuals who may receive by inhalation. ingestion, or through contarinated pound an estrated body deposit of plutonin greater than the 0.6 ug liait presenti accegted as safe. present mon ledge is based on andial studies and limited clinical experience. Three individua ls haring arountz too sall to cause concer have been treated zicconju citrate was mor two cases and Ca $\mathrm{ZDT}$ was used for one. Vith passing of tine, coutine urine studies of olutonia torters indicate increasing rubers of vorkers vith aeasurable body deposits less than the

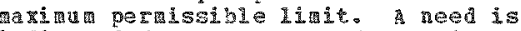
indicated for treatment os chronc cases not presentl atailable. Pron anial studies, it vas postula ced that the wost effective dose of zirconiug citrate in man would be at least $100 \mathrm{mg} / \mathrm{kg}$ of body weight, of $7 \mathrm{grams}$ for 70 ky an. To administer 79 of zirconiun citrate reguires giving 29 g of sodiun citrate. This results in possible lethal effects, and less toric sale than sodil

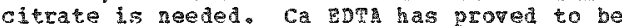
reletively non-toric and removes olutonius Eron the skeleton as vell as sort tissues. Based on atensive experiantal work and litited cinical experience, a methon of treatrent of actate plutonim poisonitu using both zirconis cirrate and $\mathrm{CZ}$ EDTh is recomended. Early treatment following an accident is effective in increasing excretion and decreasing bhe body deposition of

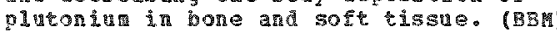

$\langle 387\rangle$

not given, International Comission on radiologica 1 potection. Conitte 2. 1959

Per issible Dose for Internal Radiation. ICRP Qublication 2. Perganon Press, Men York Mew Vot

Recorrin arded valnes of body butedas of radionuclides and garion permissibe concentration (lipt) of these vuclides in aix and water are given. onlp the more inportat radionuclides are consindered and the reconthended wanes are applacable primarily to occupationd grposure. Revisions of previons Tnternational Con ission on Radiological Drotection ICBPl reports are included in this volube. Fajor changes froc the 1958 Report of the ICRP are: instea of a reekly lipit, a guarterly libit is recontanded thus giving oreater flemibility for may orerations: a linit on integrated dose is imposed in the case of exposure of the hlood-forming organs and gonads, but not the -yes: explicit recomemations are given for sone non-nccupational groups and Hates are suggested for the phole population. M11 maxitu perabsible concentrations are given for $40 \mathrm{hr}$ tek as well as for continuous exposure. i.e. 168 hr meek. The recomandations cover the following catagories of exposure: occupational asposure: erposure of special groups incl mding adules who work in the picinity of or enter controlled areas and mabers of the Qublic living in the vicinity of controlled reas: exposuce of the population at 1 arge and redical erposure. Secowendations ith regard to individual exposure are given only for the first two groups. Doses resulting frow natural backgroud radiation or welical ma demal exposure are in adation to

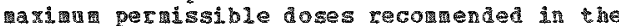
repore. IRC values are listed only for relatively insoluble an for the more comon soluble conpounds. and these componds are specifled ony by the extent of solubility rather than by speciric chenical structure. The on It wethods of intake considered are ingestion and frhalation except in a fer cases. 11 calculations are based on standard an. For boneseoking radionuclides estinates of maximu permistibie raposures are based on a comparison with 226 : 20 : a 11 other radi on or 1 ititing the veeky relative biological effective dose received by the various organs of the bodi. pactors used in calculating 
<387〉 COWT.

equations were effective energies, standard nan data, and other biological and related physical terts. The exponerntal or compartment rodel vas used to deterimine retention and elimination: the power sunction model was used in adition to calculate mpC and body burden values. (5T)

2able 1 Iists the maximu peraissible boly burdens and raximn permissible concentrations of 240 radionuclides in air and water for occupational exposure. Tables 3 and 4 give maxinutin permissible concentrations of uni dent ified radionucl ides in vater and air. Table 5 gines frectiverergies of radionuclides. Tables 6-11 list sone paraters of standard man.

<389

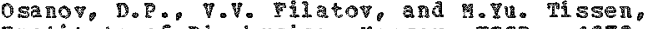
Institute of Biophysics, moscor, ISSR, 973

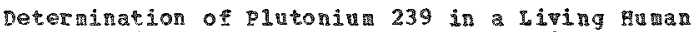
orgarist from the pate of Its Elinination.

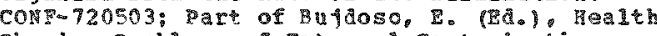
physics probiens of Internal contamnation. procoenings of the IRPA 2nd European congress on padiation Protection held in Budapest, Rugary. May $3-5,972$, P. 491-496), 655 po

on the basis of a rodel of the eransport of inhalea $p$ lutong in the hum organsw the relation has been estalished between the content of plutoniun in the entire body. and the rate of its excretion vith the mine at the same time surerval. This correlation vas obtained as a function of tive for different reginens of plutoni a with aiverse degree of ajspersion a solubility. The mesults presented graphicaliy ray he utilized for assessing the content of plutonin in the organis followng single and constant rate chronic intake. Hut

$<3893$

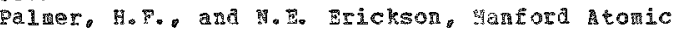
Prodncts operation pichlana, 15

Pactors Influencing Measuremer of rluton

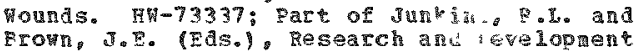

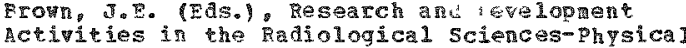
seiences portion, Janury through Decenber 1961. (0. 39-42), 308 p.

The efficiency and accuracy of plutonin

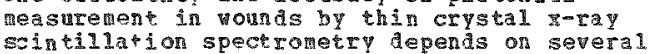
seintillation spectronetry depends
factors including ath and area of contaninaton in the wound position of the mound with respect to the crystal, and seli-absorptom of the 17-kev $x$ rays the contaninating haterial. Lack of allowance for wound devth wil cat se less than about 20 error for depths ap to 3 wo vo correction is necessary for lateral size or a displacement of less than 7 m trat the center of the counter. Measurerents of Pu in large particles ala be inaccurate because of self-ahsorption in the source. (B Bll

<390>

Przyorowsi. 5. National Center for Radiation protection, Seriin, Geran Denocratic Repubilc. 1993

Primary Deposition of Berosol Particles in the Human pespiratory pract in Ratation to particle size. Breathing parameters and pegion of
Deposition. Con-720503: Part of Bujdoso, E.

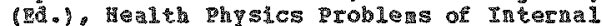
Contarnation. proceedings of the IRP $2 \mathrm{na}$ European Congress on iadiation protection held in sudapest, Hutgary, $3-5,1972$, (p. $239-243), 655$.

In vivo investigatlons of prinary deposition in the hutan respitrory tract are describer

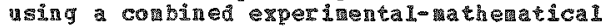
proced ure. The obrained depostion values are discussed in relation to the reglon of the respiratory tract. breathing paracters and particle size. The gplicability to proz atosol is shom. (Ath)

\&391>

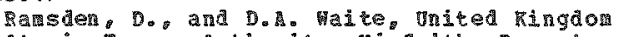
Atonic Bnergy Authority. England. 1972

Thalation of Insoluble Irom oxide Particles in the Sublicton Range. Conp-711104. IAE-SM-150/52: $5 T$ TP UB/290: PaTE of Proceedings of a staposiut on Assesstanc of ratioactive organ and Body burdens hela in stockbolm. steder, toverber 22-26, $197 \%$, (p.65-81), $698 \mathrm{p}$.

Pecent studies at these labora tories have been concerned with the production of a erosols of insoluble perric oxide in the size range 0.08 to 0.5 picrons using an ultrasonic nebulizer. The traging of these particles ith radioactive labels, the inhalation of such aerosols matr controlled conditions, the detection and distribution of the raterial in vivo together with studies of its excretion frow the body are discussed in this paper. Tho groups of inhalations vere studied: (1) chroriut-51-1abelled arosols and (2) Pu 237 labelied aerosols. (1) Iung retentions and etrretion curves were obtained for eerosols labelled ith Cr 51 (0.1 falcrons

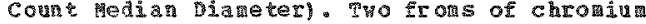

label retmed leachable and non-leachable vere used. The conbination of in-vitro

leaching stribs and urine analysis enabled both sets of inhalation dat to be nor to $g$ iw the retention of the iron oxide particles in the lusg. Long-tern retention of $80 \%$ of the initialiy depostied aerosol with deep-lusg location and half periods of clearance of the order of 270 days were

found. (2). In the contest of this paper Pu

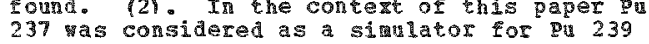
because of the close match of their 1ov-energy u-ray enissions. To typas of breathing patcern were ased aiving lung retentions of $90 \%$ and $5 \%$ with deposition in the pultonary region and upper respirator tract respectioly. The lung-retention curves and excretion patterns are presented and the extrapolation to the cases of inhilation of pu 239 considered. The resulis are conpared vith predicitions ade from realistic ches phantors calibrated for pu 239. (A uth)

<392》

ichond, C.P., Oak Ridge national Laboratory. cak Pilge, Th, 1974, Decenber

Bionedical Effects of platonium on Humans.

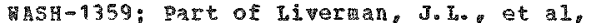
proceedings of the U.S. Invironentel protection gency Plutoniu Standerds Hearings on lutonju and other Transuratum rements: Sources, Envicontental Distribution and Biomedical Effects held in washington. D.C.. Decenter $10-11,197 \%,(0.235-269), 327$ p.

The development of marima permissible body burder (MPBE) is aiscussed and the value of 
《292> Ca

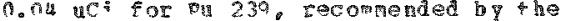
Trtergational commssion or patological

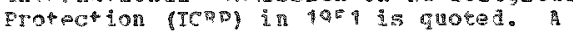
revion is pregerted or thw varions groups of persors that hate heen aposed to vin

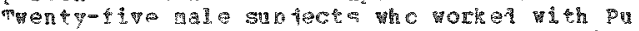

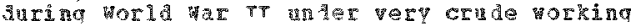
conditions, fare bas followed melically

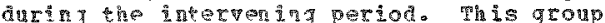

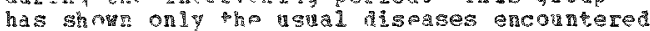
in their age zone, In an atrempt to

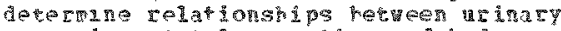
excretion, eqa excropon an bodi content

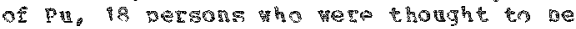

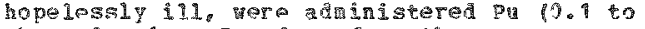

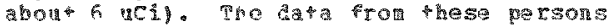

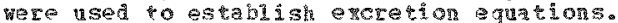
some information can se oble ined on the a wount of tu in the gonad of these subjects. whe traction of administered pll found in the

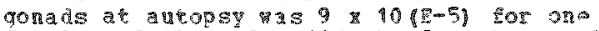
forale an alout 3 \& 10 (T) subyects. The parpose of the p.

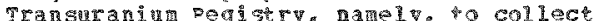
inforntion on person potential

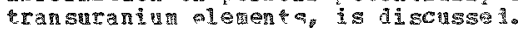
permission is obtaing on a voluntary basis for postarter analuses of tistses.

Comparisons can ther be rate bereen estinets of the bod burder base upon tissue andves ar estimates vade previgus on the basis of pealth physich and operational data. cor 1 aerabie a mont of inforwaton has been obtained from accidental occupetional exposin res to Pu. petzeen 1957 and 1970 , about 209 personne: had depositions areater then $25 \%$ of the MP3E for $P$ u intalation being the ajor portal of entry. Pu from allow is oresent it sall guanties in warious organs of aan. The current lung burden as estinated for persons in the vniced stafes is about $0.3 \mathrm{pci}$. Pu 239,240 and a rough estinate of the total amongt in the bodp is 3.5 bi. It. Is concluded that the lace or denonstrable effects of pu in man represents orasuptro equence that the standards are not grossly inadecuate. (ment

Table 3 shors Pu bod burden escinates for

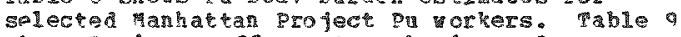
shows $\mathrm{D}$ u in man from atmospheric nac leat weapons zests.

<393>

Row pational Laboratory. center for puram Radiobiology, Argonge, I. 1973

qadiological and Fnvitonental mesearch Division Annual Report, Jul 1972 through ange 1993. a

During the report pariod aed ical extrinaton and radioactivit veasureanes of 302 radiu patients were nade at the center for Human Radiobiology. Fre papers deal primaridy ich patients wo have carried measured burdens of radiu for pany pears. The parageters studied include chacteristics a distribution of malignant a tors, iannity. tumor pirases, chrowosone breakage. c\%togenetic studies. excreton rats, blood levels, plasma clearance, and bone concentrations. In adition, $z$ ray ex mintion doses, techniques of one study. radonucilae concentration determintions. instrugentation for wonitoring and neasurenent, bone turor induction in mice,

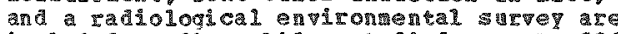
included. Padionulites studied vere 225. $\mathrm{Pb} 210,0210$, Th 228, Th 220, 23\%, 249. and ce 240. Thenty seren paptrs are

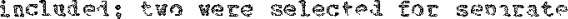
abseraction for the data base, (ST)

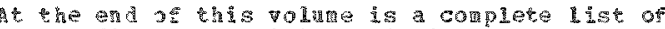
1346 radi

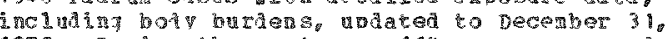
1972 . Tha ring the past pear 114 cases nea sured

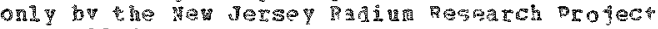
wers and

<394 \$

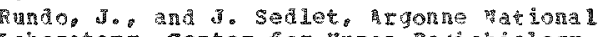
Iraborator center for tuman Ratabology. Aryonfe. TI. 198

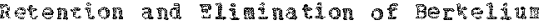

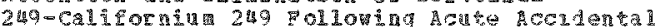
Intalation. Avi,-an60 (Pare 2): Part of

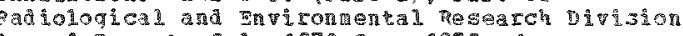
A $206-217), 326 \%$

A case of accidertal Inhation of a 5 mall and its deca oroduce CE 249 mas studied by nod raloactirity measurenenes for ct 2491 and excretion analysis for both nuclides). The results obtained thus far cover the fint yar after intake. taterral geasurenents of the garat rays from the CF 249 indicated an a poronimate chest content of 3 nci of this

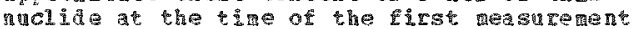
(da 7). Fhe 300- Fold wore abratat parent 3t 249. conla not be detected. Subsement measin erents of the activer of the cer 249 conla be reasonably well described by the sum of tro croonential conponets. $17 \%$ hating

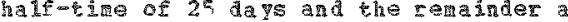
half-tine of 1210 days. Except for an initha rapid clearance pie the feces arino the first 10 days, che ncinary and fecal

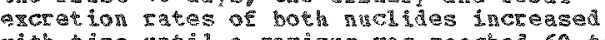

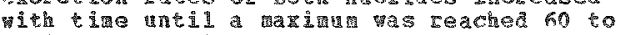
70 days after intake and thereacter declined. If the early secal excretion tas meglacted the resilts could be zeasonaby yoll described as the difference be ween to exponential conponents, one with halfutines of 15 to 30 tatys representing the initial Increase and one ith halt-tines betrean 90 and 120 de decrease in excretion rate. The increase suggests soae chage in the thrabed naterial after incake, possibily an increase in in rate of aissolution. (Anth)

<395>

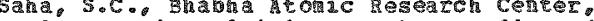
Realth Bhysics Dipision Bonbay, Indi. 1972. voverger

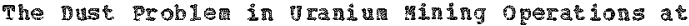
Jalugade. Indian Jourmal of occupational Hea th, $15(11) \cdot 1-7$

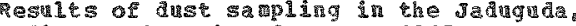

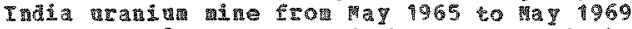
are reported. Becarse of the retness of the

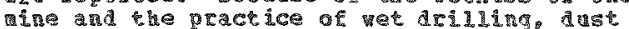

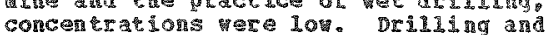
chand sapling were accompanied by the

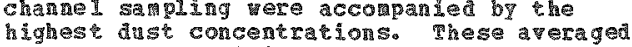

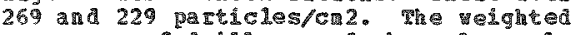
exposures of arillers and channel saplers were 0.89 and 0.88 or the threshold 13 mit value (TIV) Eor sillca bearing dusto Dust

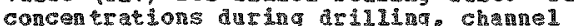
sampling and loading increased ae deeper sewels of the nase (ST) 


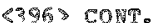

and G. Ho Dohnh

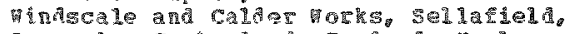

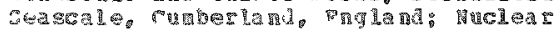

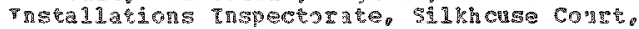

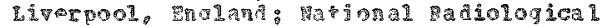

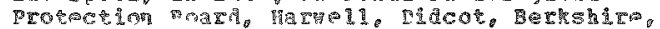

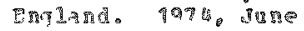

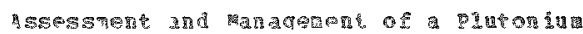

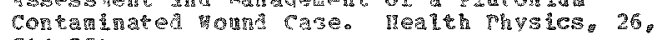
5470554

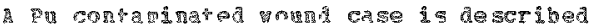
together of

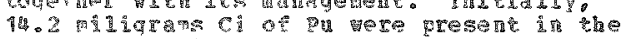
ทoung.

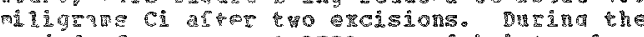

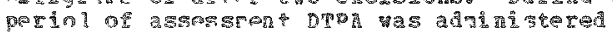
and 卉影

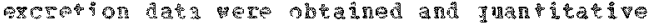
morishefir of

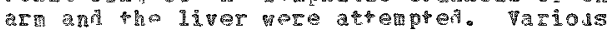

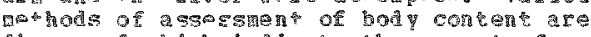
औiscussed

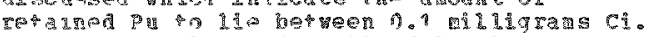

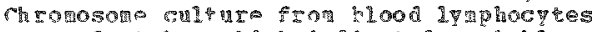
va proremential id

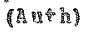

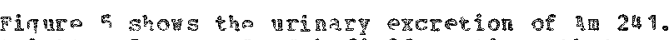

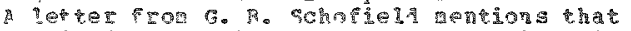
Cortinuting surveildance of the case is boing

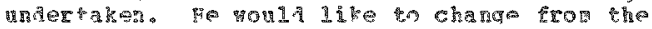

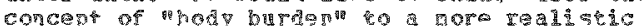

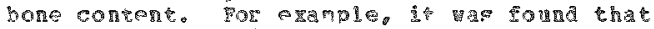

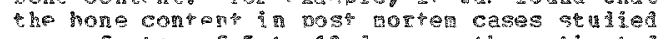
was a ractos of 50 in

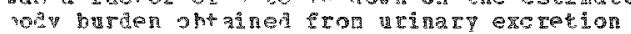

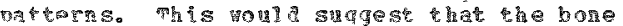

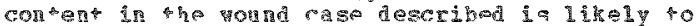
be logs the the to nct rentioned.

$<3973$

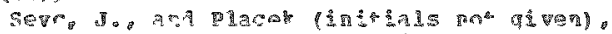
Tretetute of

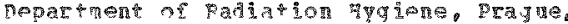
Crechos ingary an

bung Cancer pist in selation to Lorg- Ter

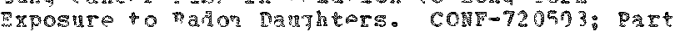

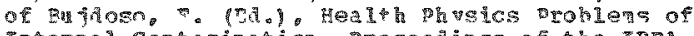

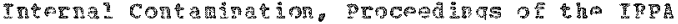

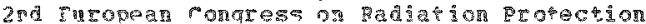

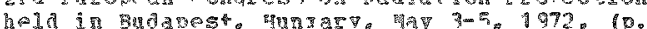
$129-13 \%$, 655 .

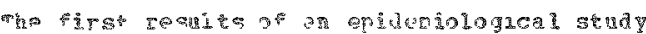
carrich

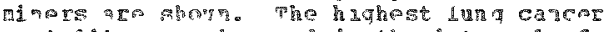
For $15-19$ ged

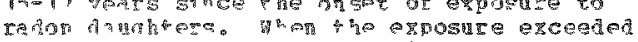

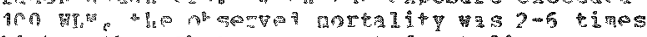

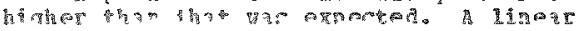

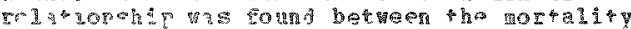

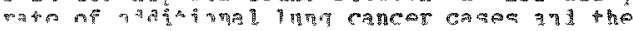

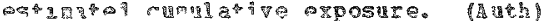

$877^{2} 8^{2}$

"bis

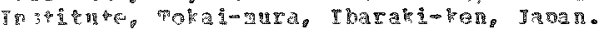

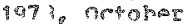

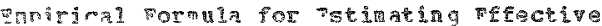
Tisent The

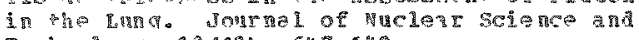
7echolog\%, 10 1901, $647-649$

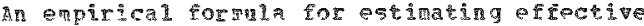

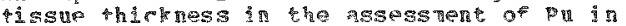

She in

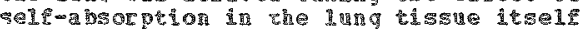
into account paraneres used were chest

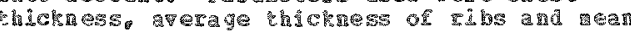

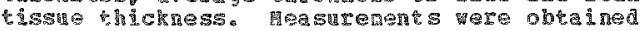
from 393 subjects using an

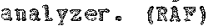

$\langle 399>$

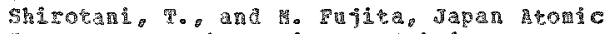

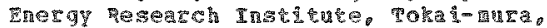

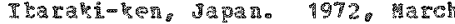

Fot

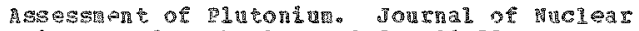

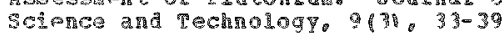

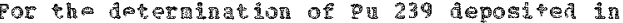

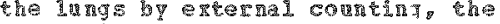

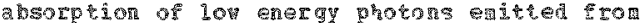

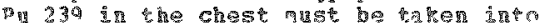
consideration hecalase of itc hich

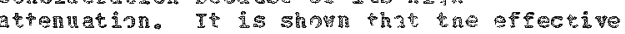
issu thicluess of the the tho can be estinated by comating the

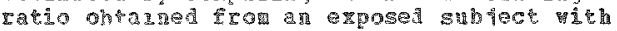
that obtaned berorehan

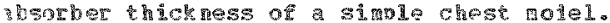
rhe âd

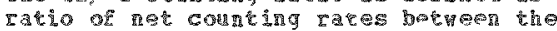

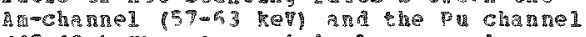

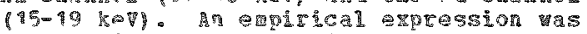
2.so derived from experinents on a phatron to

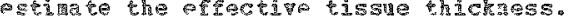

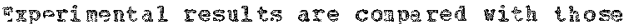

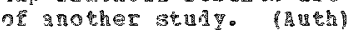

<40?

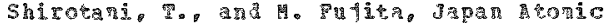

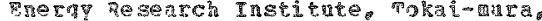

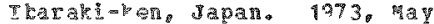

A pethod of Deterninaton of Correction Factors

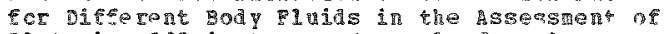

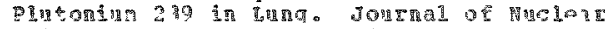

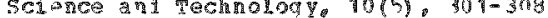

Tr the thetertination of Pu 230 isepositer in

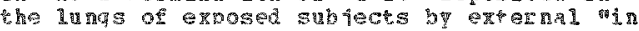

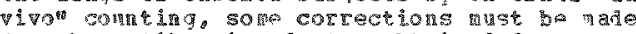
fer the calibrator factor obtained frot a whentory to take account of dieferefces in

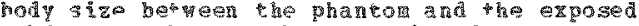

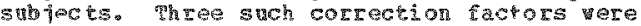
considered in this work, and deternined

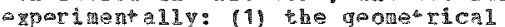
offuciency of the exposed subject as estidated using lungosher plane sources of actin size: (2) the shieland effect of the sternu and ribs viewed by the

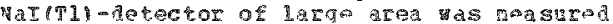
wrob chest m-ray nlates of tho fintern subinct and to the offoctive chess 11 thichness as avaluaten by mens of an omoirical formia. Fstida tors of Pu 239 in

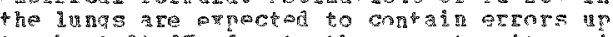
te apout 2 a. $8 \%$, ilue to the nucertadnities in

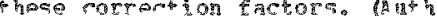

$\langle 401\rangle$

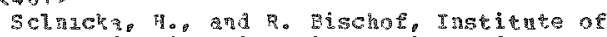

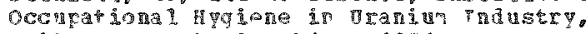

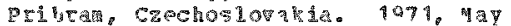

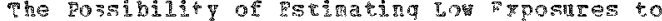
Shortol ived Decay products of

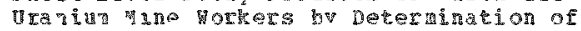

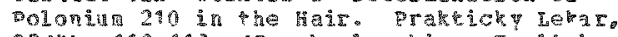

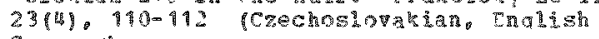
Sหม

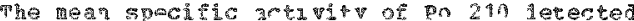


《401) COHP.

in the hair of a group of 17 persons not occupationaliy exposed to short lived decay products of Rn 222 mas determined to be 0.048

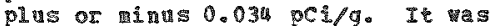
ascertained on the basis of this walue that the analysis of 90210 in the hais affords under nornal condit lons the detection and determination of the occupational exposure of uraniug rine vorkers to short-lived decay products of Rn 222 in an environment vish a considerably lower potential energy of alphe radiation than the maxim permissibie concentration hich is is $10(54)$ me $P / 1$. (A A e the h)

<402〉

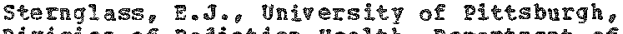
Division of adiation mealth. Department of

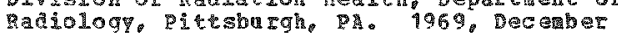

Evidence for tom-level Radiation pifects on the

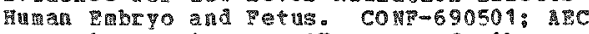

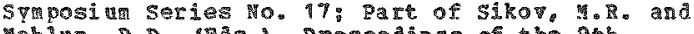

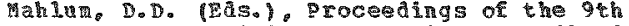

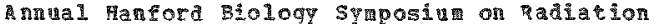
Biology of the setal and Juverile mal held in

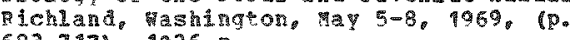
593-717), 1026 .

Fvidence is presented that indicares high

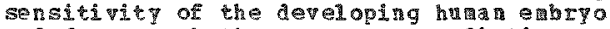
and fetws to both acue $\mathrm{s}$ ra ratation ac dianostic Leve is and low dose rate radiation from allot. Whe effect expresses itsele by increased rates of childhood leukeria accompanied by a shift in ale distelbution at death, as vell as by increased rates of stillbirths, neonatal deaths, and infant deaths in large population groups that have been exposed to known a our ts of $10 \mathrm{k}$ - level tallont. The earliest evidence for low-ienel and lon-dose-rate eriects as obtained frot a detailed andysis of the leupenia inctease arong chidren 0 to 10 Tears old in the Albany-roy, New Yok, area following the rainout of radigactive debris frow a is 3 kt nuclear detongtion in Kevada in April 1953. The subsequen doubing of the chillinood leutenda rate ower a period of 8 years was characterized by a 4 to 5 year delay in onset sititar to that obserped for children who received $x$ ray radition in utero or early infancy and $a$ shift in age distribution at onset toyard older age similar to that noted by sterart nd hewit for incravterine $z$ ray irratiation. Hore recent evidence for the effects of low dose and low dose-rate radition on the de loping fetus encyo. and young infant comes fron a stud of fetal. neondel, and postnati 1 ortality rates for each state in the litited States and for a nuther of foreign countries. Analysis of the changes in mortality rates following the detonation of specific nuclear peapons shows a geographical distribution that coincides with the know long range Eallout paterns. The changes in motrality rates for diferent regions of the onited states and the worla are found to be closely correlated with the reasured amounts of $5 \mathrm{E} 90$ in the rilk and the observed a monts in the bone and teeth of the fetus and newhorn. (Auth)

\section{$\langle 403\rangle$}

Stokinger, H.F., U.S. Dulic Health Service. Division of occupational Health, Toxicology section, cincinnati, 9H. 1966

Recomended Hqien ic linits of Exposure to Berplifum. Dat of stokinger, H.E. (EA.).

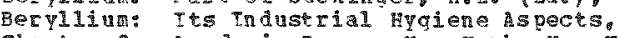
chater 8. Acadenic Press, New York, Nev Tork,
(0. $235-244) \cdot 394$.

Liaits for the concertration of beryl1iun in air for the palat workroom and conaly adopted by the thomic rergy con rission in 1949. mhese inits are hased on diagnosis of acute beryliosis (preumontist in plat horkers exposed to levels of 1 a/mi a large numer of pneumonits cases in coman ities surrounding processing plants. Coincident vith the strict application of

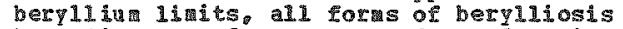
have disappeared. Arguments for and against changing the inato ace given. The meed for studies of the relative toricities of the several berpllina componds and for drinking vater standaras is stressed. (st)

<द⿱

Stokinger, H. E. (RA.). U.5. Public Health Service, Division of occupatonal Healihe Tcricology section cincinnati. on. 1966

Berp11itu: Its Industrial

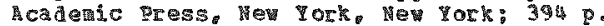

The monograph provides aetailed accomnt of the know ledge accumiated from $1946-1966$ on the industrial hygiene a spects and toricology of berylia and its comercially useful compounds. The tagineering control aspects of ber 1 lin disease are stresed: clinical aspects are rentioned on 1 where necessary for the understanding of the industrial hygiene control procedures am for the potivation of the berylinu toxicologic research studies. Prominence is given to the chenistry and physics of the ind utrial compounds, particularly to the anditic methods. The definition of the disease and the findings of research intestigators are thorouthly discussed. Individual chaters vere contributed by athorities in their respective fields. Fhe monograph vas mitten to provide basis for environental health practice in the becylling industry and orovides wath For those interested in research a developuent. Fon chapters pere selected and abstracted separately for the tata base. (ST)

<4 $05>$

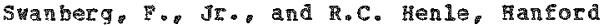
tomic Products pperetion, Richland, HA. 1964

zacretion of Plutonis 239 in a patient th Plutoniun Contarinated Infury. pare of poceedings of the 7 th An mal mestern Industrial Hea th Sy a posin held septerber 27-28, 1963. published in Journal of occupational hedicine. $6(4) .174-178$

8 reportis given of plutoniulu-contarinated 国inor in fur sustained by a intenance aplayee in a Hanford purnanufacturing cacility. The accident. medical treatment. urinaty and fecal excretion of the radionuclide, and evaluation of the body burden are described. Twenth-eight grams of DTPA were administered to the patient in four series of treatients. The total arinary excretion of pu during the first 24 hr ateer treation daly rate of pu excrecion in the feces was consistenty less than in urine. Deriodic exandintons vere rade to deteraine the quantity of radionuclide ceraining in the site of ingury. Administration of chelating agents. wth resultant elevated excretion rates of raionuclide, make assessment of the body burden difficult. Treatment may affect egeretion rates for as $10 \mathrm{ng}$ as 200
days after administration of DTP, requiring 
〈une> Cond?

long-term follow-up of such cases. The warked variablity in the fecal-excretion tote precludes inse of thess ata for evaluating the bon burten in tho case, but they are of value as indicators of the

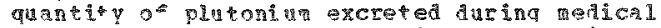
troatment. Felvina on the uninary-ercreion ata. it wa concluaen in this case that. 400 days afrer the exposure. the internal

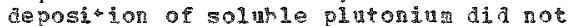

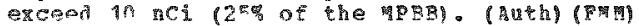

<496:

marasov, 9.I. Fot. Smorodintseva, A. F.

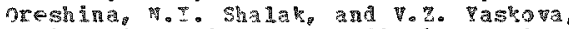

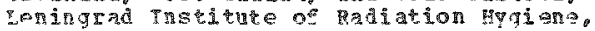

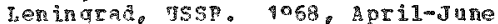

Sntry of plutonium 239 into the fuman Body from

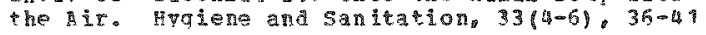

Itwostigations vere carried out on saples

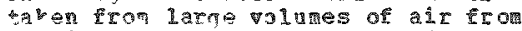
continuous aspization on Ppo-15 filters, the total yolat of air aran through the filter Being 50,090 to 119.900 ras. The 1 ings of gersons older than 5 . ho carhiovascular ajseases were studied. The kinetics of the piatoniu 239 content in the air, he lungs and he lyphat ic odules yas stullied for 1954 and 9965 . Bszesswent of the possible hazara of the aerogenic introduction of pin oni 239 into the body of persons. hating accupationi contact ith the isotope. was carried out. Data on the atmospheric concentration of pu 239 showed that in 196 is-1955 the concentration aid not exceed n * $10(\mathrm{E}-21) \mathrm{Ci} / \mathrm{l}$, which $\mathrm{s}$ s four orders of manithe lower than the saxinu permissible concentration of this isotope. confirtation was obtained for the date reported in the it terature on the accumatich of $\mathrm{pu} 239$ in pulmona tissue. The dose loads on the lungs due to the isotope aid not exceed o. 3

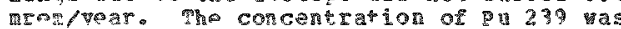
consiferably hiqher in lymph nodes than in pumonary tissu (by an average of to orders of gagnitude?. (Aush) (Fry)

Table 1 shows the atmospheric concentration of Pu 239 for 1054-9966. Table 2 shous the Du 230 concentration in hulan ings in $1963-1956$. Table shows the concantration of 239 in human tracheobronchid lyaph nodes in 1965 and 7965. Article also titled the water of aerogenic Introduction of lutonin 239 into the Huan sody."

<4 07>

Teste C. and A. S. Site, Combato

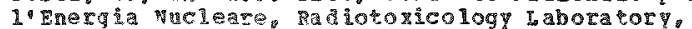

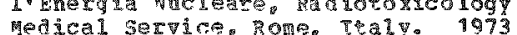

The strity of a case which Tryolved wouna condaina

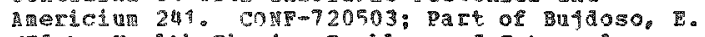

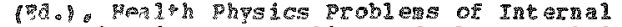
Contrination, Proceedings of the IR: 2 2nil suropean congress on $R$ adiation protection held in Budates. $503-599), 555$ p.

Meing a polishing operation of a 102 ceramic sa vounded his right inder singer, $\mathrm{s}$ say counting rough y indicarad glutoniug activity of about 120 nCi. 12 mal 1 ereision of the wound as carried out within 30 minutes. As a prewationary weasure DTP was given intratrously ithin 90 anntses com the contaminaton. samoles urine. blood. skin and cotton mool mere collected and the activit of plitonin was folloged for 10 mone hs. A 0.2 \% was foud. Fhe results indicated that the

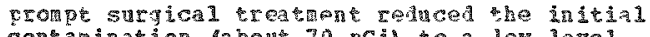
concarination (about 70 nCis) to a low level (about 0.2 nci) and iniminged the systenic burden (about 0.5 mCil. Eecaise of the insolubility of the plutontan the Dat treatrent dia not appear to cause a signifleat effect. (A the (ST)

Q408>

poryall, A.9. Havne State ingersity, School of Medicine, Department of occupational and

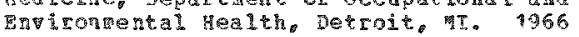

Meacal Aspects of Beryling Disease. Part of

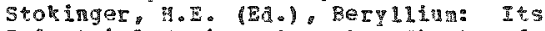
Industrial Hygiene Aspects, Chater 6. Mcatenic

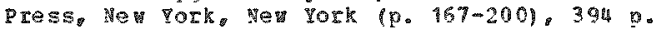

Berylli in aisease has occurred in relation to a varety of occurational and to some nonoccupational situetions. Funan cases of the al sease have been observel in association vith exposuge to many bery 11 in a conpounds, notahl the oride, forrides, sislate, and synthetic silicatos, ant to the metal, but not in association ith the mining ant iling of beryl ore. The disease is cased promeriv by the ithalation and pulnonary deposition of toxic beryilian in the for of dusts, Eumes, and wists. The clinical features and patholody os acute ara chronic forms of the aisease ar poreved.

biagnostic difficulties and some teatures peciliar to the disease are given. General conclusions from data from varions studies of beryl1 ium in tissues and bodi fluids are stated. Therapy is briatiy revieved. The Berv1lin case Registry contains acumented cases of workers and "nejghborhoom disease. (5T)

<409:

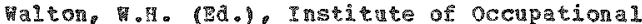
sedicine, zdinburgh, England. 970

Inhalel particles. IIT. CONF-700931;

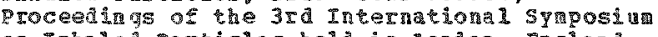
on Inhaled paties held in tondon, England. septemer 14-23, 1970, Tols. 1-2, Unvin Brothers lithited. The Greshat Press old working, Surrey, England, $1090 \mathrm{p}$.

minety-one papers re presented at the 5yposiun: relevant ones have been abstracted seprately for the data base. other papers dea 1 ith inhalation and deposition in man ant aninals, biologica leactons to aust. cigarete shoke, 502 , quartz and asbestos. I physiology of pnenroconiosis, dust in hum 1ungs. characteristics of airborne asts. eplatedological studies such as chronle bonchitis and fibrosis in British coal riners, dust sampling and the introducton of ney dust standaras for British and herican col mines. (Fu保)

<4 90 ?

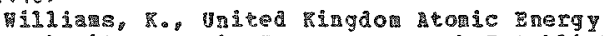

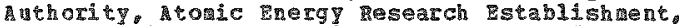
parvell, Didcot Bersshre, mgland. 1956. Aี หgด

Sone cases of Internal contamintion and Thes Barly Detection for Possible Treatrent by

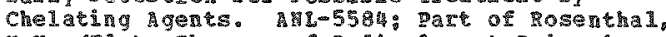

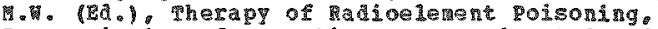

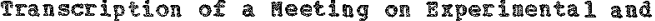
clinical Approaches to the Trantgent of 


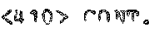

Poingni $20-21,1952,(0,45-47)$, I 310

Uring excretion tosts have proved to be valuable aid for derecting cases of

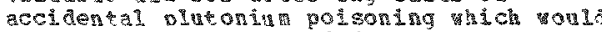
not otherwise be ilentiejed ealy. pronpe treatment provides he best opportinity for paxinging excretion of the radioelenent. Tmpdiato urine saples are collested in any case os snall, possiby contaninted puncture vounds. incine estimates also vork vell as an alynet to air montoring.

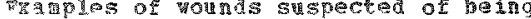

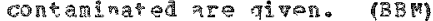

《4 11)

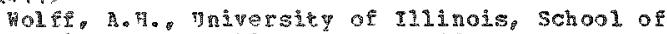
public Hexth. Chicagr, Ito T973

Scientific asis for atiation Protection Guiduce for viderground uraning

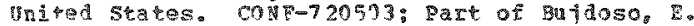

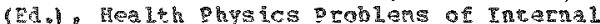

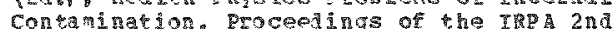
Europen congress on padiation Protection held in Budapest, Hagary, May $3-5,1972,19$ $136-1430625$.

The use of the porking tevel torst (the as a

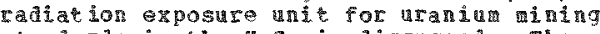
standards in the U.3. is discussed. The celationships of the wh wat to lung tissue dose and cancer Induction and to the ICRP/NCPP secomendations for occupational radition protection ote also discussed. pecentir the guitance for the rajation recerty the guifance tor the cadiation

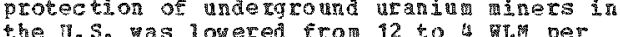
the 7. 5. was lowered from 12 to th year. This action as based or radion lologic and ideriologic evidenco that indicates that the 1 ung is a zith respect to the radiation induced cancer. The orincipal exteniologic information leating to the revised standara came from

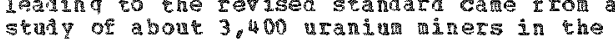
5evy of abot 3. id radon daughers down to at least $120-359$

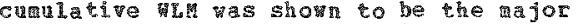
causal factor for a high incidence of

respiratory cancer among urani miners. (Anteh) 
<4 12>

Baker, S.I. Hational Accelerator Iaboratory. Batavia, II. 1973. Auquse; 1973, March 23

Environmental mitoring Report for calendaz Year 1972. WASH-125\%: Part of guviconantal Monitoring at major v.S. Reome Energy

Comission contractor 3 ites calendar year 1972. (D. 553-596). 1217P.

Analyses for residual radioactivity are performed specificalip or

accelerator-projuced nuclides as mell as for radinn and thorint znvironental radiation data are collected ron radiation detections throughon the accelerator and experi mental areas. Except for a inute arount of tritiu in the closed 100 in the putrino Area. no accelerator produced activity other than 53 day half-iffe berplitur 7 has been found in the water. The concentration of $\mathrm{Na} 22$ in soil was determined to be $9 \times 10(\mathrm{E}-6)$ u $\mathrm{Ci} / \mathrm{g}$ just outside the Mentrino area parget Tube. Penetrating radiation is ronitored at the Bnvi ronmental padiaton montoring station located in the National Accelerator Iaboratory iliage. vo evidence of accelerator produced radiation has been seen by any detector in the station aning the reporting period. The neutron mon ltors have indicated an arerage neutron dose of approximately $0.0005 \mathrm{aret} / \mathrm{hr}$, which is consistent neutron background. There pere no untusu? incidents or releases during the Fepoting period. In ditin. here vere no non adioactive material produced in guantities which could poll inte the envitonient and there vere no abrord natural occurrences thich conld have jesulted fron or have had sone inget ron the facility or its operation. (Fin)

〈413>

Pircha11, I. United Ringdon Atchic Energy suthority, Authority pealth and sarety ranch sategulads Division. Platoy. Bngland. 1960

Radiation Dose Rates for plutorilum Isotopes. ARSB $(5)-20 ; 0 ; 27$ 。

Caleulations haye heen ate of the expected dose rapes arising from the prisotopes ans their daugher prolucts. resulting eror irradiation a 1009 Rin The results have hoon extended to includealoha $n$ reactons, oxide fuels, and range of wossible fission product contents. (A)

〈HTi⿱亠乂

Bishop, C. 等, H. Bolton, M.I. Curtis, J.

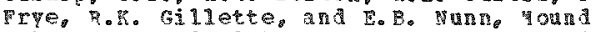
Lahoratory, hidisburg, ar. 1971, June 39

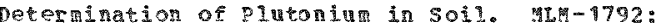
Part of chemistry and Physics Progress eport. october-December $970,(\mathrm{p} .17-19), 36 \mathrm{p}$.

I method to determine the pre content in soil was hevelopen conbing a fingion and dissolution process. The fusion procedure involves fusing the sarole vith anhydrous $\mathrm{kp}$ followe by a purosilf late rusion to conpletely deconpose the soil. The solidified melt is aissolved and the pis separated from the solution by coprecintation it haso4 by Miliat 336 nitratin-xylene, an interferinj olents are removed by hachertractions before the pn is finally back-extracted, evaporated to arvness and prepared for electrote bostiton. mectrodeosinion is achieved from an (NH4)
Sou mediu or from a ixed oxalate-chloride lectrolvte. Ater electrodeposition onto stainless steel slide, the $P$ u content is deter ined by alphe pulse height analys The efficiancy of the solvent astraction sceps in the pu soll analyst bi fuston vas deternined using a pu 238 standare and liguid scincillation couting. The results shower that no appreciably quatity of $\mathrm{ga}$ is lost in the solvent retriction portion of the proced ire. torever, ilectronte position eficiencies less than $90 \%$ have been observed wen either of the two cechidues vere used. (RE)

《4 15>

Bramson, R.R. H. Corley, and H. L Hees, Batelie hemorial Instivte Pacific vorthest Jaboratories, occupational and Environmental sarety Departwent, Richland, MA. 1973. September

Environment Status of the Hanford Reservation for C $\mathrm{C}-1972$. BNo $\mathrm{L}-\mathrm{B}-278 ; 70$ p. (0) Cancelled)

The report sindarizes data collected during 1972 fron locations ithin the Hancora plant for the enviormental survellance prograr. Gronduter and offsite samiling data are not included. Sone offsite data are used for colparison with sinilar measureates made onsîte. concentrations of radionucidies andor radioactivity in Colunbia piver vater. arinking water, swaps, ditches and fords, birds and ands, als, and soil a vegetation and gesults of surf ace contanation and exterral exposure rate raliation surveys are given. Columbia Biver hater gulity nesureants are zucluded.

pasits of the andises we generally hith the expected range. (ST)

《41\%)

Bragon, P. memorial Irstitute, Pagific morthest laboratories, Occupatione 1 and Fro i ronmental

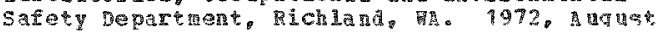

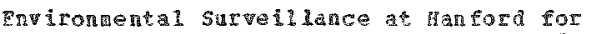

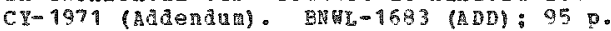

This supplemental report is compiation of results obtained fron both a enviromental saples and from radiological measurenents bate in the ranford envigons Aning 1971. The significance of these data is discussed in the parent report

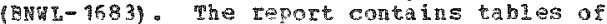

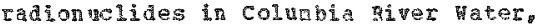
radionncliaes in aring ing ater radionuclides in fish and wid forl. radonulides in shellfisho rationucides in the at wownera. radionuclsaes in farm prouce and comercial foodicuess, meanurant of

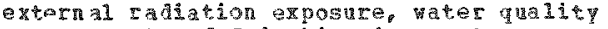
weasuretrents of Collngia chenicals in drinking vater, suspenter particilates and notrogegi in tho atronptere. and radionuclides in soil má vegetation. (sis)

<417>

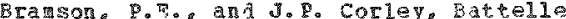
Bransong por and Laboratories. occupational and Eurrongat

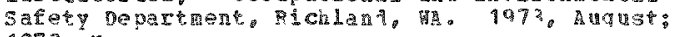
1973 .

Eny ironental Surve 1 lagce at pantord for

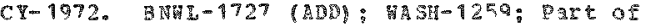
Environeral wontorind at mator U.S. Atomo Eneru comasion contractor sites ralenda vear $1972,80.975-10861,9277 \mathrm{p}$ 
<4 $97>$ CONT.

This suppletental report $1 \mathrm{~s}$ a complation of results obtained fros both analpses of environ rental samples and from ratiologica weasurements ad da the marord nvirons during 1972. The significance of these dat is discussed in the parent report

(Bwh-1727). Which has already been lncluded in the ala base. The tables in the supplament are groiped into eleper appenizes and coner the folloning sibjocts:

radioncildes in Colubia niver ver, in drinking vater, in Ess, vild Forl and stellish, in the rosoher, in fari produce and comercil foodsturfs and in 501 ind vegetacion: aed surewents of extermal radiation exposure; acer qualit reasure cheicels in arinking rater. and suspended particulates and nitrogen in the twosphere. (5) (19)

See also Report Bit concentrations of severel radionuclides (including and pul in ale water plants,

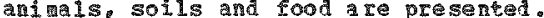

<4 198

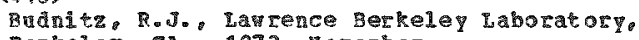
Berkeley, CA. 1973, Noterber

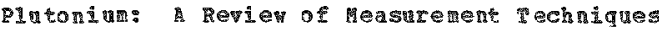

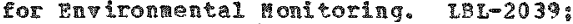
conp-731112: Part of proceedings of the ITE puclear science syposin held in San Francisco. california roverber $14-16.1972,(9 \mathrm{pol}$

overviews are given of the typical levels at thich plutonin is found in environantal media. of the radiation protection giates. and of sore of the types of measurement technigues which have been developed for plutonin and other metia. Enphasis is on easurenents for surveillance and protection in anvironvental and occupational situtions. The discussion concertrates on the various broal categories of instrinents and techniques, their senstivities, areas of applicability, and lintutions. moassay methods are not discussed in derail. (WT)

<419>

Budultz, R.J. Lavrence Berteley laboratory. Derblev, CA. 1974, Febriary

Radon 222 and Its Daughers, A Revier of Instrumentation cor ocenpational ard Fnyironental tonitoring. Heal th Physes, 26. $145-153$

an overviev is provided of the tochniges that have heen developer for ter and its daughters in warious media. The 222

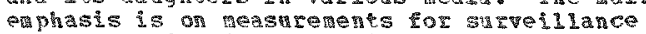
an protection in occupationa 1 and

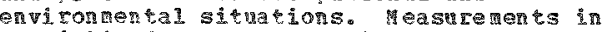
soecialized research applications are not treated in desia. Overviovs are First provided of tho phisical cheracteristics of prin 222 and its alaghters: of the sonpces of and trpical leve?s of concentration in the natural environent and in occupational exposures: and of the radiation guides. phe varions onsurenen technitues are then สำ scusser. (2)

<420>

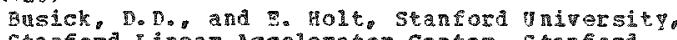
stancora tinear Accelerator center, stanford.

CA. 1973, Auguse; 1993, vareh

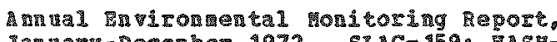
Jan ary-Deconber 1972. SHAC-159: $\mathrm{ASH}-1259:$

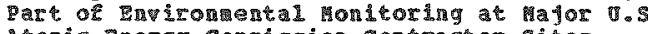
tomic nergy Com

The starord Hnear accelerator center regional survelliance progra is intended to assess the coneribution if any frow Slo operations. to the emsting rajation entironant. Saples of soll. vegetation. grcand storn severs are periodically collected a actîn to levels deter ined. hurborme radioa cet ity is is easured an recorded continusin a the release point.

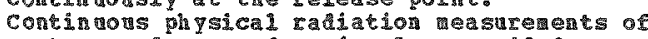
mentron and gama dose is also provided near the site bonndary. The results of the environient andysis for gross beta activity

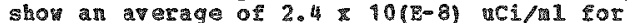

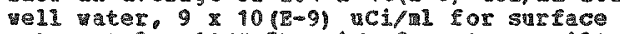

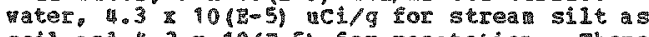

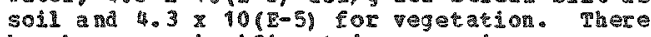
has been no significant increase in radiosctilty in ater, soll or vegetation since suc operateons began in 1965. The measusenents of anmal dose from garma an neatron radition near SLAC's boundaries indicate a slifhe increase in total dose over the background alue, resulting in a dose above background of $3.5 \%$ of the individual standard for the general

population。 (Avt面)(F知)

Table 2 shows radioactivity content of environuental saples (tater. sile. vegetcion collected at stanfor intar Accelerator center in 1972. Tabie 3 shows antul tadicion dose measured near stanford hinear Accelerator center"s boularies.

<4 21$\rangle$

Cantelow, H. . I a wrence serkeley iaboratory. Sarety Services Deparenent, Berkeley, CA. 1973.

Amual Environtertal tonitoring gort. 1972. ตAST-1259: Part of En wironental ponitoring at nator 7.3. Atonic Energ comission Contractor sites, Calendar Year 1972, fp. 1115-1129, 1217 p.

fentron an gama fields re neasured at each of four perineter stakions as mell as at several locations tithin the site at the Iamrence Gerkeley iaboratory (rBI). It is shor that the total radiation jevels are vell below the standards set for the genesal pabic. An environarent air sampling progra is carrien on to make sute no releases occur, and to provide a direct mosurenen

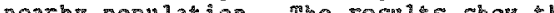
there has been no sign icant exposure fro

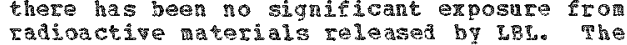
results of weer savpling show that the total concentration of eadioactivito, IL B!o in

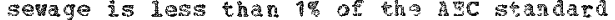
For A scharges to setrers and the radioactivity in ongite streas is sately belor the standard for deinking water.

Table 4 shows concentration of tritiun ard $c$ th in ais.

$<422\rangle$

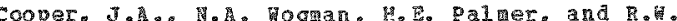
Ferkins, Batelle mevorial Institute, Pacific Morthest laboratories. Jny ironnental and

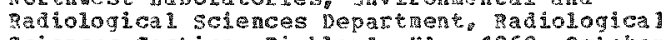
sciences section, Richlard ha. 1968, nctober 


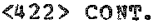

The Application of Solid state Detectors to Environtental and Biological Problens. givi-715 (Part 2): Part of Nol sen. Pepor for 1057. (p. 119-122), 230 p.

Investigations involving the behafior of complex mistures of cadionuclides in environmental and blological systens require highly sensitive and selective measureregt techniques. Atificial radionuclide mixtures present in the entronment a re usually extremely comples and are often present at concentrations comparable to or lower than those of the natural radionuclides present. The applieability of the nev high-resolution solit state detectors has been eva late the analvisis of several conplex radionucide mintures which are encountered in both natural and neutron actipated envitongental and biological samples. These invegtigations have shown that, in wan cases, the increased selectivity of the solid state conting syster, han conbined vith proper sample prenaration, allows much more precise andivsis for many of the constituents than is possible with rather elaborate par (7il) detector systels. (A the

Fiqure 1 shows a gatra ray spectrum or airborne radionuclides collected on an air filter at pichland, washington. Figure 2 shows a comprison of the gar rav spectrum of a nemtron activated haman lun tissue sample as measured vith a vI (T) scintillator and Ge(1) diode. see also Health Phyics. 15, 499-433 $(1968)$.

<423>

Corley, J.9. Batelle Mearial Institute. Pacific Northest Iaboratories, occupational an Brvironental safety Department, Richland, 9973,8 ing

En igonnental Surveillance at Hanford for CY-1970 Data. BNGT-1569 (ADD): 118 D.

This supplepental report is a cotpilation of results obtained frow beth analyses of environental samples ama from radiologica 1 measurements nde in the rantord envi rons during 1970. The report consists of tables of concentrations and estinated rates of transport of radionuelides and beta activity in collubia $\mathrm{R}$ iver หater, concentrations of radionuclides and beta activity in arinhing water radondides in fish. shellfish, tarm produce, con aercial

food stufs, soil, pegetation and the atrosphere, and measurements of external radiation exposure. Included in the table are andytical lints-othe concentrations at which the laborator can peasure the radionucides ith a precision of pus or minus $100 \%$ at the $90 \%$ confidence level.

(4) 245

Cushing, Co. D.G. Hatson D. B. Robertsong and  Pacific porthest Laboratories, Fnvir onenta and ife sciences Division, Ecosyster Department, Richland. WA. 1974, Janu ary

Decline of Radoactivity in the columba

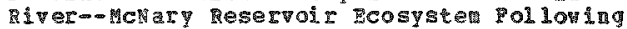
Shutorn of panford Reactors. Bhm-l 350 part 2): Part of vaughan, S. E.. et a1. Annal peport for $1973,(0,34-89), 200$ p.

Since January 1971, a specta 1 stud of the rates ard rechanish of the radilon uclide integactions in the Colmbia River has heen in progress ath the purpose of characterizing the long-range behavior of the radionuclide inventory which was discharged into this ecospste auring the reactor operating period. Radionuclides currentiy present in the river syster are those deposited in the sediments auring previous reactor operations and those currefth released frot the aral purpose

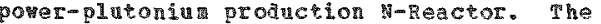
concentrations of wh 54 co 40 , and $7 n$ in 65 in the suspended materid of the river decreased approximately tenfold during the first year following the shutown of the original Hanfor production reactors. N-Reactor radionucides vere deposited to a large degree in the sediments behind mcvary par and here not significantly transported down tiver. Plutonizi 239 concentrations in presently deposited sedinents are at backgroun, fallont levels. concentrations of gar radionuclices have generally decreased in the biota sampled in Reservoir, bat at a slov rate. The concentration of $2 n 65$ in plankeon. periohton, chironomid larvae, and suckers from $1971-1973$ is shown in graphical for. The effects of seditent sconring, radioactive decay burial of radioactive sedirents biological turnover. radianclide solubility. and biota concentration factors are includer in the discussion. (ST)

《425)

DCyle, J.P., C. Jupiter, and G. S. stobie, EGs. Inc. Herial Surveillance Departaent, Las vegas,

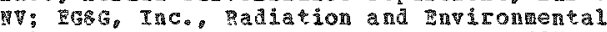
sciences Departuent. Las Pegas. NV. 1972.

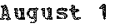

Fadological Survey of the Nevada mest Sise (Surver period: $1970-1971$ ). EsG-1183-1552:80 p.

The Hevada Aerial Tracking systen UATS operated for the Inited States Atomic Enery conission by EGgG. Inc.. vas used to perform aerial radiolodical sureys of the Hevade Test 5 ice (NTs) and surrounding rea during 1970 and 197\%. $1 \mathrm{H}$ areas of the Hrs and areas within five riles of the rTs bonndary over which the Mirs alrcraft conld operate at 300 feet altitude were surveyed. The data collected on these surveys include the gross count rate for ga a raiation betwen 50 keV and 3.0 ve a 300 feet altitude. The gama gross count ata tere used to deteraine radation exposure rates, which fere nor eguivalent value three feet above ground and processed into isoexposure cate contours. Gara ray spectral plots are given ant radionucidies are listed that are consistont vith photopeass cound in tha spectral plots. (Anteh)

\section{$\langle 426\rangle$}

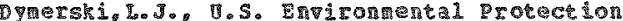
Agency. Division of Rajological pealth Denver C. $965, \mathrm{Agr} 1$

oraniu Hill Tallings studg phase is progress qeport. Hal Repor: 56 \%

study was undertaken to evalute the inpact that tailing piles from urandu nills inpose ucon people tho reside in certain toun near the operations. It w estinated that near Durango. Coloraco 1.5 t1 11 in tons of tailings containea $150 \mathrm{ci}$ of Radiu 226 , and 2 vilion tons or talings near grant Junctiong Colorado contain $200 \mathrm{C}$ or radin 226. Air sanples vere collected on gy paper at 17 locations in thase toms and the 


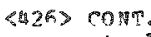

control cities of Delta, colorado and

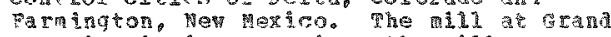
Junction is in operation; the mill a Durango is closen. Samples vere collected during the period sentemher 3 to Novenber $5,195 \%$. The radiation contamination at selected sites in the two cities all showed oreater levels than dit the control dities. The at it contrination at Grand Junction as appraxiratel y tuice that at Durano. Al hovogh the radiation levels taken as a thole do not indicate a serious problem, individul stations. tailings and in the direction of prevailing pinds. indicate a potential radid ton exposure problen. The ertent of the insult to the cities shoula be decerained, and it was proposed that a are detailed volutetric air study be instituted in $A$ pris. 19R5 in order to define nore adeguately the air

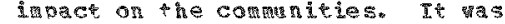
recomended that it would be desitable to learn what the total intale of radium 226 by residents of these contunities ara be. Other enviconmental sedia (rood. rilk. ater) should be stuated in connection with the provosed ais studp. (BBil)

<27>

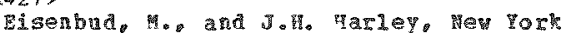

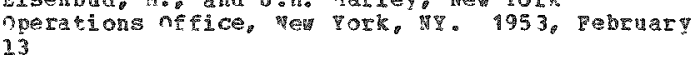

Radioactre Duse fron muclear Detonations. Science, $117,141-14$ ?

phe wontoring program for weasuring changes in radioactityt levels caused by fallout fron nuclear detontions and a sunary of

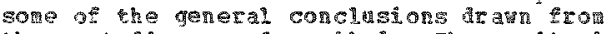
these stuties are described. The monitoring syster consists of 121 stations located at Heather Bureal station across the phetion and

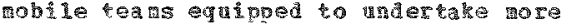
intensitye measurements in the region 200 to 500 miles irom the test site. For brier

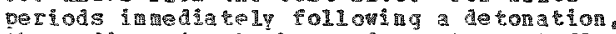
the Eadioactipo background can be markadI increased in some a reas.but the curatatio

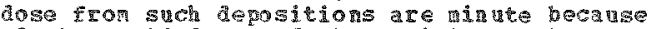
of the rapid aecey of the actirity. The long-15ted componer ts of the radionctivity are of a loverder compated wh the gatural

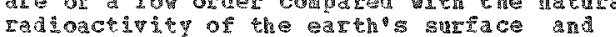
atrosphere. (B⿵⺆)

$\langle 28\rangle$

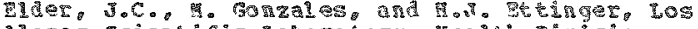

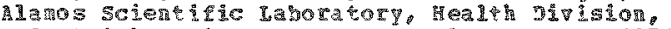

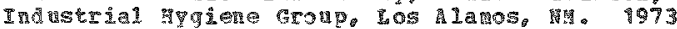

Pltonturerosol sige characteristhos. I. of the 16th Annul meath Dhyics society

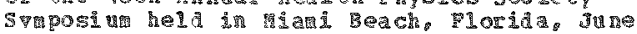
$1 \%-21,997,17 \%$

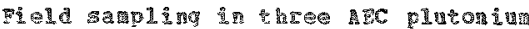
crocessing pants has provided pise character istics and activer concentrations

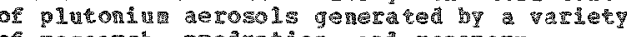
of research, production, and recovery operations. These data provide basic inforation for the design and testing or air

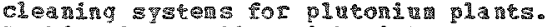
Isokjet ic sampling

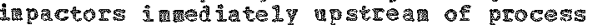
ventilation aha particles representing mors nor challinge erosols. Whare particl a wet established statstical cricera far lognoral d d

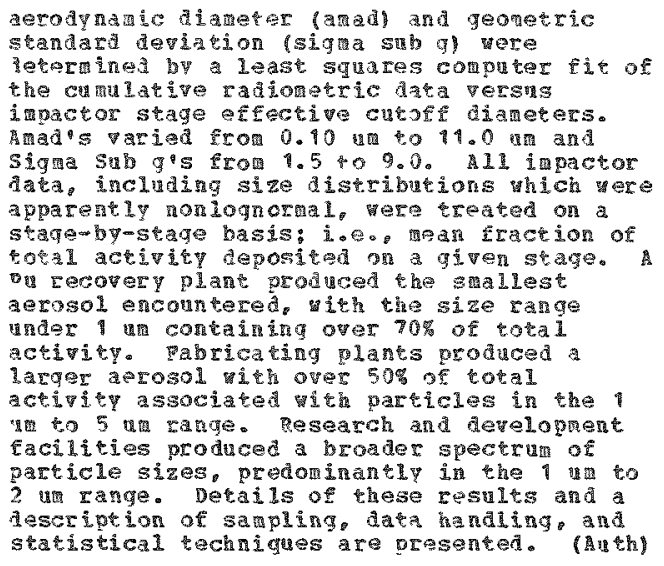

$<429$

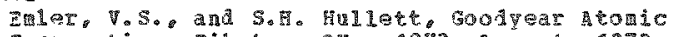
Corporation, piketon, 0\%, $19 \%$, Angust: 1973, February 28

Portsnouth Gaseons Ditf

Environental monitoring Repore, 1972. GAT-740: MAsm-1259: Part of Environgental honitoring at

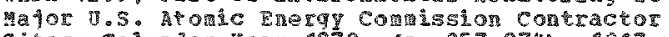
sites, Candar Year 1972 (

te the portsoouth Gaseous Diftuston lant.

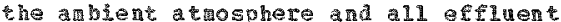
stream are moritored and andized regularly for conforance to the aplicable. specifiea

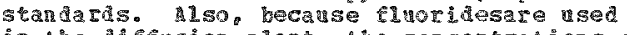
in the difrusion plant one concentrations of fluonites in the abieg atrosphere are reasurea routnely. concentrations of Florides in vegetation are fluoride ingestion can cause a arerse effects

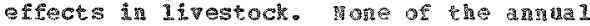
average concentrations or radionctitipy measired at the many samping polnts a romat the plant eacesd 1. is prerent of the

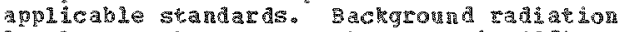

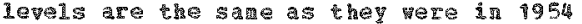
berare the pant began to operate. Merage

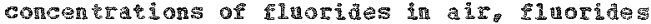
in

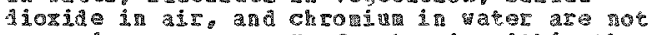
excessive: arerage gh of pater is whith the specified range. Mralyes for particulare

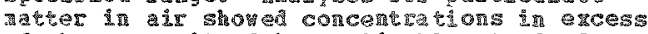

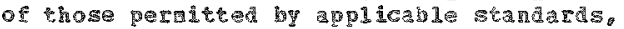

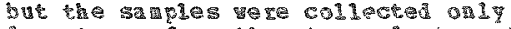

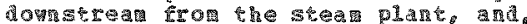
the (A)

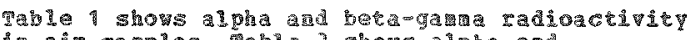

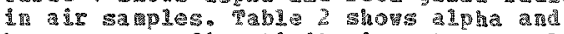
bet -

<40 30

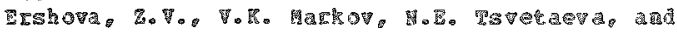

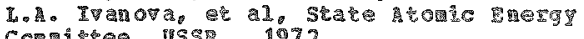
conatree.

terhols of Deterain

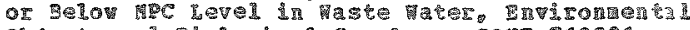
nbjects ant

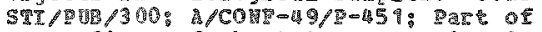

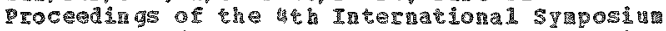

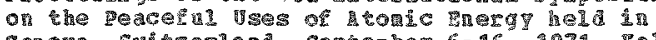

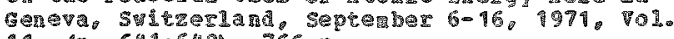

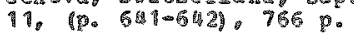

As a result of the arpararace in the 
$\langle 430\rangle \mathrm{CONT}$.

envisonent of man-made radionuclides. particularly those such as $\$$ Pue 239. daily monitoring of their spread has become necessary. Existing method sor the guantitative deternination of these radionuclides are surveyed an new methods are described for determining Sr 0 (in the presence of $Y 909$ and $C^{2} 144$ and $C_{5} 137$ in salt-free and salt-containing aqueous solutions. These nethods are besed on the nev. very effective principle of comentrating certain radioisotops, whereby liquid-liquid extraction is combined with coprecipitation. The extractant used is an organophosphorus compound, the ronoisoocty ester of methyl phosphonic acid $v i$ th this method, particular radio isotopes gan be al ost completely $(98-100 \%$ recovered from la rge volumes $(1-2 n$ litres $)$ of a queous solutions the time taken being less than 30 win. moreover, it is possible to carry out a separate determination of these radioisotopes fron the sane sample. The combination of 1iquid-1iquid extraction and coprecipitation has tro advatages: first, a very high distribution coeficient is attained for the three $a$ bove-mentioned radioisotopes: second. a solia organic phase is for med bhich is radily separable frol the aqueous solution. Due to these tho properties, a very high degree of concentration can be attained with these radioisotopes (factors of more than than 10(5-3) with suricient 14 corplete and selective extraction. Because of the simplicity and speed of the proposed methods they can be used for singteratic monitoring of effluents from separation facilities, surface and unferground waters, atwospheric precipitations, etc. even under fiela
conditions. The possibility of using the gethod where macrocont aminants are present is discussed and the analytical conditions for determing $5 \mathrm{~s}$ an. Ce 144 and $\mathrm{Cs} 137$ contents in statater, foodstuffs and varions biological samples furine, bone tissue lung

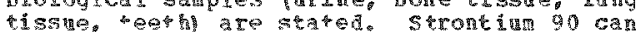
he deternine satisfactoril in biological socimens even when below the Mpc. a method is described for deperning pu 239 based on

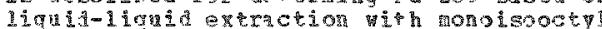
methyi phosphnic acid a me a mixture of isoany phosphorice acids with a phase rolume ratio up to 100 . Phis rethod is asez for Aetersing $\mathrm{P}_{1} 23$ a content is lung tissue, bone tisine, surtace waters and other

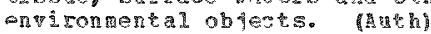

<4 31$\rangle$

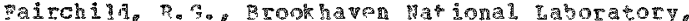

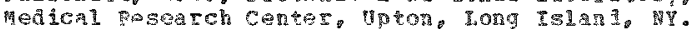
4969.5 andary

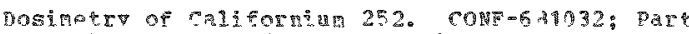

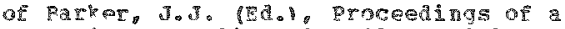

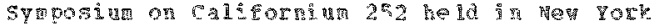

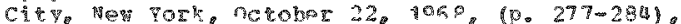
$\$ 76$.

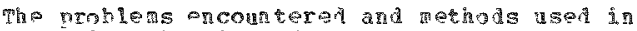

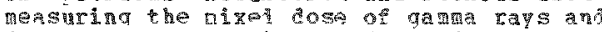
fust noutrons to tissues from ct 252 are revieved, In particilar, Aosiated calibration, tissue tolorancs to of 252 ixtadition, Felationo biological

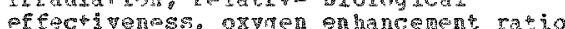

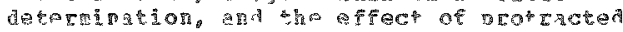

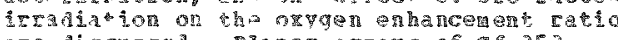
कर contain Mation

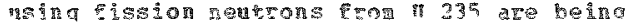

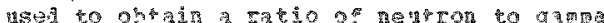
rey dose that
<432\$

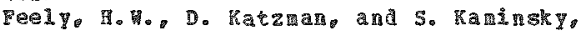
Isotopes, Inc. Westwood Laboratories, westrood, N. 1968, Janiar 1: 1967, october 31

Fight Data and Resilts of Radocherical Analyses of Pilter Saples collected During ApII-June 1967. HASL-184: Dart of Hardy. E.P. 37. and Rivera, J. Pallout Progran Quarterly Stumary Report, september 1, 1967 ehrough December 1. 1967 ? (p. III-2" III-21). $406 \mathrm{p}$.

Flight fata and results of radiochendeal andyses of stratospheric at tropospheric air filter samples collected anding project stardust are presented. Fron early 1965 to

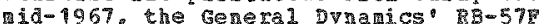
aircrart as the primary a a aling vehicle msen. Saples were analyzed cor fission products such as $S_{1} 90$ and $S_{5} 89$, also pu 239. Pu 238 and Ca 109 and tables shoving the activities of the various radionulides in oci/100 5mp) are included. (F m

《433》

Folson, T.P., VoF, Hodge, and $x_{\text {, }}$. Fong, Scripps Institution of oceanography. Soladad Environgertal Radometivity laboratory, Ia Jolla, CA, 1972, 耗 31

1972 Results of the Continu Interconparisons of methods for Analises of cesium cobat. silver and other iatonucidaes soonsored by IAEA. Part 2: malys 25 of Dried seaneed samples collectea by Brish Pisheries Radiobiological Jabotatory. TID-26206: 3 p.

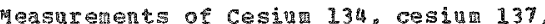
Cobate 60, and silver 110 in subsantes of three In reportet. precise intercomparisons of the

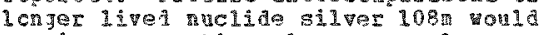
recujer a ten thes larger sample.

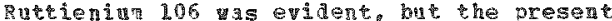
standards of this mulide are beldeved unreliabie. A pre 1 intinat mas surement of plutortin has been made in one of the seaved maples, but becanse ruch note actirity coung than expected, the plutonsul Geasureant most be repeated and reported later. IB

<434 \$

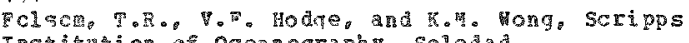

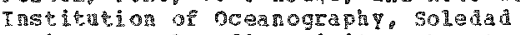
Enw Ionental Ralioactivity iaboratory, La

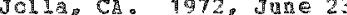

Plutonim concentertichs of IABA seareed

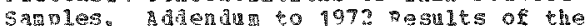
cortinue intercomprisons of mothods for

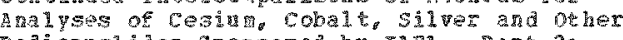

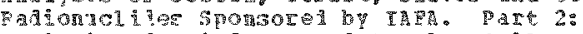

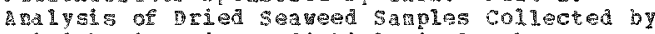

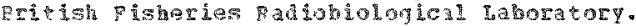
?T $26208 ; 3 p$

Whe gothod ase tor depercination of plutshin in copoted, and values connd were givon. Activities in picocuries per gras of drien sarived vere $3.4+$ or $-0.1 .3 .2+$ or -0.1 . a $3.3-0 \mathrm{r}-0.1$ for platid 23 and 22.9 - or - 0.4, $2 \uparrow .5$ or 0.0 .4 and $22.5+05$ -

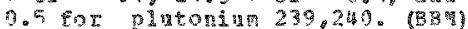

This is an Added

44. 35

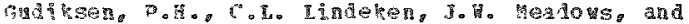


<435>cols.

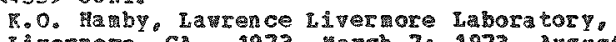

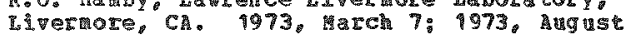

Environgental Leve1s of Radioacentit in the

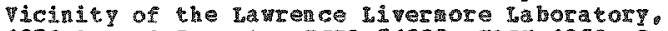

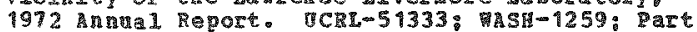

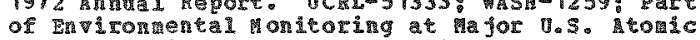
Enerot combsion contractor sites, calendar कear 1972 (p. $1131-1176), 1217$ p.

The tavrence foiverare Labotatory continonsiy montors the levels of radioactivity the Liverwore for rross radioaction and for specilic radioi sotones of incerest in a variaty of environgental saples are presented. Aishorme particulate semples tere and for Pu 239. Pu 238 , 235 , and 238 activities. The momil averaged Pu 239 activities vere in the sange of $5 \times 10(\mathbb{E} \rightarrow 17)$ uci/Bd hile the pa 238 activitses re re bout an order of aquitude lover. These activities are tipical of those ane to global fallow. Air sampes taken at site 300 vere anclvzed for uraniu. These analyses showed a lower than norial ratio of 235 to 0239 . soli samies collected within the inger wore Palley and site 300 vere subjected to

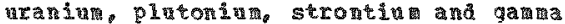
spectri analyes, salules collected ithin several handred meters of the firing buskers several handred wetes of the firing bunkers samples collected on the site peri geter and offste showed nomal $235 / 0236$ tatiosa the mean pu 239 deposition value on soil is about

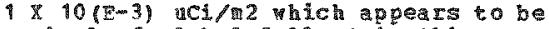
tyolcal of global fallout in this area. Traces of plutomiumere detected in one of the dry holating ponds at the inverare sevage preatment plant. The raxial pu 239 activity in the plant effluent was less tha $3 / 100$ of one percent 10.03 of the $\mathrm{BC}$ drinising water standard. Game spectral analyses of vegetation sambles revea led no gas a-eritting radionuclides other than those present naturally or in global eallout. It he vegetation samples collected in areas qenerally down ind fron the ilverrore Laboratory revealed alevated triti un activities but theso activities aro jthin recontended standards. Assessment of the radition aoses to an individual from the obstrod risonmental actitities indicates the contribution fxom atificially produced

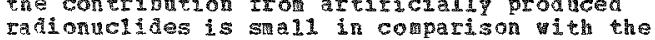
radionulides is stall in comparison mith the

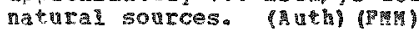

Table 5 shows activity leveis of Pu 238 , Pu 239 and Sr 90 igs soils. "rable shows activity levels of varjous garna iting rationdides in soil. pable 10 show tiverige senage treatrent plant 3anpling results during 1972 with concentrations for trition. $5 x 90$ and 239 activities. Table 16 shous gu and concentrations in site 300 afr during 1972. Tables 20 and 21 show 0 and $P$ activities in site 300 soils.

$\langle 436\rangle$

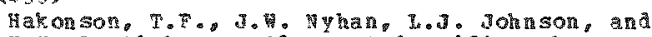
R. T. Bastick. LOS Alamos Seientific Iaboratory.

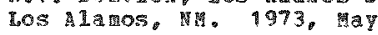

Ecological Investigation of radioactive Materials in For the period July 1.1072 throngh arch 31. 1973 . IS-5292-15: $47 \mathrm{p}$.

This reporf desctibes the ecological restarch program at the los Alamos seleneif ic taboratory and, in ardition, suratizes the peogress vich has been mate on current. project activities betven JuI 1.1972 . and

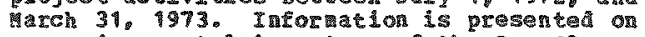
an environmental invertory of the fos hlaros area, a radionuside inventory in three 1.quid waste aisposal areas, studies to deter ine the applicability of the honeybee as an indicator of envipon radiocontanination and a resirvey of the Trinity area to deteringe the biomailabiley

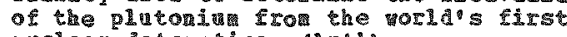
puclear detonation. (Inth)

<437>

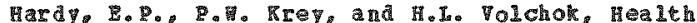

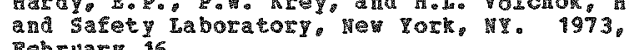
February 16

Global Inventory and Distribution of Pallout

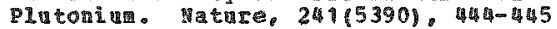

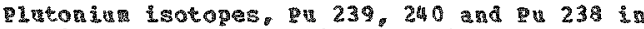
particular, wave bean injected into the particular, ave bean injected into the ntriser weapon tests, and have reached the gourd a perticulate fallow. An acidental atmospheric infeetion of Pu 238 in 1964 resulted in linge a 3-fold increase of the global fallout of this isotope. The accurn lated fallout and geographical distribution from this unexpected release. as

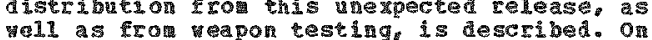
wall as from teapon testing, is described sate11 it as lauched frow andenburg ir Force base in califoria. The payloat

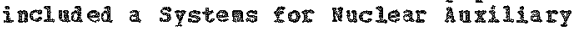
Power generator, SHAP-9A, containing $17 \mathrm{kCi}$ or about $1 \mathrm{~kg}$ of 2 u 33 . Bece use the rocket falled to boost the satellite into orbital flight, the pailoa reentered the atmosphere in the southern tealsphere. Stratospheric checks indicated that the generator conplete1y burned ap during ze-entry and turned into small particles a an altitude of

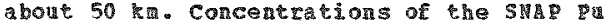
23 in the stratosphere vero seasutable at the end of 1970 when 1 t less than a ki revained above $12 \mathrm{~km}$. Soll samping technines were epployed as indicators of culariative fallout. By

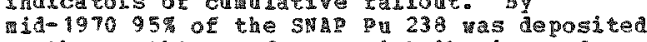
on the eath's sartace. Distribution and records of ground deposi vere inpestigated. The distribution pattern for veapons" platonitu shows heaviest deposition in the Platonin shows heatiest deposition in the inim in the equatorial reyion. There is a slight rise in the solthera Henisphere terperate zone which, at its peak. is about one-fifth of the porthern terisphere

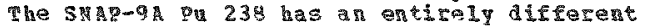
distribution pattern. post of the Sure debris qas deposited in the southern Hewisphere here the tives that in the lorthern Peisphere. (A)th) (RAE )

438>

Hardy, Z.Z., JE., Heath atd Safety Laborator.

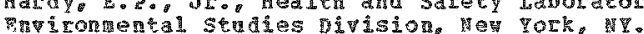
$1974,3 a n$ ara

Health and sacety Iaboratory. Pallout Progra

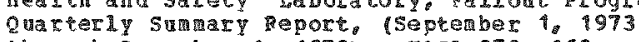
through Decerber 1. 1973)。 Hits?, 278; 163 p.

Current data frot the Hast Fa1lout Program and the radological and Finicontent Research ivision a Argonne vacional Labotatory are presented. The initial section comists of interpretive reports 3 na notes or the dose to war from 239 fallout the respicable fraction of $5 \mathrm{P} 9$, Pu 239 , and stoble lead in surface ain: $C_{5} 137$ and $5 \pi 90$ 
(438) contr.

In bone; the quality of 1972 surface air analyses, agd qualty control of 1973 samples of fallont, aist. tap vater, and haman bone. subsequent sactions include tabulations of radionuclide levels in fallout, surface air. stratospheric aix. milk, diet, and tap vater. a bibliography of recent publicatiche presente (A the

4439>

Hardy, E.P., Ir.. Healeh and safery aboratory,

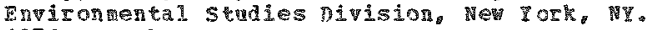
1071 , Octoher 1

Fallont Program ouarerl. Sumary Repore (June

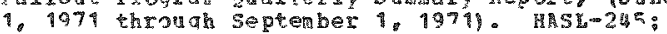
$254 \mathrm{p}$.

The report presents current data from the HASI Fallout Prograt the pitional gadation

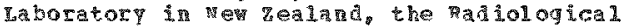
Thysics bivion at mone lational

Laboratory and the gtringw Joint muclear Research Centre at Ispra. Italy. Three papers have been abtracted separasely for the data base. The initial section consists of ata surmates and notes covering the polloving topics: stronting 90 fallout and precinitation by ten degree latitu le bands the statospheric ingetery of pu 238 , and strastorer ic inventories of ission orolucts. Subsequent sections include tabulations of rafinacide levels lin surface air. strabospheric dis, fallout, milk, and tho tater: a hescriotion of project

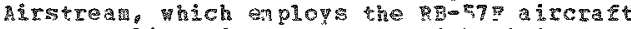
as a saming plater or balloon sampling prourat and the ho mone prom rav. A biblitonzaph of recens puhlicarions related to rad onuch de straies,

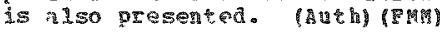

$<40\rangle$

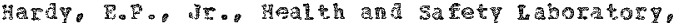

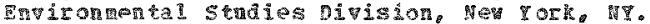
1973. nctoner 1

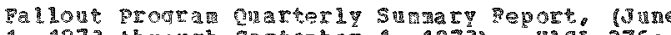
1. 1973 throunh 5eptomber 1,1973 . MASL-276: 176

This report presents curerent dat from the

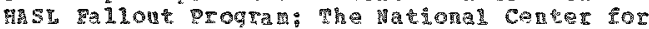
Atmosoheric Peseatch in Bonlar, coloralo:

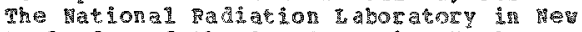

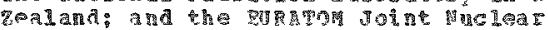

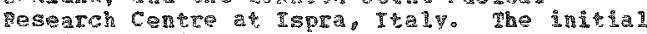
section eonsists of sntogrotive reports na notes on the alohal heposition of $\mathrm{st} 90$ through 1972, sulfere concentrationg in the lowar stratoswere, glohal fallow in $a$ forest compared

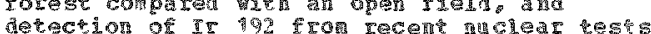

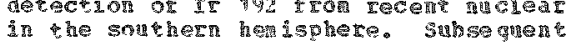

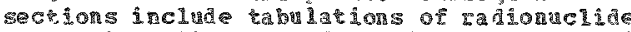

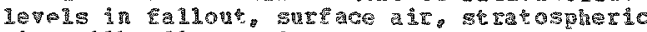

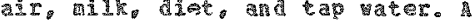

biblontaph of recen pubicator gelated to rationve 11 tho sthaies, his also presenced. one atricte, concerning fallour in a forest

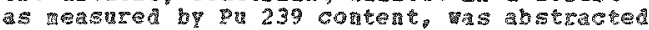

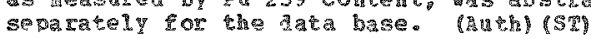

<द⿱

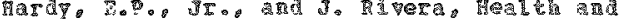
Safect Iaboratory

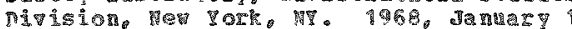

5allon Progtr

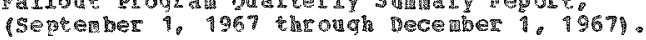

HASI-784: $406 p$

Current data is presneted from the past Pallout projean Tsotopes Tac. pational Madiation Laborarory in nev gealand, the

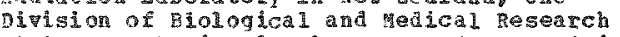
at Argonne gatiol Laboratory Buraton Joint viclear Research Centre, the pivision of Biology and medicine, JsAEC, and the Air peson ces Laboratory, TsSh. Five articles have heen abstracted separately for the data base. In the report radionula le lels in stratoshert air, surface atr, fallout wil, other diet conponents, and tap water, are tiven in tabular Eora. The initial section consists of interpetive repors and motes covering the following topics: Fu 238 fallot from shap-9A, significance of Cs 137 levels in ${ }^{2}$ an, seasonal stratospheric aistribution of $\mathrm{CA} 109$. Pu 238 , and 3590, stratospheric radioactivity in vorerher 1967. and the YASI quality contuol proqran. Also Tescribed axe the surtace hir sampling

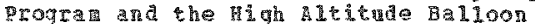
sampling progra. A progress report on project stardust is given and bubliography of recent pardictions related to canionuclide stadies is presented. (F)

《442>

צar

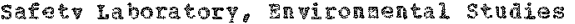

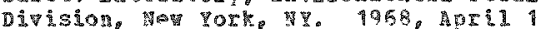

Pallout Deposition. HaL-193: Part of Fa11ou

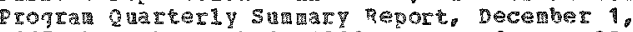
1967 shrough tasch 1, 1968, 10. II-2 - II-25i. 303 .

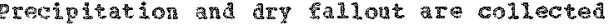
over wontiv periods at stations in the yy a walyzed for gerontiug and strontin 89 when th is erpected to bo present. Fission Drouth are neasurea in monty depositson at a

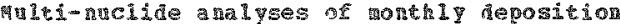

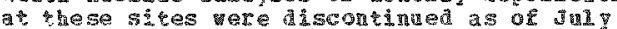

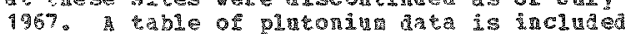

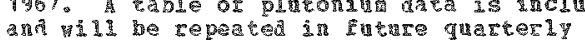
repors, as deposition sampes vill contin to be collocted ard andyzed for po 23 a a

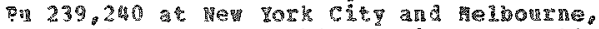
Agrsta In. In the tahle the isotope ratios are a 150 jiner. heasurement of Iadiostrontin precipitation and op fallout collowions at four V. S. coast Gura Stations in the lorth Atiatic ocean axe carried oub for comparison the land stations

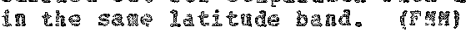

<4⿻

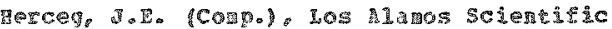
Laboratory. Mate

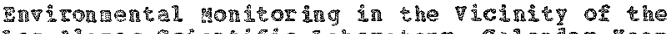
LOS I La 1972. Fa-5184:

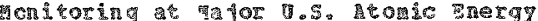

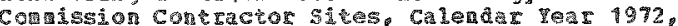
\&. 39-969. 9217 p.

The a effect at the fos lamos scienticis Laboratory at one Onzersity of califoria 4or calendar pear 1972 is destribed. Results

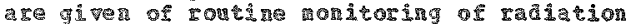

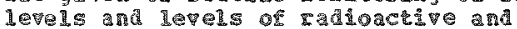
nomran

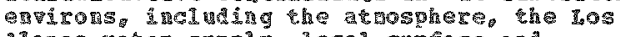

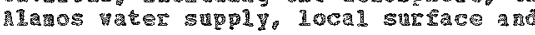


<443>

〈द 43$\rangle \mathrm{CONT}$.

groundmater, sediments, and soils.

concentrations and levels are conpared with applicable guide palues and with zesults obtained at other geogranical loctions and loca 1ly during othex reporting periods. Descriptions ate given of special programs aived describing the physical and hiological orocesses ingolved in the biological processes involved in the radionuclides in liguid waste disposal areas. there is a Isc a aescription cf an enviromental survey of certain AC-controlled land parcels, as vell as geologic. soismic, and peteorological studies of the los lamos area. Technical notes discuss the use of the honeybee as biological indicator of radioconealination, a ney game-ray pllse height andyzer syster intended for fiela use, a ntomato neteorological data acquisition systen, and the deteranation of salt in wine trees near IOs Alamos roadxays. (Auth)

Table 7 shows $\mathrm{Pu}$ and A concentrations in air. Table 8 shows tritiated woisture and total uraniu concentretions in is. Table 12 shows analyses of regional surece tater saples including range and average of Pu $239, \mathrm{Pu} 238$, and $v$. Table 29 shovs pu concentrations in tisstes of rodents.

$\langle i 44>$

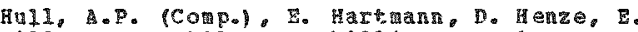
Hiler, J. robile, J. Phillips, D. Si J. Sto gers. grookhaven National Iaboratory. tpton, Fong Island, He. 1973, Angust: 1973, Hay

9972 Environemel monitoring geport.

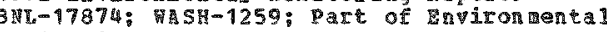

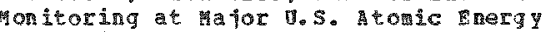
connission sites, Calendar iear 1972, (p. 49-4561. \$217 p.

Watural background and $r a d i a t i o n$ levels in the licing is of Brookbaven pational Laborator atcributable to its operations during $\$ 972$ are sunarized. mong the data reported a excemal radiotion levels: aj particulate tritiu and radioiodime concentrations: precipitation and liquid ef 1 uent-related concentrations in strom groindiater and surveiliance alls, as well aslevels in ail grass and soil samples. other than tritiug there as no indication of $\mathrm{HL}_{\mathrm{L}}$ effluents in environmental air and precipitation samples. In $a j$ the largest But afluent-ralatad tritin concentration *as $4 \mathrm{z} 10(\mathrm{P}-12) \mathrm{w} \mathrm{i} / \mathrm{m}$ lach is $0.002 \%$ of the applicable stadard. In precipitation it was 2.77 \% 10 (3-4) sci/7, wich is $0.01 \%$ of the standard for arinking water. quarterly min samples we obtained from tro nearby daIry faras. berween $C_{5} 137$ levels in these ni those generally prevaling in the northeast inited states vere pparent. pro sets of grass and soli sanples vere 1 so collected fron these and three other fargs, as vel1 as from

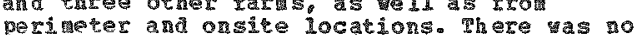
sichificant difference between ofs site

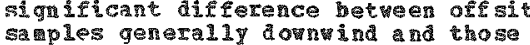
general1 1 uptind of Brookhaver. (Muth) (PW

Table shoms total activities and average concentrations of identifiale nuclides is groundwar, site boundary and former perimeter. Fables 10 and 11 show concentrations of re-erteting nuclides tincluding ma of in Peconic river, carmen's River sediments and carman's River vegetation. Table 12 shots concentrations of enteting nuclides in tureles and catish obtained from the peonic aiver. other tables shor concentrators or nuclides in
Mill, grass, soil and waste disposal areas.

〈4 45>

Trenale, P. and G. Himder, United Kingăom Ato ic Bnergy Authority, Atoric nergy Research stablish went, Electronics Division, Harwell, oldcot, Berkshite, England. 1962

The Detection of Aitborne plutoniag hazards. A $E-2=3783: 17 \mathrm{p}$.

The detection of the very low levels of

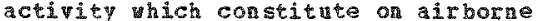
plutoniun hard is litited in practice to methods based onalpha actilty measurement, and assessuent of ratina perasisible concentrations for long term exposure is made more difficult because of the large variable hackground of alphactivity produced by the aecay of the products of radon and thoron. To instrinents have been investigated both of which alse corrections for the activity of these maturaly occurring products and inprove the threshold sensitivity of air sapling monitors. In the first the activity of radon and thoron derivatives on filter paper is estinated from the count rote for beta-a lpha coinciaence and this is usea to compensate the total alpha-count rate for the contribution of the natural activities. The second nethod istinguishes the 5.1 tie alpha-actipit above 6.0 hev energy. The spectrometer method of detecting plutoniu is slightiy less sensitive than the coincidence aggratus but has been chosen for further development because of its insensitivity to beta and gama-ray backgrounds and its greater sinplicity. It should be possible to operate the montor with a threshold of integrated dose of approridatel 40 mPC hous in an trosphere of unfiltered ais. (duth)

$\langle 445\rangle$

Ishiquro, H. S. Terunua, S. Sekita, and

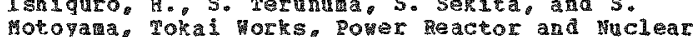
Fuel Developaent Corporation, Tokat, Ibaraki. Japar. 1973, Decelerer

Mey Phermoluinescent Dosineter for Personnel Dosinetry Systar at atc Tokai works.

ENCT-831-73-02: Part of Toka Horks Semannual

Progress Report, January-June, $1973,(4) .1 .122$ p.

I nev personel dosineter badge with a theralingescent dosineter (TID) was developed. The hadge can measure the radition exposure doses due to gara, beta. and netron radiation. It ias not only satisfactory response to coutine montoring but also to accialental dosimetry. The specifications of the dosineter badge. including the THD elements erployed and the range of radiation dose reasured, are given.

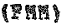

<447》

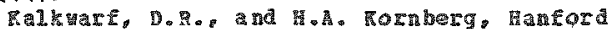
tonde Products operation. Blology section.

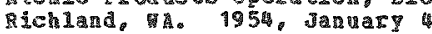

Deternination of lpha Barticle enters in the

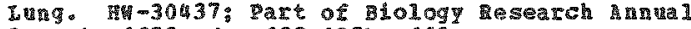
Report, 1953, (p. $122-125), 163$ p.

The a pha-particle induced decorposition of nitrous oxide was investigated as a reans of detecting isotopes enteting tis type of

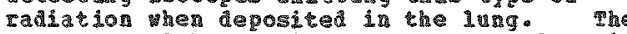
source of lphe garticles med vas a depost

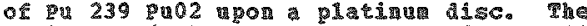
activity of the source carresponded to 1 : 
《447) CONPT.

of Pu 239 and the rate of enexgy emission as alpha particles to the surrounding gas yas calculated to be 6.5 \& 10 (E+12) P/oin. Hitrous ozide alone and in mixtere vith other cases was admitted to the reaction vessel for definite time periods. The w02 formed during the irradiation as used as aeasure of the extent of 120 decomposition. None of the gas mintures used produced a significanti greater yield thas could be obtained yith pure $\$ 20$ although small amounts of $\mathrm{CO} 2$ appeared to lover it. osing pura t20, it would take approsinately one day for a detectable a gount of wo 2 to accuralate with the source used. Thus this reaction does wot appear suitable as a means of determining microgran a ounts of Pu 239 in the lung. (F)

<448>

Rearny. C.H. Oak Fiage National Laboratory. Hea Ith Physics Division, Civil Defense Research section. 0ak tiage Fy. 1973, Noverber

Trams-pacific pallout and protective countermeasures. osm $-4909: 22 \mathrm{p}$.

Date fron the measured $10 \%$ r tropospheric fallout deposited in the ynted states from past chinese nuclear tests yas extrapolated to estimate tropospheric rallout rates froa a theoretical war in which 65 megatom of weapons are detonated on or over china. the resultant trans-Pacific fall cut volla dagcerousl contaginate oilk in most of the 50 states grth $T 131$. protectipe countermea sures are discussed. Hazards and expected long-ter casilities from eating other fallout-contaninated foods ad from exposure to total hole-body gama doses of 4 to 10 reas fon such trans-Qacific fallout in the year following the war are salariged. pecomended protective courtermeasures and the osychological-political advantages likely to be ataned if the govarnment ore

pepared to gate an arly. actual account of the apveoaching trans-pacisic fall out angers and of the protective counertedsues being taken to minimite casual tos and a conomic losses are outined. (uen) (s)

$\langle 449\rangle$

Keefer, D.H., and Haner, W. Deproment of Health, Facation, and wel are Burear of Rad lological Health. Training hanpower Developgent Drogra, Vashington. DC: University of mani. Graduate School, Departwente of Radiology, pian, Fi. 9970 , September

Matura1 Fovitonmental pachoctivity in son Florida Sands and soins, rebruary-june 1968. Padiation Data and peports, 11, 441-448

An investigation of the naturally occuring gama-emistion radioncildes present in selected sands and solis of south lorida

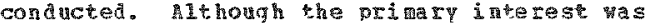
in the natural enwirongenta radionction from uraniu 238 , radiu $22 \%$ thorium 232 . and potassintin $0_{0}$, the concen erations of fipe fission products we also deter med to winitize the error in computing the concentrations of the four natural it occurrina radionalides. The deterination of these ine radionuclides in 45 environmental samples as performed by the ijnear least-squares method of analys utilizing a computer. Tt was rond that the uranitu 23 comcentration in sands an soils of southers Forida is approxigately 0.75 ppr. This level of natural radioativit is expecten hecause of the higher uraning content of spectsic lingstone fortitions mative to south Forida. (huth) (Fin)

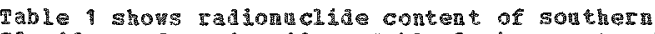
Forida sands and solis. Thabe 2 shons natural ervirongental radioactivity id sands and soils of southern Florida.

$<408$

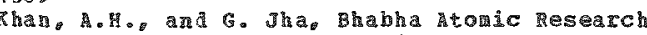

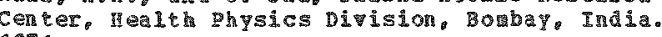
1971

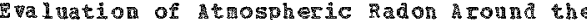

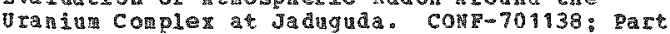
of proceedings of the vational 1 yposium on Radiation phisice held in Trobbay, India. woverher $24-27,7970$, (p. 487-491)

A brief account of surveys to evaluate the atmosoheric radon concentration at jadugua turing the period fron 1965 to 1970 are describea. The probable sources of atmospherdc radon is presented. The average atmospheric concentration of radon in Jadugual auring $1966-1970$ vas 4.60 times $1012-101$ uCi/3. AIthough day-to-day variations vere onserved, the aw erage value. hovever, was of the same order over these years. The cotal radon output fon the rines vas foum to have increased from $0.76 \mathrm{ci} / \mathrm{d}$ in

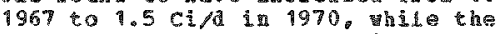
concertration inside the aines came dow by nearly a tactor of 2. nlthough the fadon outpat from the rines has sibstantialy increased over the years. there appears to be no significant ise in the atmospheric radon concentration. This, perhaps, may be atcibuted to the large allation ayallable at site. conparison has also been made yth the avilable data or atospheric radon in

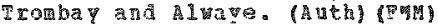

$<45$

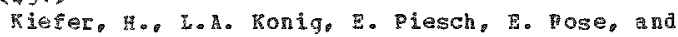

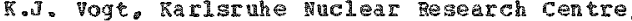
Rarlsruhe, German Federal Tepublic: Julich

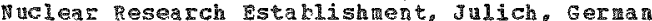
Federal Republic. 1972

Personal Dose Burden Caused by Murlear Research Centers, Experience Gained at the puclear

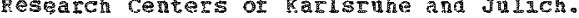
Conf-710901: 5TT/PRE/300: A/CONP-49/P-395: Part of Proceeding of the th thernational. Symposiu on the peaceful Uses of storic Energy held in sener, Shitzerlend, september 6-16. 197 ? $10.41-159)$

At the Julich and Rarlstuhe Nuclear Research Centres in westigations on the assessment of the personal doses to the persons vorking in restricted and controlied areas and to the poplation in the environs of the plants have been carried out for pany pears. They have taken into accout both raciation exposures Fror external sources ard those arising from incorporated radioactive substances. For measurerents of $100 \mathrm{c}$ and personal dosinetry Eill, per, RPL and Tosineters re encoyed. Incorporation measurements a re perfor wed wh whole-body counters and sensitive excretion measurenents. The anvironantal cospure resulting from potentiall radioactive gaseous effluents is deternind by neans of sensitive enission measurements and compahensive toterological assy programs. Moreover. data are avaliable on the radoactivity of the liquid effluents ascharged. The evaluation has shoun that the external exposure of the individual groups of persons dus to nuclear tacilities a mouts to only a fer percent each 
$6451>$ COHF.

of the dose levela peraited by legislativis

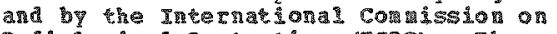

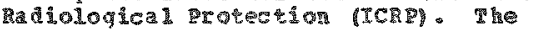

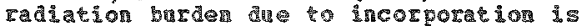

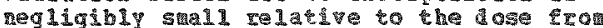
external radiat

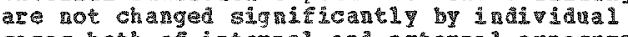
cases both of incernal al omternal 1 exposire in vich the perrissibe levels ha been reached or erceeded since tritiu and is $239 / \mathrm{Pu}^{2} 240$ in the body cand be derected by a body conter, regular urine checks are perforred on personnel anding these

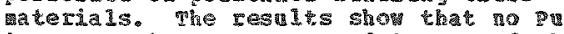
incorporatio as detected in an of thesw

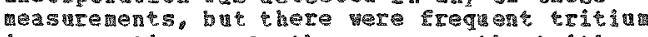
incorporations. on the werage. the trituing incorporations expressen as a percentage of

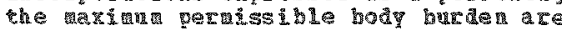
higher than those found for orher nuclides.

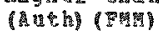

$452\rangle$

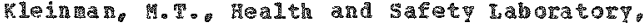

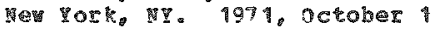

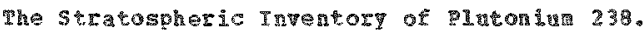

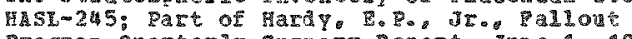
Program ouarter1 sumery through septerber i. $1971,(10.1-34-I-102)$, 254 .

The stratospheric concentrations and butens

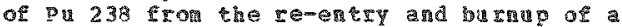
set1ite contaning the Sta boher source in Rpri 1964 a re presented. The period covered is A aguse 1967 - Hoveraber 1970. At the beginaing of 1971 about $5 \%$ of

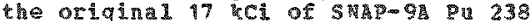
renaided in the stratosphere. (Amb)

《453>

Roranda, J.J., and J.R. Martin, Lavrence

Radition taboracory. inernore, $\mathrm{CA}$. $1969 . \mathrm{Ju}$ 15

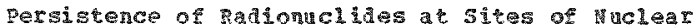
Detonations UCRI-71967: Coll-690303: Part of Procerdings or 3 traposium on the Biological Inplications of the viclear has held in

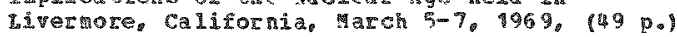

Research was aind at dering the distribution of radioactivity detomation sites where earth has been nowed to create crater or trench. Subsequent ecological studies intolved biological systers the cone in contact ith the rabloactive sulistratud Studies of detonation sites are revicied and wone of the sulient re

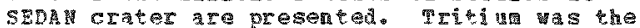
most abundant radionclide in the efecta five vears postshot $(2.39 \times 10(\mathrm{E}+4) \mathrm{uCi} / \mathrm{fr} 2)$ and in the hiologica systers, both plath and andal that are present in tho 3 Ban ecos yster. Ir mas the rose abrinda radionclide uresent in every sante analyed. Besults of the studes showed that triti concentratons aecreased in distance frow he crater: soil-kater trit ua profiles peaked between three and four feet ate $31 \rightarrow$ of eject depth--indicating distributsonal paterns produced by ranell

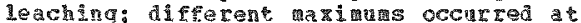
differest depth sin sumer and vinter: surface air above the efocta containd

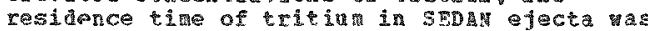
short. Fissue-tate trit growino on the tecta and tritium content in bodv trate biological halt-1tfe. and specific activity in tissue of stall ma (kanga roo rats) vere also studied. The

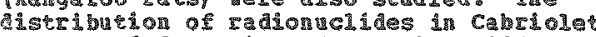

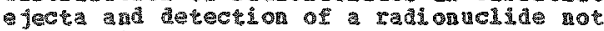
menchones. aㄱ. nuclear ctater jecte is given. (5\%)

<䑸4

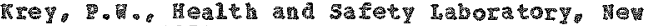
york, H. 1974, Jand

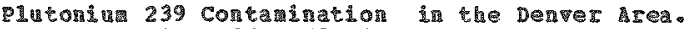
Hea 1 th

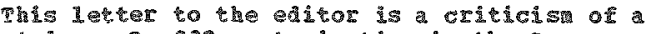
straty on par 239 comeanation in the perver

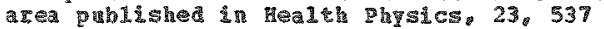

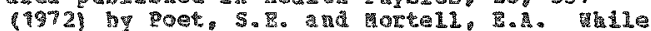
acknom ledging the value of che zeport. possin le orissions, errors and misconceptons in the areas of soil salging and analysisg E1 a

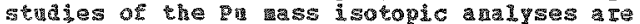

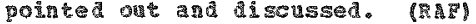

$6455>$

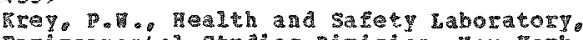

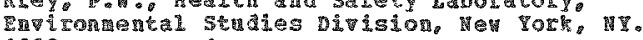

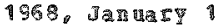

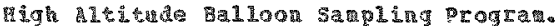

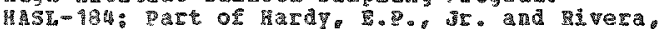

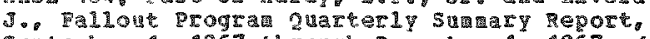
sepremer 1.1957 through Decerier 1.1967 . (E. $I I-26-I I-86) \cdot 606 \mathrm{p}$.

Mesults of andyses of noper stratospheric nuclear debris collected by ba 1100 -borne piltaria devices from octoher 1965 thromah 3une 1967 a re presented. Deterainatins were

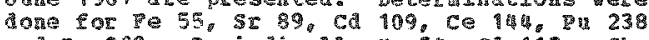

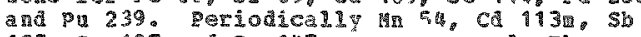

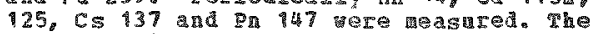
concentrations of gemeral radionuldes are

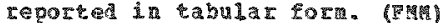

<456>

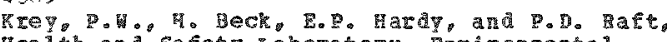
Health and safet Iaboratory gronentel Stules Division, Hey tork, HT, 1973, October 1

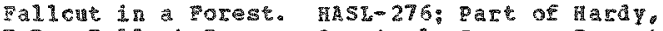
E.P. Pallout Progra crarterly sumary Report. Iune 1. 1973 through septaber 1. 1973 (p. I-27 $-\mathrm{I}-39 \mathrm{i}^{\circ} \mathrm{175} \mathrm{p}$.

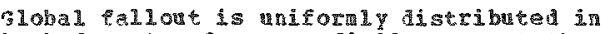
both corest and grassy ield areas at the Brooks a ton rational laboratory. The total fallont in the rorest. as measured by celatively imobile $\mathrm{p}$ il 239 , is only 15 hither then in the grassy field. This aiference is with the statistical uncertiont of the masirements. It the ditherence vere real, it colld be due to a increase in deposition by inpaction in the

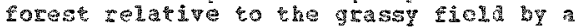
factor of abont 2. (nestin

$<457>$

Krep. P.

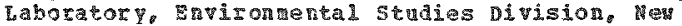
Tork, No. 497 i. October 1

yigh Aleteude Balloon Saming Proqrat. Fiss-245: part of Hardy. 2. If. Fallout

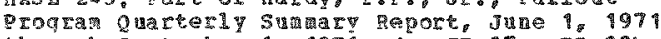
through septenber 1, $1071,(0.25-37-$ II-93). 254 p. 
〈457〉 CONT.

upper atmospheric nuclear debris nas collected by balloon-borne filtering devices and analyzed ratiocherical 1y poz $5 \mathrm{~F} 89 \mathrm{Sr}$ 90. Pa 233 ant $\mathbb{P}_{13} 239$. The results from samples collected in calendar years 1970 and 1971 are given. For Pu 239 the results range from 0.512 picocuries per $10(2+3)$ standard cubic meter of air (pcif schito 28.3 pci/rsch, where the standard deviation of the counting error is less than $20 \%$ of the count. (E)

<458?

Krey, o. Iaboratory, Mvirophental stadies Division vork, it?. 1071, getoher

Project Airstream. HASL-245; Part of Hardy. E.P. JTo, Fallont progran guarterly Sulary hesort, andue 1, 1971 through september 1, 1971 . (D. $I T-8-T-36), 259 \mathrm{p}$.

2aAioactivity in the lower stratosphere was studied emplowing the go-s7p alrerat as a sampling platform. The radicchemingal data trom the povewber 1070 missicg is reported and includes cesults for St 89. St $90 . \mathrm{Pb}$ 210, Po 210, po 238, po 239 and Pu 240. The values for Pu 230 range fron 0.007 picocuries per 100 standar cubic meters of it (oli/1003fm) to 11.900 oci/100sch were the

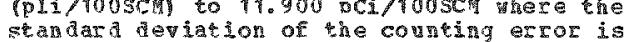
less than $20 \%$ of the count. (Frith)

रद्येग

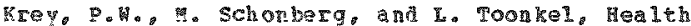

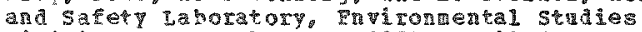

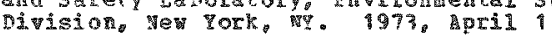

upating stratospherie Inventories to tarch 1972. HisI-273: Part of

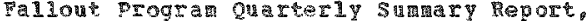
Decenbe 1,1972 thrond $-I-63), 227$.

The stratospheric inventories of $3 \mathrm{r} 90$.

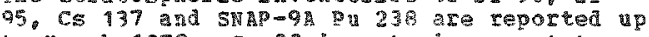
to larch 1972. Sr 90 invencorid react to recent large atwospheric tests while $5 \mathrm{HP}-9 \mathrm{~A}$ Fa 238 Jecreases

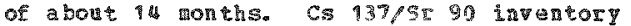
retios are close to the champeried

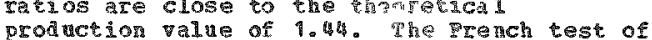
production value of 1. 90 into the southern gentsphere strasphere. (A) 10 (h)

\section{<460>}

Kristan, J., and I. nobal, Iniverstiy of

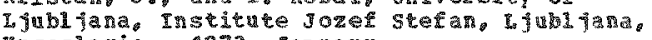
yagosiavia. 1973 , Jandary

A llodified Scintillation cell for the Derernination of $R$ don in Mctosphere. Healch physcs, $24,103-140$

Tho moditied alpha scidtillatior sells having inder and onter tubes vere used to reasure

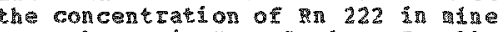

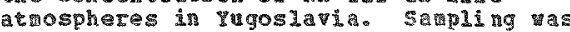
performed by panding the a is of the sampling site through the ce 11 by reans of a rubber

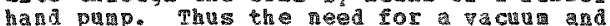
vacu punpsis al ininated. pithour radon

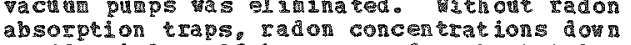
to 10 pei 1 conla be mesured. The toral errot of neasurement mas about $5 \%$ ro he

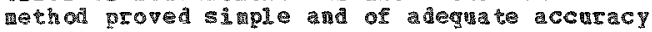
Sor Fid it reasugements. (ST)
<461)

Larson, K. Calsfornia, neatcal center, ibaratory of

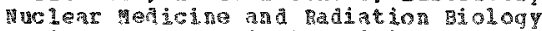

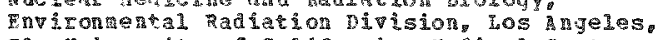
CA: briversity of california sedical center, daboratory of yclear meatcine and radiation Binlogy, Fiophysical pelationships section, Hos

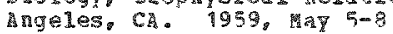

Sumaty statemt of Findings pelated to the Testing Progra a the Nevada Test Sito. Bart of Hearings Ferore the special subcomatidee on Badiation of the Joint conditres on Aromic Energi on xay $5-8,1959$, Wol. 3, (D. 2006-2019)

Droxitity to ground surface as vell as increased lass of suppor and cas structures increased fallout is areas adjacent to the Fevala rest site. Aerial bursts vere not derectable by ground survay athous ithin 200 ofies of Ground zero (Gq). Tho $1.500-$ foot be1100n shots which dit not intersect the sol1 surface deposited less than $0.2 \%$ of the therretical fallow activity vithin the 1 math radiation intensity contour fat 12 hoursl betwen the distomce of 1 aile frou $\mathrm{GZ}$ and that corresponding to a rallout time of y+ 12 hours. A balloon shot hich intersected the soil suriace deposited 2.12 of of the theoretical fallout. Fover shots, which in some cases intersected the soil surface and in other cases dì not, deposithed 6.7 to 2 t. 5 \% of the theoretical tallot activity with the save distance 1ints. pallout particle sizes decrease vith distance from $\mathrm{GZ}$

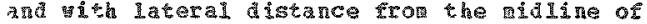
fallout. The relative a

radioactivity associated with sall particle sizes lless than 4 aicron and hence the amoun of sallowt occurring at greater diseances fron to was increased by decreasing the mass of support and cab raterials. It foudt was pound that vegetation in the environs of revada atest sife during the

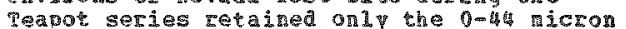
callon pareicle fraction. vithin the lints of 1 ilde from 6 to a a istance corresponding to Ho 12 hour fallout time. 500 and $700-$ foot towe shot: had aptroxinativel 30 \% of the trilont activity associated th particles

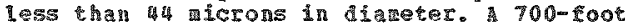
ba sloon shot had $70 \%$ of the fallout activity asoci at with the sate size fraction. on the averace. 38 to $50 \%$ of the less shan 4 in icron diamer fallont activity of tover shot fallow samples was associded the the less than 5 acron dianeter particles and 51 to $83 \%$ in the case of balloon shot saples. Tarious percentage contributions of less than 5 micon diamer fallou garticies vere

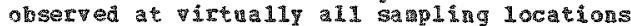
for both tower and balloon shots. Fhe solubilities of balloon por rallout material exceeded those of tover shot: in both wher

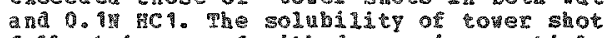
fallon incressed wh decreasino particte size. However, in salloon shot lallout, the swaller particles sere somerhat less soluble than large particles. (Aath) (1t)

44623

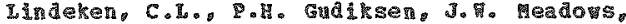

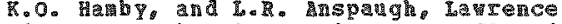

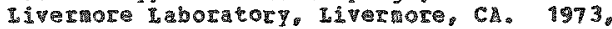
Apri1 16

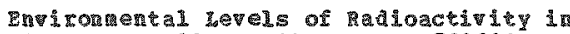

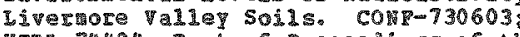

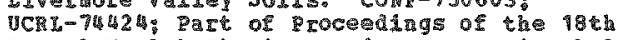

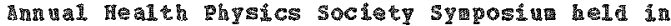

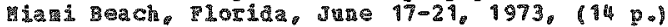


$\langle 462\rangle$

〈दि2) Covक्ष

Soil sarples collected trom areas surrounding the Iavience Li torate Labotaty in the ifyermore Valley gere a 233, AR 241. $5 \mathrm{r} 90, \mathrm{Cs} 13$, and

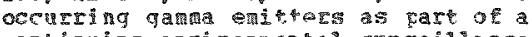
continuing envitomental surveilla bce progtan. "phe vedisn 239 activity corresonas to a sirice devcsition value of 1.1 acikh (2). Activities fron Pil 23 and 24 were lower than 239 activity by factor of abont 10 . median $S_{2} 90$ and $6 \mathrm{~s} 137$

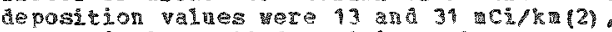
resnectivil. A11 ceposiczol values appear to be topical of those expected from global fallout in this area. present, Cs 137 is

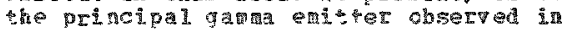

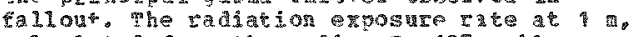

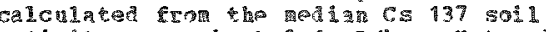

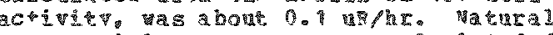
terestrial ezposure Iates calculated from

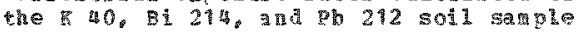
activitues vary from 3 tor 7 uRfhr. These qalues are ja good agree

measurenents made usinu Car $2: D y$ TL

dosideters and these obtaned uith a

fileld-operated Ge(Li) tetector. (A uth

Table 1 shows the compatison of 94239 content

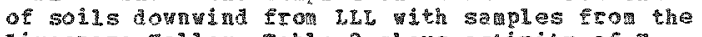
Hitpernore valle $230^{\circ}$, th 232, w different stations.

$\langle 463\rangle$

lossner. T. hational Center for Radicton protection, gerin. German Rerocratic Republic. 1973

Assessment of Low suergy Photon Futers in Technical Rspects of Detection. Conp-720503: part of Bufdoso. E. (ta.). Health phisics problers of Internal conta ination, proceedings

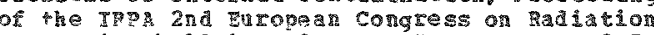

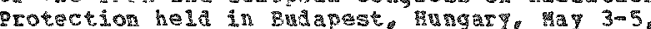

1972 (1). $499-463), 659$.

For in vivo wea surements of radon uclies

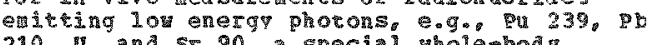
210. and $\mathrm{SE}$ 90, a special whole-bod couter syste vas built consisting of tho large-area proportional counters and a

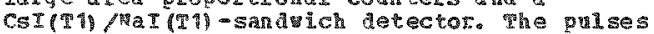
from both detection ststems are whod and analyzed in respect to pulse-height and

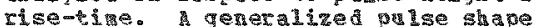
an 1 tre as developed for this purpose. block diagra of th proportiona 1 counter syster. especialiy designed for pu 239 is shown. (anth)

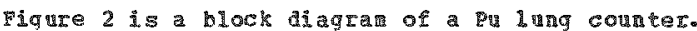

<464>

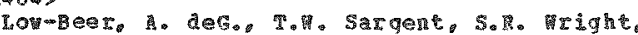
.C. Buklew and D.J. reager, lavrence Berkeley Labortory. Berkeley, CA. $19 \% 3$, Ta

peport of the Bioasay Laboratory. 1969 to 1972. I.B $0-799: 9 \mathrm{p}$.

Th teport covers activities of the Boassy progran. including vhole-bod contheng of

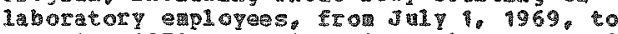
June 30, 1972. Restits of routine ron toring and investighion of caser of suspected expostre co radionucildes re preserted. The soope and acromplish gent of the research and

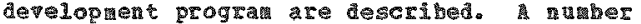

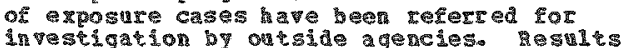
in these ingestigations are presented. (Am
《465

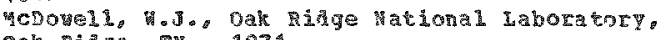
Oak Ridge, Th. 1974

Liquin Se ine Llation Conting Fech miques for the Hoher Actinges. part of organd Selntillators

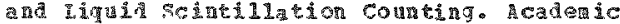
press, He vork, Wer York, (0.937-950)

I igla seintillation con defelopad in studies of the aqueous complexes

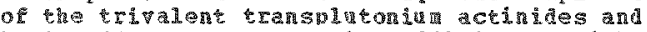

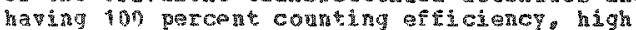
accuracy an very simple, convorien sate preparation are Aescribed. Isiquid

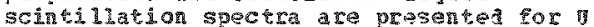

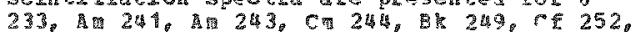
and 25 taten hoth on a conaereial istaid scintillation detector Parkard Tri-carbi and

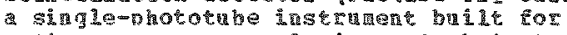

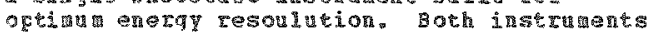
give a linear relationship between alpha energy peak and chingel maber. The comerchal instrument gave an average alpina marg resolution of 26 percent while the

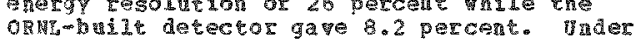

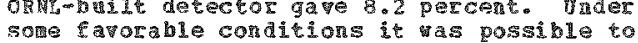
count one actinie in the presence of others Tr in the presence of other radotracer bromrities. Condithons there this tas

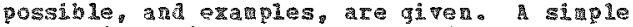
extractive scintiliator consisting of scintillatos olus a sultable extractant in coluere vas shom to be an efiective neans of coluere vas shour to be an effective neang meation. Tt was devonstrated that subsegatent 5eropl 1 of the barren avpeous phase from contact wh the scintillator not necessary, that the same counting etrictency was chtalned wh and thout bulk water plasent, a a $^{3}$ that liquid stintiliation spectra obtaned with bulk water prasert qa nis good, or betrer. resolution that those taken fron ary scintilator solutions. (1)

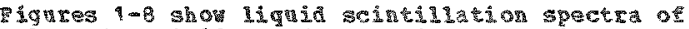
selected actinides under paryimg conditons.

$4466>$

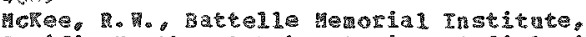
Pas if lorthest I aboratories, Radiological sciences Departart Richland mat Bente Menorial Institute Racific northast Laboratories, Phpsics and Instruentation

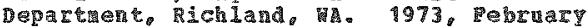

Qopulation Radiation Exposuce. B 4): Part of Halsen, J.h. et al, Anual Report for $1973,(1 ., 101-103), 117 \mathrm{p}$.

whe objective or this project is to develop reliable estinates or the radiator dose to

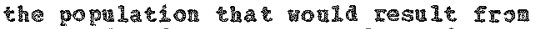
success 239 ivired articicial heasts.

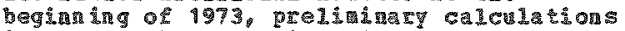
indicated the rost sagnifican component of

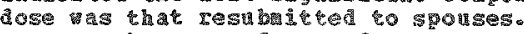
gecals the ge and ser of persons exposed

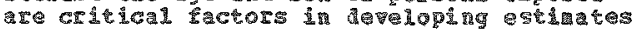

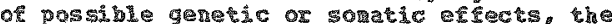
- trectives of the study vere broddened to develop greater desindtion of the age ad ser of persons potentill arposed. An atenst surper to collect requined interpersmal distarce data vas carried on in the salt

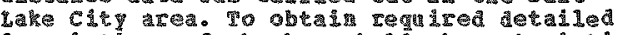
deseriterons of the household characteristics

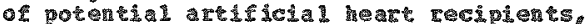

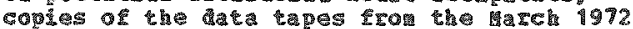

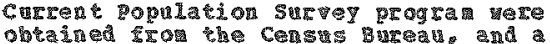
special compiter progra was ritten to 


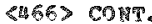

process these tapes. At year end, the principal effort was bejn devoted to the compurer prograt to carry out the detalled arse calculations and sumations. path

\&467>

Moore, J.D., Atomics International, Camoga Park。 CA. 73 . Aurgest

Tnvirongerta 1 matoring Annal peport, 1972.

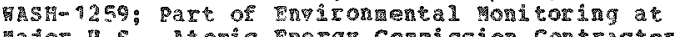
major

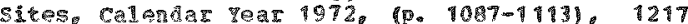

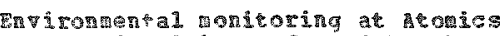
Trtercation is perfored by the operational

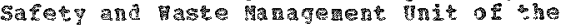
Health, Safery ant padiation Services

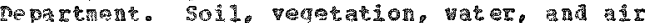
are rontinely sample 110 to a distance of 10 are routinely sampla up to a astance os 10 miles ron tomics International stes Site perdmers are montorea for radiation le

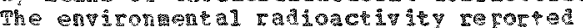

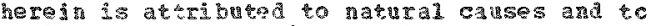

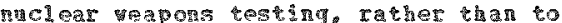

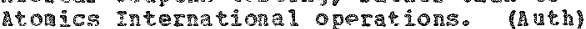

Table 1. 2 and show soth, vegetarion and

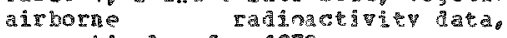
respertively, for 107 \%

दु6 69

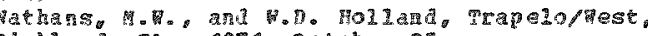
Tichlag, CA. 1971, Mctoher 25

Arelysis of plutonia 239 particles collected

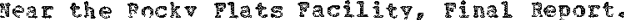

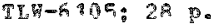

The results of the anatysis of some a

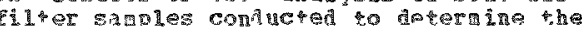
relation between the size ad ahe platong

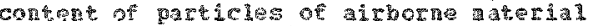

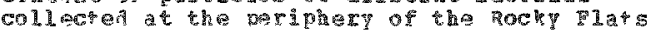
D1 an are reported. Plutoning oxide

crulvalent diameters ant the size

distribution of piutonitin-containing ant becharour partioles are gipen in tabular torm. It as concluded that the plutonia contert of particleg in the air saples vas a sal 1 fraction of steir total contert: D 1 ton in as a sporsed fhroughout the on r icles; olutonin-containg oncteles had a size Adstriburion larger than that of a

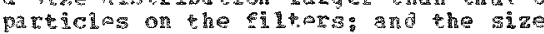

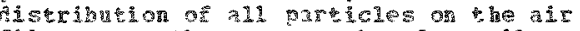

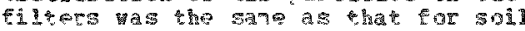
samoles, except that vary large particies we not present an he ate samples. (5\%)

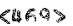

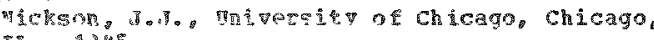

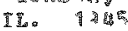

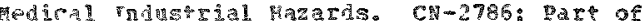

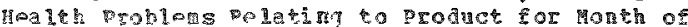

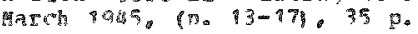

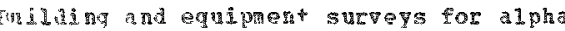

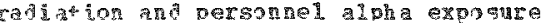
surveve are reported. Althoths several

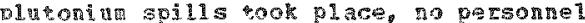

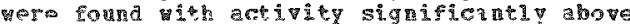

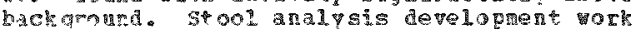
is coneisuinge (ST)

《470》

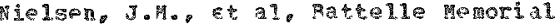

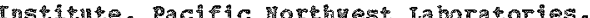

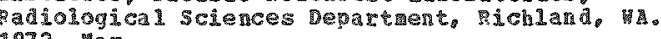
1972 .

Mna 1 aport for 1979 to the USAC Division of Blology a Sciencas. Part 2: Rablological schences.

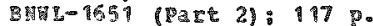

The report covers work aore in the fielas of environertal and radiolonical cheristy.

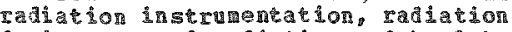
dosi In Par rafiator is fallot pates and cechno

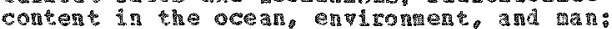

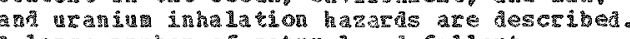

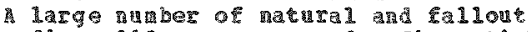
Tadiondides are covered. Sin articles tere selected and abtracted separately for the

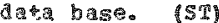

$<479$

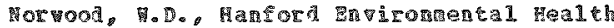
Foundation, 等,

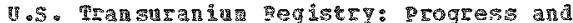

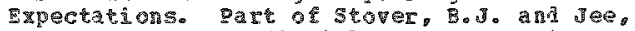

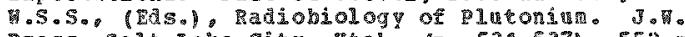

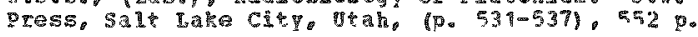

The getroose progress and expectations of the

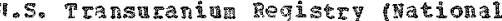

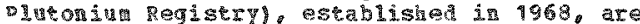
diserssed. problers of estivating internal

hose and husa and a the transwarita elewents are revieved. The

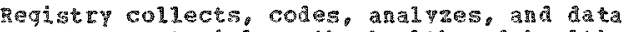
orocesses waterial on the health and health phyzics aspects of present and past exposed envloyers during life and compares these date

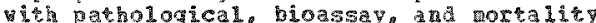

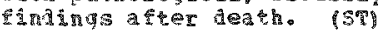

64728

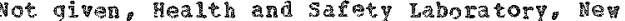

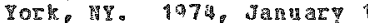

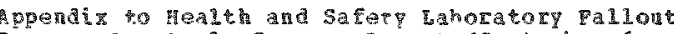

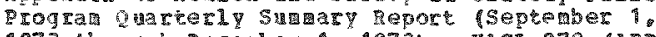
1073 thrsag Decerber 1,1973 ). 7hSI-278 (APP): 459 p.

Mata are oresented for $5 \mathrm{r} 90$ and $\mathrm{st} 99$ i.n monthl deposition at porla land sires. There are 35 wonthy ind ing sing in the pilat states and 90 in other countries. severa 1 tables are presented for the concentrations of raAionacildes thu 54 , Fe , ST $90, \mathrm{Cs} 137, \mathrm{Cl} 109, \mathrm{Ce} 144, \mathrm{Pu} 238$ and (4) 239$)$ in surface ar in varions countries.

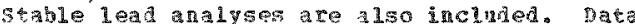
are given for the 50 contert in Her Tor city tap rater and will and finaliy there is a thie of corversion fartors and a isting of radionelides of interest in the $\mathrm{xA}$

a 110 or prograto(

$<473$

Fot giveng mational Envisomental Research

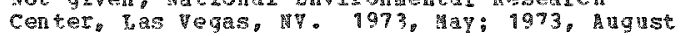

Environgatal poitoring Report for the Nevada Test Site nut othes Test hreas used cor ynderorona viciear jetonations

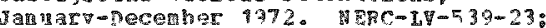

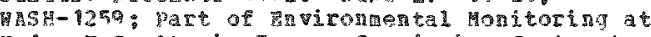

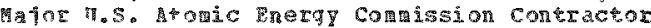

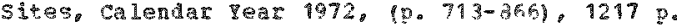

Duriga 1972, the wontoring of gaman 
<473> cots.

raaiatim levels and concentrations of radioactivity in the enirons of the Hevala rese SIte (NTS) wa continued through the use of offsite netrorkg of radiaticn a osi meters and gamm-rate recorders, air samlers, and selected locations at which monthi saples ar vater and will were collected for radiologhes andiras. Por each of the undergrowat whelear detomatens an the segen experimental tests of the Muclear Furnaces.

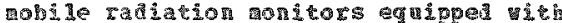
radiation monitoring equipaent and suppies were on standby in offsite lecatons. The oniy radisactipingroduced by ruclear tests

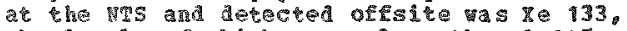
the levels of vihich pere less tha 0.04 of

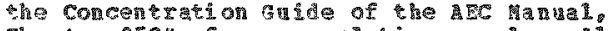
Chaper 0524, for a population sample. Mll onher ingereases in radioacitivity concentrations observed is nedia collected around the wiss pate attributed to seasonal variations in old atraspheric fall wut and fallow from nuclear detomations by the People's Pepubic of China on Jantary 7. 1972. and mareh 18,1972 . RaÁloactive noble qaseg vere releasel during the muclear

Furnace- 1 test series and detected by aircraft sagyling. An estimate of the potentiel rahiation exposure to of Esite populations was detarnined to be less than $1 \%$ of the Badiarion protect ion standards of the ACC Mantal, Chapter 0524. The results of soil samples collected around the Hrs and analyzed for plutoning content shoved that Pu 239 is present outside the boumdaries of the ys at levels greater than that which would be expected rop world-wite falleot

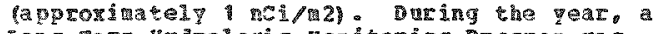

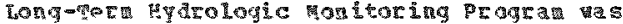
begun for off-oy underground nuclear tests. These sites are located Rar Fallon, Metada (Project Shoall. Cencral Hevada Test Area (Palless pest). Grama Junceion, Colorado Project Rulison.

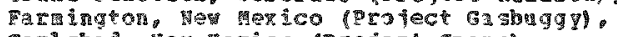
carlsba, men mexico project Gromel. Hat tesbur Dribie/nacle play.) Ali radioactivity concentrations in the samples collected तuring the year were at natural background levels with the exception of samoles collected at USGs yells mos. 4 and 8 at the

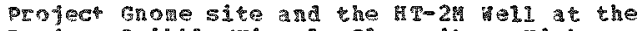
Project Bribblefpiraclo play site. Inigh levels of $\mathrm{k} 3$ and $S T$ Q 0 vere observed in sevples collected from both wells while $c$ 137 yas detected on 17 in the sample from No. 8. The sighest concentration of radivactipley was for $5 r^{30}$, which was 4.3 tiaes its concentration fuide of $3 \times 10(\mathrm{Q}-7)$ ufi/l 1 for exposure to individuals. Righ Levels of $\mathrm{H} 3$ was derected in the HT-2n well at the pribble site. the highest being $6.7 \mathrm{~g}$ $10(3-5)$ ict/mi, which is $2.2 \%$ of the contertration Guide For II 3. The potential radiation dose equivalents receiped by offsite populations near the UTS and other locations referrod to above were all estivated to be less than $1 \%$ of the Raliation Protection Standards of the BFC Hanua chapeer 0524. (Auth) (P)

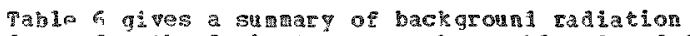
doses for the dosinetry networ. Tales 3 and give sumaries of anditol results for the ailis and vatar surveillance netrork.

$\langle 474\rangle$

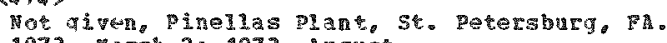
1973. घharch 2; 1973, Agust

Environgental monitoring Rezort, 1972.

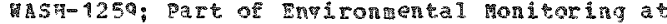

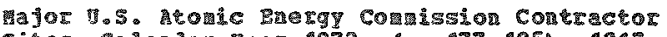

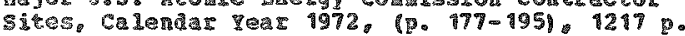

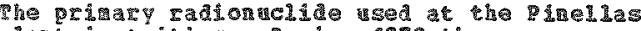

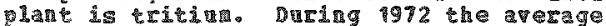

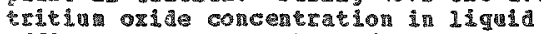
efreluenes vas less tha 2 算 of the

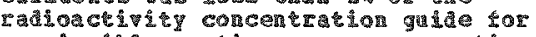

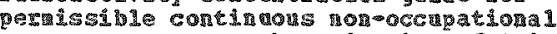

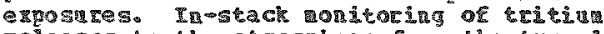
releases to the atrosphere from the tho plate -rhast stacks revealed that the evorage gas concer trations vere $0.05 \%$ and $0.6 \%$ or the

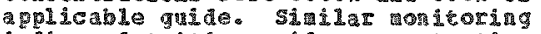

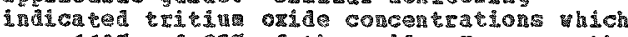
yere $110 \%$ and $95 \%$ of the guide. Powerer. the asociated gromd level concentrations nere 1.s5 the 0.0055 and 0.000 in of the gute. Discharges of rali eactive krypen ga. nasured in stack resuled in an average

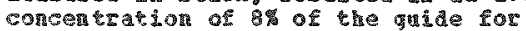
coptinuous ron occuptional exposure.

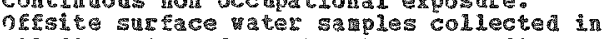
a11 inectons fron the plant to a distance of six $11 \mathrm{les}$ and a nalyed for al1 shored less than the minam detcetabe leve1. (연

4752

Met given. U.S. Atomic Energy Comission。 Division of operational safecy. 1973 . 1 u $1 \mathrm{gst}$

Environent 1 rontoring at tajor Energe Co Yex工 1972 .

The entirongental montoring reports of the

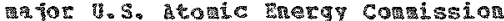
contractor sites are presented vith the facilitiles grouged according to the various oper mons offices, naty the 1 buquergue. Chicago. Idaho, Hevada, oak Ridge, Richiand. san Francisco and savanah River operations Orfices, and the aval eactors Facilities. Separa te lotracts are prepared ror the data base for each faclint wh the exception of

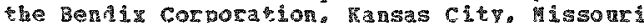
which loes rot nathine or process any

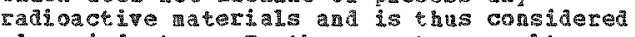
clear industry. In the reports. results are given for concentrations of radoactily in

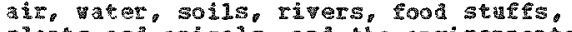
plants and and 15 , and the environdental data is analpzed to deternine wether the operation of the facility hat an significant erfect on the qualicy of the harin envitonment. (F以⿵)

$\langle 476\rangle$

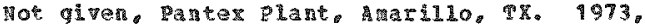
Aug use

Tnvironmental montering and Dollutant Invantory Progran Roport for Panez Plapt Covering

Calendar pear 1972. $5 \mathrm{sH}-1259$ : part of

Environgental tontoriag at afor

Energy Conission contractor sitos, calendar Year $1972,(0,129-176), 1217 \mathrm{p}$.

Drring calendar year 1972, a total of 45 test shots involving radioactive ato tols were Hred from Fing site 10 . 5 as compared to 333 test shots fired from the sawe location not involving radioective raterial.

Folloning each test fire, a sall quatity of rajoactive raterial is susperded in the lust clond that accorpanies the explosion. As the dust cloud dissipates, the potertial exists for depomition of raboctive materils on entisonment soll and vegeration. Rourige a bear perfor 
<476s comp?

and platonitu in the environgent surrounding

the Danter fact lity to aetrer

samect of Pantar onerations upon the

surronging environent. meteotologied

conditions in the area are such that there is Erequert blowing af area tog soil. A summert

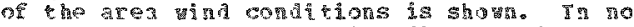
case vas excessive detivity disconted for any of the andyses performed. For soli depositson, the it 238 concen tracior tras appeorimately 0.0gh ugfo or appronimatoly 3 \&

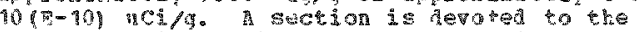

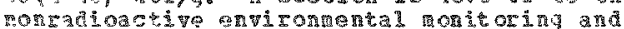
poll uty

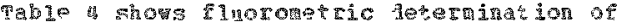

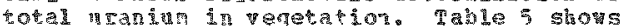

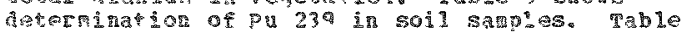
6 shovs raxtometric ana ysis of environental นator samples.

<47\%

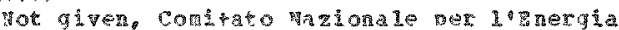

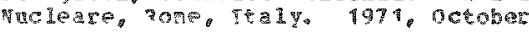

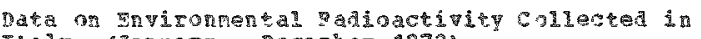
Italy. Pamaty - Decerbez 1972)

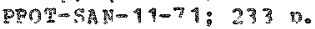

Data are presented tor the content of sr 90. $5589 \mathrm{cs} 137,2 \mathrm{r}$ a ที丶 sanoling samle treatrent, alpha, beta and

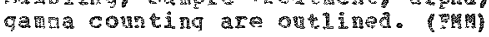

《498\%

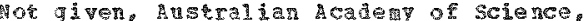
Canberra, Agstalia. 1973, Hari

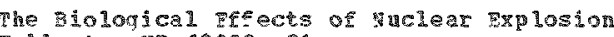
\$21 10ut.

The stray mas undertaken to assess the actual

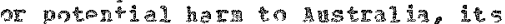

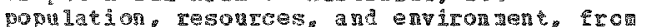

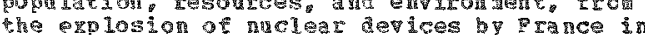
the acific Th the first section the Pacifico Th the first section
assessuents were nade of the tadiation doses

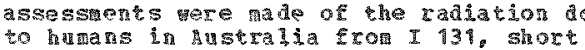
iived fission products, Sr 90, Cs 137, and $C$ 14 and dowe rates vere calculate In bhe second section cancer and gentic effects iton the calculared hose cares rese

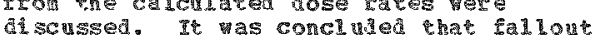
discussed. It mas conclued that fallobt

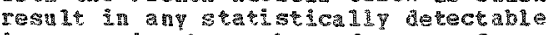
increase in the nuber of cases of cancer or

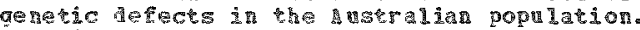
Ginding agans radiation is an phasized. (ST)

The apentic comtains an estivate or the fallon in anseria fron mucl eat weanons explosions at the grom

《49)

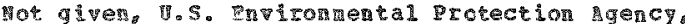
office of pact

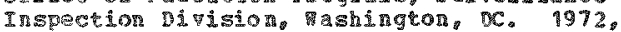
septentar

Procerding of the sathern conserence on

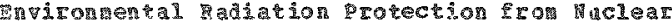
Power Plants. Apri1 21-22, $197 \%$ ORP/SID-72-4: 2350 .

The purpose of the southern conference on

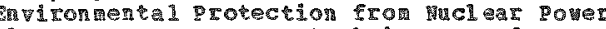

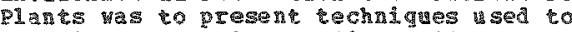
identify and monito radionuclides contained in liquia and gaseous aftuents produced by operating nuclear poner plants atd to specify Fathvays shrough thich radioactive gaterials relared by the nuclear power industry may

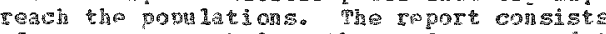
of paper presented at the conference ant the deliberations collowing their delivery. The follow papers were presented: van and ho envisonental responsibilities: probleas ítis

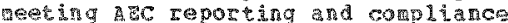

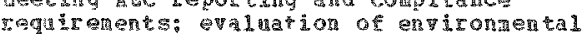

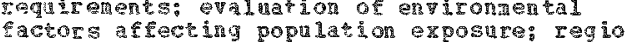

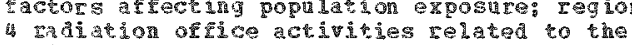

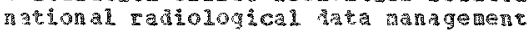

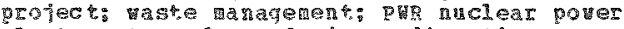

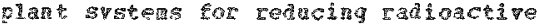
releases: revilatory experience and provections for futw design critaria: wat the futre bols bor guclear power: the terrestrial radiolomical monitoring progras terrestrial radiological nonitoring pogram nuclear station: aguate ratiological monitoring. Browns Ferry nuclear pong: al ecological aproach to rarine ratiolonical monitoring at the Fiorida porne corporation erystal piver nuciear piation

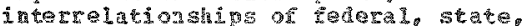

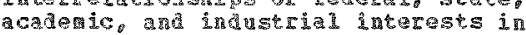

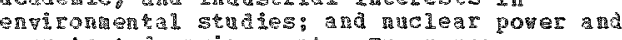

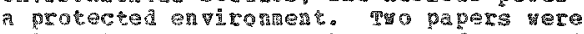
selected for sepirate abstracs for the dat base. 19Th

$<4803$

Hot given, y.S. Atomic Frergy Comisgion, washingto, DC. 1959, October

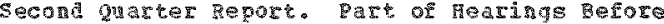

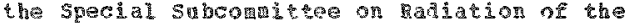

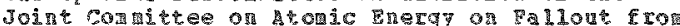

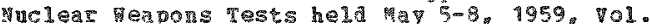
3. (p. $2191-2198)$

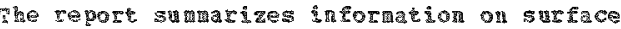

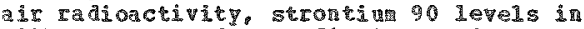

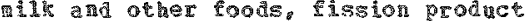
radioactivity in soìs cesin 137 levels in

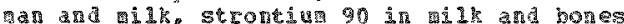
or mevala cattie, and monthy fallout collections for the second quarter of 1959

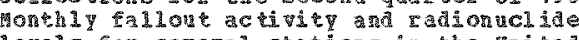
levels for several station in the united States are given in tabular form. Concentrations of total fallout beca radioactivity in sarfice aiz decreasen somewhas in both hem spheres in

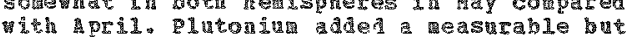
swa 13 portion to the dose fron fission paduct fellous. (ST)

<481>

Hot given, Congress of the rnited States Join

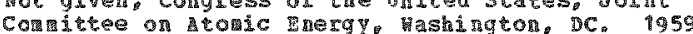

Fallout from ruclear Feapons Tests. Hearings Before the Spechal

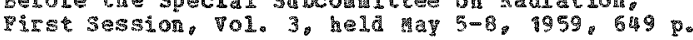

Volume 3 is an appentid to the hearings contaning adational a terial pertinent to the discussions. Fhese wheridis cover supplimental statemen on general aspects of the fallor probles: the hot spot probler and

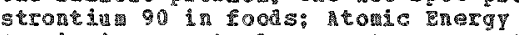
comalsision grarterly reports: coments on the General havisory Comittee rapor: maxian

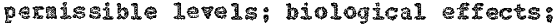

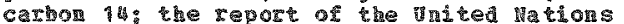

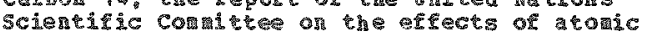
rafiation (1958: nuclear desonation and vefeorological aspacts: classificaton and declassitication: raliout research and organization: and bibiography. Several parts of the apendices vere cbstracted 
<481)

<481\$ COIPT.

separaty for the data base.

44823

Not given, Savanah River Plant, Healeh Physcs section, Mire, SC. 1973, August

Environment 1 Monitoring in the vicinity of the

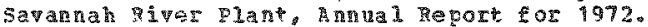
DPSP $-73-30-1$ :

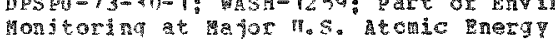

consission contractor sites calender Toar 1972. (p. $1189-1217), 1217$.

A contrinuons montoring progran has been ma inta nol since 1951 (before plant startupl to aetermine the concentrations of rmioactipe meterias in a 1200msqure mile

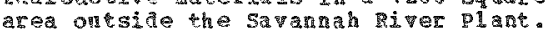

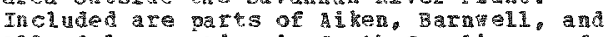
Allendale countes in south carolina; and pichnond, surke, an serever conteis in Georria. lebough wery small arouts of areous and Iiquid radioactive aterials are discharged to the environment entrontental levels continue to be far belov levels considered significa frot a pubic heath vievpoint. The guatity of radioactivity seleased by 5 p to its onvisons during 1972 is, for the most part, too sall to be dis 3 e radiaton and fallowt rom world

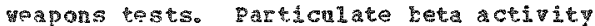
decectole in ir is due entrey to glob fallowt. This concentration in atr at the Dant perineter and 25 . 0 . If of the concentration Guide. Tritiul oxide sin air et the plant perimeter is greater than in aig a wore distat locations: homever, the average cancentration at the lant perineter is on 1 y. $0.1 \%$ of the

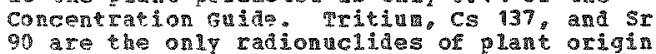
90 are the only radindildes of plant origin an average concentration that erceeded $0.2 \%$ of the concentration side in river ter sapled miles domstrean from the lant.

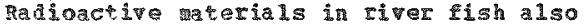
continue to be pertow. Parious water-auditi anelyses of river ther saples by $5 \mathrm{RP}$ indicate that 5 vannah River vater is not adversely afectea by SRD operations. this is substantiated by survers of the hea 1 th of the Satrana 1 iver biota by the scader of tatural sciences of philadelpha and pesticide analyses of tiver trat and sedilment by the united states Geological Surver ater oulity daboratory. ashington, D. C. (A th)

Table 3 shows fallout and caineter nalyses. Tables 5.6 and 7 show radoactivity in vegetation, mher a Tale 9 shows cs 137 concentration hogs. Tato 10 shovs average concentration of radionuclites in savanah River pater.

<483>

Not given, Dov Chereal conpang, colden, Co. 1973 , Aprid

Rock Flats Dlant, Jan gadiation Data and Reports, $14(4), 267-2 \% 1$

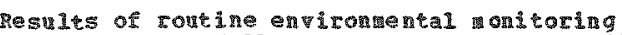

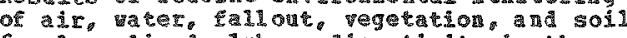

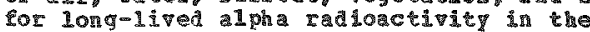

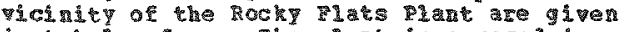
in tabulat form. The glant is engaged in rout ine production operations intolving

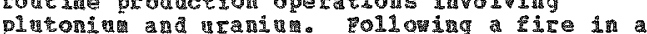

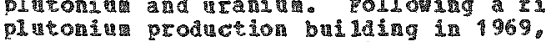
pictonin analys of en mas etpanded. (ST)

<द⿱

Wor given, Union carbide corporation, wueleat nivision, office of safety and Environaental protection. Oak Ridge, Ty. 1973, Mugrst: 1973. March 26

Tnvironental montoring leport, onited states Atomic Fnergy contission oak Riage Facilities Calendar Year 1972 . vCC-ND-244: VASH-1259: Par

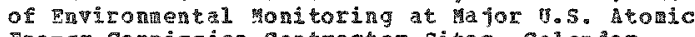
Energy Conasion contractor sites, Calendar Tea $1972,(\mathrm{p} .389-929), 1217 \mathrm{p}$.

The Entrongental foritoring Progran for the

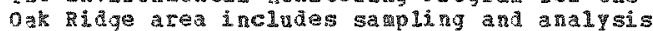
of a ir. verer from surface streans, severa 1

coot products filor. and soil for both cadioactive and nonradioactive raterials. A surary of the results of the program for calendar pear 1972 is presented. Surveiliance of radiactivity in the oak pidge environs indicates the atrospheric concentrations of

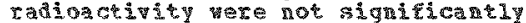

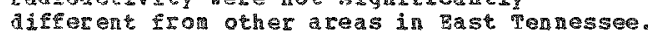
concentrations of radioactivity in the clinch River and in fish collected from the river vere less than ore percent of the permissible concentration and intake guides for individuals in the neighboring envidroment. only very low-level ratioactivity is being released to the resilting concentrations in 31 of the redia sablea zere well below peraissible standards. Surveillance of nonradioactive aterials in the oak Ridge envitrons shous that established lirats were not exceeded for those aterials possibly present in the air as 3 restlt of plant operations. The dete obtained from the ter samping progran obtained from the vater samping progra indicate colpliance in phite oak Dan and chromiu, ph, and dissolved oxygen at the outlet of wew nope Pond on East

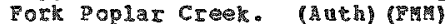

Table 8 shors radionuclides in the clinch Birer. rable 9 shos araniu comcentration in surtace Fale shows arandu concentration in surtace streals, Table 16 shows radionclide content
clinch River ish. Table 19 shows Bu and content of soil saples fron near perimeter air sappling stations. Table 20 shows y in sol. vine needles and grasses at a five-rite radus Eron the oak sidge Gaseous Diffusion Plant.

〈485>

yot given, kational load company of ohio, Health and safet pivision cincinnat. OH. 1973. August: 1973. Peberary 16

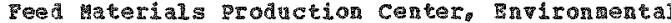
y critoring AnRua Report for 1972. MICO-1098.

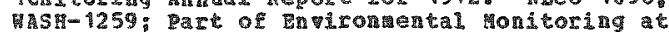
hajor . S. Mtome Energy Condssion Contractor sites. Caiendas year $1972,(0.867-897), 1217$.

Invironental montoring data collected a

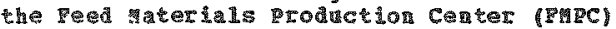
aring 1972 are suararized. These dat shows that the arerate osfsice concentrations of radioactive contaninants from FMC operations vere less than 0.5\% of the guide levelis

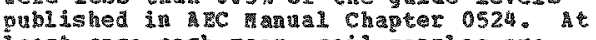
lease once each year. soil saples are collected near the si oudary 5 ming Stations and andyzed for math to obstrve the possible contrabution rron stack eptuents. The ar arage concentrations of

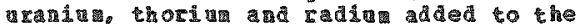

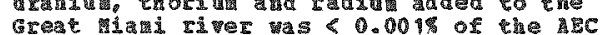
Radis lon protection standards. The arerage 


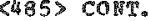

upstrean concentratsons of raduna 226 and radiut 228 tere 2.8 and 1.4 of the stemard for uncontrolled areas. state criteria for gross beta and dissolved alpha radoactivity tere not exceeded in the ritrer. phe average radionuclide concentrations in air. at the boundary sapling stations, vere no greater than 0.4 of their respective standards for offsite areas. It is concluded from these data the of

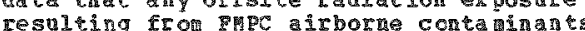
woula be a stall fraction of the standards.

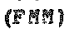

Table 1 shows ratioactive cottannats in ait. TabIe 3 shows radioactive contaninats in water. 9abte 5 shons arandu in soil.

$\langle 486\rangle$

Not diven, finolis ton le Power laboratory Schenectady. 弹. 1973. August: 1973 . JuIy

Knolls Atome Pover Laboratory Anual Enviconental Monitoring peport Calendar vear

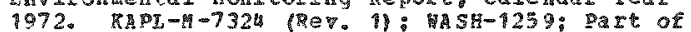

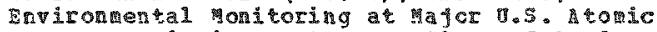
Energy conission contractor sites, calendar Year $1972,(0,655-698), 1217$.

The results of environantal wontorng at the three sites, namelf knolis site, Kesserling sice and indsor site are reported. The radioactivity released in veter hich totaled 10ss thas $0.0064 \mathrm{ci}$ and less than 0.5 percent of the ofi-site concentraton guide the point of release to the mohath River. had no discernible effect on the radiactivity concentration in river water and sedilent downriver from rnolis site. Similarip. the airborne radioactivity concentrations in stack effluents, except for noble zases, al1 average less than 1.5 percent of the applicabie concentration guides at the point of discharqe. pater released from the kesselring site to the Glomegee creet aring

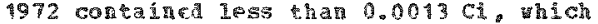
results in avera ge concentration of less than 0.0083 percent of the reference concentration guide for release of cobalt 60 . ther released from the tindsor site to the Farmirgton iver during 1972 contained less than 0.001 ci which results in an arerage concentration of less than 0.02 percent of the reference concentration gulde for relezse of cobalt 60. is a result of the effuent and

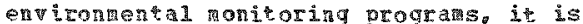
concluded that operations at he three sites do not significanty ateact the natural radioactivity level of of he local environment, and an not cause significant radition exposure to the public. (FMm)

$\langle 487\rangle$

Not given, gettis hromic power laboratory. piteburgh, PA. 1973, hugust: 1973, wine

Efrluent and Fuironental tonitoring popt for Calerda part of Enyirongental honitoring at afor 0.3. tomic theray connission Contractor sites calendar yoar $9972,(0.629-654), 121 \% p$.

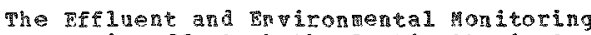
Progan in effect at the Bettis Atomic Pover

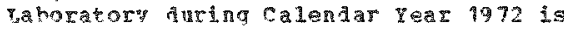
described. The results obtained amonstrate that the extsting controls fer solid, liquia ant airborne effluents ensure the all such releases have been tade in accordance ith the andicable federal regulations. The guantity of radioactipty nelease in yat duing this report period amounted to 0.0011
Ci. The average concentration of

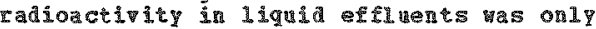
0 - hy percen of the Radioactivity Conceneration Guad all ligalds vere released concentrations far below the Radioactivity Concentration Guide. Mirborme particulats Ielea sed to the atmosphere contained less than 0.024 ci and were generally bion the sensitivity of the reasuring equipnent. The airborne particulare radioaction concentration was less than 5.7 percent of the applieable Radioactivity concentration gaide for unk ristere of radionuclides in air. Solid radiogetive aste materils age shipped in Department of Transportation aporoped sealed contalners to at Atomic Emergy Connission approved burial ground water guality veasurerents are wade on water samples. which are collected from the small streals on the baboratory site. In addition, andysis of the radioactivity in silt crow these streas is also perforted. conservative celculations or the estidated radiation dose to the public based on the radioactivity released from the laboratory indicate that the estingted exposure to an indivizul or population oroup as less than one percent of the applicable standards. Bvaluation of these environiental data shows that the operation of the Laboratory during the period from January through Decenber, 1972 aid mot have an significant efrect on the grality of the h una envi ronent. (Ath) (r)

〈द⿱ 8) 8)

Hot given, Durgesne Iight Compan, Shippingport Atonic Pouer Station, Shipoingport, PA. 1973. gugust; 1972, anary-Decerber

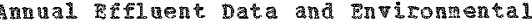

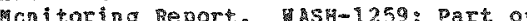

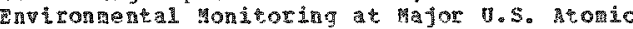
Enorgy comission contractor sites, Calendar Year $1972,(p .699-712) \cdot 1277 \mathrm{p}$.

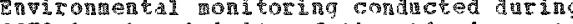
1972 in the ricinity of the sappingport Atoric pover station is hescribed. The shippingport environgental monitoring program consists of satpling the ater and bot ton seaidant of the ohto piver and posting fill badges in the area or the power staton. Peleases of stall quantities of radioactivity ot the air and to the onio River, are reported. Adajtional analyses of the effluent from the portion of the facilitit o ich is operared under ysare contract is perforned to ensure that the vater qualit standaras specisied by Atomic prergy compission manul chater 0510 and the Comonvelth of Pemsylvania have ben met. The resulss of environental wontoring describer by the regort show that Shippingoor operations have not auyorsely affected bo surronding onvironent. fart

Table 2 gives cosults of a alyses of ohio pivet water during 1372 . Concentrations are given for alpa, beta-jama and 40 wadonctivity.

<48.

Wot given, taho operations ofice.

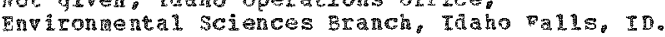
1973. August; 1973. Bori

1972 Nationel peactor Testing Station.

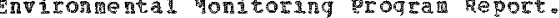

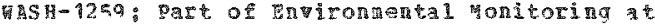

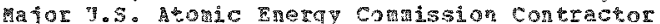
Sites, calentar wear $1972,10.507-6271.1217 \mathrm{p}$.

The resules of the air gonitoring program for 
<489> CONT.

1972 indicated thet onst te and offstte ait concentrations resulting from Reactor Testing station releases vere

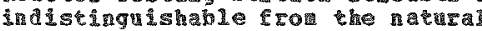
radianctivity in air. However, spocial technigues vere ased to meastre vorlatude radioactive fallout, which is usualip auch less than $1 \%$ of the nater ral radioactivity in ais. These sensitive techniques indis ce ted air. These sensitive techrituos indica ted

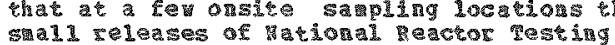
station radionctivity ere ceasurable above the worldride fallont. There vas no evidence

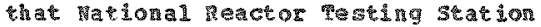
operations caused an lncreased alr concentration at of fsite com of the of site mell weter or surriace water saples contained an gross alpha, gross beta. or tritiun activi linits of the amaly ses. The only elission or activation product detected in milk samples YaS SE 90. However, the $\mathbf{S E} 90$ concentrations are siailar to those reported for the region in the 0.S. Environinental protection henci' Radiation Data and Reports and the source is assured to be tallowt from nuclaar device testing and not WRTS operations. Wheac samples collected at harwest also contained

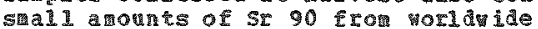
fallout. (gath)

Tables show 5 arpling dat for air, vell vater,

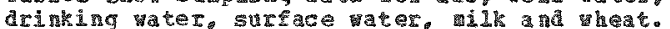

<490>

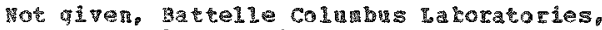

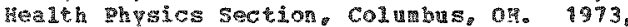
Auguse: 1973, February

Frvironeral Report for calendar Pear 1972 on

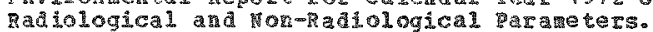

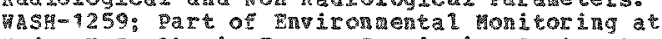

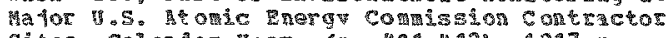
Sites calendar par (0. 401-492) 127\%

The Bater 1e-colusbus conkract nualea activites are conducted at tho locations. the primar naclear area the tuclear

sesearch center. is located approrimed 17

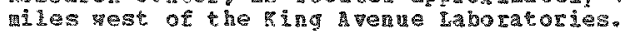
The contract operations at this location are prinarit associated the aetellurgical

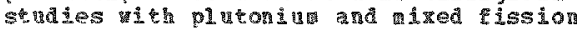
products. Beactor ful element stidies comprise nost of the research affort at the

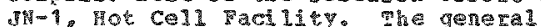

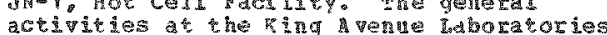
actipledes at the ing

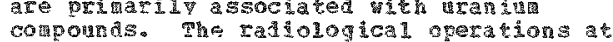
compongds. Fhe radiological beration a were bastcally without incident in respect to the envixons. The ting Avenue, Bisiting 3 site has experience a substantal decrease in contract uran

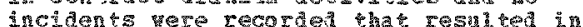
ercessive ai or ver efrillent releases to the engisons. one ingeance of ina dvertant auping of mor ater the Jy-1 Hot call into the sanita syser occurred This was detected and renolied uthout serions consequences. sampling at the relsase poin of the filter bed shoved that concentrations

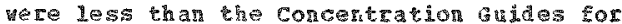

release to in nothtrol ied areas as per 0524 . (ath) (स)

Tain le 1 show restits of the ratioassay of the

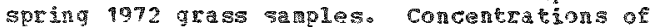
gross a Ipha and heta gotivitye Pu and SP $90-790$ are 9 inter.
<4913

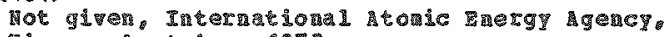

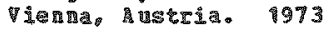

Bny I

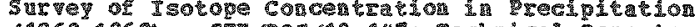

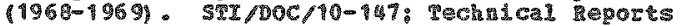
sertas:

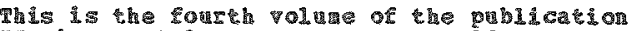

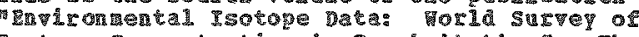

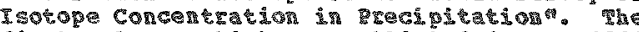

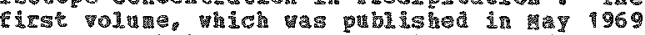
as Th Technical Tepork Series

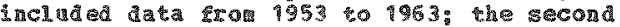

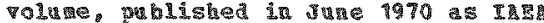
Technica 1 meporés Series 10.17 , Imcluded data fron 1964 and 1965 and the chird voure. published in sepremer 1971 as IEEA Technica. peports Series 1966 anc 1967. This forrth polume is pritrarily concerned with the concentration of the environiental isotopes ftritus

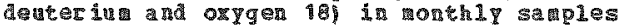
of precipication taken by a a lobal netrotk of 177 station in the period $1963-1969$. selected mereorogica data. auch as amount 2f grecipitation. Way pressure and terperature are also presented. Data before 1968 wich were 0 of appropriate or mere unaraidable at the time of the earlier issues have a lso been included in the later part of this volude as late reports. The collection of the precioitation samples is carried on of the preciditatin samies is carr bu networ sarples are ade in co-operating laboratories in canada Dentar. India

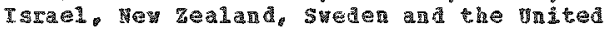
States of arica and in the IDSA laboratory in $\nabla$ Lemna

$<92>$

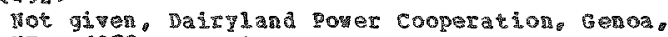

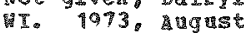

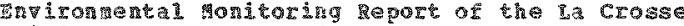

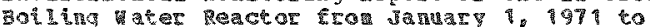

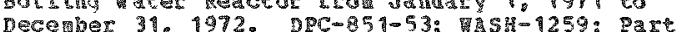

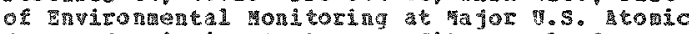

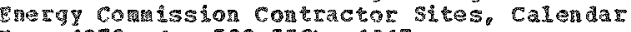
qea 1972, (1.529-552): $1217 \mathrm{p}$.

The anitoring progran at the da crosse Boiling hater Reactor (LACBrip) includes gonitoring or liwaid and gaseors releases

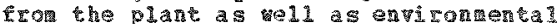
sapdes of surface ait. river vater.

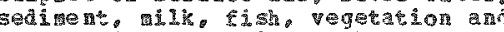
penetrating radiation. The penetratiog

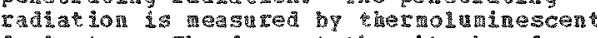
dos:

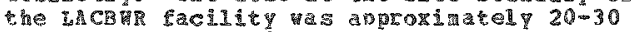
rerar. The of folte exposines received rom

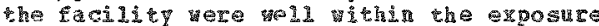

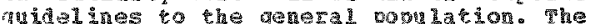

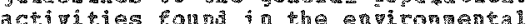
samies, ti.e.

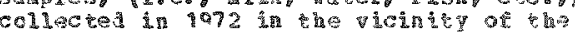
HCB

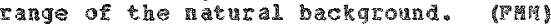

Thbles shov the concentration of rantoact i

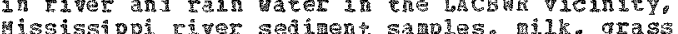
and rish sapelas.

<493

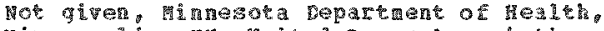

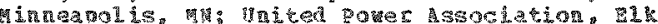
글

3ำ 
$\langle 493\rangle \mathrm{COHg}$

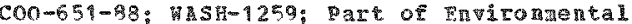
Monitoring at lajor to. S. Heoric meruy

comassion contractor stes, calendar rear 1972. (10. $467-528), 1217$ p.

8. consterable increase in radiosctivity in al1 media analyzer occurred in the dale of 1961 due to fallont crot nucleas topons testing. The pak for grosis beta activity in Minnasota surface uaters was reached early il 1963. A peak for ar particulates 1963. A peaken in the later half of 1961 . Followed

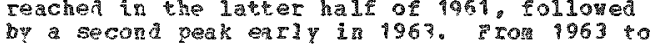
1955. the general trents of radioartivity precipitation surface aters and air have been downtard. Since 1955, levels of radiodetivity in these pedia have generally stabilized. rhe values for the gross beta radioactivity of air particulates from seven environdental stations operated by the onated Poner Associarion (bP) in the Elk Riter Vicinity for the period Januar. 1972 ehrough Decenther 1972 ranged firon a low of 0.01 to a high of 1.11 pci per cubic teter. whe average value of the Heekly samples from the

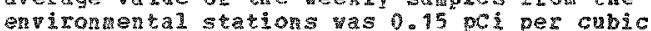
envicontental station was 0.15 pci pe aeter. The atrerage value or the equ per cubic meter. not statistically different prom the results of the offaise stations. Gross beta activity or the water vas deternined at three pointso one point upstrear, one fust downstean fon the reactor, and one about fiftor miles downstrean frow the reactor site. During 1972 the low yas 5 and the ligh in pcifl. The average concentrations for the twelve-nonth period vas it pcill. The concentrations of I 131, S5 90 and CS 137 in mill samples are given and range frota pCi/1 for I 131 to < 18 pCi/1 for Cs 137 . The oross beta concentration in surface soil at gross bera concentration in surfack soli at

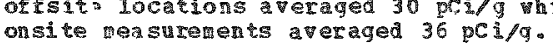
Results for vegetation satioles indicated an arerage gross beta concentration of 59 pCipo

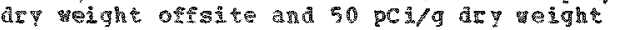
onsite. (Fin

《494)

Wot given, wion carbide corporation, muclear Division, office of sefety and Environgent

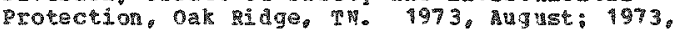
Pagch 26

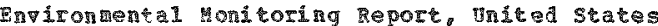
aromic Freray Comassion, paducah Gaseous Diffusion Rlant, Calendar zear 1972.

vCC-1D-245: $A S H-1259:$ gart of Evpronaneal

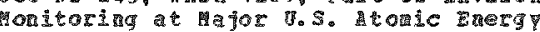
Comassior contractor Sites, Calendar Year 1972. 1p. $931-955 \%, 1217$ p.

Air water, soll, and grass in the vicinity of the Paduch taseon a if continuously of periodicaliy sapled durino 1972. Analyses for materials known to be in plant effluents vere made to provide erinent

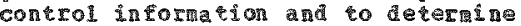
compliance with applicable air and water qualit standards. me air a nalyses for radioactipt indicate concentratis an 11

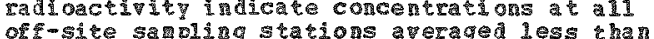
of-site savilig stations a eragad less tha concentration galde. Al and gress orfosite analyses for fluorides ret the kertuck air quality requirements. soln saviles collected to provide back ground dat vere aly

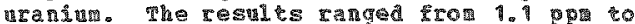

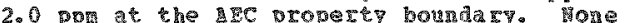
2. por at the of these comcentration would be rpected to

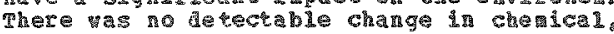

physical, or radioactive characteristics or

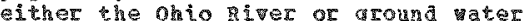
atcibutabal to Ea ducah Gaseous Difrusion plath opex acions. The results of seroles alyses of the oh io $\mathrm{B}$ iver shot the

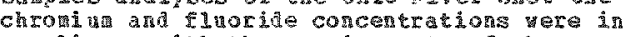
copplance rith the requiterents of the applicable Rencusk togulations. The concentration of heravient chroging at the

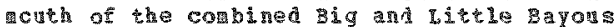

is sinhtiy in excess of the oh

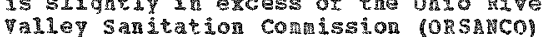

discharge standara of 0.05 ppto (puth)

Table shows uranin in enviromental hater sangles. pable 12 shows concertrations of uraniug in soil.

$\langle 495\rangle$

Not given, Thiversity of Calisornia, CBTO Laboratory, fercury, 沚, 1973, July

Rock Valley Fcolog" study Irea and Imraiation Facility Procedure. Tock Valey Miscellaneous Publicetion

The Rock Palley Ecolontcal stany areat the petada Test site is a lock racility designed to provide anicors doze rate (s or or Fayl from a partaly shielded cs 137 source over a 22 acre area. The area is used for ratiation studies and the l. Internat lonal Biological Prouram. Operating procedures, the irraticion factity and safty thas tor the site are detailed. (bill)

<496?

Not giver, Savanah River Plant, Health Physics Section, dike

Enviponmental Moritoring in the Vicinity of the Savanna River Plant, Mnal Report for 1971. DESPC-72-30-1: 19:

continum andtoring progra has been

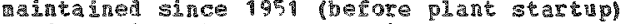
to detering the concentritons of cadioactive a terials it a lagonstrare area outside the Savanah piver plant.

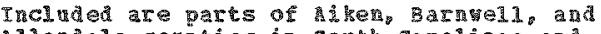
Alendale counties in south carolina: and ichond, surke, atd screven counties it Georgia. Alekoug very sall alougts of gaseous and ligula radioactive arerials are Ascharged to the envizonmentenyironment levels contine to be tar bein lovels conshater signicican fron a pulic health

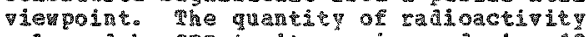
releas ed by SRP to its envizons dumping is. Eor the most part. too small to be aistinguished rrob natural backoround radiation and fallout from vorddy meapon tests. Particulate beta achipicy

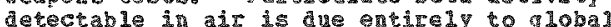

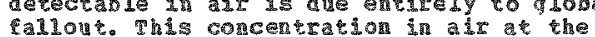

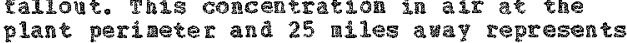
0.2 of the concentration Gride. Trisine oriae in alr as the plane perineter is greater the locations. The a Lanc perineter, only 0. 篎 of the Concentration Gade is the largest percentage of any aj concentrabion fude por

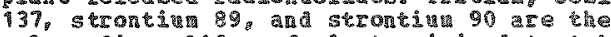
ony radionulies of plate orgin detectrbie in xiver vater. Hore of these hal an arerage concentration that arcerated $2 \%$ of the Concen fration Gu

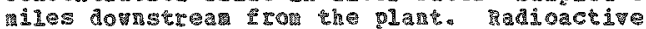
materials in river fish also continge to be very I0w. Various water-guality and

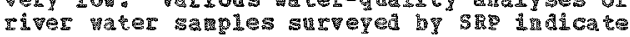


495> Co 2 m.

that Satranah River vater is not advorsely affeced by SRP operations. This is substantiated bit sivevs of the health of the

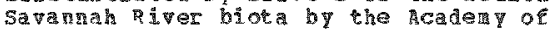
Natural sciences of Philadelunia. The standards apolicabie to concentrations of

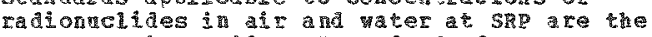
concentrator fujdes, "Standards for

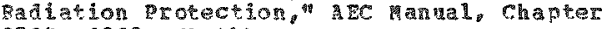
$052 \%, 1053$. 18खth:

〈497〉

osborne. R.W. Royal Cancer tospital. Institute of cancer hesearch, Doparthent of Physics. gondon, zndatid. 1963, July 13

Q1utonin 239 and other unclides in Groud tovel

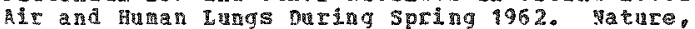
$199(4899), 143-146$

A technique using apha spectronetry that allows mea sureaent of Pu 239 and/or pul 240 directly in ground level aj ar concerticions as low as $5 \mathrm{z} 10(\mathrm{R}-17) \mathrm{ci} / \mathrm{kg}$ is described. Samples of ase from ground lewel air at sutton. Surreq vere collected and complete lungs together vith assciated

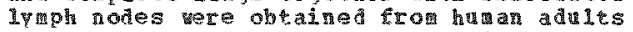
from sonthern nglat and analysed for $p u$ 239. From Februm-iulu 1962 Fy 239

concentrations and 20 concentrations 20 ere aso measured. The aperage 1 tag burden of vu 239 yas 0.16 pci. Zirconiu $95-1495$ burdens acreed well th those of previous studies. Resalts vere insed to evaluate sole of the paraters of standard an. (5T)

\section{<4983}

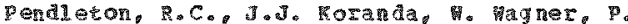

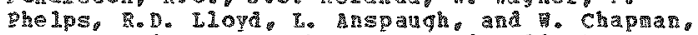

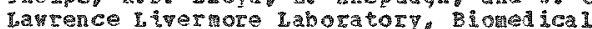

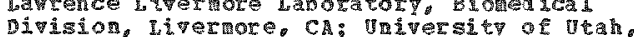

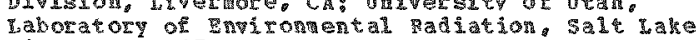
city. WT. 197?

Fadioecological studies in 10 tah 5 ubseguent to the Banebers Event. CowF-710501: Pare of velson, D.J. (Pa.). Ralionuclites in Ecospsters. Proceedings of the 3rd mational Splaposid on

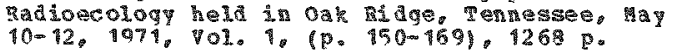

The baneberry event as an unerdround meapons test conducted the thevada Tosh

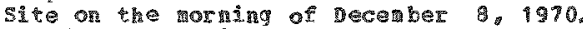
hccidental venting occurred producing clor of radionctivi in ty

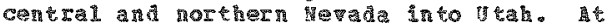
the tine of the Ban eberry ventiag th

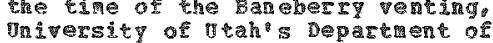
Rad sological Health a d the Blomed lcal Division of the lomirence Radation Laboracory vere conducting cooperative redidocological studies throught the state of tha The

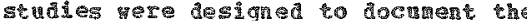

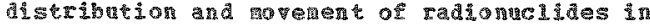

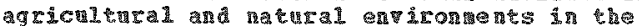
state of ptah.

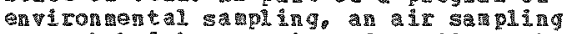
network had been activated on 30 ctober

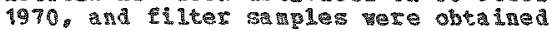
through 11 becerber 1970 . These salples, when conpred wh those obrained during passage of the paneherey cloud, enable precise description of the radioactivity precise descripeion of the radioactity

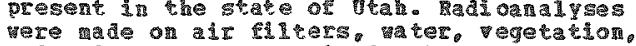

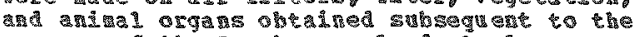
passage of the ga mebrer clow. Analises vere ade by conventiona 1 WaT seintildation

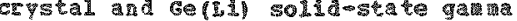

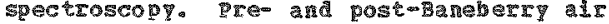

radionctivity levels in be compared. Fadioisotope data for nine radionaclides uill be given for air fibters exposed aring

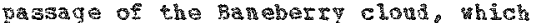
contained a highl fractionated nuclear lebris. The concentretion of I 131 in thyroid glands of deer, sheep, and rahbits vas also geasured subseguent to the meberry event. The butidup and deca of 1131 in various entironents it veah til be described. large sample of sheep thysola glands obta nea

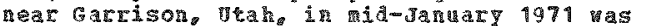
found to contain low bur guancitatable levels or I 131. An analysis of the hatan hazara the result of the raneberty venting based on actual leasurements and conditions during clord pessage, and on predictive models, rill be rala. Dose calculations for various radioisotopes have beer wade for a child 1. ving in norehern istah. (Anth)

<499>

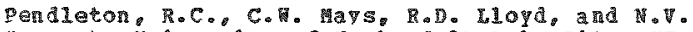
Macock, giversity of ytah, Salt iake city, vT:

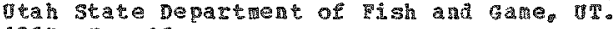
1964 . 解 16

Fallout Plutorium 239 and zircomin 95 in the Lugs of Deer. Nature, 202(493), 715-716

To evaluate the inhaled allost activity in

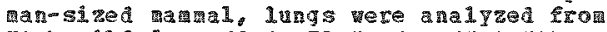

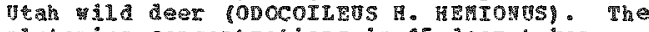
pluton 1 un concentrotions in 15 deer taken

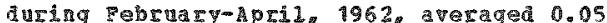
pCi Pal $239 / \mathrm{kg}$ wet lug ranging fron 0.01 to 0.27 pci/kg. concentrations of zircondu 95 in the luags of deer taken at vatous times ranged rom 35 co 5,700 pch/in. Because of it ts 65 dat half-1ire, zirconiu 5 is present in fallout for sevaral worth after a fission

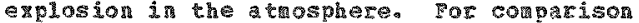
of the contribation by ol aton 239 and zirconin 95 , the concentration of several

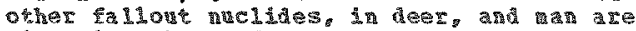

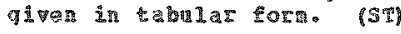

Q500:

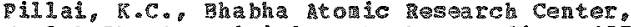
Healeh PETics Division. Bombat. India. 1970

Aqute Poldution control systeratics for Discharge of Radionctive RE I vent:

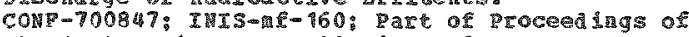

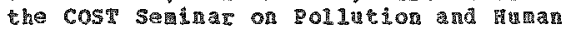

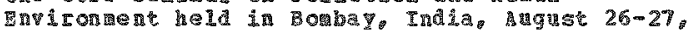
1970. (P. 164-191)

Since Bhabha Atoric Research Centre discharges lon level radioactive 11 iquid efrluents inco Bombay harbor bay. dethiled

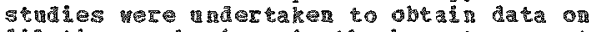

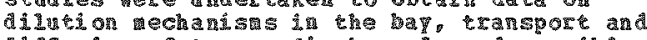

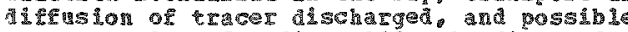

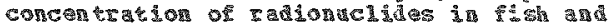
criss havested frot the hay and sal

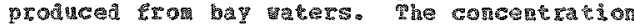

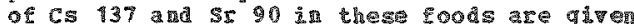

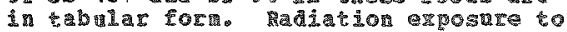

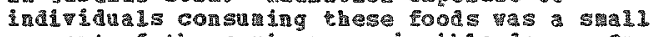

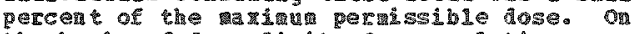
the basis of dose idits cor popration

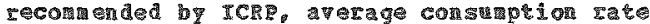

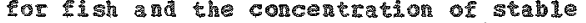

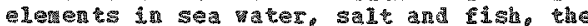
aren

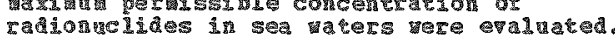
Tha operitions

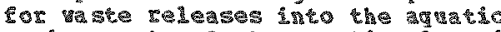

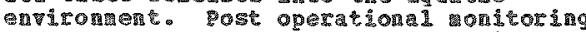
results ind hated that the level in sea 7. to the ajscharge point 
<500) CORT

in sil and botron sediments indicated higher concentrations of some radionuclides but radation exposure from such sources were mequigible. In the case of the preshater environment of Chambal R Iver-Rana Pratag Sagar. evaluation of acceptable li nits for radocontannants are ale vilizing the

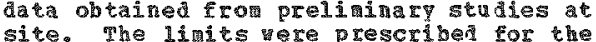
site. The limits release into the river. The linits will be reviested then nore data is ava $1 \mathrm{able}$ on the

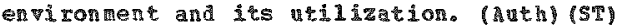

$<501>$

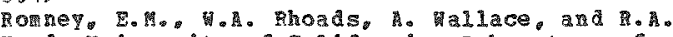
7ood, indversity of Californic. Laboratory of vuclear pedicine and adiation Biology atgeres, Ca. 197

persistence of Radionuclides in soll. plants.

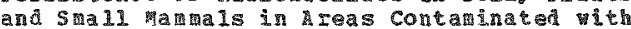
adioactive Faliour. conp-710501: Dart of Mel sor. D.J. (Ed.). Rajonuclides in Ecosystens.

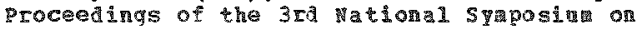
Radioecology held in oak Rituge, Ten nessee, hay 10-12, 1971, Vol. 4, $10,170-176), 1268 \mathrm{p}$.

phe persistence of radionuclides in soil.

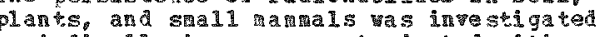
periodically in areas concal 1 nated fellou for abovegroud muclear detonations at the mevadm gest site. Study sites pere established at pariolis locations out to abont $225 \mathrm{~km}$ from around zero. Erath as is placed

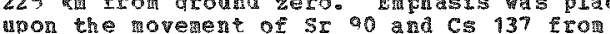
abiotic to bato jc colponents. Several meutron abiotic to biocic conponents. Several at rallont areas located inin $5 \mathrm{~km}$ of numear excavation tests. Radionuclides continged to be taken up through plant zoots in shall anounts, as time rogressed, and sole continued to be aeposited on foliage as resuspended dust particies. phe in halation Fout of entry heche less i goos hal passing time, whicas ingestion conting to be the nost inpareant ronte throush onteh radionuclides enter sall warmals living in

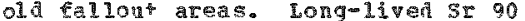

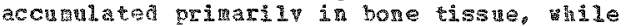
cs 137 accumblat 1 . most of the neutron activation proaucts are

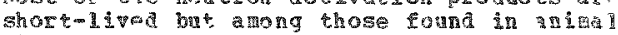
* issue tere isotopes of Co $\mathrm{Mn}_{\text {. }}$ and

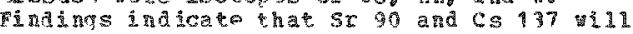
continge to tope in stall ancunts from

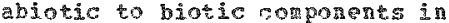
rallobtorontaninated areas njth passing hine. (A) $\mathrm{a}+\mathrm{h}$ )

$\langle 902\rangle$

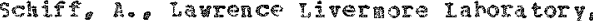

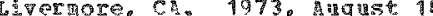

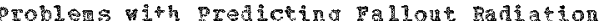

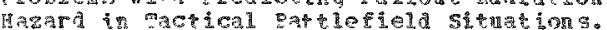
1CR $-51440 ; 30 \mathrm{p}$.

prodiction capabilities are revien est to aetermine yhether they are snitable for

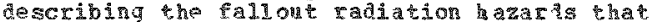
mex exist in tactical nclear battletield situatias. nye aspect of fallout predictabilitw is illustrated by g collection of aberant results from nuclear tosts

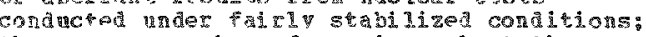
there are a munther of conflaence that anded be placed on

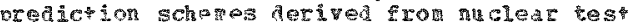
shots. a conparison of curtent fallont

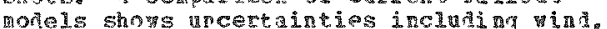

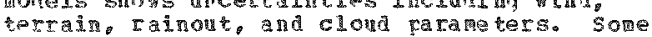

consequences of depending upon fatly predictions are sertous. The search for the best-of-all-possible preaiction schemes will

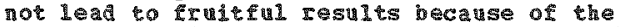
conplezities involved: a set of 1inits to the upper and lover bounds to expected fallont should be atopted as a practical means of using prediction schemes for tactical using prediction schenes for tactical
Marfare. It is elohasized that there is no substitute for hard data and that a computerized rabition data collection. reduction, and display syster should be conterpleted to setisfy the need to respond to ralou problens on the battiefield. (ath)

$\langle 503\rangle$

scott, Lo Inion Carbide corporation, Y-12

glant, oak Ridge, ${ }^{2} .1973$

Fuvironenta 1 wonitoring and personmel protection in irani processing. part of modge, H.C., et al (Fds.). pandbook of Experinental Pharmacology, Uraniu, glutonju, the wransplutonics, chapter 6. Springer-Verlag. per york, yev York, (0.271-294), 995 D.

The problems of environental monitoring and persominel protection are revieved and criteria and guidelines for establishing a rogitcoring progran are given. To ald in setting guidelines, maniula is classified accoraing to the rate that it leayes the critucal organ. The type of process equipuent design usad aepends on the specific activity of the gerial. complete environental ronitoring system consists of geseral air samping, diagrostic and breathing zone sapling. monitoring of stack onissions and eftuents, surtace containation sapling. optional personal air saplers, and study of particle size distribution in processing ateas. Whe kind and extent of personnel montoring depends inon the type of material andor operation and past experience and is usully linited to unine sapplina. In the case of processing of arranivation enriched in $U 235$, in wo lung wonteoring by gasma spectronetry has cone into routing use.

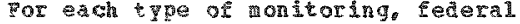
requlations and International condission on Pachological. protection limits are given The fifficulty in estallishing a relation between uramiut in air and in vivo measurements itll uine excretion rate is

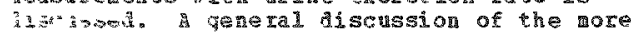
i gartan por establishing and con anal tes for prean in air and sme saples, soil ard plant water discharges, and stine samples is jiven. (ST)

<504>

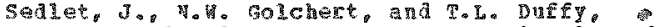

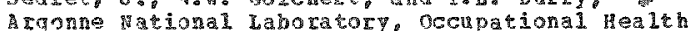
and Satet Divisiong Argonne, Ine 1974 , Mach

Enitontental honitoring at Argonme mational taboratory. Annul Re port for 1973 . ANL-8078: 8 .

whe results of the eprirongent nonitoring progra at sronne pational taboratory for 1973 are presented evaluat the effect of Argonne operations on the environent, measurerents were made for a variety of radionuclides in air, surpace water. Argonne efrivent water. soils grass. herthos, and 51 k: for a variety of chemical constithents in surface and argonne effluent vater: and of the environgenta 1 penetrating rabiation dose. sample collections and measurements uere wade both on and off the 
<504〉 COKT.

Argonne site for colaparison purposes. The results of the grogram are interpretei in terns of the sources and origin of the radioactive and chemical substances (matural. falloue, hrgonne, and other) and a co compared with accepted environmental quality standards. The Pu 239 concentrations in air averaged, respectivelis, $13 \times 10(2-18)$ and 10 $x 10(T-18)$ uci/mI on and off the site, about

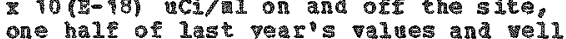
within the range reported by the ARC Rew York Healeh and safecy Laboratory for pu for veapon tests. The monthi 1 variations

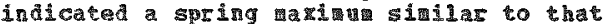
olserved in the stratospheric fall out of other radionuclides. Pei concentration in soil showed the same general range on and off the site. The average Pu 239 concentrations were $2.7 \times 10(\mathrm{E}-3)$ uCi/ 2 on-site and $2.8 \times$ $10(\mathrm{~B}-3) \mathrm{uci} / \mathrm{m} 2$ offesite. The corr esponding Eu 238 averages vere $0.17 \mathrm{x} 10(\mathrm{E}-3) \mathrm{uci} / \mathrm{m} 2$ and $0.22 \% 10(\mathrm{E}-3)$ uCi/m 2 . The Pu 239 content of grass wa similar to that found in previous years both on and of the site. 0.1 \& $10(2-6)$ to 0.3 \& $10(2-6)$ uCi/m2. The Eu content of samples from the beds of a number of streas contained from $x$ lo (g-9) to 32 \% $10(\mathrm{~B}-9)$ uci/g of $\mathrm{pu} 239$, a range found in previous years to be nornal for fallout qu in such aterials. saples from 2 lagoons contained $62 \% 10(\mathrm{E}-9)$ uCi/g and $147 \mathrm{x}$ $10(E-9)$ uci/g respectivelv. (Auth) (RAT)

Table 8 shows plut oning thoring uranin un and strontiu concentration fin air filter saples, 1973. Table 16 shors radioactivity in Sarrili Creek water, 1973, Table 17 shows argonne National laboratory radioactive efflueat and dose values for Sammil. creek mater, 1973. Tables 18 and 19 show radioactivity in De

Plaines River vater and IMinois River ter. 1973. Tables 20 and 21 shov pu concentrations in onsite and offsite soil. 1973. Tables 22 and 23 show eu 239 concentrations in grass and benthic material. 1973. Fable 31 gines concentration guides and detection 1 indus.

C5058

Sediet, d... No, Golchert, and Tol. Duffy, Argonne Mational Labora tory: occupatiomal Health and Safety Division, Argonse, Tu $19 \% 3$, August; 1973, harch

Environmental Monitoring at Argonne ptonal Eaboratory, Annul Report for 1972. AML-8007; WASH- 4259 ; part of Environmental Monitoring at Ma jor U.S. Htomic Energy comassion contractor Sites, calendar Tear 1972, tp. 331-400), $1217 \mathrm{p}$.

The environmentel monitoring progem at Argone Nation 1 Iaboratory for 1972 is descrihed and the results re presented. To evaluate the efect of Argon me opertans on

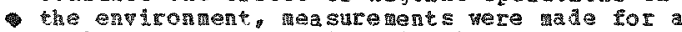
variety of $\mathrm{I}$ dionuclides in $\mathrm{in}$, surface water, soil, grass, berthos, and alli for a watietp of chencal const tuentes in surface and Argonne efr 1 went entirontenta 1 penetrating radation dose. sample collectons and measuremots yere ade both on and off the argonne site for comparison purposes. Alt sampling tor Du was conducted on th Argonn site beginning in Warch. The $\mathrm{Pu} 239$ and 201238 concentrations in monthy saples varied from 1 to $45 \mathrm{x}$ $10(\mathrm{~s}-18)$ uci, mell ithin the range ceported by the AEC health and sakety uborstory for fallout pu in ar saples coilect a d a from Huclear installations. whe averate

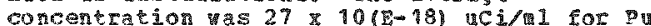

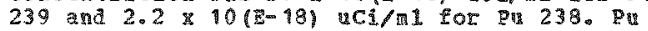
concentrations in soil shoved the sare genera? range and arerage concentrations on axd of the gite The

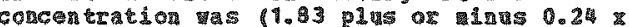

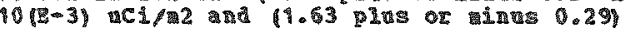

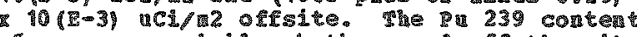
of grass was simiar both on and off the site and ranged from $0.17-0.67 \div$ 10 $(E-6)$ uci/a a cactor of tro thousand to five thousand lover than in soil from the same lacation. whe Ie mults of the progra are interpretad in teris of the sources and orial of the radioactive and chemical substaces fnatural callout, Argonne, and other and are conpared

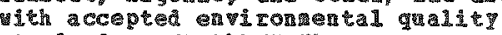
standards. (Aath) (Pral

Table 8 shors Pu, Th and 0 concentrations in

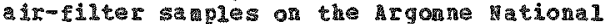
Laborator shte 1972. Table is show Pe concentrations in onsite soi1, 1972. Table 16 5hows tu concentration in offiste soil. 1972. gable 17 show Pu 239 concentrations in gras, 1972. Table 18 shows pu concentrations in benthic aterial. Tables 12, 13 and 14 show

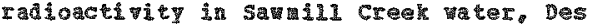

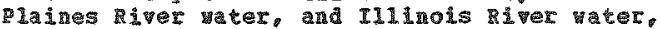
1972.

$<506\rangle$

Seided, Rarlsrahe Institut fur strahlarbiologie karlsruhe, German Pederal Repulic. 1972

Rapia Deter

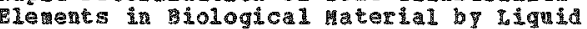
Seintillation Conating. International Journal of Applied idation and isotopes, $23,1-4$

4 rapid and simple procedure combining acid digestion and liquid selntillaton counting for iletermination of the activity of the

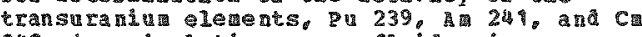
242, in animal tissues ot fluids, is presented. Recoter $y$ al counting eficiency a mouted to $9 \%$. Connting efficiency ras indegendent of organic residues and quenching factoss. The lower 1init of detection thas about $20 \mathrm{pCi} / \mathrm{g}$ of iresh tissues and $0.3 \mathrm{nCl} / \mathrm{c}$ of fecal ash. (Ateh) ( $\mathrm{ST}$ )

<507

Siek, R.D., and 3.3. Baird, Colorado Departaent

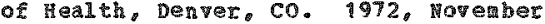

Traniur 11 Tailings Rroblem in Grand Junction, colorado. Health physics society ver $s$ letter, $12-21$

ihe grobleas resulting from use of uranin tailings for fill in the Grand Junction Colorado area and studies and actions taken to aleviate the problens are reviewed. In particular the dangers of exposure to Ra $^{2} 26$. the ${ }^{2}$ se signiflcant radioactive aste product in the railings, and its radon danghers and the rndoor Radon and Indepth studies are ascussed. Preli nina results of

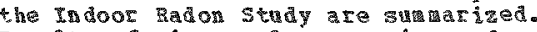
Results of air sadple screening and integrated air sampling in or king level (tht ranges are given in tabular forr. pesults of house-to-house ga ma screening surveys conducted through Rugust 30,1972 are also given in tabular forth. of 149974 gama screened locations about $22 \%$ or 3.362 locations vere fonnd to have taining waer or adjacent to the building. (5F)

<508>

Stannard, J. No, Injuersity of pochester, School of pedicine and Dertistry. Rochester. MY. 1974, December 
<508> CONT.

Standards for the Transuranic Elevents.

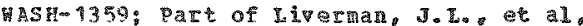
Proceedinf of the M.S. Environment Protection Agency $P 1$ intonin standards Hearings on $\mathrm{R}$ intonin and other Transuration Flements: Sources, Environmental Distribution and Biomedical effects held in Washington, B.C.. Dec aber $10-11,1974,(0,291-305), 327$.

The basis of present standards of transuranjc -lements yol a bief history of theis aerivation is given. sody burden standards for pu are hased on a large volure of biological work in rodents, dogs, and to some extent in primates and man. pindings suggest no najor differences in the metabolis in the huma as compared to the anil 1 spacies. The enpirical ratio of the toxicity of Pu relative to Ra found in anil al experinents Ied to a reversal of proposed early standards based on energy considerations alone and to on present standards ith bone as the critical organ. Body burden and stuaris for organs other than hone, however. pere calculated of the amoun in the organ which wil pield no more than fhe waximuallowable dose or dose rate. For ost tissues it is 15 ren/yeat: The official prinary standards for

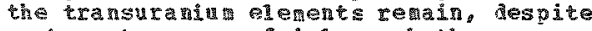
much controversy, farly nuch the same as thay we in 1959 exept for sowe additions. Quidk changes conld be expected if serious fIats were found. The author recongum reexamnation of strnards in five specific areas: 1) changes in models and araters

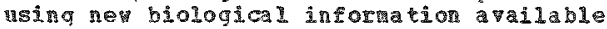
since 4959 such as nev values for some metabolic paraters, more versatile nodels. more knowledge about standard man 2) cancer mote knovedge abou standard man 2 can aiseraberon and hot-particle problems, 4) popalation exposure. and 5) lyoph mode problems. It is the author's vaev that some of the aspects of current recomenations regarding exposure to transurangs rill be changed by national and international bories.

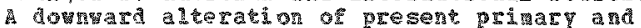
deriped stamdards 15 sen or magn tudes which wonla probably mot strain current technology. (解)

<509\$

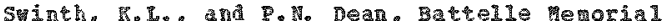

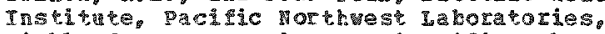

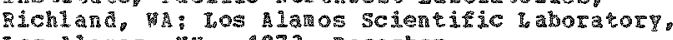
Los Limos, y. 1973 , Decener

Intercalibration for Ior-Emergy photon Mee sulerents. CON

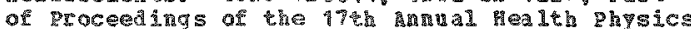

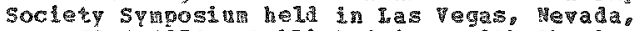

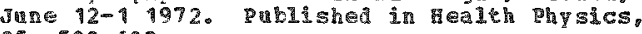
25. $599-603$

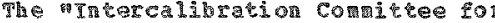
Lon- Tne rov photon easurements

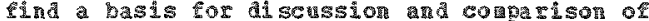

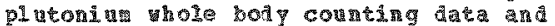

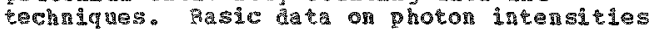
frot ine ischope of interest vere acculatiod ara tabnlated. Intercomparison of conntimg systers was perrorad using 2 source

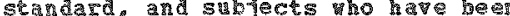

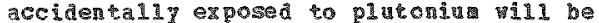
courter. The intercalibratiog indi cated good ingerumental contry beveen laboratories (with the exception of 1$)$ and hat cater that calibration aifferences are prinarilo due to

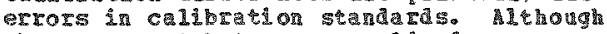
the agreenen betreen moral

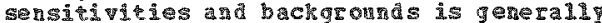
govi the disagreenen Betresn practically

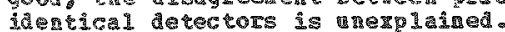

Difterence in coincidence techniques (mant of the detectors vete CsI-MaI phoswichsl, it effective areas of the detector and nataral radoactivity of the construction aterials ma explain the aifferences. (HP)

Table 1 is sumary of the 8 ray intensity data collected for Pu, $\mathrm{A}, \mathrm{U}, \mathrm{Cl}$ and $\mathrm{pl}$. Table 2 shows background cont rates and counting rates thith 2.5 cr 02 added absorber. pigures 2 and 3 show the ratio of individual laboratory deterined activity to mean activity of the laboratories for Pu 238 and an 24 calibration scurces. Figure if shoms plots of normalized sensitivities (counts/min/nCi-craz) for A 241 and Pu 238 sources ith 2.5 ca of added absorber.

$\langle 510\rangle$

Telegalas, K. Enviromental Science services dinistration. Air mesources Laboratories, Ias

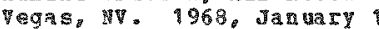

The Seasonal stratospheric Distribution of

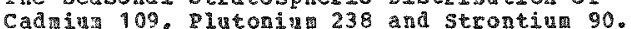

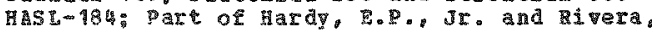
J. Fallout prograp guarterly sumary geport. Septenher 1, 1967 through Decenber 9, 1967. IP. $I-53-I-1181,406 \mathrm{p}$.

In the report 11 of the trown stratospheric data on cd 109 pu 238 and $\mathrm{SE} 90$ are documerted in the form of latitudimel cross sections of meat seasoral stratospheric concentrations and their inventories are isted to ald in the understanding and modeling of gtratospheric motions through the use of radinactive tracers. The 0.2 dpo/1000 SCl isolite for Pu 238 progresses dom vard. more rapidy in the fall and inter seasons than durging the spring and suraer. The highest deposition values of melbonne. A ustralia tere observed uring the southern Herisphere spring of 1966 While t Hev York the occurred during the horchern Hewisphere sperigg and sumer of $196 \%$. (JM)

$\langle 511\rangle$

Thoras, C.T.. Battelle Memorial Institute. Racific worthest Laboratorias, Atospherio Sciences Prograr, Richland,

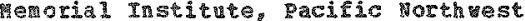
Iaboratories, Rajological Sciences Departaent. pichland, 1973 , Apri

Plutorian Concentrations in surtace Mir at

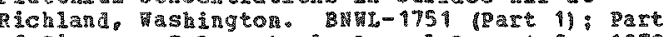
of simpon, Col. et al Anual meport for 1972.

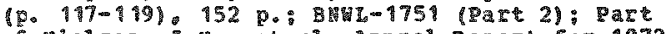

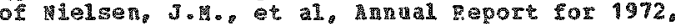
(5. $40-421,1160$

The a rospherte concertrations of par 238 and 239 were reasired in surface ain saples

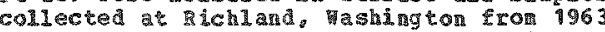
to 1972 as a pare of a progra to define the takes of long ter stratospheric processes in the norther hem isphere as mell as the rater of intorhenispheric ming. The seasonal pariations in the concererations of $\mathrm{Pl} 236$ and pu 239 in surface aj those of other nuclear-ueapons-produced radionuclides of stratospher tc origin: arinu concentration occurred in the late spring and 四 Ining The rate of decrease in the Pul 239 conce correspond to a stretosheric hal-residence time of 10 to 11 ronths. The Pu 239 concentrations reaned fin 17 constat tron 1967 to 1972, prisarily becarse of yearly 10iections of pu bo heranuclear tests conducted by the chiness at Iop nor. and the Teneh in the South pacific prom 1962 
〈519> CONT.

through 1965 both the pu 238 and the pu 239 in surface air at Richland came primarily from the 1961-1962 V.S.-Russian test series. The Pu $238 /$ Pu 239 , ratio averaged 0.015 in 1964. The ratio increased siightI in 1965 ; by the spring of 1966 it had increased to 0.042 . indicating that $\mathrm{P}_{2} 238$ from the 1964 SMA-buraup over the Indian ocean was present. Calculations indicate that $\mathrm{P}_{1} 238$ in air from 1967 to 1971 cale grimarily from SHAP-9A. From 1967 to 1969 Pu remained fairly constant indicating that the Pu was fairly constant indicating that the $\mathrm{Pu}$ was
being transierred across the equat or into the northern hemisphere at a rate comparable to the rate at which pu 238 yas being deposited on the earth's surface. Concentrations of SNAP-9 have decreased rapidiy since that tige. (Anth) (RAB)

Table 1 shows the aperage yearly ratios of $\mathrm{Pu}$ 239 . pu 238 and 5590 in surface air at pichland, Washìgton.

$\langle 512\rangle$

Thomas, C. Ho H. Silker, and C. B. Jenkins, Batelle genónil Institute Pacific morthwest daboratories atmospheric sciences Progra, Richand, Battelie Memorial Institute, Pacific Morthest Laboratories, Radiological Sciences Department, Richland, Aat Balle Rerorial Institute. Pacific porthest waboratories, physics and Instrumention Departrent。 Bichlano, HA 1973, April

Behavior and characteristics of Radioactive Debris from Chinese uclear wea pons rests.

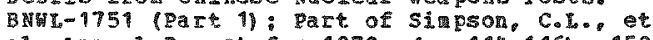
a1, Anual Report for 1972. (p. (14-116), 152

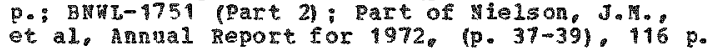

The concentrations of trace elements. cosmogenic radiontcilides and nuclear-papons-produced radionuch ides were measured in air. precipitation, and seatuter to study the rates of atmospheric and oceanic aixing. the rates of ait-sea interchange, and the rates and wechansis of precipitation scavenging. Padioative debis frol the chinese nuclear test on march 18, 1972 ys peasured in air and in grass sapoles collected on tro arcs from san rancisco to seattle and from Tias to chicago to deteraine the path of the debris, the rate of deposition on the earth's surface, and the $I$ 131 dose to man. The concentrations of plutoniu isotones resulting from nuclear tests and frol $S$ in -9 a nclear generator burnup vere measured in a ir samples collected from 1963 to 1972 at Richland. Whington. (10th)

$<513\rangle$

Toonkel, L. Bo, Schonberg, and H. Volchok, realth and safety tabormtory, niron mental studies Ditision.

Wealth and satety Iaboretory surface Al Saning Progra. the gualte of Analysis. 1972.

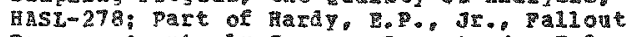
Progka Quarterdy Su $I-159.163$

Talocherical analysis in the sureace 1 in

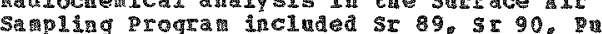
5e.

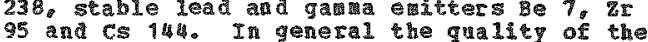

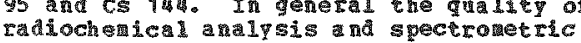
anaysis was satisiactory. I tendency towat a regative bias vas present in rost of the

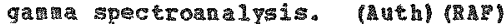

$<514>$

Valchok, H. I. Health and Safety Laboratory,

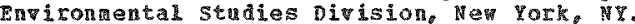
1958. January

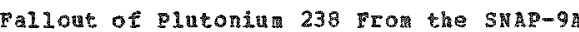

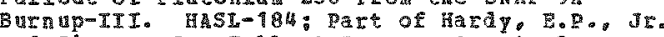
and Rivera, J. Fallont Progra garterly Sugary eport, septe mer 1, 1967 through Decenber 1, 1967, (P. I-2 $-I-10), 406 \mathrm{~g}$.

Dlutonin 238 was released by the disintegration of $5 \mathrm{NBP}-9 \mathrm{~A}$ power sonrce upon ce-entry into the atmosphere in april of 1964. The health and Safety laboratory (ast) initiated a sapling and analysis pronra in 1956 to document the deposition of aterial. frow the burn-up. targe area collections (about one square meter) of falout are ade each onth at melbourne. nustrita and ver rork city. pesults of the plutonilu analyses are presented in tabular forr and the Qu 238 to gu 239, 240 ratios for each onth are given. The actual monthly deposition of the Sa P-9A Pu 238 at the tyo sites is compared in a graph. It shoved that the "le Yor rollout of Pu 238 attributable to the SpAP-9A was unexpectedi greater than that at libourne for three out of four wonth -- April through July 1967 and the seasonal erfect is discussed. The herispheric and worlduide deposits of the $\mathrm{Pu}$

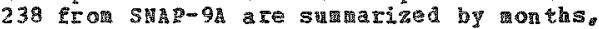
through July of 1957. Fron these data it can be seen that ju 1966 a little more than 1.3 kci. 1as deposited on the earth "s surface while allost as ach cale down in the first

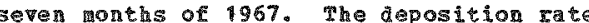
i creased substantiaily in 1967 and based yon the last five onths a stratospheric hif residence ine of a littie over three years vas calculated. (Frin)

$<595$

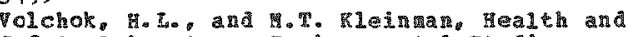
safety Laboratory, Tnvironental studies Division, Ner York, WT. 1968, January

Surface is Sapling Prograt a

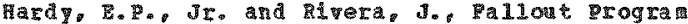
Quarterly sumary Report. Septeviber 1. 1967

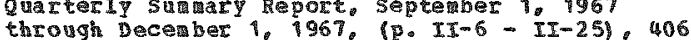
.

The spatial and terporal distribution of whelear weapons debris in the surface alr was studied. Since the last jor nuclear wean pon test series occurred at the ond of 1962, only the longer lived artificially produced radionuclidas we prosent in the filters andyred prior to 1966 . Conseguent 19. ardyed prior to 54. Fe 55. Sr 90, CA 109, Ce 144, Pa 238 and Q 239. In saples collected after $196 \%$ rallowing the chinese rad Fench nuclear eapon s tosts, daltiond shoter lived nuclides were analyzed such as $\mathrm{sx} 89, \mathrm{zr} 95$. and ce 14 . surface dis during 1966 of the radionuclides surface air aring 1966 of the radiond lacations tabular form. (Fur

$\langle 516\rangle$

Tolchok Ho Ho and Safety Iaboratory, hetrork, H. 1968, October 1

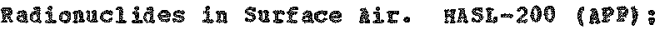
Part of Fallout Progra gearterly suarary Repore sune 1, 1927 through September 1968. $(P+c-1-c-66), 363 p$.

The spatial and temporal distribetor of 
<516〉 conts.

nuclear veapons debris in the surface air from about 76 degrees lorth to 63 degrees South pas studied. Amalyses were done for the following radionuclides: fra 54, Te 55,55 90. Cd 109, Cs 137, Ce 144, Pu 238, Pu 239. $\mathrm{SE} 89 . \mathrm{ZI} 95$ and $\mathrm{Ce}$ 14. The activity concentrations for the $r$ adionuclides and the results of gross ga air are reported in tabulat for for several locations. (Pr日

65178

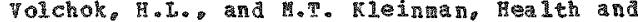
Safety Laboracory, Hew York, NQ 1971, october 1

Badionclides and tead in Surface Air. MASt-245 (APP): Part of Fallout Program Quarterly Suluary Report, June 1,1971 through september 1. 1971. (p. $c-1-c-102)$, $139 \mathrm{p}$.

The spatial and terporal distribution of nuclear heapons debris and lead in the surface air frot about 11 decrees North to 90 degrees South yas studied. Deterninations were ande of the following radioniclides m $54, \mathrm{Fe} 55, \mathrm{Sr} 90, \mathrm{~d} 109 . \mathrm{Co} 137$, Ce $144, \mathrm{Bu}$ 238, Pu 239 , Sr 89, ar 95 and ce 141 . In response to the growing concerm over air pollution and the known hagard lisked to stable lead, analysis for thas element was added to the progran. The actionty concentrations for the radionuclites, gross gasma concentration in surface air and stable lead analyes are reported in tabular form for several locations. prmp

¿518〉

Yolchok, H. l., and M.T. Rleinman, Hea lth anu Safery Laboratory, Heit York, NQ. 1970

Padionuclides and Iead in surface Air. HAst-224 (APP): Part of Fallout Progtran quarterly Sumary Report, December 1.1969 through march

1. 1970, \&P. D-1 - D - 9), $399 \mathrm{p}$.

since January 1953 the mealth and Safety Laboratory has bov cond ucting a progran of samplinq and analysis of radioacti vity and leat in the sureace alr. sapling stations along vith their coordinates and elevations are listed. The activit concentrations for 211 of the radionuclides, gross gama and stable lead analyses conpletec to date are presented in tabular form. (ST)

(519)

Volchok, H.I., L. Toonke1, and Ho Schonber, Health and Safety Ioaboratory, Mev Zork, ND. 1973 , July 1

Radionuclites and teat in Surface hir. Hast-274 (ADP): Part of Fallout Program Quarteriy Sulary Report, March 1.9973 through June 1. 1973, (D. $\mathrm{B}-1-\mathrm{B}-194)$. $439 \mathrm{p}$

The spatial and temporal distribution of nuclear reapons debris and leat in the surface air from about 75 degrees worth to 90 degreps south was studien. The follong radonuclides were deteraned: Mn 54 . Fe 55 Sr $90 . \mathrm{cd} 10^{\circ}$. Ce 144. Pu 238 and pu 239 . in saples collected after some rrench $a$ chinese atmospheric weapons tests, aditional shor-1ived nuclides vere analyed, such as

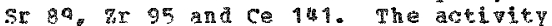
concentration for the radonuclides. gross gan concentrations in surface air and stable lea analyses are reportad in tabular

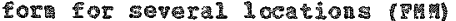

<20>

Yoss, H.D. Tona State Jn Inersity, mes taboratory, Pres, IA. 1973, mgust: 1973. Febrexis

Survey of Environental Radioactivty Jamury 1. $1972-$ Decerber 31,1972 IS-3048: YA 5 - 1259.

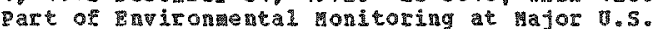
look ic ergy conassion contractor sites. calemdar vear 1972, (10.285-329), 1217 g.

a report is given of the enironental onctoring progra of the aes babatory of the vSAcc including the tos maboratory Research Reactor (ALRR). The environmental progra consists of determinetion of gross alua and beta radoactivitin aix. soil. vegetation. Fiver vater. IRR outrail. bottor sedinete, precipitation, well ater, and pond water saples. The average radioactivity

concentration in air for 1972 as $3.0 \mathrm{x}$

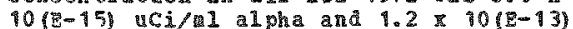
aCi/l beta. This is the nor a 1 backgroma at the samping lockion. phere was no teasurable increase in airborn radoactivity attributable to Ales Laboratory operations. The alpha and beta radioactivity in strear water was determined upstream and donstrean Iron the confulunce point of strears forming the draimage pactern frow the HRR. Fhe average concentration durino 1972 for 211 salples not in the direct fiow (pustreand was $7.2 \times 10(8-10)$ uCj/MI alpha and $6.5 \times 10(E-9)$ uci/lit beta. In the difect rlow pattern

(downstrean the avarae concentration aci/ril beta. There is no radioactivity in the strean wer samles teributable to anes laboratory operations. (a ach)

Several pages are devoted to environmental radioactivity data.

59

kchenberg, H.A. Law rence berkaley Laboratory. Berkeley, CA. 1974, danuary

Madioactivity of Nevada Hot-Spring Systens. LBE-2492; 14 p.

Píld ตa cay spectrometry of waters and spring deposits vere accomplished for some hot-spring systems in northern Nevada. cana-ray dose rates measured onsite range tron 2 to 500 up/hr, anc depend wain on the a routs of the matural radioelenents in the 5rring deposits. At seperal locations 222. emanating from the water causes recogizable gama ray anomiles. High

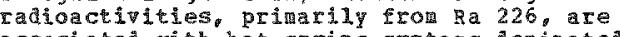
as sociated uith hot-spring systems donnated y $\mathrm{CaCO}$, while silica dominated systers are relatively 10\% in radioactivity. Gama spectronetry disclosed the enrich ment of pa 226 ith respect to its parent 0 in Cacos dominated systems. Ra 226 preferentially doninated ststems. Ra 226 preferentilly associates with ca: therefore, yere tufa an the calcareous material is aighest in râioactivity. spring aposits at fast-Floning Caco 3 dorinated systers a re generally less ralioactive than calcareous deposits at slover flowing springs. (nuth) 
-

- 
<522>

Casaret, A.P. Cornel1 universte Hev York stete Veterinary College. Departien of Physical Blology. Ithaca.

Radiation Phyics. Part of Raidion Biolog. Chaper 2. prentice-1 all. Tre. Inglerood

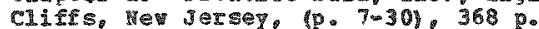

min is chapter covers basic tadirion physics inclating a revier of tom $1 \mathrm{c}$ structure. de physical half-life, ratomctive series, and sources and types or radiation. I order to understand the aechanst of radition action on biological sptems the differem ionding ratilations are comared. (5T)

$<523\rangle$

Cooper, J.A. 9.0. Jackson, J.C. Langford, and

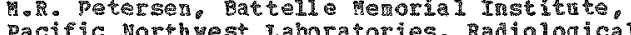
Sciences Departwent, Schlas,

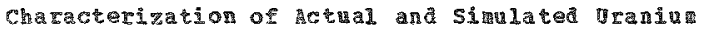

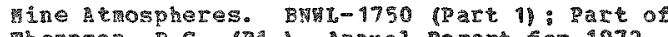

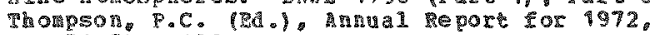
(10.51-52), 103 .

Palioactivity versus patiche size studies in exposure chabers containing Rn da nhoters uith ore anst andor diesel enine erhause showed activity peaks cor all kil aughters a approzinatel 0.1 wo The chaber receiving Ra dauqhers lone contained up to 30 第 unatched Ra ray fluorescence analyses showed Ti. V. Fe. Cis $\mathrm{zn}, \mathrm{gh}$ and 0 at levels $\mathrm{x}$ anging from $0.06 \%$ to $2.5 \%$ in airborne ore in chabers and mines. High rolecnla weight polycrelic hydrocarbons correl ated closely wh soot loading a diferent sige levels. (A unh)

$<5243$

Denham, D. H. Battelle gemorial Institute pacific porthest taboratories, Richland 1969

Health Ihysics Considetetons in Processing

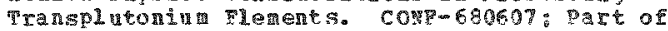
procedings of the $13 t h$ annal mealth physics

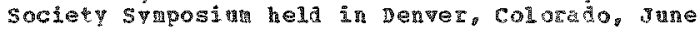

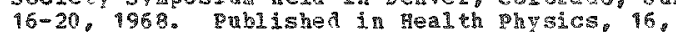
$475-487$

The tadiation hagards of elements 25 through

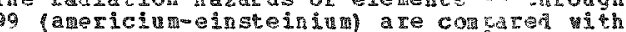
Pu 239. Most of the tran splutonic nuclides decaly by alpha particle enssion a hat have higher specitic activities then Bu 239. This increased specific activitu creates potemetaliy oreater contanínatson control problers, qreater i pha-neutron reactions, and vare $x$ and gama rays per un experienced with oluronin. The spontaneovs fission half lives of these radionuclides aro orders of magnitule shorter than for $p_{11} 239$. leading to prongt fission neutrom and gana exnosures not heretofore encounterea. Disregarding fluorescent radiation the combine rama and neutron ase rate from tens of ilograns of 1939 is equivalent to that fron GIans of Co 244 , tenth of 7 tans of An 241, and on y metograts of CE 252. The

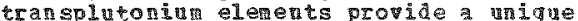
combiation of hazards--high radiotoxicity. excernal arpogure motential ane critica 1 ity- - which akes their control a challenge to the practicing health phtsicist. (Auth)
5258

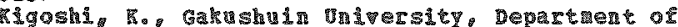

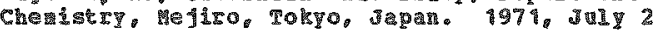

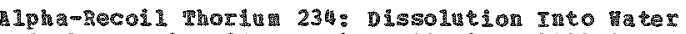

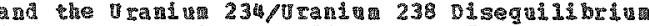
in

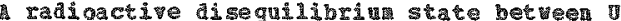
238 and 23 bas been observed in matural vates. The probabilisy of dLssolution of th 234 atom producer by the alpha decay or 238 located neax bhe surface of solid silica perticles contributing to the

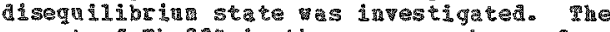
a systen consisting of tine gimon potder and diluted ateric acjer or sodiug carbonate solution tas observed to increase ith time. The rate of jection or alph-recoil Th 23 th into solution gave an alpha-recoll range of 550 angstrons gocted alpham recoil wh 234

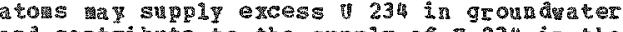
and contribate to the suppiy of 234 in the sedilieneary colugn of pelagic sediments. (ST)

《526>

Sehel.G.1.g and P. Hoyd. Batelle herorial Institute pecific vorhest raboratories. Atrospheric Sciences Erooral, Fichland, 1973,105

InRI uence of Soll Resuspension on the Airborne Pareicle Size Distribution. BNem-9751 (Pare i) Qaxt of simpson. C.t. at al anual gegort for 1972. $(0, \mid-5), 152$

The alrborne partiole size istribution function of resuspended soil has been acer ined as anction of particle dianeters scol 1 to 230 an and sapling helghts for 0.3 to 30 . An apparent lower Iivit is deterined for the sine distibution Eunction. Soil sesuspersion can callo relatively high soll injection rates into the atosphere which increase the ragnitude of the size aistribution function above this lover linit. The soil resuspension rates are aitect function of the bours of high wind speed occurring during dusty time periols. Hoverer, the resuspension rates nust also be a forction of the persisterce of these high vinas since less resuspension accurred for the sa ne total houts of hiof winds unen these hours rere accuralated over longer time period. Aath

$\langle 527\rangle$

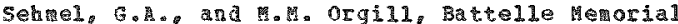
Institute. Pacific porthest id boratories. Atospharic sciences progran, Richland, W. 1973. April

Resuspension by (Part il: Pare of sipason, C.I. et al, Annal 19eport for $1992,(0,15-22), 152 \mathrm{D}$.

Airborne plutoniu concentrations are being related to neteorological paraneters at poci - lats in anticipation that these data til increase understanding of environmental cesuspension processes. Heekly airborne olutoniur concentrations reasired at one station have shoun the best correlation ith wnd direction and spea, gustiness. precipitation and snow cover. A pad developed hich relates airborne plutoni concentrations at the station to vind speed for one time period from July 1970 to Jamurt 1971. (Aath) (ST) 
$\langle 528\rangle$

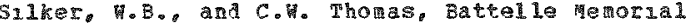
Institute. acific horthest in choratordes.

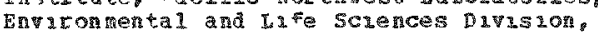
padiological sciences Department, Richland 1969 , June

Fractonation of padonuclides purang welear

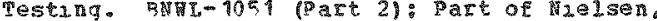
J.

$108-119,234$.

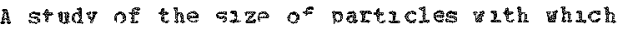
various radiondelides combre follong a nuclear detonation showed that the

concentratsons of $\mathrm{Es} 137$, Sr 89 , and 140 increased as the particle 5 z 2 decreased. and

the aruatities of 214 103. I 13\%, I 133 and

others present decroased wh particle size.

mhis fractionation of fission oroducts gas

explaned yith respect to the menbar of the

zsobar present at the thme of partiche

formation. The asobars $89,90,91,137,140$ and 141 are cormed as exther noble gases or alkali metal 1sotopes with a significant hallolife and their assocyation vith garteles as delayed ather und the chan has decayed to its alk line earth nember or untel the particles have cooled to a

tenperature below the bonling pount of the

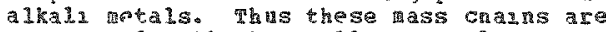
assorated hth tho sad Dathachates result ing fron delaped condensation of iterial vanormed by the nuclear device. The lsobars $103,131,133$, and 141 oragnate un therenth that are more refactory and are thus avalable for condensaton wht he larger partictes formea by exposira of anvironental waterial antroduced into the fireba11. Trssion vroduct fractionat on 25 aso denonstrated by a arect correlatzon betueen the ar concertration of Ession oroducts and the nalp-1nte of thesp

respective gaseous or volatile recursors. (Auth) (ST) 
<2, 29:

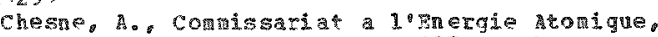
ponena-auk-poses, pance. 1971, February

some Aspecs of the Proatuction of Tra natrandu

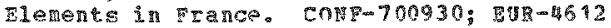

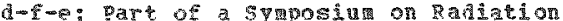
Protection Probleng Belating to Transinta

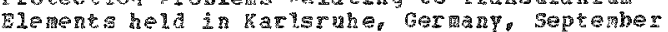
$21-25,1970,(0.62-68), 660$.. (French.

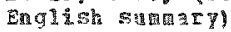

Development of the production prodrar of transurinin elenents during bhe last decade in rance is breri reviened, whe chemical rrocesses currento used or being stupied are discussed and the produstion Eacilities are mextinned. (3T)

$<530>$

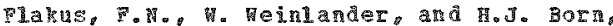

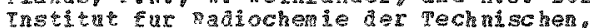
Hochschule Mnchen Garching. German Fearal pepulitic. 1971

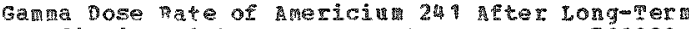

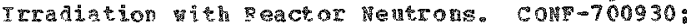
Fut-4612 aProtection Drobleas Re lating to Transuran Elements geid in parlsruhe, Germany. Septeaber $21-25,1970,(p, 353-362), 660$ p. (German. English suำ

Duting the prouldrion of ch 242 by irradiation of 3 in 1 ith reactor neutrons. a series of fission prodicts are generaced that shaty increase the ga mandoge rate of the saples. In order po povide adewlate protective shielding duting froduction, the qa a lose rate of sevari samies measurea. Saples of 1 m 241 up to 19 in weight were Irradiated for a perod of

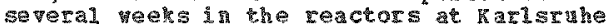
and Mol. The tine deperdent chang of dose rate for long periods acter irradition is given in tabular form.(5T)

$\langle 531\rangle$

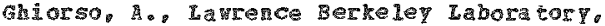
Berkeley, CA. 1971, औaly: 1973

A Istory of the pansplutonic Flements. LBI-213: pat of Hodge: H.C. et al (Eds.)

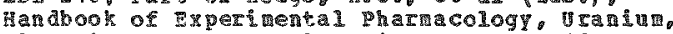
Plutonin the Traspletonics, chapter 16.

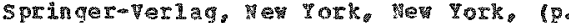
springer*vertag.
$691-715) .995 \%$.

a history of the aiscovery of the

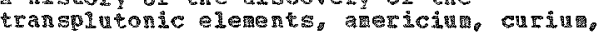

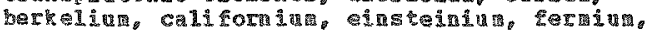

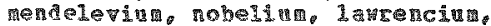

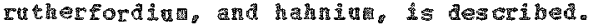
The developient of exper 13 enter an

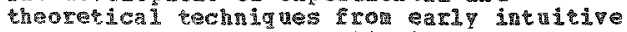
appoaches to is trared over a prenty-seven pras period. The prouaction and iaterticherion of alpha

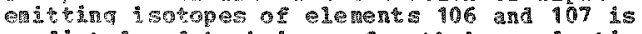
prediced and echnigus for thent production

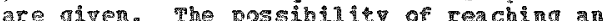

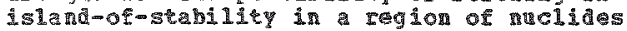
near neutron ribber 184 and proton nubers

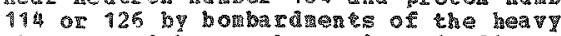
e1, ener (ST)

$2532>$

Hohlein, G.. and R. Gasteiger.

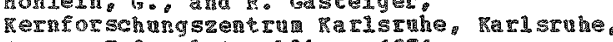
German Pedera 1 apulice 1971

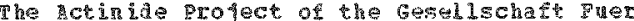

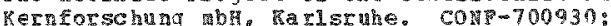
Evi-4612 a-f-e: Part of Proceedings of a SYmosium on Radiation Protection Problens pelating to rrasuraniug Blenents helf in Karlstuhe, Germant. Septerber $21-25,1970$. (p. $69-89,6609$.

survey is gitwen of work done so far in the

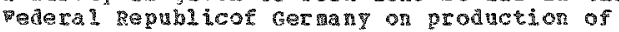
transantanir elements. on the basis of aperierce gathered in the course or this

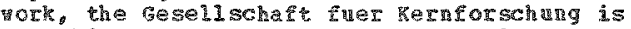
launching a pogran for the production and aplication of actindes. The ain of the brolect is to roduce the guantities of $\mathrm{p}$

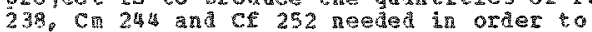
prapare the ay for industrial use, and to estabish the cechnical reguimenents in

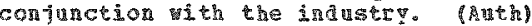

(53)

velson, I.C., A.J. Faverfield, and atelle gerial tustitue Pacific Morthest laboratories, EIology Deprament Richlard, $196 \%$, I

Prodaction and Dosinetry of

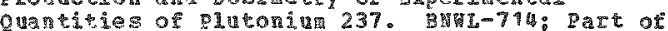
Thowson, R.C., al (Eds.), Angal Report cor $1967,(0.5 .24-5.26) \cdot 253$ p.

Plutoniu 237, an electrom capture isotope bhich exits a 60 rev gana ray and $\mathrm{K}$ alpha

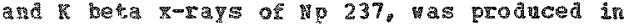

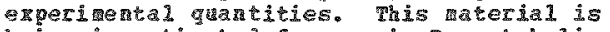
being investigated for use in pu fetabolic strdies in anials or possible extension to

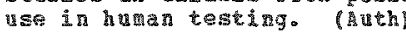

<534s

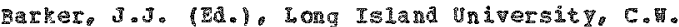
gost college. Greentrie.

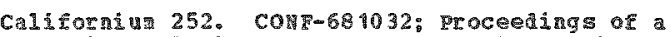

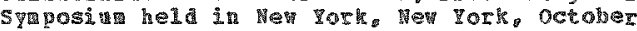
$22,1968,376 \mathrm{p}$.

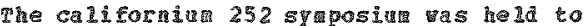
helo develop industrial apdications of calicornitum 252. make industry mare of progress on apolications, and provide inforation on the problens and potentals of

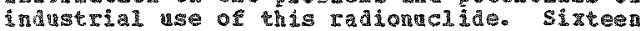
papers ascicing the potential production of calicornitu in large guantities and its application to 2 ide spectru of practical

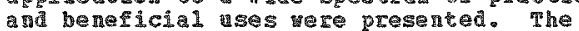
pagers described the discovery of califormin 252 , its muclear. physical and chemical properties, and the reans and plans for its production in large thatites: as mell as Trierous foreseea $1 \mathrm{le}$ practical aptlica tons Three papers ere abstractod separaten for the data base. ( 5 Th?

$\langle 535\rangle$

Berger, R.p R. Boncher, and J.C. Dastan, Com issarlat a 1 inergie tomidue centre

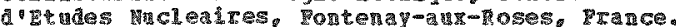
1972

Fance's Erograr for the production and ver of

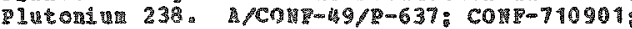
Part of Proceeds 3y nosin on the zeacef

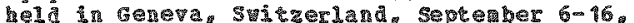
1971. Vol. Th. 237-255?

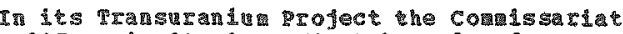

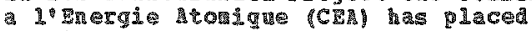

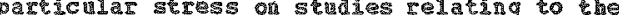


$\langle 535\rangle$ contr.

prod actor and

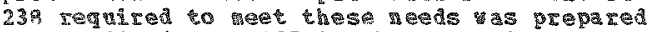
by irradide ing 237 in the celestin prodsction reactors and 241 In the ostrs research seactor. Tech

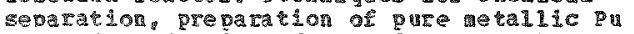
233 and Deduction of sealed scurces have ben studied and feveloped by the Huclem

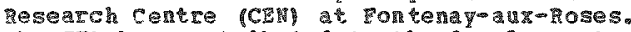
The con has contributed to the dereloparat of

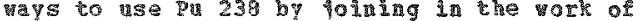

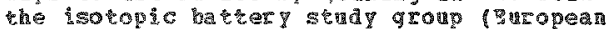
desme the

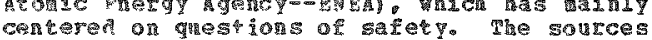
cencerer on questions of safetro The sources engaged in the study and doveloperent of isotopa bateries meet the specifications contalned in the practical guide on safery

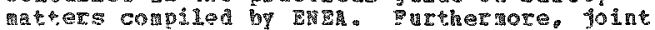
action th the Delegation genera le a recherche scientifigue of technique, in association tith the crit ilcated co. an the Brovssats Hospitato has 10 de to the construction of a protope relap hat

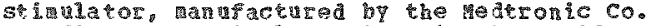
The first hum inglantations in the world mere monehs of acil and

applications are exvisaged COL PLtonitu 233: in pasticular this 250 cope seems provide an inea? solution to the problen of porering a theremanam

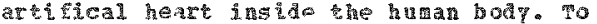
evalute the uncerta int developing and aring browder use of the areifical heart techulue, the cth has

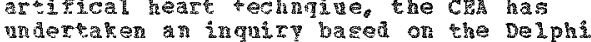
procedure. Fre comparison an statistical grouping of opinions given by a warared experts guestioned under a sequencial savoling grogran has rade it possible to deternine the extent of the crabable derarid

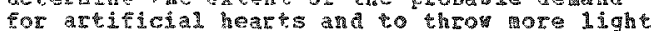
on the feasibility of using this conngine on a broader scale in pance. A similar study

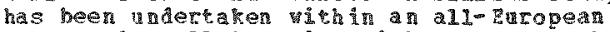

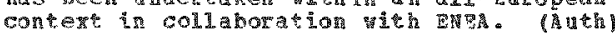

$\langle 536\rangle$

Jacobs, D.G., Dat Ridge Hational Iaboratory. Health physics Divisiog. Naclear safety
information Center. nak piage, Th. 1968

Sources of Tritiut and Its Dehtor vpon pelease

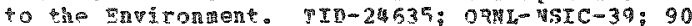
D.

I state-of-thew at study is presented that revidus published inforation on trita production ard the pertinent cactors that affect he behavior of trition in the envi conment. Pstimates are made for production and accinalaton ce tritelu in an expandug nuclear power econony, ncluaing the inpact of an increased triture production on local and porldide populations. pther topics corerel are the properties or tritin

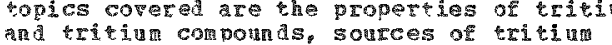
production and its release in fuel processing plagts and thermonclear reactors procedures

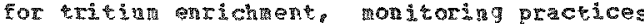
and instrunents for the detection and assay of tritu and noverent in air, soil, surface veter and uroun

$<577$

I

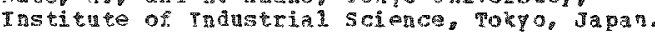
1972, povember

Develogment of najoisotove Products and

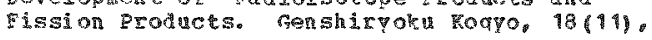

\section{4-2e (Japanese)}

Current processes an furce gethods to be tsed for the recovery and nsage of Iadiol sotopes in astes in Japan are ovtlined. These include use of radiol sotopes for lectic gemerators and late ratiation sources with recovery of the noble gases: curren thethods of fission product recovery: future techniques for recovery of

transuran ran

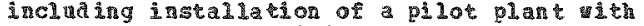
vaste recovery capabilities: and formation of a collective syster for devel opwent and utilization of radiolsotopes. Internationa cooperation is enconraged. IST

$<538\rangle$

Hot given, Toka horks, pover Reacer and 1uclear Fuel Developnent Corporation, Tokai. Ibaki. Japan. 1973. Decenber

Toka morks semannul 1 Progress Report. January - Jume. 1973. PhCT-831-73-02: 122 p.

whe in activities of the rokal torks are the fevelopient and eabrication of plutoniumearing fuls the reseatch an development of centritugal uraniu enrichment technology, the construction of the roke Reprocessing Elant and the related research and developtent vork. The progress report contains 21 articles, two of wich here abstracted separatell for the date base. They deal of the develovment of thermolumesent dosimeter for personnel. dosinetry and a of Pu in biological specimens such as urine and feces. Included in the other papers ate tests done dreing fuel fabrications and eval hation of reactor cloddings. (Fin)

$<39$

Seabora G.T. J. B. Cranda1, R.R. Fields,

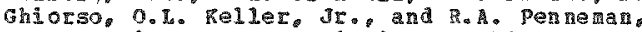
U.S. Ato ic znergy Comission, washington, DC: Savana miver Laboratory. Aiken, SC; Argonne Hational Laboratory, Argone, If: in rence

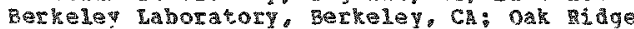
National Laboratory, Gak

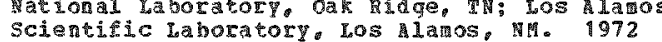

Recent divances in the united States of on the Transurantu Elenents. Conf-710901; STI PUB $/ 300$ : Pare of Proceedings of the 4 th International 5 yorosin on the Peacerul vises of

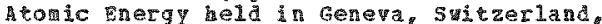
5eptember 6-16, 197\%, (P. 487-529)

In the period of time elapsed since the Third Internationd conference on the peacesul toses or tomic Emergy. tho additional sythetic dewants have been synthesized. any new isotopes of the know transuranin alewes hate been identified and theories of nuclear stability have been developed which hold further prospects for creating a nev farily of lements in the atom nuber range of 110 to 125. The paper covers highlights of transurinu research in the united states of Anerica over the past tev years, being addressed to nev elements ad isotopes, the physics and cheristry of tha known

trancinan in lements and hypothetical super-heavy elements the search for these olementa in mature. and the large-scale prouldion of transuraniur elepents for use in tesearch an practical applications. (nuth

C540.

Hilrich, M, and m. B. Talor, Thiversity of 
L540> cont.

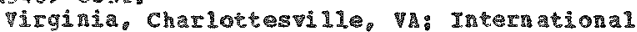
Tesearch and Technology Corporation ArIingron ง. 1974

tuclear thert: Rish and safeguads. Ballinger

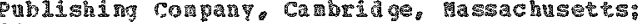
$252 \%$

The athors andize the poss

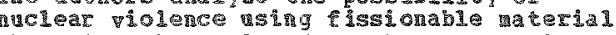

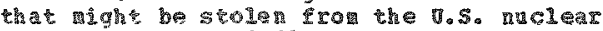

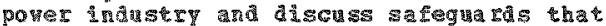

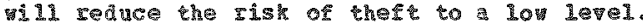
The strat contains no classi filet

information. To aescribes in cemeral terms hov nuclear explosives tal radiological

devices car be wade. vhere poser madusty the materials for aldig such veapons are present, an why

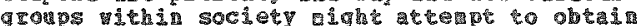
and yse chen. The

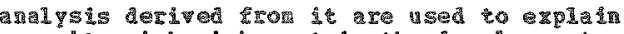

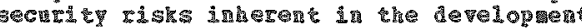
and provide a bas

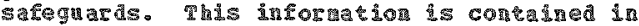

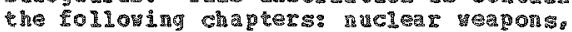

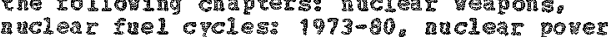

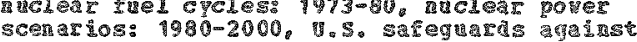

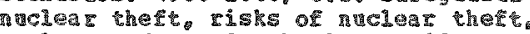

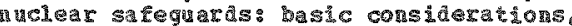

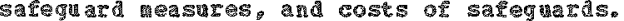

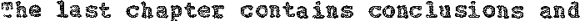
recona 
○

0 
<4 91$\rangle$

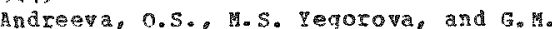
parkhonenko, Institite of Bioghysics, hoscor, USS?. 1973

Assessment of Radiation Safety and Rfficiency of Prophylatic measures in atural iraniun Operation. conp-720503; part or Buldoso,

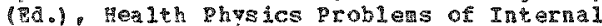
Contamination, proceedings of the IRP 2 nd European congress on Radiation protection held in Budapest, Hungary, MaY 3-5, 1972 . P. $145-147 \%$ : $555 \mathrm{p}$.

Working with uranin the personnel are exposen to the effects of various radiation factors. The post potential hazard is associated ith the inhalation of uraniur aerosols. Therefore. the effective air protection in the working previses from penetrating arosols and the raintenare of radiation paranets at the levels not exceering the average annul permissible concentrations are verp incortan. It is ingortant to control the uranium aerosol concentrations and to estimase the uraniun content in the body and critical organs. The workers are lso pzposed to external gama and beta radiation. The greatest mounts of alphactive aerosols are produced in the drying, pounding, and annealing, of the powdered componds. whe most effective nerhod powdered conponis. ex lipent and olove bores. The concentrations of the alpha-active uranin aerosols did not oxceed the pernissible level

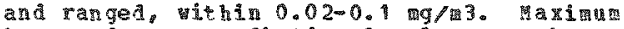
bet and gama radicion levels vere observed at the ther 1 al treatment of metallic uranium ate to the redistribution of urani un alaghter products in the surface 1ayer. Thus, the beta-cay irradiation was $230-470$ beta particles/ca 2 sec at a distance of $0.5-0.3$. from the block of the netali ic nra gin. close to the block the intensity of the radition ezceeded 500 beta-carticles/ch2 sec. After cleaning the blocks and remoting the zlag, the Ievel of the beta radiation decreased by $40-60 \%$. at melting a treatuent of retallic uraniu the gamalay dose tates vere $0.2-2.5$ un/sec mensurea close to the products. So the individual radiation doses of the exposed orfers were considerably beloy the pernissible level and equal to $0.004-0.005$ ren/dav. This ts due to the rechanization of loading-unloading operations, installation of athomatic processing lines ald the rencte control and

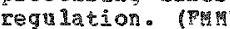

<542\$

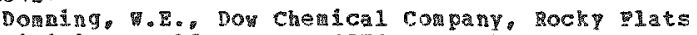

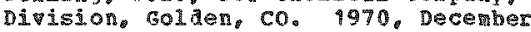

Mev pre Protection Ststems for Futer Plenum. CONF-100016 (Vol. 2): Part of Irst, Morgan, Joll. Ji., (Eds), Rroceedings of the 11th EC hir cleaning STrposiun head in Fichla $1970,(\mathrm{p} .791-805), 969 \mathrm{p}$

A fire test facility has been constructed at Dow Rock lats, consisting of a govebox and a filter plesu which contalns 12 filters. The purpose of this facility is to study the efrects of fire originatio thith in the glowebor on the entire glopebor syster wich includes the filter plenu. The atalls of construction or the facility are shoun and the results of several experiments are aiscussed to show the capability of the facility. Exhaust ar temperates from birnging shielded al aweboxes range betreen burning shielded 1 lovebox range beteen filter integrity under these conditions it is jecessary to ccol the ir strea orior to filtration. The ast successiul air cooler tested has been a water spray-cooled bafele inserted ipstrean of the initial stage of filtration. This barfie vas effective in cooling 1672 degrees inconing air to 125 zegrees $F$ ithin one antute after actution. (Anth)

<543>

Drent. T. and Fundiger, Furocheme, Wol Belgina. 1971, Pebruary

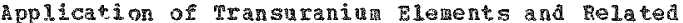

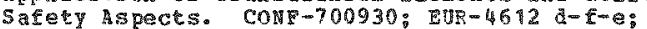
Part of $P$ roceediugs of a $3 y$ mosium on ratiation Protection problems ELATIG To pransuranim Eleqents hela in Rarisruhe. German Septerber $21-25,1970,(p, 99-113), 660$ p.

The paper focuses on the apolication of transuramia blements as radiation and energy sonices here high emergy densties are reguired and were the choice of the source is sixed by several 1 injting factors such space or weight. It enarates those transuraniu elements usea in prototypes. series, or in future projects. whe related safety problems are manifold and difficulo especiall as transuranium ele nents are and mor applied in incusery and public services bit persons ot used to rorking with radioactive aterials. For specific applications very fer standara regulations are established for insing adequat protection for the users. Appropriate proposals related to the variots healeh and safety aspects are outined. (Auth)

$<544$

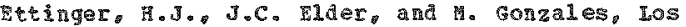
lamos Scientific laboratory, bos Alamos, $1973, J 41 \%$

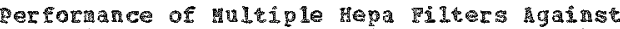

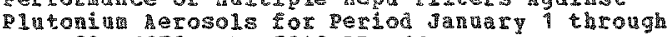
June 30, 1973, $\mathrm{L}-5349=\mathrm{g}: 11 \mathrm{p}$.

Field sampling has provided general criteria defining olutonitu aerosol size

characteristics and activity concentrations

crom typical plutoniam operations. Two

fabrication facilities have aerosols

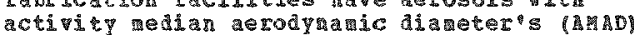

ranging iron 2 to 5 m : the two research and

developart facilities indicate ALD'

ranging frot 1 to 4 to and a recover.

facility consistently shows a sub-ricron

aerosol ith of of 0 . 3 a

recovery facility lso produces aerosols as

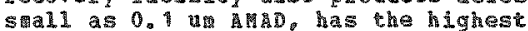
activity concentration. and constithes the most difficult air clearing problex. ising laboratory produced plutonim test aerosols w th size chatacteristics similar to those defined by the fleld sarpling prograr.

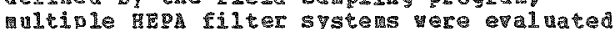
to provide guantitative data defining perfor filtars ana filler performance as a function or particle size. Test date show that the first ad second HPR Rilter each provide veral efriciencies in ercess of $99.99 \%$ thile the thira an average eificiency in excess of 99.87

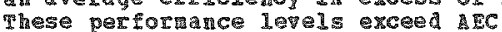
reguirements. Data defining perforance of the first and second hap fithras a function of ploton

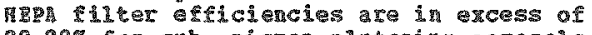

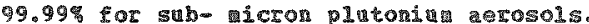

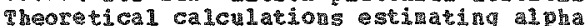


(5) 4 4) cons?

radiation dose to the filter fibers from particles collecter on the fibers indicate a bose on the order of $10(\mathrm{E}+6)$ rads per hinute. ath

$\langle 545\rangle$

Hayns, C. E. Oak gidqe lational Laboratory, oak pidge, ge. 1971

Treasuranin Fienent at oak Ridge National I abordory. cont-700930;

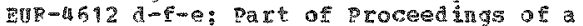
Symposilu on sadiation protection Problews

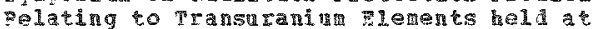
Tarlaruhe, Ger $291-3251,650$.

The health phosics and sater design and operatint as rects of profiction and research prograns of the Transuraniu pocessing Plant (Thi) and he ransuraning Research

Iabordtory (T2ly at the ak nidge Rationel loboratory (ORH) are reviewed. The liealth physics and safety usion and oparating aspects involve tho pribeipu

areas-preventon and andysis. Preverton is concerved with the chstar enginesing of necessary physical and adrin istrat safeguards into each facility and its operating program based on the lomards

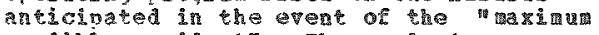
credible accident. The andysis proqra routinely involves assessing hazar ds in the work area ma nonitorinq quantitutivel porsonnel radiation expostres and radioactive

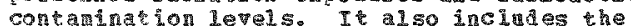
special investigation and ralpses of radicion accidents. parametererered to as the HDo Which is considered to express the amonte of a radionuclide that is equi valent ing inhalation hazard to $99 \mathrm{Pu}$

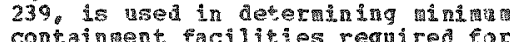
radioctive operations of varions eypes. cells and shielded manipulator boxes are used atboth TRy and ThL instellitions to provide necessary gawa and neutron shiding isollation iaboratories egrigea with fure hoods and gloved bozes prow de necessar contanintion control of these highly toxic naterials. containment is chieped bi the use of vel 1 designea pen tilation use of rel designea pentilaton 5 sters and absolite filters that are tested in oparationa 1 problew and production aperations ith the

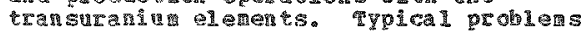
include 11 rites and combustion a rolosions. (2) miscellaneors releases or ratinactiva riaterat, (3) Eliter clogging and filter

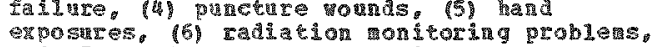

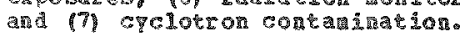

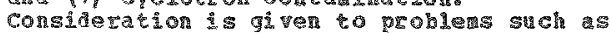

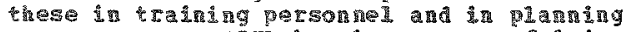

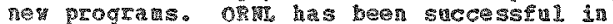

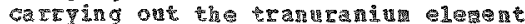
prerat isos tell

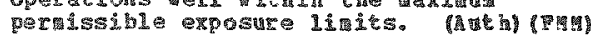

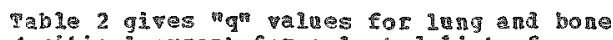
(criticai organ for selected 1 ist of transura

<546>

HolLiday. 3.s

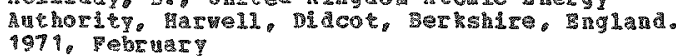

Radological Protection of Morkgrs Ha nd

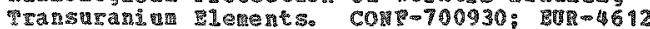
don-e; Part of Proceedings of a spros siun on
Radiation Protecton problems nelating to Transuran in toments hela in Rarlscuhe. Germany. saptember $29-25,9970$, (p. 483-514). $660 \mathrm{p}=$

The primary purpose of routine envitonmenteal monitoring is to chect he working environant and confirm that operating conditions are stistactory. The paper ontines hot the results of enticonint monitoring in a cachliey handing

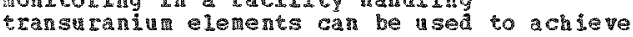
this purpose and to define routine indivalianjoring program. Shgnifican changes in the arerages of the monicoring levels over an exterded period can and should be used as the basis for regular revievs of the scheduled routine prograws. Routine rontoring results also provide the priart trigger for special investigation of the individual in ters sef retention of

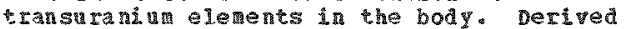
rorking levels and investigeton levels hato beer proposed for assessing enplronental conditions and triggering special intostigations respectivily. (Auth)

Table 2 gives the biologica11" signiflcant

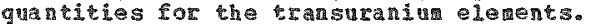

<587s

munzinger, of Vuclear Batteries, Rern, Suitzarland. 1972

Safety Aspects of Incorporated Radation sources. Con-720519: Part of proceedings of

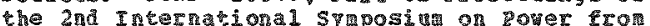

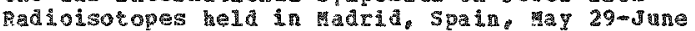
1. 1972, sp. 805-808\%, 985 p.

The sa fety pinclples of sotonde sonrces inplanted in a freely roving han are outinged. They focus on the exposure of other poole to penerrating radatore or artia 1 loss of the radioactive aterial.

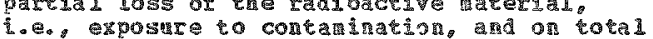
loss af control over the sourco. rise control of exposure of persons other than the bearer are achleved by 11 the selection of the isotope, $(2)$ its purity, and is) its quantity. Th the prevention of loss of materid, concinenent is the onlu possible sater reaser conts

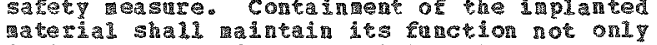
Guting contact ish body Eluda but also undar extrese envisontental colditions lburia 1, creatom. exposure to glaciers.

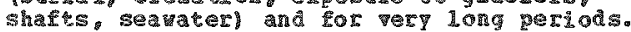
Fhe ost difficult sarety fistget is the asingance that the radioactipe source, arter in satoty control. In order to nisine the

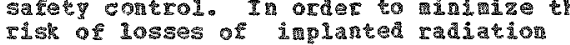
risk of losses of inplanced radiditi cogether ith stringen theasures for the conted

《S48>

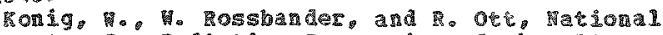
centre for Radiation Protection of the GIP. Berlin, German Derocratic Repriblic; German

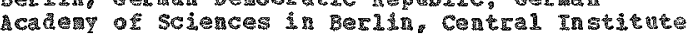
of Iuclear Resereh Roszendorf. Geran Denoratic Repulig. 1973

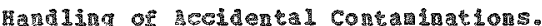

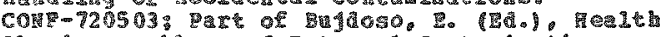

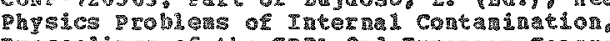
proceedings of the IRPA 2nd Impopea Congress on

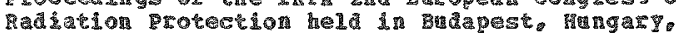

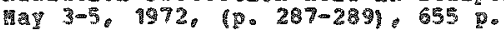

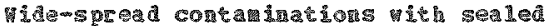


<348>con co.

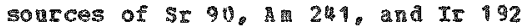

radioisotopes caused hy accidents jis handing

are asscissed. The aifrerences bet ven the

prescribed and realized neasures are

esplained. The results of tomitoring for sureace-contanination and

internal-contaninaton as vel1 as of the netical examation of persons involved are presented. The contribation of such accidental containations to the esposure of occupationalip exposed persomel is discussed. (Auth)

<549>

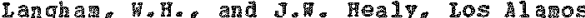

scientific Laloratory, Hos lamos, 1973

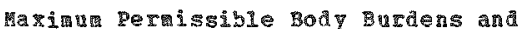

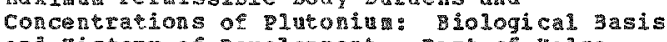
and istory of pevelopment. part of hodge.

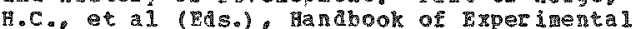

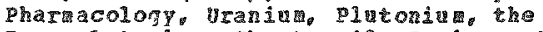
Transplutonics, Chapter 12. Suringer-Perlad, Nev rork, Wew Tork, (p, 569-592), $95 \%$.

she evolution of protection standards for olutomin is reviever in approxinate chronologic order. Eaphasis is placed on those biological observations that had the most inpact on the derivation of currest values. The chapter is subdivided chonologically berinning in radiation protection criteria prior to 1943 and ending vith carret (1971) standaras. (si)

\section{$<55 n\rangle$}

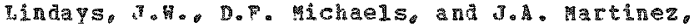
Dor chemical Compang, Rock Flats Division, Golder, $C$. 1973, February 12

scaverging contaminatea soil with polyurethane Foa. RFP-1949: $10 \mathrm{~b}$.

Polyurethane foan has been evaluat ed as a stabilizing agent for radioactivel contaminated soils. Results show that the foan can be appiled efticientiv to a vite variet of terrain and solis to Eotra lasting protective coatinge In aditition the foan has a high capacity for picking yp contagination. soil. and rocks, and has relatively low cost. Its aechnical properties rake handing and asposal easy. PLAnts covered totally by foam are ki11ed presurably by sothering rather than by the toxisity of the foan. A laborator procedure has bern a the ability of foans to pick up particulate materials by wich conrarisons between forms

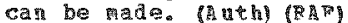

$\langle 551\rangle$

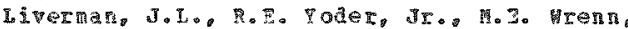

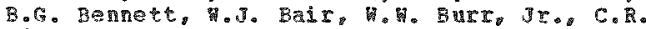
Pichond, R.C. Thompsor, a.

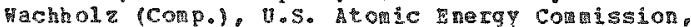
Divisian of B tomedical and Envixonental Research, washington, DC. 1974, December

Plutonitu ard other Transuramin mlerents: sources. Fnvi ronmental pistribution and Bionedical fefects. HAsm-1359: Proceedings of

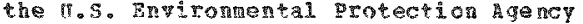

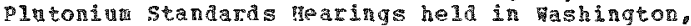
D.C. Decenber 11011, 1974, $327 \mathrm{p}$.

The pretiol vas pepatod in response to notice which seated the jintent of the vi. 5 . sn iroratenta 1 potoction mgency to hol publin hearings to evalute the envitrongental inpact of pu and the other tranguranis alements and to consider whether new gh aequa te protection of the general antient envisonient and of the prbitc health fror potentlal containation of the envisongen by radionucides of these lements. Twelve articles wave bea abtracted separatel for the deta base. These include papers on

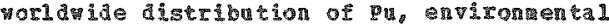

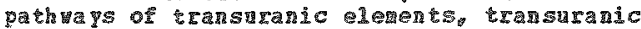
elements in the marine environ ment bionedical efiects of a on huans.

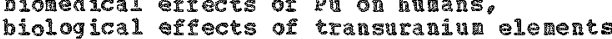
in experiantal andals and some material pertaing to standas and control measuges,

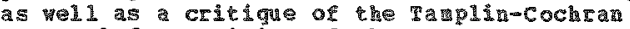
groposal for revision of the curreat 2 n expostre standards. (TFM)

$<52\rangle$

Morgan, R.Z.: Oak Rige lational Laboracory

Growth and Developant of Responsibilities in the piela or Radicion protection. Rart ot Rajersily. (TA.). proceetings of the 9 th International congress os

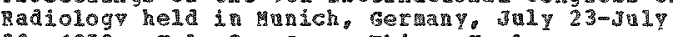
30. 4959, Tol.2. Georg Thiene Verlag.

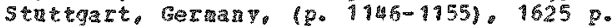

Health physicises, as a grou engaged sn research, engineering, education and applied activities vere first organized in 1942 just prior to the operation of the first wa trade nuclear reactor. Their activities inrolve the study and practice dealing ith ant an all cactors relatiag to dasage from ionjug ranistion and the prevention of such darage. In the eacly yeas , there yer many new a aifficult groblens: hov and in what antes to weasure neutron dose: hat met to assign to nentrons and alpha redintions; how ro dispose of radioactive waste, hou to vork with thousards of curies of the extreme dangerous olutong in 239 withous getting it into bhe body and in talen into the bod

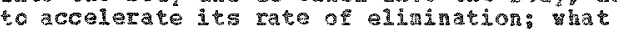
gexinu perisisible concentration of pluton in 239 , strontian 90 and handreas of ather new y a scotered radoraclides to allow in air and vater: how so geasure the body burden of these radionuclides: how to prevent criticality accidents: how to train health physicists. Folay lealth physicists are assigned responsibility for the sate opertioli of nuchear gactors, high voltage crele rators, isorope separtion pants. netaluryical and chemical operations, and

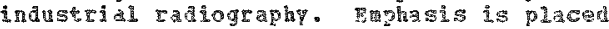
on the bererits from ton

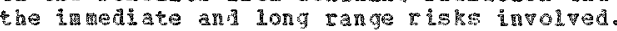
(Bsm)

$\langle 5.53\rangle$

Morgang R.

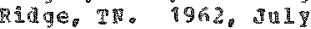

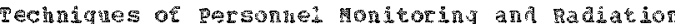
Surveting. part of 5 me13, A. H. (Fo.). Nucleat Instruats and Thent 0 ses. Vol. 1, chater 7.

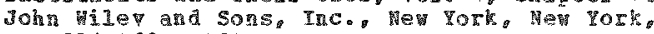
(p. $301-469)$. $494 \mathrm{p}$

This chaper atscribes techaigue of bersonne 1 monitorido a

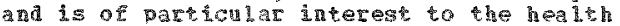
physichsp ghe discovery and uses or ionizing radichon are traced and the rolo of the health physicist is regietev. Padiation orotection is aiscussed under the headings: worting at

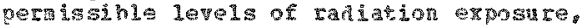


4553) Com?.

instrugents requidred by a sall laboratory and their use, the health physicistg special monitoring probleas. disposal of radioactive maste, and energene precaut ions. Although the discussion is witten for the laboratory that handes large acouts of rad oactive substances, it is of palue to industries. unversities an hospitals. Relative hatards of radionuclides. HC RE and ICRP regulations, personel nontoring instruaents For different situdions, and persont decontamination methods me rewiem ed. In adequate health physies rrogran at all institutions is aphasized. (5T)

\section{<554}

Morgan. R.Z. and C.P. Straub Cak gational Laboratory. Realch Rhysics Digision,

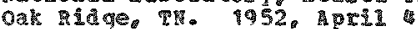

Etcernal and Internal Fxposure to Ionizing Radiation and mari

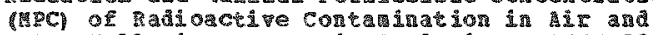

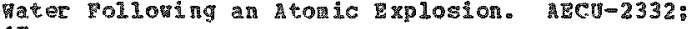
17 p.

If an atodic boll s exploded at sufficient - Levation to take cull dvartage of biast and theral tects. thate ordinariv will not be an appreciable anont of suritace radionctive con underoun explosion the rotal curies of

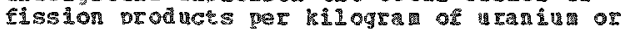

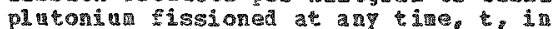
seconds after the rplosion is given approzinated bo the equation $C$ sub beta $=$ $2.7 \times 10(2+13)$ (E-1). In adition there worlu be a soll I fraction of the

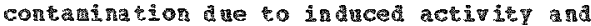
fissile naterial trow the bomb. If a person

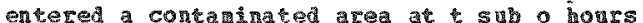
after the atomic explosion where the dose rate yas 5 in o reps per hour and rearing ati $t$ sub houss after the explosion. the

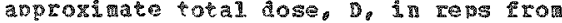
external xposure is given by the equation $=2.3 \mathrm{sub}$ of sub o log sab 90 te sub i) (t sub ol. It is estinated that the energency vilues or pc or the radioisotopes in aci/ce is giver approrisatel by the equation MpC =

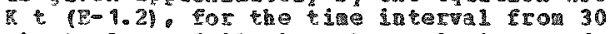
mis to 3 yrs following the emplosion. If

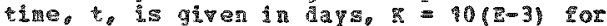
dri contaninant aitting lpha, ceta or game ratiation. In case of contarinted a

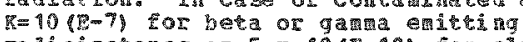
radostsoropes of $5 \mathrm{~F} 10(\mathrm{E}-10 \mathrm{l}$ tor alpha eateting radion sotopes. (A.

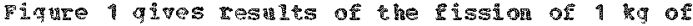
pon of uhich hals the scaped arutrons are captered in 301 a na unissioned plutoniu scapes as alpha pritung contranition.

〈दम5>

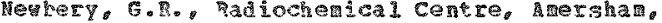
Enqland. 1964, rata

measurement and Assessment of 5 lin Dosem from Skin contandion. A wray. I.T. (ER.). Proceedings of a symosiu on

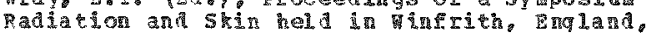

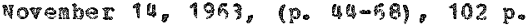

In order to assess shin dose after

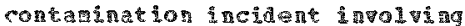

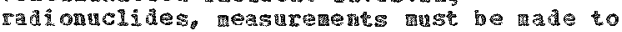
defervine the aount of activity on the skin and the lengen of ime. the extent of penetration of the whrece of the shing vich radionmildes vere 1nvolved and ther

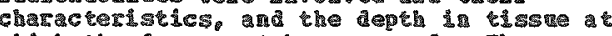
which dose whe be asessed the practical reguizerent is to rola obserped counth rate the stinface of the

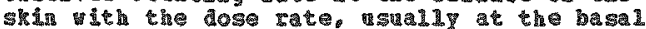
layer. This papar derives such relatons for three typical adisdes carbon 1 bete reter of 10 renergy: phosphorus 32 . a

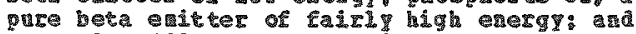

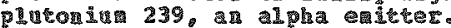

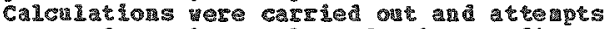

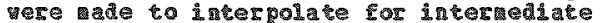
sItwations. It was concludet that for sin contanination, garticulariy the alpha enteters, he assessment of dose is boun to be only an approzination, unless the điseribution of activi accurately knova. onl in race cases wil this be possible, for exande when some of

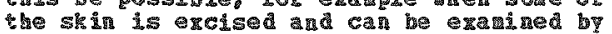
autoradograph or by sectioning. In ractice the dual 1 incertalney of the

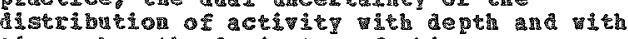
tive anes the dosinetry of shin

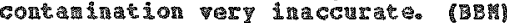

〈556>

Hot given, J.S. Emironent 1 protection ggery. Tadiaton office. Hahington, DC: J.S. Department of tealch, Eacation and Telfare,

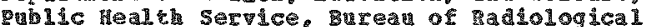

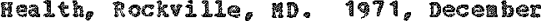

Thit an mal atonal conference on hadation Control Hev torizons. Covp-710562:

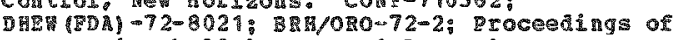

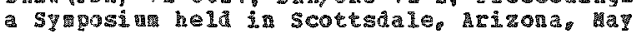
$2-6,1971,378$ o

The proceedings of the phird Anthi Fational ccactence on Radition control, tat $2-6$.

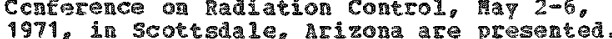
1971. in Scotesales Arizona are presentea. control Progra Direchors, the 1 iseau of rajological Health of the vepartent of nealth. Fucaton, and welfare, and the Patiation office priviranenta protection

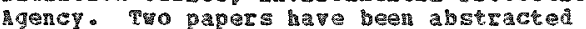
separatel for the de base. Participants. representig all state and rajor local radiation control program, as vell as federal agencies, concentrated on haling arts 3 rat erposinge to the pubic and ervironertal radiejon protection issues including the levels of fallout foriting 233 . P 239 a I 131. $3589,5590 \mathrm{Cs} 137$ is

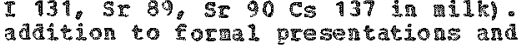
aducationa 1 seninars. the proceedings contain the reports of yorkshops dealing vith specicic r ray and on spostre prob1ens. hesolutiton by the conference of $2 a d a t i n$ Conerol pogram Directors and the mex litioctions and organizational phi losoghy of the Envizonental protection Agerey are 1 so incinded. (Auth) (P)

(559)

yot given revnol a slectrical and Enginearing

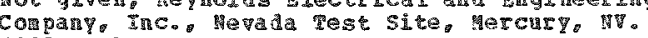
1969. Iu

Padiological Fargency operations, Instructor

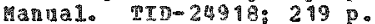

The Tostructors" anda 1 provides guidalle and A. of a course in patiological sergency prerations. The course includes the studip of energency tesponse arganizeion energency radiation ronjtoring theory an applier 
$\langle 557\rangle$ CORT.

techniques, radiation safecy practices, emergency equigment and procedures. suclear weapons accident hatards and leqal and pulic information considerations. The manul includes: a scheale for conducting the putire course in ten days, a list of publications recomerted as texts for the course, infornation on where to ontain the recomended texts, a bibliography of references, movie fillo for use in this course and where to obtain ther, outlines for each elass period, sample quizes and fial examination, and suggested ccurse evaluation and reviev sheets. (futh)

See also Student's Manual, TID-24919.

$<558>$

Not qiven, Revnolds Electrical and Tingering Conpay, Inc., Hevada pest site, mercury, wy. 1968 , Jै।

Radiologiral suergency operations, student"s ค月anual.

The student's manual provides quidance and information for the student atending the ten-day Radiologica 1 raergency operations conse. The manual includes: the schedule of classes, a list of publications recontiended as texs for the course. information on where to obtain the recomended texts, a bibliography of references, movie illas used in this course. a bief outline of the subject mater covered in ach lesson. study questions and asters on the wain points in each lesson, and technici? reference inforation pertinent to the subtects covered. Section 4 of the manua 2 contains a chapter on cach of she twenty-two subjects covered in the lessons. trong these topics are: radialon detection

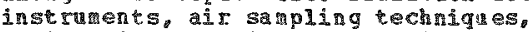
radioactive naterials fincluding to tho 7. CS. Tritius and 5 ) radiologica acidents. biological exfects of radition. erer gence tean operating procedures. sare handing of radioisotopes, decontaination and lega 1 atd press responsibilities.

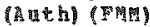

See also Instructor's fanual, TTD-24918.

4593

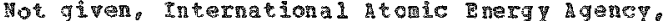
viend, Anstried, 1973

Radiation Protection Procedripes. STIPOB/257: Safet Series No. 38; $198 \mathrm{p}$.

The three principles which can be aptied to prevent or control the aposure of personnel to radiation hazards are: (a) Rerome the hazard, (b) gura the hagard, and (c) guard hazard, (b) grard he hazard, and (c) guad
the worker. The first is an obvions one the

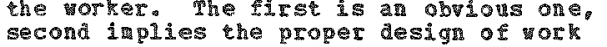
places and the prow sion of appropriate equipment and shielding to ensure the axing aront of protection. and the thicd refers to the measures required to whe a periodic check on the continuing adeguace of the controls. the personal protection mea sares and the equiprent. These topics are

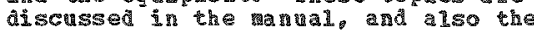
magenent of radioactive vastas. trangort

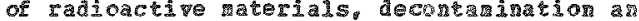
radiation accidents and emergency procednres L collection of useful healeh ohysics data is presented in tabular form in the ander or the book, (PMI) $\langle 560\rangle$

mot given, gyiversity of ashington, welear Reactor I aboratories, Seattle. WA. 1972

Platoni ur contanation Incident of Jume 13. 1972. Pare 1. DOCKET-50139-1: 30 p.

During a series of experiments in progress at the rnitersity of wahington puclear peactor. 24.29 of lutonita 239 vere irradiated resulting in a contatination of the reactor room and exposure of personnel. Incidents leading to the release, dosinetric neasurenents, and recovery of he contarinated area are reported. Permissible ir concentration standards vere excgeded and the actual air concentration at one point

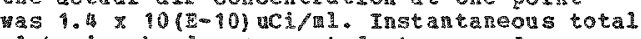
plutoniug burden on a student exposed was 12.5 monocuries. Acaitional wole dody counts on the student and others ate planged. (B)

$\langle 561\rangle$

Mot given, Kerm-kctee Corporation, herr-hcBes center, orlahoma city, ok. 1971, ropenber 13

Cimarron glutoniu groanction Plant Hicense

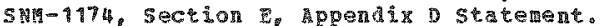

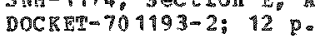

Descriptions of the phitical facilities. processing techniques. al aste treatrent at the cirarcon plutonin production Plan are given. Reasons ohy plant operation should not be suspended during corpletion of the hrig environamtal reviev are stated. During 18 conths of operation 3.45 aci of plutoniam hive been released. It is concluded thet operation of the plant has no atuerse ef on the enviconemb.

$562\rangle$

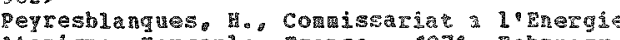
Atomiqu, parcoule, prance. 1971, gebruar

Radiation Protection in peprocessing Plant and Study of the Differene 3afecy Factors.

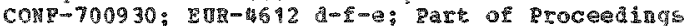

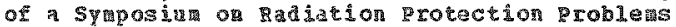
Felating to Trasuran rartsrahe, Gerrany. Septerter 21-25, 1970, (p. $403-491.660 \mathrm{~g}$

Safery in a reprocessing plant is deperdent on technical and Bspchological factors. The inferent aspects are revieved ad several typlcal acciderts are stuated as regards

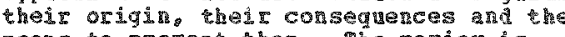
neans to prevent the The reviev supplenented by staristical data on risk

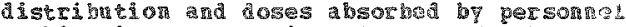
working an topacessang plants. (Akth)

$<563\rangle$

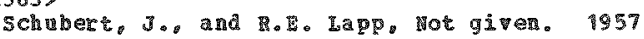

Radiation:

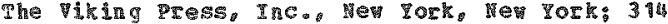
p.

The topic, radiation is introduced wy a discrs șon on the resulted Irom the atomic borb asplosion over Hitroshina. mhe history of rays is iscussed as vell as the Aagage ca used by its

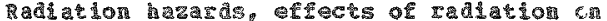

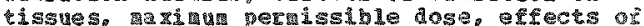
radiation on the fetrs and abryo in anjas and a prasented. accldents leadig to the

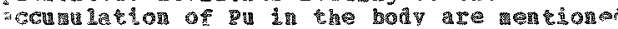


<563〉 co

such as the 27 indivituals at Los Alatas and porkers at the canadia atonic energy plant at chalk River. The measurement of pu in the body is discussed a also treatrent chelates. Sone case histories of aceidental exposare to Pu 239 are given. Pallotit from bonb tests is discussed wh rererence to the Bravo borb detonated on March 1.1954 and the fallont fron it onto the Japanese fishing boat the tuck oragon vuber 5.

peasurenents of $5 r 90$ in dalry products and content in bones are given. Suqgestions for bringing radiation hazards under control and thus minizing the assaut upon the fucure of the race are presented. (gith)

《564\$

Shappert, 2.B. W. A. Brobst, 3. W. Langhar, and ఫ.A. Sisler, Oak inge Matioral is aboratory? Nuclear safety Infor tion Cencer, oak idige. iN. 1973, Noverber 11

Probability ant consequences of Transporation Acciden Tnvolving Radioactive aterial shipants is the melear ael cycle. Conp-731105: Dart of procesdings of the minter lieeting of acrican societr of techanical

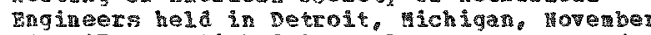
$11,1973$. Published in welear safery. $14(6)$.

For 1980 the projected electrical generating capacity of nuc lear poner plates in the Capcity of nuclear power plarts in the turn, yili generate thonsands of shipaents of radi oactive materials annally. The orabability or accidents involving these shipents withi is the pubic domatin bes been estinated a broken donn into fite severity categories. It is estinated the in 1980 the shipments considered rould be involved in less than 20 accidents, gost of which rould result in on 1 poderat dange to the shipping syster and 20 sigh nuclear-rel ted hazards a estinate vas ade of the effect of an extremely severe accident involing loss of contagnated coolant frov a spent-fuel shipping cask an the nossible exposute to the public. As result of the estitates. it is conclided the the likelihocd of an serions ratiological

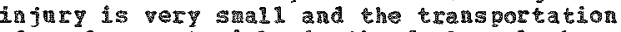
of muclear meterials in the fuel yole has a high degree of safary. (Auth)

$<565\rangle$

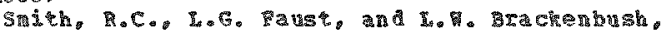

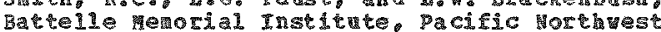
Laboratories, pichland,

Plutom

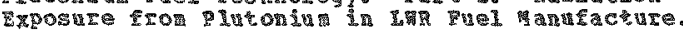
muclear pechnolog?, 18,97-108 Parsonnel radiation exposure probl ens in described. The eritects of ratiotion in

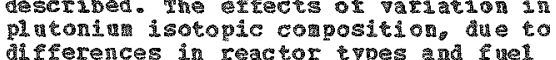
differences in reactor types and in on personnel tadiation exposure, re also described. It is conclured that increased shio Laing fabrication 2acilicies ven tull-scale plutonin recycle is ander yay, due to the higher radiation 1 ivel associated ith high

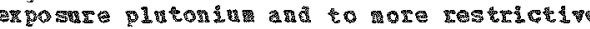
personnel $\mathrm{Fadi}$ diton those currentig used. Horever, it shauld be possible to hande completed pluconin tul

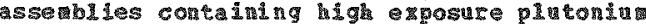

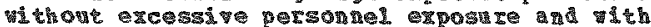

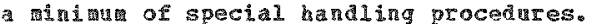
(Auth)

$\langle 566>$

Spoor, H. H. and J.E. Hursh, Univeritg of pochester, Rochester, RP. 1973

Proction Criteria. Part of Hodge, H.C., et al

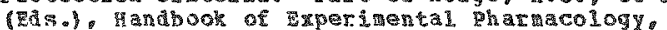

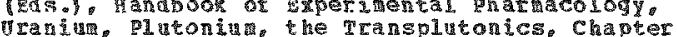
5. Sprimger-Verlag, ne Tork Hev York, fp. $241-2701,995 \mathrm{p}$.

The history of deveroprent of protection

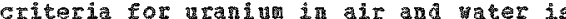
outlinet and the principles on which protection criteria are based are reviewed. The calculation of linits for radioactive nuclides in the working envinonsent is based on the general premise that injury is caused by and directly proportional to the energy absorbed per gram of tissue. Bnergy absorbed Eror alpha particles is ten tires as effective as that absorbed frow beta particle a issions. For bone seeking radionuclides, axeot radin isotopes. an aditional effectiveness factor of tive is applied. second premise is that dose rate litits are set sufficientiy lov so as to take juth accont lifetive accuratations. hethods of setting lifits depend on the critical endpoint-chenical toxicity or radiation injury-and the organ involved Maxisua peraissible concentrations for industrial orlers and odificatons for application to the general pulic according to ICR. 4he general pulic according to ICRE tChP routine urinaty assay is discessed.

Eretical consider atons aplicable to

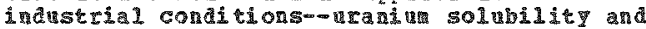
enchch went-are also included. (ST)

《567》

sterglass, E.J., got given. 1972

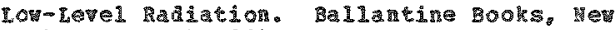
Tork, Ner York: 21 is

The bok describas battie of over 10 jears to bring evidence of haritul erfects of low-level radiation before the scienticic comstarty and the trold. This book is directed to the lay audence ith soac entional overtones. The anthos atterpts to call pubis $c$ atentor specipically to

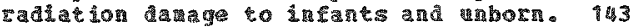
Feferences are cited. (RR

<568>

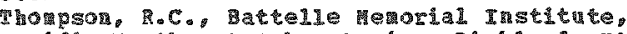
Pacific orthest daboracoties, Rhchand, ma 197 . Decenger

IrpI criterion al. proceed ings of the D. S. Bnviconent

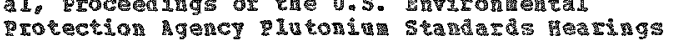

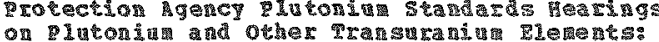

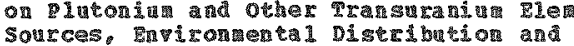

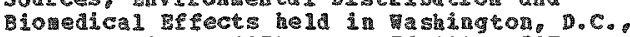
Decevar 10-17, 1974, (p. 271-299), $327 \mathrm{p}$.

The oroler ofpu and otber transuranc elemen in the enviranden is revierea in

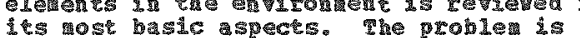

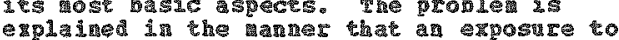

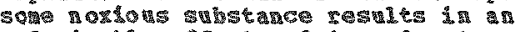
wndesiabie rect and in order to control the exposure at a level that does not prod uce

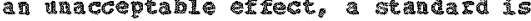

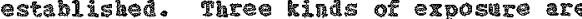

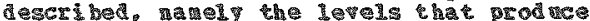




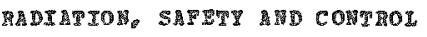

$\langle 568\rangle$ COR⿴囗十

effects in nits $1 \mathrm{~s}$ the levels that hape

occuried in an, and the levels vhere

protechion of the general popalace from Du

protecton of the

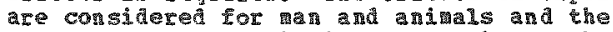

problens of extrapolations to esti nate the

heal th consequences in horans are discussed.

The cancer risk predictions, stated in ter

of cancers oroduced per

are described. A gagh is givan lot ing

arerage organ dose equivalent, to bone or

arerage organ aose quipalents to bone or

10\%

practicable is a good idea fer pa exposure

standards in vien of the uncertainties

prescrte. Trposure of total populatens

should he controlled at some feacton of

natural back ground lovels, because it is only

in this range of exposure that tere

assir rance of assura uce based upon the survival, over past eons, of the hum race. Decanse the

dispersal of yu ang the general populace

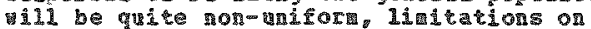

person rens canoc be accepted as a cotall person reas camot be accepted as a cotally

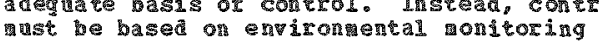
inth atention paid to food chains and inhalation pathway. The potertial for genetic extects frop a deposited in gonals is nepinged and comcern is expressed exposine of ato opulation since the are usalit considered to oxhit an enhanced Ialiosensitivity. (5)

Pigure 5 shows aprerage organ dose equivalent to bone or bones in rell and against erfects in unspecified units. 
SOURes

$<5698$

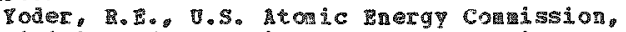

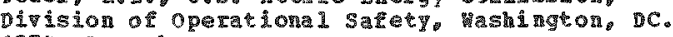
197 . Decerber

Potertial Source Terms and Control teasures.

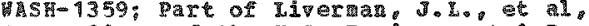
proceedings of the U.S. Environ mental Protection

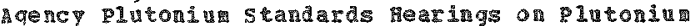
atd other Transuraniu wements: Sources.

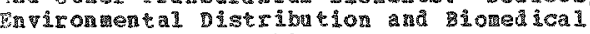
Bffects held in thington. D.C.. Deceaber $10-11,197$, (p. $(3-86), 327 \mathrm{p}$.

This reviev is interded to highilght the

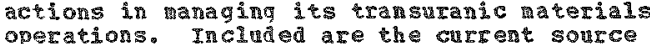
op eransuranumaterials operations. an indication or projected inventories, and an overviev of control measures taken to reduce efrinents. There have been releases of $p$ and these have been

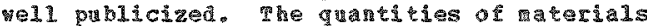
involved in rhese instances have ranged from

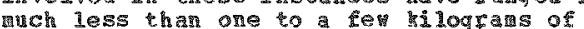
material, and steps have been taken to reduce the acciderte potential in $A C C$ operations. The mator releases associated ith

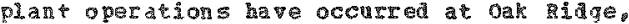
Rock Flats. Richland and hound comparsison of the quanties. released to the guanties 5 in ase shovis that a very small amonit has been released in accidents. Mil routine enissions are now very lov and stíl decreasing. Because the $\mathrm{AC}$ is concerned about nyironatent a scharges and any atendant buildup in the environgent, it is
Ful1 inolerenting the ma 10 as practicable concept. or sample if coutine instons conthu the present levels by the year 2000 less than adicional curies of prill be ajschargea to the mironment comared to the kilocurie quntities already present srom atrospheric vapors testing. The intensive environenta 1

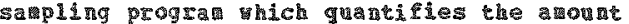
of pu in the enviroment and its specicic location in identisjed parma provide confir arective. Intoration developed in this PFog before a potental problen exists and vill 110 arole tibe to the effective action. Th those instances in which anvirontental cleamu actions have been reguired specitic neasures tailorei to the situdion have been w sed. (RAB)

Pigure 1 sumarizes the total pu release data fron all zo sites haing significant releases Sor the year 1967-1973. supplenentel

information is giver on potential pis source teris for medical uges, oste managenent of tratsuranic solid vate, space nuclear systems operations opervien on Pi and trensuranics solrce terns all operations overview on reactor research and development progras areas source terws and ogerations, costs of pu facility

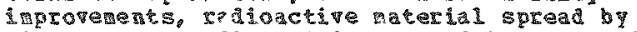
fire, veapon radoactity spread by detonation 1 moct, and radioactipe arerial spread by aireraft erash. 
○

○ 
$<570\rangle$

Anderson, J.D., Atlantic ichield mafora

conpany, Fichland,

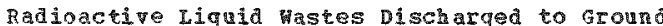
in the 200 Treas Daring 1972 . ARP-2757 (Part 3): 1 is 1 p.

The radioactive liquid wastes that have been discharged to ground thin the chenical Processing Ditision control zone are sumarized in tatular torm. Data for 1972 and cum 1 ative data since plant start up are presented. Fraiviar tables list radioactive waste detivity discterged to inaividual ponds, cribs, and specific retention sítes. The mastes discharged during 1972 to each site are detailed on ath to month basis in tables 4 through 40 . vev this year is a in tables through 40. vew this year is plant sites. The tabular data includes

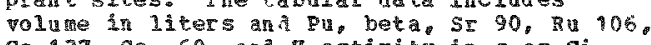
$\mathrm{Cs} 177$. Co 60 , and activity ing or $\mathrm{Ci}$. (ST)

$571>$

Belter, par. J.S. Henic prergy Comission,

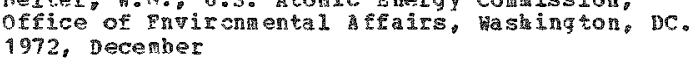

Deep Disposal systems for hadioactive Me Proceedings of a symposiun on undergrond taste Management and Environmental inplications held in Houston, Texas, Decenber $6-9,1971$. The Collegiate eress. George sama company. Ins.

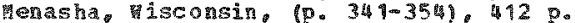

Geochein ical research and extensive field exploration and den onstracion studies have been carried out on several deep a isposal systems for radioactive vates. including the application of hydrotracturing techniques in bedilen shale for low heat-producing wastes

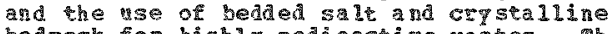
bedrock for hidhy radioactive vastes the

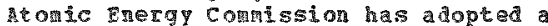

regulatory policy ohich revulises that 11 high-levil 1iquir astes fon icemsed irradiated-ruel-reprocessing plates lust bo solidified and shipped to a rational

repository on 1 and owned and compolled by the fideral government. A tentative selection of a site near to been aade ror an initial salt-mine reposicory For the derantration of long-tern storage for both 501 id high-level and long-lived al pha-contantated wastes. Because of a general requirement for adequate ontoring to assure the safe and effective operation of a deep-reli injection syster this method has nor been used generally sor al sposal of radionctre wastes. It appears that in jecrion into deep per weable formations way we a practical solution for the disposal of

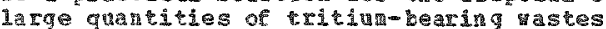
from Hater reactors and

nuclear-fuel-reprocessing plants in the

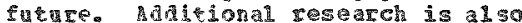
required on the potential deep aisposal of

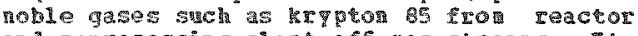
and reprocessing-glant off-gas gtreans. It is estimated hat by the pear 2000 betrean 2 and 3 解illion cu. Et. (56,000-84,000 3) of

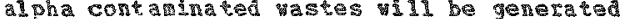
aprualit as a result of the mpanding nuclear pover inautry, includin fast-breader reactor levelopment. Because of he pu contarinetion deeo underground disposal of these rastes mal so be needed. Extersive

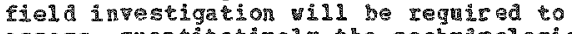
assess quanticatyely the geohydrologic suitability of specific siches to receive high

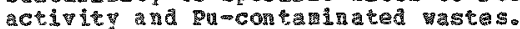

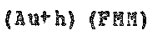

$<572\rangle$

Clark, H. . and Iaborarory Chenical Technolog Division. oak Ridge, Th. 1373 , wover

Pressurized Aqueous Combustion of Alph-Contaninated haste, Final progran Status

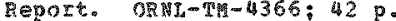

This report aescribes the status of the Qtessurized Agyeons Combation of Apha-Contaminated Haste Program (formerly called the plutonium Burning Progrand at the tide it tas canceled on June 1, 1973. Pesilits of laboratory investigations involving reaction studies, liquid and gaseous ef luent cleanup problems. and
corrosion research are sumarized. The status of the process plowsheet design. the eguiprent design a procurement, and the construction of an engineering-scal axperiment capable of treating 0.1 con of combustible raste per day on a continuous basts is discussed, ant some equiprent cost ata a re presented. Recomendations for Eurcher laboratory vork and pilot-plant develophent are also included. (Auth)

<573》

Dentan, D.H.. D.A. Baker。 J。长, Soldat, and J.P. corley. Battelle Memorial Institute. Pacific

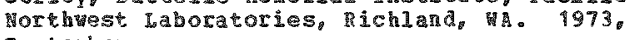
septerber

Radiological Evaluations for Adwanced haste

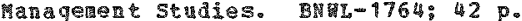

Adegrate risk evalutions of aste disposal concepts include estidates of radiation doses that ight be received by hums of releases of such aeterials should occur to men in Thould indicate incentives for additional radionucile separations in high-level waste

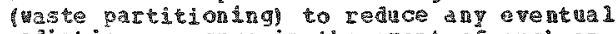
radiation a posure in the event of such an occurrence. A compreherisive dose conputational aonel, was used to assist in evaluating alternative means for aisposal of high-1etel vase. Typical inpat terrs inelude seurce ter

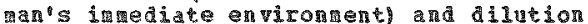
factors. Outputs incluale indi idual pathay doses and total doses to maximum individuls for bork an urban and rural population. Fhole body doses plus doses to other critical organs are obtained. as pell as the

Fractona dose contributions of individual melias. Doses sor one year or toral aoses

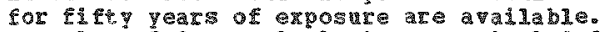
Eraples of dose calcuations are included to demonstrate use of the rethodology for a hypothetical geological aisposal concept.

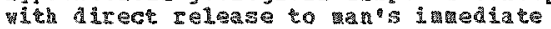

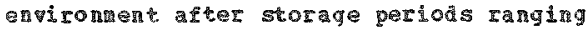
from 100 to $1.000,000$ years. The rose

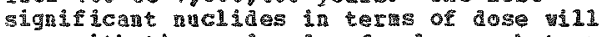
vary ith time and mode of release, bue are iffely to be $5 x$ go ard Cs 137 at 100 years.

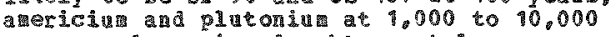

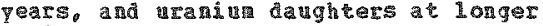
periods. (7)

Tables show radiation dose to individuals and populations from hypothetical surface vater and airborne releases. Apendix gives a tale of radioncting in waste accur 2000. 
〈574>

Hanson, Gan., Atantic Pichield Hanford Cotapary ichiand 1971 , January 29

?adioactive Effluent peduction fron 200 Area Facilities, RPH-1972: 28 p。

A comprehensive study of radioactive yastes discharmed to the enticons in 200 areas vas made in 1967. It as fond that gasaous taste cassion guides were heing at for the discharge of $\mathrm{T} 13 \%$, st 90 . ired ission products, and $P u 239$. Treatment systems for reduction of $\mathrm{HO} 2$ from several stacks vere proposed. Arototype systen is presently being tested on 003 plant stack gases. proposed treatment of Iiruid hastes emphasized removal of the long-1ㄴ.t rationuclides (Sr 90 , Cs 137, Pa 239 ) from those strezas being discharged to the environs. Significant raductons of ratioactivity to the ground have been realized during the past three to four years. realized during the past three to four wea heta. Pu, Co 60. ST 90, CS 137 ) to the ground in liqu id astes from 1965 to 1969 are presented in tabular for a The radioactivity content of waste streans discharged to the environent is under continuous strveillance. Purther mator reductions in radioactive discharges are planned to pet the goal of less than ten grams ot plutoniu nd less than four hundred cotal beta curies. other plans include facilities for plutoniun efluent leanup, separations effinen control, and for low-leyel effluent analysis. The above coal should be realized by the end of $\mathrm{C}-1975$ by installation and beneficial use of these fracilities the shutarn of the Redor aste concentrators, further refingent of the purex process condenste rectcle and/or reevaporation systems and lover analytical detection capability. The disposal or wastes to an undergound field

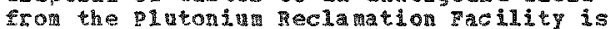
ai scussed and future plams re describea. (?)

\section{<575>}

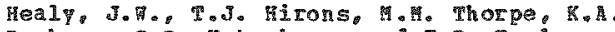

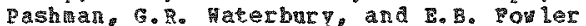
(comp.) Los alamos scientific Laboratory. Jos ilamos.

Transuranic waste Repository studies. a $-5127-45$ ( 01.1$): 18 \mathrm{p}$.

The progress of the los Alaros Scientific Laboratory's efrort related to the Transuranic taste Repositories strafes for the period July 1 -hopember 1,1972 is revieved. Iiterature walues ceporting thermal and radiolytic degradation of certain wastes, an vaste storage probleas related to products of degradation are discussed. Preliminary data on the chemical characterizetion of several wate types and thei impications in storage of transuranc vastes are reported. The retional for acreening starions and onitoring of large volumes of solia vate is developed as vel as preliandir radiological confideratons for the twenty year storage of ransuranic waste. Dose rates and heat loads are probanly of sall concer 11 ith 2412 possible exception, hovever, package integraty (under shallow earth burial) poses serious problers which are being

investigated. (Muth)

\section{3}

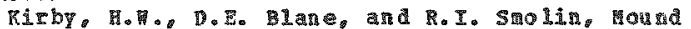

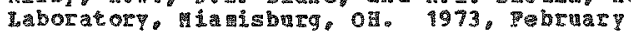

- rocess for peroving Radioactive tates from Liguia strears. Colp-721030: Part of Drocedings of the $\mathrm{ACC}$ pollution control Sprosing hela in oak pidge. Tennessed, ocober $25-27,1972,(1.480-515), 549 p$.

A process is under development at mound Iaboratory to remoge radionctio saste (principal1y plutonin 238 from process vater prior to discharge of the ter to the viani Miver. Phe contaninated tor, as normal 17 received, is at a pll between 6 and 9. under these conditions plutoniur in all its oridation states is hydrolyzed: howeyer. the level of the zadioactive solids varies Exol about 50 ppall down to abont $50 \mathrm{ppB}$ and the plutonin rea ins in a colloidal or subcol loidal condition. The permissible concentration for discharge to the river is about 50 parts per trilion. pilot plant tests show that $95-99 \%$ of the radioactive material is removed by adsorption on diator ceons earth. The remander is removed by passage throngh a bed of either dibasic or tribasic calcita phosphate. Ground phosphate rock is equaliy effective in removing the radioactive aterial if the row rate is controllea to perait surticient contact time. paraneters for optinizing the process are now undew stady. puture plans include apolication of the process to wastes froa seactor fuels reprocessing. (Auth)

$\langle 577\rangle$

RMO 1. R. R. Rattelle Merarial Institute, Dacific morthest faboratories, Che mistry Department, Richiand, Wa. Mot given

Reaction of

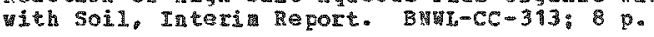

A study as ade to deter ine if it wand be reasible to put a high salt, acidic aqueons vaste mized with organic compounds into a $\mathrm{z}-1 \mathrm{n}$ ile fiela. The factors considered the extent of adsocption of plutonin and areicicis by the soll and the effect on the infiltration of the aste into the soil by the organic compounds present. It pas concluded that soll has considerable capacity for hich salt, acidic yste containing organic compounds and can inbibe ft luost as rodil as vater. These data obtained from colum reasurements in the laboratory, would be less favorable than those obtained in the fild as the notsture cannot spread

horizontally in a colluas. uptake of

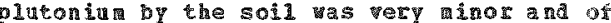

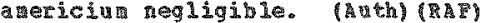

$<578>$

Loh se. 6. E. Mied cheical Corporation, Ida ho cheical prograss operations office. Idaho Palls, ID, 1972, Jan

Safety Malysis Report for the TePR solid Radiogctive aste storage acilities. ICP-1005: $155 \mathrm{p}$.

at the Idaho che rical Processing Plat. radioactive solid vestes resth th Firidi zed-bed calcination of extraction-colur refrinates and nuclear facilities Aecontanation 501 a

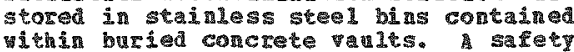
andisis of the storage facinitres indicates

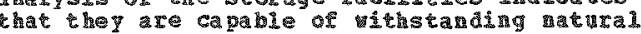
occurrences such as ecthonks. tornalos. high tinds, or floods juthout serions darage or spread of radioactive aterials to the envitornente. Afuli range of Eission 
<578 costs.

products exists in the calcined solids. Total plutonin concentration is $0.009 \mathrm{ci} / \mathrm{kg}$ in Fuoria type waste and $0.016 \mathrm{c} / \mathrm{kg}$ in monfluoride type wate. In prevols studies the rate of leaching of transuranics from calcined solids by water was shogn to be yery low. (Auth) (ST)

$\langle 579\rangle$

ishina, J., and I.C. Schwention, Battelle Menorial Institute, Pacific gorthwest

Laboratories, Atmospheric sciences Progras, Richland,

Airborne Release of plutonj and Its conpounds During overheating Incidents. BNm-1751 (Part 1): Part of simpson, C.Io.e et al, Anaral meport for $1972,(0,28-32), 152$ p.

A study has been in existence tor some time to evaluate the amount and distribution in aerodynanic size fraction of plutoniu airborne under some conditions found in postulated accidents. Tro recent studies are covered here. Data are presented from forty experiments performed in the wind tunel in the radioactive Aerosol Belease Test pacility to rea sure releases under vatious conbinations of parameters involving uraniu (a olutonia siandant corns. surfaces, ind speed and the presence or absence of a gasoline fire. The second study involves airborne release during the burning of contalinated aste in the Radioactive merosol. Release Tank. (Auth)

$<580>$

pishina, J., and L.C. Schwendinan, Battelle morial Institute, pacific morthwest

Iaboratories, Atgospheric sciences progran, Richland, 特. 1973, A pri

Fractional Aitborne Release of Radioactivity During the Burning of Contaminated Solvents.

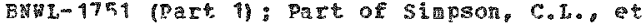
a1. Anual Repot for $1972,(0,26-27), 152$ p.

Laboratory scale experiments are being conducted to indicate the airborne release of radioactive materials in the event of a fire involving flamable solvents used in the separation of nuclear aterials. The fractional release of materials ab ring the burning of 30 percent nornal tributyl phosphate in a kerosene diluent is being
measured. The soivent contains realistic amouns of aterials representative of those found in contaninated process

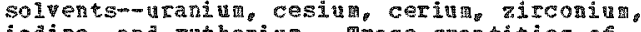
loane, and ruthenina. Trace quantities of active isotopes are used to follow the distribution of the raterials excent in the case of uranium. Melease measurel this far under nominal conditions tistillation of the dinent) have been under 1\%. (Auth)

5817

Not Given, D.S, Atonic Bnergy Congission Division of operational safey, ashington, DC. 1973, May

Monitoring Control and Disposal of pritiun A selected Bibliography. TID-3337; $74 \mathrm{p}$.

Meferences to 351 publications that bate appeared in $5 \mathrm{SA}$, volume 21 (1967) through volume $26(1972)$, are contained in the biliograph. The references were retrieved from the conputerized RESPONSA search system and were formated for publication with inderes by the

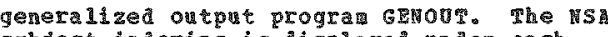
sobject indexing is displayed under ex citation to provide information on the contents of the docusent. The bibliography vas prepared to assist in certain ton Energ con studies and for the use of others who way have an interest in tritivalu haling. monitoring and asposal pratices whis the AE and private industry. (F)

$<582\rangle$

pot given, Batelle memorial Institute, Pacisic Horthest Laboratories, Naclear waste yechnology Department。 pichland, KA. 1973, A ugust

overviev of migh-Level Radioactive maste magenent stuales. BNI $\mathrm{m}-1758 ; 42 \mathrm{p}$.

This report is a sumary of activities at the Pacific porthest laboratory related to the managenent of high-level radroactive wastes. Tyo of the major areas being investigated are vate fixation-converstion of the vaste to a stable solid for and advanced disposal concepts-a syster atc evaluation of candidatisposal wethods. Technology is being develoged through the pllot lant scale to incorporate the high-level waste into extremely inobile solid forms. The objective of these form is to minimize the possible rate of aste release to wan's environat should the contalnat suster for the vaste be breached. 3pecific investigations are currently centered on the production of stable. low solubility silicate glasses. Alternative concepts for ultiate aisposal of solidified high-level radioactive vastes are being evaluated on a systematic basis. The evaluation includes consideration of technical feasidility, safetr. cost. enviritonental inact, wolicy conficts. public acceptance and research and develophent needs. Waste disposal concepts under evaluation include geologic, seabed. ice sheet and extraterrestrial disposal as vell as transtutation trams forting by irradiating certain waste constitutents into - levents having more desirable mate managent characteristics). Is a complenent to studies on wate fixation and advanced disposal concepts, studies are being conducted on aste partioning (separation of radionuclides in wate into different elenents or groups of elements according to their seitability for different disposal rethods). Application of this technigue is useful for some aisposel alternatives and it may inove overall waste disposal technology. In adition, radiological evaluations are being conducted to assess by what reas radionuclides in waste conld

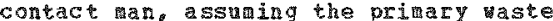
containgent barrier fails. (ST)

<583》

Hot given, organizaticn for Economic cooperation and Developrent, Paxis, France. 1973

gangement of Radionctive vastes from Fuel Reprocessing. con-721107: proceddings of a symosiur heid in Paris, France, voverber 27-Decerber 1, $1972,1266 \%$.

The 46 papers presented during the parious sessions of the syposiun as well as the ensuling aiscussions shoud the considerable ovolution in the past fev years of the wethods for the control of gaseous effluent releases and for the treatsent and storage of kighly-radioactive vastes. Six papers vere abstracted separately for the data base. Anong the topics aiscussed are the future 
$\langle 583\rangle$ con\%.

implications of some long-1ived figsion product nuclides discharged to the envi ronment in fuel reprocessing astes, $\mathbb{R r}$ 85 disposal. study of bituriatuation as nethod of treating high activity astes. design of an industrial. facility for the incorporation into glass of fisston products and the storage of highly retroactive glass. dísposal in a geologic environaent such as clay formation. Salt mines and deep anderground cavi.ties, and deep-mell. disposal of tritiul containing liquid effluents. (PHa)

$\langle 384\rangle$

Not given, v.S. Atomic Bnergy Comission Technical Informetion Cencer, oak sidge, TH. 1973. ugust

Radioactive vaste manatuen t, Buliography of pabicly Available fiterature pertaining to the osME's Hancord. Washington production Site. TID-3340; 157 .

This bibliograph contains abstracts of 1098 pablicly a journal articles which have appeared in Nuclear science Abstracts from Jan uary 1951 through July 1973 pertaining to radioactive waste management at the lanford site. The abstracts are grouped into the folloning categories: en and radioactive surveys: Colubia River studies: ground disposhl and soil studies; geology horology, and meteorology: stack disposal; aste storage tank and corrosion prohlers: aste firation and solidification. vaste processing and properties; wate managerent: and miscellaneods. within the categories, abstracts are arranged by $\mathrm{NSA}$ yolut and abseract nuber. a supplement to this bibliography il1 be issued. (ST)

$<585\rangle$

wot given, y. S. htomic Energy comassion. Division of operational safery, hashington, DC. 1973. February

Proceedings of aEc pollution control Conference held at oak Riage. Tennessee pctober $25-27$. 1972. CONF-721030: 549 p

Currenty the tomic Pnergr Comassion is spending about ten willon dcllars per pear on actions to remedy or control and abate pollution from AEC facilities. The conference was held to provide increased coordination of techrical in increased he $1 p$ avoid unecessary dmilcation of effort in resolving comon pollution abat enent problers at AgC facilities. The following sessions yere held: evironental protection policy and reguiretents, air pollution control. alternatives to open bur ing mater pollution control, and radioactive wasto treatment systers. Aiscussion of $A E C$ polic and position regarding the inplementation of federal. state, and local pollution control stadards and taqureants by $\mathrm{ACC}$ facilities waste treatment systens included those for tritiur, plutoni 238 , transuranic and krypton 85 enrichnent by thernal

diffusion. Sonrces of releases pere stack enissions, processing area releases to the atmosphere, and liquid efflients. Sy stem for controlling or abating radioactive and nonradioactive releases vere discussed.

\section{<585>}

yot given, nak Ridge National Laboratory Naciear sefety information center, oak $\mathrm{midge.}$
露. 1973

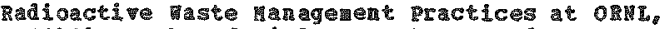
Ribliograph of pitles, athors, and Abstracts. OAd

The bibliographl 11 its sore 360 reports and articles that have beer published at orm or

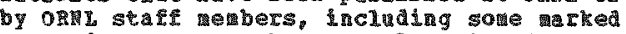
"roprietary" on the general topic of cadloactive yaste ranagenent practices. Host

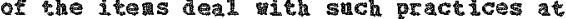
OWH others dea 1 with practices at other Ecilities or in aneralized sense. Together they constitute a derinitive stateicnt of oRH vaste mage aent position. The bibliography contains sections ith abstacts, athors, titles and keyoras.

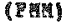

$<587$

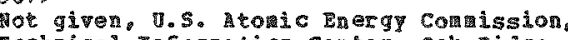
Technical Inforation center, oak idge, wo 1972 , Apris

Radioactive taste Processing and Disposal. TID-3311 (Supp1. 3): 592 p.

The 2249 references in this bibliography supple ient reports mTD-331\% TID-3311 (Supplement 1), and TID-3311 (Suppleaent 2). The references were

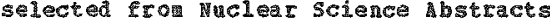
(45) VOluge 21 (1967) through issue of Vluae 26 (1972) by the BIPONSA computerized search echnine. The references include ts abstract nuber, report nuber or fournal citation, title, athor date of publication. corporate author page nubers. and subject index terms. Separate personal author. corvorate athor, report ruber, and subject inderes follow the references. (ST)

$\langle 588\rangle$

Het given. Organization for Pconowic cooparation ad Development, paris, prance. 1972

Disposal of Radioactive faste. Conpo 720453 Part of proceeaings of an Information Symosìn on Disposal of Radioactive Haste hela in paris. France, pril 12-14, 1972,290 p.

The basic objectives of the Fuclear Energy Anency (nsA) Inforation meeting vere technical, health and psychological aspects of radioactive waste disposal. The five principal areas covered were: il production and treataent of wastes, 21 racioecology, 3i exposere to ionizing radiation; principles and theth of radiological protection, if storage and disposal of astes, and 5 i admistristion and control. Seventen papers were presented. (RH)

$\langle 589\rangle$

mot given, v. S. Atoric Energy Comission, Technical Inforation center, Oak Ridge, TH.

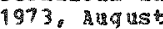

Radioactive Waste Management, A Bibligraphy of Publicity a valable I iterature pertaining to the IBsi RC's lational Reactor Testing Station. Idaho. TID $-3342: 56 \%$.

This bibliography contains 272 technical reports and journal articles thich have appeared in luclear Science ibstracts from January 1951 through 3 uly 1973 . The articles pertin to radioactive waste magement the rational Reactor pesting station i Thaho, The ecology of the site, monitoring, and al 1 phases of waste storage, treatment. 
$\langle 589\rangle$ coptop

and managenent are covered.

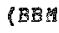

$<590\rangle$

Not qiven, "S. Atomis nergy Comission,

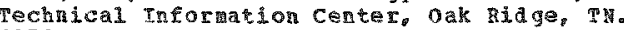
1973 . Engust

Radioactive haste fangenent, Bibliography of publicly Avilable literature pertaining to the USA EC's Saranah Rivar, south Carolina. Production site. TID-3341: $36 \mathrm{p}$.

A biblography has been conpiled of abstracts of all reports and articles pertaining to radioactive waste managerent at osacís savannah iver production olant. These papers appeared in Nuclear Science hbstrots Frow Janaury 1951 througl July 1973 and inpolve ecolorical studies and montoring. Savana River studies, and all phases of waste storage and hanagenent. peports invovle release, storage, and treatrent of various radionuclides including plutoniu an

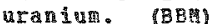

$<591\rangle$

Wot given, organization for teonolic cooperation and Development, paris, Prance. 1971, september

Padiation Waste Ma magent Practices in Western Rurope. Report of the steering comitte for Nuclear Energ: $126 \%$

This reviev gives information on: oxigin and different types of vaste; safety aspects with a discussion on the recommendatons of the International comission on adiological Protection (ICMP): technological and economic considerations with respect to radioactive wastes: specific Western European Haste vastes: specilic western suropean aste solid rastos: secial groble areas such as solid tastos: special proble areas such high-level liqu loha wases. decomissioning of nuclear installations. Conclusions of this reviev are: problems of radioactipe weste are comple a bu mangeable: high standards of safety and considerations for the huan environgent are steressed: at present radicecological aspects are not a initing factor for radioacive ste mangement: pubijc interest and information are encourager; optinu development of nuclear taergy need not be i peded by probleas of radioactive waste mana gerent which ill have to be dealt wh. (REP)

$<592\rangle$

Wot given, los Alamos Scientific dobotatory. Health bivision, aste manarent secrion,

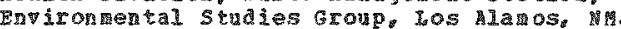
1974. pebruary

Transuranic solid grogra quarterly Report for Jul 1973. IN-5512-PQ: $22 \%$

The progress during the perlod of

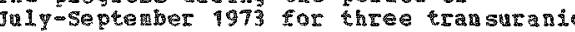
solid aste wangesent research programs

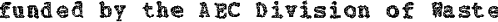
Manament and pansportation is revieved. The three programs inclade transurande solid

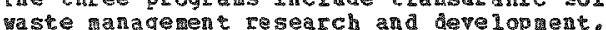
wasce mana denen research and aeveloparent facility, and the bur.al 1 romas evaluation. The interid storage criteria are now ready to be issued for general reviev. Experiments in radolysis and container corrosion have been reorganized and expanded to provide inforation for optiaization of interi storage, hile waste sorting experitaents have begun to determine ore accurately the character of astes being produced at LASL. several task forces have been organized for the aste treataen facility to evaluate incinerators and determine atisfactory operat lonal size for the facility. Mork has bequ on developing a nodel for the risk analysis of radioactive burial grounds. A questionnaire has been developed to obtain the necessart information for the analusis. (Auth)

<593>

yot given, 8.S. Btomic Energy Con Technical Inforation center, oak Ridge. Th. 1973. septerber

Racioactive waste thagement, A Bibliography of ablicl Available li terature Pertaining to the

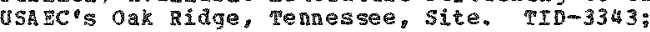
85 p.

This bibliography contains abstracts of 448 technical reports and fournal articles which have appeared il aclear science Abstracts from 1948 through July 1973 pertaining to radioactive waste managenent at the oak idge, Tennessee $\$$ ite. The abstracts are gronped according to is volume and abstract nuaber in the following categories: Environs monitoriny, Ecology, al Radiological

surveys: hice oak lake and clinch put Strdies: Ground pisposal and soil studies Geologi, Hyarology, and heteorology; stack Disposal: waste storage tanks and corrosion problems: waste pixation and solidification: Waste processing a to properties, Vaste anaterent and iscella reons. (BBH)

$<594$

Tarura. T.p oak Ridge Mational laboratory Health Physics Divisicn, Oak Ridge, w. 4972 Deceaber

Sorption phenomena signifleant in Radoactive haste Disposal. Heroir 2.D. (Bd.), proceedings of a symposing on vnderground aste anagenent and znvironnental Inolications held in Houston Texas Decerber 6-9. 1971. The Collegiate press, George Danta company. Inc. Henasha, wisconsin, (p. 318-330). 42 ?.

Disposal of radioactive liquid vastes poses a particularly vexiag problen, because these vastes contan arious radionuclides and chericals used in processing operations which are potentilin dangerous, even in $10 \%$ cadionucide concentrations. Sorptive properties of midals, particulariy ion-erchange reactions. have been studied for potential direct appication in waste treatrent and for the purpose of defining the fate of raliontides her released to soils and geologic formations. Becanse most vaste stred nor na I contaj state ion

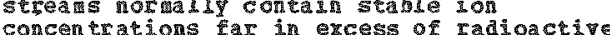
ions. sorption reactions of interest a those vich exhibit high selectivity for the radionuclides. Structura 1 andor steric factors are ganerally of highest significance in selective reactions. Alicaceous inerals selectively sorb radiocesiun from high-soding, alu priaridy because of eavorable structure. certain ions by excluding other ions wose sizes excead paraneters. Som sorbents show selective sorption sections nder particular conditions, thus, alumina and related hyirous oxides selectivel sorb ralidactive 
<594> CONT.

cobalt and radiostrontium in alkaline sodium

systems. In adition to the exchage

reactions sorbent properties, such as

flocculation swelling and absorption of

iiguids, and chemical properties of

radionuclides re iapor tant considerations in waste-disposal operations and magerent. In practical applications of the sorptive

phenomera in waste disposal. it is necessary

to know the solution characteristics, sorbent properties, and for as ion characteristics, as vell as the interactions of these factors.

In the hylralic fracturing techngue

emploved at oak nage, the vaste-solution

characteristics influence the choice of

sorbents used to prepare vaste-cerent.

slutries. The high-sodiun salt concentration requites attapulgite instead of bentonite. and illite is added to fix radioactive

cesium To ingoblize the is after

injection underground, cement is added, but the cenent rurther cotplicates the reactions

and behatior of the clay slurries. Fhe behavir during injection and utimate setting of the grout is further influenced by the characteristics of the formation. Each ndergrouna-disposal operation vill require uderstanding of the environent into which the raste is to be placed. The final

facility and technigue shoula be tailored to facilit and technigue should be tailored operation and insuring long-ter safety for future generations. (A the 


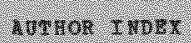

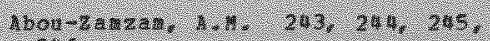
3136.

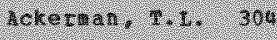

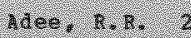

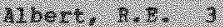

MItetanger. 6, $243, \quad 244,246,246$

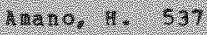

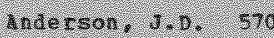

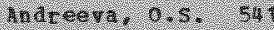

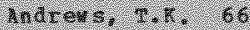

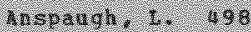

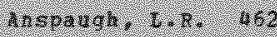

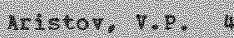

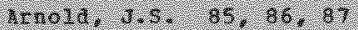

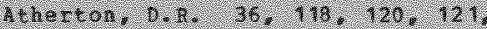

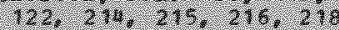

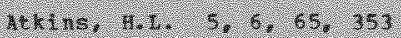

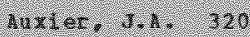

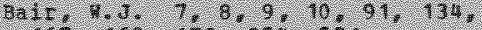

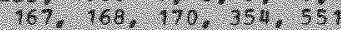

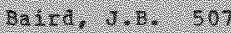

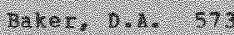

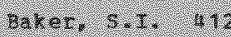

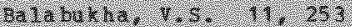

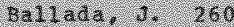

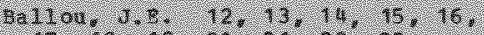

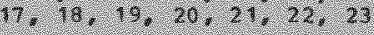

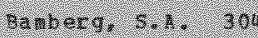

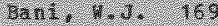

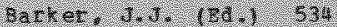

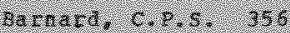

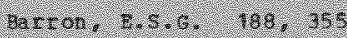

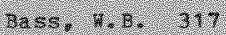

t.t.

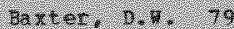

T.t. I.t.

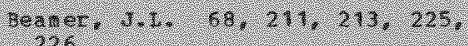

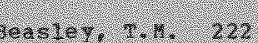

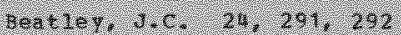

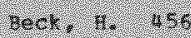

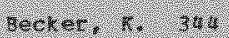

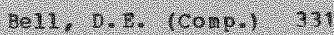

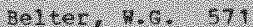

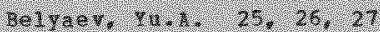

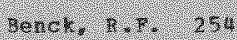

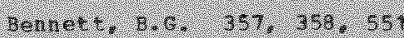

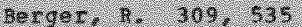

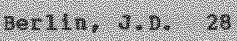

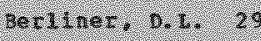

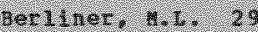

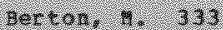

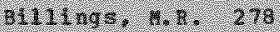

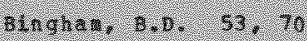

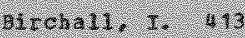

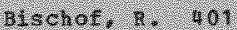

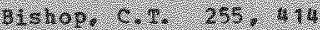

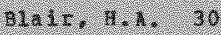

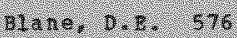

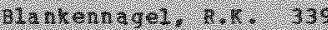

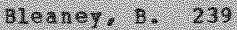

$310.05 \%$.

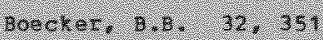

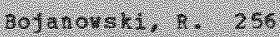

Boltan. I. W. 255.44

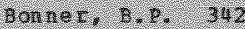

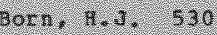

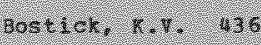

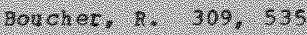

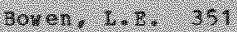

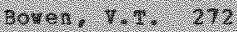

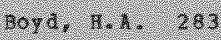

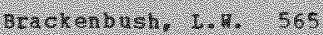

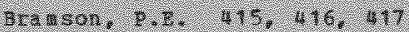

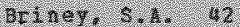

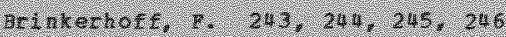

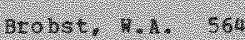

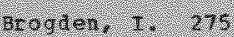

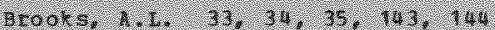

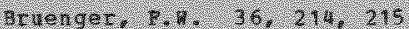

ariner.

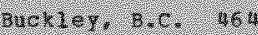

text.t.t.

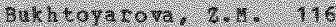

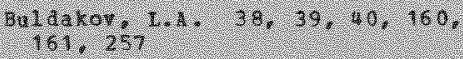

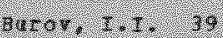

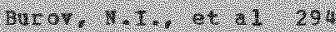

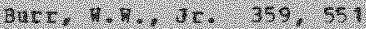

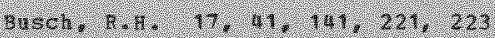

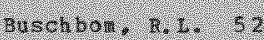

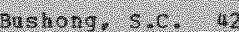

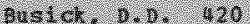

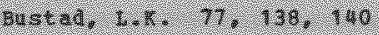

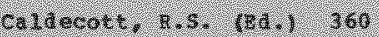

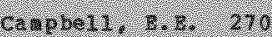

cante16u. 4. 2. 421

carnact:c.t, $243,214,243,246$

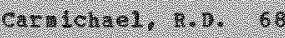

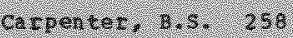

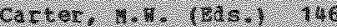

carter a , ? : $104,105,466,101$ $100.109 .150 .1,1,1,12,112$

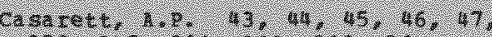

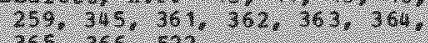
165. $36,6,52$

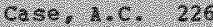

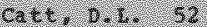

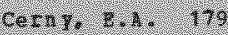

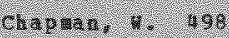

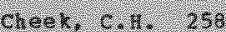

buerdratser: t. tr: 30

1.

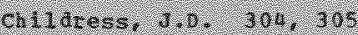

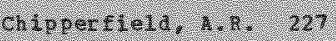

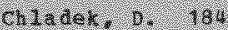

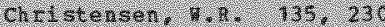

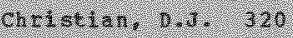

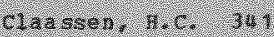

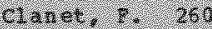

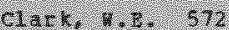

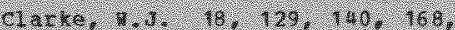
$165 \cdot 170^{3} \cdot 15$

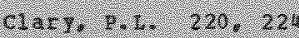

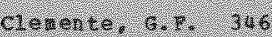

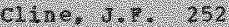

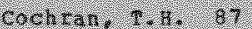

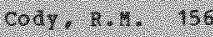

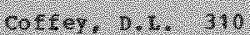

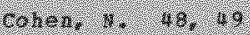

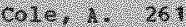

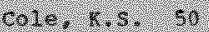

cortate t.

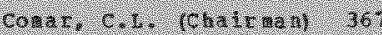

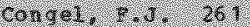

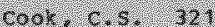

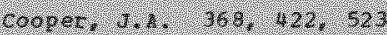

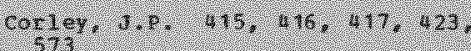


107:1108 $\operatorname{tang}$

Cyor. if.5. (3.1.) 275

i. wibchanski. I. R. $120,125,257$

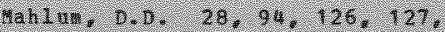

$126,129,130,131,132$, 433 ?

202, 203 , 20 i

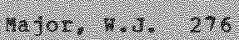

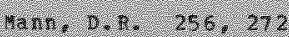

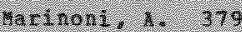

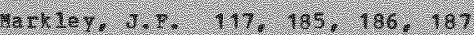

V.t.

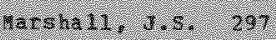

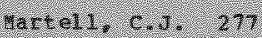

artin: J. 2.: $334,335,153$

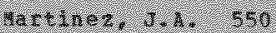

cosse. P. 142

Mats stoka: 0.592

4acsusaka, No: 134

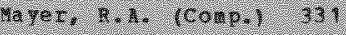

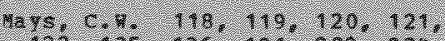
122, 135: $136,101,229$, 231

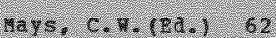

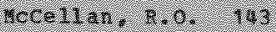

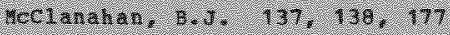

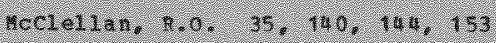

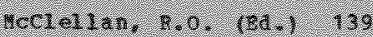

Menona $1 \mathrm{~d}, \mathrm{x}, \mathrm{B}, \mathrm{x}, \mathrm{14}$

Hedove11, 9.9: 278, th5

metreftio, J.R. 155

terentand, 8.5. 120

trosec. 2. 2. 16. 466

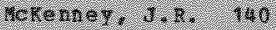

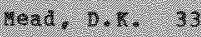

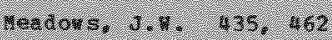

gedter. P.A. 286

Getiriter. H: 142

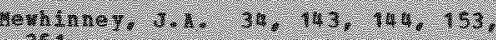
35 .

191.ce1. he. 98

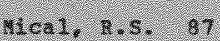

michael: 0.3 .550

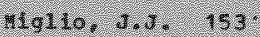

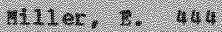

miller. R.C. (Comp.) 383

Miller: S.C. 195

Hishing. J. 379.580

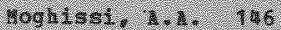

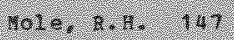

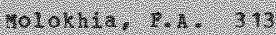

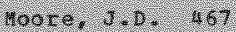

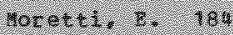

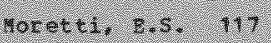

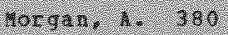

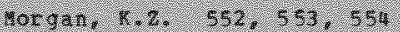

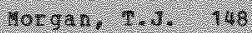

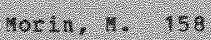

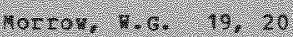

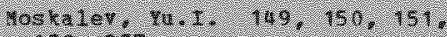

1.52. 257

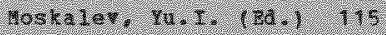

to.6.6. 1.6 .0 .6 .270

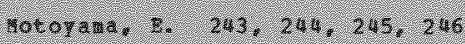

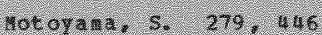

$106 x+2=0.198$

r.

4r.9.9.

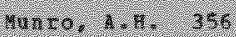

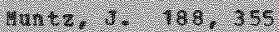

andrachera.tit. 154

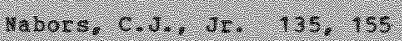

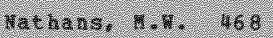

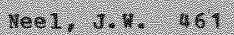

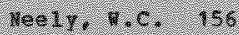

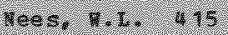

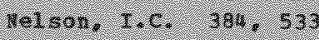

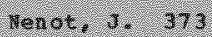

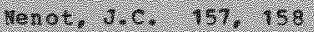

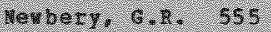

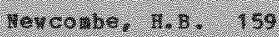

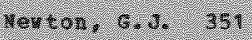

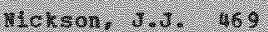

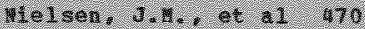

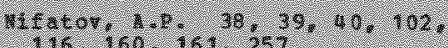

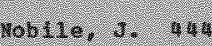

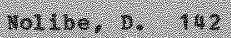

Iranta. To: 279

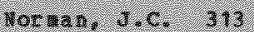

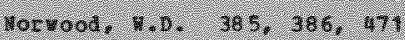

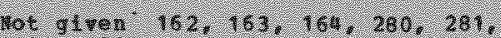

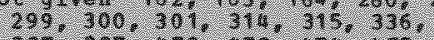
3.37. $367.472 .473,474.175$ 476. $477,478.470$, 486.487

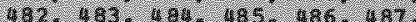

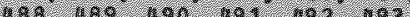

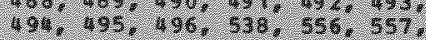

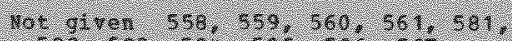

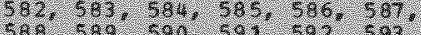

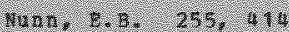

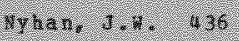

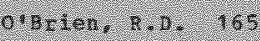

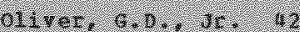

$01500,8.7 .7: 0.171$

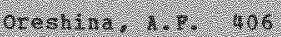

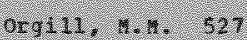

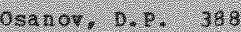

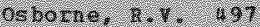

6.:

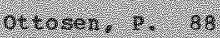

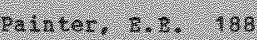

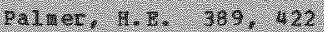

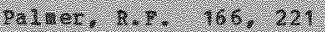

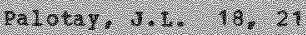

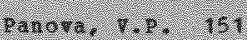

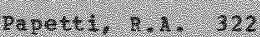

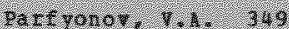

7.4.

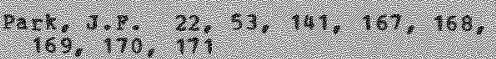

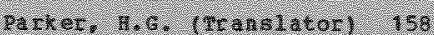

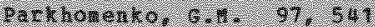

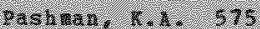

catcatict. c.

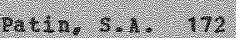

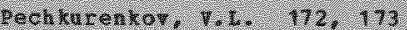

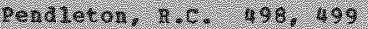

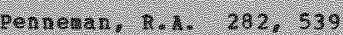

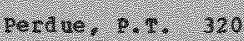

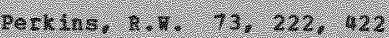

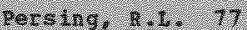

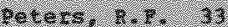

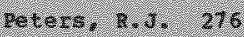

petersen. it. I. 521

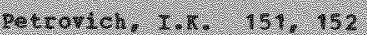

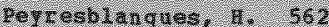

matos. 2. 490

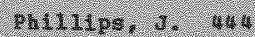

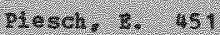

m11. A. . . 500

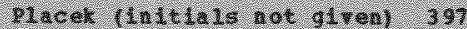

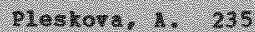


etrmok troes

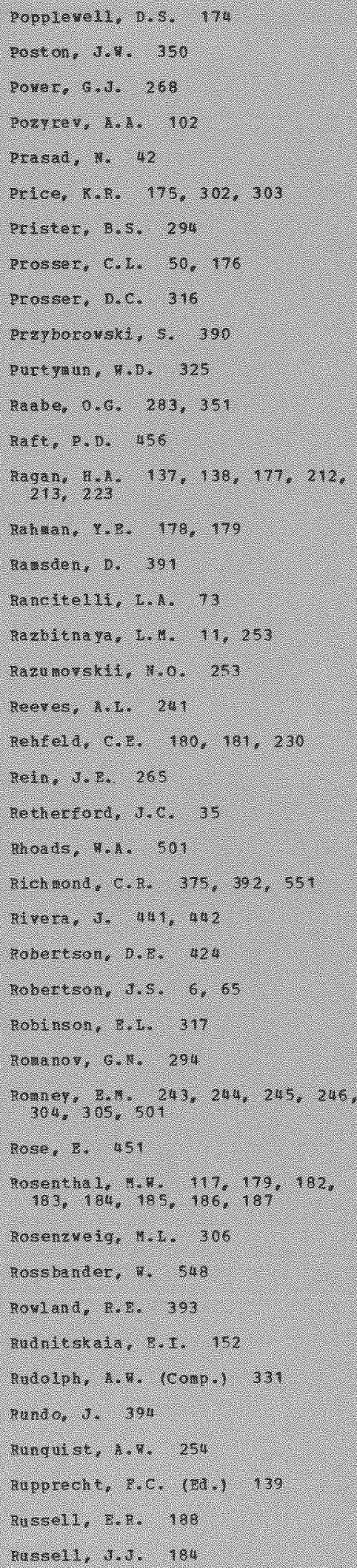

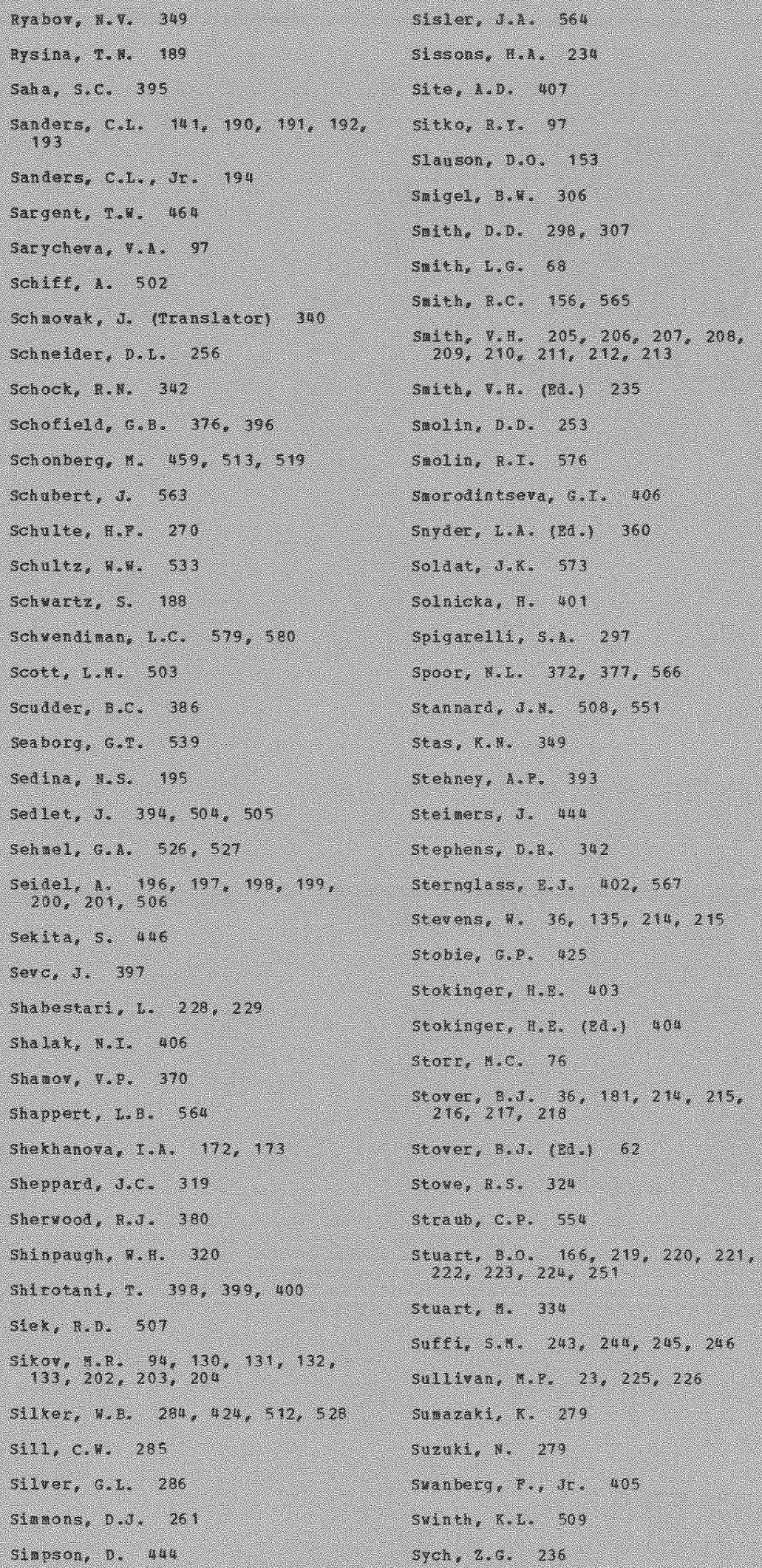

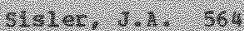

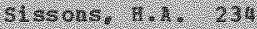

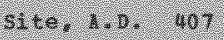

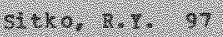

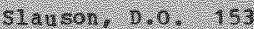

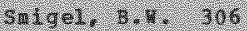

sintt. 0. 0. 298, 30 ?

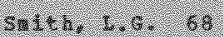

sinten: a, c.: 156, 565

saith, I, 月. 205, 206, 207 , 2018 209: $210.211,212.211$

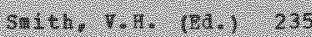

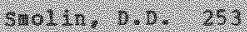

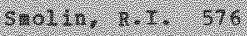

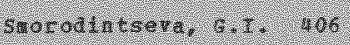

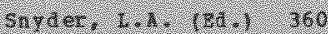

soldat: 7.16 . 37 ?

50Inicka, I1: 401

spirare11. . 5. 1. . 297

spoot, if. I. : 172, $377,5,66$

Stamnard, 3. H: 808 , 551

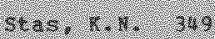

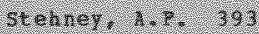

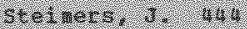

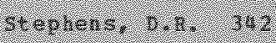

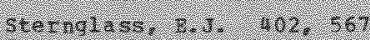

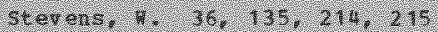

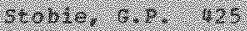

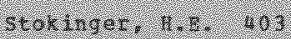

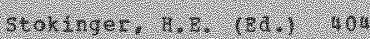

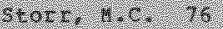

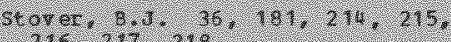
$215: 217,218$

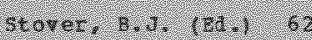

stowe. : $: 5.5 .52 .32$

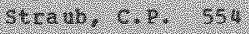

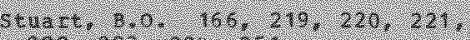
$222.221,2,213,251$

3tinat: : at: 3

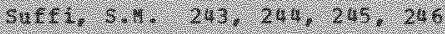

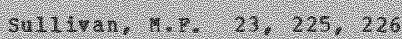

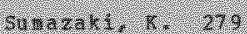

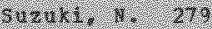

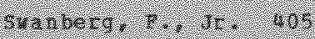

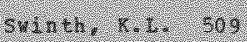

s.ret. 2: 6. 23 


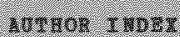

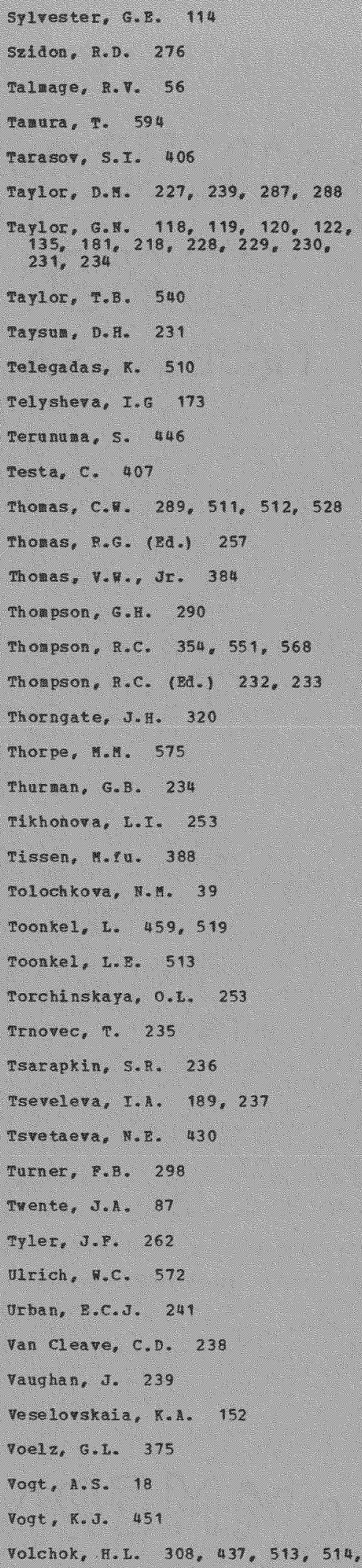

mood: 2.: 1.: 501

1 -

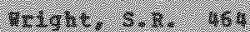

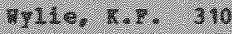

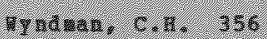

rask or 6. 1.2.2. 406

tates: C.tin: 56

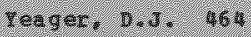

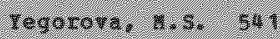

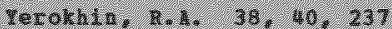

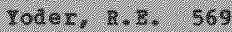

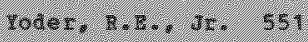

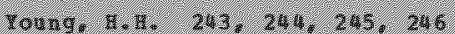

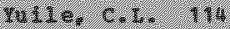

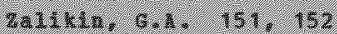




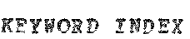

ABDO成等 70

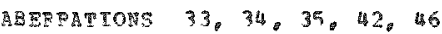

ABSORPT Ton 7, $9,15,25,39,50 \%$ $67,96,131,137,162,205,211$, $233,240,245,357,360,377$, $379,390,400$

ACCPERATOPS $412,420,475$

ACCIDEN 47, 314, 326, 332, 35\%, $371,373,375,377,378,380$, $383,385,392,796,405,407$. $410,469,514,545,548,556$, $557,558,559,560,562,563$. 569,573

ACCTDEN" POTE

ACCTDERTS. STHULAGED 579,580

ACCYHULATOH 10, $14,16,18,26$, $37,95,97,115,124,125,943$ $172,178,193,206,237,294$. $, 406,501$

ACPTHIDSS $292,275,291,465,532$ ACBIVATION 226

AC

BDREAL ELANDS TH, 29, 31, 197 . 214,229

ADSO शำ TOH 172

Bgosots $2,9,31,32$, औ, 52,53 $54.55,72,7498,99,114,12 \%$ $13 \% 149,153,15 \%, 163,168$. $169,171,193,194,29,220$. $\begin{array}{lll}169,17 \%, 193,194,29, & 220 \% \\ 330,347,348,351,368,388 .\end{array}$ $330,347,348,351,368$.
$390,391,428,4 \%, 548$

AG $94,127,130,131,132,133$ $203,230,232,233,233,239$, $298,303,397,466,568$

AGING $776,217,366$

AGRICULTUER 294,498

到 $53,99,165,251,267,29 \%$ $315,322,323,326,332,34 \%$, $35 \%, 359,369,372,374,387$, $403,405,13,45,416,517$,

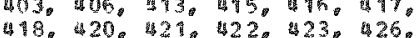
4 $18,420,421,422,423,426$, $429,40,432,435,43 \%, 38$.

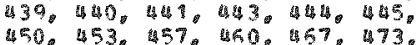
450, 453, 457. 46. 450, 47.

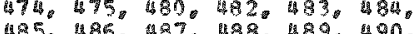
$45.48,487,488,48 \%, 490$, $492,493,404,496,497,498$ $503,504,505,507,511,512$ $513,515,515,517,518,58 \%$ $520,526,536,542,544,554$. $550,566,573,581,55$

ATRCRAPT 432, 439, 458, 473

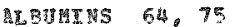

A 6 , 295,309

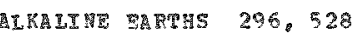

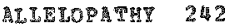

THA PATCLES $3,7,31,54,56$ प2, $78,83,84,87,89,91,1030$ 136. 149. $157,776,180,199^{\circ}$ $231,239,256,261,262.259$. $273,27 \% 29,281,289,330$, $332,34,344,34,399,383$,

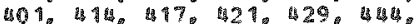

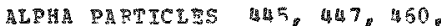
455.469 . $483,485.485,489$ $520,522,524,525,53,549$

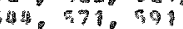

ALTITUS 292

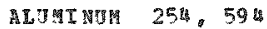

A

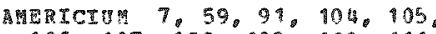
105.107.108.109, 110.111 $112,13,292,390,702,357$ $383,524,539,573$

A

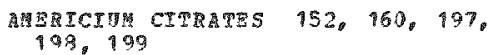

A

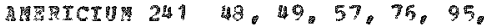
97, 118, 119, 122, 123, 149, 150 $15,152,158,160,175,197$ $198,199,200,201,22 \%, 229$. $237,244,245,24,256,296$. $289,30 \%, 304,308,31 \%, 37$. $326,332,350,352,370,379$, $396,396,399,407,413,43$. $452.45,505,509,530,535$ 546.548 .577

APERTCTUM $243 \quad 256$, 465

ARTHO ACTDS 189

AMONIU 124

AMP

AHI

ATTRAS $2,3,4,5,6,7,9,10$, $11,12,13,14,15,75,97,18$. 19, 20, 21, 22, $23,25,26,27$, $28,29,30,32,33,3 q_{0}, 35,36$,

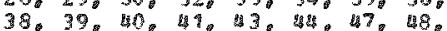
$49,51,52,53,54,55,56$. $57,58,59,60,51,62,63,64$, $65.67,68,69,70,71,72,74$. 7 79, 79, 90, 81 $82,83,8$

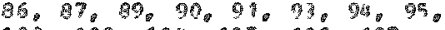
$100,102,104,105,106,107$. $102,109,110,111,112,115$

$115,117,110,119,120,121$,

$12,123,124,125,126,12 \%$ $122,123,124,125,12,12 \%$ $128,129,30,131,132,133$ $134,135,136,137,133,140$

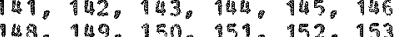
148. $149,180,151,152,153$. 170, 1720973.174 $775,879,178,179,122,183$ 124. $186,188,189,190,191$. $192,193,194,195,196,197$, $199,90,200,201,292,203$. $204,205,206,207,20 \%, 210$. $211,212,218,219,2160217$. $29.219,220,221,222,223$ $324,225,226,228,22 \%, 230$,

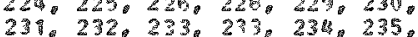
$236,237,23,23,239,230,24$. $250,251,294,295,298,300$ $301,302,305,306,30 \%, 3130$ $325,330,331,34,352,354$, $360,363,3640366,378,383$

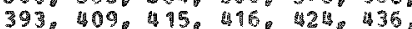

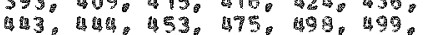
$501,506,508,533,55 \%, 563,560$

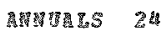

AVTI IODT 256
A

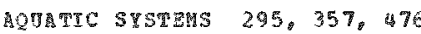

ASBESTOS 2. 191, 409

ASHIMG 1

ASSI ATIATION 302

A7TOEST:5 377, 384, 392, 396, 497

8ABooks 48. 49, 142, 313

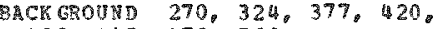
$429,445,473,568$

BACTERIA 156

BALEOONS : $39,441,455,357$

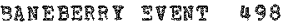

BASIDE 294

BALIU⿴囗十⺝木 139

BA⿱乛龰บM $137 \quad 449$

BAEIU⿴囗十⺝

BARI 249,252

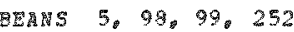

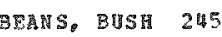

gEES 436,443

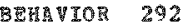

BETEICIAL USES 31\%, 312, 313. $319,353,365,431,466,534$.
535,43

BEHTHOS $295,308,404,505$

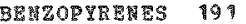

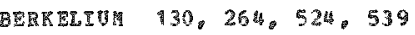

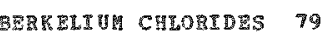

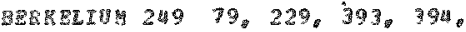
题 6

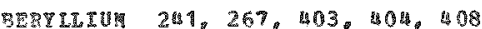

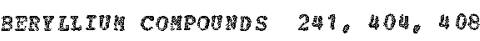
BERT ILIIU⿴囗十 72,513

BTE PARTCE $31,72,103,126$ 136. 176. 180, 262. 26\%, 294. $347,417,429,421,423,429$. $444,446,465,480,482,485$. $488,489,493,496,520,522$.

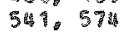

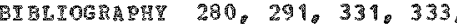
$336,337,37 \%, 383,438,49$

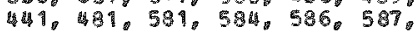
$599,590,593$

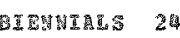

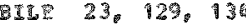

BIE DUCT 23

3HDIMG $20,145,163,188,214$, $227,239,253,287,298,355$

BIOASSAT $273,274,397$

B 
REYHORD INDEX

BIOGEOCHEMTSTY 360,424

BIorvareators 436

BIOCOGTCAL FUUIDS 20,283, 453

BIOLOGTCAL, EALF-IIPE ?. 10, 33 。 $59,79,120,121,125,143,1440$ $213,237,372,377,399,394$

BTOLOGICAL WATERTALS 44, 258,267, $268,271,275,279$, \& 30,538

Bromass 301.304

BTOSPHEP 115,360

BTOSYNTHESTS 29,95

BIOTA 422, 424, 436

BIRDS 495, 495, 417, 423

GISMOTH 214462

BIAST EEFECTS 305, 307

BSOOD $8,18,22,34,59,75,80$ 93. $116,117,151,160,163,176$, $188,190,214,258,287,357$.

Buon cerrs 59,95

ELOOD CELLS, RED 4, 90, 93, 105 , 236

BLOOD CEILS, MRITE 58, 90, 105. 152, $150,179,188,223,236$

BLOOD PLASMA $20,71,197,214$, $216,258,355$

BLOOD PLATELETS 58,177

$\underset{355}{\text { BLOOD SBRE }} 20,51,64,155,283$.

BLOOD VBSSELS 4, $80,158,220,229$

BODY $3,13,15,92,120,121,149$, $306,323,370,371,377,394$, $400,413,45 \%, 54 \%, 546$

BODY GUPDEY $22,33,48,86,934$, $167,168,169,170,183,193$, $194,273,294,357,356,372$, $375,378,380,388,392,393$. 396. 405, 407, 45\%, 497, $500^{\circ}$

BOHE FRACTIRES $88,115,181$

BOHE HARROW 18, 31, 35, 88, 89, $90,109,151,182,184,187,228$ 236,239

BONE REODELIR 86

BONES 7, $8,13,11,18,19,22$, $25,26,27,39,33,35,38,39$, $40,48,50,56,57,59,60,61$ $63,56,74,76,78,79,84,82$. $83,84,85,86,87,88,95,96$ 103. 107, 190, 112, 193, 196, $118,19 \% 121,122,124,125$,

$126,131,133,135,136,13 \%$

$138,143,148,955,149,151$.

$158,153,158,160,161,167$,

$169,177,180,181,182,183$,

$169,177,180,181,182,183$.
$184,185,185,18 \%, 190,192,8$

$193,190,199.200,201.203$,

$205,206,207,215,224,227$,

$228,234,237,239,240,299$

$261,287,295,330,350,354$,

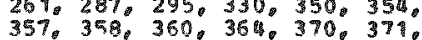

BONES 372, 393, 396, 400, 402, $430,438,439,480,508,563,568$

GRADYCARDTA 152

BRATN 122,195

BREMSTRRALUIF 37

BUTEDTGS $320,507,542,561$

BHRDER 22, 34, 54, 120, 122, 14 $153,194,205,239,452$

BURIA $303,574,575,595,592$

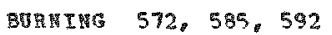

CABRTOLET ETERT 453

CADUIEA $109432,441,455,510$,
$515,516,517,519$

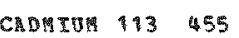

CAECTEICATON 76

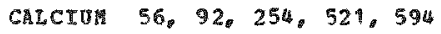

CAICIU⿴囗十⺝ DTPA 20, 174. 197. 198. $200,201,20 \%, 210,240,240$

CACCIU⿴囗十⺝木 EDTE 385,386

CALCINH 45

CALCIOU 4776 CALCELATIOS 124, $294,310,399$.
$358,400,413,466,555$

CAIIURATION 391, $398,400,509$

CALIPORRION 5\%,264, 524,539,546

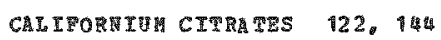

CALIFORTU1 $24958,120,121,122$. $229,234,393,394$

CARTORYTOH 252 5, 6, 42, 51, 58, $65,120,121,122,143,164,225$, 226, $231,311,312,319,333$. $353,431,465,532,534$

CARBOHTIDATE 259

CAROM 329

CARON DTORTDE $1,248,447$

CAREON TETRECHORTDE 116

CARBOH 14 \&1, 478, 41, 555

CARCT WOGTHETS $3,62,66,84,129$.

150, 199, 192, 194, 227, 231

$232,233,241,324,366,382$. 41. 508

CAMCTHOGENS 33,129

CACIMOMS $66,169,191$

CARCI WOHAS, ADENO 17, 129, 142

CANOTITE 220,224

CARTIATE 229

CASE HISTORIES $373,374,375,380$, 393.563

CA

CATTER DATRE 67, 307
CATTLE, RAYGE 307

CERE NUCLEI 84,145

CELL ULTRASTRUETURE 4, $28,36,178$

CELLS, ALVEOLAR 4, 9, 54, 72, 189.

CELLS, BTOLOGICAL 2, 5, 14, 28. $37,47,42,46,56,79,80,83$ $+6490.92 \% 94,95.145,162$, $\begin{array}{ll}54, & 179,189,229,235,236,\end{array}$

CELLS, CULTURED $42,65,66,72$,

CER E, HELA 5, 174

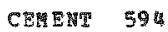

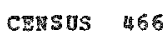

CERTUR 31, 253,580

CERI IU⿴囗十丁 5

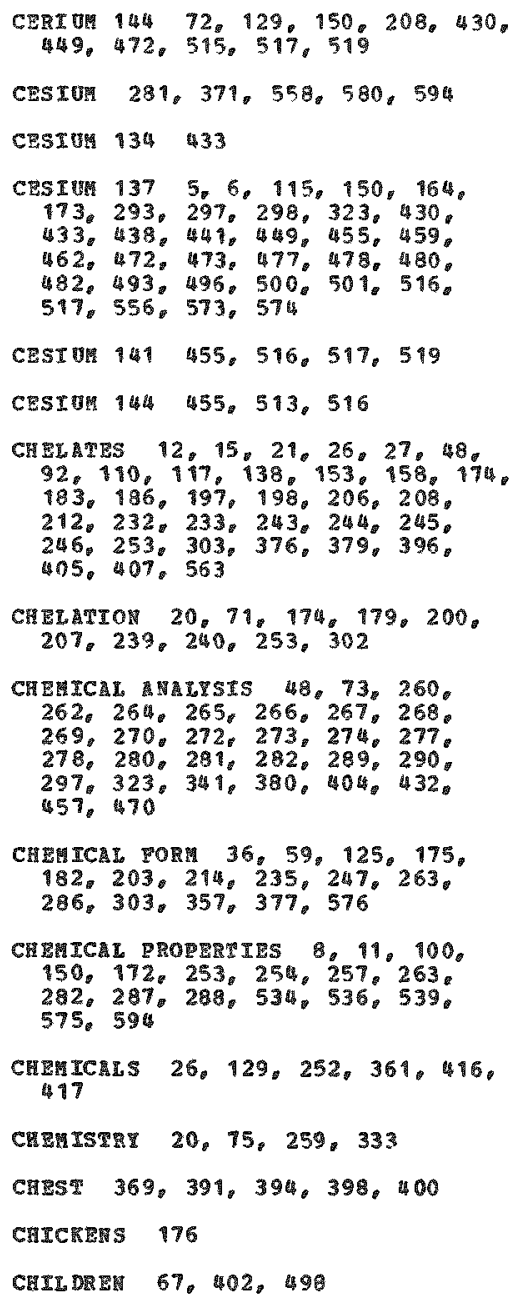




\section{REYพORD INDEX}

chPonIOM 2, 277, 429,484, 494

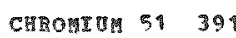

CHROMOSONES 33, 34, 35, 42, 46, $65,393,396$

CHYMOTIYYST 138

CIRCULATORY SISTES $31.75,150$, 319

CTTRATES 33, 208, 214, 229, 231。 354

CZASSIEICATYOH 481

CLAYS 72

CLEARA MCE $9,19,12,15,21,27$ $33,117,143,144,159$ ? $188,192$. $206,215,239$

CLINTCA STVDIES $8,73,97 \% 163_{0}$

$239.287 .317,346,353.3540$

$355,356,357,369,370,371$

$375,377,381,384,386,388$

$390,393,394,397,398,400$,

$463,469,478,497,563$

CLOUDS. RADTOACTIVE 476.498

CORI 409

COBALT 277, 281,293,594

COBALI 60 89, 280, 323, 424, 433, 486

COCARCTHOGENS 232

CORNzTrSS 29

COLLOTDS $98,178,202$

COHMUITISS 45

COMPARTMENTS 200

COMPI $288,302,303$

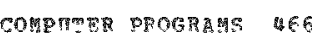

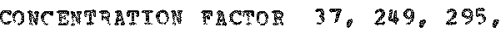
3ns, 325, 424, 500

CONCRETES 320,978

CORABCTIVE TISSUE 122

CONTAIRES 592

CORTAI V.

CONOPATHAT ON 15, 97, 146, 156. $294,296,30 \%, 314,315,320$, $325,325,332,333,357,373$,

$374,376,381,383,396,426$

$443,48,454,524,545,546$

$547,548,554,55,560,564$

$547,548,5$
$57 \%, 592$

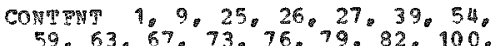
$59,63,6,73,76,79,82,100$, $101,103,117,121,122,125$ $128.133,130148.169 .171$. 184. 189. 197. $201,202,205,206,214,215$ $224,228,229,237,244,245$ $248,249,265,266,276,279$ $284,285,285,294,295,302$ $303,304,308,325,32 \%, 329$ $332,334,335,340,34,342$,

$348,356,358,368,370,371$

$372,374,379,392,393,394$.
COWTENT 396, 402, $403,406,412$. 413.414,45, 417, 49, 42.

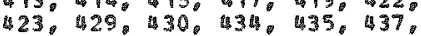
$443.444,449,450,452,453$. $454,455,460,492,473,474$. $475,476,479,482,484,495$. 480.487 .489049004940492

485.497 .489 .490 .491 .492$,

49. 49, 496, 498, 499, 504.

$505,510,511,512,515,516,5$
$517,520,541,54,563,578,59$ Cortrot $165,194,391,524,547$.
$569.585,588$

COPPR 293

CORHL 328

CORMOSTON $309,572,592$

$\operatorname{COST-BEVEFIT} \quad 327,569,572$

CRA 500

CRATERS $334,335,339,453$

CREOSOTE BUS $292, \quad 301$

CRITICAL ORGA 508

CRITICALI票 524

CRTTICTSM 3, 454

CROPS 294

CRYSTAL COUHFERS 346

CULTVR YPDIA 152,362

Cogrut 7, 282, 302, 357, 524, 539, 546

CURIV $242290,308,505,509,530$

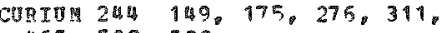
$465,509,532$

ECETHG $115,360,424,501$

CYSTETHE 361

CMOLOG 4

Cquste 100

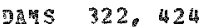

DAT TRG 340

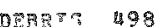

DECR 498,524

DECAY PRONDCTS 222, 401, 525, 41 。

DECOMPOSTTOM 447

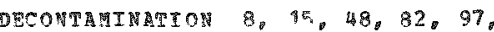
14., 148, $151,9 \varepsilon_{3}, 174,179$

186, 197, 198, 200, 207, 208,

$232,233,347,384,373,393$.

$394,396,407,550,557,559$.

559,569

OPT $307,482,498,499$

DPRY DROFENASES 177

DERSTH 292, 304

DEPOSTTTON $7,9,10,14,29,32$, $35,36,48,54,55,74,81,98$, 110. 112, $113,122,143.144$.
DEPOSTRTON 208, 215, 219. 222 . $228,233,237,241,249,250$ 。 $251.314,323,326,332,358$. $370,378,395,386,390,391$. $400,405,400,435,437,456$. $462,472,476,510,511,514$

DESETS 242, 292, 296, 300, 301 . $304,305,306,501$

DESTE 80, 318. 319, 343, 351.

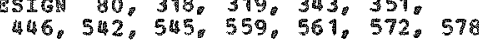

DETECTIOH $66,251,266,274,418$ DETERGEPTS 15

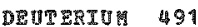

DIACARE 01.92

DIET 440

DISEASES $17,19,32,51,75,133$, $167,169,217,241,365,368$.

$381.403,404,408,409$

DISPERSION 380

DISTANCE, INTERPER SONAL 466

DISTRTBUTION $7,93,14,16,18$, $22,25,33,35,35,36,37,49$. $87,92,94,102,115,119,119$ $121,122,124,133,135,143$, 14. $451,152,153,161,170$,

$174,178,184,192,196,199$.

$202,203,204,205,214,229$.

$239,241,249,254,299,29 \%$

$302,325,326,329,332,334$,

$335,350,352,354,357,370$,

$377,390,391,402,28,441$,

519,551

DISTARBYTON, GEOGRERTC 292. 304. $437,454,498$

DNA 45, 95, 190, 101, 162, 189,

Dhaso 154

Dogs $7,20,29,51,57,59,64$ $75,80,88,114,136,151,152$,

DOGS, BEAGLE $, 10,22,32,36$ 41, 52, 53, 54, 55, 58, 59,60, $61,65,71,72,85,86,87,88$, $118,119,120,12 \%, 122,135$. 139, 14\%, 153, 155, 167, 168, $169,170,171,180,181,214$, $215,216,21 \%, 218,223,224$, $228,229,230,250,25 \%, 351$, 352,354

DOST DEPEYDENC $14,62,80,118$ $160,198,199,200,350,354$

DOSE RATE $6,35,42,59,60,62$. $83,87,89,90,103,132,136$. 164, 175, 192, 239, 399, 310. $319,324,377,402,413,425$. $431,470,478,521,524,530$, $541,555,565,575,215,508$

DOSI UETERS $419,451,462,553$

DOSI UEFER, BIOLOGTCAC 350

DOSIMETRY 84 
KEYHORD IMPET

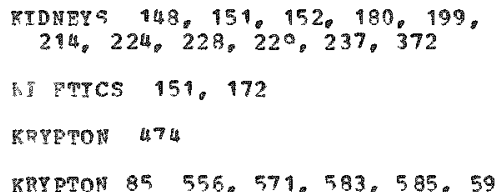

LABOEATPEY STUDTES $1,2,4,6,8$, $9,10,11,12,13,14,15,16$, $17,19,18,19,20,21,22,23$ $39,36,38,39,40,62,43.5$ $50,51,5154,56,57,59$ $50,65,64,58,71,72,74,76$, 77, 79, 80, 81, 94, 85, 86, 87, 9. 93.94 .98 .99 .101 .102 . $19 \% 18,19,120,121,122$ $125,126^{\circ}, 127,123^{\circ} 129^{\circ}, 130^{\circ}$ $13 \%$ 132, $933,134,136,138$ 139, $140,14 \%, 142,148,145$. 148, 149, 151, 151, 152, 153。 $154,155^{\circ}, 198,159,160,122$. $143,166,967,163,16 \%, 170$ $172,173,17 \%, 175,177,178$. 179, 180,181,182,183, 184, $175,986,88,189,190,191$ $300190 \% 195^{\circ} 197^{\circ} 198^{\circ} 199^{\circ}$ $10.190 .195,197.190^{\circ}, 199$ 200.201 .202 .203 .205 .206$. $207.200^{2}, 212.210 .21 \%$ $213.214,215 \cdot 221,223,225$. $226,228,229,230,231,232$. $233,236,237,239,240,242$. $24,245,248,249,252,255$. 262, $265,271,277,299,290$. $300,303,313,31,347,348$ 。 $350,351,36 \%, 36 \%, 379,391$. $414,422,465,45 \% 506,544$ $550,572,575,577,578,580,246$

บAบ บSE 322

I.ARTHANTDES 256,290

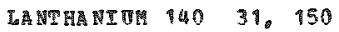

LARV $172,173,42 \%$

IaA 339

4AFRECT UR 539

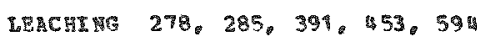
LEAD 244, 293, 438, 472,513, 517, 518,519

IEAD 210 9. 224, 252, 393, 455 $458,463,497$

TEAD $2 \$ 2 \quad 162$

LEA 294.379

IEGA ASPECTS $557,558,588$

II ET 136

ETTHAL DOSE 111, 164,203

TRTRER DOSE 50 40, 47, 89, 90。 110. 149, 152, 15\%,299,236

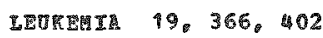

LEUEOP ETI 40,960

IITE SPE $30,32,38,40,116$. $15,151,160,221,223,298,366$ LTEIDS 75, 179, 189,259
LTOTTDS $451,465,570$
IVER 7, 8, 13, 18, 19, 21, 22 $25,26,28,33,35,36,39,48$, $50,59,61,64,71,75,79,92$. 94. 96, 100, 101, $110,112,113$, $116,120,121,122,125,126$, $128,129,133,13 \%, 13 \%, 138$, $143,144,151,152,95 \%, 160$ $167,178,176,177,178,179$ $180.103010501000198 .199^{\circ}$

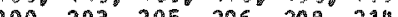 15. $224,228,229,235,237$. $240,330,354,35 \%, 358,370$ 375,396

\section{ITRARDS 298,300}

IVWGS 2, 3, 4, 7, 8, 9, 10, 17, 19, $62,72,72,31,41,50,53,93,102,114$, $12,125,134,141,142,949$, $15 \%, 153,154,15 \%, 158,167$, $15 \%, 153,154,15 \%, 158,167$, $190,192,193,196,210,219$ $220,221,222,223,224,228$. $229,237,24 \%, 250,25 \%, 287$. $320,325,326,330,346,354$, $355,357,357,358,358,369$ $370,372,374,375,45,391$ $392,397,398,390,80000506$. 409. 411,422, $430,447,463$ 897. 499

IYYPR NODES $8,10,22,31,71$ $102,114,137,138,168,169$ $97,224,229,300,372,374$. 406.508

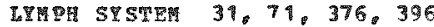

I.MPROCWTS $34,55,57,58,66$, 90, $223,250,251,395$

IYW 171

\section{LTSOSOMES 36, 178}

MACRODUAES $2,72,189,221,223$

M Gะ

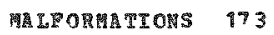

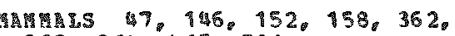
$363,364,415,501$

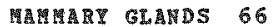

14. $20,22,32,46,65,67$, $75,97,135,136,142,146.159$. $163,174,176,234,239,257$ $258,260,267,279,293,299$ $302,314,317,320,323,324$, $310,346,349,353,354,355$. $356,357,358,359,360,362$. $363,354,365,366,36 \%, 369$ $370,371,372,373,374,375$. $376,377,378,380,381,382$, $383,384,355,386,382,390$ $392,393,395,396,398,399$ 100. 393. $395 \% 396,39.39$ $0,401.00$ $407.08 .409 .410 .41 \%$ 35. 438. 4. 446. $451,463$. $464,456,469,470,47 \%, 475$. 4.78, 480,508, 512, 533, 538. $541,547,548,551,553,559$. $562,563,564,565,566,568,573$ 487

HA

4A $515,516,517,519$

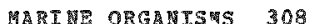

HARTNE SYSTEMS $255.269 .28 \%, 295$. $299,300,328,329,551$

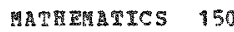

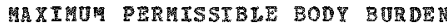
$359,387,392,405,451,549$

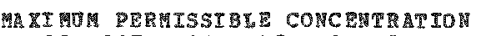
123. 387. 406, 445.481, 541。 $546,553,554,566,401$

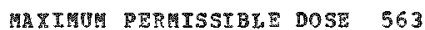

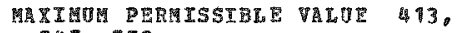
545.559

MEAN RESIDENCE TIRE 329, 453, 594, 308, 269

MEASURERETT $65,84,91,103,146$. $247,255,256,258,260,261$. $265,267,258,275,281,300$. $320,326,332,343,344,346$. $320,326,332,343,344,346 \%$ $401,406,417,418,419,427$. $401,406,417,418,419,427$,
$43,434,454,460,466,467$. 48. 506,559

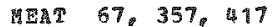

MEDICINE 146, 353,365

MEARALS 46, 92, 172, 178, 202 . 204,229

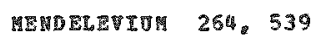

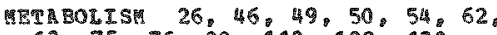
$63,75,76,88,110,122,130$, 135. 150, 463, 184, 190, 203. $206,232,233,235,239,362$, $371,372,377,508,533$

METLS 243.293

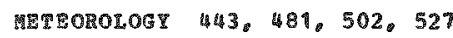

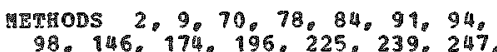
98. 146, 174, 196, 225, 239, 247 $255,256,258,260,261,264$, $265,270,279,272,273,274$ $275,276,278,279,281,282$ $285,300,344,349,351,352$. $369^{\circ} 388,389,399,400,4140$ 418, $499,422,430,445,447$ $460.44,465,468,503,506$. $52 \%, 531,55 \%, 561,576$

GICE 7, 30, 43, 59, 89, 90, 92. 166. 179, 183, 184, 185, 186, 231,393

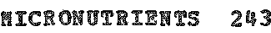

MCROORGMISHS $1,162,247,248$, 29. 362 MICROSEHERS $190,194,209,250$,
251

MIL $67,402,416,617,432,439$

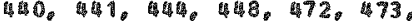
480. 482. 489. $92,493.504$. $505,556,563$

MIILI局 322, 426, 50 
IREYตORD INDER

\section{MTHEREIS 340,594}

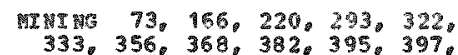
$\begin{array}{lll}333 . & 356,368,382,395,397 . \\ 401,409,41,450,460,490,52\end{array}$

MITOCKONDRIA 4. 36

MTTOSTS $33,164,236$

FODELS 225, 324, 357, 358, 371. $38 \%, 388,390,399,498,502$.
$508,573,592$

MODELS, MATHRATCAL 89,90, 162, 527

MOISTURE 320

ROLL 1855

MOLY EDEYUR 294

MOXIFOPIWG $53,54,446,163,273$. $315,323,338,348,349,400$. $415,416,418,420,423,424$. $425,435,436,440,450,444$ $470,473,474,475,476,479$. $480,482,483,484,485,485$. 部8, $500,503,504,505,507$. $48,500,503,504,505,507$.
$518,520,536,545,54,548$. $518,520,535,545,546,548$,
$553,556,557,559,568,575,581$

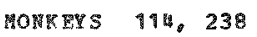

wonomps $33,36,92,94,117,182$, $183,184,203,214,228,354$

MOPPHOLOGY $29.150,151$

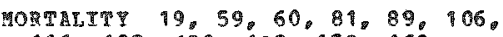
$11 \%, 123,130,133,159,160$.

170, 173, 176, 192, 217, 219.

$324,356,397,402$

MUITICHA

MUSCES $75,96,146,184$

MISSIS 308

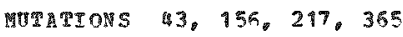

WATYMAT, GRS 333

HEOPIASHS 5.7.40,59.114, 116.

$\begin{array}{lll}128,129,136,149,169,170, & \\ 175,180,183,185,193,330,568\end{array}$

MPOPLASHS, BHETE 38

NEOELSMS。 MATGMAT 17, 19, 38.

$130,142,158,192,194,217$.

$324,353,356,365,367,368$,

$382,393,397,411,48$

NEFHRY 575

YEPTทกTU 291, 302

WEPT UNTYM CTIRATES 206

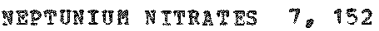

NEPT U1T 237 14, 28, 149, 150 。 $152,175,202,300,505.509$. 533.535

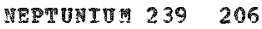

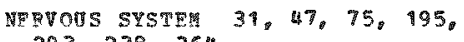
$203,238,354$

ИEUTEON RCTVATION 73, 294, 374, 422,501

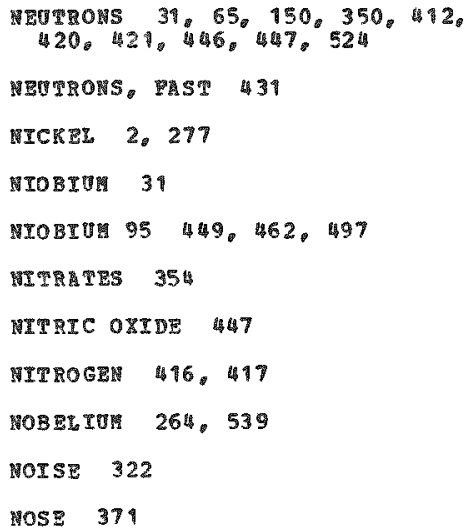

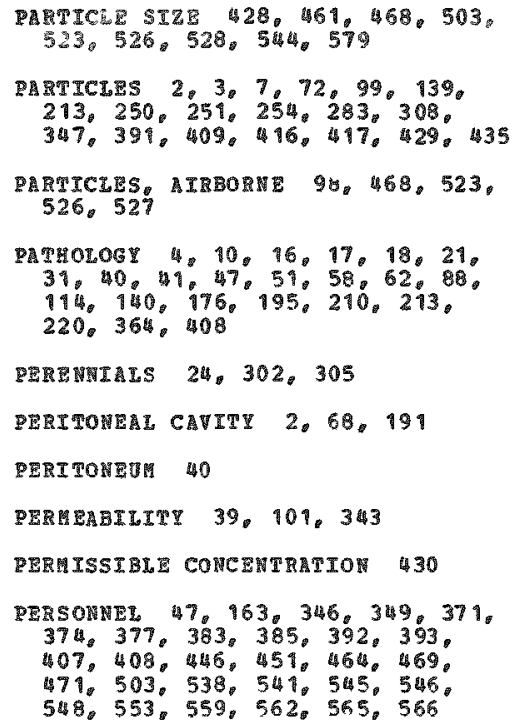




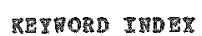
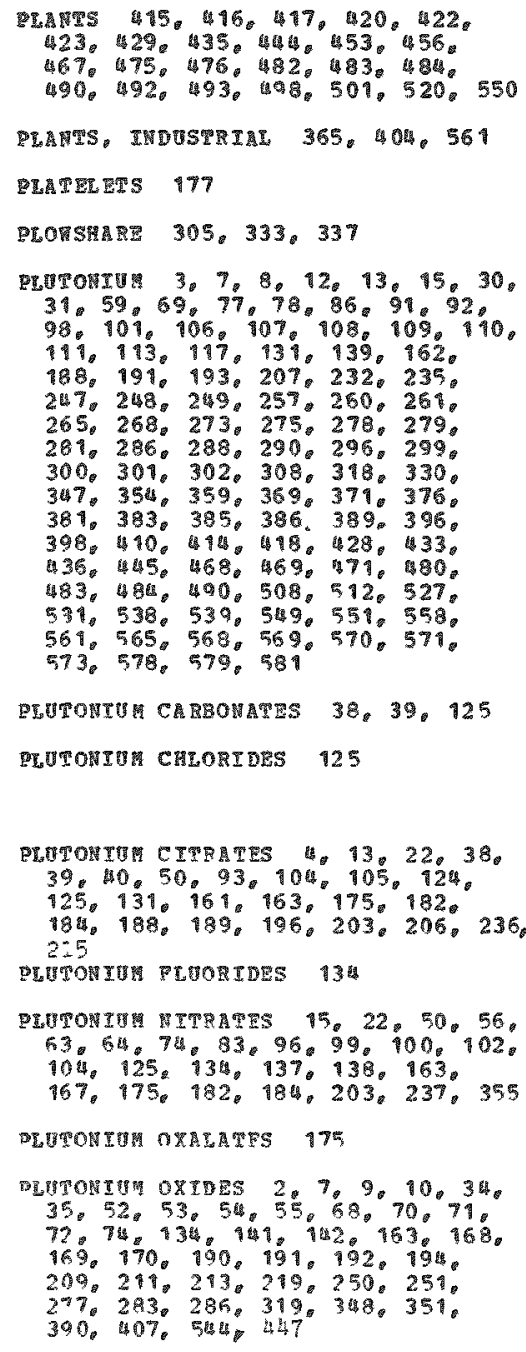

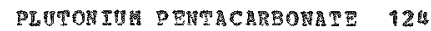

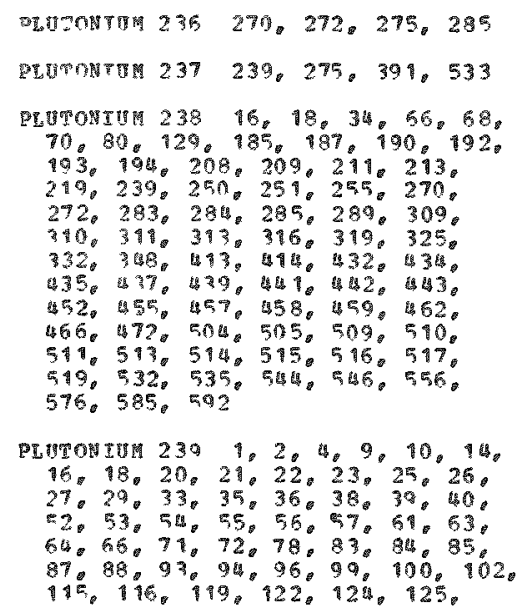

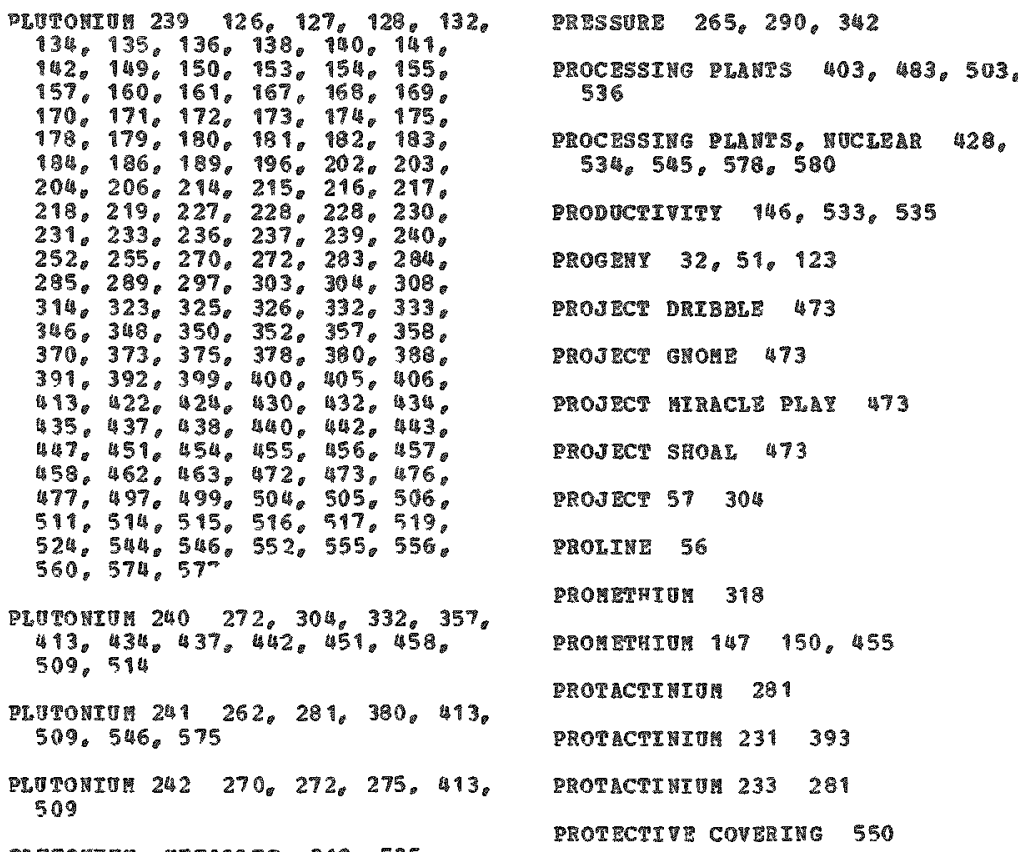

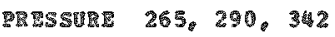

RROCRSIHG DIAHTS $403,483,503$ 536

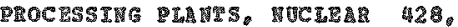
$534,545,578,580$

RODUCRTER $146,533,535$

DOGE $32,51,123$

EROJ

2ROJ ECT GNOME 473

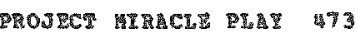

POJEC SHORE 473

2RO3 ECT 5\% 504

POLIHE 56

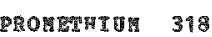

FEO

PROTHCTT

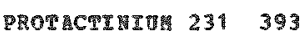

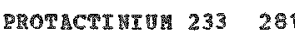

PROT ECFIV COWERTG 550

PसOT $18,189,216,227,259,287$. 288,355

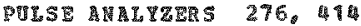

RABBTS 63, 64, 100, 152,154 176. 182, 184, 498

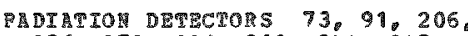
$256,279,281,319,344,345$. $346,348,350,370,373,391$. $400,412,422,45,463,465$.

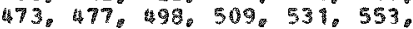
$557,55 \%, 550,581$

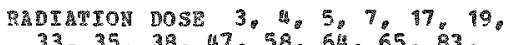
$33,35,38,67,58,64,65,83 \%$ 64, $89,90,103,191,114,123$ $126.12 \%, 128,133,83.136$ $149.150 .15 \%, 155,159.160$ $162,171,181,191,193,194$ $314,320,323,357,358,371$. $374,385,411,417,420,4210$ $435,438,466.451,462,466$ $473.45,455,486,492,495$

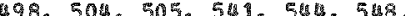
$55,556,562,565,568,573,487$

RABTATON DOSTERTE $76,319,345$.

RADIATOR DFECTS $3,4,5,6,7$ $16,9,28,29,30,31,40,42$.

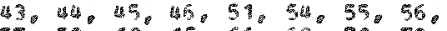

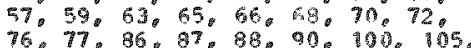
$105,10 \%, 108,109,110,11$. $118,115,123,126,12 \%, 133$, $136,130,160,150,151,154$, $157,159,160,162,163,171$ $176,180,181,185,213.21 \%$ $219,220,225,225,230,231$. $232,233,236,238,239,259$. 280, 294, 298, 305, 313, 314, $324,362,364,365,378,3810$ $382,392,396,397,402,466$, $199,213,215,217,231,294$. 
KEYMORD IWDEY

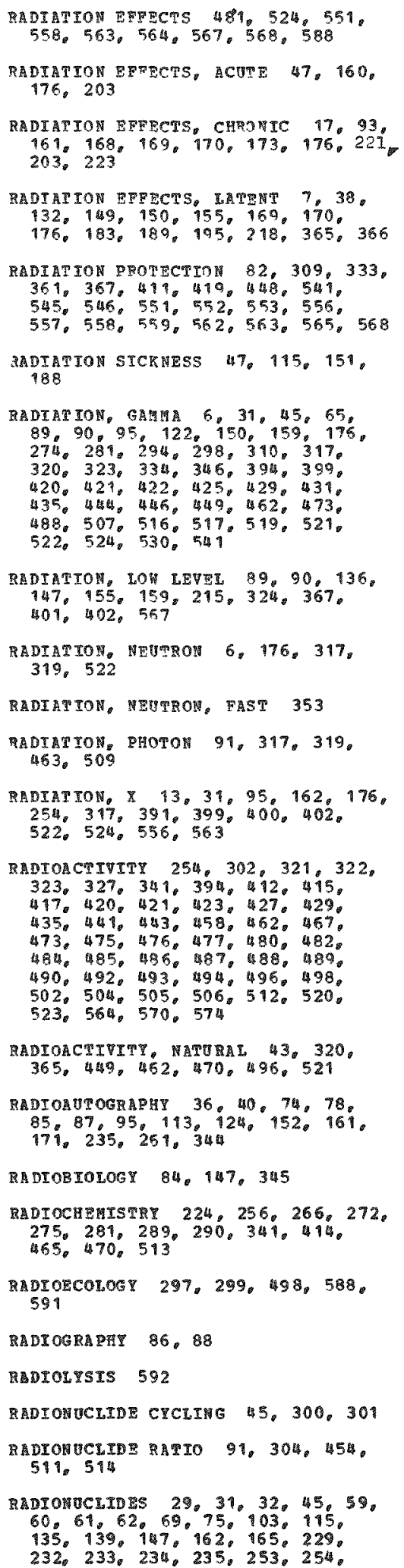

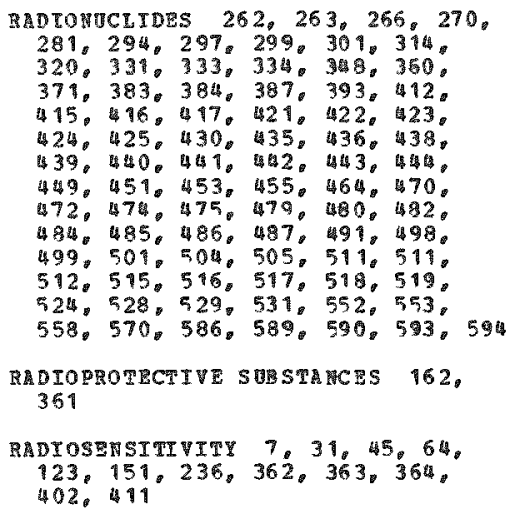

RADIOTHERR PY 65

MADTEI $30,31,42,231,354,37 \%$ $393.412,508$

RADI YM $224136,230,382$

RADIJ $226,29,57,85,87,88$, 136. $140,180,181,217,218$, $225,230,293,382,425,449$.

BADOY $220 \quad 393$

RADOR $222382,401,49,460,521$

RRRE EARTHS $150,235,281$

RATES 171,512

RATS $2,3,4,7,11,12,13,14$, 15, 16, 17, 19, 19, 21, 23, 25 $26,27,28,30,38,40,50,50^{\circ}$ $61,74,76,78,79,81,82,83$, 33, 94, 95, 10\%, 102, 104, 105. $106,107,108,109,110,111$, $112,114,116,117,123,124$ $125,127,129,130,131,132$. $125,127,129,130,131,132$, $151,152,157,158,150,16 \%$ 163, 166, 176, 178, 189, 190 $191,192,193,19 \%, 195,196$, 197, 198, 199, 200, 204, 202。 $203,204,205,206,207,200$ $210,219,222,238,237,240$ 354. 366

RATS, JUVERTE 76

MLTS, 罢A

2EACTORS 19., 280, 302, 314, 322 $473,475,490,536,538,539$

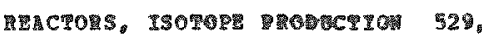
535

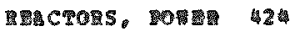

REACFORS, RADIONECLIOTS 530

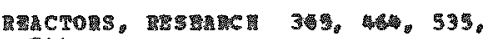
54

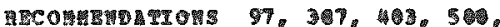

RECOMUENDATIONS $540,543,566$

RECOVERY 5\%,90, 154, 164

REDISTRIBUTYON 303

REGENERATION $4 \%, 235$

REGULATONS 566

FEGULATIONS, PEDERAL 503,585 REGULATEONS, INTERMATONAI 503 REGULATIONS, STRTE 585

RELATIVE STOLOGICAL EFPECTIVENSS $5,6,42,57,65,160,164,225$, $353,387,431,566$

RELEASES, AIRBORHE 579,580

RELEASES。 CONTROLIED 332,580

REPROCESSING 537,565,591

REPROCESSING PLAMTS 562.571

TRPRODUCF TOH 298

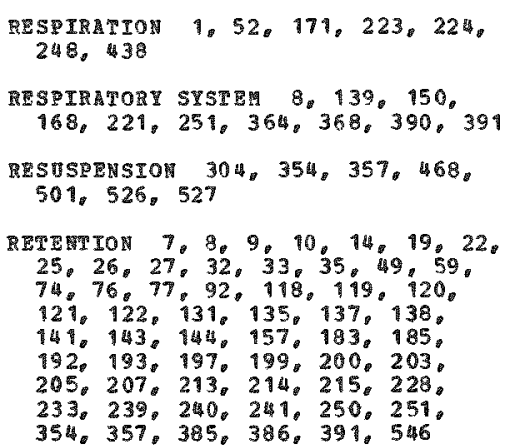

TIVTS $299,416,417,423,424$ $444,470,475,482,464,485$. $436.480 .492,43,496,504$.

กำ 101, 129, 259

RU1 154

recrs 339, 340, 341, 550

RODEATS 32, 135, 136, 306,325, 
REYMORD INDEX

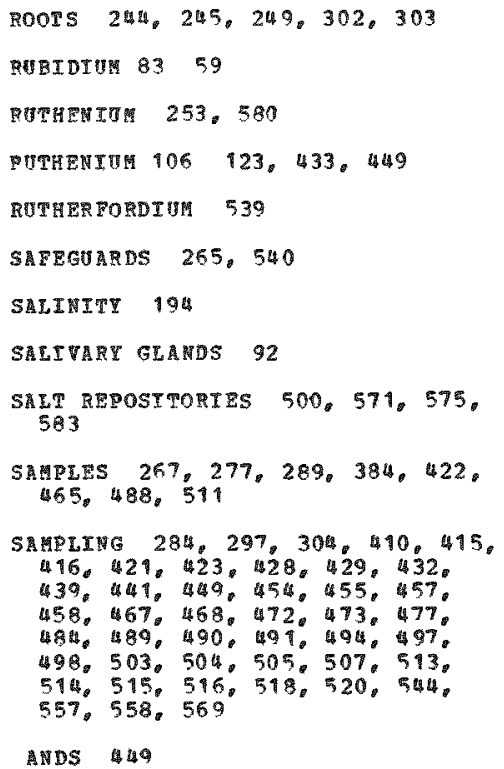

SHTELDTHG $310,400,545,559,565$

\$HOOTร 175, 249, 303

इसकास: 29\%, 292, 296, 301, 304, 305

SIIICA 254, 395

SIL ICON 277

SIIT 420, 487, 500

SILVER 78

SILER 110 433

STMบลTION $20,166,283,391$

STI EVALETION $304,315,323,500$

SIZ 32, 93, 148, 306, 400

SET 3, 6, 7. 8, 39, 38, 39, 51. 77. 78, 96, 97, 126, 127, 120. $205,325,364,381,41 \%, 555$

SMORB, CIGARETTE $41,223,224,409$

SHAP $3: 6,332,437,512$

SNAP-9A 441, 452, 459, 511, 594

SODIu用 $75,226,339,594$

SODTUM CARONATS 75,82

SODIVI CITRETS 240

SODTH: $22 \quad 412$

SODIy 2431

SOII PROFIEE 53, H5

sor.s 146, $175,242,247,248$ 249. 252.255.271, 275. 278 $285,293,294,295,296,300$. 301, 302, $303,304,320,323$. $326,331,332,334,335,357$. 360.412, 414, 415, 416, 417. 418.420,423,436,437, 443. $446,49,454,462,467,473$. $475,476,480,483,484,485$. $493.54,501,504,505,520$. $536,550,573,577,594$

SOIL5, CALCAREOTS 244, 246, 379

SOILS. SAMDY LOM 296

SOIIS, SIL EOAR 1,9

SOLOEIITT $1,7,11,125,153$. $209,248,249,283,357,377$. $387,389,391,407.661$

SOL 19: 194

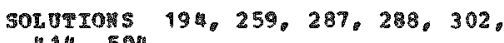
1) 594

SOLV

5ORETIOH 594

5OFEAM 246.303, 379

SPECTIC ACPT ITI 66, 244, 524

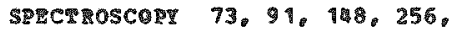
277.320 . 45. 462, 465

5EECT:OSCOPT, ALP 279,419

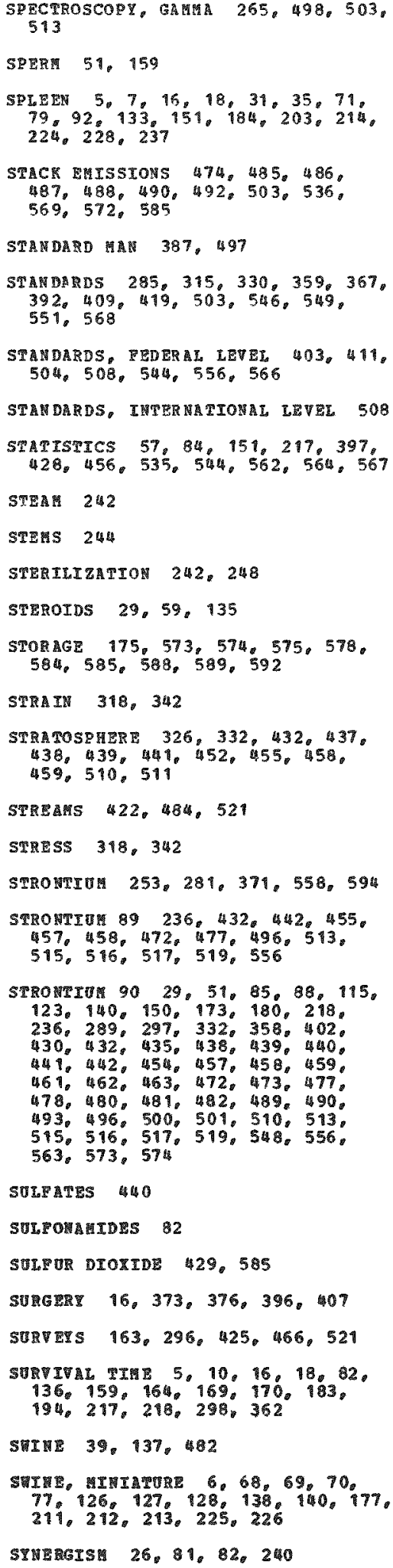


RETYORD IHDER

STMTIESTS 101

TAGIMG 165, 306, 391

TAIIINGS 26.507

TRGET THEOM 362

TAUTIN 55

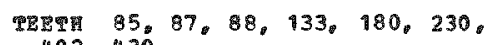
402,430

TELETRTH 294

TEMPERATERE 137, 138, 148, 233, $292,301,313,318,491,542$

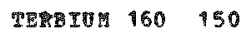

TER R A 550

TERRESTRIAL STSTEMS $24,45,292$. 295. 298, 300,301, 302, 304, $338,357,420,436,440,453$, 475,501

TEST $31,33,123,364$

THALIIU $204 \quad 127$

THEORETICAL STUDIES $198,217,286$, $314,324,398,400,502,525$. 531,565

THERAPT $5,12,20,21,32,48,71$, $75,112,117,137,139,141,141$. $145,153,158,174,179,183$. $185,186,206,207,208,364$, $373,376,383,385,386,396$ 。 $405,407,408$

THER HOLUMIRESCERT DOSTHETERS 446 , 538

THISTTES, RUSSTHN 305

THORAX 6\%, 70

THoRIU $285,320,42,44,485$, 505.558

THORITY $22829,57,85,87,88$, $136,180,218,393$

T\%O TUM $230 \quad 222,224$

TYORIM $232 \quad 382,449,462$

THORIU1 234275,525

TPYORON 445

THONOTRRST 382

THY IDITE 56

THYศ 31

THYROTD 121, 122, 197, 214, 229, 317,498

TI

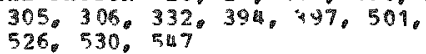

TTSSUES $3,7,10,19,18,19,220$ $27,37,40,47,59,59,62,55$, 12. $73,75,79,85.87,92,110$ $160,16 \%, 170,184,202,205$, $160,166,170,184,202,205$,
$207,208,219,213,214,223$. $229,233,237,325,350,358$ 。 $364,369,371,392,394,377$.

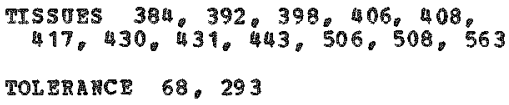

TORICOROGI 8

TRACE FLEMERT 328,512

TRRCER STUDIES 94, 95, 146, 255。 $256,270,272,276,285$

TRRCERS 270, 279, 289, 465,510

TRA

TMEA

TRAMSPERTIN $36,71,214,227$

TRAUSLOCATION 7,8,9, 10, 61, 71, 125, 131, 138, 167, 168, 190, $245.247,249$

TRA $\mathrm{S}$ S 1 UTATTON 531

TREA

TRAASPLUTOMIIY EL EMENTS 232,274, $297,311,332,465,524,531$

TRAMSPORT $71,72,202,204,239$. $245,295,297,300,302,303$. $325,332,334,416,423,454$ 。 499,536

TRAMSPOR TAPION $162,315,559,564$

TRA AS URA IC ELEMETS 7,357

TRARSORANT UM EL EMARS $57,97,149$, $150,152,175,235,273,289$. $302,303,309,330,370,383$,
$471,506,508,529,532,537$, $539.543,545,546,551,569$ $575,578,585,592$

TRA 392

TRES 291,443

TRIAITITE 323

TRIMITT SHOT 323

TRITI $37,123,146,148,150$ $281,322,334,335,371,412$, $421,435,443,444,451,453$ $473,474,482,489,499,495$ $536,556,558,579,581,583$. 585,591

TRITIUU ORIDES 474,482

PRITIOU⿴囗十 $90 \quad 490$

TROPOSPRERE 432,448

IROUT. RAINBOW 159

TUF 339,342

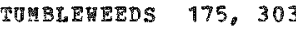

TUMOHIGE HESTS $65,132,147,150$, $192,239,366$

TणY A 308
Tण

พข

TVRMOVER 146

TOMTLS 44

VLTRAIITRATION 20,117

VLTERSONICS 369,391

UPTARE 56, 63, 96, 148, 175, 182.

$227,235,240,244,245,246$ 。

$247,249,252,294,299,300$.

$301,302,303,304,328,357$,

$360,384,453,501,577$

TRA IU⿴囗十⺝ $11,31,41,73,75,81$

82, $114,165,195,212,220,221$,

$222,223,224,232,233,253$ 。

$258,263,271,278,289,285$.

$293,295,299,320,322,329$ 。

$356,369,37 \%, 377,382,383$,

$395,397,401,407,409,411$.

$426,43,444,450$, 460, 463.

$470,483,484,485,490,494$.

$503,505,507,523,538,549$

$558,56 \%, 573,578,579,580$

ORAIIUH OXIDES 114, 372, 574

UR丨 233202,465

ORA IIU $234224,269,328,329$,

340,525

ORA

503.566

จคล

DRAN IU⿴囗十 $238222,269,328,329$ $435,449,462,476,525$

DRAMIUN, MATURAL 67,374

Oก A

VRA ARY CARBOWA 295

TRE WI NITRATES 81,82

ORI 8 T $8,9,10,13,48,55,67$, $75,78,79,80,81,104,110$. $112,122,138,158,163,179$, $188,196,211,226,260,276$ 。 $279,281,371,375,376,380$ 。 $385,388,391,392,394,396$, $405,407,410,430,451,464$, $469,503,505,538$

TTY

VALERCE $36,50,74,125,163,188$, $250,263,269,274,286,287$ 。 $288,290,354,377,465$

VEGETABLES 357

VELOCITT $98,339,342,526,527$

YENTIMG 498

VESSELS 364

MASHING $32,41,72,141,153,223$

MAST DISPOSAL 299, 325, 443, 487。 $570,571,573,578,582,583$, $584,585,586,590$

WASTE TREATM PRT $572,574,576$, $578,582,583,584,585,586$, $587,588,589,590,592,593,594$ 


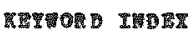

ทีSE

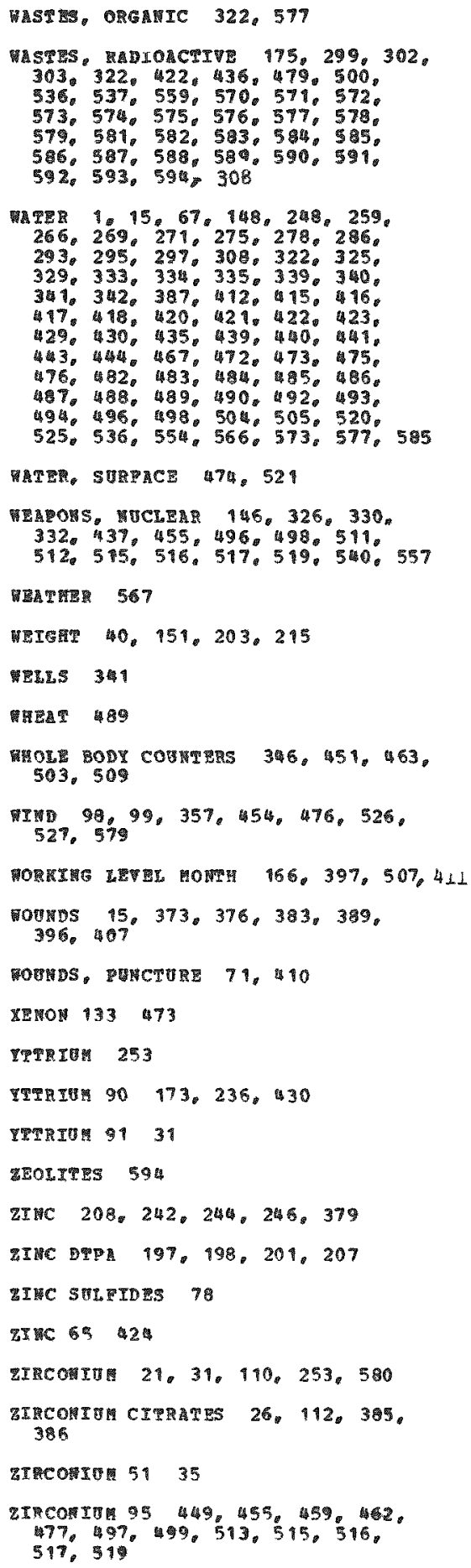


GEOGRAPHIC LOCAT TON IMDEX

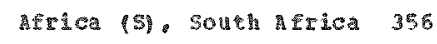

Asia 101 USST, Kitgiz 295

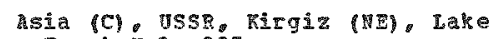
Issqk 295

Atlantic ocean 269

Atlentic ocean (N) 442

Australia 293,478

Austra 1ia (5E). Melbour ne 442.
510,514

Canada * British Columbia (Sy). Vancouver Island, Samich Indet 329

Barth 499

Brgland (\$). Surrey, Sutton 497

Rurope 379.402

Burope (C). Germany (ST). to asuhe is 1

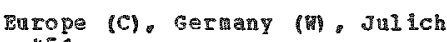
4. 5 9

Europe (1T) Sweden 402

Europe (5). Italy 477

Europe (1) 591

Zurope (m). Germany (Wh) Rarlsruhe 432

Tndia (to

India the Bombay 450

India (ต). Bombay Harbor 500

Hediterranean sea 269

Pacticic ocean 269

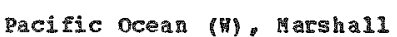

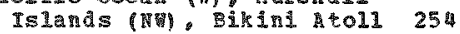

mrobay. Inda (Sw) Rerala. A maye 450

Thited states 402

Tnited States (C). Iow (C) R R daboratory $520^{\circ}$

united states $(\mathrm{C})$. Iowa (C). Ames. Iow state universte 520

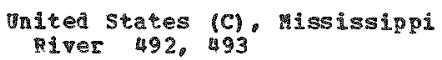

Tnited states (C). Texas to Chlcago 512

Jnited States mCl, Hinnesota $(C)$ Il River 493

ปnited states (xc). Misconsin (5) vernon county. Geno $\$ 92$

Dnited states (WT), Connecticut

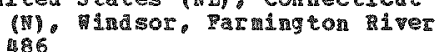

Prited states (ne) Connecticut

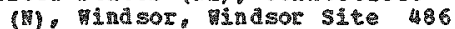

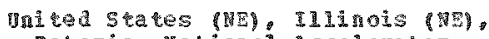
Batariar. Hationa Accolerator Laboratori 412

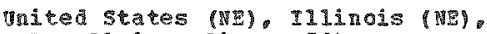
Des Plaines River 504

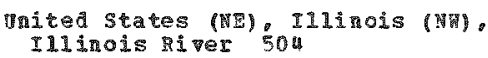

united states (ME). IIIInois, (N⿴囗十) Des laines River 505

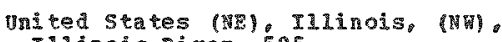
IIIInois River 505

inited states (HE) I11180is Argonne, Argonne National I aboratory 504. 505

united states (HP). IIInois, Argome, Samil creer 504, 505

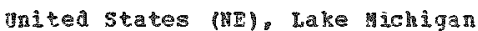
297

mited States (me), Ney Zork 358

united states (RE). New York (I) Mibay 402

Tnited states (PF) Hew Yori (D). Schenectady, Rnolis stolc porer Ts aboratory 486

Inited states (uE)。 Mem york (E)。 rov 402

Initud States (mp), Hew York (BC)。 Mohavh iver 486

Wited states (HF), New York (52) per por cit 590.514

United states (mE) Hev York, Long Island, Cartans River

inited 5tates (ND), Hev York, Long Island, peconic Biver

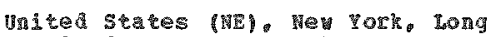
island, upton, Srook haven

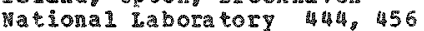

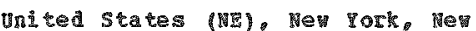
gork city 42

United states (HE), New qork. Hiskayua, Rnolls site 486

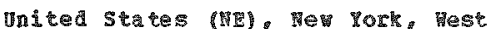
121 ton, Glonege creek 486

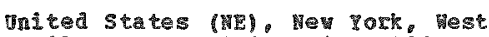
Mitor, Resselring ste 486

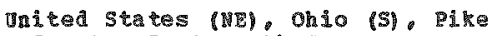
Connty. Bortsmonth Gaseous Difeusion $\mathrm{P}$ lare 429

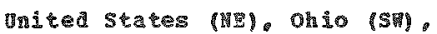
cincinat. Feed haterials production certer uas

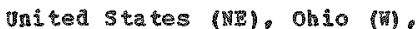
Great ian River 485

701 Hastsburg. Mound Iaboratory S4

onited staces (me). Pengy (SE). Pittsbugg Bettis, Acolic Dover Laborator $\$ 87$ 4n (1). Beryer courti. Shippingport. united states (NE) peñsyirand (v) onio River 498

Unted states (NM), Alaska. Anchitka Tslant 336

United States (n⿴囗十) Columia Biver 47

Inited States (NW), Idaho (St) raho Falds, National Reactor Testing station 489

Jited States $(N)$, Idaho. lational Reactor Testing Station 589

vat ted Stres (N), Washington (S), 䠄anford 497

yิ (SD)。 Richland 511

ชn ited states (17m) Washington (SE) Richland, stlantic icheiel Hanfora company 574

United States (Mv) Washington. Colubia iner, McNar heservoir 4. 24

United states (n) pichand 512

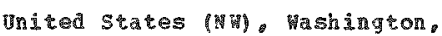
ichland. Harora Sites 303

Jnited states (N) , washington Seattle University of vashington 560

Unthed States (SE), P1orida (S) 母.

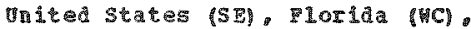

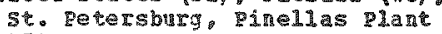
蚂7

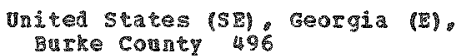

United States (SE) Georgia (2),

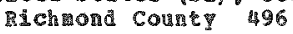

Tnited Staces (SE) Georgia (2) screver contry 496

Vె日 8ducah, Qaducan Gaseous

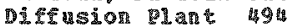

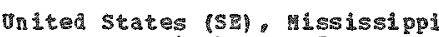

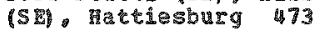

(17 (5) Sarturell county 496

United states (5m) South carolina (Sm) H Lendale county 496

Trited staces (ST). South carohina (1) A Mken County

Dinted states (SE) South carolina

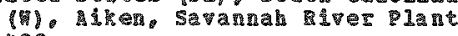
482

0nited states (SE) South carolina

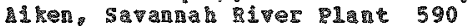


GEOGPAPHTC EOCATTON ITDEX

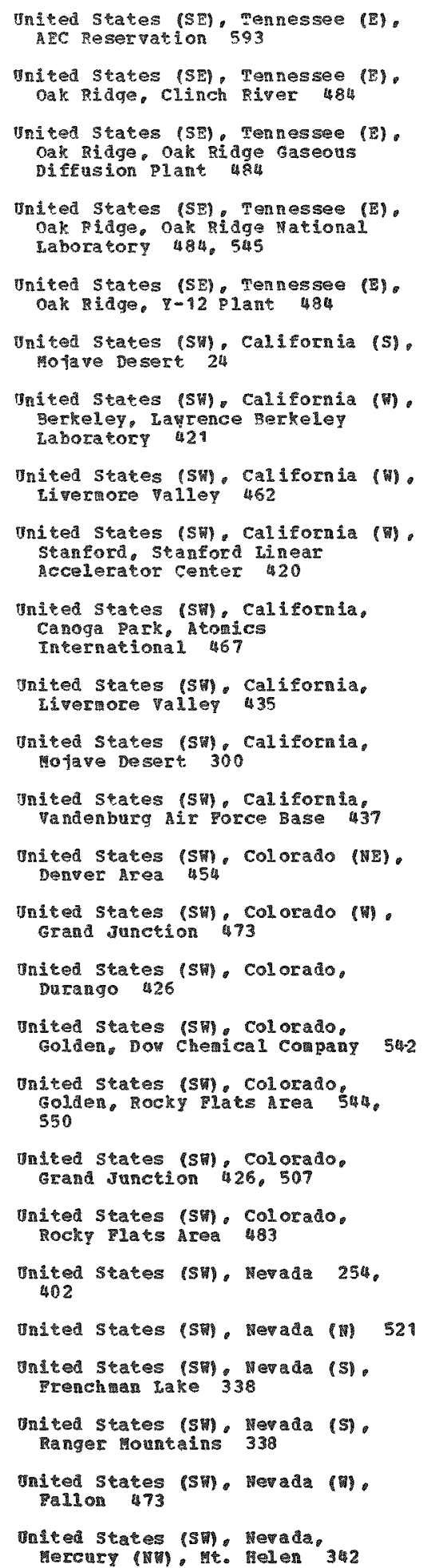

Mnited states (Sin) Mevada Mercury, revada Test site

United states (sw). Nevada. Neva Test site 24, 29\%, 296. 300. $301,307,327,335,338,341$. $343,25,473,498,501$

unted states (Sw), mevada, Hevade Test site (sw) 24

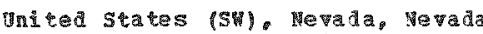
mest site. ATE 11296

United states (Sm) Mevada Nevada west site, Area 13296.304

Jnhted States (sty) Nevada Wevada Fest site clean slate 196

Jnited states (Sh) mevada Metada rest sit. clean slate 2296

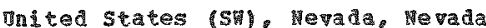
Test site. ciean slate 3295

United States (ST). He Had Hevada pest Site, Double Track 296

in mest site, Frenchan Rlat 305

United states (Sh), Newada, Mevada Test Sit, Eench man lat (sm). Rage: Mountasn 24

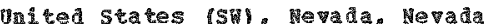
Test site, Gry Area 296

Inited states (s). Nevada, Hevad Test site, Jackess Flats (T) Ilpper jada 24

inited states (Sh) vevada, Hevada Test site, Jackass Fla 政 Valey 24

Inited states (ST), Hevada. Nevada Test Sice, Mojave Desert 292

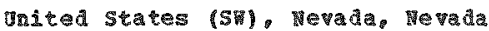
rest site tre Contry. Pahtre मesa 339

mitod states (5n) Heqada mevada pest site, Qhute Mesa 305

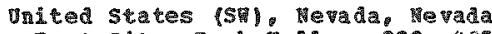
vest site. Rock Valley 298,

Wnited 5tates (5) . Wevada, Test site, yce plat 305

United states (\$พ) - Mew Menico (1) Faring neton

vnited states (Sm) Mev (sc). Trinity site 323

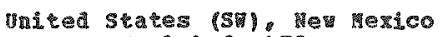
(SM). Carlsbad 73

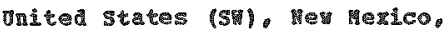
A la oogordo 436

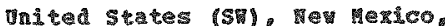

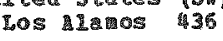

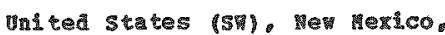
tos 1 1aros, Los Alamos Scientific Laboratory 375, 43. 54

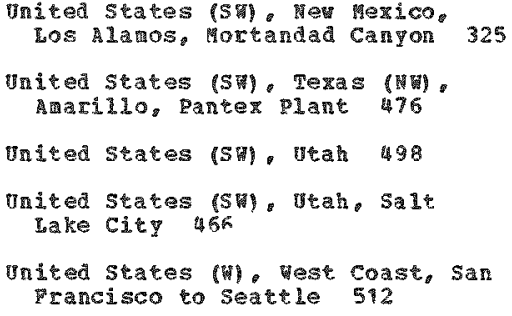




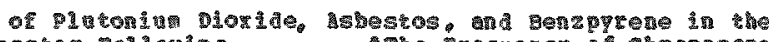

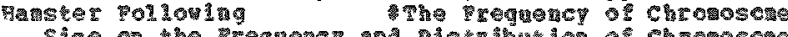
S12 on whe pred o 7 a

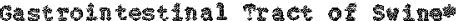

the subcutanes is

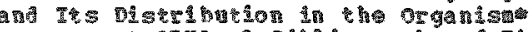

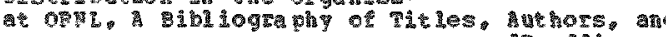

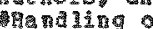

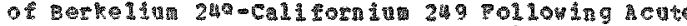
27 of p1 4 Theoret

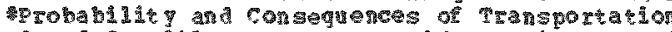
1 s. 춘 स11nina Caleำ

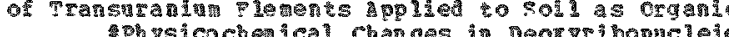

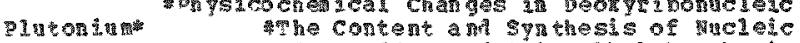

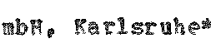

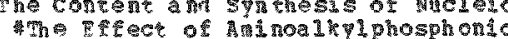
营

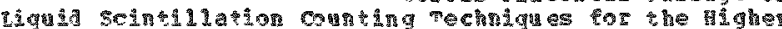

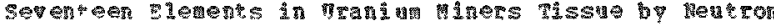
Rerpere

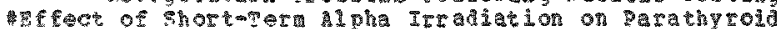

of citrus poos stock and chelating agent on specice

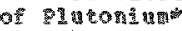

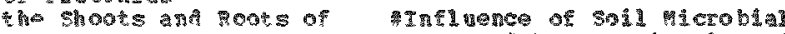

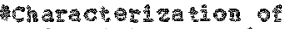

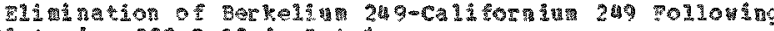

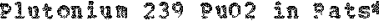

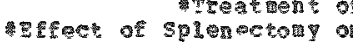

Eeaglest

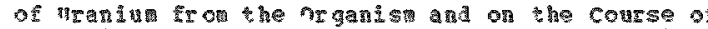

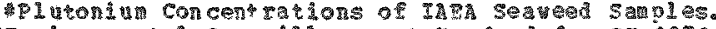

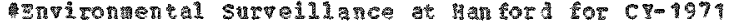

230 슨

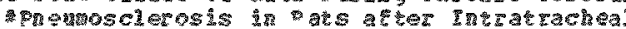

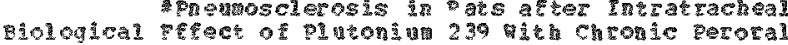
Soly or ats

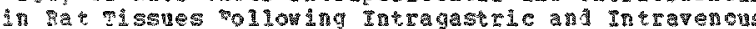

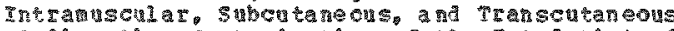

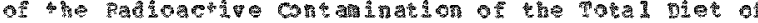

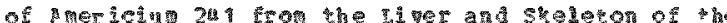

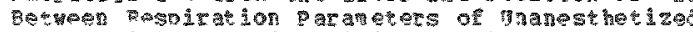

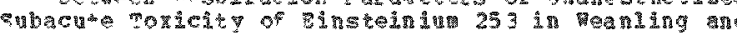
*

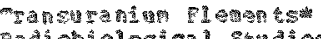

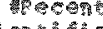

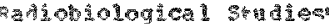

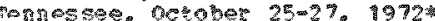
Pola ti Privary 3oposis

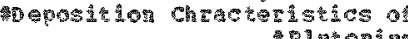

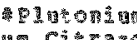

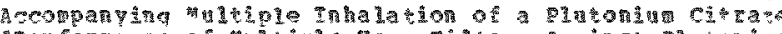

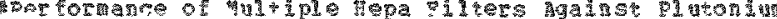

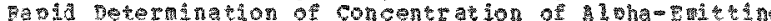

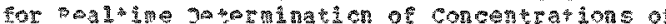

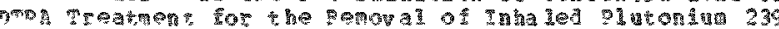
IT

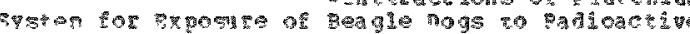

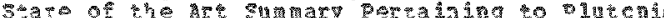

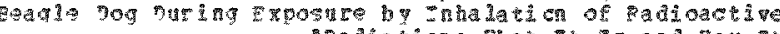
Spat thon

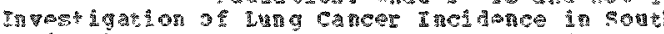
Tar The But sis 73

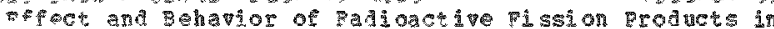
3

A I I I

COmport

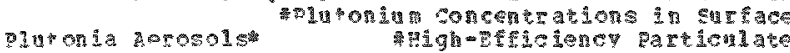

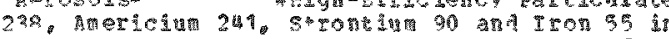
7.

3 훈

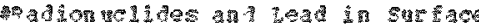
桑 $\mathrm{a}$ iton apan

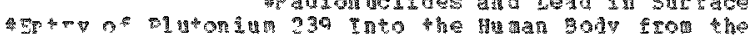

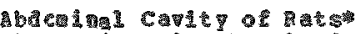

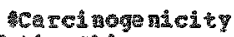

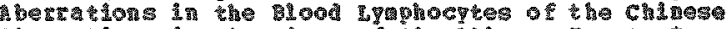

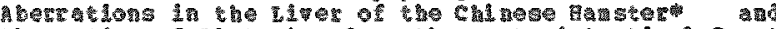

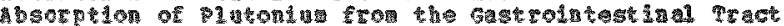

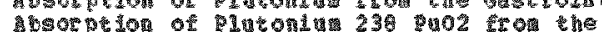

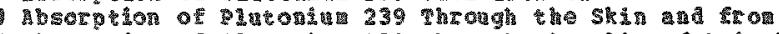

Absct ats tracts

Accidental contarinatons

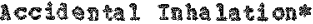

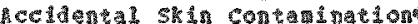

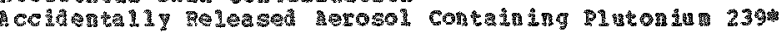

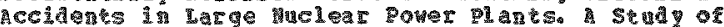

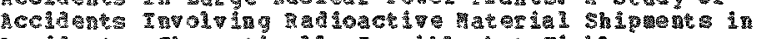

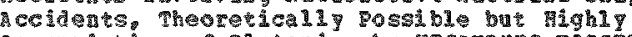

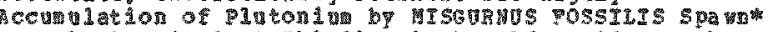

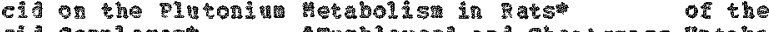

mc con cones

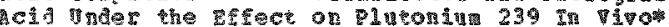

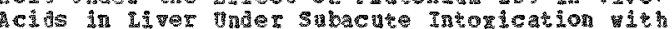

Act an on the 1 in

Actinide poject of the Geselischate Fuer Rernfor schung Actin

Act 3 in

คำ act

ACtivin an osteoclast mulars

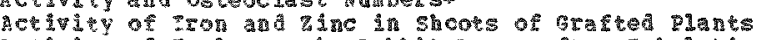

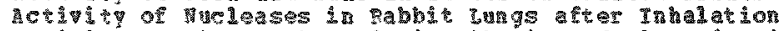

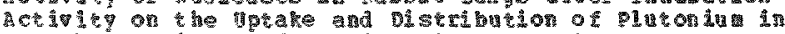

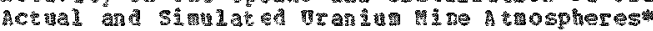

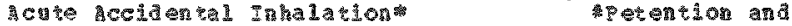

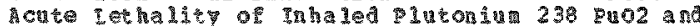

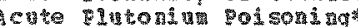

Acere or

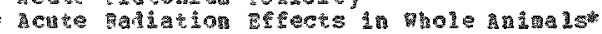

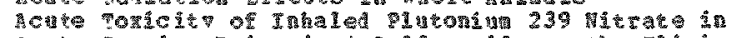

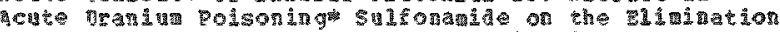

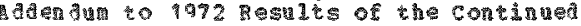

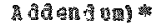

Ad

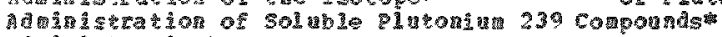

3

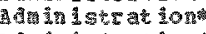

A

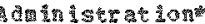

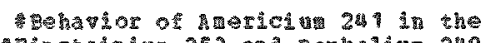

*

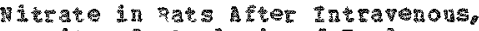

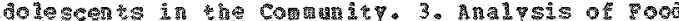

A

Aat 1 t

Ache iation

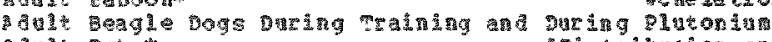

Actur 1 :

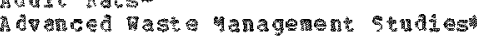

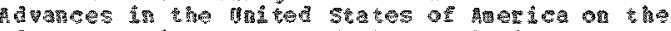

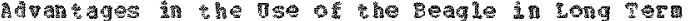

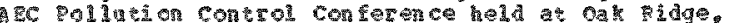

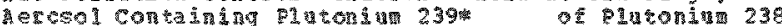

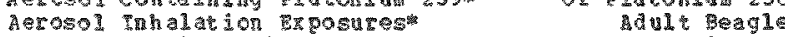

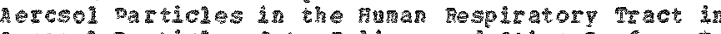

Aerosol particles onto

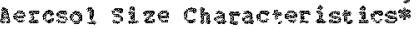

ercsol an Aerosols for Perlod औan

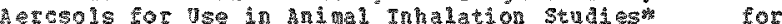

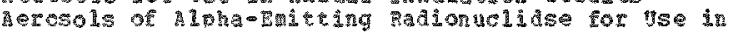

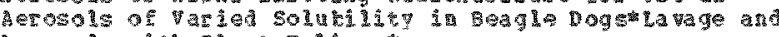

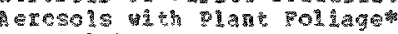

serosons

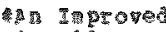

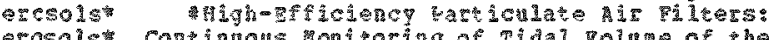

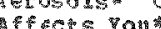

है

H Riostatistical

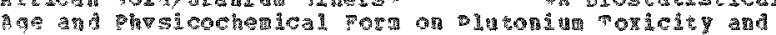

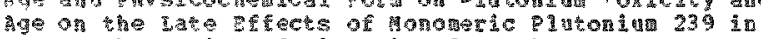

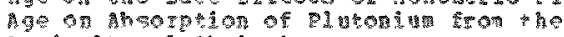

Agratoutura 1 chasing

A

B

A

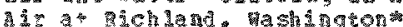

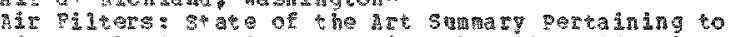

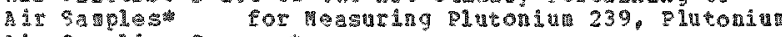

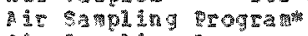

月.

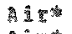

Af 3

A I th

A $x^{2} x^{\text {क }}$

A I I tw
20019

00003

ติงติง 35

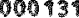

00021

000039

000996

00058

000548

000394

000380

000283

000314

000564

000314

000172

000082

000026

000975

000100

000101

000011

000532

000202

000365

000073

000315

000056

00024

00015

0002 然

00952

000219

000386

000016

0000 at?

000167

ดอบิด 02

00033

000 缐 16

000161

000102

000940

000237

009079

000205

000379

000013

000028

000052

000133

000539

000135

000585

000283

000052

000290
000098

900098

000 स 28

0005 站

000054

0003 3

000453

000099

000351

000347

000053

000563

009356

000203

00031

000294

00029

000497

000554

000ิ 11

000347

000289

000515

000516

000597

000519

000518

000406 


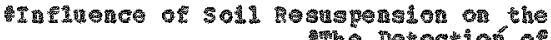
owerhereng 2 nes dents cont a

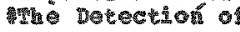
ำ 政roject

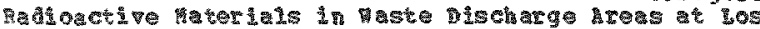

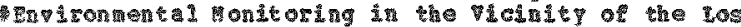
of PIutonin in t.

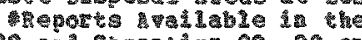

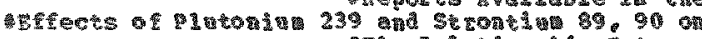
票

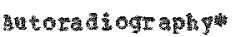

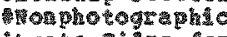

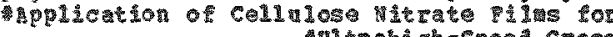

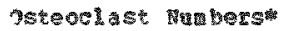
1.E

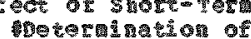

* Tatanshe of a

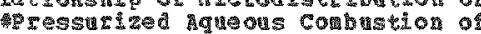

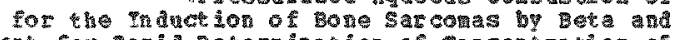

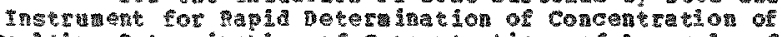
Real tine Deter

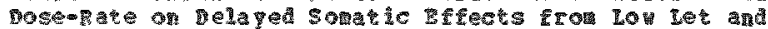

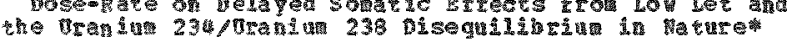
* 10 Th

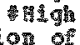

Pused clay artates or

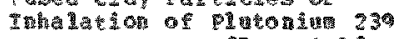

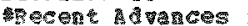

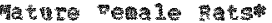

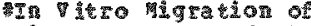

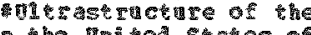
Whin states The Eatachas Perative zifects of * Relative ERfect: of Telative Ereots or

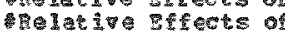

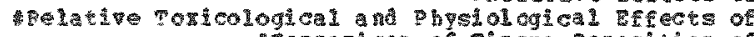
Afroner

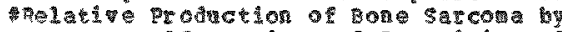

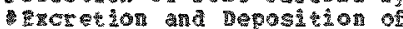

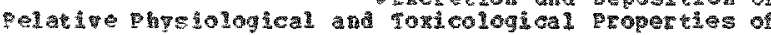

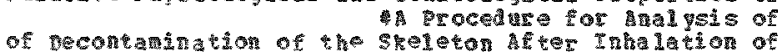

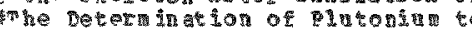

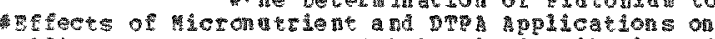
cospared ?at

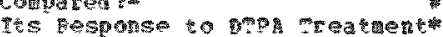

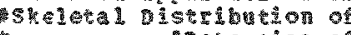

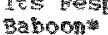
actenton of

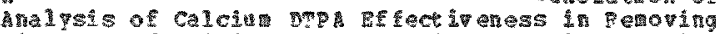

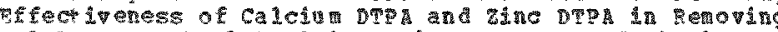

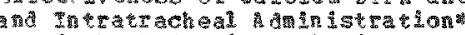
ग of Webatot of 点 etransiocation of

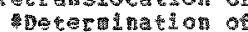

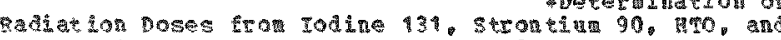
Neverons

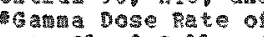
soxicisy to siond cells of

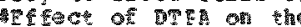

Gger

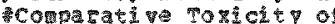

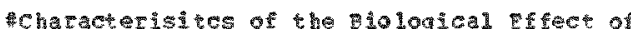
a

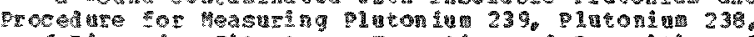

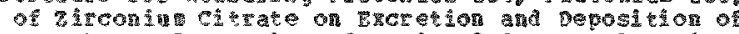

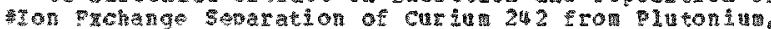

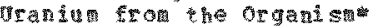
Whe Ereet of

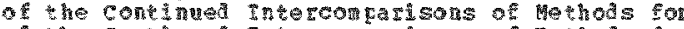

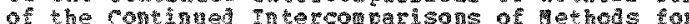
1967 然

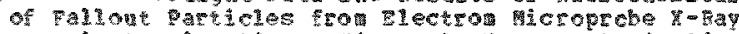

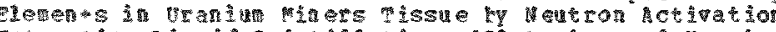

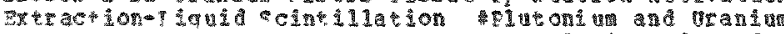

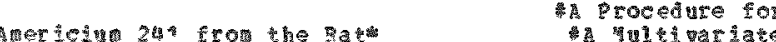

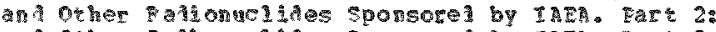

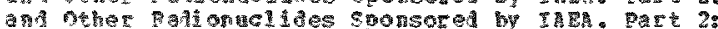
of the rotal 1 ith of

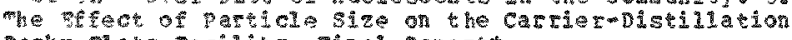

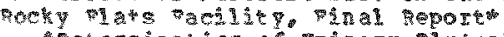

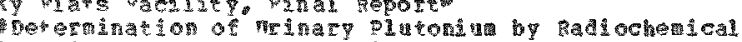

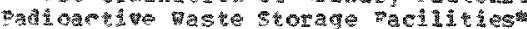

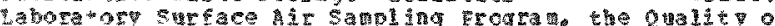

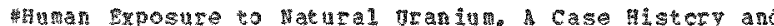

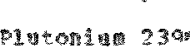

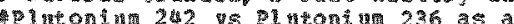

2.

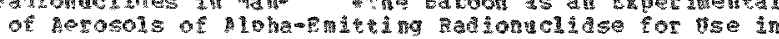

II

A 1 L

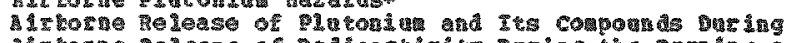

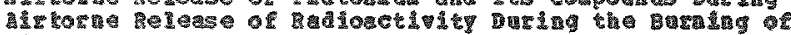

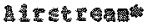

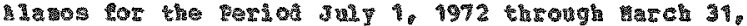

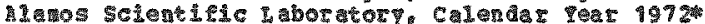

4. Ias

Q 1 ash

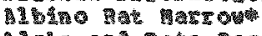

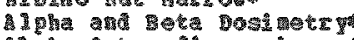

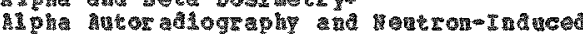

I Iha suroratiography of poret

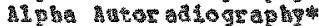

1 I He

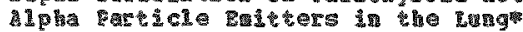

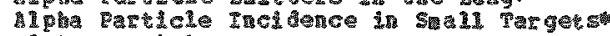

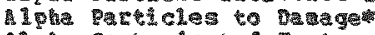

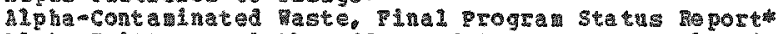

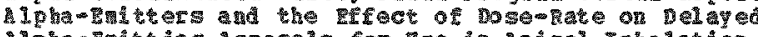

APha-

(10)

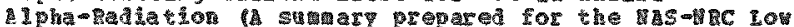

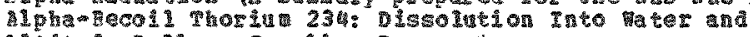

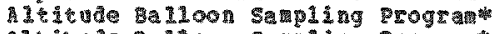

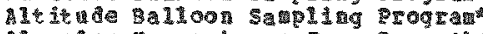

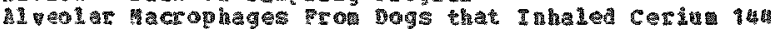

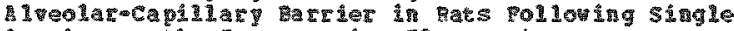

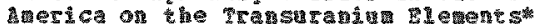

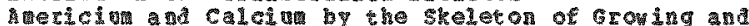

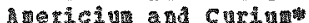

Anericin and gratonu on the sone marcow

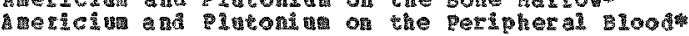

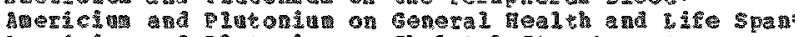

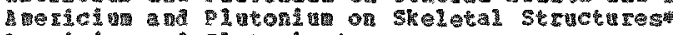

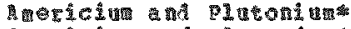

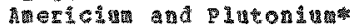

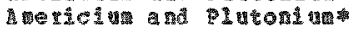

B⿺辶大

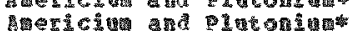

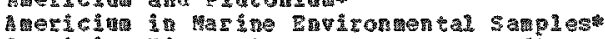

Aate

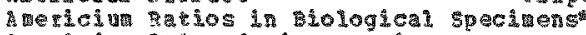

the

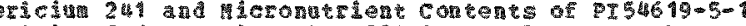

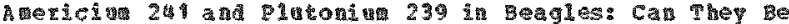

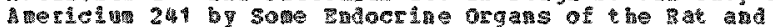

Arercich 241 from the

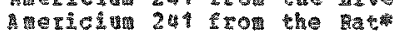

Anericion 241 from the rat

an 10

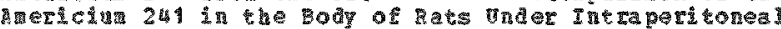

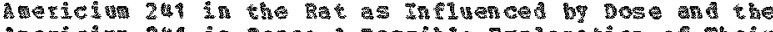
peri

月。er

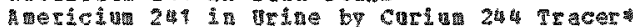

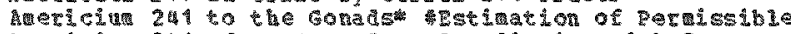

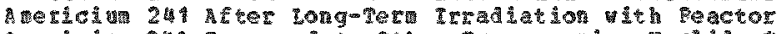
A

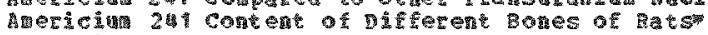

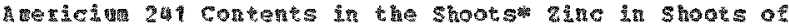

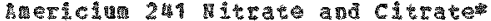

A tericin 241 skeletal Distribution in seagles.

8.

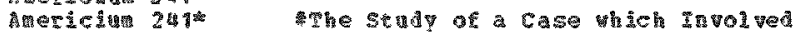
म Aaticis

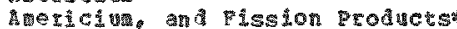

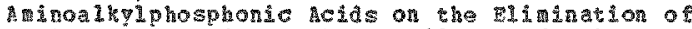

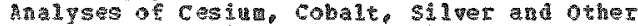

halyses of cesin

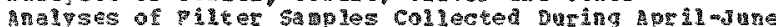
An

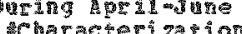

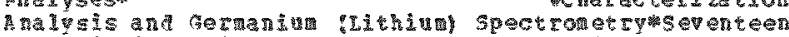

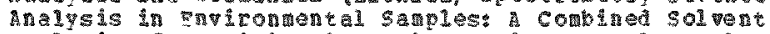

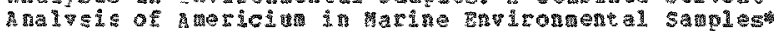

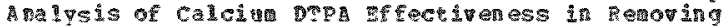

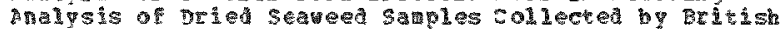
nan matisis of Pood Consumption in the Institutional Diet

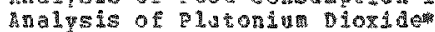

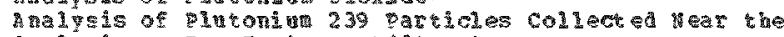
Bralysis on zon zxchance pulers

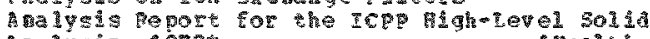

Healch and sect

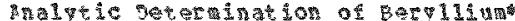

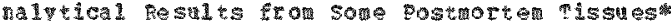

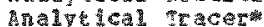

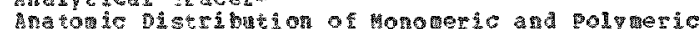

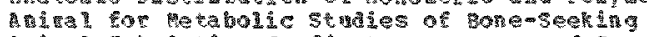

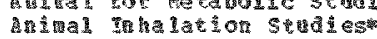

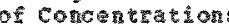

00052

cooves

$09057 \%$

1906ำ

000458

00436

00045

000325

40033

00025

000 క

000251

$00007 \%$

000056

000447

000084

0009:

000572

000136

0005

00036

000136

000525

00045

000457
000082

00000

000539

000076

000282

000109

000105

00010

00041

000113

000108

000104

00013

000158

00024

$000 \div 1 \%$

000197

00034

000200

00019

000237

000195

000227

00635

000276

000123

000530

$00415 \%$

00120

00024

000150

000118

$00015 ?$

000407

000289

00014

000290

000011

00063

00043

000632

000254

000073

00027

000256

000200

000433

00043

000379

000277

000468

00026

000578

000513

000267

000372

$0002 \%$

00022

$0000 \mathrm{~g}$ 


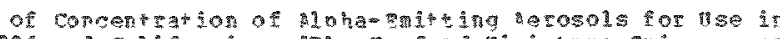

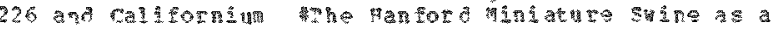

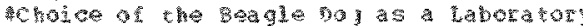
4

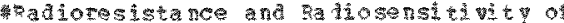

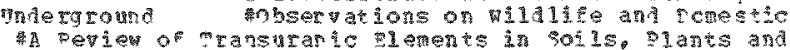

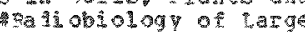

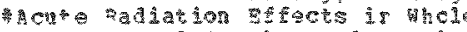

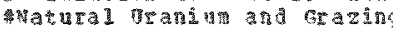

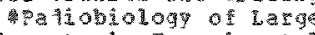

굴 of thy

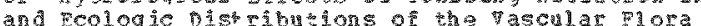

$1972 \%$

Docentor 1992

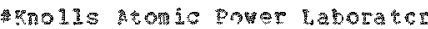

wor $120 \mathrm{~s}^{\text {ol }}$

1973

an

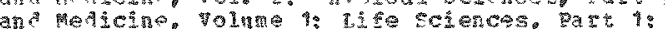

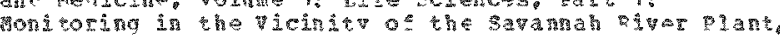

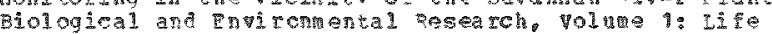

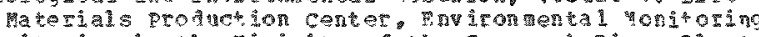

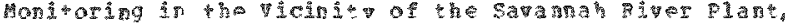

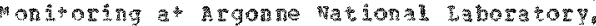

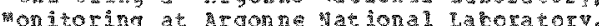
troadiation program

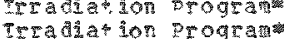
कpesearch in adioblology.

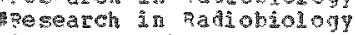

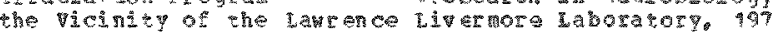

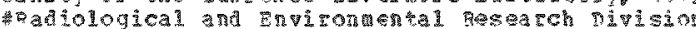

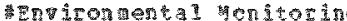

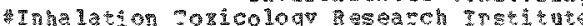
g f Dinide

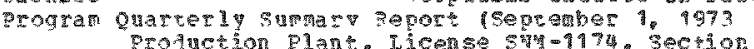

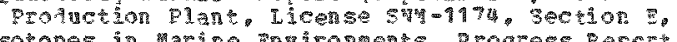

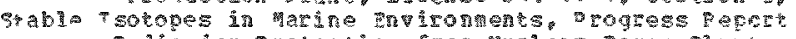

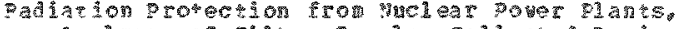

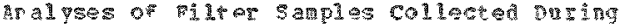

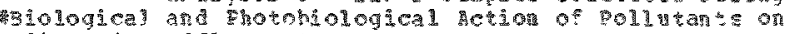
Dadion

program Staters sepor

aresencized seacenton of

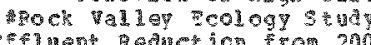
19a

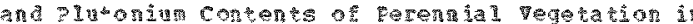

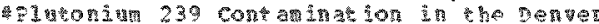
of 군

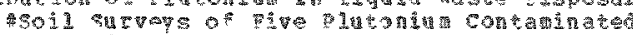

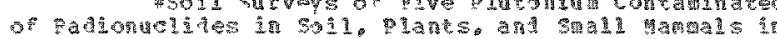

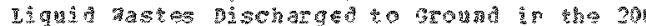

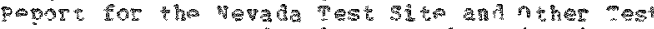

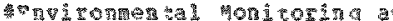
춘.

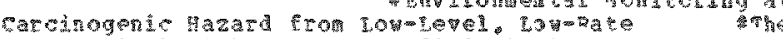

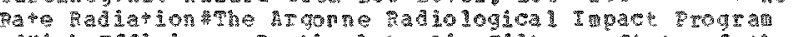

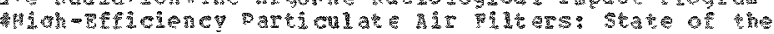

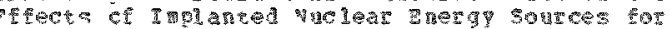
幽

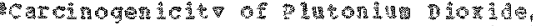

Wouna cases

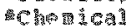

tomat

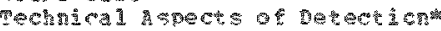

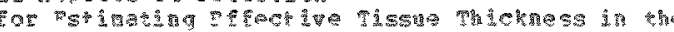

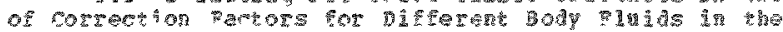
군

Prophy

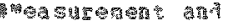
Ther

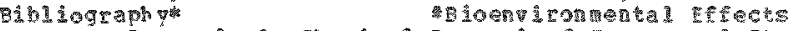

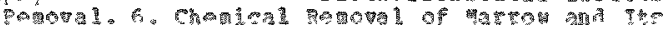

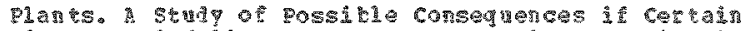
Polation (2.

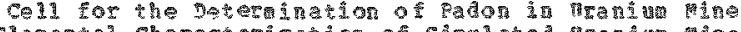

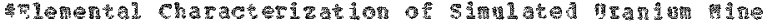

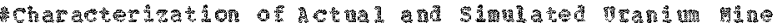

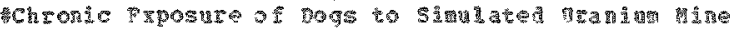

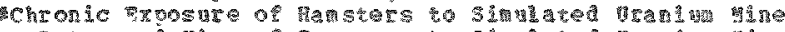

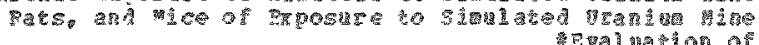
vear 1972s

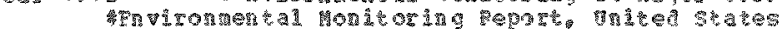
21 1.

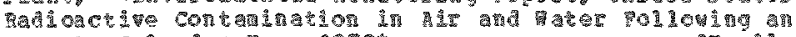

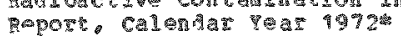

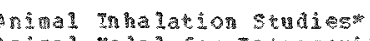

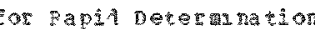

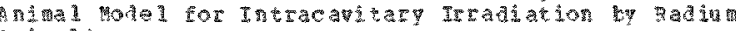
a

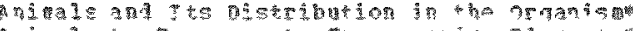

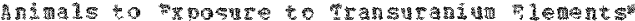

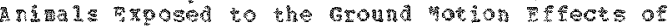

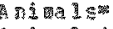

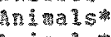

Anina 15

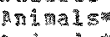

An

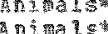

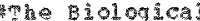

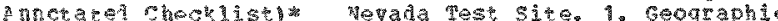

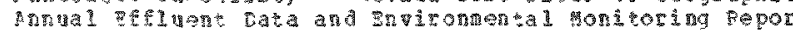

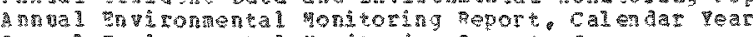

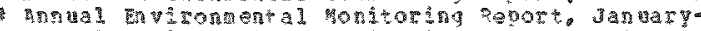

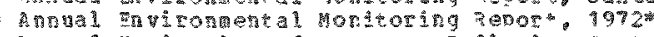

at

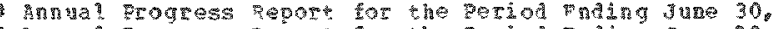

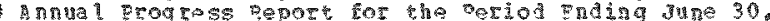

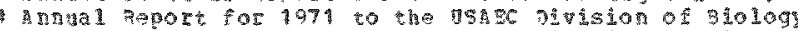

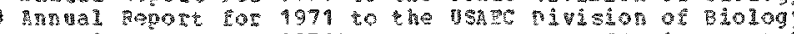

A กิ

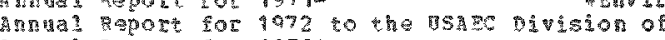

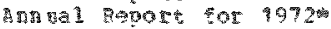

A

Ang

Fed

ann

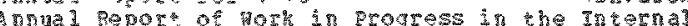

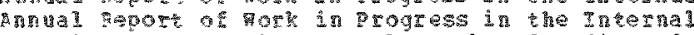

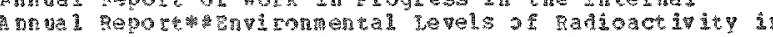

andent

A

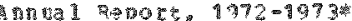

Hes :

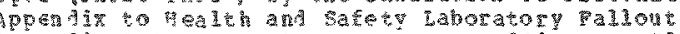

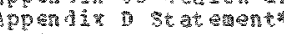

等

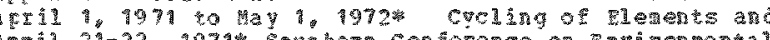

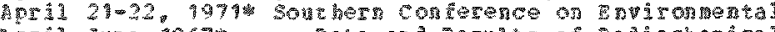

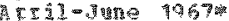

月1

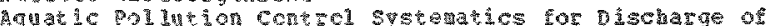

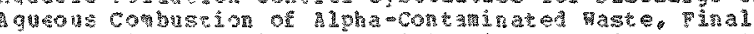

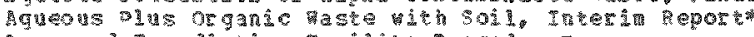

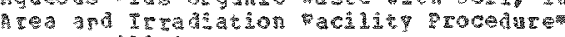

a tea acing

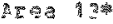

*50\%

T.

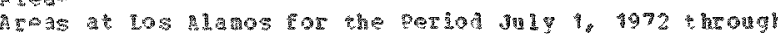

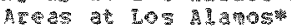

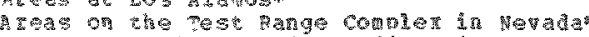

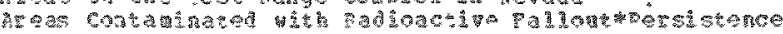

A

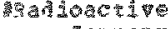

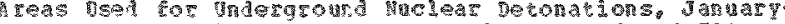

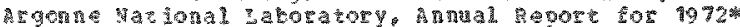

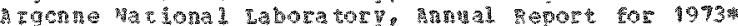

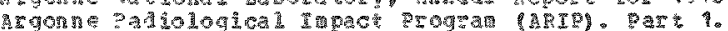

A

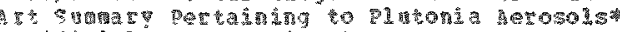

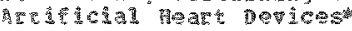

\%

120.

Asses

As:ess

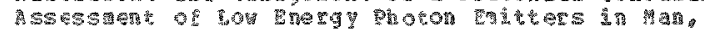

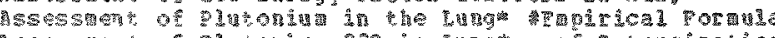

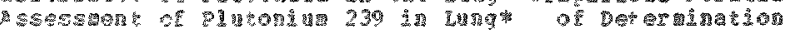

ASSE

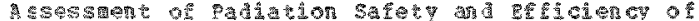

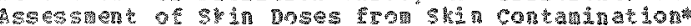

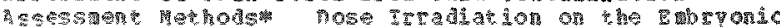

Ascolital

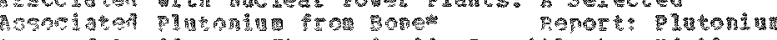
1 ร.

G G

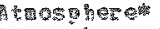

露

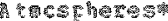

a

trospheres

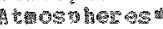

A tespheses

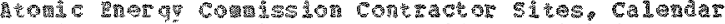

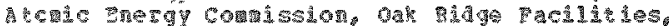

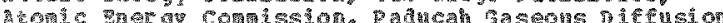

Hor

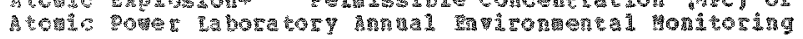

000054

$00022^{2}$

000032

90096

000152

00307

000302

000090

00004 ?

000067

009080

00307

$0032 \%$

000488

000 \& 86

000420

09042

000300

00030 ?

9004: 70

000233

000496

000232

000485

000482

010050.4

0005

000061

00043

000393

00046

000139

000329

000142

$00047 ?$

900561

000328

000479

00032

000156

000500

000572

$00057 \%$

00045

$0005 \%$

000304

000145

000436

900325

900296

40959

0 onswo

0043

gonso

00032 연

000324

0003 3

000051

000191

000376

000376

0ิ40)

90998

000400

000398

$1005 \%$

0055

00017

00033

000314

00012

000460

090368

00053

00022 暗

000230

601 156

000450

90075

00004

0099

000456 


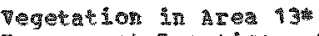

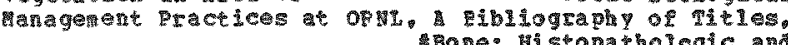
Hone: thil stopatholegie an

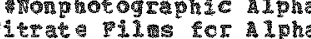

Hppicaton or collulose

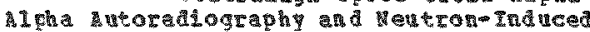
Feports T) ports

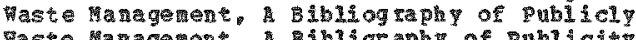

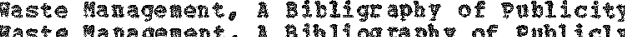

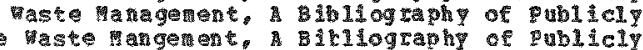

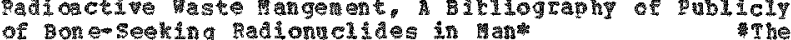

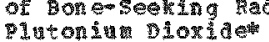

Heplas Induced in

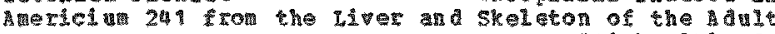

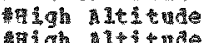

Fadoecological stades in ptan subsequent to the

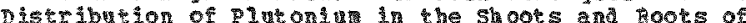
P1

Herplezion of the Injection Thase of the

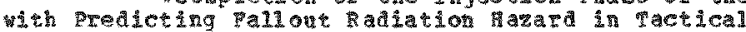

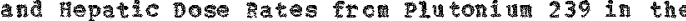
Some scientific divantages in the ise of the tholce of the

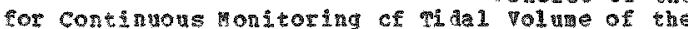

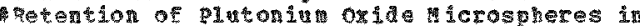
*ararine Exeretion in That E

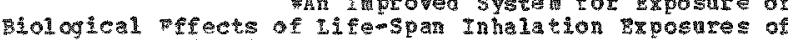

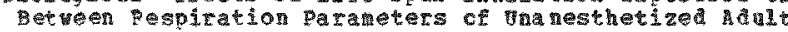

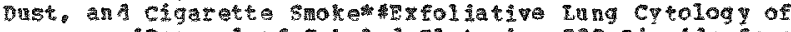

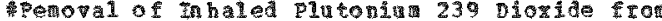
Inhal ed putonivis 239 zetosols of Vacted solubility

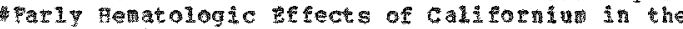
ot Divtontu 239 (4) in the bod plasma of the betection of cytotor ic ly

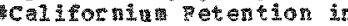
gelicornitu petention in * Fractre Inciance In

P1 1 con Fracture incidence In

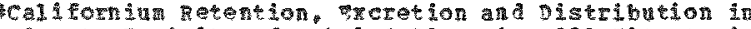

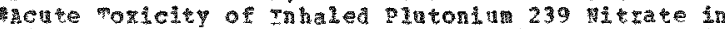

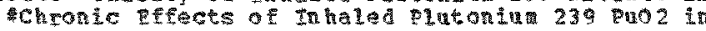

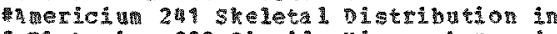

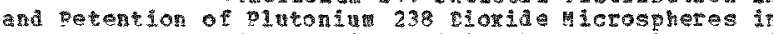
249 and erkeling 249 in the sott pissmes of

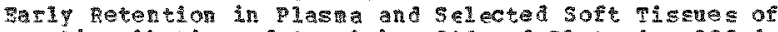

Distributon of Anericin 24 and Plutonum 239 in a petranslocation of Anericin 249 in insh Ch these Finclear

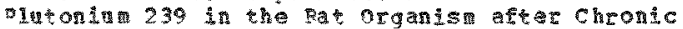

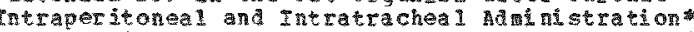
of Bancli and anperature on the Distribution and

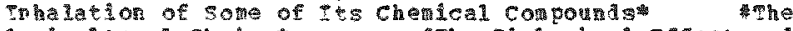
Hegricultural chalds

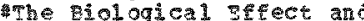

Low Doses of Ionizing Radizton

poses or Ionizing adiation

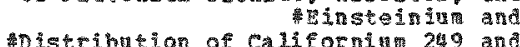
Intruterous adninistration

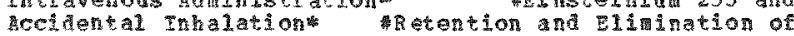
acedcal spects of Exper inetrat

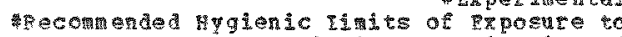
An Alytic Decerintion of

Felitionships for the Irduction of Bone sarcomas by

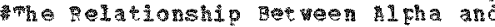
费adionetive aste pagenent.

Detcting to the the pertainging to the Dertaining to the oshec

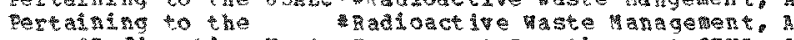

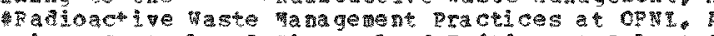

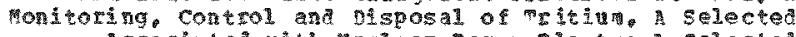

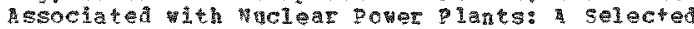

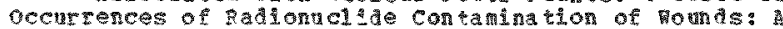
the 然aneys ton the sunificance of the peaborption of veposition sion

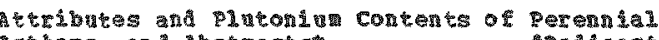

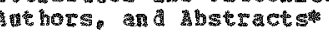

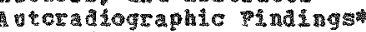

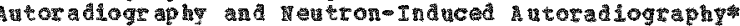
At toradiography of somes

Avtor a dogr aph

Atoradiogr aph

A tetadiographwo

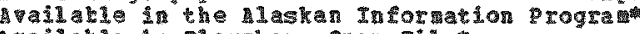

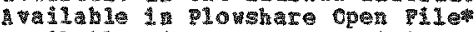

A

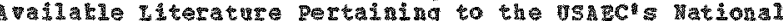
Avilatie iteratre pertaining to the vSARCis oak

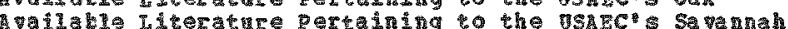
Babcon as an Experimental Anial for hetabolic studies

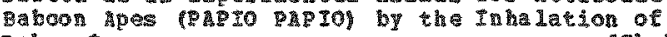

Sabcon

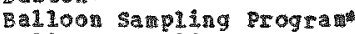

Balloon sating Progra

can

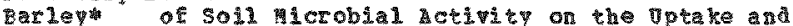
Barrier in Rats

Basic Characteistics of molear Radiation from Fallowt Easie Toricity periatent

battefiela sitrations

Beagle as a punction of Dose Level

seagle fin tong

Beage Dog as a wabratory Antral.

Beagl pog buring Exposure by Inhalation of Redioactive Beagle Dog Lungs

Beagle Dogs after Inhalation of Plutonian oxidew

Seagle Dogs to Radoactive Metosolst

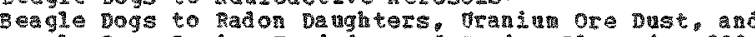

geagle togs During Traing and puring Plutonilu 239

Beagl Iogs Fxposed to Radon Daughters, vran

Beagle Dogs\$

Beagl Dogs

geaglew

Beagle*

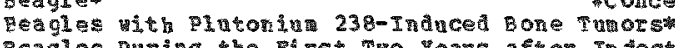

and DFP mreatment for the Repoval of

Beagles During the risst To tears ater In fection

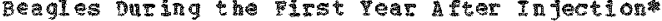

Eeales Reciving Single Injections of Radiu or

teagl as Soon after in fection

veag es:

Eeaglo:

gea 91 es?

Beagle

Eeagl es

Wistribution of califoraid

By cal-Cherical State of Plutongun 239 on Its

Beans

* Behayor and characheristics of adiotctive Debris frol

- Behavier and rature of the Microdistribution of

Behavior of hericing 241 in the Body of Rats under

Behawor of IBRRE TRTDER

Behavior of Plutonitu 239 in pats 1 teter a single

Shat

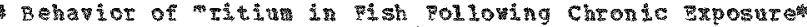
Eehatior of haste adionuclides in sail-plant systems Behavicr mon pelease to the Environtut

- Benefi and Hara fron Exposure of vertebre sper to

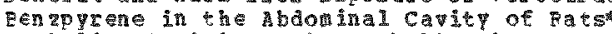

serkelum poricity and Hetabolisin in rats

Berkeling 249 in the soit Tissues of Beagles

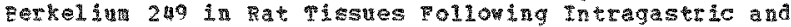
Berkeliva 249-Californin 249 Following Actute

Beryllitum Disesse*

Bexylitur oricology

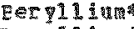

BerYII 1 wam

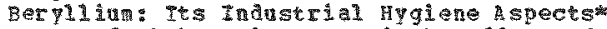
Beta and Alpha-Initers and the effect of Dose-Rate on Pet Dosiderty

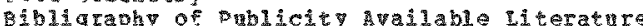

Bibliagrang of Fublicly Available Iitemente

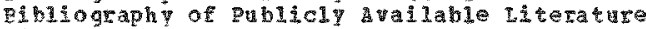

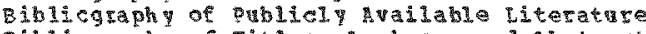

Eiblography of Tites, uhors and Abstret

Q ibliograb

3 iblograto

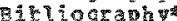

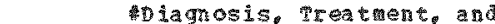

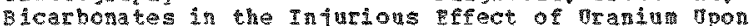

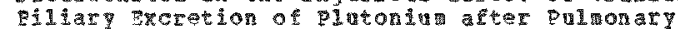

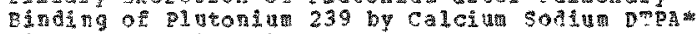

- Bioassay of plutoris un

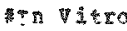

4 Doassay of Transplutonin Flements

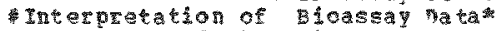

kepore of the B10assay Latoratory. 1969 so 1972

theath hysics and safet
000304

000586

000088

0003 勘

000269

000078

000346

00033

0003

00058

000589

000593

000590

000049

000142

000048

$00045 \%$

00045

000490

000249

00000

000321

000218

000502

000215

000135

000032

00005

000250

000055

00035

000223

000052

000041

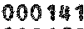

000153

$00005 \%$

000216

000066

000120

000121

000181

000122

000167

000170

000118

000251

000229

0002118

000119

000245

000512

000124

00023

000292

000125

00029

000148

000303

000536

00015

000191

000136

000229

000079

000394

000408

00024

000403

00026

0000

000136

000103

000589

00050

000590

000593

00058

000581

000331

000383

00008 1

000134

000020

000273

000274

000371

00046

00028 


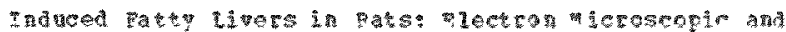
Boehentem thatios

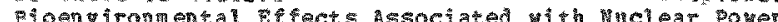

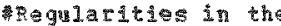

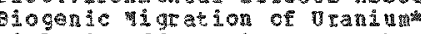

กม́

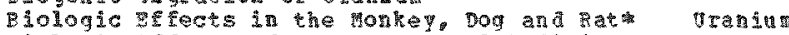
sour ces:

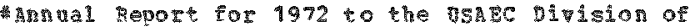

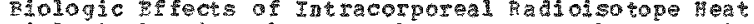

Aqua ic

Sage Inoment problens of Dody 3 ged ans an concentcation

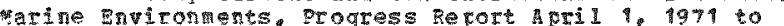
htet Intraverous. Intranusculas, Subcutreous, athe products is agricultural chains:

Intracutareous Injecton * Characterisites of the

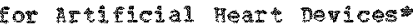

sour cest

Somress

insteing 253 chloride in pats

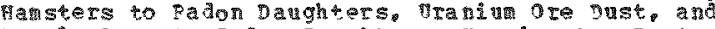

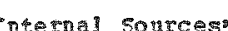

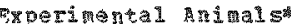

rienes

4rapid Deterination of Sone Transuranin Elenente in

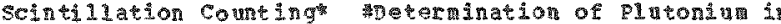
or $5013 \mathrm{~s}$ sta

MPC Ievel in

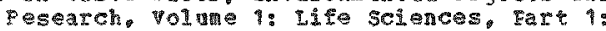
Bâlogy and Medieine. volume : Lipe Selences, part phe Deter 2: Hanual Report for 1979 to the DSRE Division of

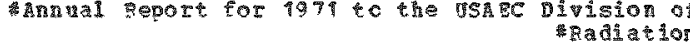

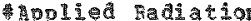
morkers

Elements: sources. Fnvironenta Dstrtibution and

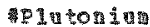

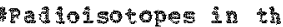

in sonth A

iv pats by citrate of gon certain hanges in the ged Transurania vuclides Toxicity to

trite Fegrency of chrop

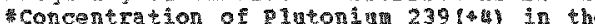

Q1uton

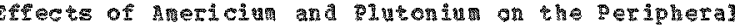
no (5)

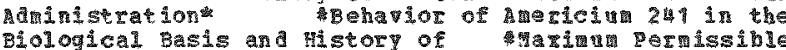

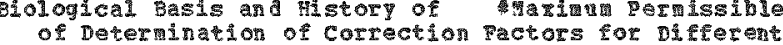
of Determination of correction Factors for Difectent Tr

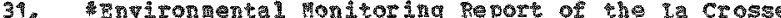

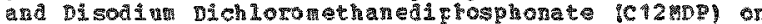

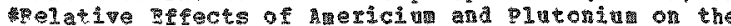
of Dose-Response Relationships for the Induction of

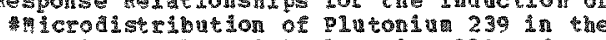

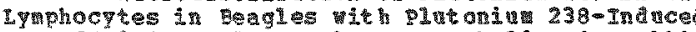
*alcion and

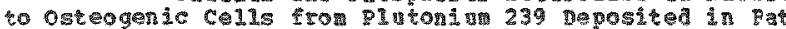

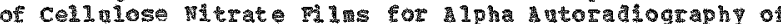

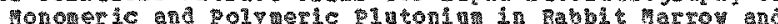

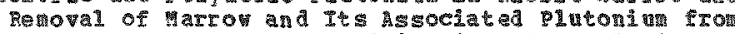

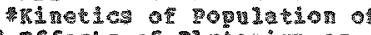

hostribution. 货

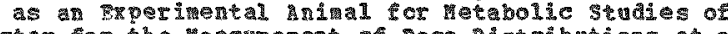

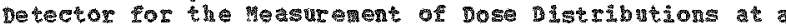
mode of FI

of by on the " wan

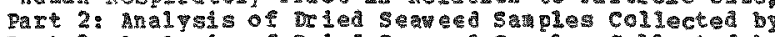
Part 2: Analysis of Dried seaved sangles collected by Beroval of Inhaled lutonira 239 herosols of paried

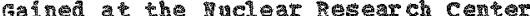

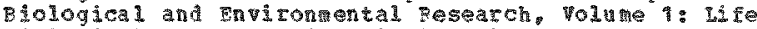

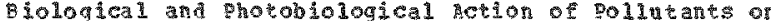

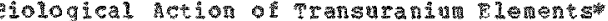

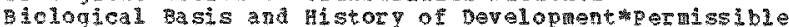

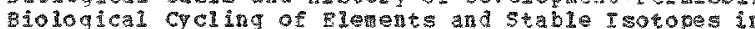

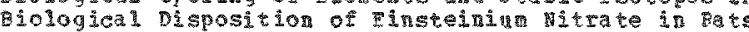

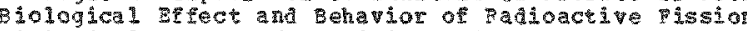

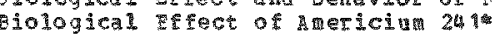

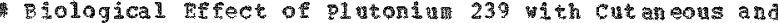
* Bological EEfect of Pluconis 239 mith chronic perora

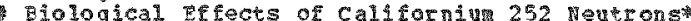

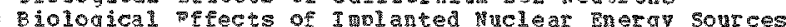
Biological pifects of Thtracorgoreal

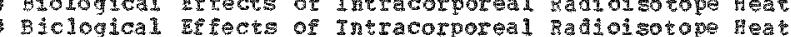

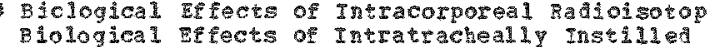

Elological Effects of ife Span Inhalation zroosures or

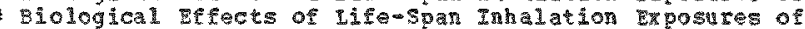

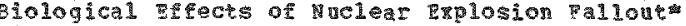

Diological gefects of Radiation fron $x$ ternal an

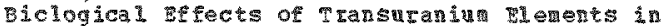

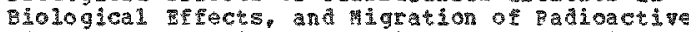
Blological aterial by 1 ssion wrace conting

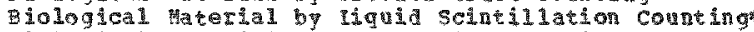
2iological laterials by Fremetion and Liquid 9 jological Fob Lens?

Biological propertes of callfornin 252

Biologica Desearch sectron

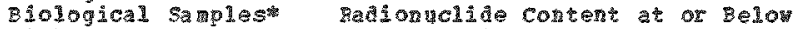

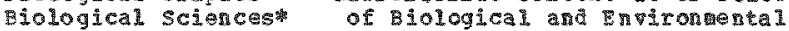
tological seíncest for 1671 to the vsage pivision of BI010alca 1 Specialenste

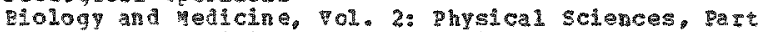
Biolog and Medicine, volume 1: Ithe Sciences, gart 1 Q10109\%

eisology

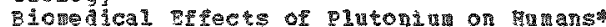

Bomedical

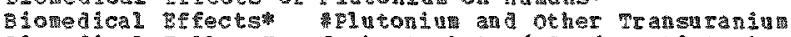

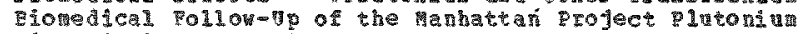
gionedical Research

Q îsoherew

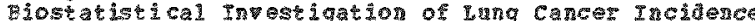
3 in Blood and memodynajes mad the Inhatation Injury of

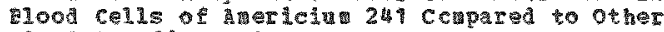

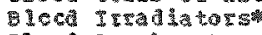

Blood Iyphocyes of he chinese rastar pollown

Blood Elasta of the seaglew

1000d ser Toed

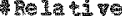

Bon from the Ant

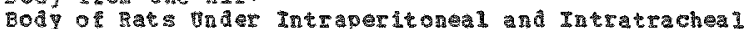

cay Burdens and concentrimions of plutoning

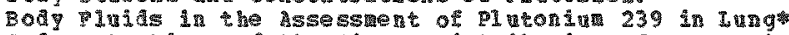

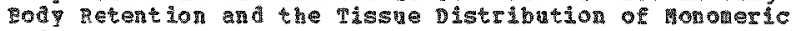
Bed

Boiling Fat er React or From January 1971 to Decen ber

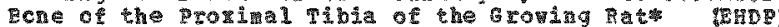
tore

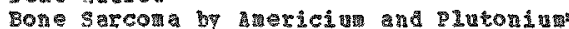

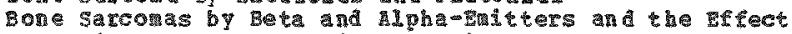
Bone Tissue of ats During chronic peroral

80 a

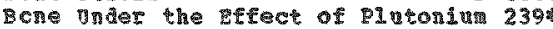

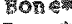

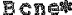

Mpeogras

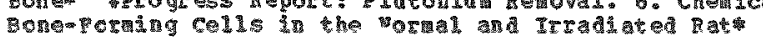
Bon - Serker.

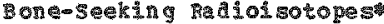

Bon

Bon - Tु

留 he Babon

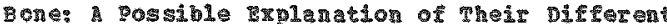

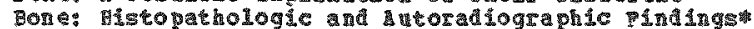

BCA 6reathang Parmeters and Region of Deposithon in the

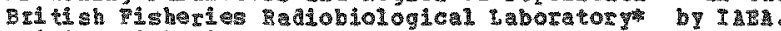

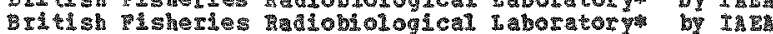

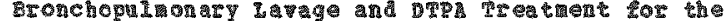

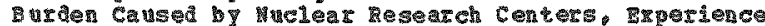

0028

00033

000295

000114

000070

00232

000156

900114

000589

000328

000205

000294

00015

00003

000040

000065

00005 ?

000068

000069

00009

000221

000223

000478

000450

000007

000115

00025

00050

000268

00042

000005

000950

000430

000232

00023

00009

000233

$000 \%$

00035

000551

000375

000356

000028

090193

000080

00003

000216

000064

000406

0023

000545

000400

000092

000945

000109

000108

000136

00016

000066

000063

000083

000261

000182

900197

000095

000239

000180

000045

000327

ธ00ิ

000201

00930

0ิ8 43

000433

000153

0004 
gass a F管

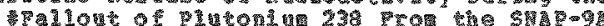

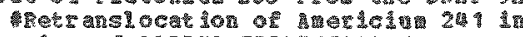

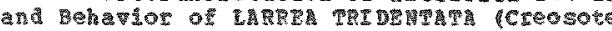

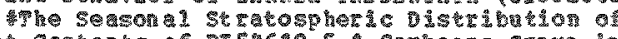

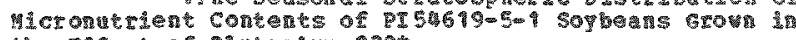

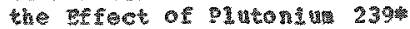

Tat

굴

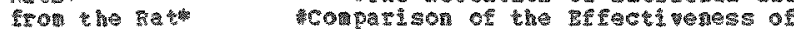

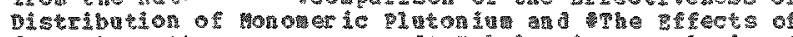
Fron the of 2 Ins

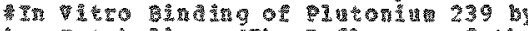

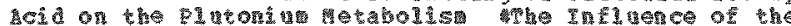
Parate te

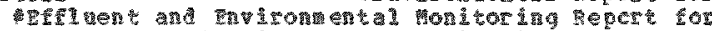

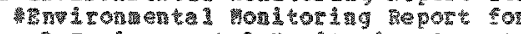

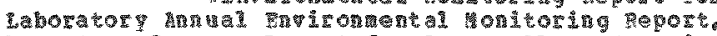

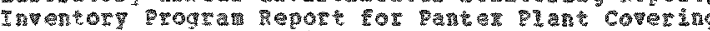

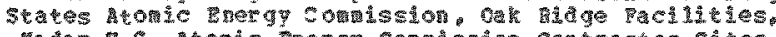

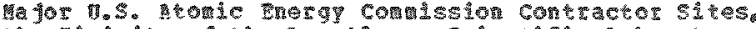

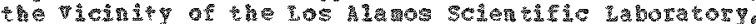

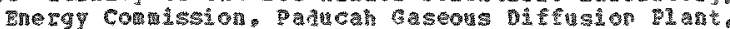

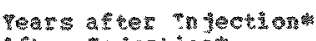

Acter in

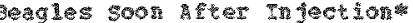

of Bag

(4) 作

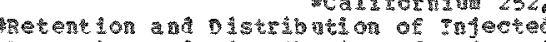

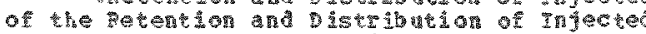

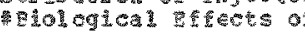

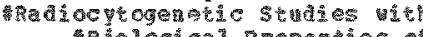

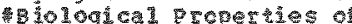
装 he

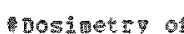

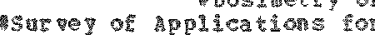

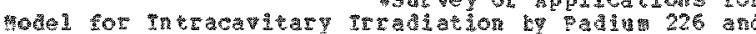

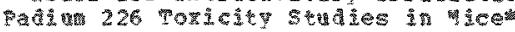

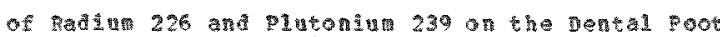

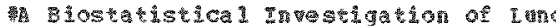

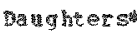

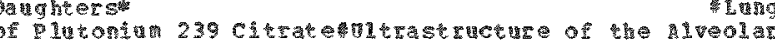

4 4

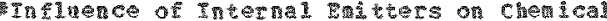

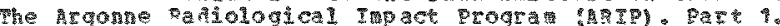

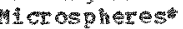

Merasphers

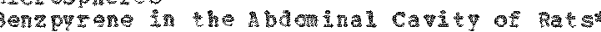

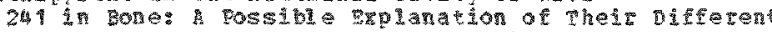
al vitcatin 238 sources ror

Percalng to the nsh

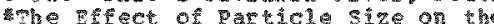

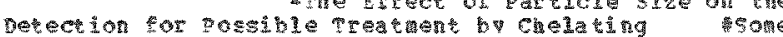

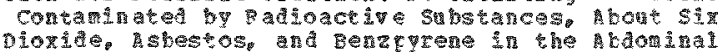
Atwospheretis

票

4PL 13tons

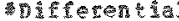

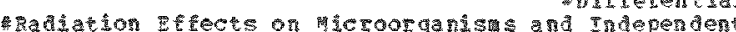

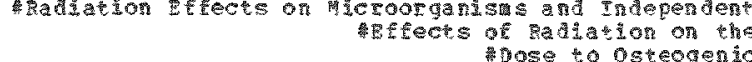

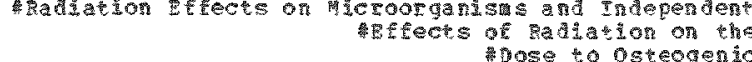

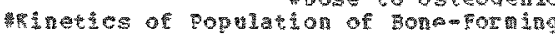

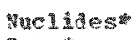
Bonew sop peed

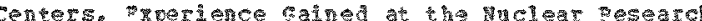

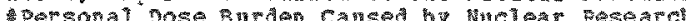

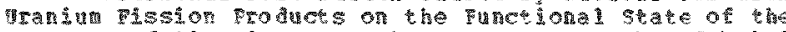

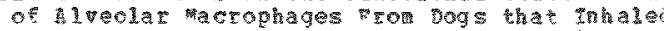

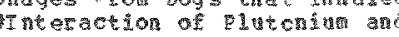

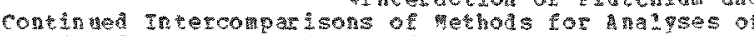
cont 249 ot Dadosch

thosphares:

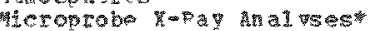

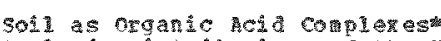

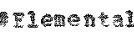

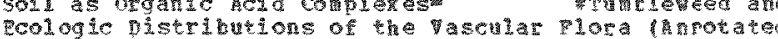

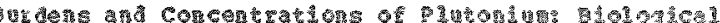

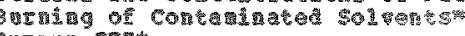

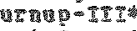

ats

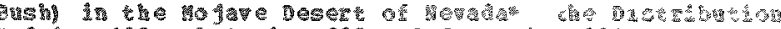

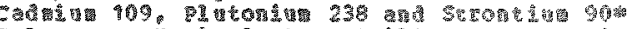

a

Canct

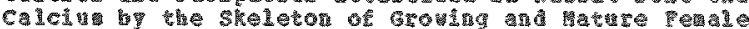

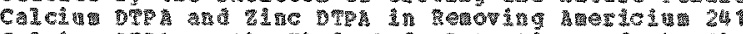

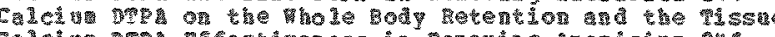

cascu Th

card b2

Ca눈

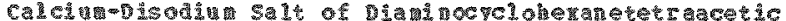

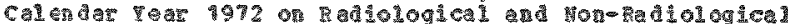

cas

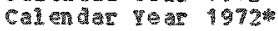

calerda

carevala 1972 \%

Catendar

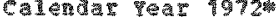

Ca

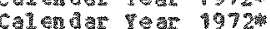

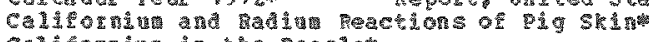

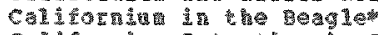

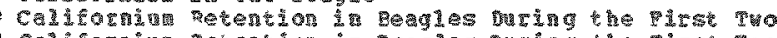

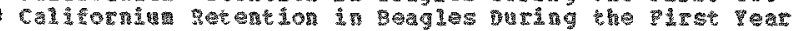

calli

callitir

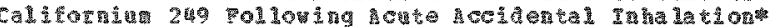

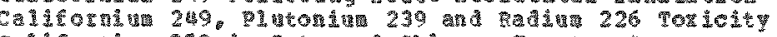

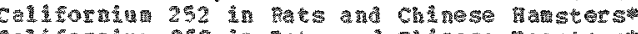

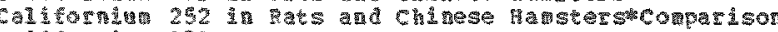

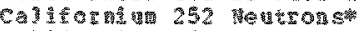

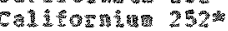

a

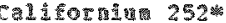

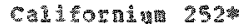

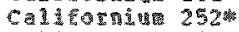

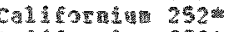

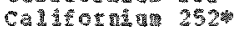

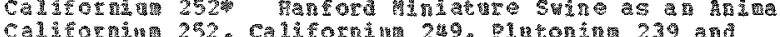

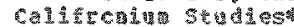

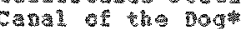

cancer the tence to

cancer

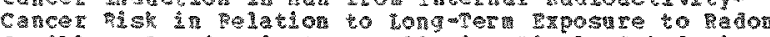

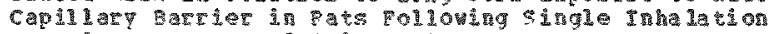

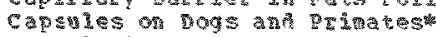

Carsulesto

Car eincogenes

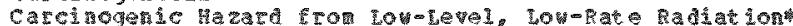

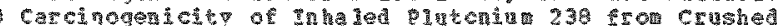

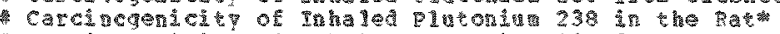

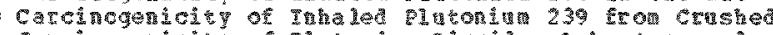

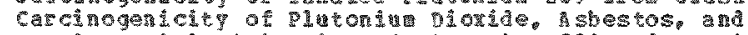

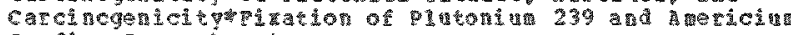
Cardac Dactuaters

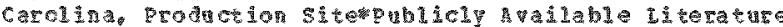
Carrier

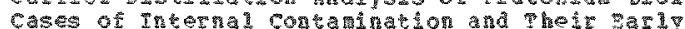

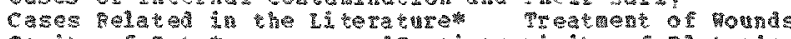

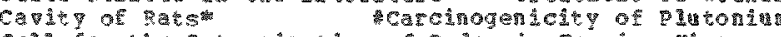

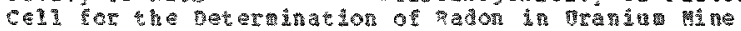

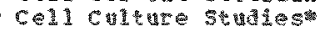

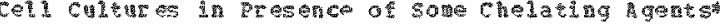

Ce 11 seme

cell susters

Cel 1 is

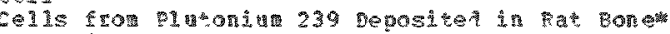

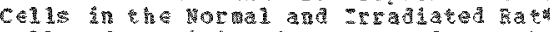

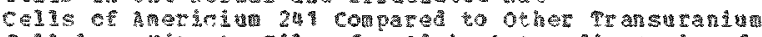

Calu10se

Cencer. Fn

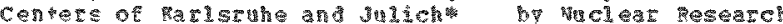

centers.

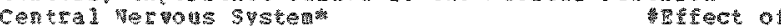

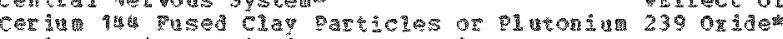

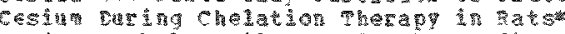

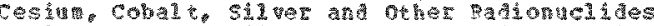

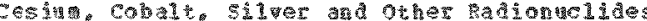

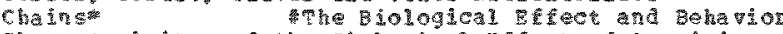

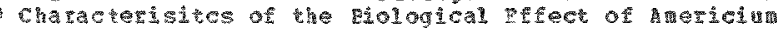

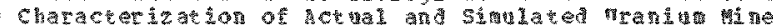

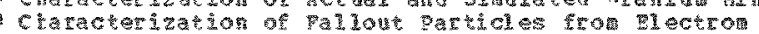

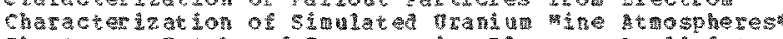

cheatorass notal of Transurat

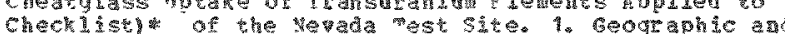

10065 64

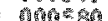

1970

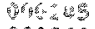

96029

10025

औrote

000976

001998

000092

000200

000207

000020

000026

1004 90

000487

10004

00045

900476

00048

coous

$00044^{3} 3$

1000醒

popone

powes:

000120

000121

000122

000229

000394

000231

000143

$0001 \frac{1}{12} 4$

000065

000042

000005

000353

000534

000 닌

000312

000225

0603

000226

000230

000356
000382

000382

000397

900313

000316

000129

00032

00015

09019

000192

000991

000227

000309

000590

000410

000372

090191

000460

00016

000363

000363

000546

000093

000095

$0006 \%$

$00026 \%$

000485

00045

000 to

000195

000972

000208

000433

00043

00015

000523

000254

$05036 \mathrm{~b}$

000175

00029 


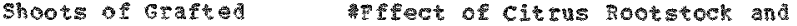
o1 uton 3. 4

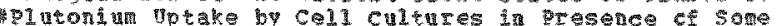

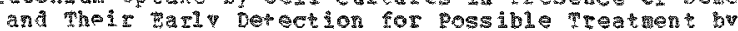
of the $\mathrm{Adu} \mathrm{I}^{\mathrm{t}} \mathrm{Ba \textrm {L } o \mathrm { m }}$

253 from Pats VISng zine and

Elenen sov

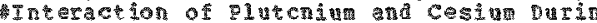

Tn fluence of Internal Inters on

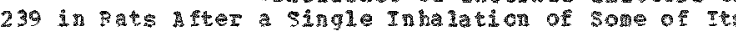
Aำ abysieal and

smon Bone Progress Report: Flut ani ur Revol. 6.

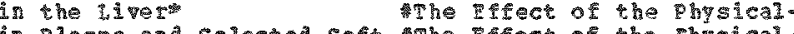

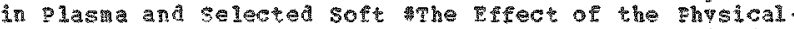
apeace 1 Apolicatons or velear arplosions

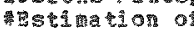
and Fetention of wonomeric plutoniun $239 \mathrm{citrate}$ in the

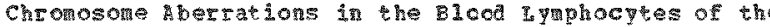
of Chromosom Aberrations

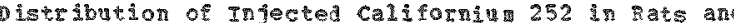
Distrons of Injected caltion 3ehavior an characteristics of paioactive Dobris from iffect of intratracheal1 instilled insteming 25

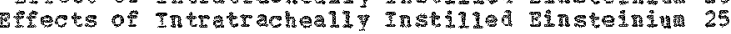

Other Sureses

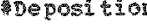

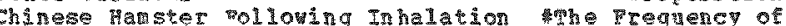

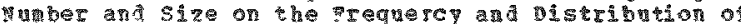

Athosphe rest

A mosphereg

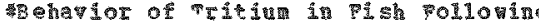

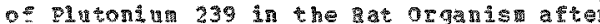
Radionuclifes on cototicosteroi a the

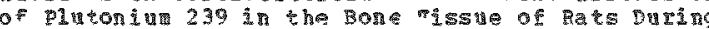

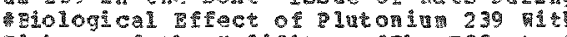

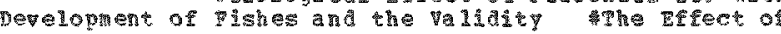

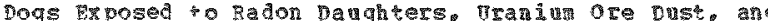

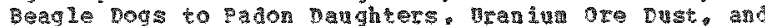
gection

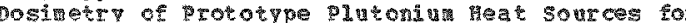

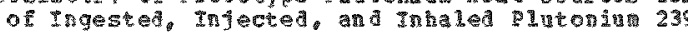

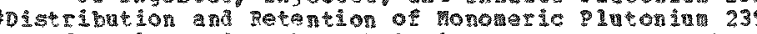

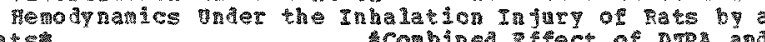
ate to

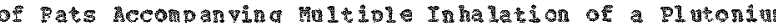

239 Tel tel to 51 frerent pethods of Preparat on of

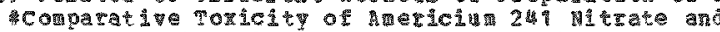

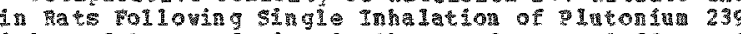

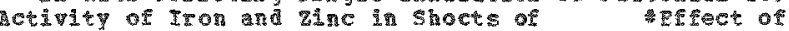

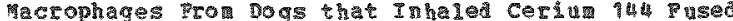

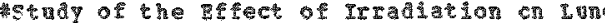

等

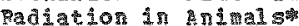

Interconparisons of Methods for Mnlyses of cestur

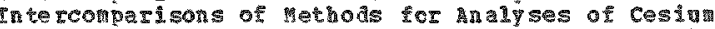

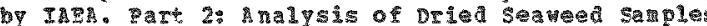

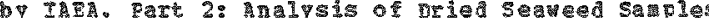
3.

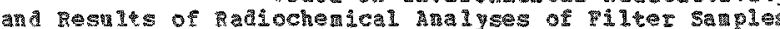

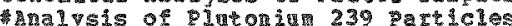
药

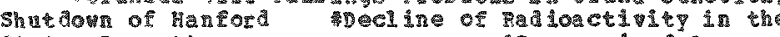
Sctus repor

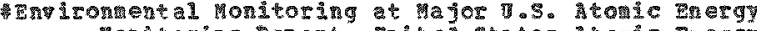

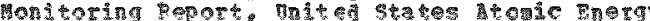

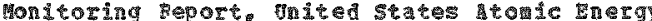

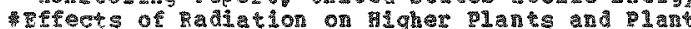
contanination of the rotal diet of dolescents in the exposure to 5 in

citrates

Q1ำ

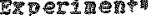

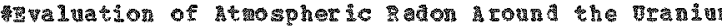
of the organ

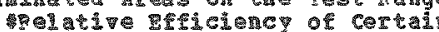

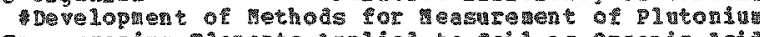

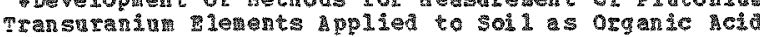

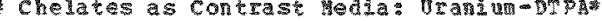

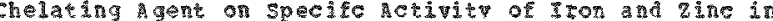
che las

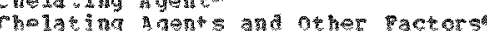

chelatina gastes

cheldting agents Some cases of Internal contaninaton

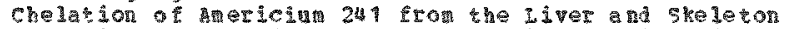

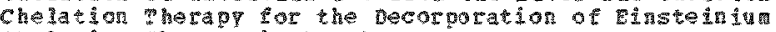
Chelarion whora in

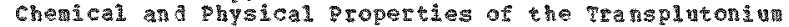

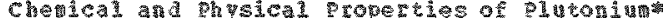

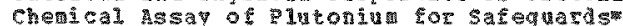
chemeal careinogenesist

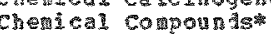

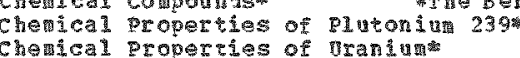

The Behay ior or proni

cherical. Removal or arrow and Its Associated Plutonin

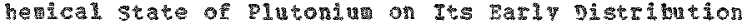

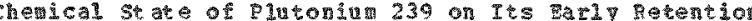

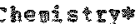

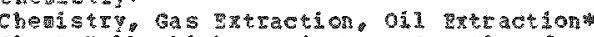

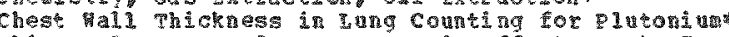

Chinese Haster and Its cytogenic 5 fect on the restes

chinese latstor

chinese natsters size on the requency and Distribution

Chinese rat

Herencion and

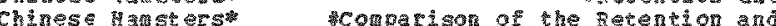

chas

Chom in

chloride in ats

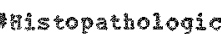

Cholce of the beagle Dor as a Laboratory

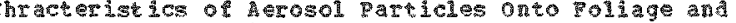

Chrenosche hberratons in the Blood Iymphocytes of tho

Chrchosone Mberrations in the tiver of the chings

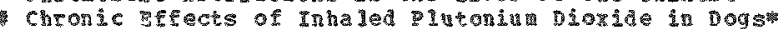

Chrcnic refects of Inhaled Plutonula Dionite in Dogst

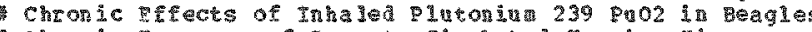

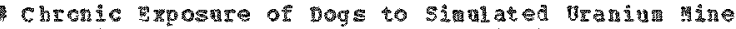

chrcnic

chron ic sicoosures

Chronsc Inhalation of Its 501 uble componnds

chronic Irradtation by Internaliv Daposited

chronic peroral adingstation of the Isotopet

chrcmic peroral aninistrations

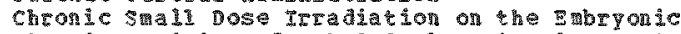

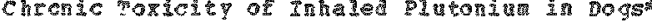

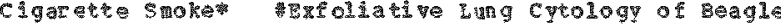

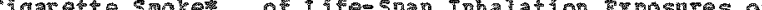

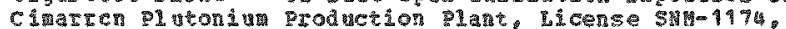

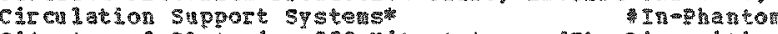

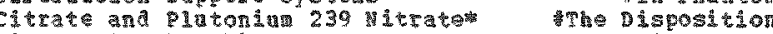

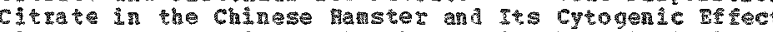

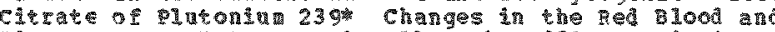

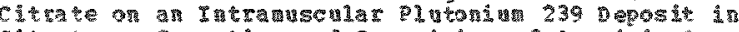

Catrtat on

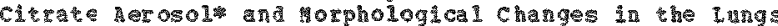

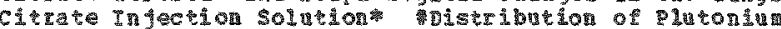
citrats

Cit.

or the lowar-Capillary Baritit

cittris

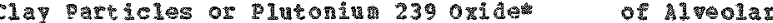

c Iearances

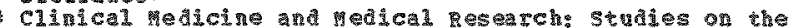

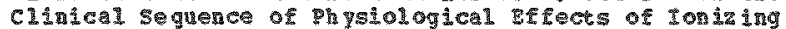

cobat $60 \%$ interature search

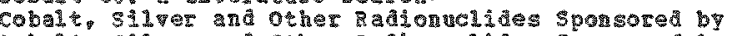
cobalt siner and other pallonvelides sponsorad by

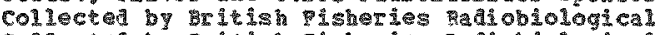

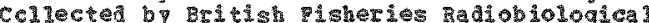

collectol

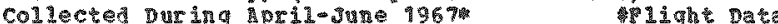

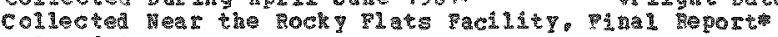

colorator

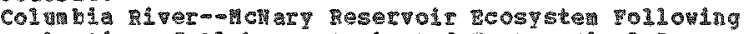

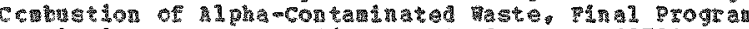

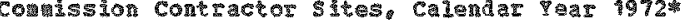

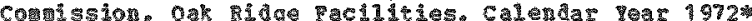

Conis

Co:

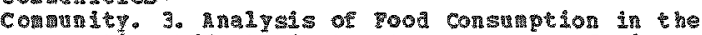

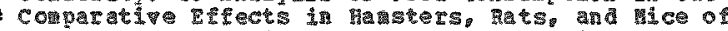

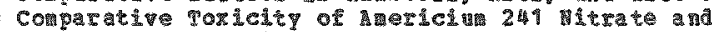

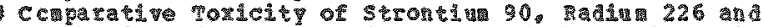

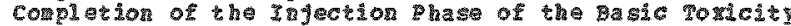

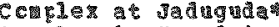

comer a Jar

Complor 501 Sthrevey

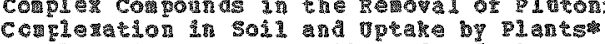

coplexess
000212

0002 स

000179

000243

00) 17 ?

0004 เी

000048

000207

000208

00028

0028

000265

000129

000125

000253

000263

00018

00021

000333

000369

000033

00003

000035

00014

000512

000077

090019

000052
000098

00003 a

000035

000169

000168

000170

000220

000148

00012

000029

000161

000040

000173

0000 .

000223

000561

000319

00002

000033

000093

000240

0012

000196

000160

$00000 \mathrm{~s}$

00024

900072

00035

0016

000290

000434

000433

000434

00047

000432

000468

00050?

000572

000475

0004 \%내

0003 현

000045

000379

000166

000160

000120

000219

000450

000296

000027

000247 


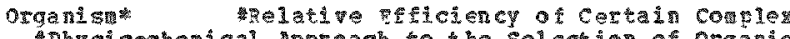

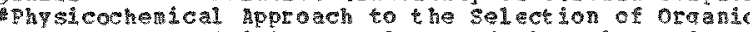

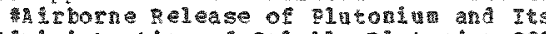

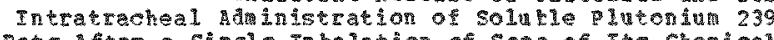

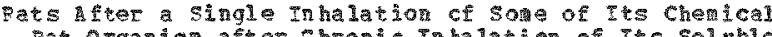

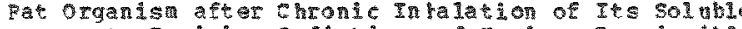

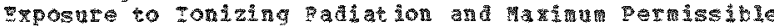

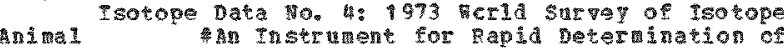
of he Beaglow

S.

Hn Instrument for Reatine Determintion of 1972 tasules of the continued

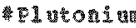
History of 1972 \% Vuclear Doner Plancs, proceding of the sonther

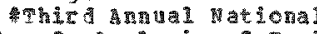

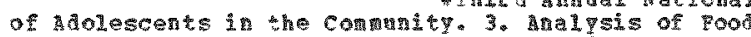

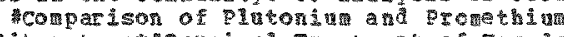

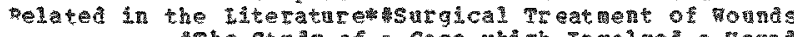

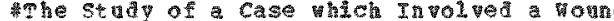

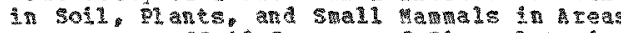

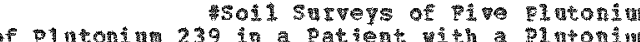

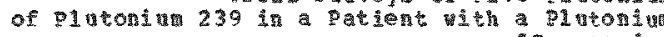
scaneng

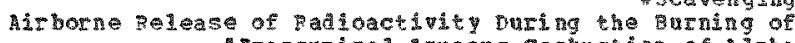
Fressur 12ed hopeous conbustion of Ipha F

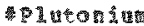
Ttement bv chelating Agent

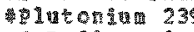
Xatrin 굴

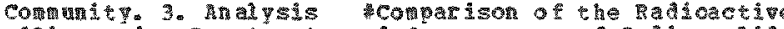

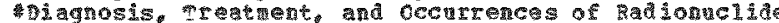

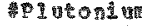

Freretion of Plutonin Following Aceidental Shin

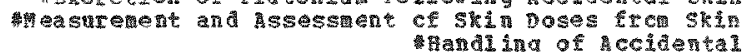
manding of hecitental

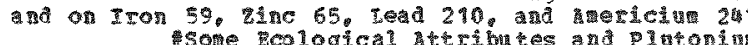

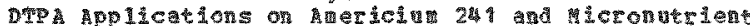

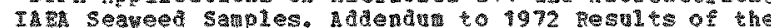

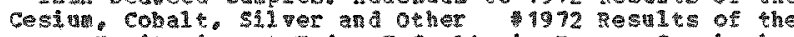

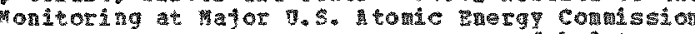
4Che 1 ats actober $25-27,1972$.

iftentes

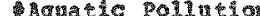

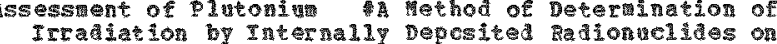

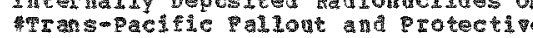

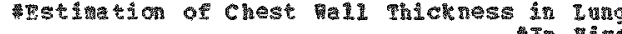

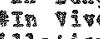

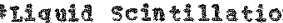

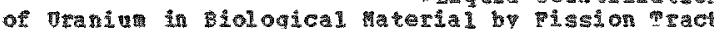

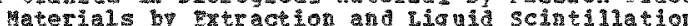

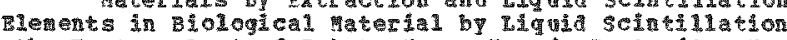

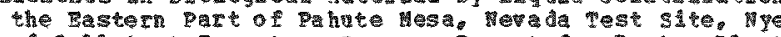

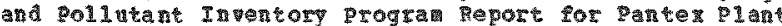

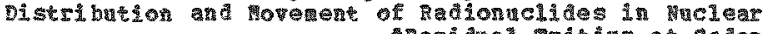

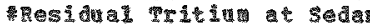

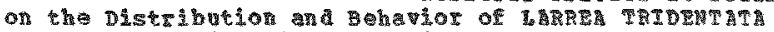

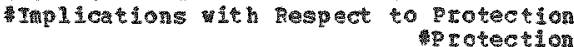

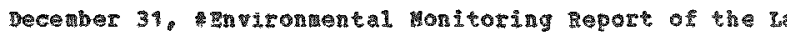

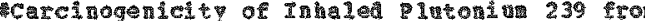

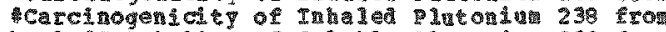

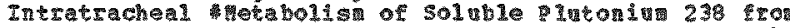
2eil Products

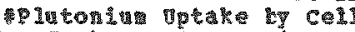

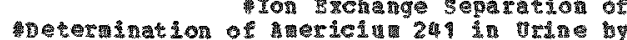
管

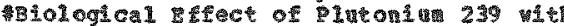

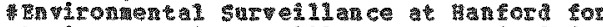

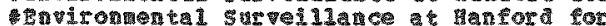

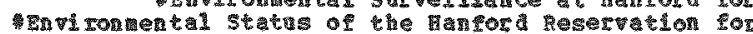

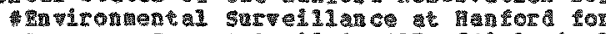

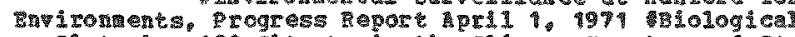

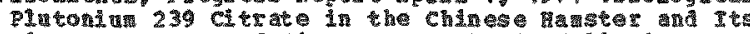

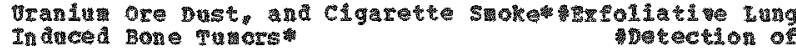
奇D象 (Hob) a 1 lationsh

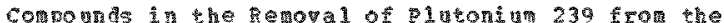

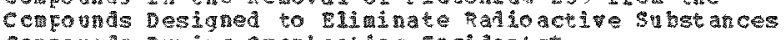

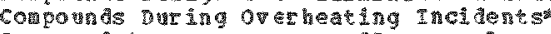

Cet Eounds:

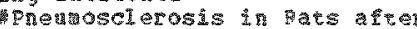

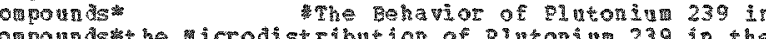

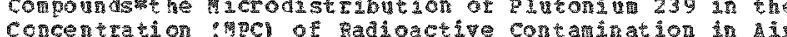

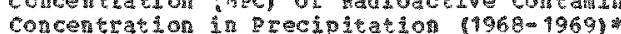

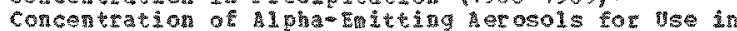

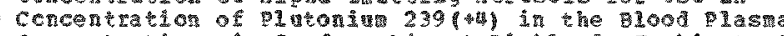

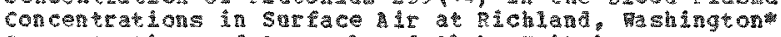

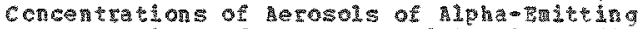

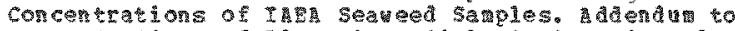

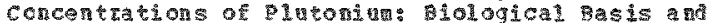
ccriterence held at cak widge, mentessee october $25-27$.

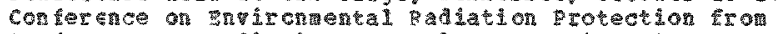
cencerence on adation control Nev Forizons

consupion in he Institucional Diet Prograt Det

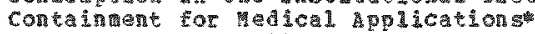

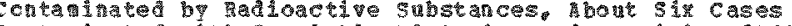

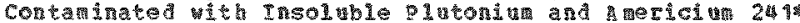

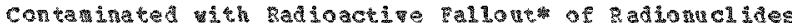
contrina

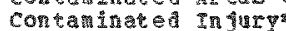

contaminate soin in poly

contaninated Sol intris 2.

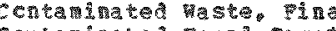

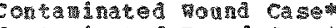

Contaninated Tound cases

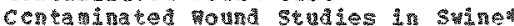

concen contanation in he dewer

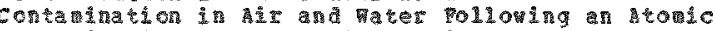

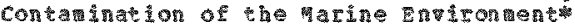

Contarintion of the poth

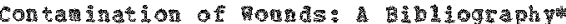

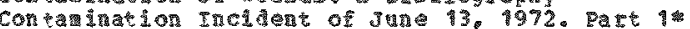

contan thato tom

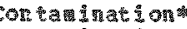

Conta inations

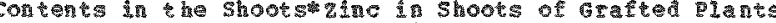
cotrents of Perental vegetation in area 13

Conterts of pr54619-5- Sotheats Groun in Calcareous

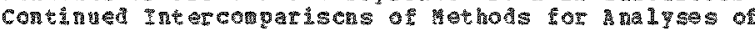

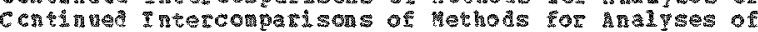

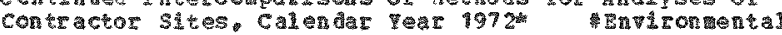
Contrast

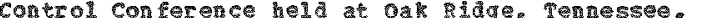

conste to

Control swsteratics for nischarge of Radioachive

centrol hev torizons

correction Factors for victerent Boly Flatis in the

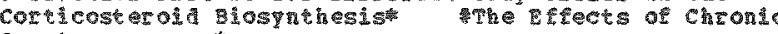
counter

Coub

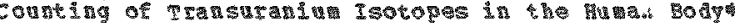

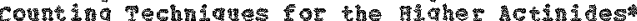

Coune 1 in g

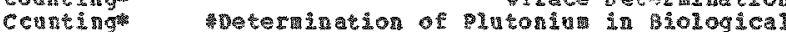
conting

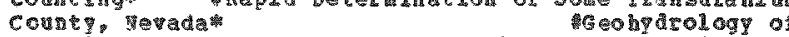
Cover 149 calend crater secter

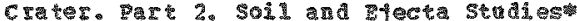

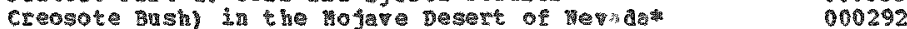

cresteria 00056

criterata 00056

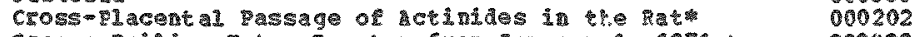

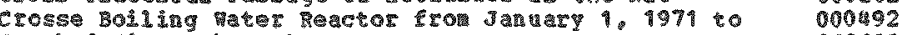

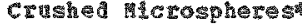

crtished hicrosing

C rus:

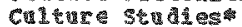

Cutrits

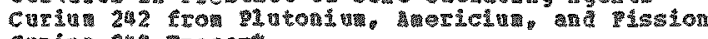

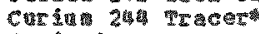

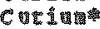

Cat

C

CY-1971 (4)

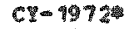

$c+1972 \%$

CYc11n of EL

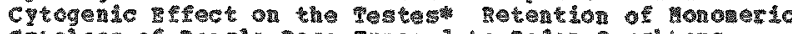

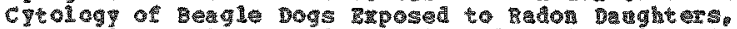

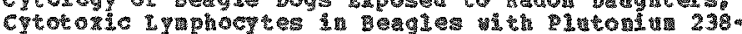

(2)

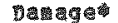

000027

900579

0 10) 25

000124

00091

0002

000511

00034

00549

000457

000556

00318

601407

00501

000405

000580

$000 \% 6$

00396

000250

00055

000379

00383

190380

000548

000304

10246

然

000569

000500

000300

000725

900369

0005

000258

00268

0506

000192

000190

000164

000178

000290

007276

$00028 \%$

000038

000423

000 年15

00045

00941

000329

00003

0000द

000466

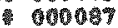




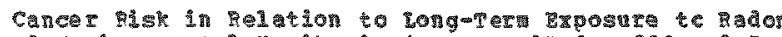
and is

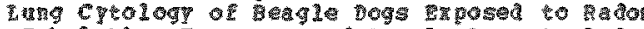
If of I

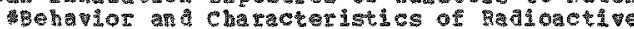

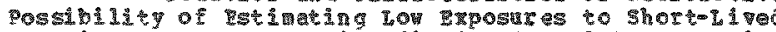

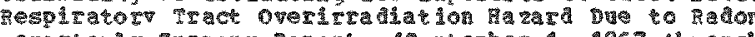

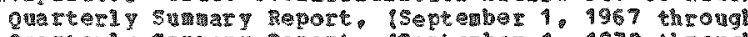

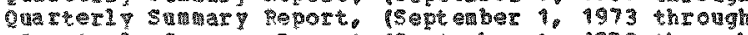

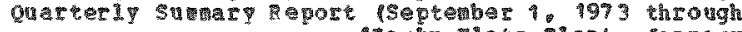

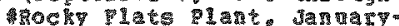

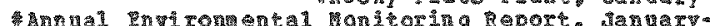

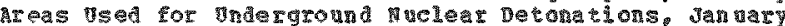

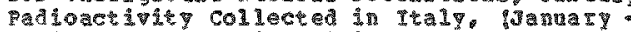

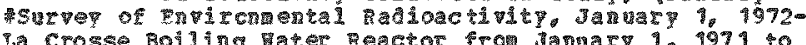
La crosse Boling

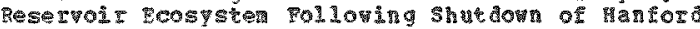
Anericing

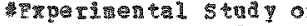

缐

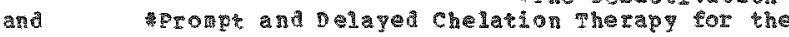

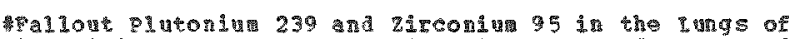

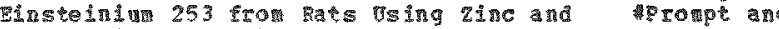

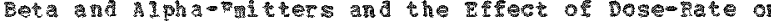

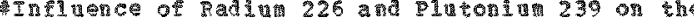

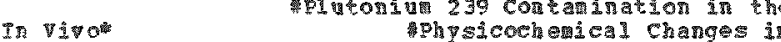

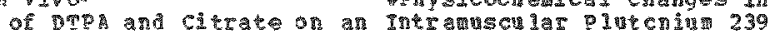
pose to ostoggenic celis from 2 utonin 239 *

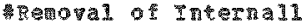

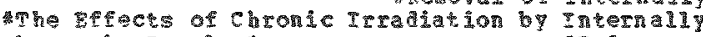

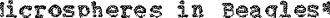
Pu 1 mona

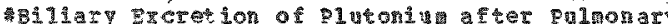

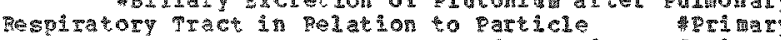
KComparison of pissu 货reretion an

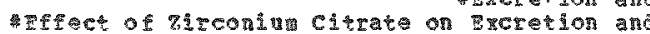

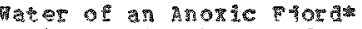

poliage and other surfases

Fa1 104

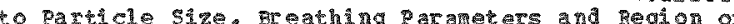

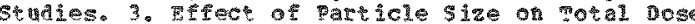

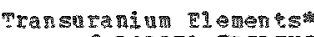

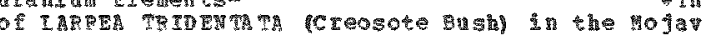

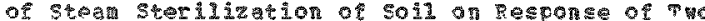

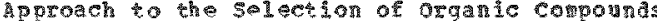

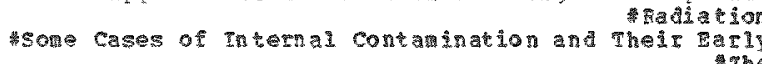

21

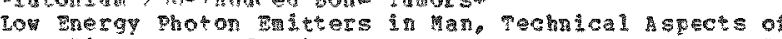

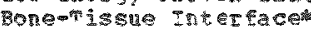

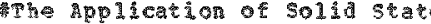
* 2 a

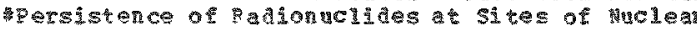

to the groun site and other Test Areas Bsed for Thderground Muclear

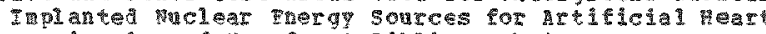

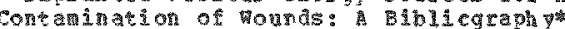

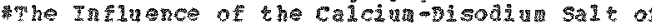

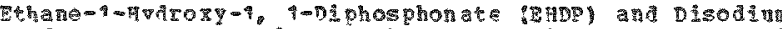

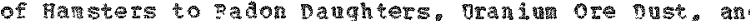

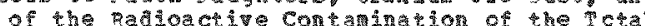

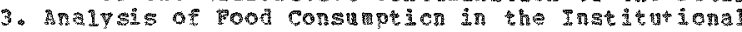

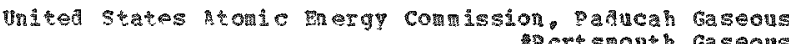
勇 crts 8 movth Gaseous

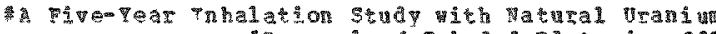

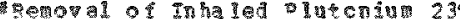

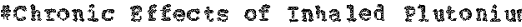

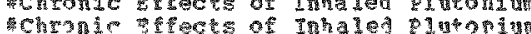

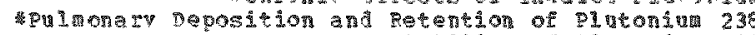

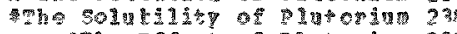

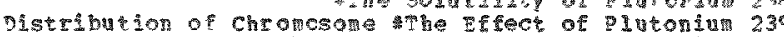

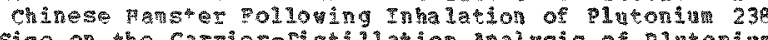

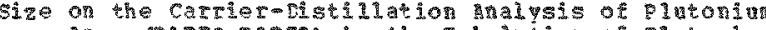

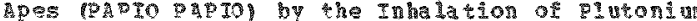

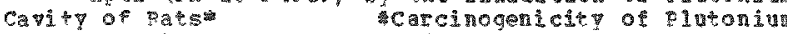

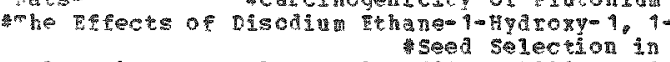

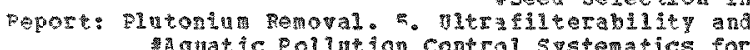

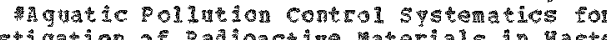

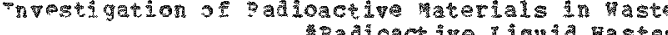
Mationctive 셕
D)

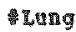

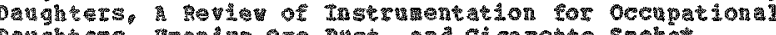

Dangh

Daghters. Dran

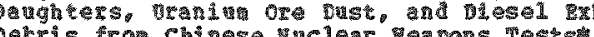

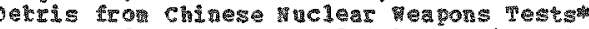

Decy Protucts of Radon 222 in tran

Decay produ th

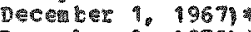

Personel chatering of of a lout sogma

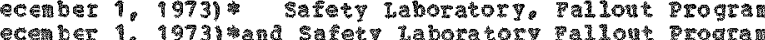

Decenser 1970 s

ocsever 1972 .

Docesber 7972 for the fevald Test site and other Test

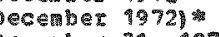

Decerber $31.1972 \%$

yot an

Deon

Decon

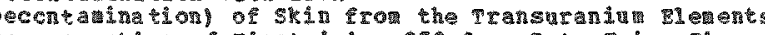

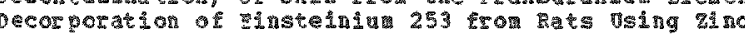

Des

Delayed chelation Ther apy for the Decorporation of

Delayed somatic Iffects ron Lo Let and Alphom

Dertal Root Cand of

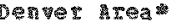

7eony Deposin 1 in

Depesited in

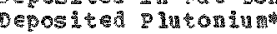

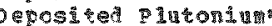

Deposited Radionuclides on corticosterola B Iostythesis

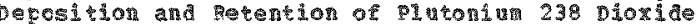

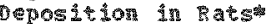

9eposition of Aetosol partictes in the tur

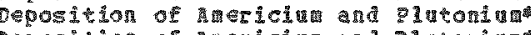

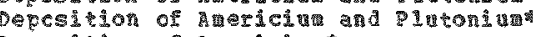

Deposition of A mericing

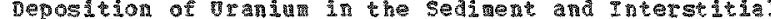

Decosition Chycteristics of Astosol Partiels on

Tepos 1 ton

Deposition in the Hum Depsition setertion and ranslocation

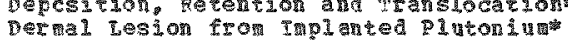

Desact ivation Decontanination of 5 in Desert of pevada on the Distribution and Behavior Deser?

DAs Cetection and Dosinetrot

Detection for possible Treatrent by chelating hents

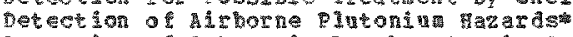

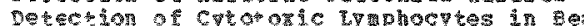

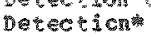

91 0 :

Isses

buteng

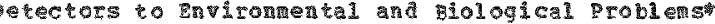
coton ations:

Tecon ations:

Defonations: on

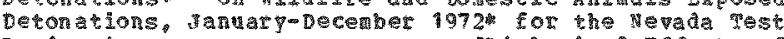
Devites rologica 1 ingets of

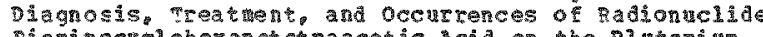

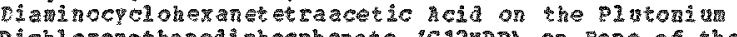

Dichloronethatad phosphonate :C12mDPl on Bone of the

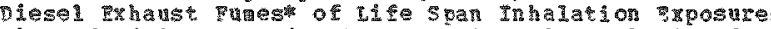

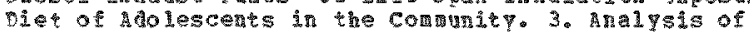

Die Progra Diterentil cell sensit th

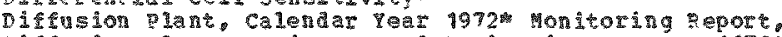

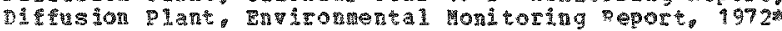

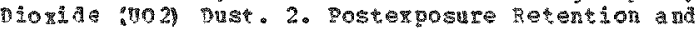

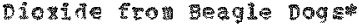

Diondat in togs

Dions in

Dionid in

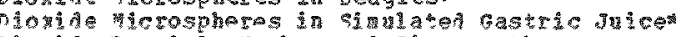

Dionife Particle wuber and size on the freguency and

vionde Pazticless

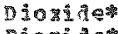

in the clood Itymplocytes of the

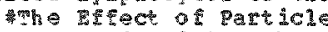

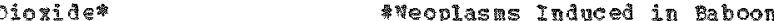

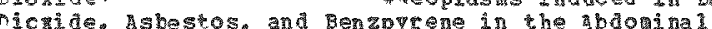

Dichosphonate (ZnDS) and Di solitu

DPCDCH.

Disappearance of Pluconiu crom 81 asma as a metion of

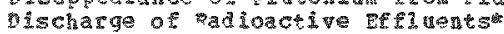

Discharga Areas at los Alanos for the period ony 1.

Discharged to Ground in the 200 areas suring 1972 \%

Diseas
000397

00949

00028

00022

000512

000349

00044

000438

000472

00048

000420

000473

$00017 \%$

000520

000492

00042

000158

000015

00009

000207

00057

o09 9

00020

000136

000230

00045

000100

000240

00008

000092

00002

000029

000251

00013

000390

000113

00010

090112

00032

000098

000442

00039

000009

00038

$06009^{\circ}$

000292

000232

000253

000345

000410

000445

00006

00146

000350

000422

00042

00045

h00 307

000473

90005

000383

000026

000145

00022

000379

000379

00036

00049

00042

000114

(1)

000169

000968

00025

000200

000035

00003

000277

$000 \% 4$

00019

60014

00030

000117

000500

000436

000570

000408 


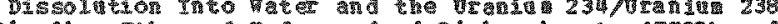
0I

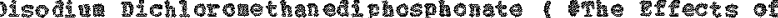
the patroni

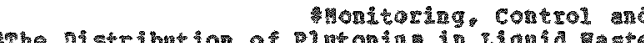

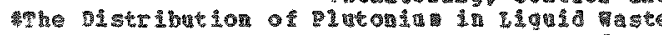

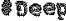

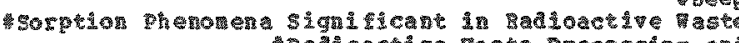

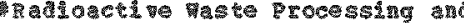

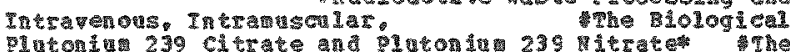

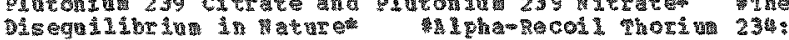

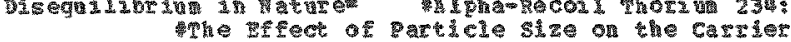

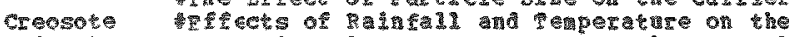

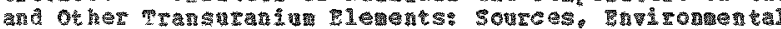
creter interta

soshot

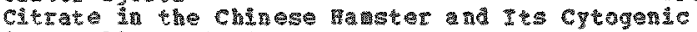

1 1

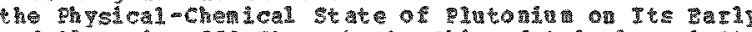

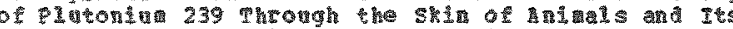

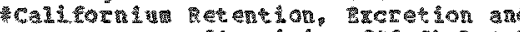

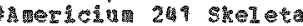

Beagles: Cat They Be con

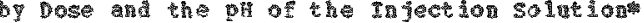

35el etal

Stronk

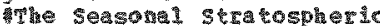

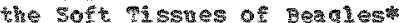

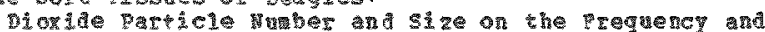
vin of the Bat

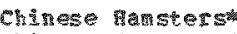
Chesese has thes:

GLobas Invertory an 4Compartser or the getertion at 4)

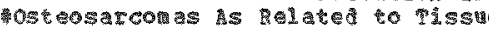

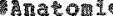

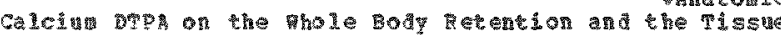
and ana?

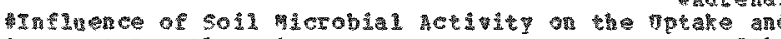

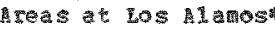
methous of rrewation of a citrate in jection Solution The 1 d Tiventerates

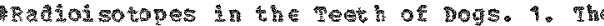

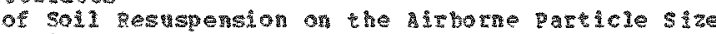

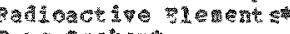

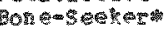

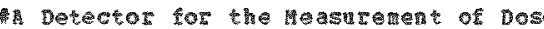

of

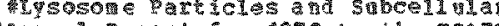

Wolne 1: If

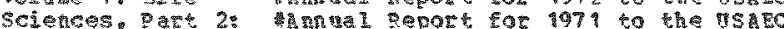

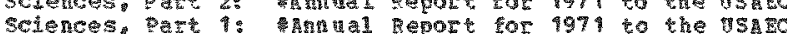
Pa

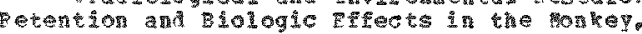
Whoje of the Bagle

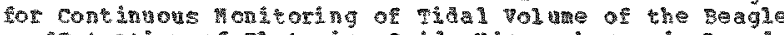

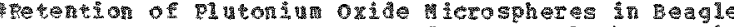

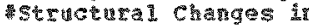

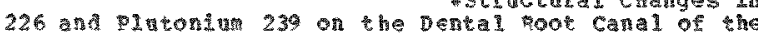

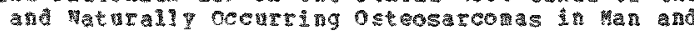

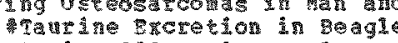

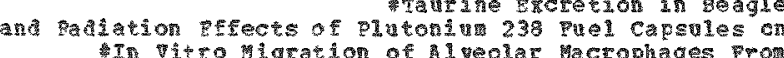

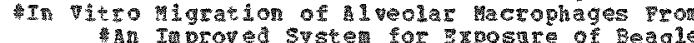

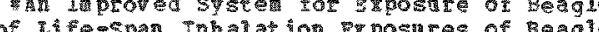

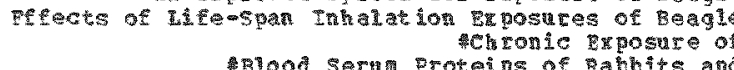

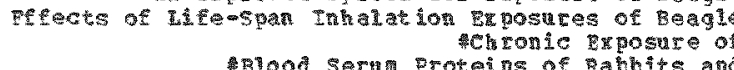

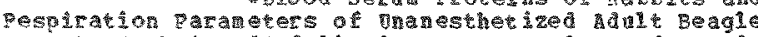

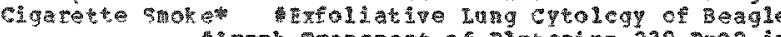

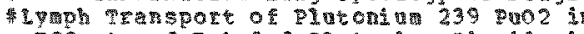

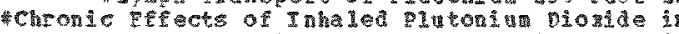

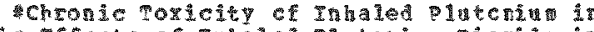

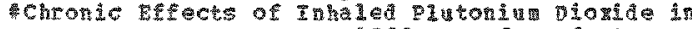
- Efect of protuc vron

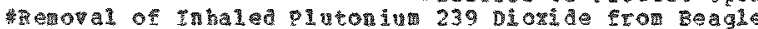

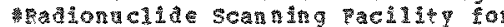

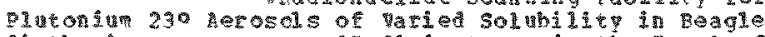

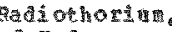

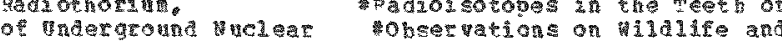

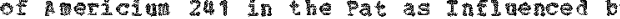

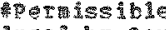

*ziocherical changes sroduced by Io

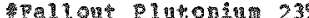

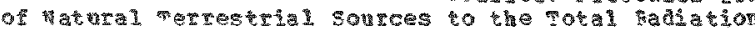
1 \%

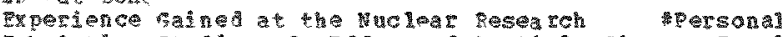
Fhalation Putas. 3.

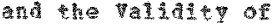

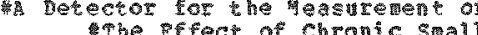

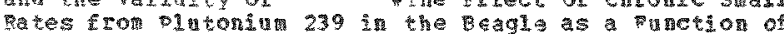

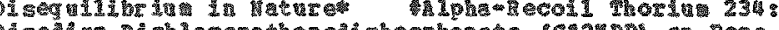

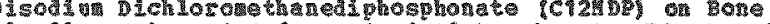
Drsod 01501

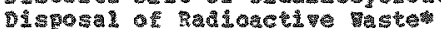

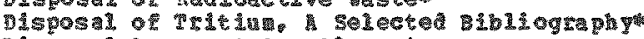

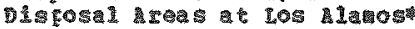

Dilsoos

1): 180

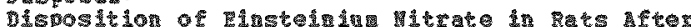

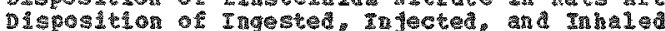

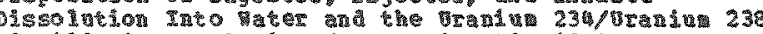

DISt1 1 1.

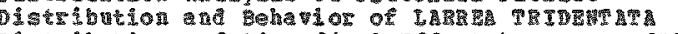

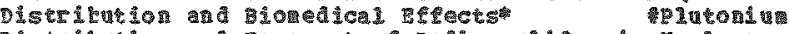

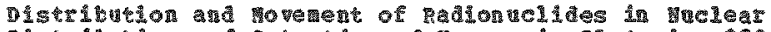

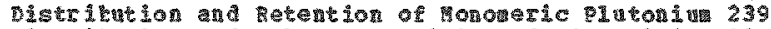

0.

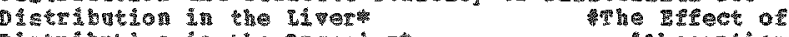

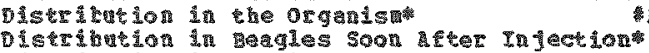

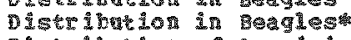

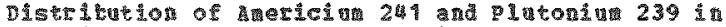

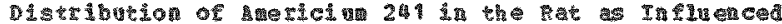

Distr hot

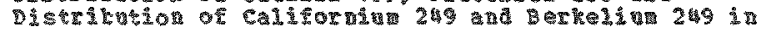

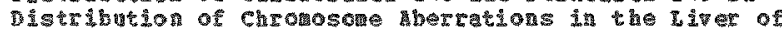

Distribution of thingeivivin 253 in the petoplecenta

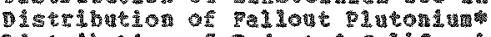

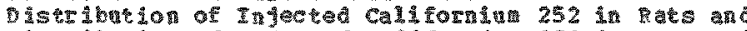

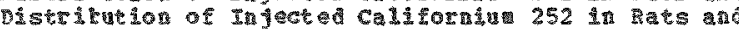

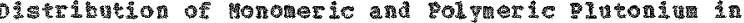

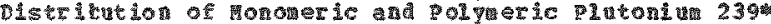

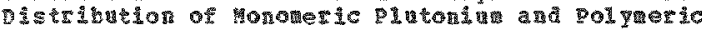

Digeribne

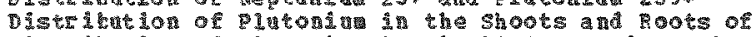

Distribution of piatong in inguid aste Disposal

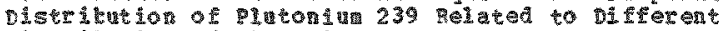

DIStris

Dis

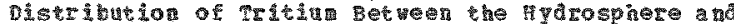

Distitution

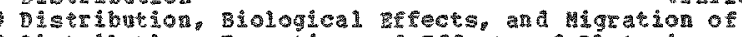

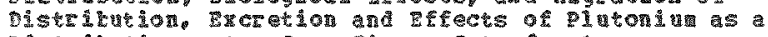

Distributions a c Bene-Tissue interfaces

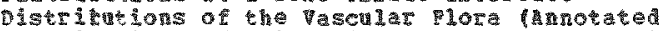

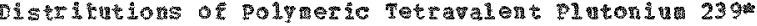

Divisicn of Biological and Envimonental Research.

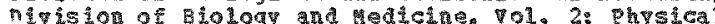

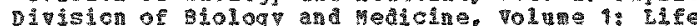

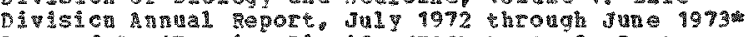

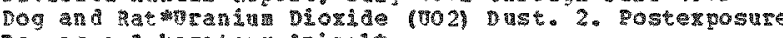

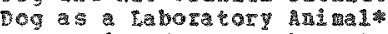

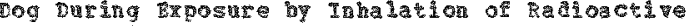

Deg $\mathrm{E}$ angs

מoy Ske

Pegit

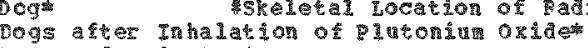

Dogs and primets

a tof

Degs to Radioactive Aerosolsw

Doge to nadon Daghtrets. Traning ore Dist. and

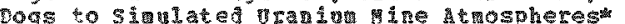

Dogs

Dogs buring Tra

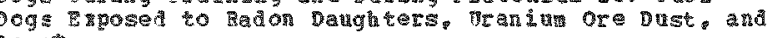
$\operatorname{Dog} \sin ^{2}$

Dogs

Dogst

Dog $\mathrm{s}^{\mathrm{st}}$

negs

negs

Dogs

$\operatorname{bog} \mathrm{s}$

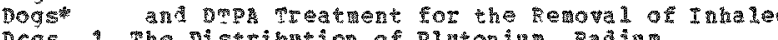

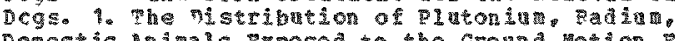

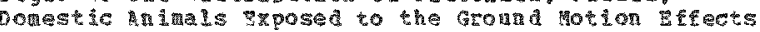

Dose and the plu of the Injection Solutiond Dese Ecr Internel radiation

Dose of atditelon

Dose to man

nose to nat

Heontribution

bose to osteogenic cells from Plutonin 239 Depositet

Dose Buther Caused by velear Research canters.

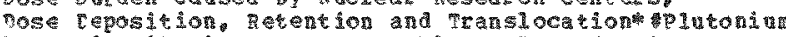
bese istributions a a

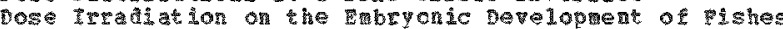

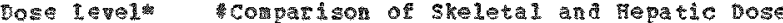

600525

00018

009145

00002

0002

0058

$00058 \%$

000325

10059

000587

000205

00002

000525

00027

000292

0005

00003

Trongs

000133

000035

000096

000122

000118

000119

00019

000510

000229

000035

06020

1004 47

000144

00014

โวกำ

000092

000014

000249

00032

000196

000326

000085

000037

000525

000115

000239

000350

000291

000233

000393

000114

000032

000053

000250

00096

000230

000055

000343

000072

00035

000223

000224

000054

000052

000049

00007

000169

000179

000168

000188

000141

000352

000085

000307

000199

000387

000155

000358

000320

000451

000009

000350 
tcomon

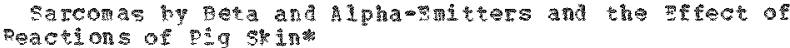

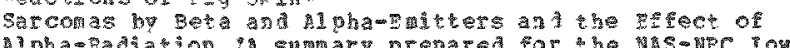

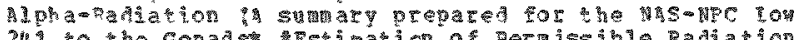

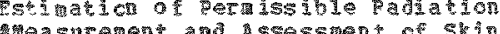

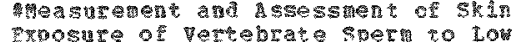
Wots and Harm from Froosure of pertebrate sper 20 Lo

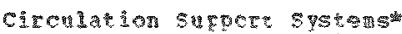
คrodecton and

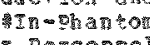

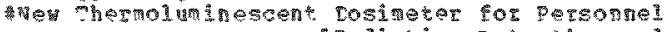
3. *me

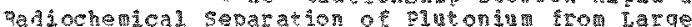

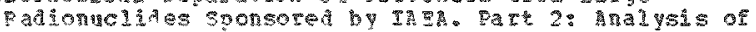

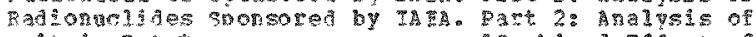

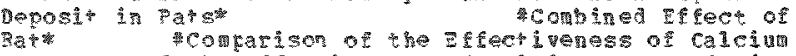
of the zisacivenes of calcin

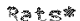

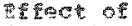

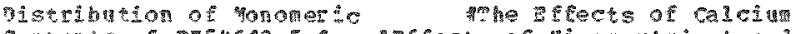
contegy

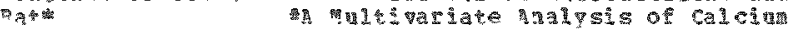

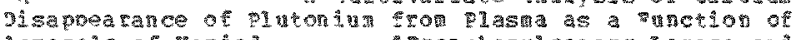
herosols of Vartion

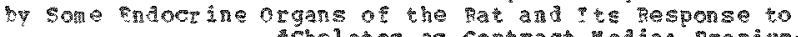
sthelates as cortras nea

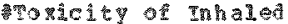

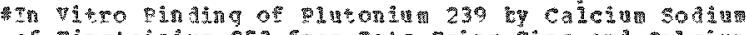

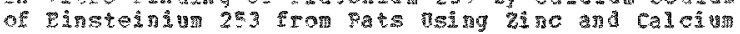

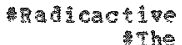

Tnha lat

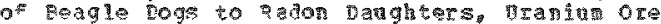

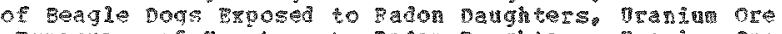

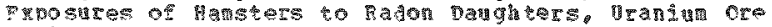

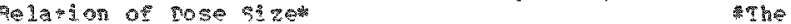

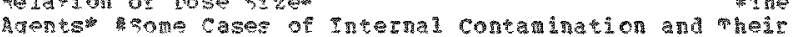

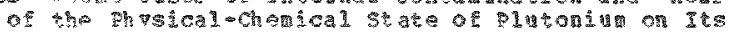

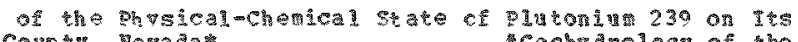

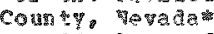
Geofyatologi of she

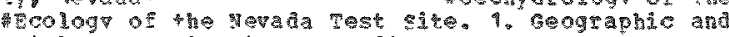

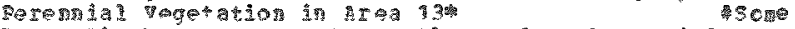
朔

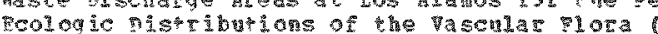

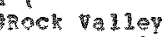

落a

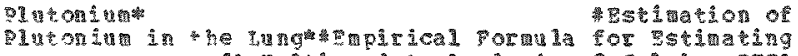

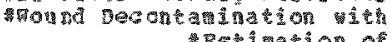

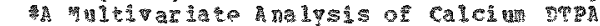

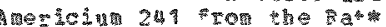
cal andar Tar 1972 Gonarison on the axp nua?

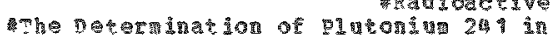
Control $3 y$ ste

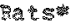
Intratasentas?

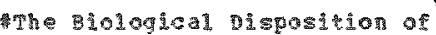

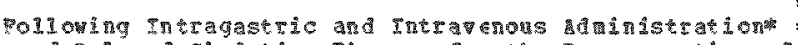

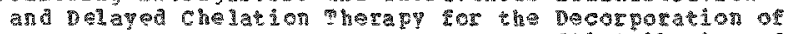

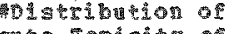

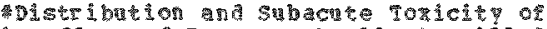

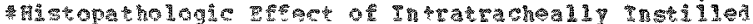

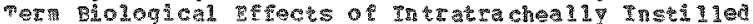

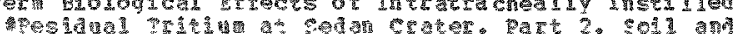

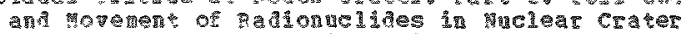

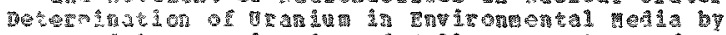

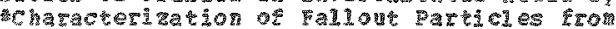

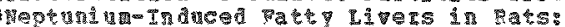

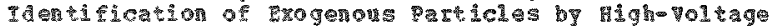
A wospherest

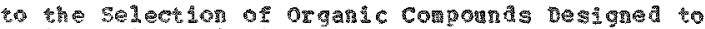

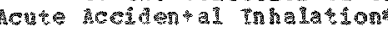
级e

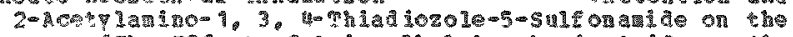

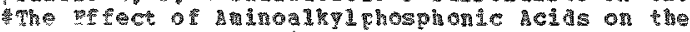

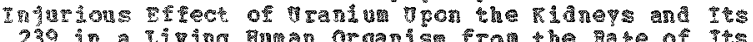

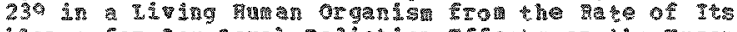

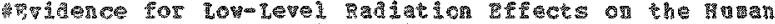

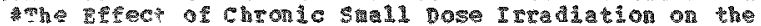

Dos Cos

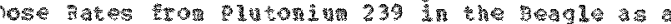

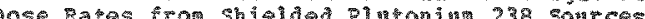
Dose size

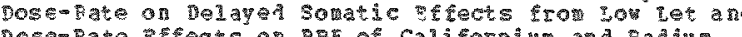

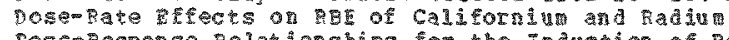

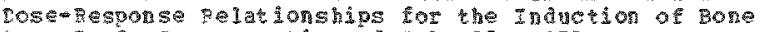

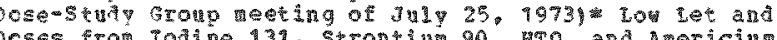
Deses from iodine 13 . Strontu

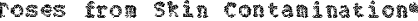

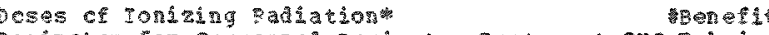

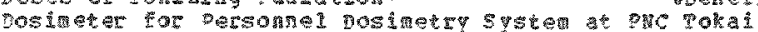

cos

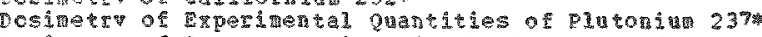

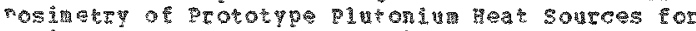

Des.

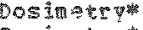

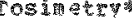

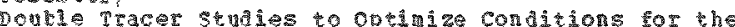

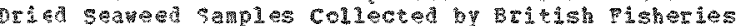

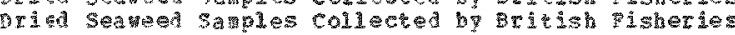

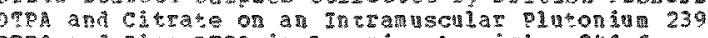

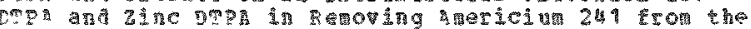

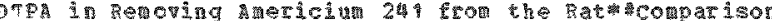

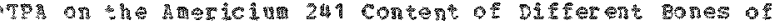

CTㄹ O

DTPA Acolications on

mo

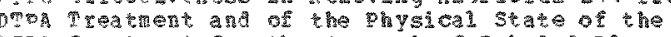

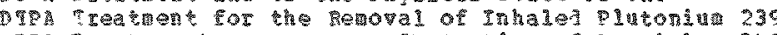

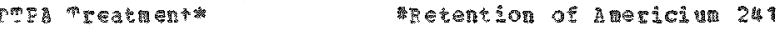

Q

D.teg

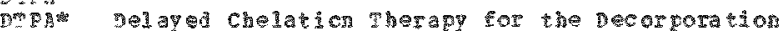

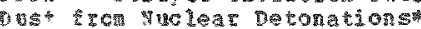

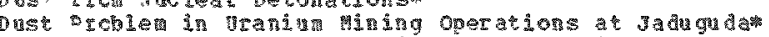

vest. 2. Postaposure

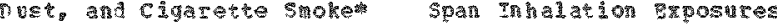

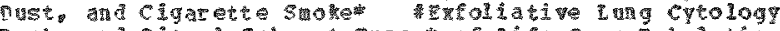

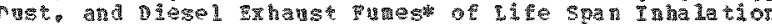

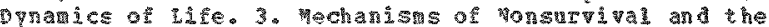
arly catecton for possible mearment by chelating

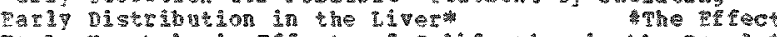

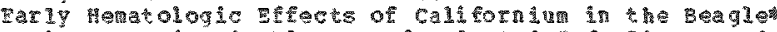

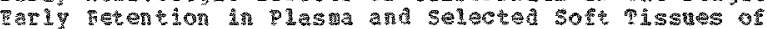

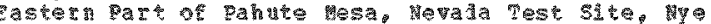
scologic Dist

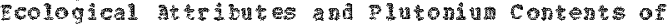

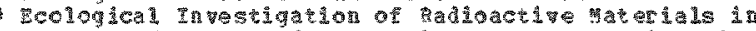

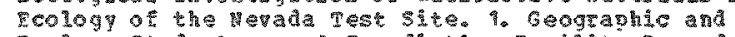
peolog stu

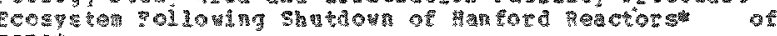

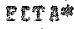

2.

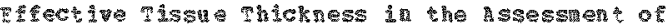

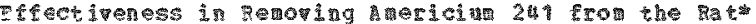

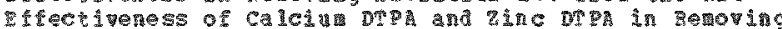
E.

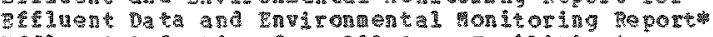
2) F.

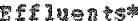

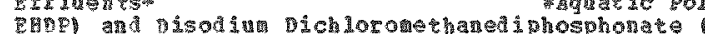
Fin

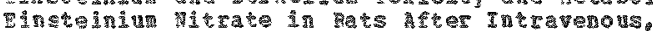

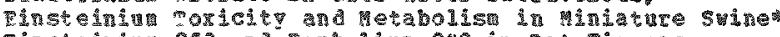

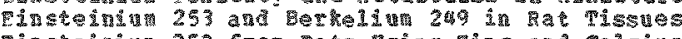

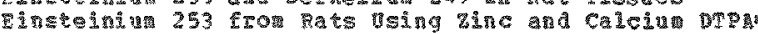
anseing 253 in the peroplacenta รin

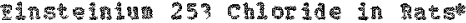

F⿻ำ

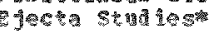

isectis

E

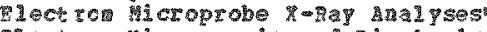

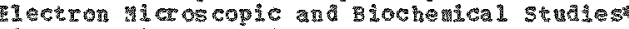

Lectron

11 1

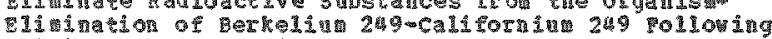

21 1

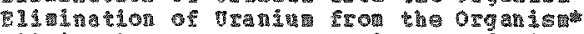

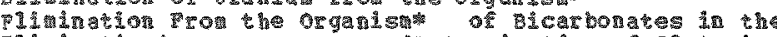

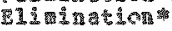

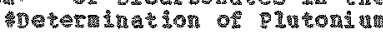

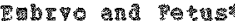

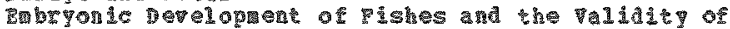

000530

00013

000219

000310

000136

000006

000136

000136

000123

00055

000431

000533

900315

000446

000385

000103

000272

000434

00043

000240

000198

000198

000201

00022

000200

000153

000197

090212

000210

000020

000207

000395

00011

000223

0000 业 1

000221

000217

000410

000036

09005

000214

000339

00029

000304

00035

000291

00045

90042

00006

000399

00039

0001

000497

090 t68

$90057 \%$

000262

000500

000145

000130

000205

$00017 \%$

000079

000207

000206

000133

000097

000019

900 33

00033

000254

000028

000002

000368

000253

000394

0000

000011

00003

00040

000173 
for the TrA

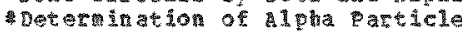
a ssessipent of ton snergi photon

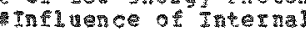

for apld Deterination of concintrition of 1 tha Detertination of Concentrations of Aerosols of Alpha

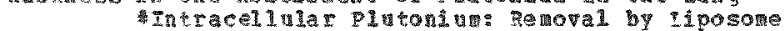

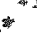

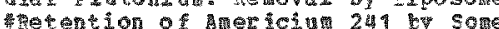

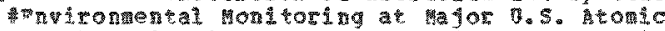
4.

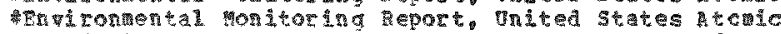
Detsetion

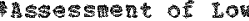
Tretcalibraton for Iow

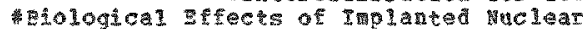

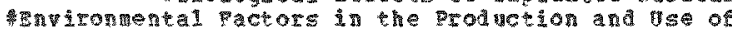

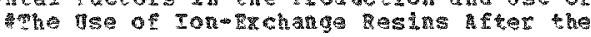

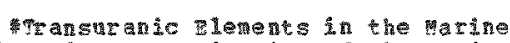

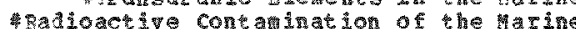
sources of Irti pre Appication of Solid state betectore to

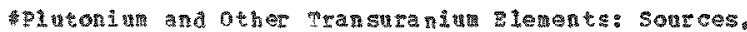
3ne tapt

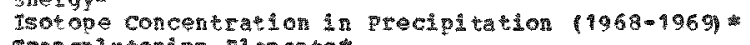

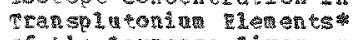

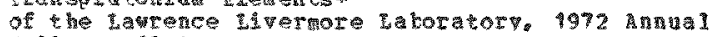
vall ev $5011 \mathrm{~s}$

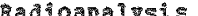

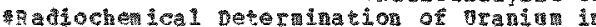
ytantu processing

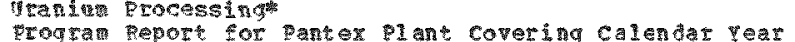

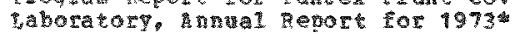

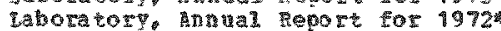

conissin contractor sices, calendaz yeer 1972

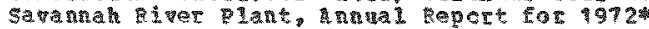

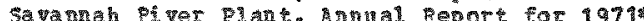

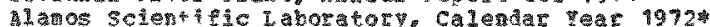

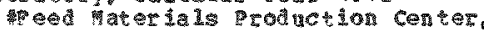

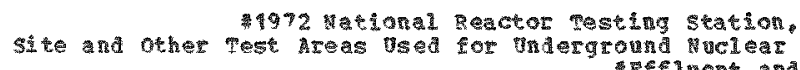

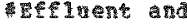

Boiling vacer Reactor

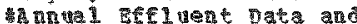
1972

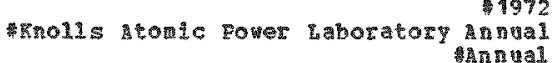

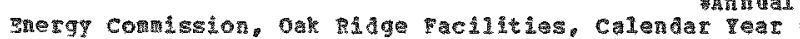

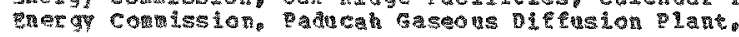

Bor

Rent:

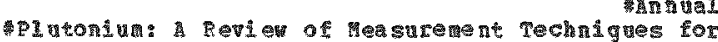

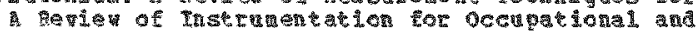

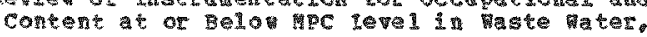

Rlarts, Hrocedings of the sonthern conference on S01.

Jankary - Decastors 19721 *

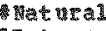

Dater of

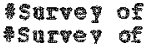

31. 1972 \%

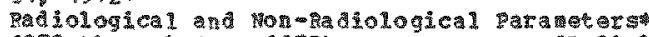

1972 throug an 1973

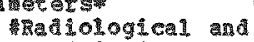

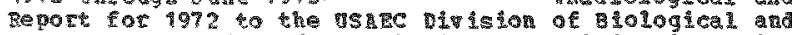

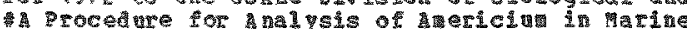
21 Progra

1972 \%

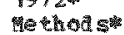

adenga

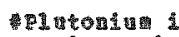

CFet

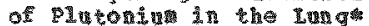

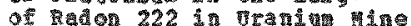
Dit ton ton

RS

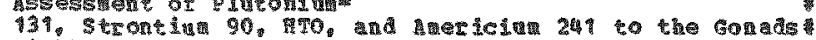

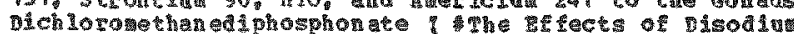

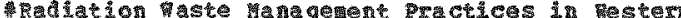

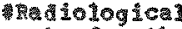

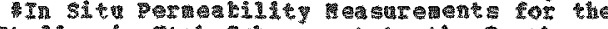

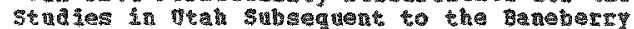

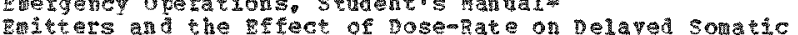

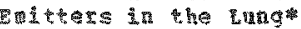

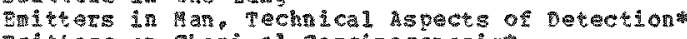

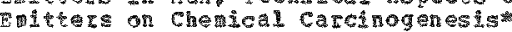

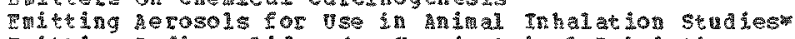

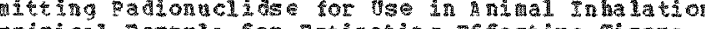

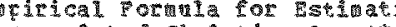

Thcasulated cheiating agent trorgy comission contractor sites calendar wear 1972

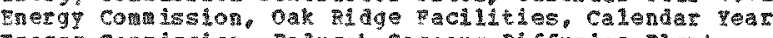

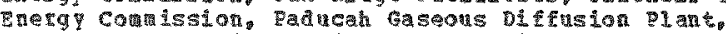
Energy photon Binters in tan, Technical ispects of Energy Photor heasurenents

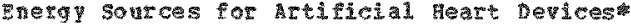

cotects

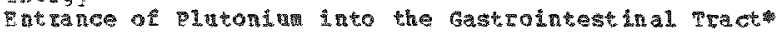

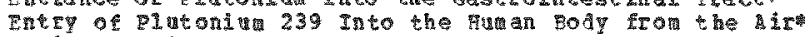
Environance

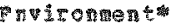

Erv วิronden

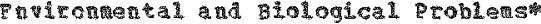

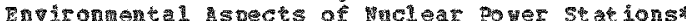

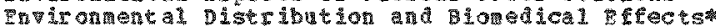

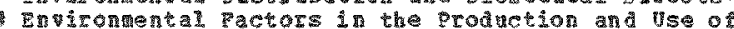

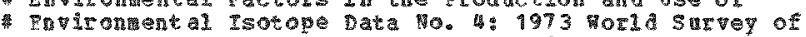

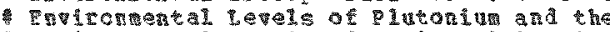

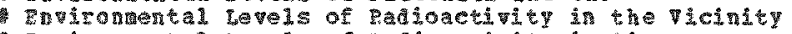

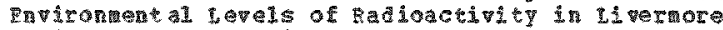

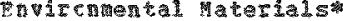

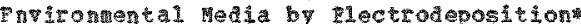

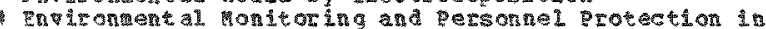

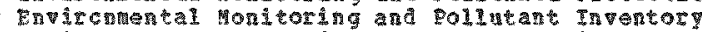

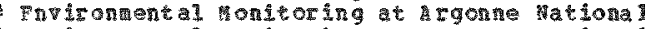

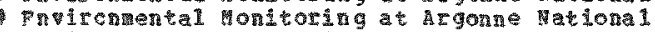

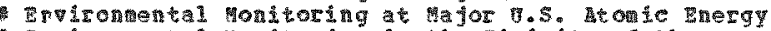

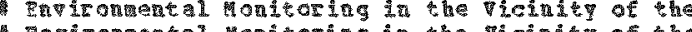

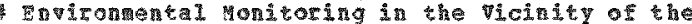

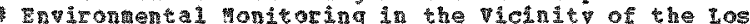

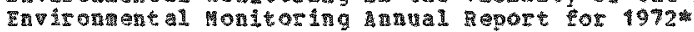

Eny

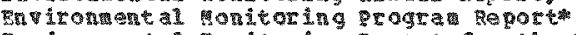

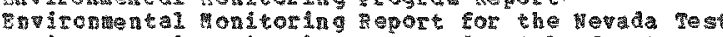
F

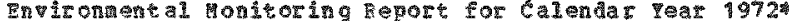
Envite nuental Tondtoring Report of the La crosse

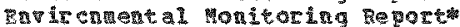

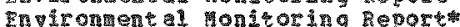

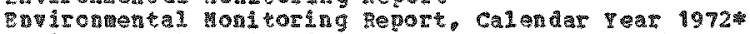

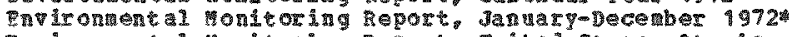

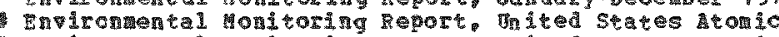

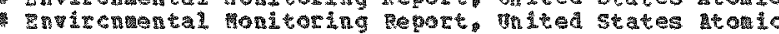

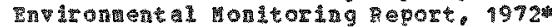

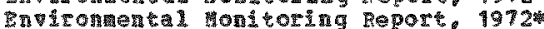

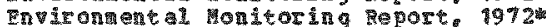

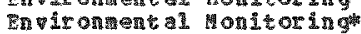

Envircmental toritoring

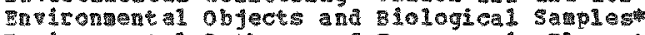

Eviroment pathats of Transuran

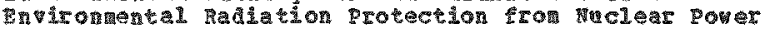

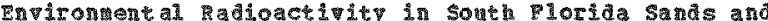

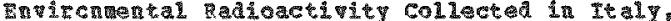

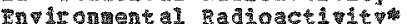

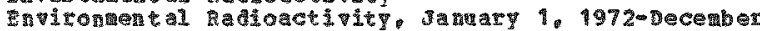

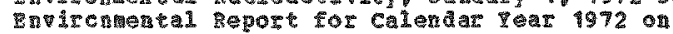

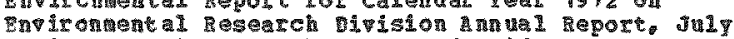

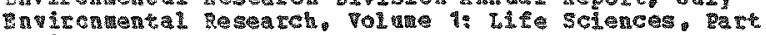

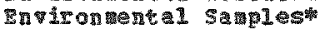

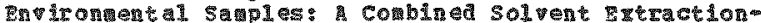

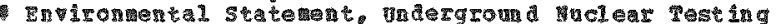

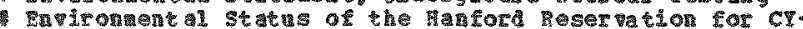

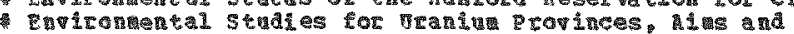

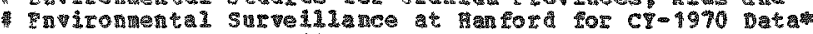

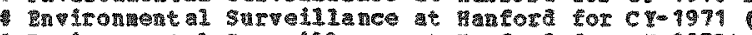

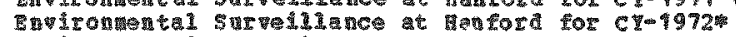

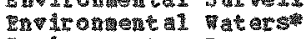

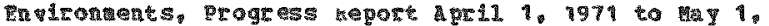

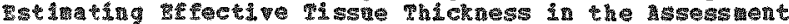

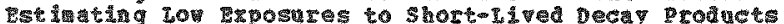

- 5 s

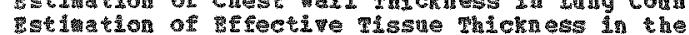

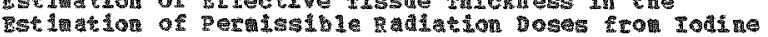

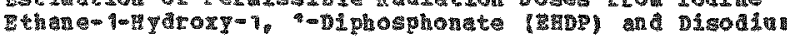

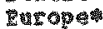

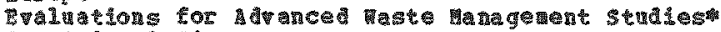
5.

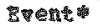

ำ
000557

000558

000136

00043

000463
000129

000129

0003 醍

000398

000173

000197

000475

00048

00049

000463

900509

00005

000322

000025

00040

00030

000299

000536

00042

000315

00055

000322

000491

000332

000435

000462

$0,0027 \%$

$0002 \%$

000503

000475

00050

000505

000475

000482

00045

000445

000 48

00065 ?

000489

$0004 \%$

00048

000412

000452

000488

$0004 \mathrm{~S}_{3} 4$

000486

000420

0004

00049

00048

000 的 29

000421

000418

00049

000357

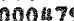

000 b5

000478

0040

00049

000520

000490
000393

000393

000232

000278

$00032 \%$

000415

000293

000416

noof 1 .

00028

000328

000338

000

000369

000309

00012

000145

000591

000573

000363

000119 
In 19eton

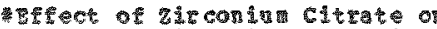

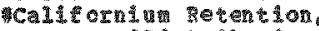

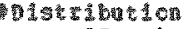
Tavine Orit de? tetsin

Contaminaton

Dlutonio cont a

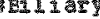

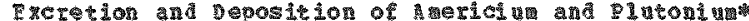

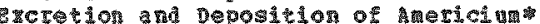

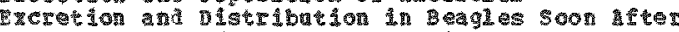

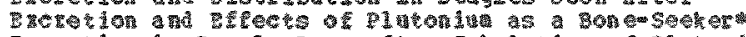

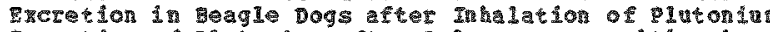

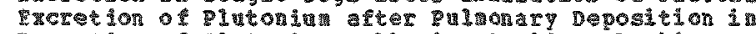

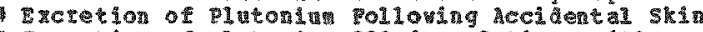

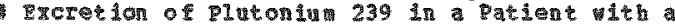

T.

Taton Da

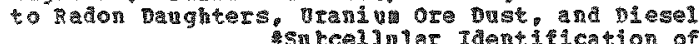

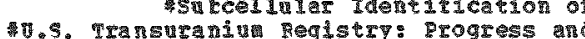
Dose Burden caused by wuld tesearch cencers. 等

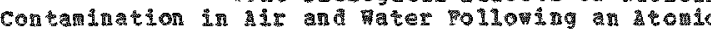

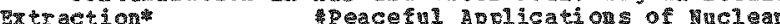
mulear

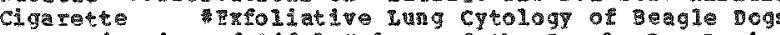
monatoring of tidal Yolude of the Beagle Dog During

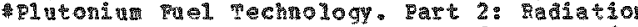
an In proved Systen hento

Atmospheres gadiation ichrente concentration (MPC) of

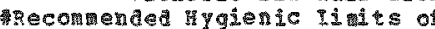
thernet and interna

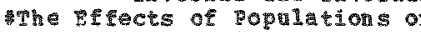
Ara I vteal Res I ung Cancer Pisk 3 n Relati on to Iong-Ter

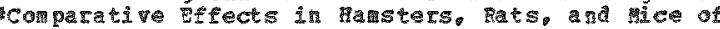

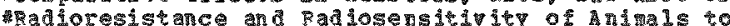
Behavier of mitiu in Fish Following chonje Pop lation a aliation

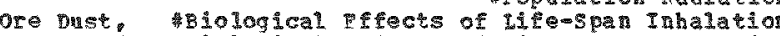
Dust and

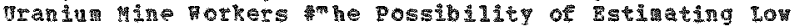

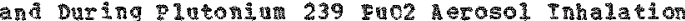
and $\mathrm{x}$ I

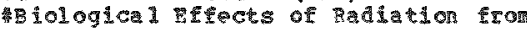

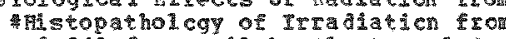
Tungoten 185, and tead 210 frot soli by plants and Ion * Determation of Plutoniu in Biological Materials b

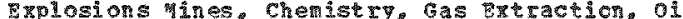

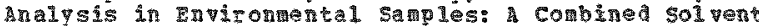
虾

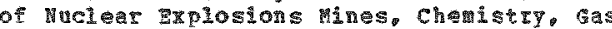

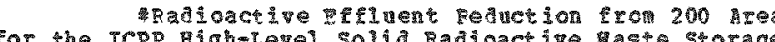
ICDP

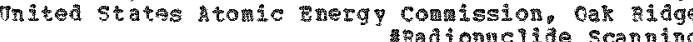

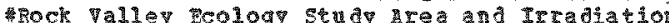
Plutoni un 239 atticles collected Near the Bochy FIats

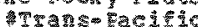

Arat 1 yse

Deers

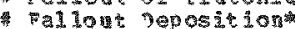

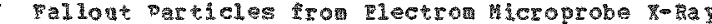

Global Invertery and Distribution of 1973 through appendin to Health and saretp wabcratory through septern 1.1971 \%

through septerber 1.19731 t. 1967 brough Decenter 19671

5ำtuatons

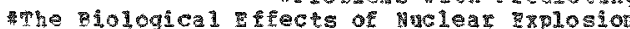

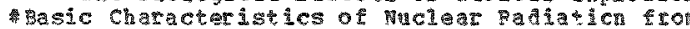

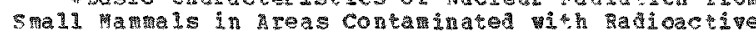
b2ochemical studiss

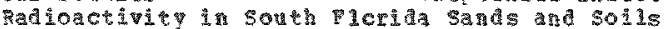

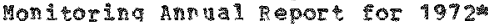

4assage ine and Pathology pol 10 wn

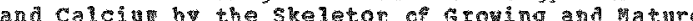

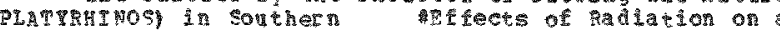

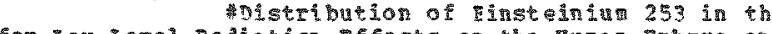
for Low-Ievel Radiation Ef fects cn the puan smbyo and

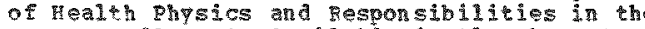
aports Avalable in plowshare open spolicaticn of cellulose ratisate Wher pire protection syaters for

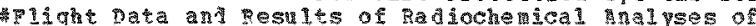

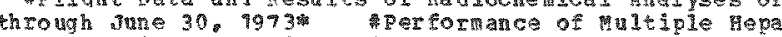
Plutoni.

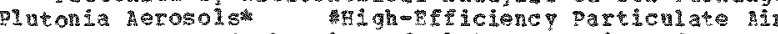

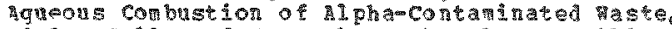

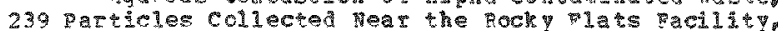

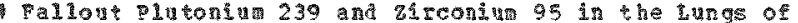

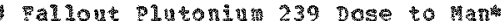

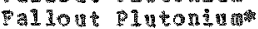

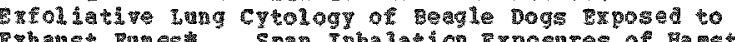

Proge rapectsens

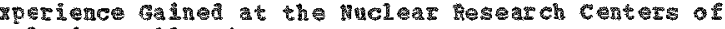

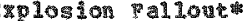

ERolosion

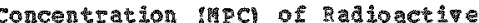

Exesed to sad Daghters, vranin ore Dusta and

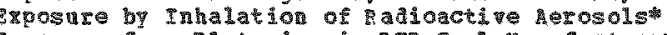

Bxposire of Beagle Dogs to Radioactive Aerosolsw

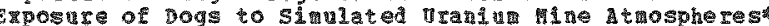

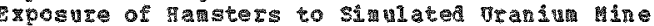

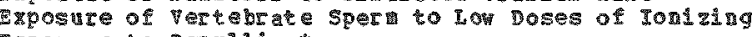

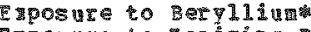

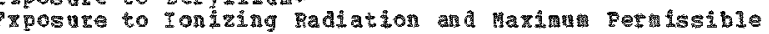

roosure to Lon levels or Ionizing adiation

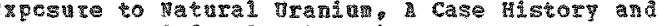

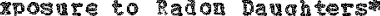

500s

zccsure to "ransuratulu

TrPos

E mposurat

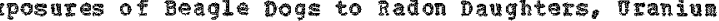

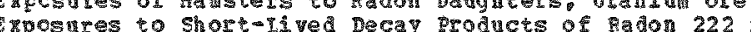

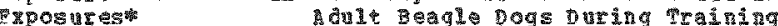

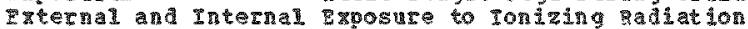

Etoryal and Internal scurces

startial sources\%

Exracing Solutionst

straction

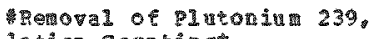

peacer a

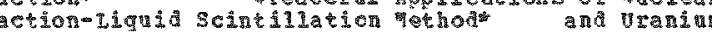

ogl Detraction

Tacilities

racilities

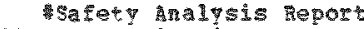

acility Toced urew

acility, inal Teport:

Fallon and

4hantis of

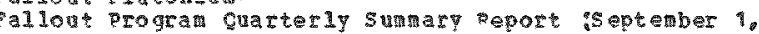

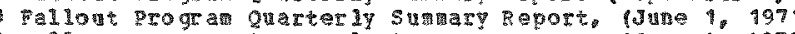

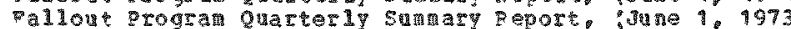

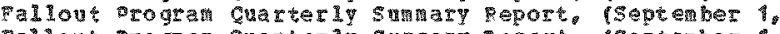

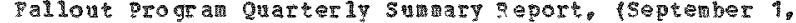

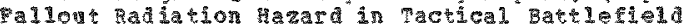

Tallou

Fillont

allo 10 at

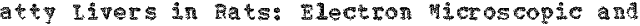

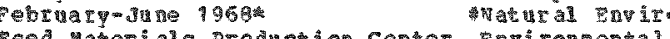

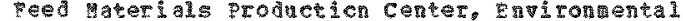

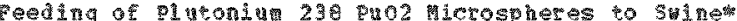

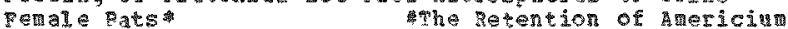

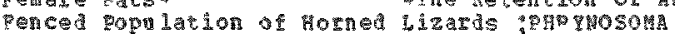

Fetcetacental init of the path

Fet

*yidence

Field of adation Protection

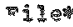

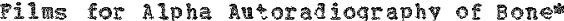

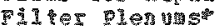

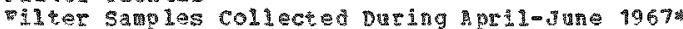

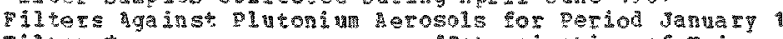
Fitiors

Fiters: state of the art sumary pertating to

- inal 1 rogran Status repors

Final perot acility for Dogs"
000104

000112

000122

000239

000055

000134

000300

000405

000023

000041

000221

000002

$000 \% 7$

000 蛅 1

000478

90055

00033

000307

000049

000053

000565

000351

00022

000220

00015

000403

90055

000367

000372

000397

000166

000152

000148

000466

000223

000221

00040 A

000052

00055

000150

000031

000252

000268

000333

000278

000333

000316

00057

000578

00048

000352

000495

00046

000481

0005 霄每

000 得 4 ?

00025

nonts 95

000358

000437

000472

00039

$0004 \& 0$

000438

000441

000502

000478

000321

$000=01$

000028

900145

000485

000213

00007

090298

00020

000402

000552

000337

000261

000542

000432

0005 年进

000260

$00034 \%$

000572

000460 


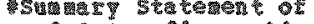

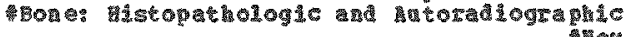

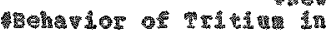
Mna 1 isis of Dr

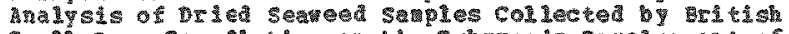

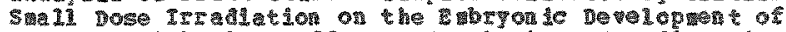

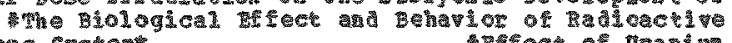
verrous s

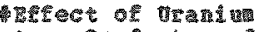

"

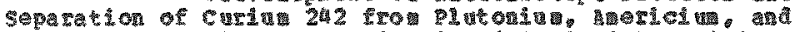

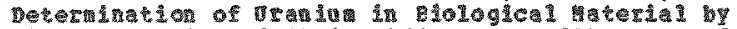
poss

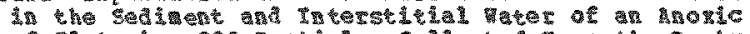

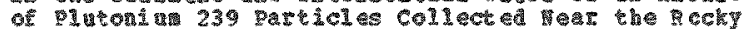
Toeky

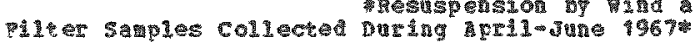

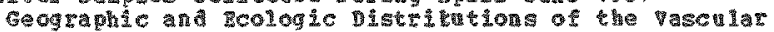
*

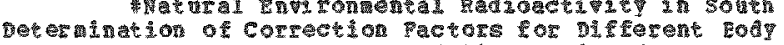

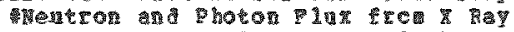

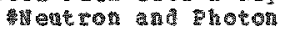

s scavenging contand

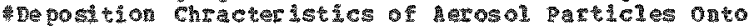

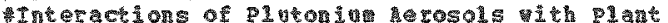
Goned cal

Diet of

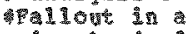

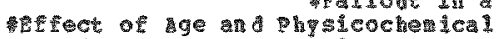

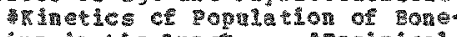

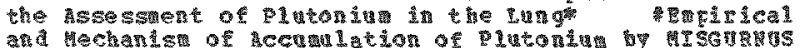

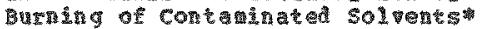

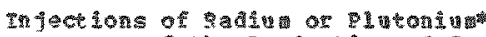

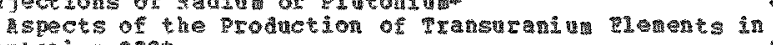
p1

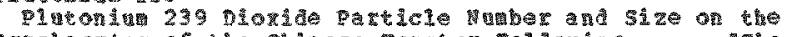

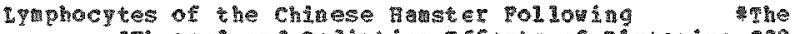

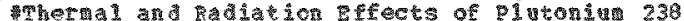

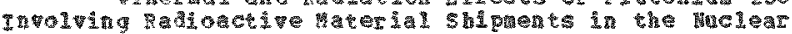

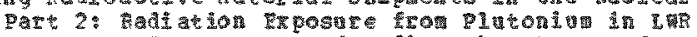

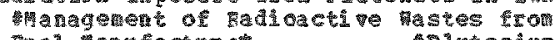

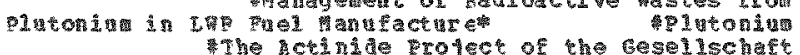

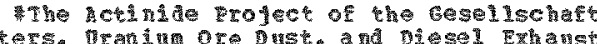

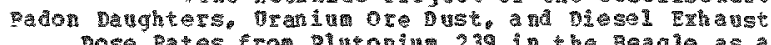
ose pates ron

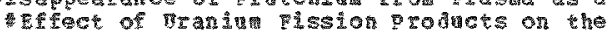

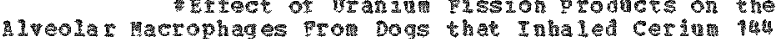

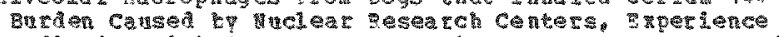

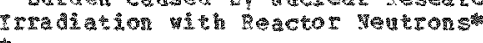

App Teport

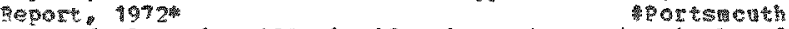

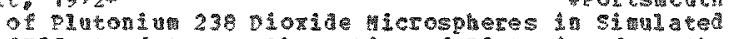

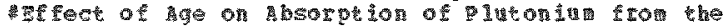

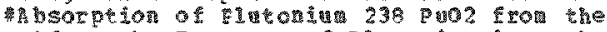

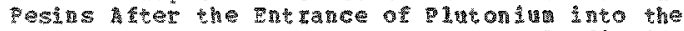

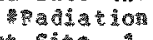

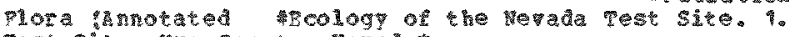

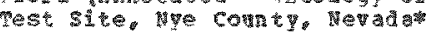

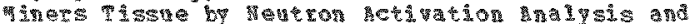

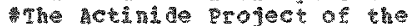

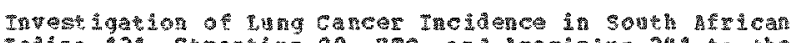

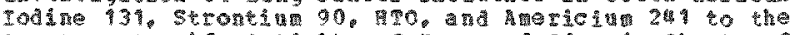

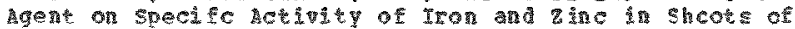

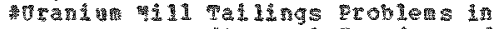

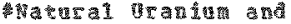

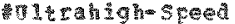

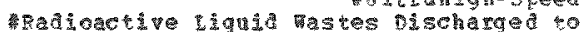

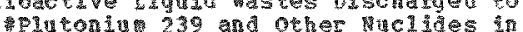

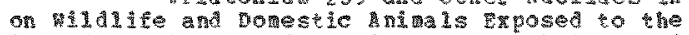

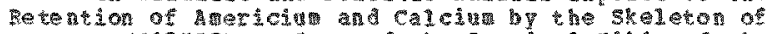

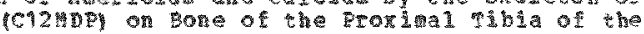

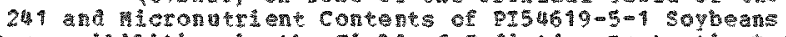

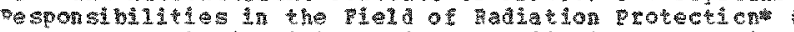

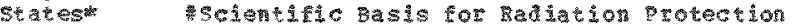

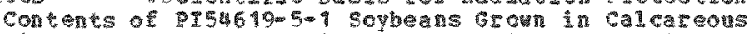

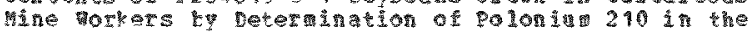

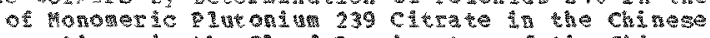

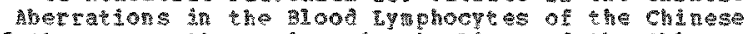
of chronosone aberrat shological Effects of

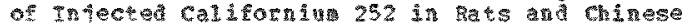

Ps

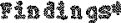

172

7.

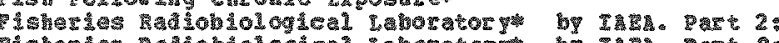

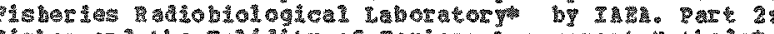

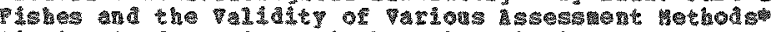

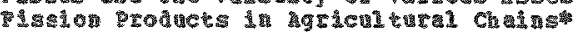

Fisston Pro

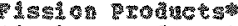

19.

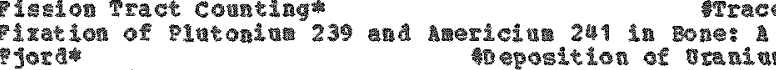

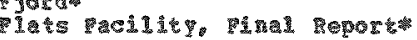

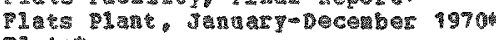

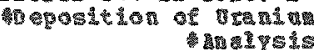

$1 \mathrm{ats*}$

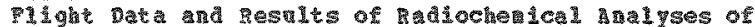

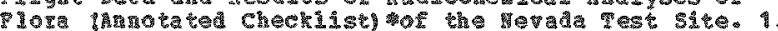

Vort

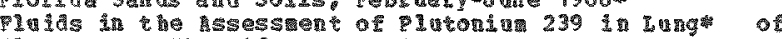

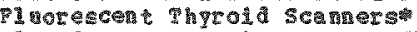

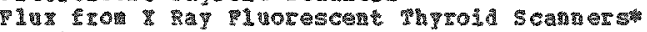

Fos

oliage and ofher \$rraces

Tol 1 a dack

FC110 -

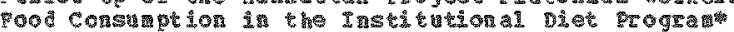
Toresto

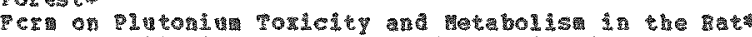

For

Ccrin

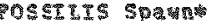

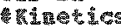

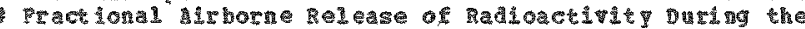

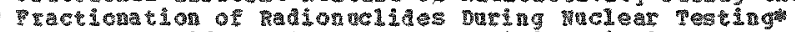

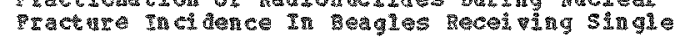
Franceth

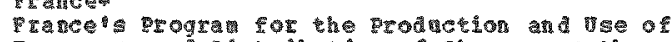
Sore

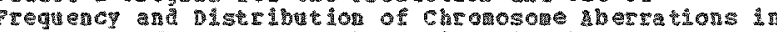

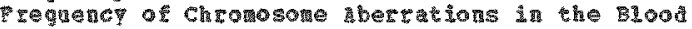

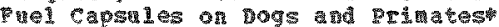

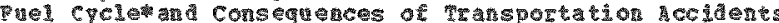

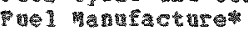

ve 1 teprocess 3 m

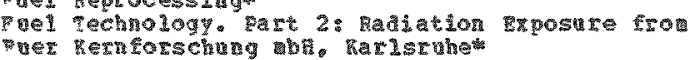

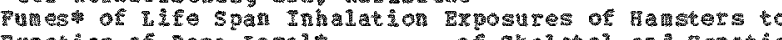

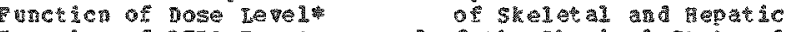

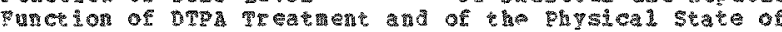
vacticnal state of the central verous syster

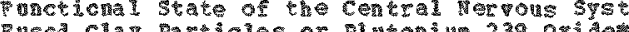

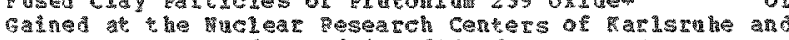

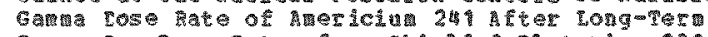

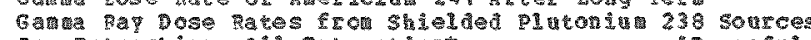

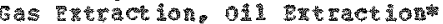

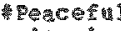

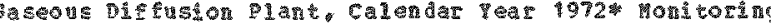

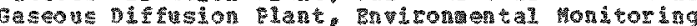

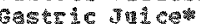

Gactroutestinal mact of atso

Gasto int

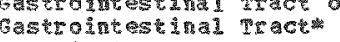

Se

Geogr aphto and

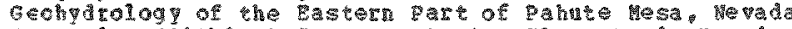

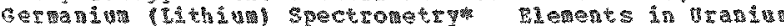

Gestischar Fut

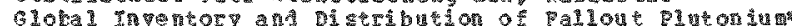

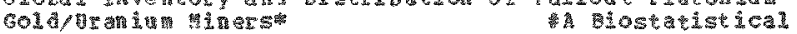
conads

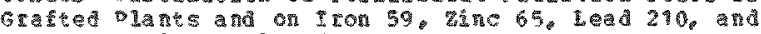

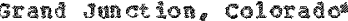

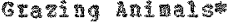

Gos

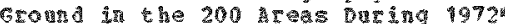

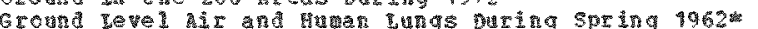

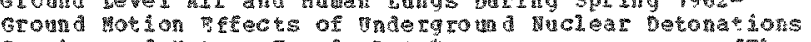
Grovit

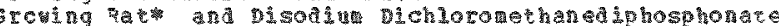

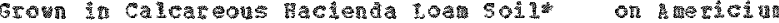

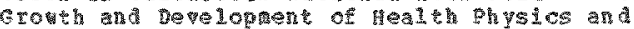

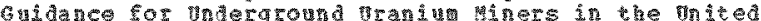

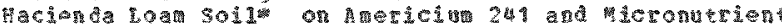
10.

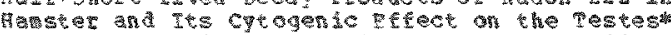

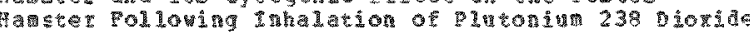

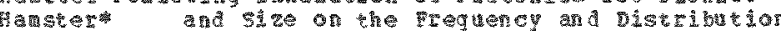

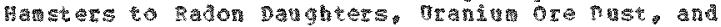

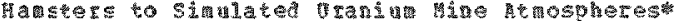

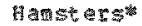

3.
006 烈6

000089

000352

000 7 ำ

00045

00033

000773

00429

0019

000360

000250

00025

000227

000329

00065

000463

010

00020

00048

000000

000317

000317

000098

00003

000375

000379

00045

000203

000095

00072

000560

000526

000181

000529
000535

000035

00003

000313

00056

000565

000503

000565

000532

000221

000215

00011

000195

000 然

090530

000310

000333

00494

00042

000269

000291

000025

00004

000291

$00033 \%$

060073

000532

000423

000356

000123

00024

000507

000067

000078

00050

000497

000307 000076

00045

000246

000532

000411

0902 स 6

000201

000033

000034

000035

000221

000220

$00018 \mathrm{~g}$ 


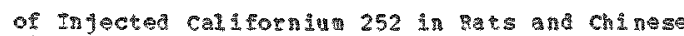

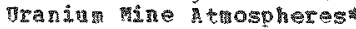
compat

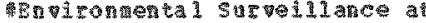

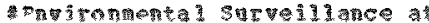

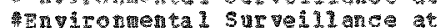
Intracevitary IrTariatan by Raju 22 and

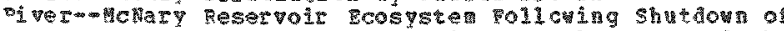

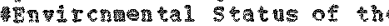

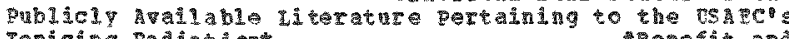
Tonj 210 Fallation Benetis and Ithact progra toritoring of pespiratory tract overitradiation

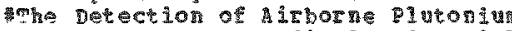

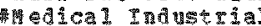
pelat

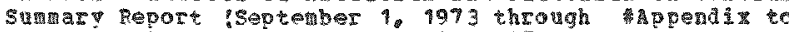
Brogra, the ovality of analvoss 1972

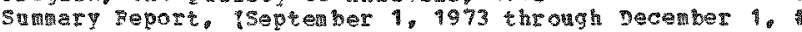

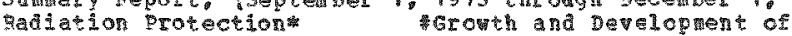
Laboratorys

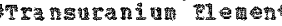

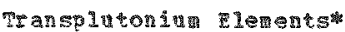

1945 \%

of Inolanted vaclear Energy sources for Artincial An-Phanton Dosidetry of Prototype glutonum

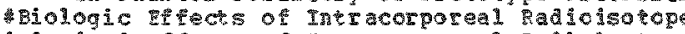
Blologieal Effects of Intzacerporea 1 Radolsotope

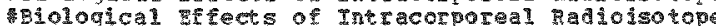

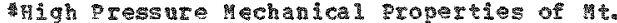

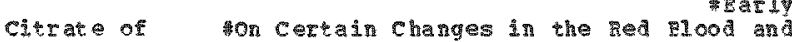
Janvary i through Jue 30,1973 Fercorance of

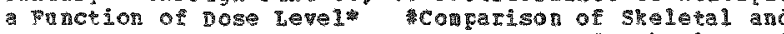

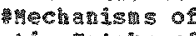
mechanis ms of mepatic protate of

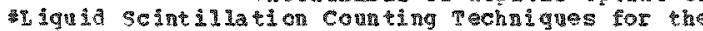
artion of ongtation on

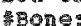

Mesothoriu and stront In and the segutrice of

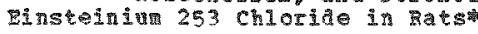

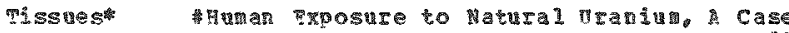

and Concentration of Plutong

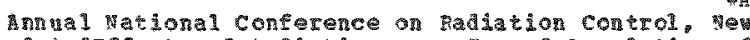
Hevada 常

Fad

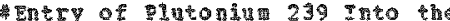

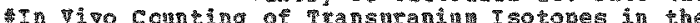

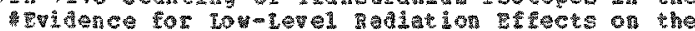

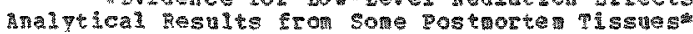

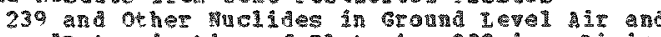

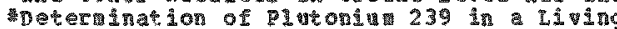

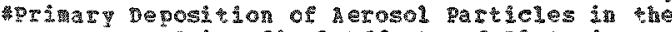
3

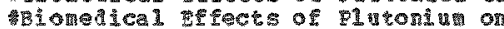

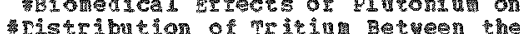

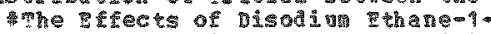

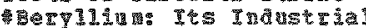
Reconerate

Continued Intercomparisons Colatit, silver and other adionclides sponscred ty

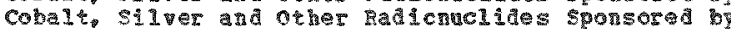

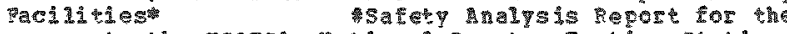

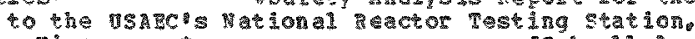
Diectron 1 croscogy

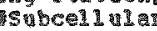

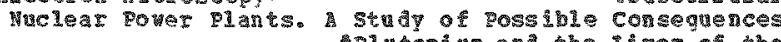

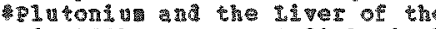

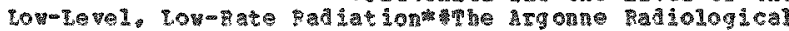
Devices B 10 Hoglea 1 ETects or

A S 10 1 a are

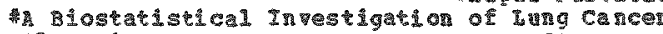

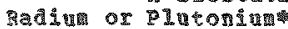

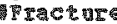

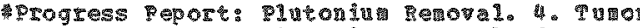

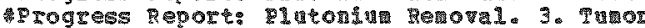

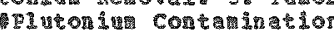

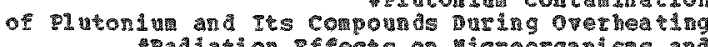

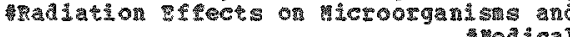

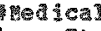

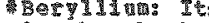
and 11 utonin 239 mitreter

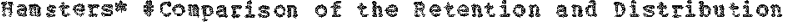
yalats

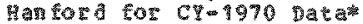

Ha

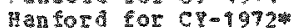

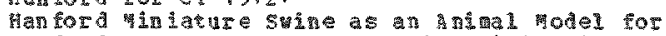
gancor gantora Reactors or radios PR

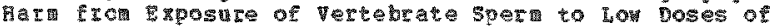

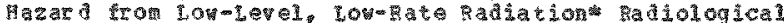
marard in Tretical Bat lefield situations* Hazar tue to padon Decay products F $2 \mathrm{zat}$

Hataras

䉽e

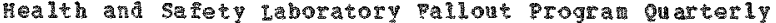

Reath and safet daboracory Surface Air Sapling

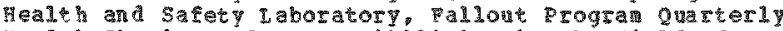
tealeh physics and Responsibilitis in the pald Health Physics and Safety at oak Rage Hational

Health Enysics and Sarety ioassay zroced num

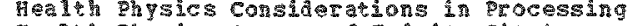

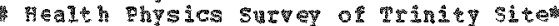

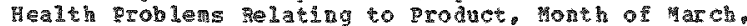
Meat tevicest Heat Sources

H:

Peat soneces

reat scurcess

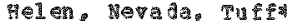

rich

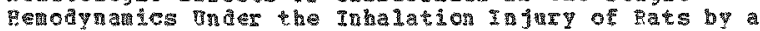

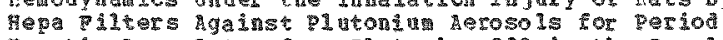
Heparic Dose Rates cron plutonin 239 in the 3eagle as

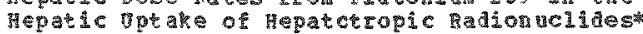
repatotropic Radion ncliflest

Hagher Mct

tigher plants and plan com

Histopathologie and a

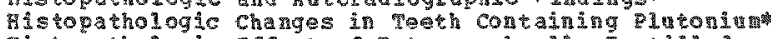

Histopathologic

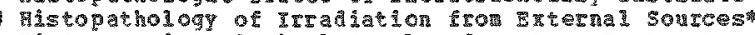

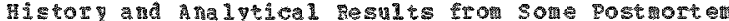

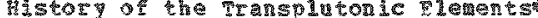

History or Dete 10 pand

Histor of Dranin Folsoning $(1824-1942) \%$

Torizonsos

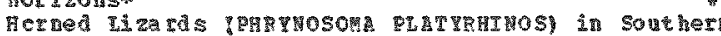

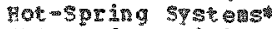

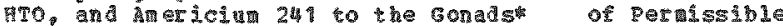

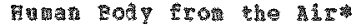

Fuำ an

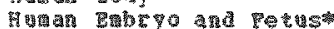

Hot

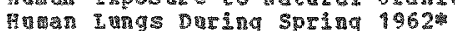

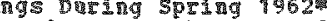

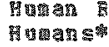

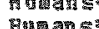

Hidrosphere and Invertedrat

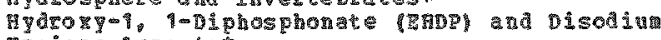

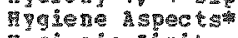

tyquenic In

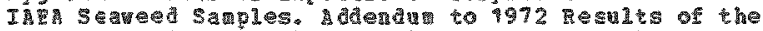

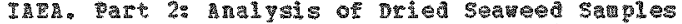

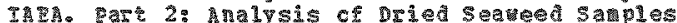

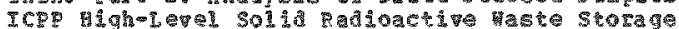

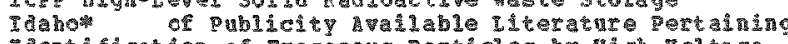
tdentis

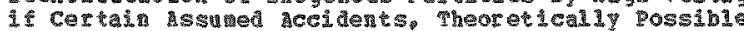
I

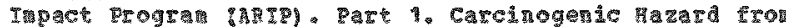
I

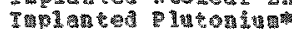

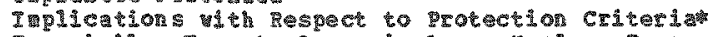

Trprok

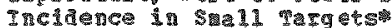

incidence î south af

Tnciarace I I

Incideree studies

Inepdence strais

Theidert of Jue 13. 1972. Part

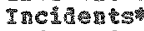

Ind a

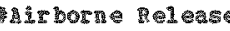

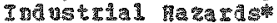

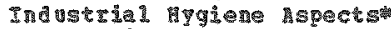

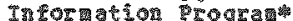

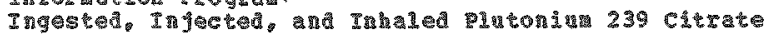

000944 000166

00023

00096

0003 然 17

000225

00042

000415

00058

000159

00032

000502

(1) 345

00045

000469

000106

000472

000513

000438

000552

000545

000281

00052 t

000323

000163

000051

000319

$0000 ?$

06008

00006

000342

000058

000093

000544

0002 25

000235

000235

000465

000045

000038

000025

000017

00003

000372

00053

000549

000075

00055

000298

000527

000406

000370

ต0)

000372

00042

00038

000390

000392

000359

000037

000145

00040

000003

00045

00053

$0005 \%$

000589

000002

000314

000094

000324

00005

000381

000568

000314

00035

000181

000115

000186

000560

000579

000352

70040

000336

000022 


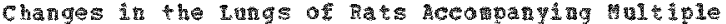

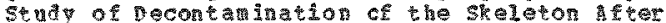
Into

of Plucon 239 in the pat organ 23 after ehronde

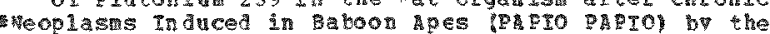

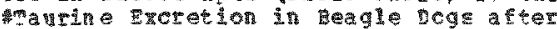

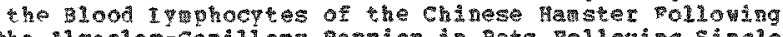

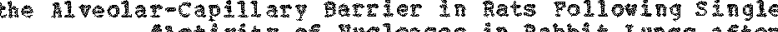

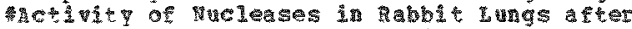

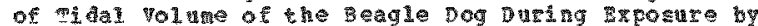

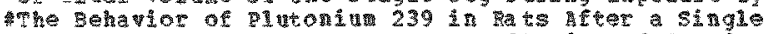
1

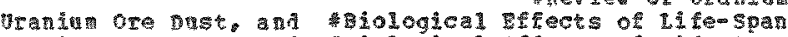
Oranin ore Dust. and

00TIng

char on Dose jepost ton. Petent in and

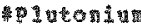

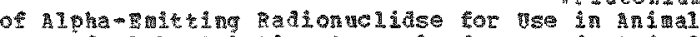

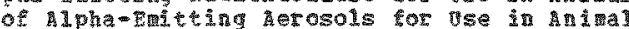
Dust. 2. Posterposure atenton and

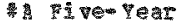
$1972+190$

240-Californing 249 Fol10ying Acute ccidental 范

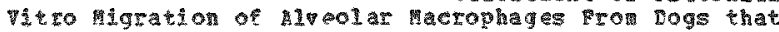

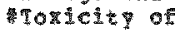

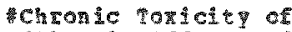
Achronie Etrects of chronic tictects of acercinogericity or

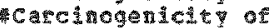

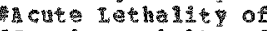

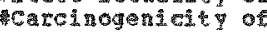

로연 Eavage and DTP

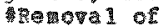
Acut to to mhoonic tefects of

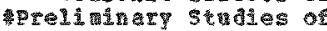
* Recentica and Distribution of mconparson of the Petention and Distribution of

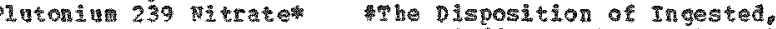

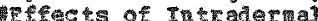
fe span by a singlo 6omplotion of the to Difieren 241 in the Rat in in

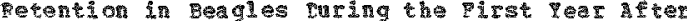

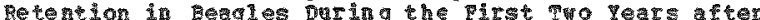

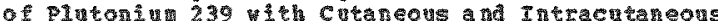

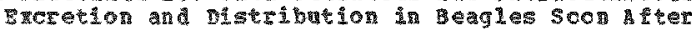

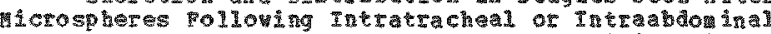

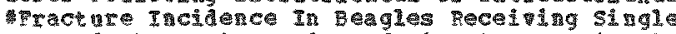
5.

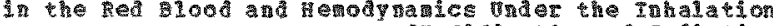

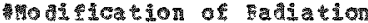
239 3 a a

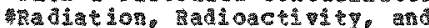

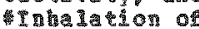

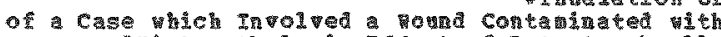

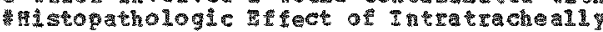

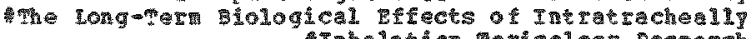

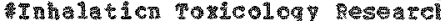

the Comand

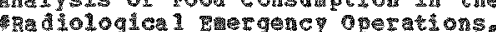

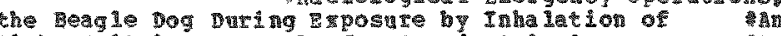

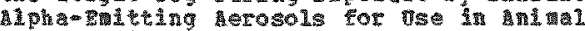

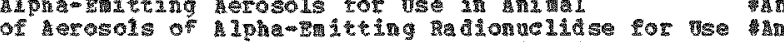

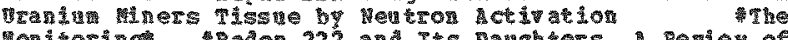

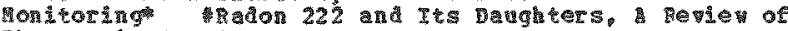
Fre

楼

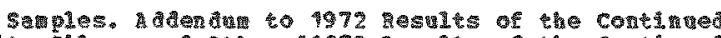

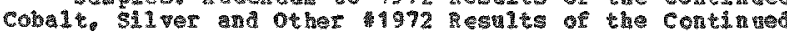

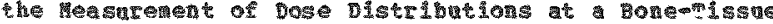

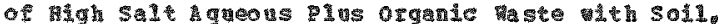

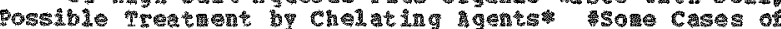

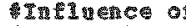

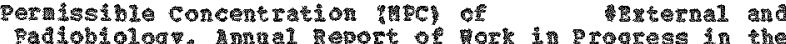

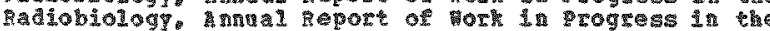
t5ome Imect of

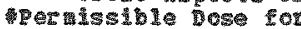
(c)

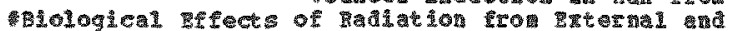

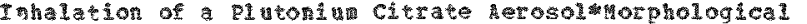

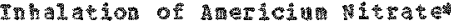

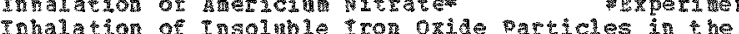

*

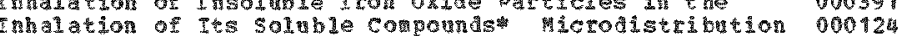

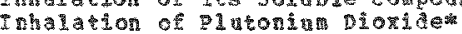

That ton of Plutonju oride

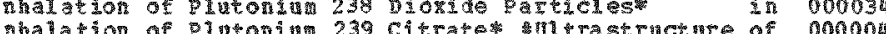

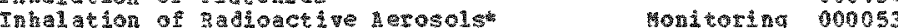

Inhal ation of Som of its chem cal componats

Trialation cases

Thosures of Beagle Cogs to pand Davghters.

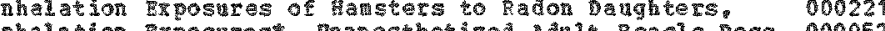

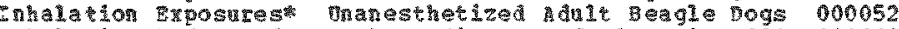

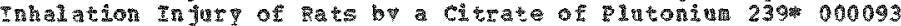

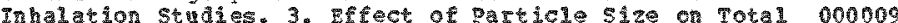

Inhatation stuaties

Inhalation stidies

or concentrations of Aerosols

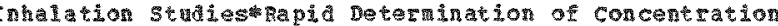

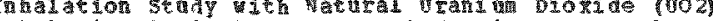

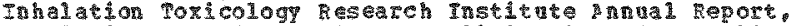

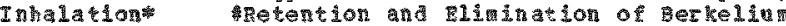

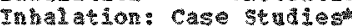

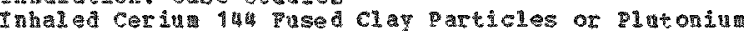

Thated 0 met

Intal ed partacles, II Th

In

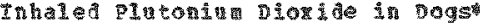

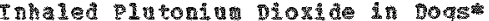

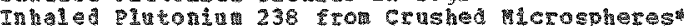

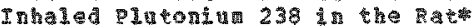

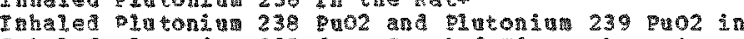

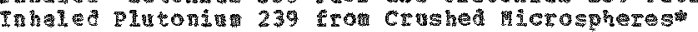

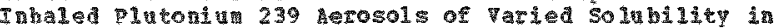

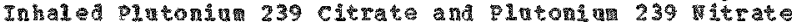

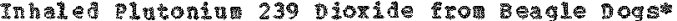

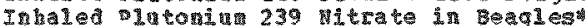

rnhaled piutonin 239 gro2 in Beagles

Ithated tran un ore

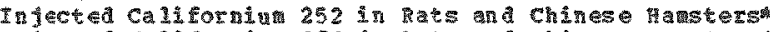

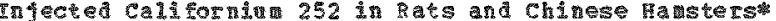

In

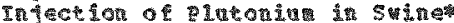

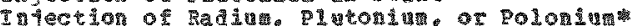

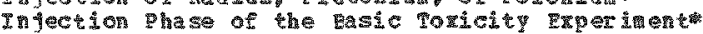

In Iect Ion solution

Intecentol solution

In jection rables

Injoction

indection

Intection

injection

In

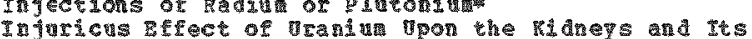

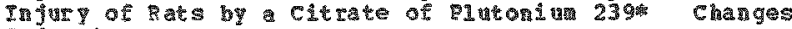

Ing

InjuE

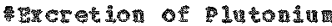

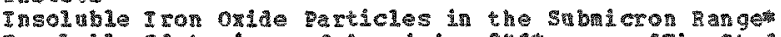

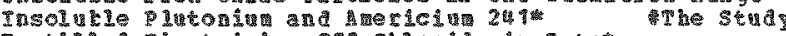

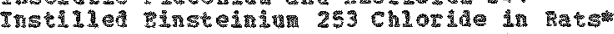

insti lited

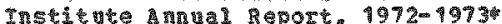

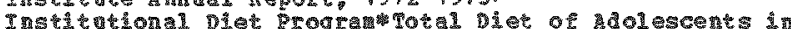
Instructor's dian 1 i

TnStribent for cont Ints

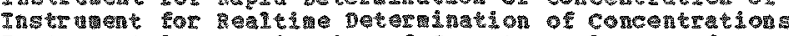

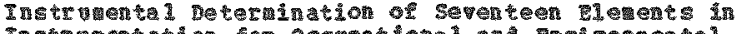

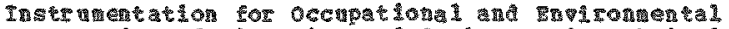

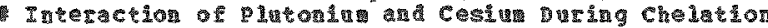

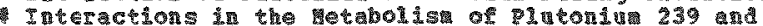

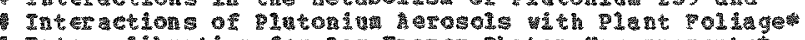

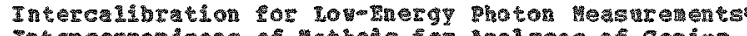

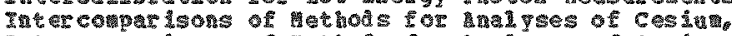

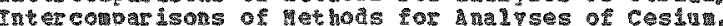

Inter

In tै

揫 Detector

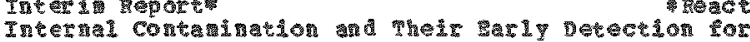

Interna

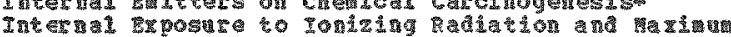

Ifterval ire

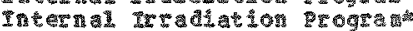

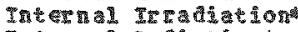

Tnter

I8terena

I 1 b
000010

000348

000054

000114

00039

000395

000072

000290

000409

000171

000169

000168

000193

000794

000192

000153

000022

00014

000167

000170

000222

000145

000022

000077

000030

000218

000196

000199

000060

000121

900120

000122

000190

000161

000081

000093

000361

000165

00039

$00040 \%$

000017

000019

000139

000379

000557

00005

000054

00034

000073

000419

000099

000509

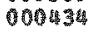

00063

000350

$00057 \%$

000410

000129

00055

000061

000059

000052

000357

000382 
3ำ omal of 7has

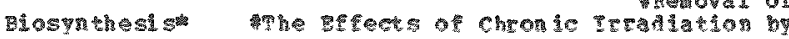

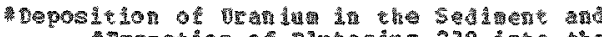

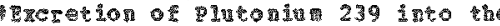

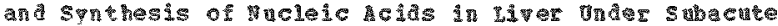

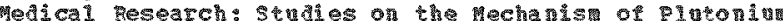

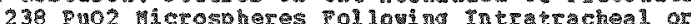

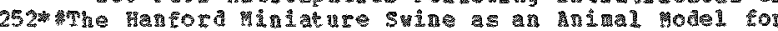

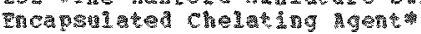

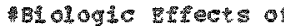

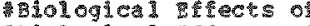
曹

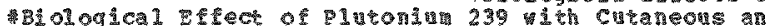
artect of

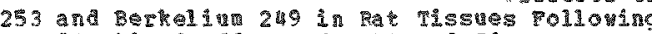

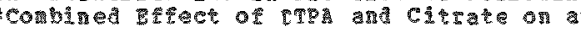

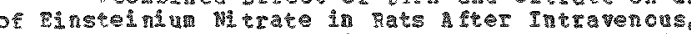
thehavior of

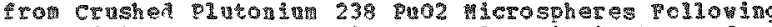
compond

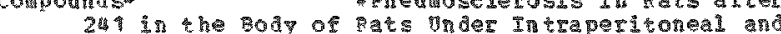
Pats

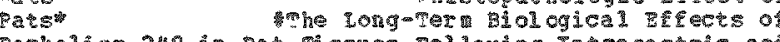

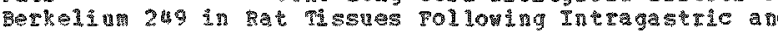
Dispostion of Einsting in

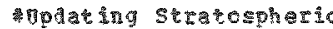
selol 1

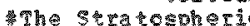

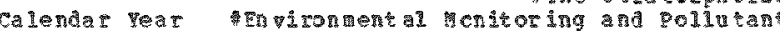

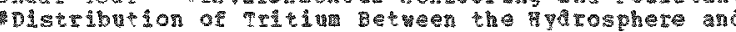
Gonads

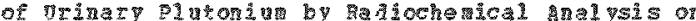

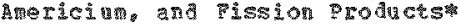

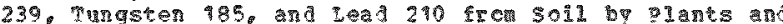
tho the Gastrotntestinal 1 Tract concentration:

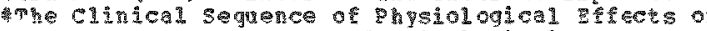
meracological hapers o

The whects or Populations of Exposure to Lon Levels or tha

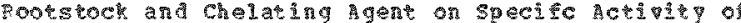

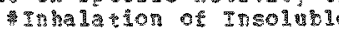

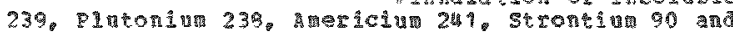

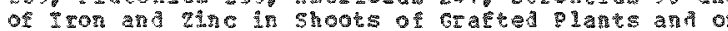

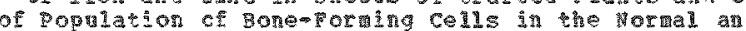

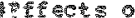

cortheosterot A

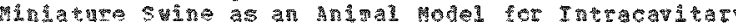

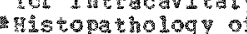

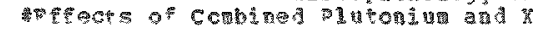

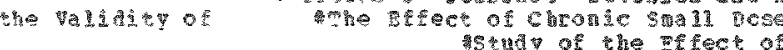
ฟทำ 然

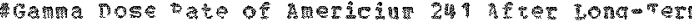
som of

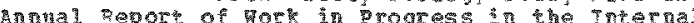

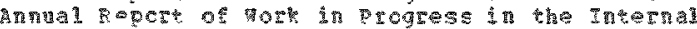

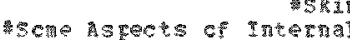

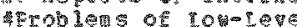

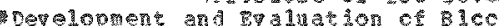

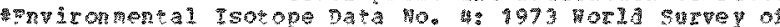

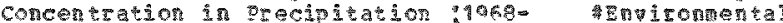

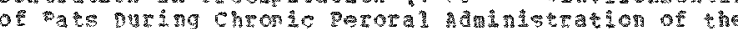

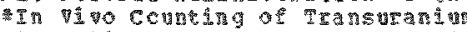

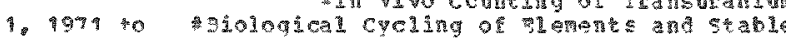

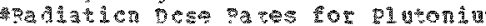

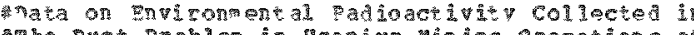

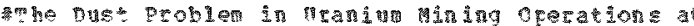

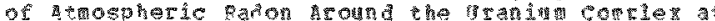

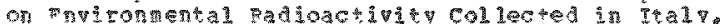

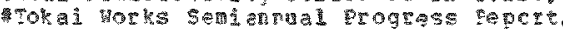

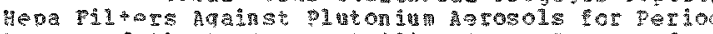

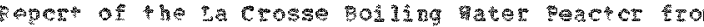

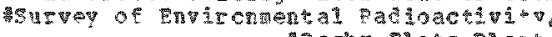

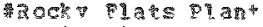

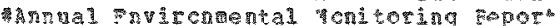
whd of the sour herr

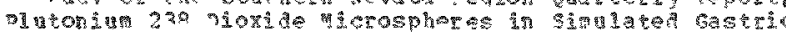

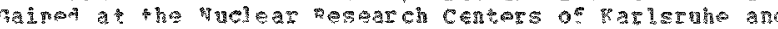

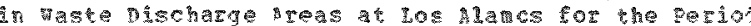
and 51 vison

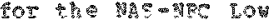

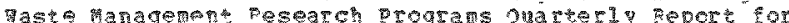

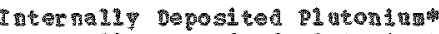

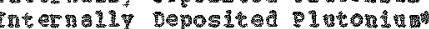

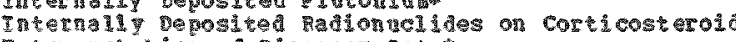

T借

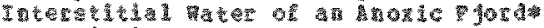

Ty

IN tor

The

Toratomal Injecton

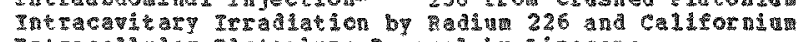
I. s.

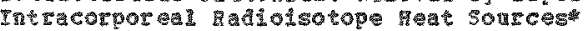

IT

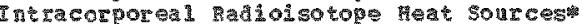

Intracheneon in inection

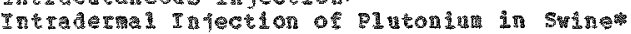

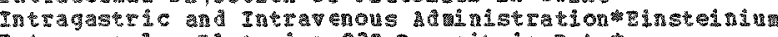

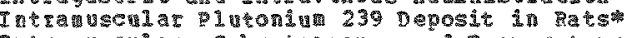

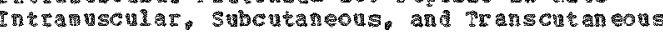

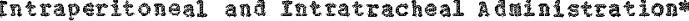

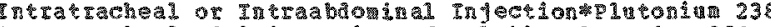

Thtratracheal a

Tneratrachegl A dainigy ation hehavior of mericiu

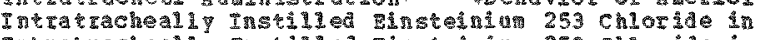

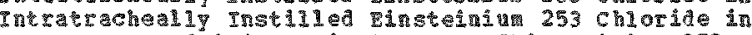

Intra

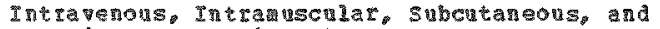

Tqutroductory mest

Inventorites to march 1972

II

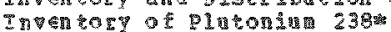

Inventory pogra part par patex plant corering

invertekratss

Tceine 131, Strontial 90,

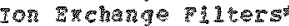

On Exchang

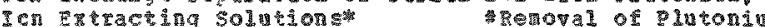

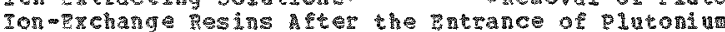

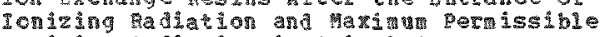

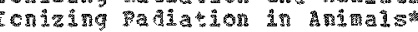

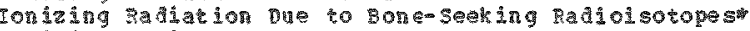

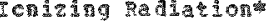

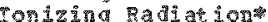

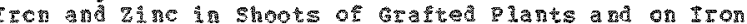

Iron onthe rax

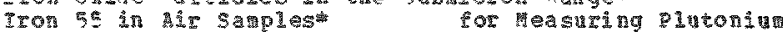

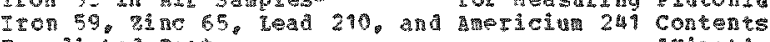
Ir

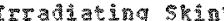

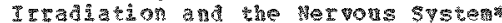

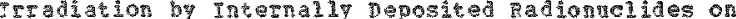

Trad

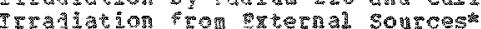

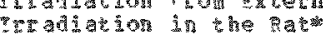

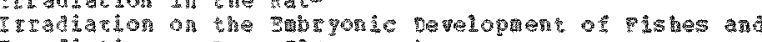

Irtatiation on Lutio clearaces

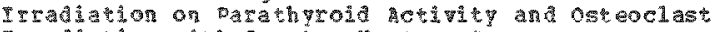

I

7rof

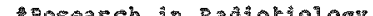

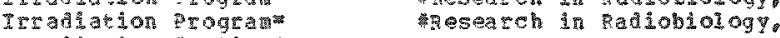

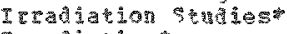

Tration

Trealion

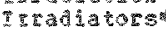

T50tope concentrator

I

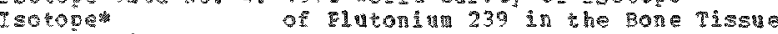

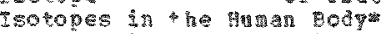

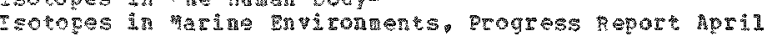

sototos

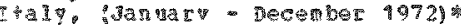

Tar

7.

1)

andary $=5$ una, 1973

Jarvery ithrough June 30 . 1993 mertormance of thitiple

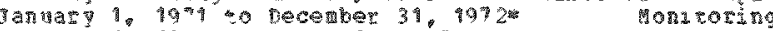

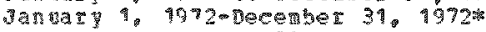

Jasuary-jocenber 1970

73)

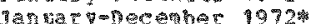

उงก

the venata Test site and other

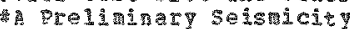
19.

whe solubsit? of

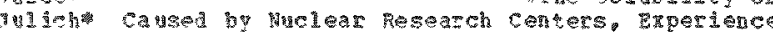

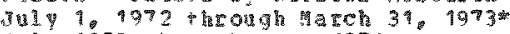

Material 1

141 1 1972 through Jane $19 \% 3$

\%

3.

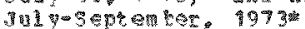

000012

000021

000029

00037

00032

000023

000101

00035

000190

000225

000979

000070

00006

000068

000038

000077

000079

000240

000205

000237

000190

000102

$00023 \%$

000017

000019

000079

000205

000330

000459

000437

000452

00046

00003

000123

000260

000290

000252

000025

000554

000176

000180

00036

000159

0002 然

000391

009289

00024

000095

000126

00023

000031

000013

960 는

00095

000056

000495

000059

000061

000127
000052

000062

00008

0 pout

00045

000161

000370

900328

000413

000477

000395

900450

000477

00054

000492

000520

000483

000420

000127

000338

000209

000451

000436
000393

000136

000592 


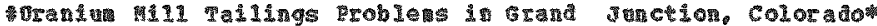

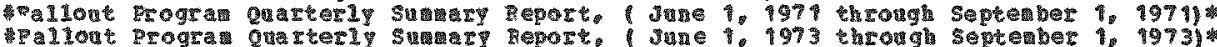

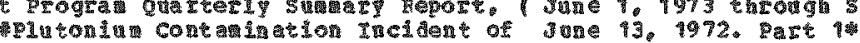

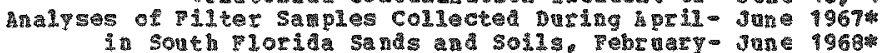
in Soue 1 ind Tesearch AnI U 1 progress

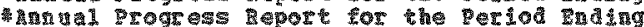

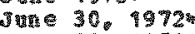
Fight Data and Results of Ratocheried औ经

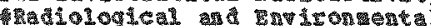

गา 30.1973 .

उune 30.9973

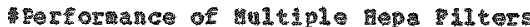

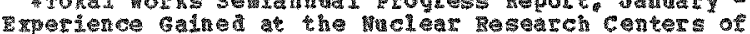

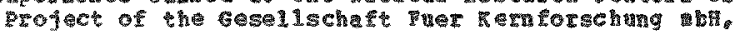

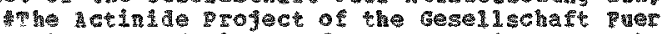

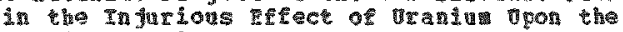

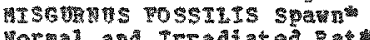

Wor

Hon toring Rerort. Calendar tar 1972 \%

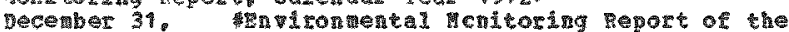

Calentas tear 1972

septerber 1, 1973

A

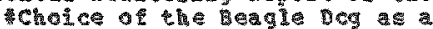
Trouls toric power 61 ppend

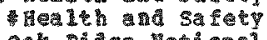

Henen

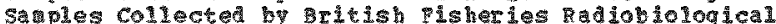

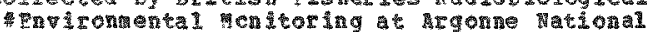

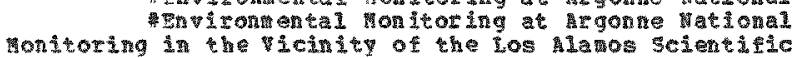

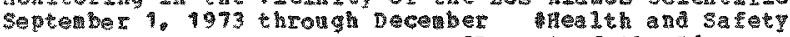
等eport of the Bloassay

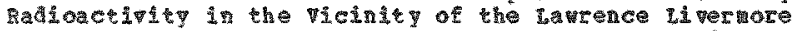
present prograt

(6)

and Ten perture on the Distribrtion and Behatior of artingence of que on the

PIutonitu 239 gerosols of varied

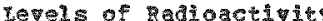
Troncropulanary 301 1973

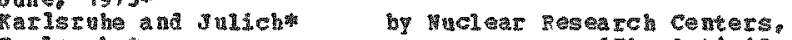

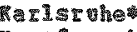

Rerntorschu ng

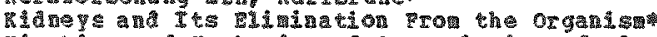

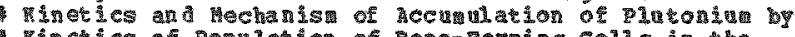

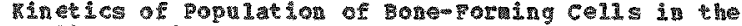

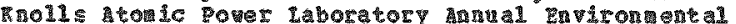
La Crosse boiling

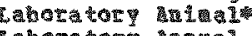

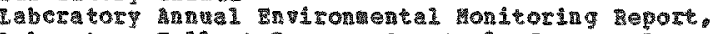

Laborator Fallou Progra our

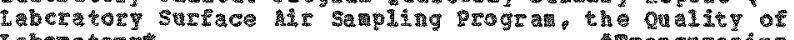
Labor a tory

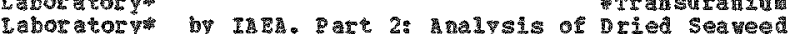
Tabretory by Laborator. Anat Beport for $1972 \%$

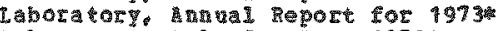

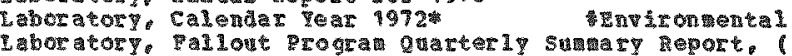

000505
000505 I. abcratory 1969 to $19 \% 2 \%$

Iaboratory, 1972 Anval Reports

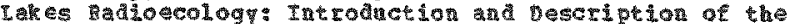
LAR

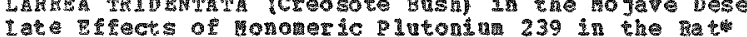

Iate frects or padiation

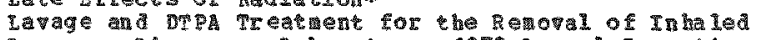

I.

I ed in $\$$ in

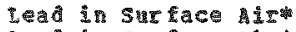

4

thadionclides and

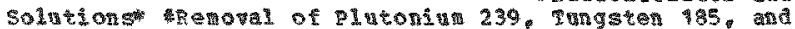

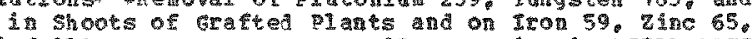

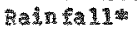
tperennation in AsTPAGLIOS

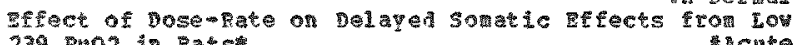
239 puos in $20 t 5$

Acute

of stological hitar

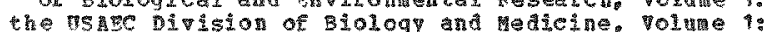
or Polons

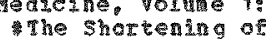

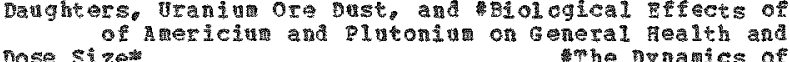
Dose stzer batchers, franin ore pust. and pecomended myolenic

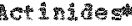

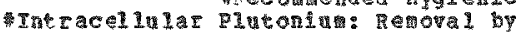

of B1

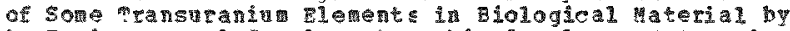

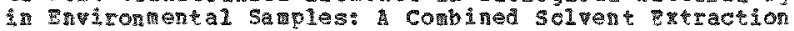
*rocess cor lemoving padoactive mates frch

Suriting 1972 - The Distribution of Plutorit in

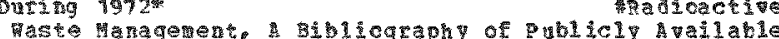

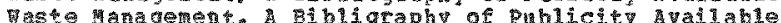

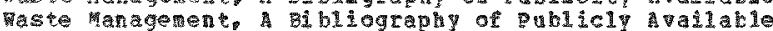

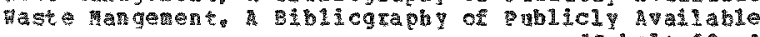
acobalt $60:$ :

pationctre subtaces, abot six cascs Related in the Tissue by entron detivation nalysis and gerwanin Phe Dossindity of stivating Low *helation and $\mathrm{b}$ istribution of chromosche Aberrations in the alutonis and the

Fo content and synthesis of tucleic hcids in

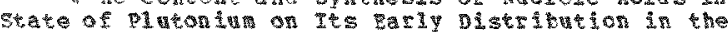

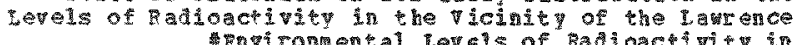
studies

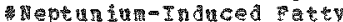
actor

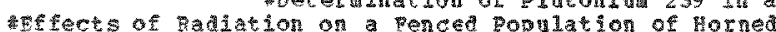

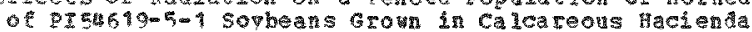

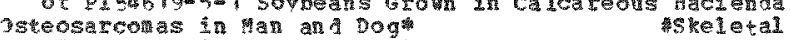

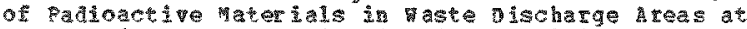

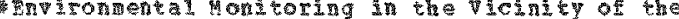

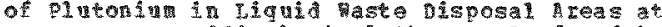

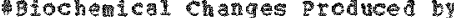

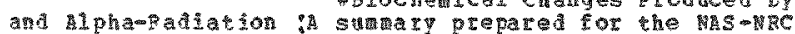

Lea

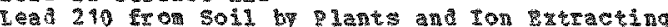

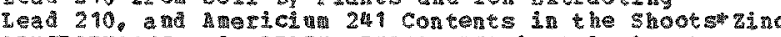

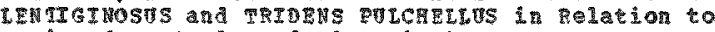

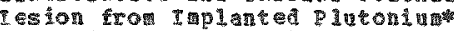

Let and Slphe

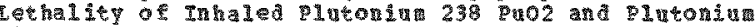

L

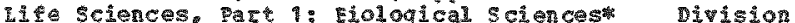

If sciences, pare i: gulogica sciences for 1971 to

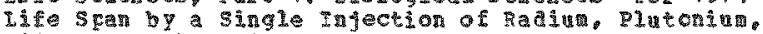

Iife 5 gan Inhalation prosures of hasters to tadon

Is 5 pant

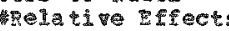

1re. 3. Mechanisms of Morsurvivel and the relation or

- Span Inhalation Ex gosures of

Limits of E

Tipcsome-meapsulated chelating haent

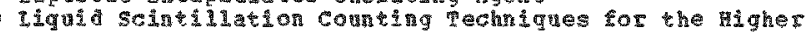

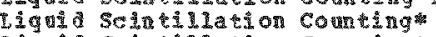

Liquid seintillation couting*

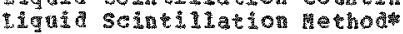

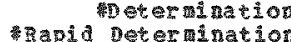
apdonim

Liguda stretas

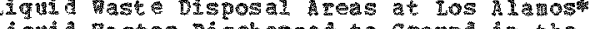

ignia

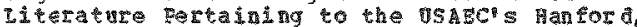

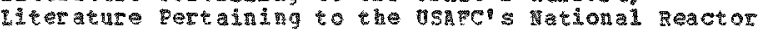

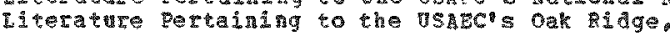

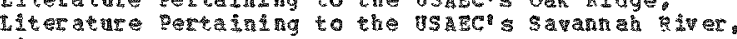

Liter ature search

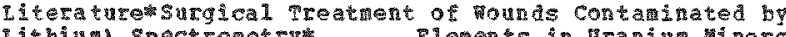

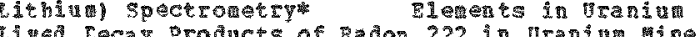

ined ceca products of kadon 22 in br

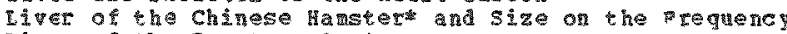
I iver of the Intature Rath

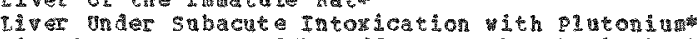
Liver

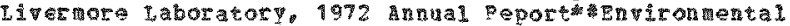
Iiverinoze valley solis

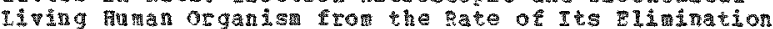
Lizar Loar solit on Anericin 241 and Location of Radiation Indeced and

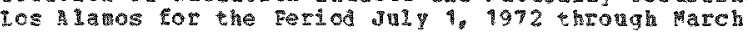
ios Alamos seientis LC: 1 amos

ICv Dose of Pagiation

The distribution

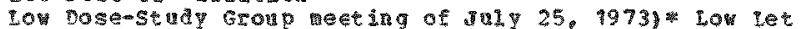

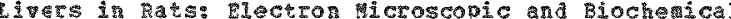

900507

0000 06046

100560

0432

000449

000300

000300

000538

0005

000532

000532

000172

000095

000486

000492

100032

000486

000472

000513

00545

40063

000438

00046

000435

00029 ?

000292

000432

000366

000153

000435

000519

000518

000517

000252

00024

00024

000381

00136

00056

000233

000030

00221

000106

000217

000223

000403

000179

000465

000268

000506

000278

000576

000325

000584

000589

000593

000590

000280

000373

000073

000401

000048

000035

00000

000901

000036

000435

000462

000028

000388

000298

000246

0002 3 35

000436

00045

000325

00945

000136 


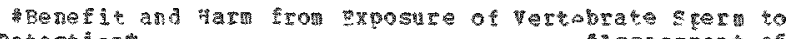
Detection

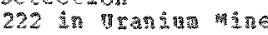

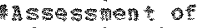
the refect of Domotion of

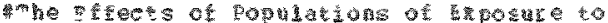

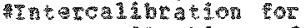
* Totens

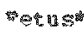
4.

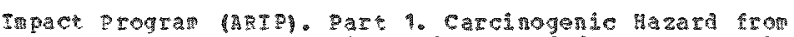

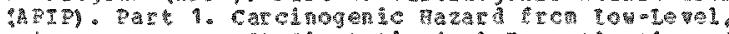
的紊 Raton Daghters a * B

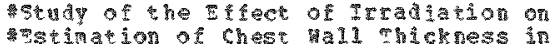

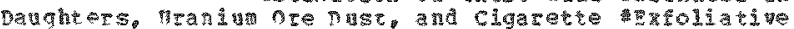

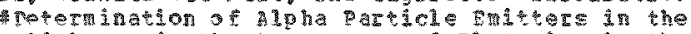

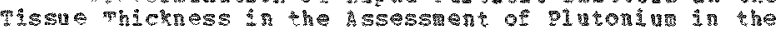

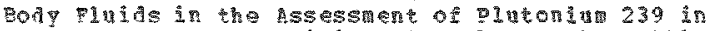

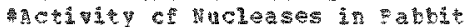

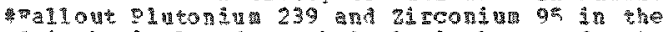

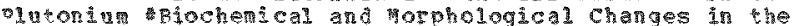

239 and ot

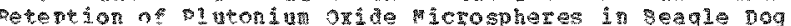

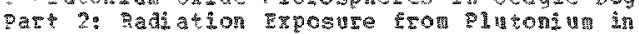

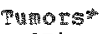

Detection of cyoteric

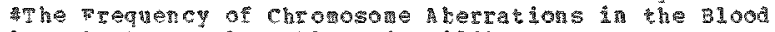

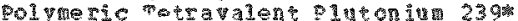

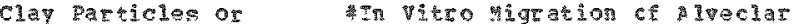

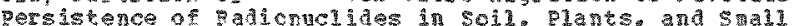

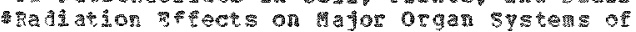
Induced a d a scancer Intucetor in

FET

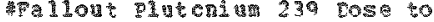

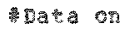

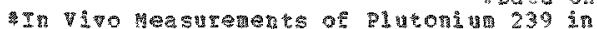

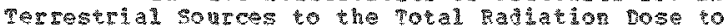

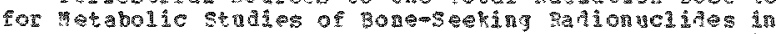

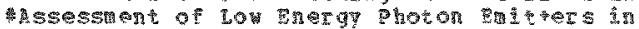
춘 की

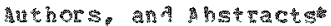

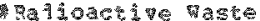

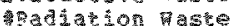
Septerber. 9973 \% ance solit haste 霍overwen of

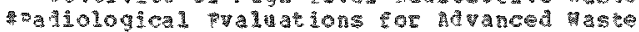
I 1

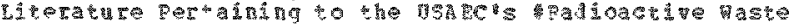

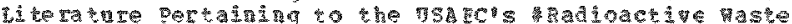

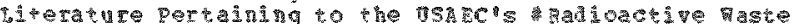

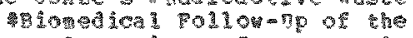

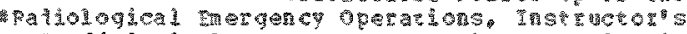

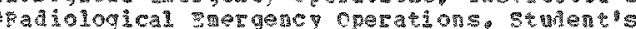

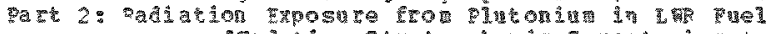

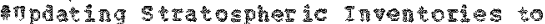
of the 50 ther 3ras at

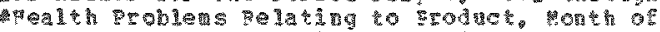

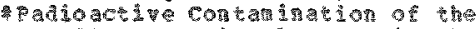

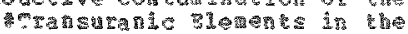

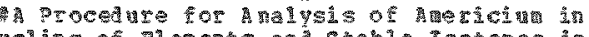

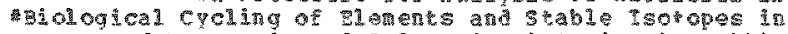
of 7eport: 51

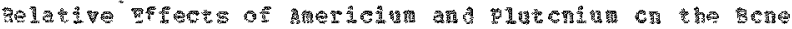

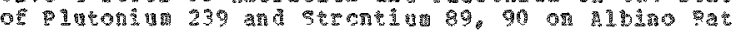

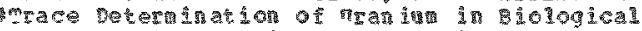

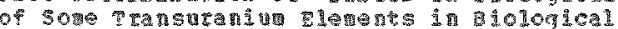

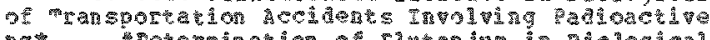
contring

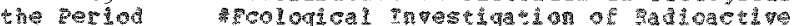

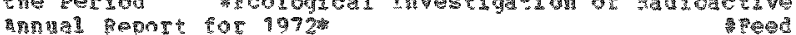

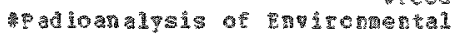

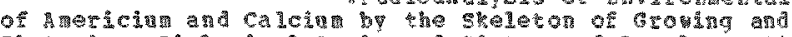
P1 140n

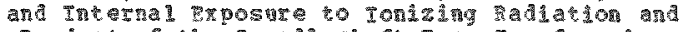

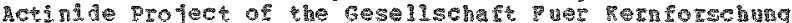
Contratinat

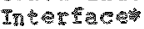

Tptate by

a

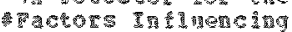

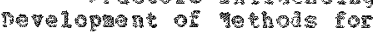

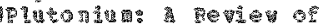

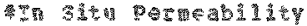

10 00 s.

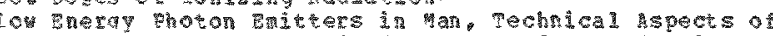

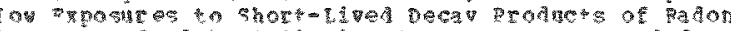

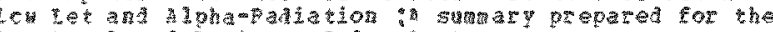

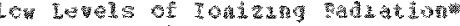
or

Eow-19vel I

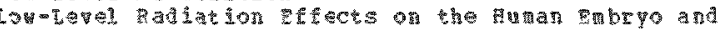

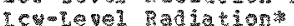

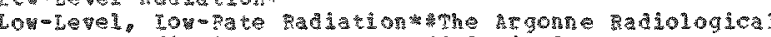

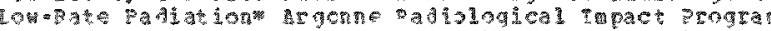

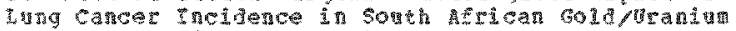

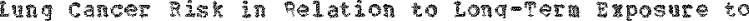

Ing clearaces

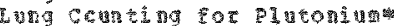

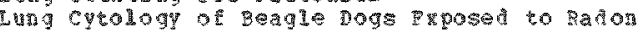

In

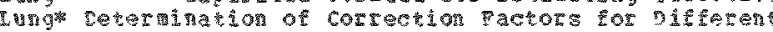

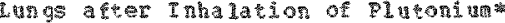

Lunos of neer

Q

cungs Dueing sping 1962 \% ำ

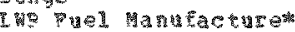

3. I ton

Iy

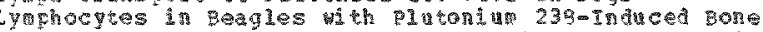

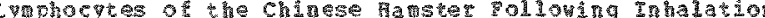

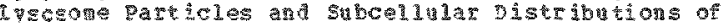

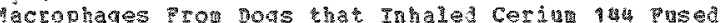

amals a

man and

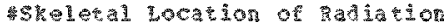

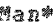

解露

and

$\operatorname{arn}$

$\sin$

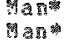

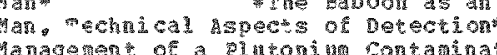

con

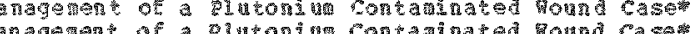

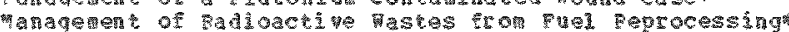

management pactices a

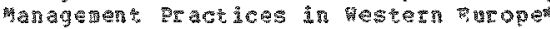

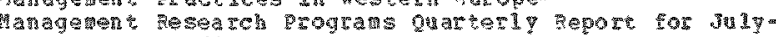

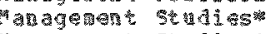

ตลก

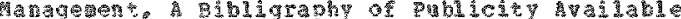

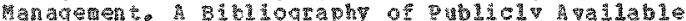



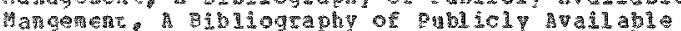

manhat an

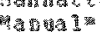

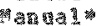

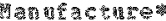

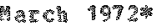

tharch 190

201

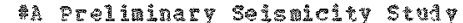

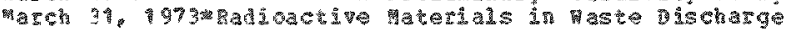

arch

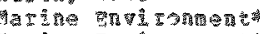

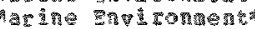

Mra

He

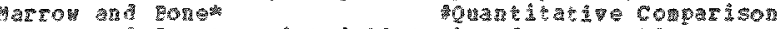

Marow an

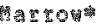

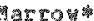

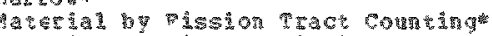

a

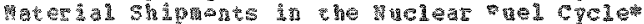

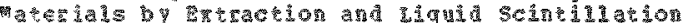

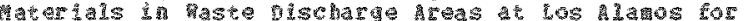

y. 镡

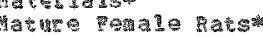

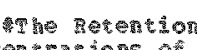

Mas

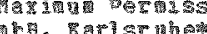

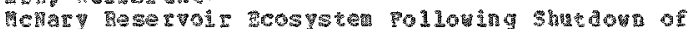

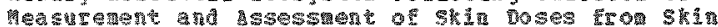

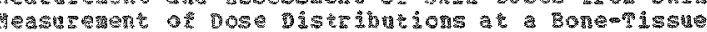

\%月ล

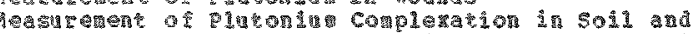

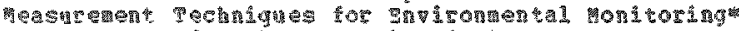

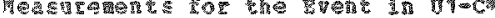

留

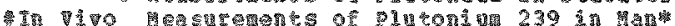

090159

009463

000 斯?

000136

5010 36 ?

00509

000102

000324

990324

000356

000397

00015

000369

$0000 \mathrm{e} 1$

000447

009398

000400

000154

000499

000189

000250

000565

00007

000066

000034

000178

000072

00501

000364

00023

000392

00384

00358
00377

00

003 娄

000320
000649

00045

900376

000396

009583

009526

000591

00592

000562

$0005 \%$

000589

0005

0003

000

900375

$004 \mathrm{c}$

40055

000565

2010453

000339

0098

000163

000296

070308

000256

900328

000 돌

0001 13?

000199

000236

90025

000506

000565

000268

000436

009495

600275

000076

600549

00055

000532

00042

00055

000350

0003 중 9

04025

00049

0003

00028

(1003 


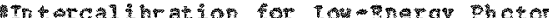
- Pa spotential scarce perns an control strontin 90 and Tron 55 in POS5ILIS Sparn High Fressing

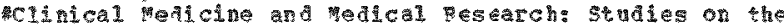
Fadion

the

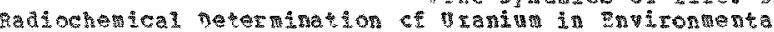
scomparison of plutonium and promethe lates as contrast Theorcatson

HCInical hedicine and

of Plutons intoxication

Repot for 9971 to the nSARC IItsicn of Diology an

peport 1974 to the USA TC Tivision of Bulogy and

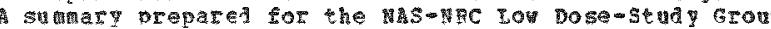
seed selection in Ditrobchy

seonvarology of the sastern tat of pabte

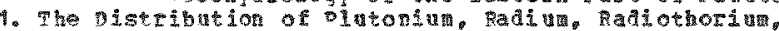

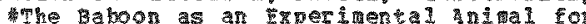
techn eas pogress enor on the

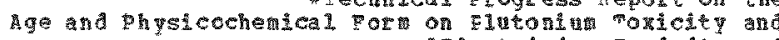
239 整insteing Acalei un and phosphozus re

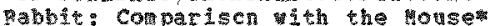

Interactions in the

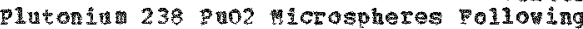

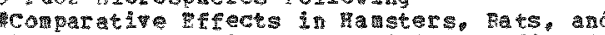

249. P1utonum 239 and Radu 226 orich studies in

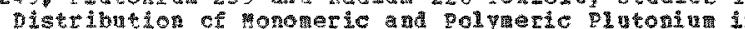

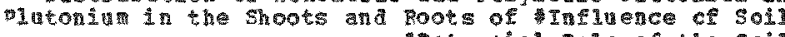
Potential Role of the soi Re1a tionsin of of Pats During chronic peror 1 in andintration of the

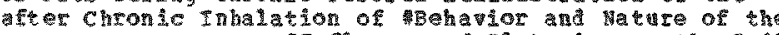

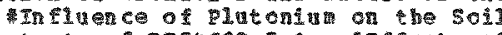
atrit other $\mathrm{r}$ (actors

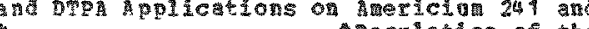
Regrilaticis of the

ant ohotoh acharactert 4 of Erogenous Particles by

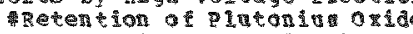

Deposition and Petention of plut on 238 tin

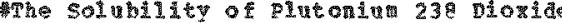

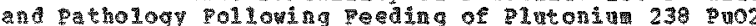

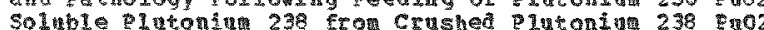
kearcinogenicity of In haled tubonin 238 from crushe scarcinogenicity of Inhaled plutonin 239 from crubhed

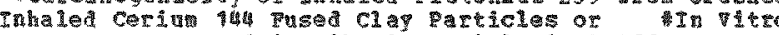
Histribution. Fegularities in the Biogenie

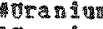
ํํำ

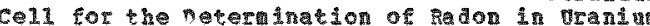

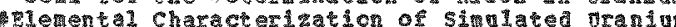

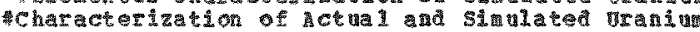
achronic

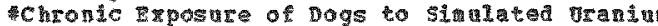

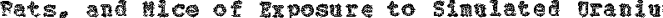

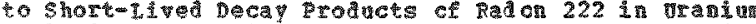

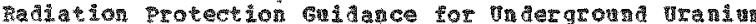
Der

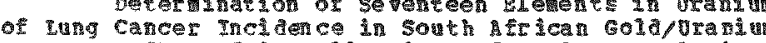
peaceful 1 polication of

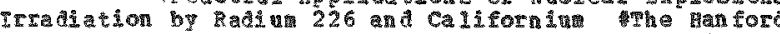
20 20 con

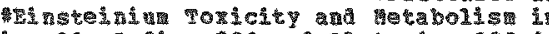

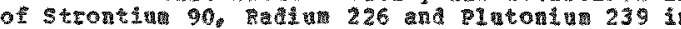

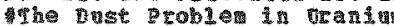
等inetics an

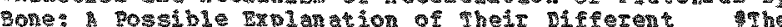

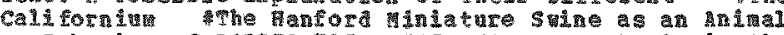
Sehator of IHPR Process ingth

Pepore for 1972

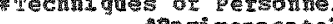

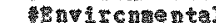

contractor sites. Calen das iear 1972\%

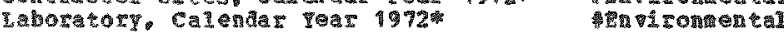

nea sisentents

easues in thasest

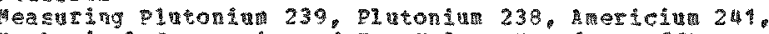

mehan ical Eroperties or ht. Helen, Hevada puft

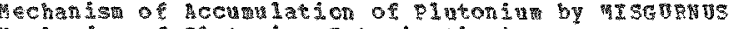

hechanis of Plutonitu Intorication

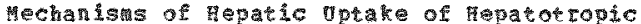

解chatisto of

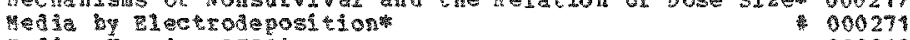

(1)

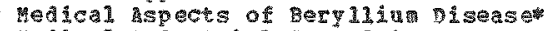

Medsca I Ind astrian

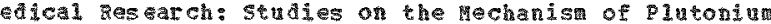
Medical lise of Californin $252 \%$

medicine ard neical Research: studies on the lechans

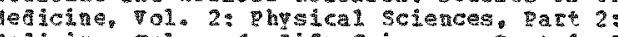

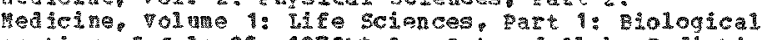
weeting of July 25. 1973 \% Low Let and Alpha-Radiat ion

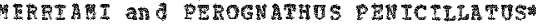

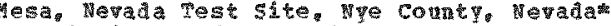

mesot moriun, strontin and the sequence of

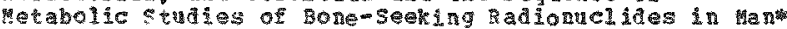
terabolic studies of product

vetabolis in the at at

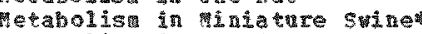
vetabolis is in its

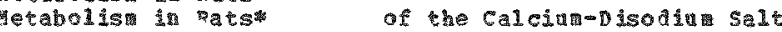

metabolis of pononeric and polpmeric Plutonin in the

metabolisa of p1utonian 239 and peotunin 239

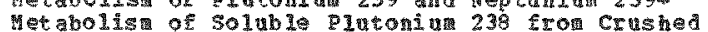

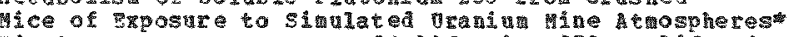
ices

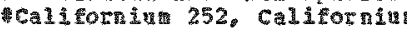

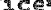

Hosteosarconas As placed to misto

Mcrobial Activity on the totate and Distributan of

Hicrobiot in the solubilization of plutonin in soil

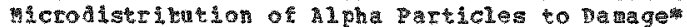

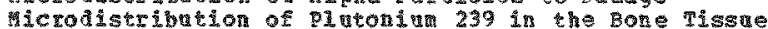

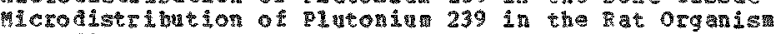
Merof Ioras

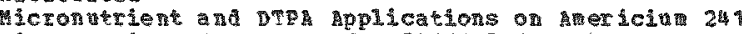

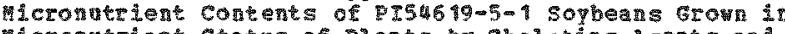

1Cronutrint Status of Plants by cholating agent: and

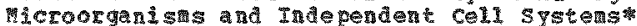

meroorganishs

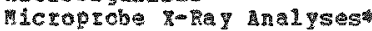

Microscopic and piochereal studist

icroscoptrit

microstheres in teagle nog iungs

000212

000318

000408

006463

000353

090355

000470

000136

000306

000339

000085

000049

000203

000177

000063

000025

000184

000206

000190

000231

000183

000249

000087

000761

000124

000001

000246

000362

000156

000254

000002

000250

ductospheres in seaglesw

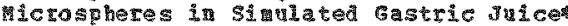

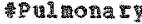

presosphos ta

I

icrospherest

ictospheres

Hgration of Aveolar hacrophages pron bogs that

Higaton of Radioactive Elentert

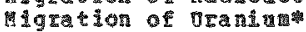

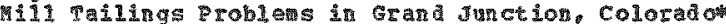

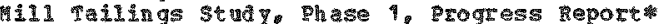

vis

4

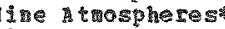

ine Hospherest

ine taspherest

4.

M the thospheres

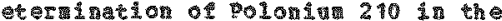

4

4iner

Finerswar

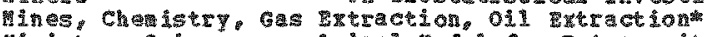

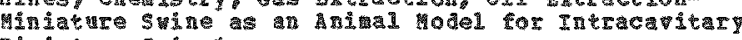

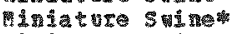

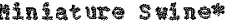

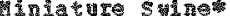

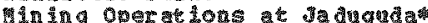

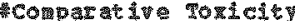

TS GI

P cte te

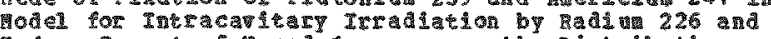

ofat Desere of the

on ํㅐ Distributior and

contoring and

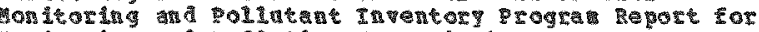

Hentoring and Ratathon surveylng

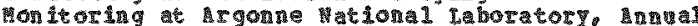

Mon

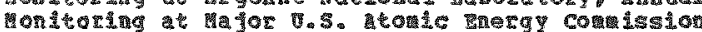

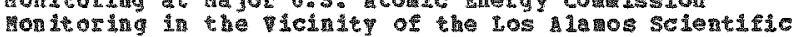

000209

000213

000190

000193

000192

000072

000195

000507

000426

000460

000368

000523

000220

000224

000766

000801

000491

000073

000356

00033

000225

000128

000140

000395

000172

000227

000225

000292

000505

000676

00053

000505

000 都教 
Tintal Report for 1972 st Antual Repor for $997 \%$

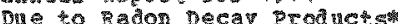

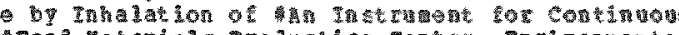

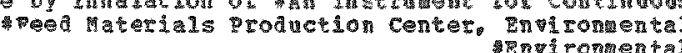

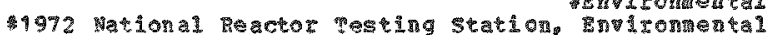

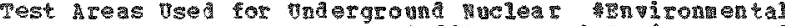

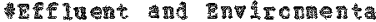

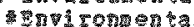

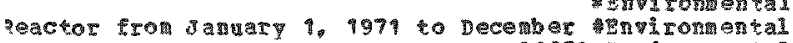
蒙1972 An * oma

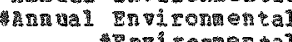

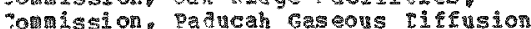

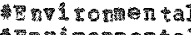

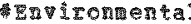

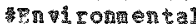

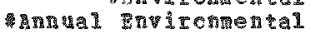

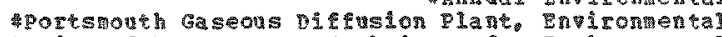
A Revier of

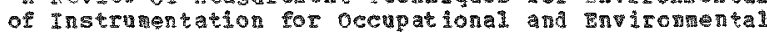
Bib1 jogeaphw

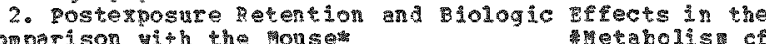
comparison th the thousen posteosarcomas as plated to pissu Distribution of

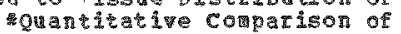
Anatonis Distribution of

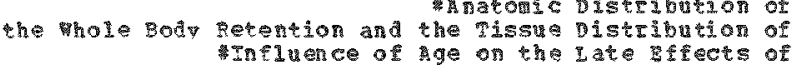
Hrifuence of Age on the iate stects of

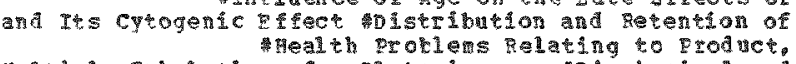

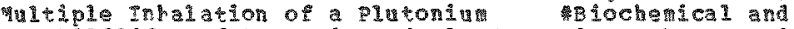

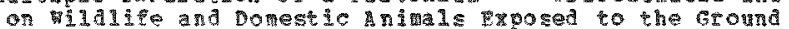

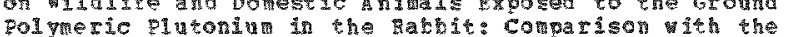
Postshot Distribution and

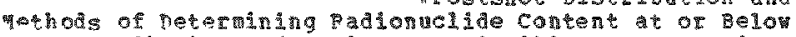
Radidion and hat

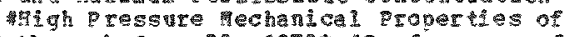

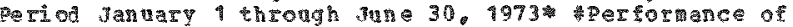
porphological changes 1 the zungs of tats accomeny

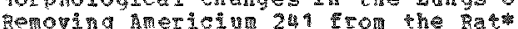

Perong A

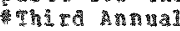
2lement mealth physics and satety cak idgo * Environmental mon

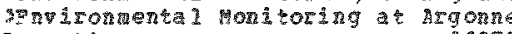
monitering progsar Peport

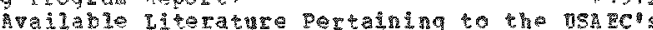

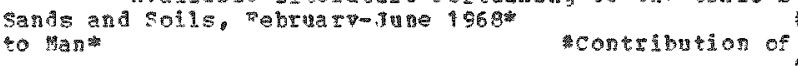

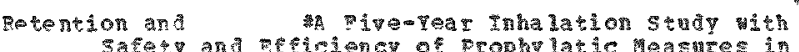

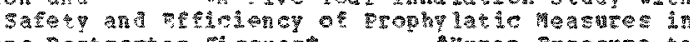
from some postmortan ris

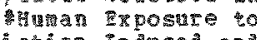

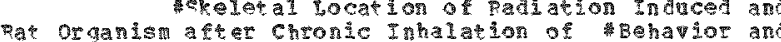

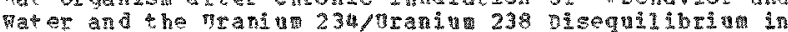

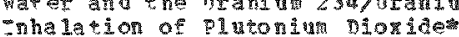

Adrenal Distetibution of

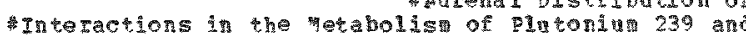
Microscopic and siocherical studies

是I tasion products on the Functional state of the central Scarners

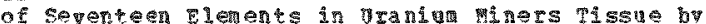
4 Homphotographic ol pha un toradiograchy and

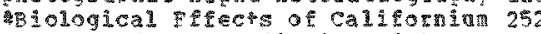
Anerictu 24 औ

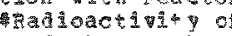

* A Prelitinar seitsicity sut of the southern *ajologácal survev of th

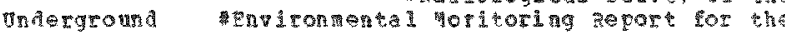
\#ato onality and Phvo jeal charactistics of oustributons of the vascular lor o thecology of the

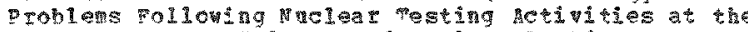

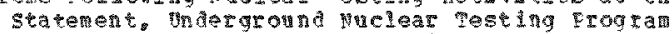
of indings selater to the resting pragram at the \% Geohylrology of the zastern Part of Pahute Par of Pante wes Contannated Areas on the metringe conplen in

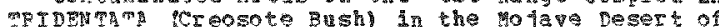

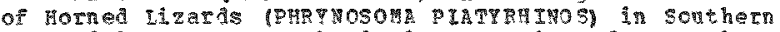

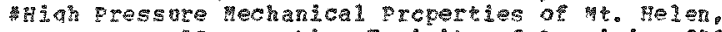

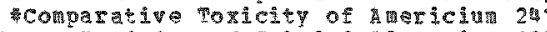
- Acute "whe Biological Disposition of thateing Apolication of cellu 1 cse of the skeleton After Inhla

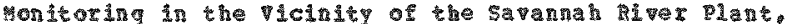
wentor

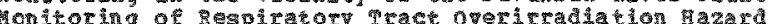

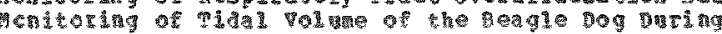

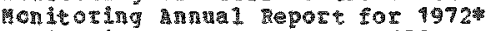

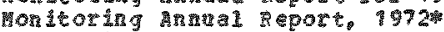

mentoring progra merert

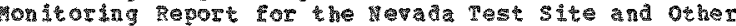

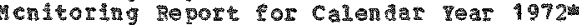

crutoring poport for caterdar pear 1972

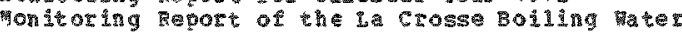

critering Reports

Monitoring Geport

Monlering peport calendar par 1972\%

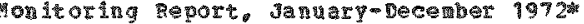

Monthoring Report, Unted States Atoric Bnergy

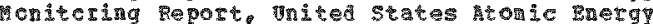

Monitoring teport, 1972

Montoring Beport, 1972 .

onitoring Risort 1972

Mom ite $\operatorname{lng}^{*}$

onitoring:

A 11 1

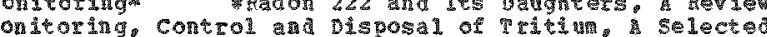

Mon

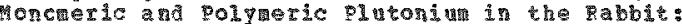

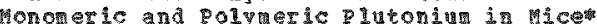

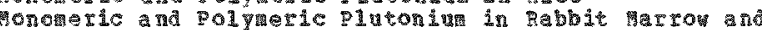

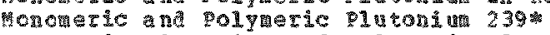

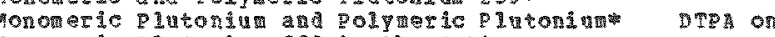

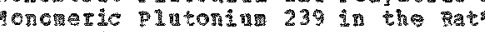

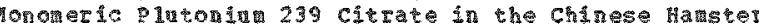
Moneh of harch, 1945 कै

morchological changes in the lungs of pats Acconomy

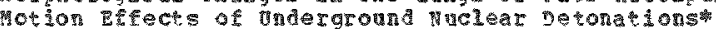

Mcuse

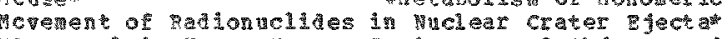

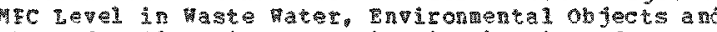

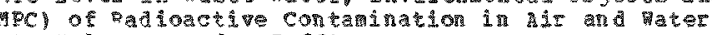
Mt. Hen Nevala, Tut

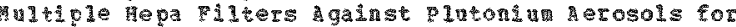

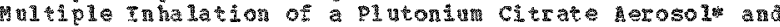

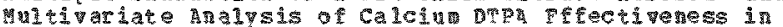

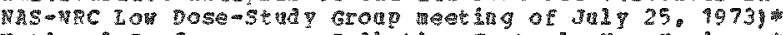

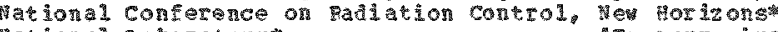
ational iaboratory

National Labora cory. Annul Report for 1972

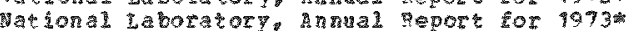

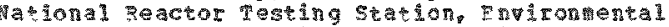

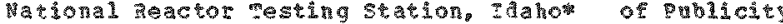

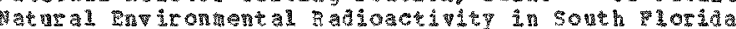

vatural Terrestrial Sourees to the potal Radiation sose

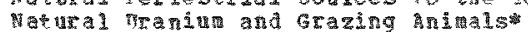

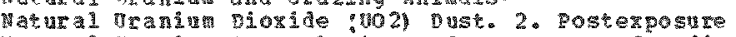

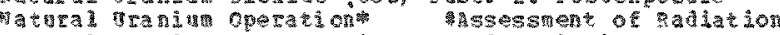

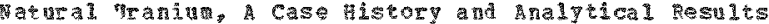

Natura Ily occurring osteosarcolas in han and Dogh

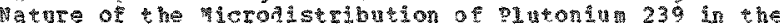

vature

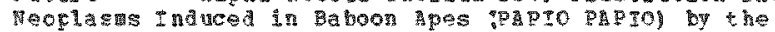

Hepunin 237 a

veptunturing 239

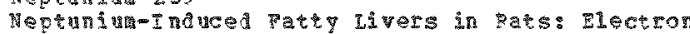

*ervous 3ิsten

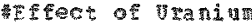

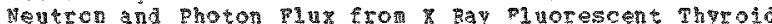

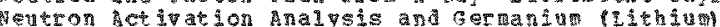

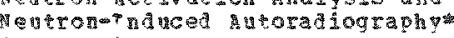

verans

70.

Nevada

*ajara pose Fate of

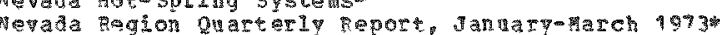

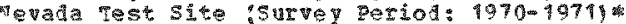

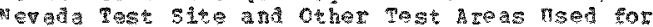

Wevad Test Site vater-5upply hellst

revala west 3ite. 1. Geograth and

vevada

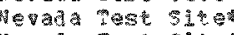

Nevada pest site*

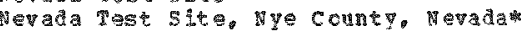

Nevada

vi

evada

Tevaca

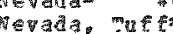

vitrate and cistatem

Yit

Nitrate in Pats After Intravenons. Intranusular,

Vistate

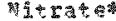

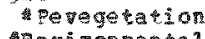

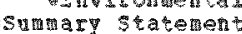
50il Sure

on the 0 istei ibution and

of

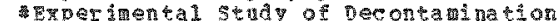

theohydrology of the pastern
000482

000496

000349

000053

90013

000467

00048

000473

000487

000412

000492

000 丝题

000688

0008

000420

00048

00049

00049

000421

00042

000418

000499

000581

00019

00018 련

001183

000182

00022

00019

00013

00003

000163

00018

$00030 \%$

00018

000334

000430

00055

00032

0075

000189

00020

000136
000556

000556
$\$ 00545$

00050

000504

00048

00058

ก004

000320

00006

000194

0095

000372

00023

000124

000525

0007 is?

0000

000206

000028

000238

000195

000317

00007

00034

00006

000530

00052

000338

000425

00069

0003 ts

00020

000305

900327

00046

090339

000339

000296

000292

000298

000342

000160

$00016 \%$

0,00205

00026

000958 
3落

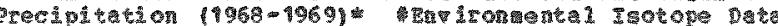

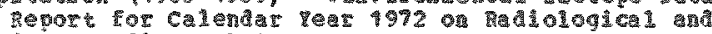
Induced Autoradography

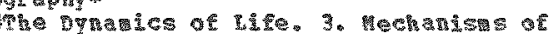

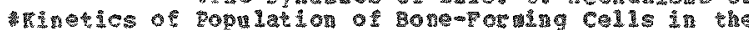

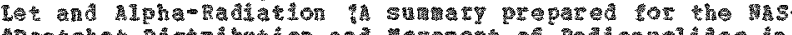
60stshot Dist

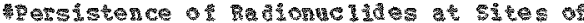

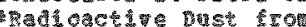

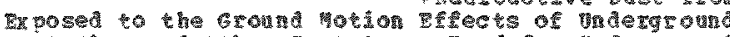

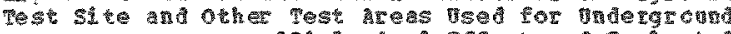

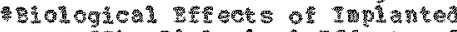
The Bologes 1 tritects of

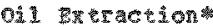

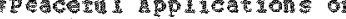

ETto

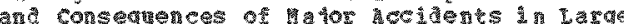

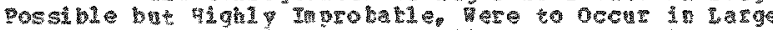

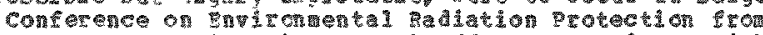

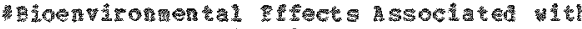

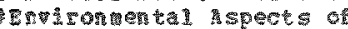

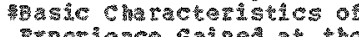

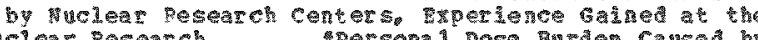

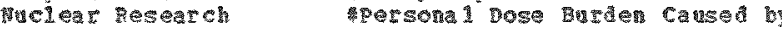

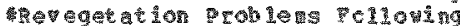

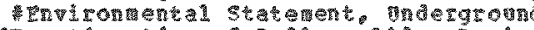

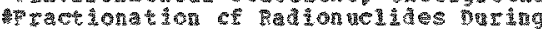

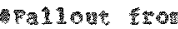

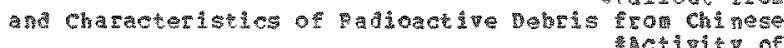

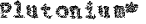

30 51962

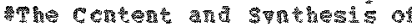

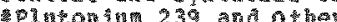
Geter

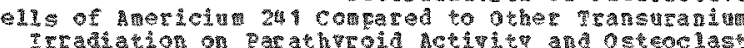

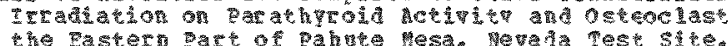

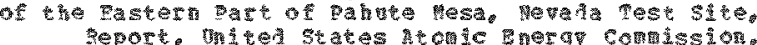

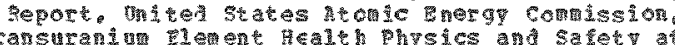

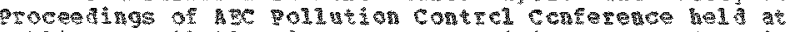

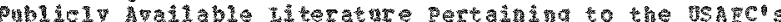
3. Or 222 and zos jagh

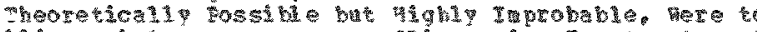

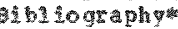

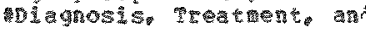

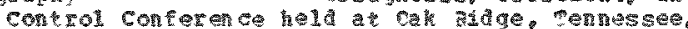

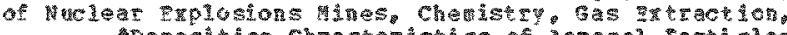

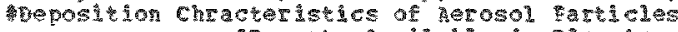

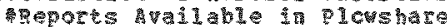

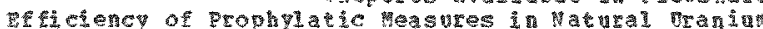

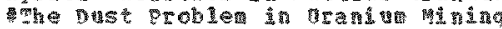
4.

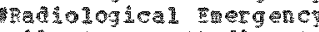

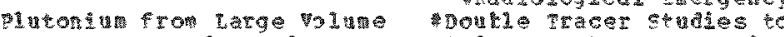

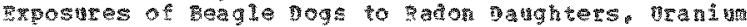

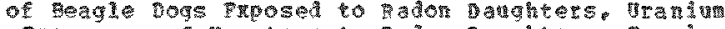

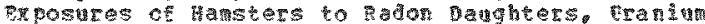

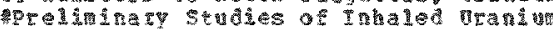

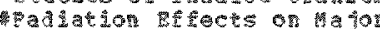

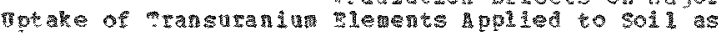

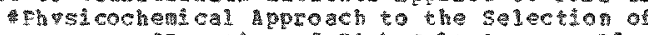
peaction of migh sal kqueous pus

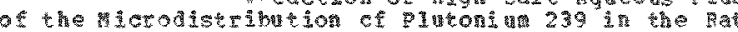

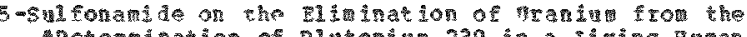

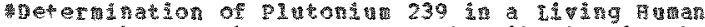

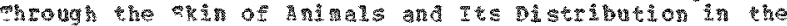

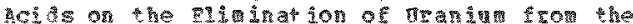

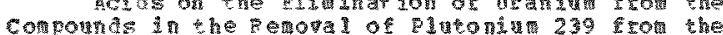

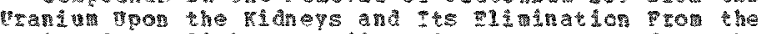

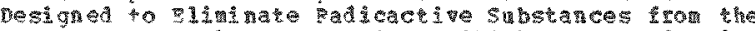

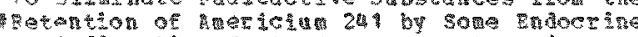

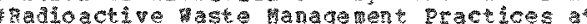

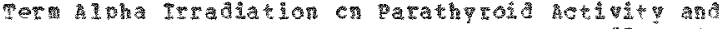
跑e

परose to

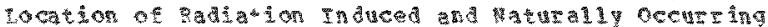
Yomomerio and

*

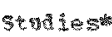

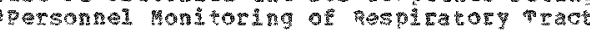

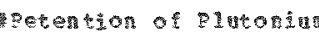

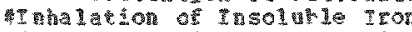

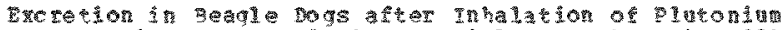

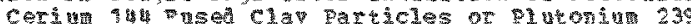

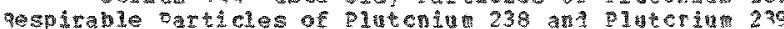
4P

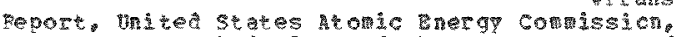

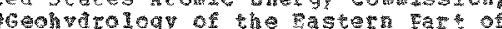

pon

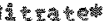

굴

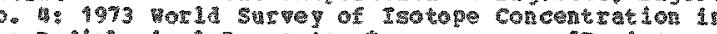

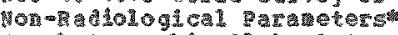

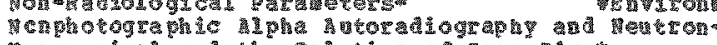

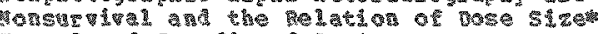

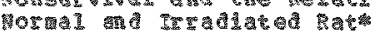

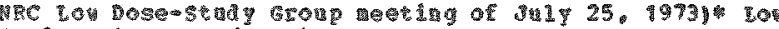

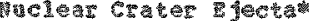

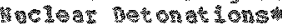

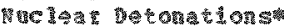

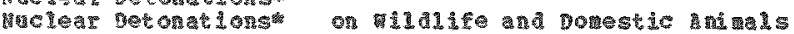

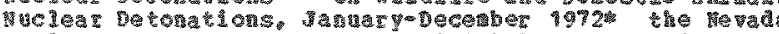
神

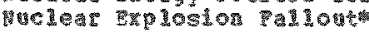

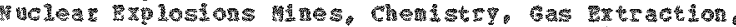

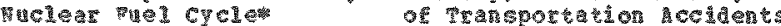

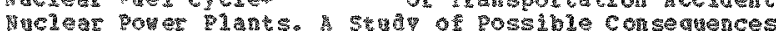
等e

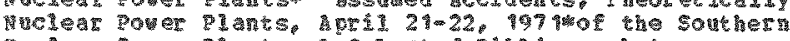
the lear Power Plation

viclear

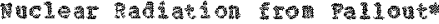

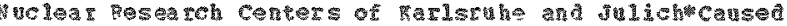

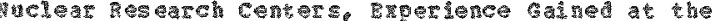

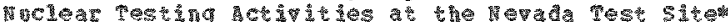

viclea pesting

victer nescing

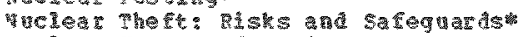

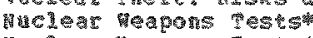

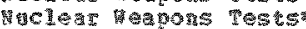

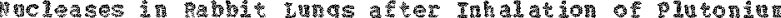

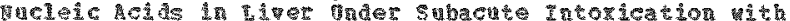

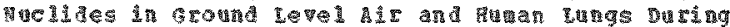

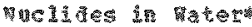

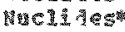

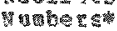
og

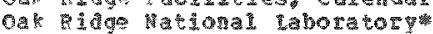

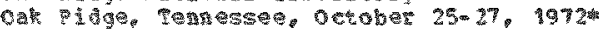

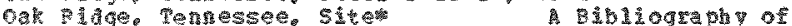
ob fects and iologion

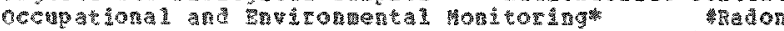
bectr in Ha 6.

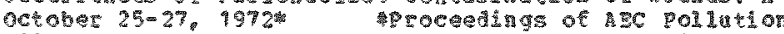
011 Es

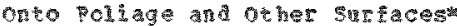

ocen Fise

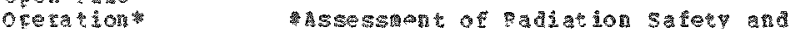
Operations at jabuguar

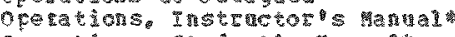

cperations, sctient

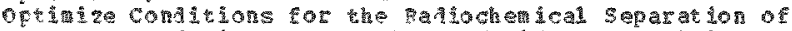

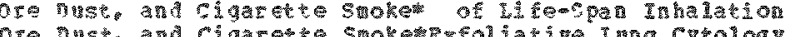
ore

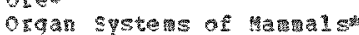

organ -

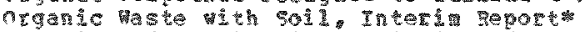

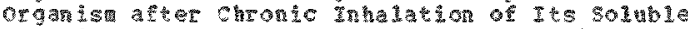

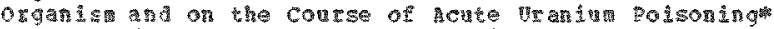
Organ

ot

organ ts

管党

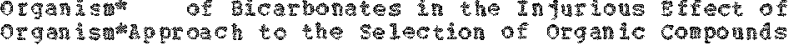

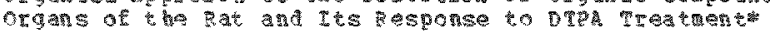

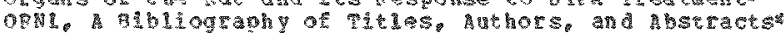

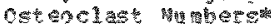

3 Eect of 3 每

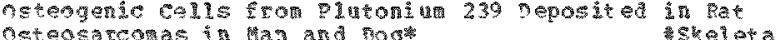

Osteosaconas a กverpeating "nc

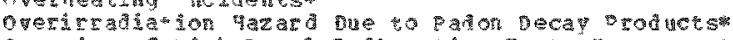

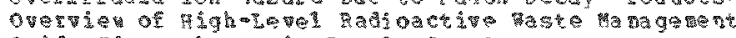

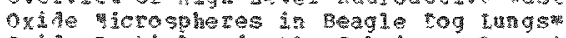

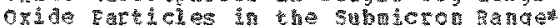

orias

*Tarise

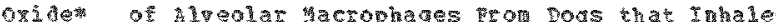

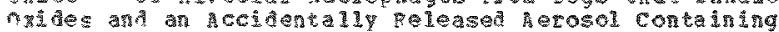
sacemakerstant

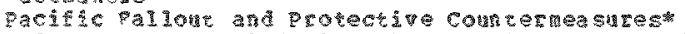

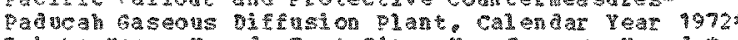

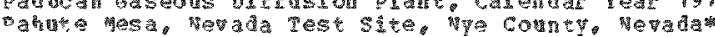

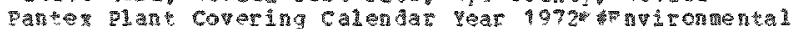

000022 00049 000490 16063 1002\% 000136 antis 00045 $00042 \%$ 000307 00045 00005 00047 00033 0000 0003 14 000314 000314 00049 00033 000315 000321 0000351 00045 000305 $00032 \%$ 000528 400540 600 000592 $00015 \%$ 090101 $00049 \%$ 00026 000057 000056 000339 000488 000545 0005 00050 000950 000498 000313 000383 000585 000333 000098 000337 00054 000395 00059 00055 900272 000223 50004 1 000221 00022 000364 000175 000253 000577 00012 000082 000338 00009 000011 000027 000081 000253 000197 000586 000056 000083 000235 000113 000579 000349 000582 000250 000391 000055 000072 000293 090396 000438 00040 000339 000476 
4Neop 1 as Hoon prae in Trand 30 and

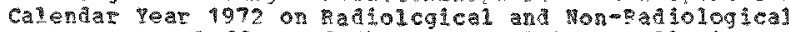

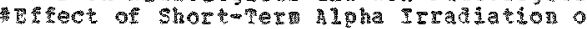

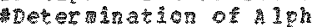

2. 1 pha

DIิ Stribution

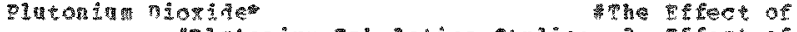

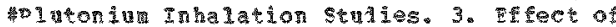
sing

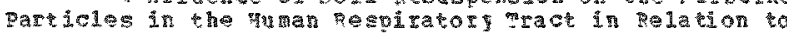
Tetravalegt plutonis 239 os

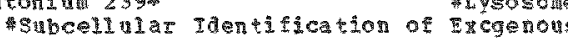

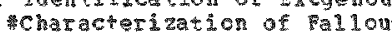

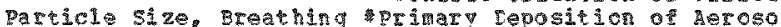

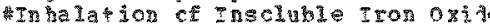
an studies of the tritro solubilitu ef Restrablo

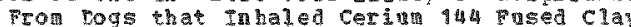
pelationsh of Final portelationsh of picrodistribution of

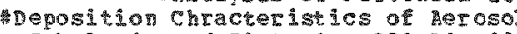

master pollowing Inhalation of Plutonin 238 Dioxide

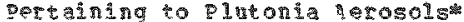

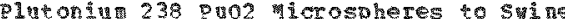
1ㅡ. 8q3 crospheres to swine Sำ

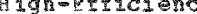
Ceoser 1 acenten

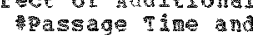

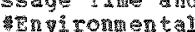

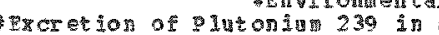

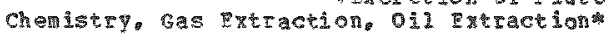

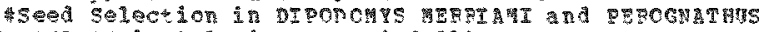
ơlC

Som cological attribures and plutonin conteris

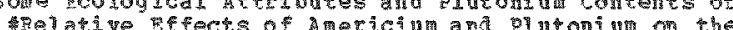

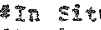

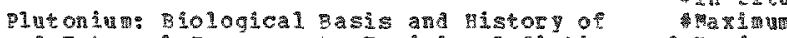

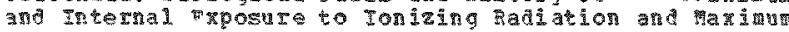

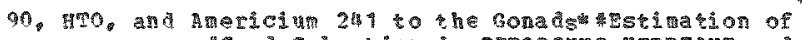

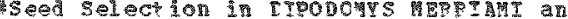

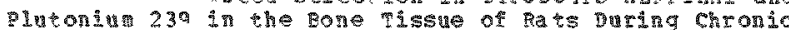
h B nemonations.

4a

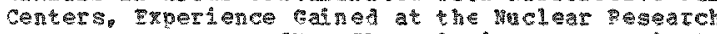
等

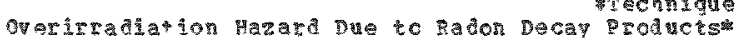

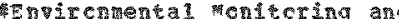

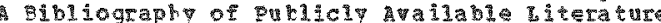
1

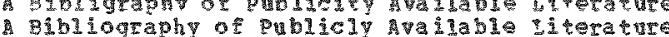

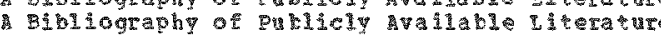

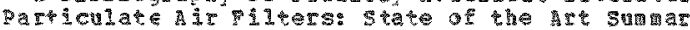

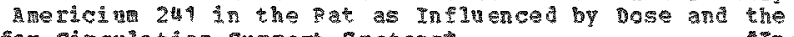
for circulation support systenst

Cosplezion of the Thiection * Sorption

of p1

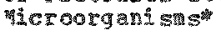

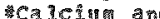
Tologica 1 anc

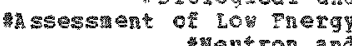
syereren an

2T Therea 1 I

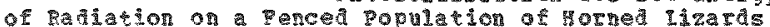

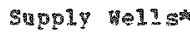

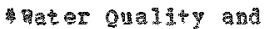
chemical as schersent

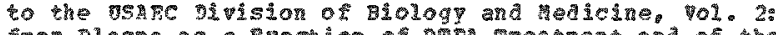

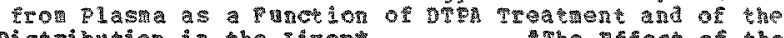
Distribution in the IIVer

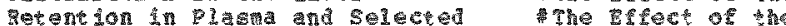

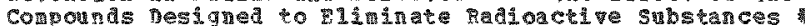
the affect on DIurogin 239 In Ivo Netabolis in in Protece

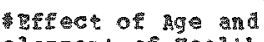

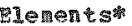

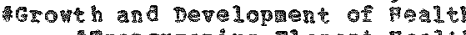

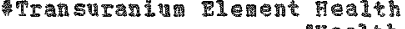

ath

the alth

and P1 uำ
Tadatom

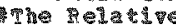

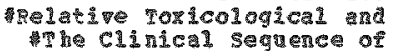

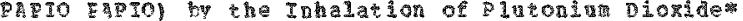

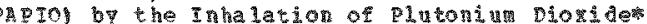

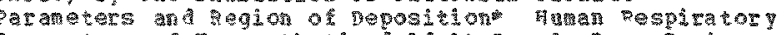

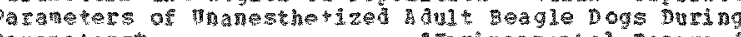
aravetersta

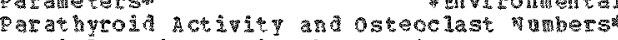

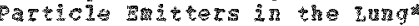

pacticie Incidence in sall targets

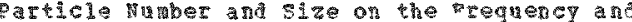

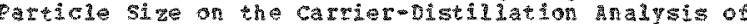

partel size on Totgl pose Depositon

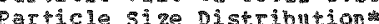

Particle size, ireathing paraters and pegion of

Farticles and subelling

particles by

Particles fron glectron

Particles in the Hutal Respitatory Tract in Relation to Particles in the subicron

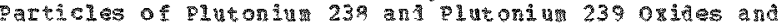

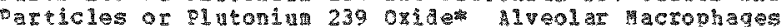
Particies to Danage

Pajticles collected vear the Rock mats acily. Particles onto plige and other sutraces

Particis

Particles, Trit n the Blood In phocytes of the chinese

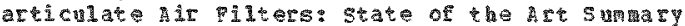

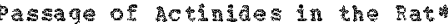

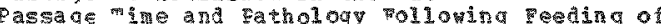

Pathological pactors on the dong pern consenuences of

Patholcgy Following Feeding of Plutonitu 238 FuO2

Path ays of Trassuranic Elements

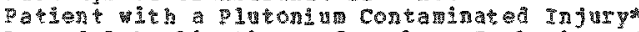

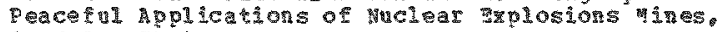

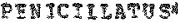

Perentotion in

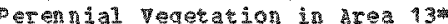

Feripheral elood

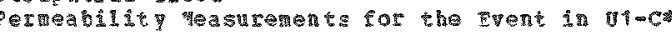

percissible Body gutders and concentrations of

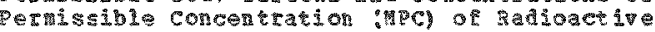

Pertisible Dose for Internal Ratation

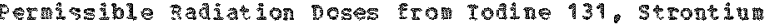

E.

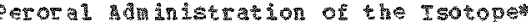

Porera 1 Aministrationt

Persistence of panionucitales at sites of unclear

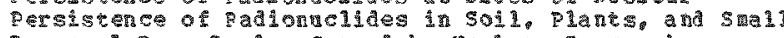

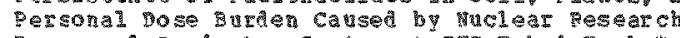

Passonul Dos

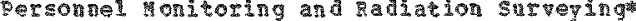

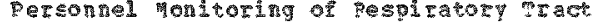

Persontinel protection in

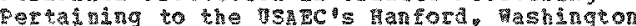

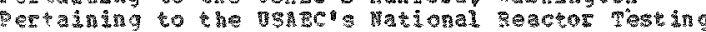

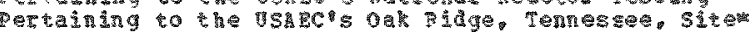

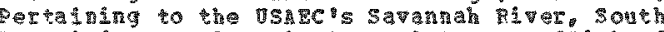

Pertaing to plutonia merosols

pr of the Injection solution

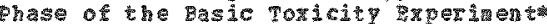

2ha i, Progress Repor th

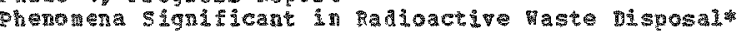

Poghoras peabolist in

photobiclogical Action of poll utants on squatic

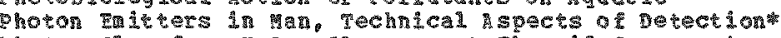

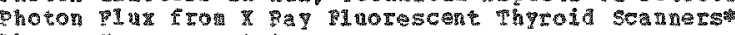
photon ifeasurenentsin

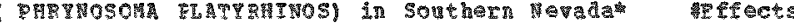

Physical and themcal Exoperties of eluronita 239

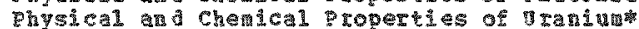

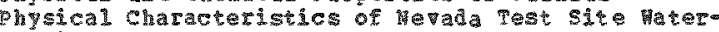

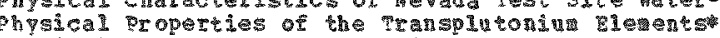

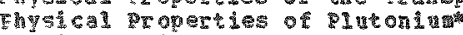

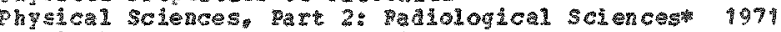

पhy

of 1 1

Phy

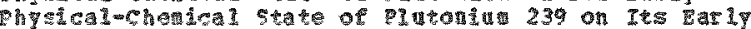

pysicocterical Apptoach to he selection of organic

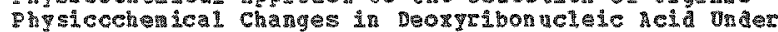

Phys coch

phys cs and Responsibilities in the pield or padation

Physics and safety at oak inge vetional Labotatorit

Thysics and sater

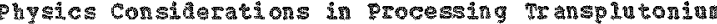

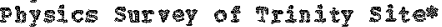

Phy

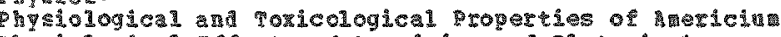
25y

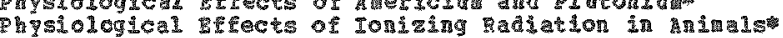

000142

000142

000390

000052

000400

00005

000447

009277

000277

000526

040390

000778

000002

000252

000390

000391

000593

000072

.

000468

900905

000034

.000

902202

000213

000213

000357

000405

009333

000306

000024

00030 .

$00039 \mathrm{a}$

000105

00035

00055

$00038 \%$

000123

090396

000306

0000tho

000453

900501

00015

000446

000553

000349

000503

0005 연

000595

00053

000590

000347

000199

000319

000216

000426

00059

000053

000156

90015

000317

000509

000298

000257

000263

0003 祭

000267

$00028 \%$

000 1 70

000117

000036

00021

000253

000900

000203

000552

000545

00028

00052

00033

000522

000110
000119

000176 


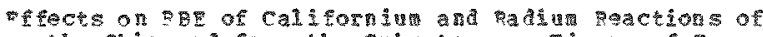
the Shan and from the sthonaneons

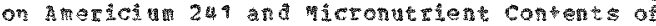

sects

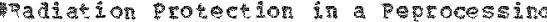

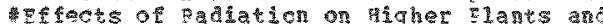

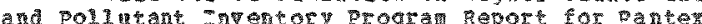
triteractions of 1 w on

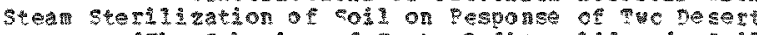

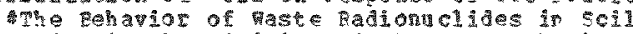
* oncoring sis the vicinity of the savantah piver

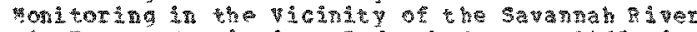
Atowe Energ com

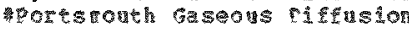

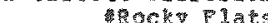

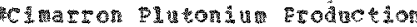
Specife heth

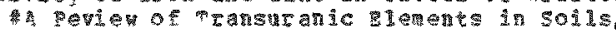

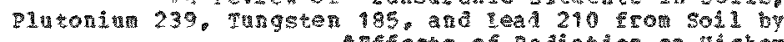
hetectis of adiation on 1 gher

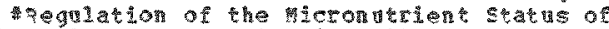

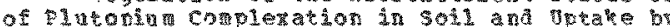

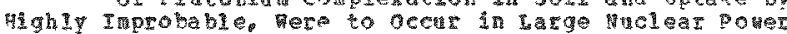

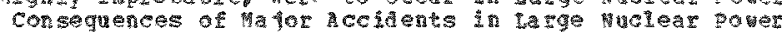
nadoes

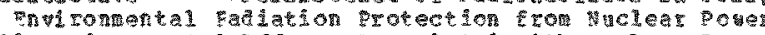

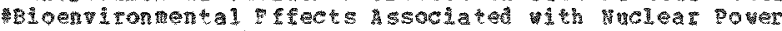

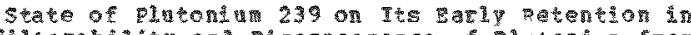

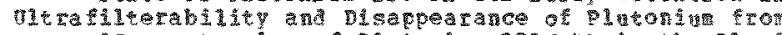

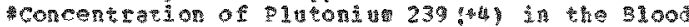

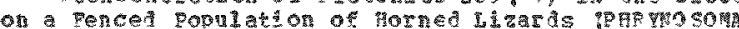

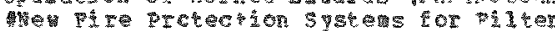

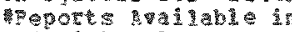

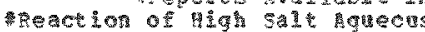
Ast

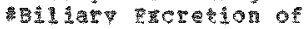

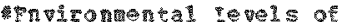

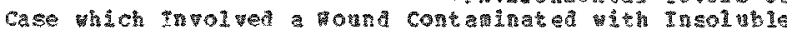

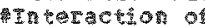

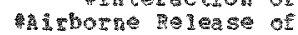

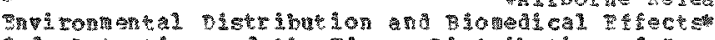

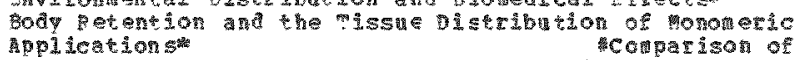
Application st $^{\text {th }}$

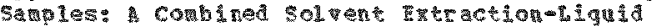
程

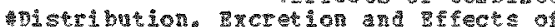

Iters 불 I

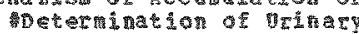
6hendeat astay of

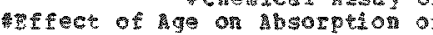

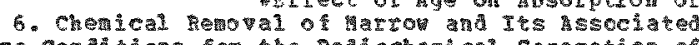

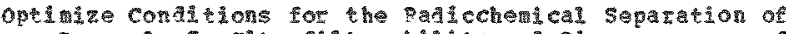
Removal. 5. vitrafinterability and sapperance of

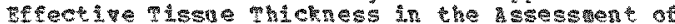
I I I

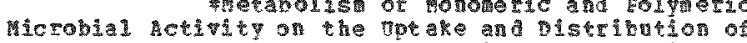

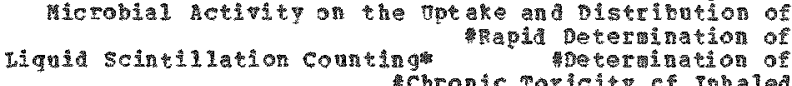

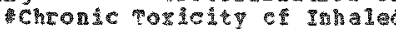

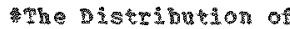

Fuel pechnolog. Part 2: patiaton prostre tron to

40. A

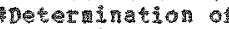
等日e

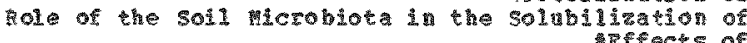

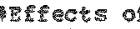

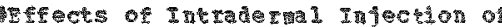

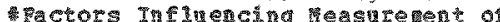

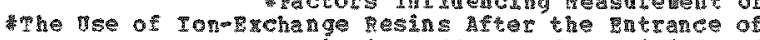

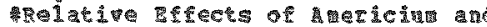

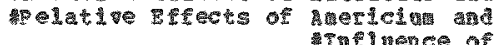

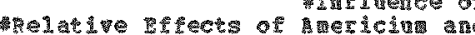
*

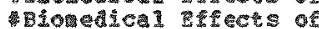
the he prect of the phy

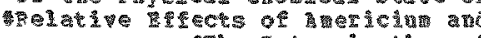

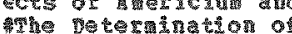

30. 1973 \%performance of firteretions of

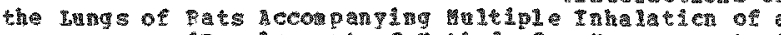

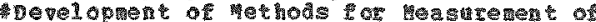

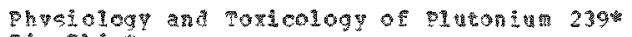
Eag $5 \mathrm{sin}$ s.

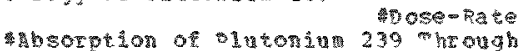
pacental passage of actinidse in he pat

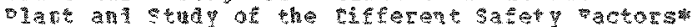

Plato comun

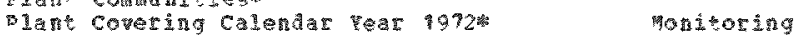

Pant

plant soectes

Plane cysterse

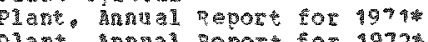

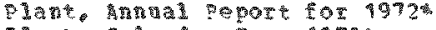

Dlant, Calendar par 1972 \%

Soporoto

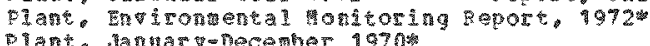

buat

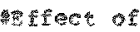

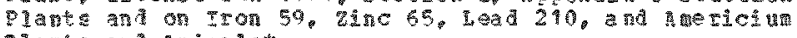
I 1 a

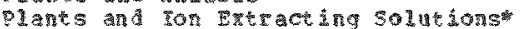

Remova 1 of

Dlats and pant com

Fants by cheldting Agents and other pactors

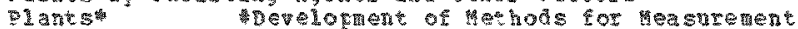

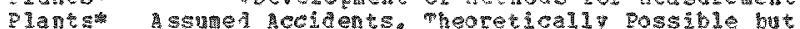

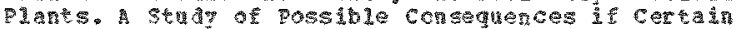

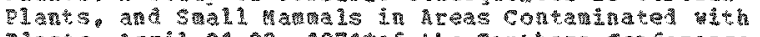

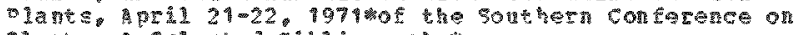

plates: Selected dibliography

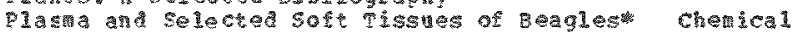

Plas as as anction of DT

Q1

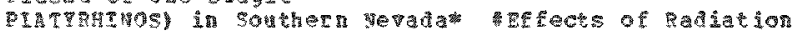

tos

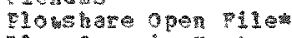

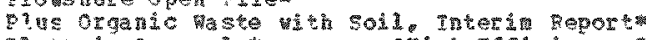

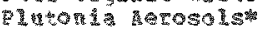

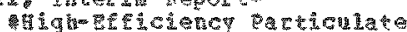

Dlutor

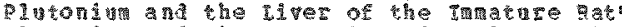

Fin 1 us

81

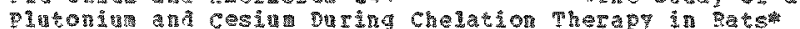

Divon

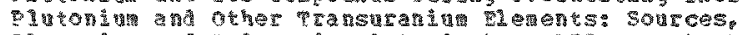

P1

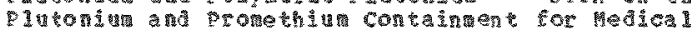

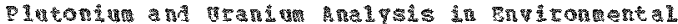

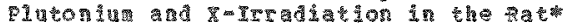

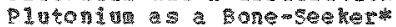

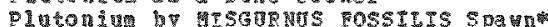

Plutoritu by sadocherical Analysis on Ion Exchange

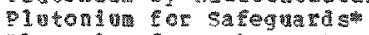

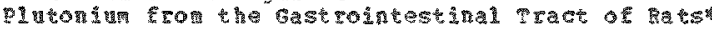

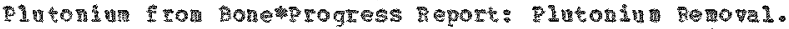

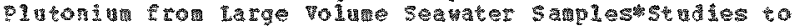

Binton In from

Bloton

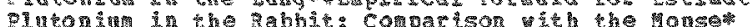

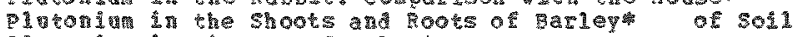

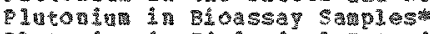

Q1 1 ton

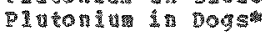

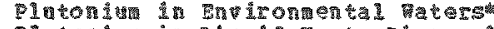

- Iverna P 1 4h

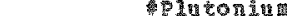

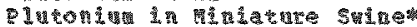

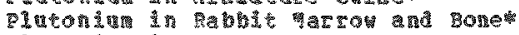

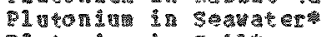

P1 1 toon ing

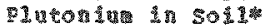

Q1utoritur

Q1

As Relatea

10

P1 1 हैंक

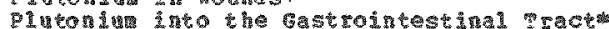

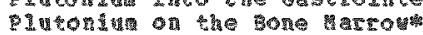

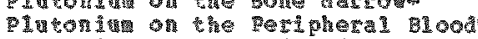

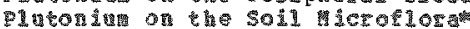

14 ton

Pidton

D toton

910

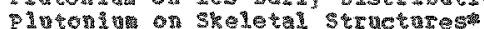

Dlotonu to Aleric

21 to to

P1

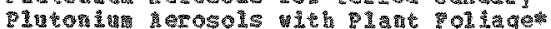

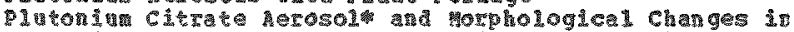

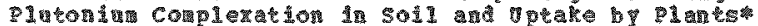

009 33

000006

000039

0

00056

0000 is

000476

000099

000232

000303

000496

000482

00056

000244

000302

000045

000283

000287

000314

000314

000509

$000 \% 79$

000331

000214

09017

000216

000298

00054

000337

000577

$0003 \%$

000134

000092

000332

000407

000208

00055

000092

000318

00027

000913

000230

000172

000260

00025

000131

$30018 \%$

0002 팩

000117

000398

000184

90124

000270

000268

000171

000286

000325

000565

000183

000128

000122

000284

000255

000 数 12

000248

00013

000017

000389

000025

000100

0001705

ดั0 00

000106

000392

00035

000036

000707

00009

000 然 28

00054

09009

600199

$0002 \% 7$ 
M

Ad

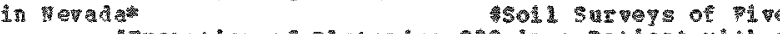

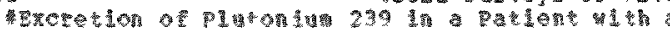

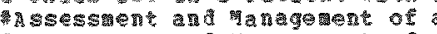

$9 \%$

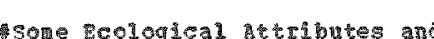

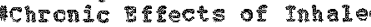

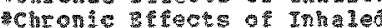

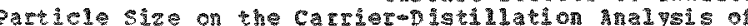

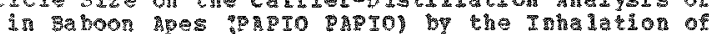

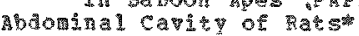
ware thination of F⿱宀

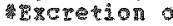

stre Detection of Airborne

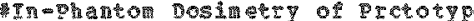

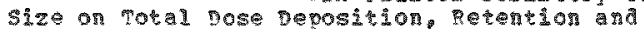

heationt of an

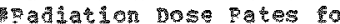

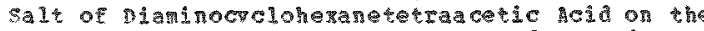

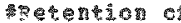

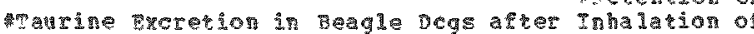

I. Appends

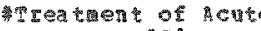
Cinaston progress peport 得 Sprogres: pepte

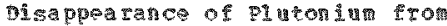

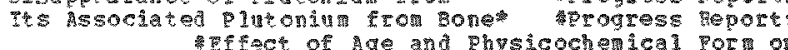

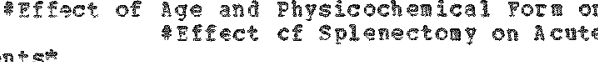

chal ating Agentest

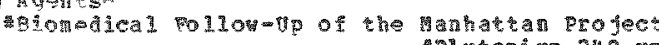

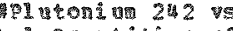

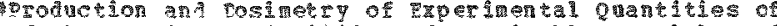
of the in 7 is

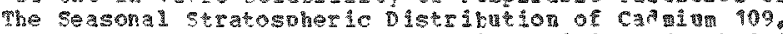

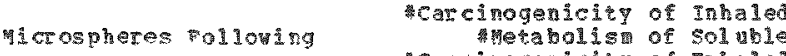
*arcinoganicity of Inhaled *

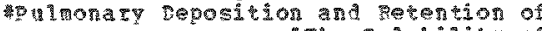

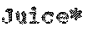
whe soluhin

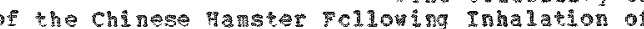
a 110 a

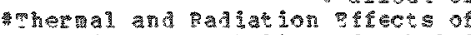

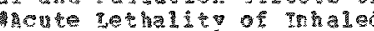

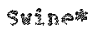
\%abotption of

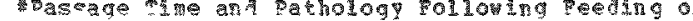

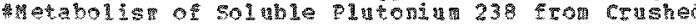

tha

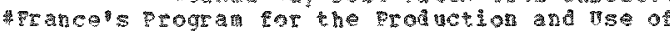
saye stratosongia inventor of

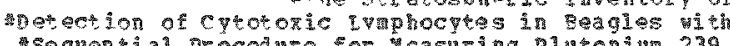

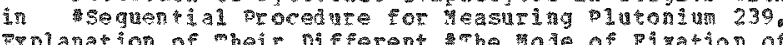

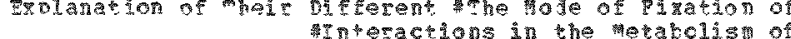
are

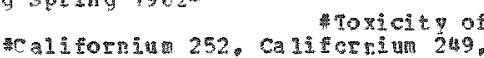
itects of

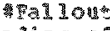

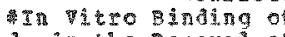

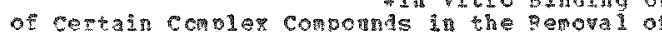

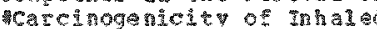

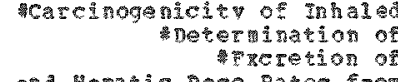

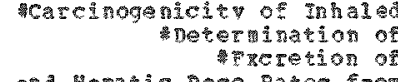

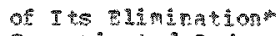
ath

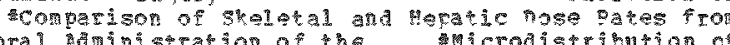

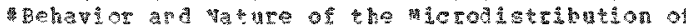

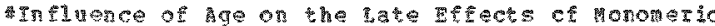

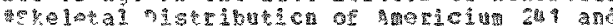

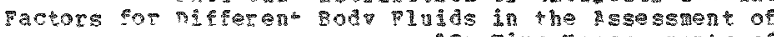
I

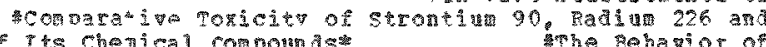

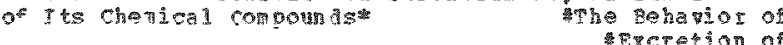
40

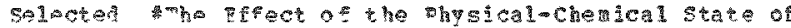
Thenesion ion tological Fifect of

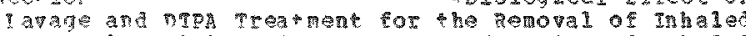

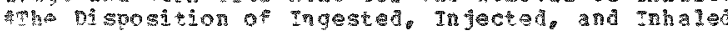

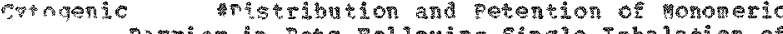

in 3 a

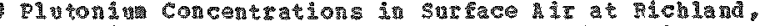

P 1

1 ncon

Q 1 h

11 ton 1 cont con

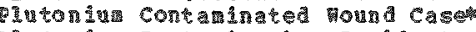

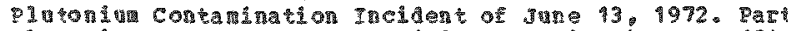

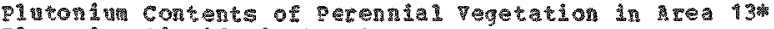

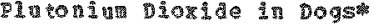

Q1 ton

P1 toris

\% 1 ton in

Dỉoxio

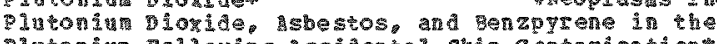

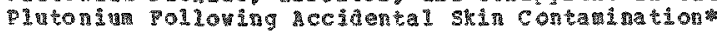

21 10ton

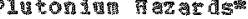

11 toñ

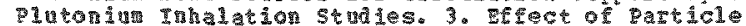

E1 aton Iu inhalacion stadiest

Q1utonsan Inhalation: case stuajesta

Q1

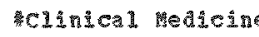

Q1 1 to to

1日tonin 91uton

914

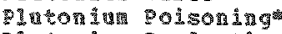

Pl to to

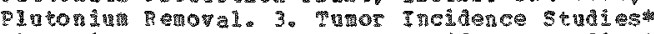

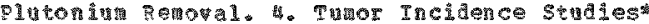

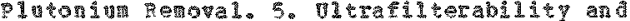

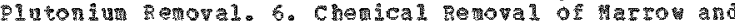

Q1

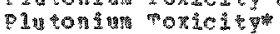

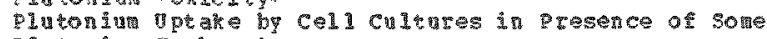

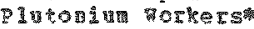

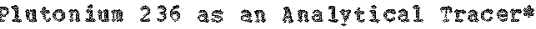

P114

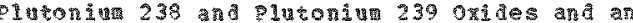

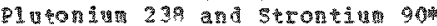

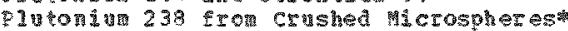

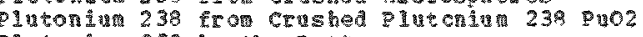

810 ton 238 in the path

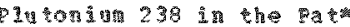

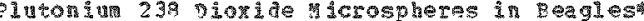

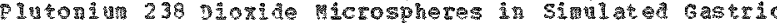

bi

Q1

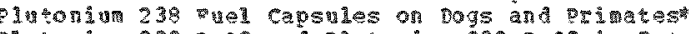

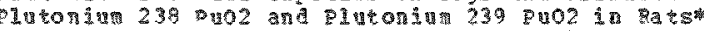

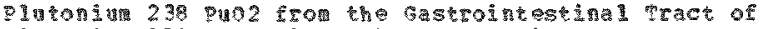

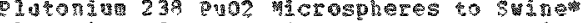

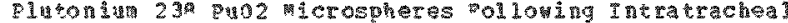

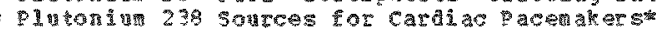

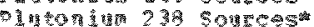

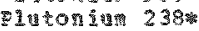

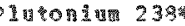

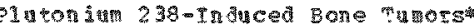

Q1utong 239 , Ane

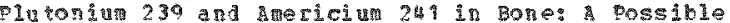

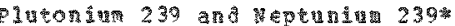

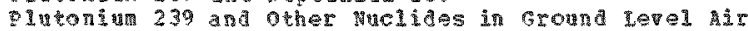

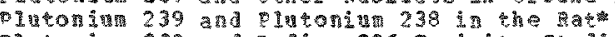

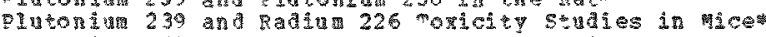

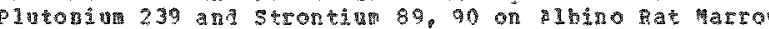

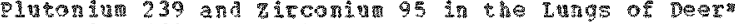

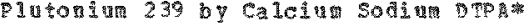

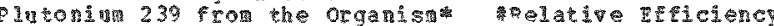

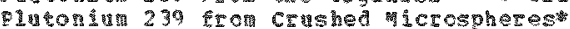

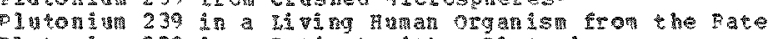

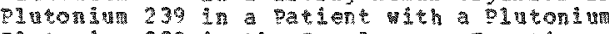

Dintonin 239 in the Beagle as a pinction of poge level

1utoning 239 in the tone missue of

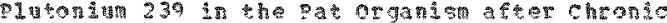

2010

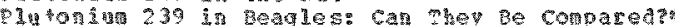

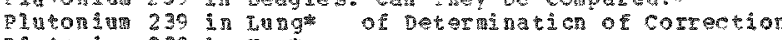

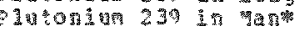

Dlison in 239 in

Plutomin 230 in

Plutong 230 into the Intestinet

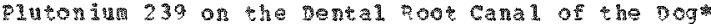

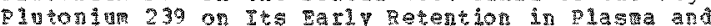

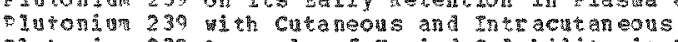

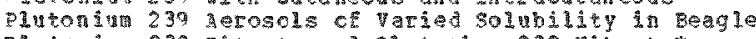

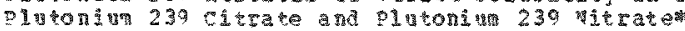

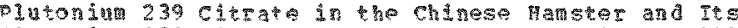

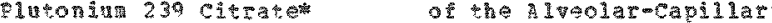

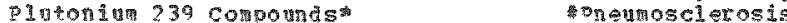

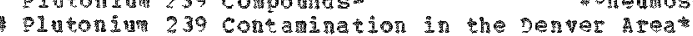

20005ำ

00063

000296

00040

000376

000396

000560

000304

.

169

000277

000142

000380

000565

000 姑姆 5

000319

000009

000010

000385

000355

000413

000250

000055

000386

00056

000186

000185

000117

000187

000203

000916

000174

000375

000270

000533

000283

000510

000193

000190

90019

000013

00025 .

000209

$00003^{3}$

000514

000393

000219

00021

900212

000190

900

000535

000452

000066

$00028 \%$

000223

000206

000497

noopis

000231

000236

000499

00020

000192

000389

$00040 \mathrm{~F}$

900215

000961

900132

000132

000500

000346

000140

000125

000023

000230

000213

000038

000953

000022

000033

000004

00045 
comb 대 Dose to Ostooge Cells 程

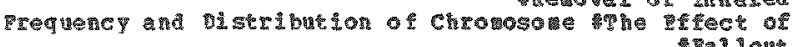

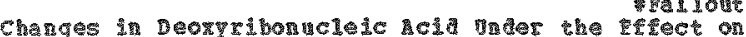

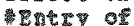

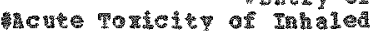

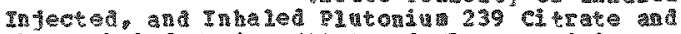

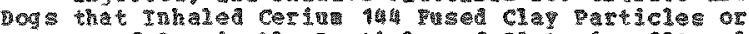

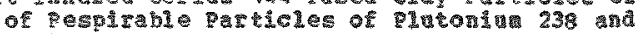

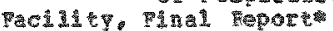
Thazys: or

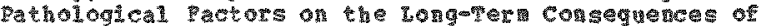

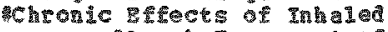

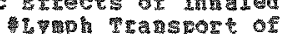

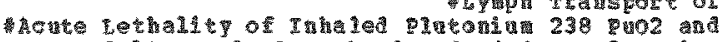

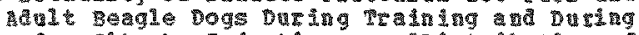

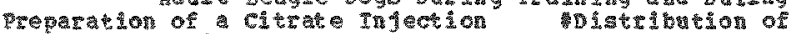

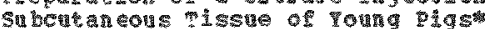

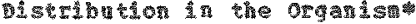
A Alorption of

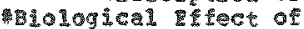
sconcentraton of

参

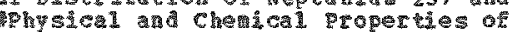

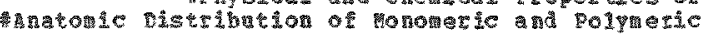

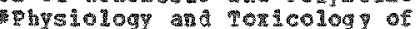

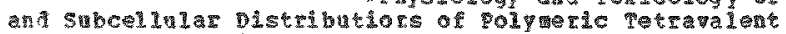
Tetabolis

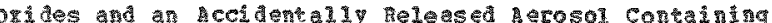

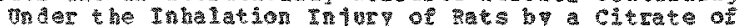
90 and

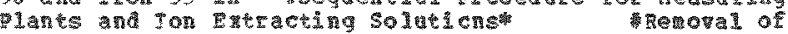

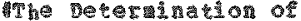

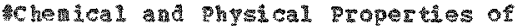
sion

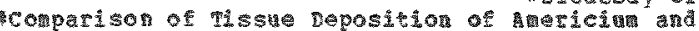

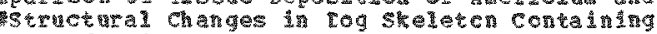
4

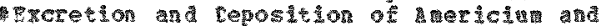

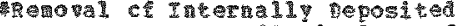

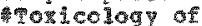

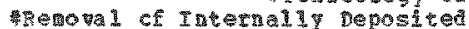

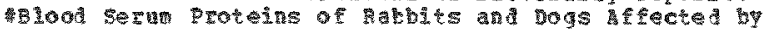

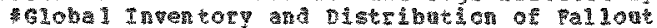

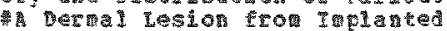

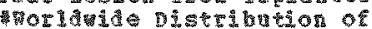

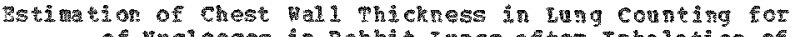

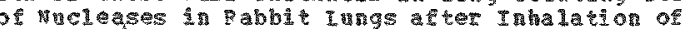

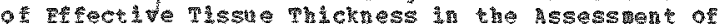

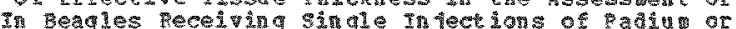

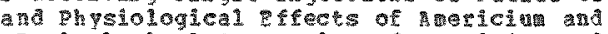

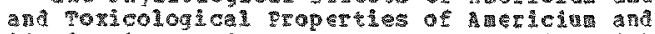
跳

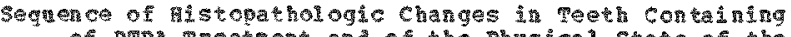

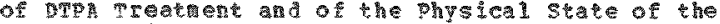

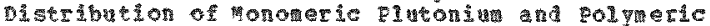

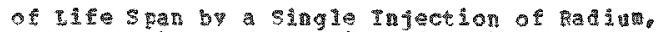

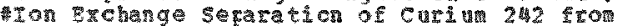

in the eeth of Dogs. 1. The Distribution of

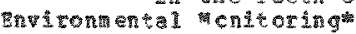

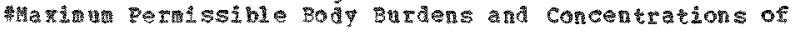

gates

4toracell

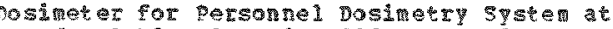

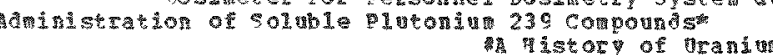

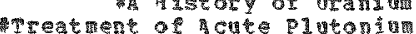

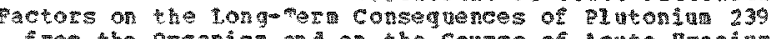

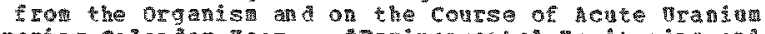

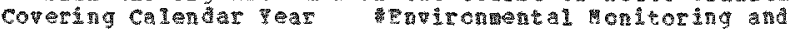

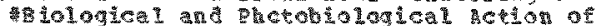

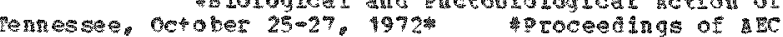
Bancs

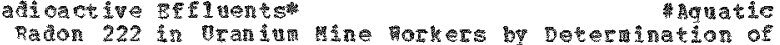

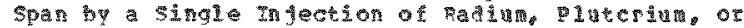
ตons

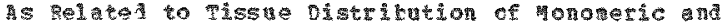

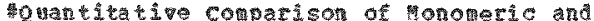
3anation

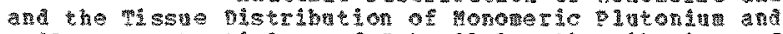

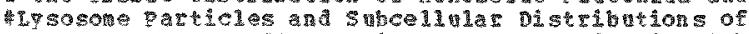

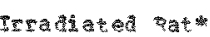
Heavenging contan nated Seil with

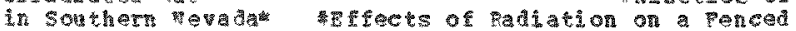

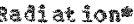

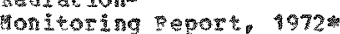

21

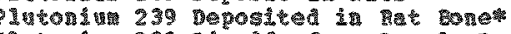

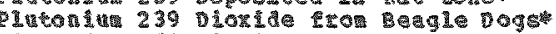

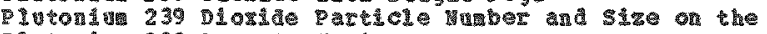

1.

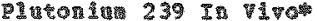

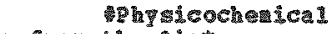

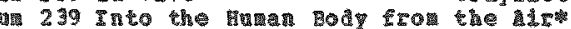

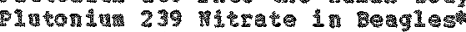

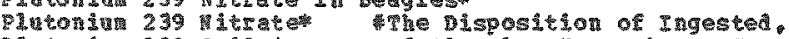

P1

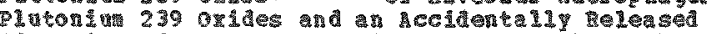

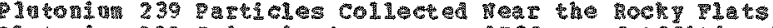

17.

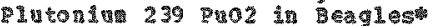

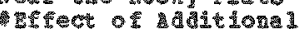

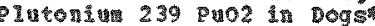

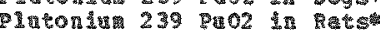

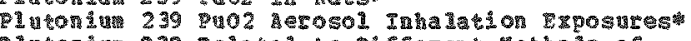

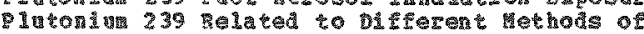

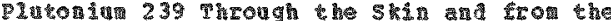

1 1

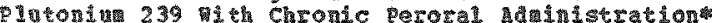

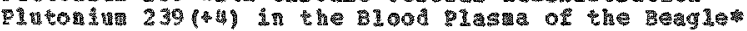

1.

1uton 239

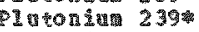

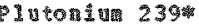

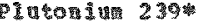

P1

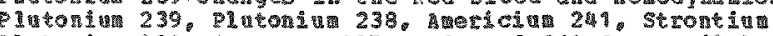

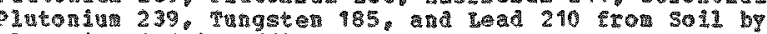

等

P I tor

₹11

Q 1 gtong ant

อ1

e 1utond

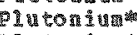

Q1 1 ton

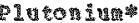

Q 1utoris

210tomin

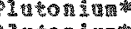

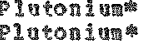

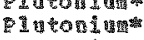

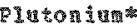

P1 vton 1

- 1 a ton

(1)

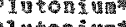

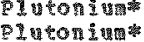

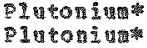

Q I tor on

P1 toton in

1 1 aton

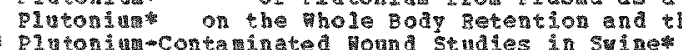

- lucontur or polonivin

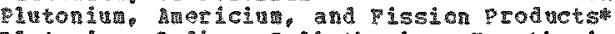

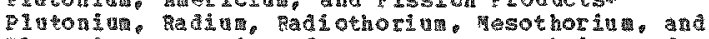

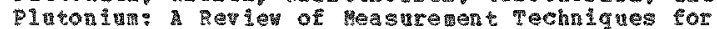

Pluton:

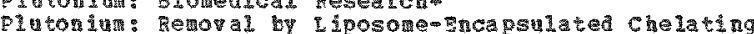

phe chat worth

phenmoselezosis in Ras ater Intratracheal

Posson 3199 ? $1824=19421 *$

ceisoning

Poisoning

Scisongry

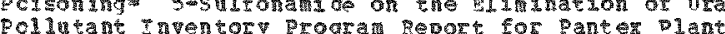

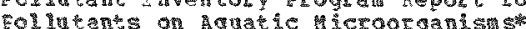

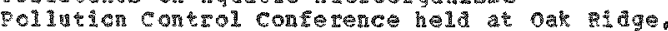

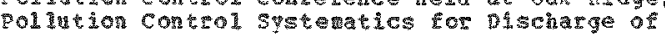

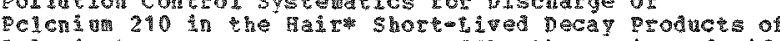

EOC

Fhe shortening of

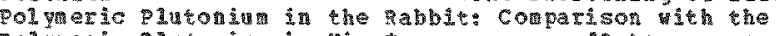

Polvmer

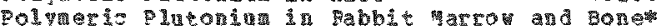

30 intor

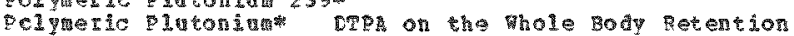

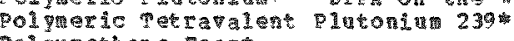

Bol yurethane roang

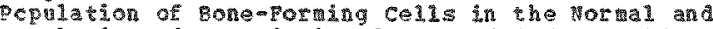

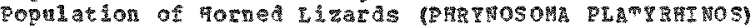

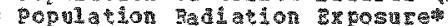

Population of Exposure to lon levels of Toniting

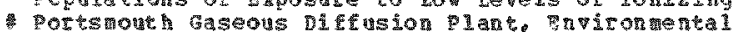

000240

00006

0 ดी 0 ?

000035

90035

000100

000406

$00046 \%$

000022

000072

000283

000468

00011

000170

00007

000215

000052

000196

000039

00009

000040

000216

000014

000257

000228

000378

000178

100063

000283

000093

$0002 \%$

000252

000262

000270

000288

00027

000113

000086

000108

$00010 \%$

000012

000008

000021

00006

00043

00038

00032

4000369

000154

0005

000181

000111

000110

00010

000055

000117

000092

000137

000030

000290

00008

000498

000549

000354

000179

000446

000902

000075

000386

000116

000082

000476

000956

000585

000500

000401

000030

000184

000183

000182

000228

000692

000176

000550

000095

000298

000456

000367

000829 


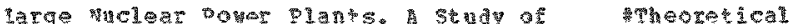

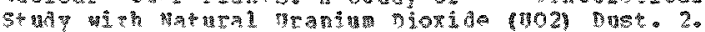

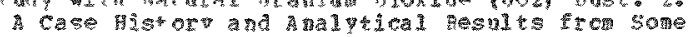

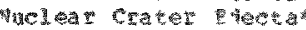

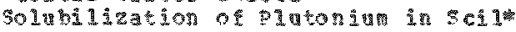

Reort, Calentar lear 1972*

and concervences of thor Taproba \% PDot a

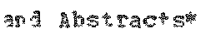

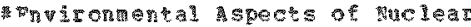

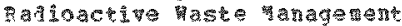

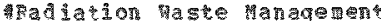

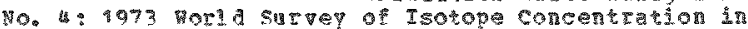

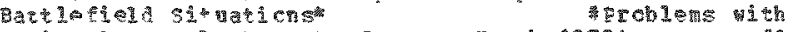
pegion Quar or

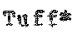

Taste. Pinal Progran status peport.

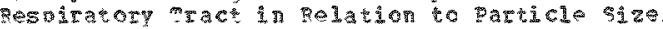

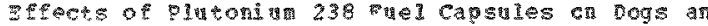

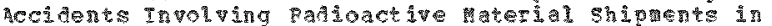

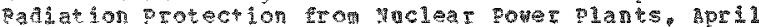
cadiation sotection for taclear powe

I.

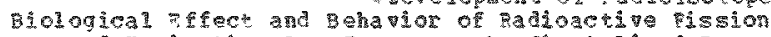

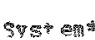

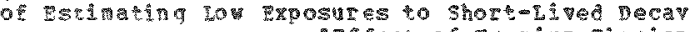

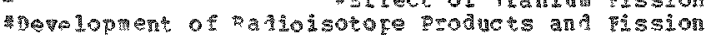

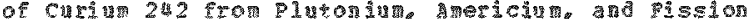

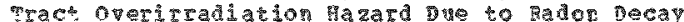

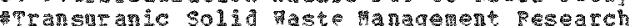

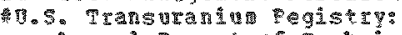

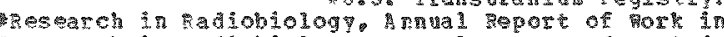

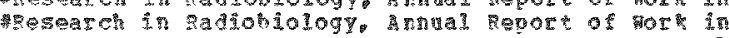

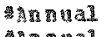

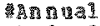

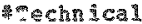

of toraniv

Studieg

Strates

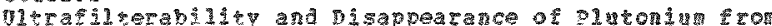
of

Rardsevhes

The $\operatorname{Act} 1$ in

3.

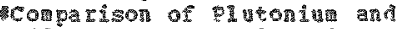

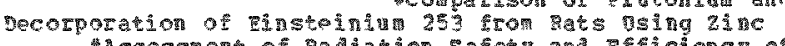

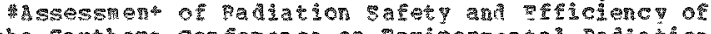

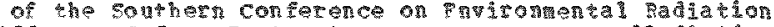

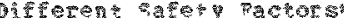
Padian

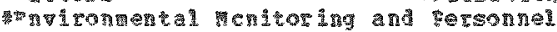
5. 票I

the Int

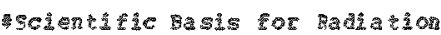

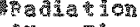
Phos and pespongion Iela of 3 $100 d$ sex

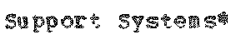

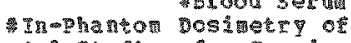

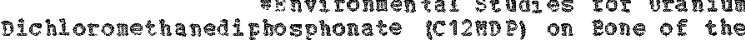

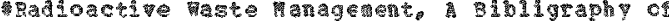
\%

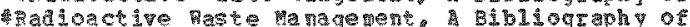
Oak haj

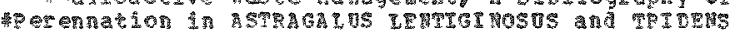

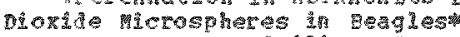

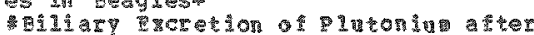
票

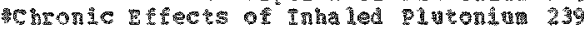

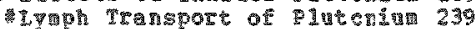
of

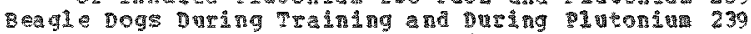

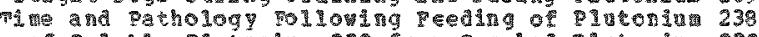

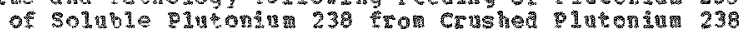
51.

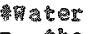

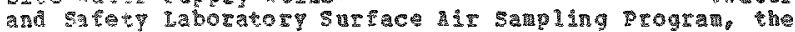
Q14

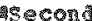

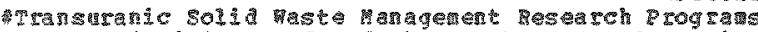

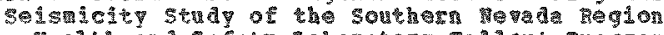

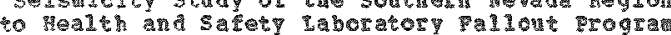

Pos Postas

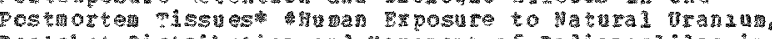

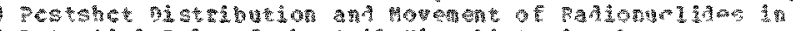

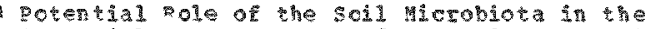

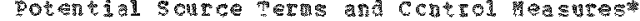

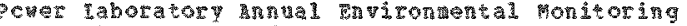

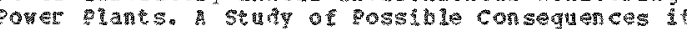

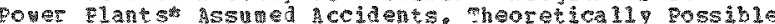

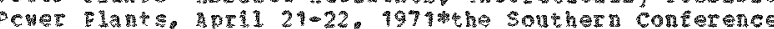

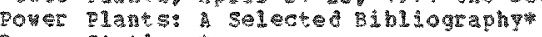

Poser stations

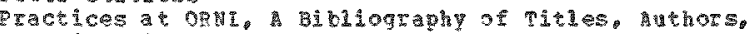

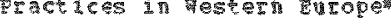

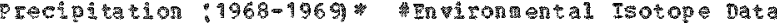
Predich

Erelif

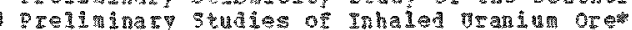

pressure hechanical Propertes of

- zressing

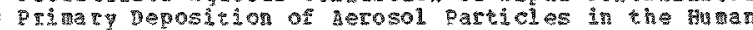

eriat

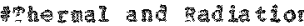

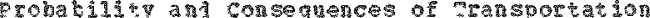

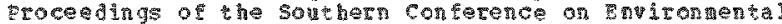

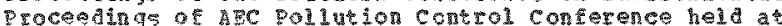

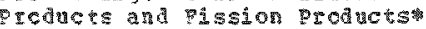

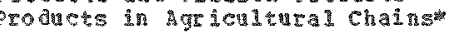

Products of Ralon 222 in trandu mine Morkers by

2toducts on the Funetiond 5 tabs of he con Eroducts

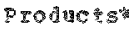

Produces:

Ton Pxthage separation

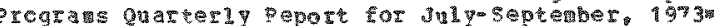

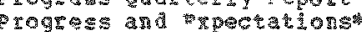

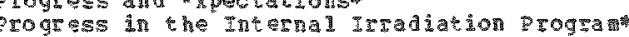

Progress in the Internal Irratiation Protra

Progress oport for the period Thing June 30,1972

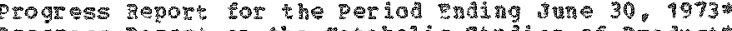

Troges: Tevort on the

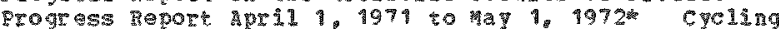

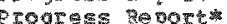

pogress peport. January - June, 9973

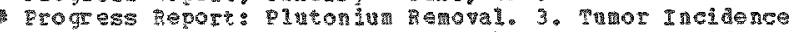

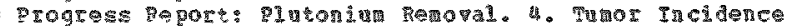

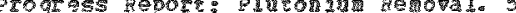

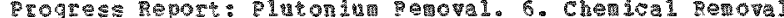

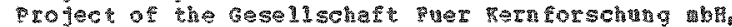

Profec a se seams

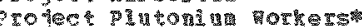

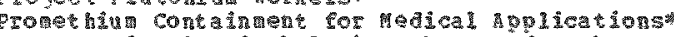

Fone and Delated chelation Therap for the

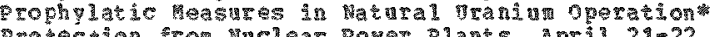

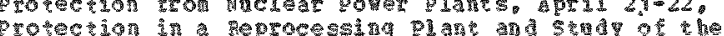

srotection in tiranu sucessing

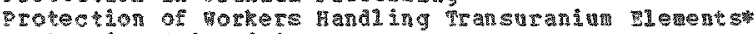
eqotecton cristeriats

Protectom criteria

grotecton Gudance for vnderground vanin

Protec sion roced

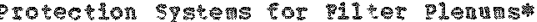

59:

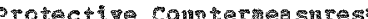

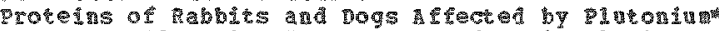

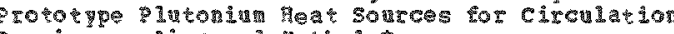

popinces, his and nethodst

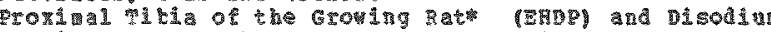

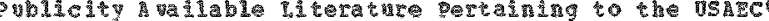

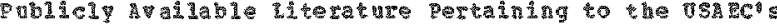

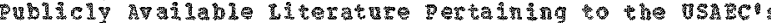

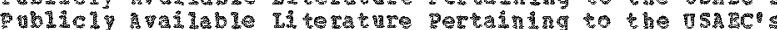

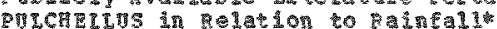

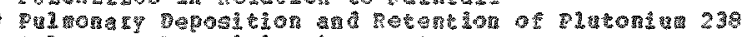

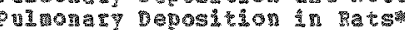

cat 2 a

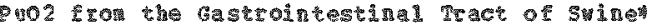

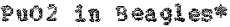

Puo2 38 Dog

0.02 政

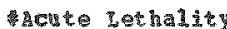

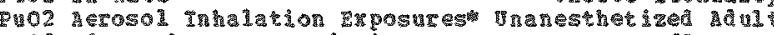

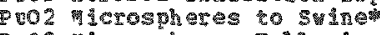

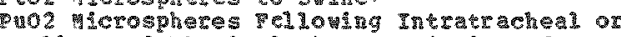

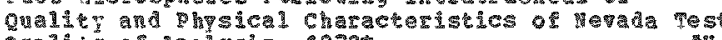

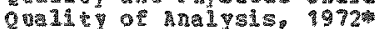

Oudatitative comparson of monomeric and polpmerio

cuarer $2900 \mathrm{c}$

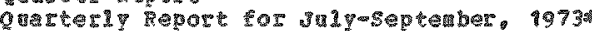

cuarox

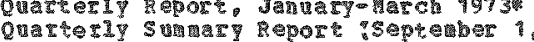

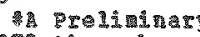

973 tich
000314

000114

$0003 \%$

thon:3 3

000248

00056

090886

000314

000314

$900 \% 79$

00033

000315

000586

00059

000499

000502

000338

000222

000342

000572

000390

005

000479

000585

000537

000294

000401

900195

000537

000290

000349

000592

00047

00005

009061

c00301

000300

001072

000328

000426

000538

000196

000185

000117

000187

000532

000458

000375

000318

000207

0005 蛙 1

00049

000503

000546
000568

000566

0004 년

000559

0005 的

000552

000 的路 8

000064

000319

000293

00011酷 5

00059

000500

000584

$000 \mathrm{~s}$

00002

00025

00013

000219

000211

000170

000071

000219

000052

000213

000190

000513

000182

000480

000592

00033

000 吗 2 


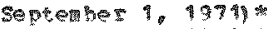

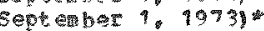
pecentor 1.1667 )

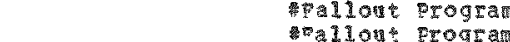

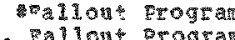

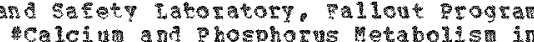
*Calcin a mo posphors hetabolis in

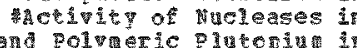

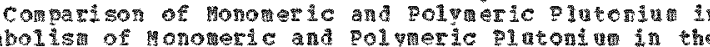

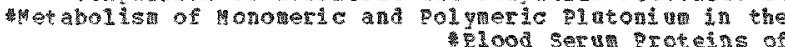

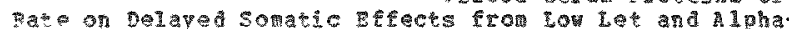
or

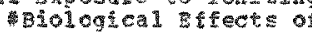
Basic characteristics of melear

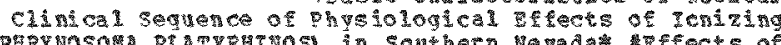

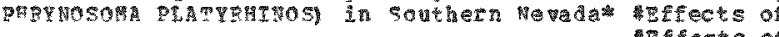
intects 0

apotied

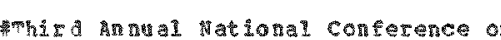
of verral Terrestrial. Sources to the Total

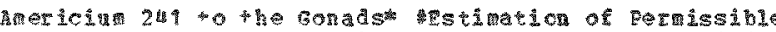
Toxicological aspects of Ionjzing

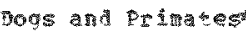

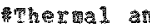

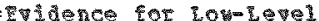

ce 1 I systers

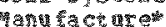

䒹PI Gopriation

in wan and $00 \%$

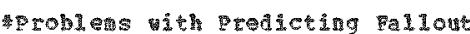

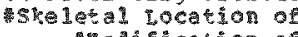

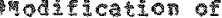

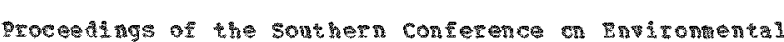
of the interent safery pacters

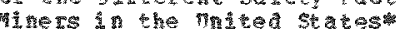
露

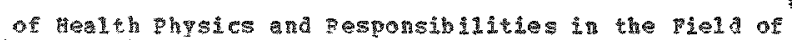

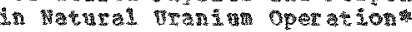

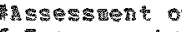
留

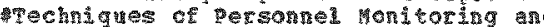
: Dow-10vel 署ate rects of

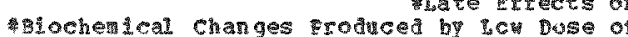
af Populastons of Expostre to Iow levels of Ion

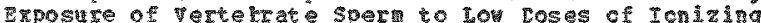

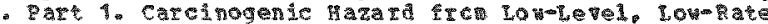

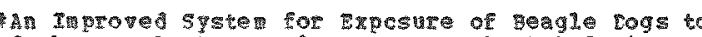

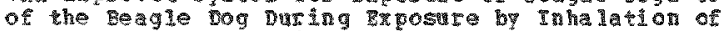
a d a

Aolescents in the con unf Tolator and charactoristics of

Noratic Polluton Control systematics for Discharge of

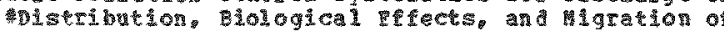

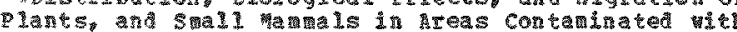

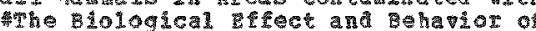

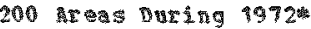

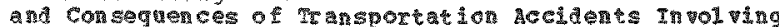
Hidos for the teriod Ju1 De rerpar

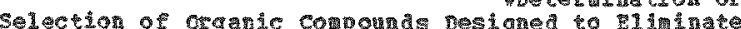

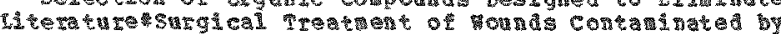

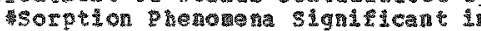

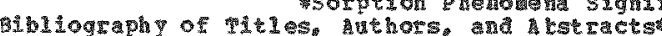

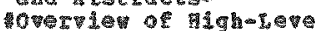

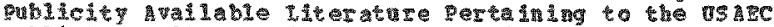

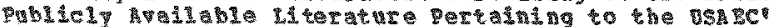

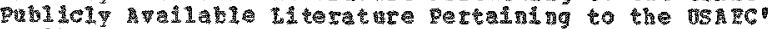

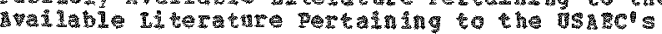

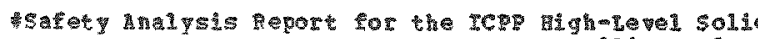

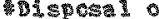
焉期 nat

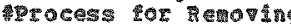

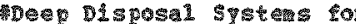

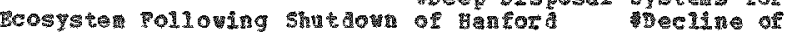

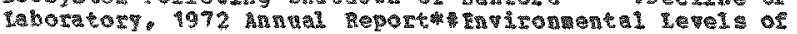

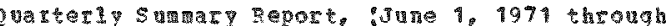

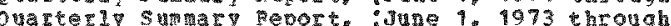

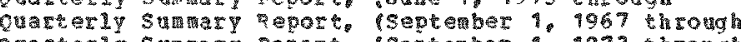

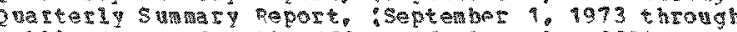

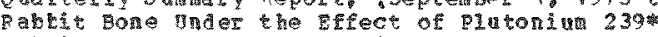

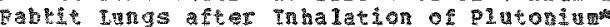

abbit man and

Hou antictative

Patbit: Comparison ith the ausew

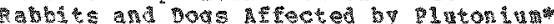

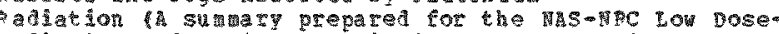
padiation and axis

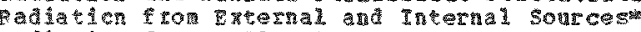

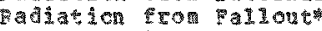

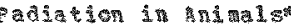

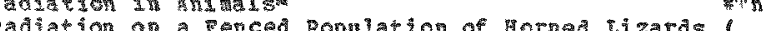

Ratiatich on the cello

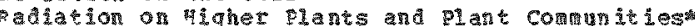

cadiation Biology

adiatien solog

padation chentivity

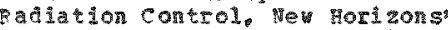

Radiation Detection and Dosinetry

Radiation josa to

Pajation

Contribution

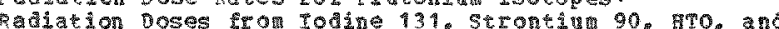
Radation Dae to Bone-Seching Rado isotopes

adiation $\mathrm{E}$ frects in whole minal

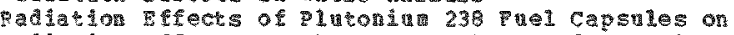

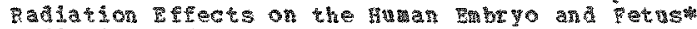

kadicion E

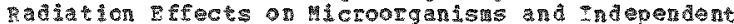

Bad iction

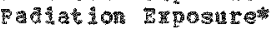

- alation Genetics"

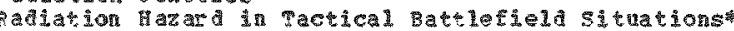

padiation Induced and atrat

asation $i n j u r y$

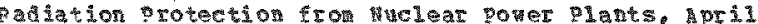

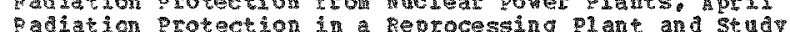

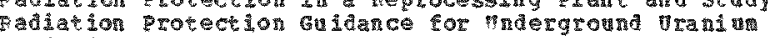

Padiaticn protection procedureg.

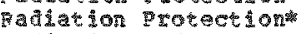

Hgron and Developen

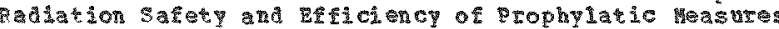

Paliation son reest

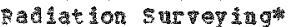

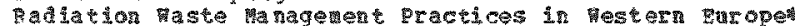

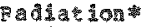

eadia $\mathrm{cr}^{2}$

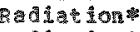

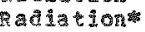

Radiatenton

Padiation*

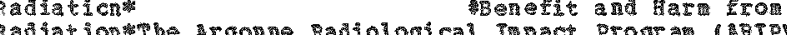

Raditar

Q a d ato ion

Badioactive ierosols

Padoactive ferosols

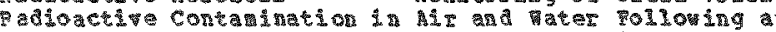

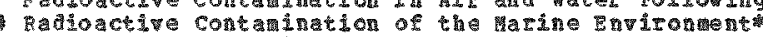

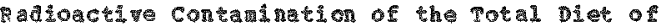

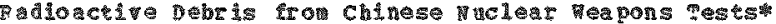

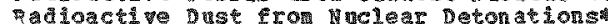

Padionctive

cariogetive Tifuents\%

adioactive Tements

adioaction

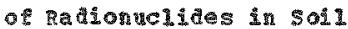



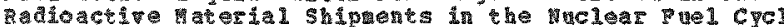

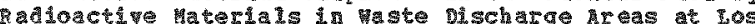

8aส

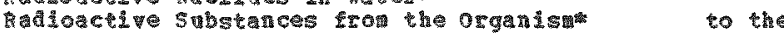

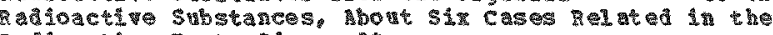

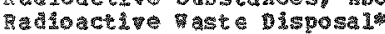

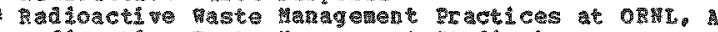

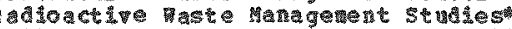

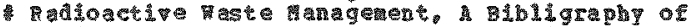

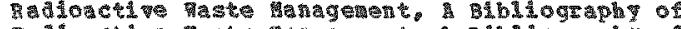

- Fafoactive aste

Fadorctive maste trocessing and Disposal

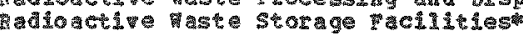

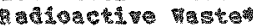

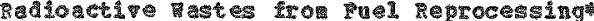

2ป10สctive

8.

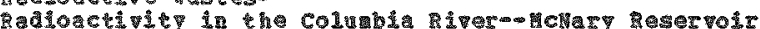

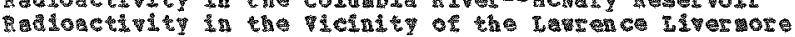

000439

090440

0044

900638

000063

000154

000182

000184

000054

090136

00955

009150

00932

000176

000298

000045

000045

000045

000045

000365

000259

000556

000320

000

000123

000180

00004

000313

90062

00036

000352

000565

000456

00004

000502

000234

000361

000522

0049

000562

000411

000559

000552

000541

00054

000553

000591

000567

000337

000366

000155

000367

000959

000324

000165

000563

000351

000053

000554

000299

000379

000512

000427

90057 is

000500

000115

000501

000294

$0005 \%$

000564

000436

00266

000253

000373

000594

000586

000562

50059

000593

000584

000590

00058

000570

000588

000583

000576

000579

000

60045 


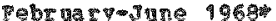

$30721 \%$

Salventa
4.

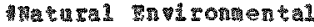

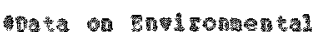
(5ractions 1 A

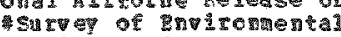

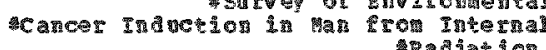

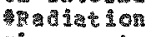

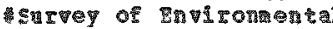

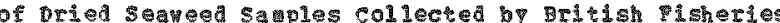

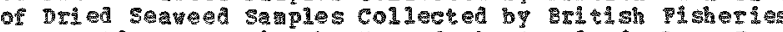
a wantages in the roe of the Beagle it Icng rat

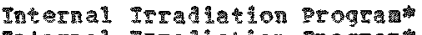
Frternal Trractation Frogran 9967\%

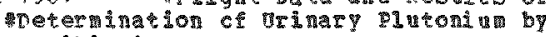
Hedia by plectrodepositison

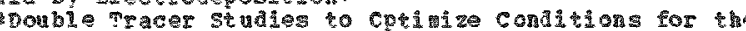
翟管e

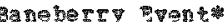
present Progra

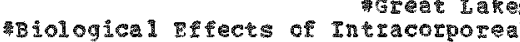
Biologic Ecticts of Intracerporal * Bologica 是 Devel opdent of

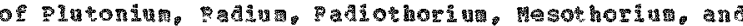

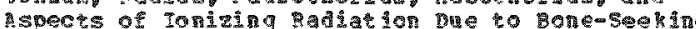

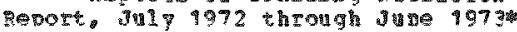

Fiviponertal Report for Calendar year 1972 on

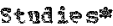

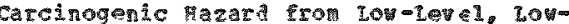

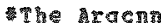

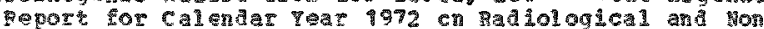
Ten

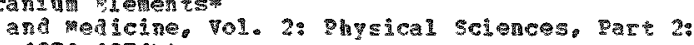
Periot: $1990-1979$ ) * Dianosis, preationt, and occurrences of tat

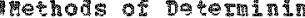

ad

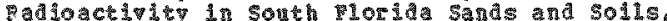

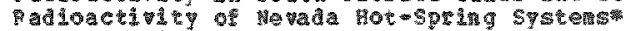

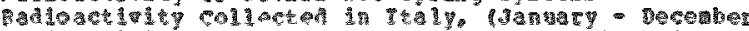

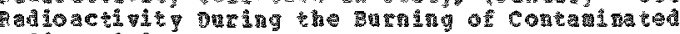
2. $230 \mathrm{ac}$

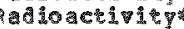

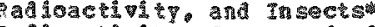

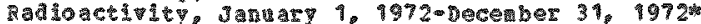

T

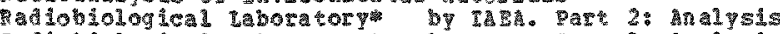

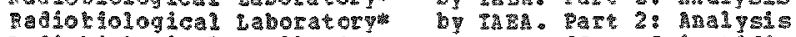

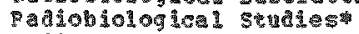

Ratiobiology or Large Anzas $1 \mathrm{~s}^{2}$

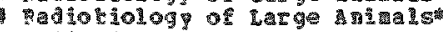

qaabiclog

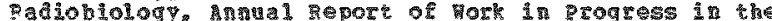

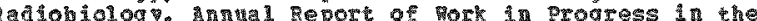

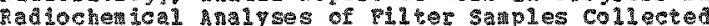

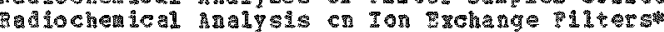

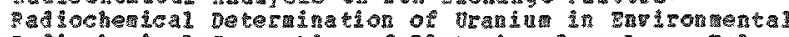

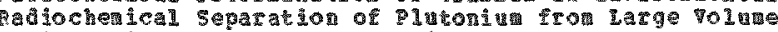

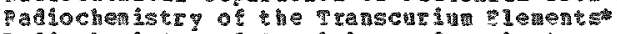

Rad

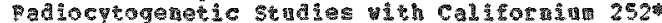

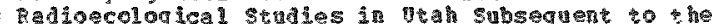
Raloeclogi: introluction and Description of Tadionsotope Meat sorres

Ratoi sotope heat sources

adolsotop Mat sourcest

Far 10 isotope roducts and Piss

P.

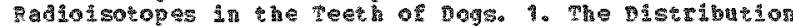

T.

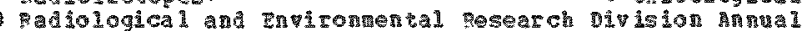
Sadological ald

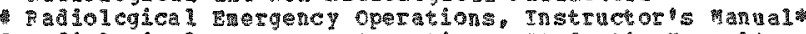

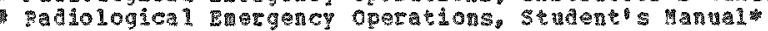

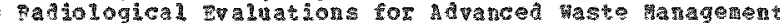

Padiolcgica 1 I

Pafiologica parameter

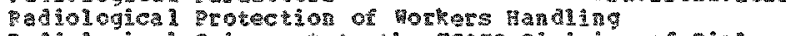

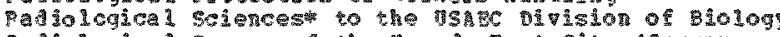

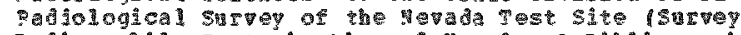

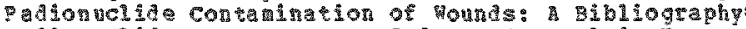

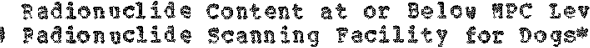

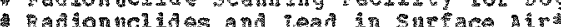

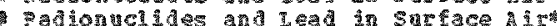

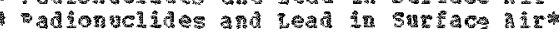

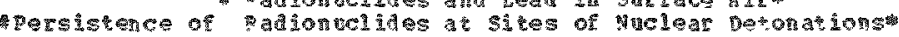

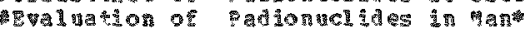

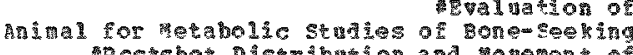
蛋

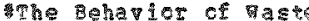

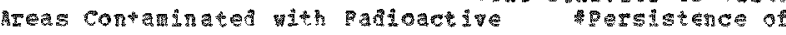

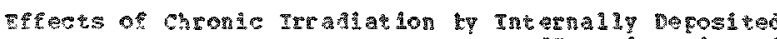

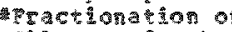

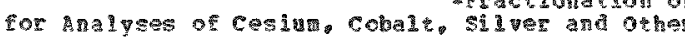

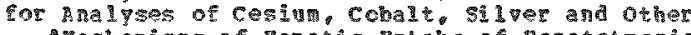

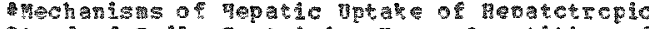

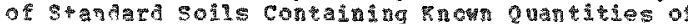
of concentrations of pecosols of loha-

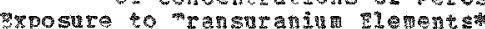

7 1 sarents

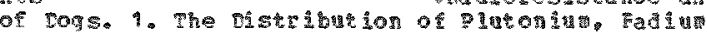

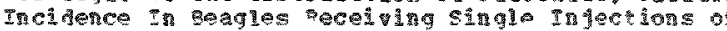

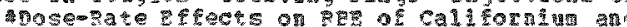

as an Anina

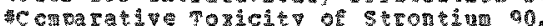

of the nog

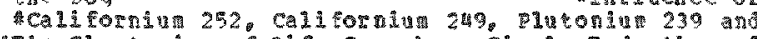

* The shortening of tie span by a single Injection of

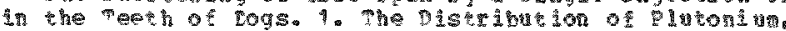

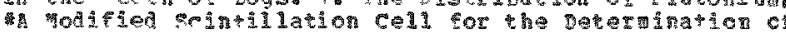

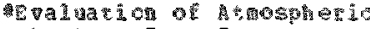

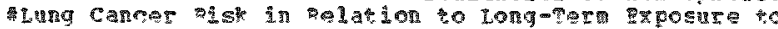

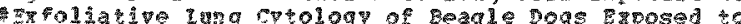

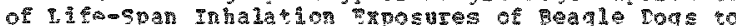

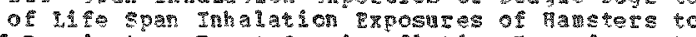

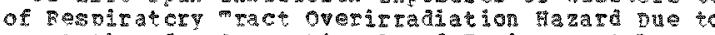

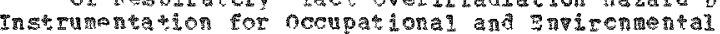

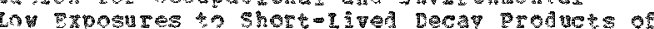
Bohavior of IhI

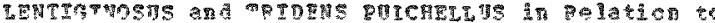
nerosols for ise in ani 政

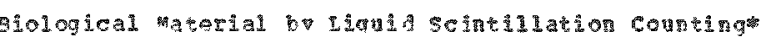

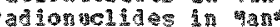

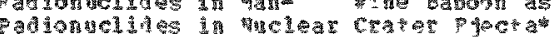

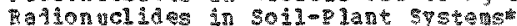

2.

a a ion

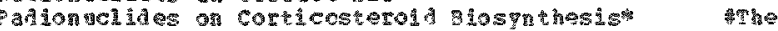

Rathonuch

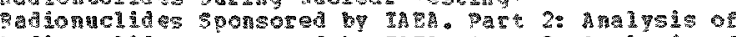

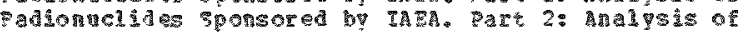

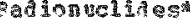

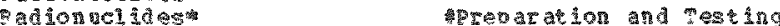

Tatonucidso for 150 in

จ to to

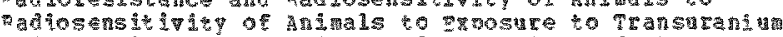

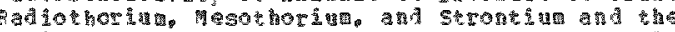

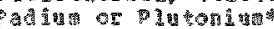

Pad

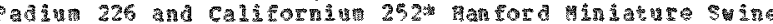

a

adin 226 and Plutong 239 on the Dental soot cand

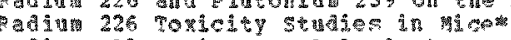

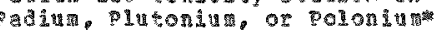

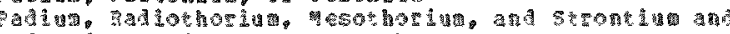

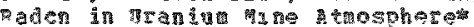

adon

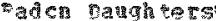

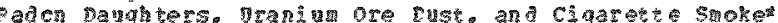

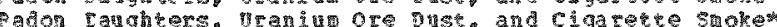

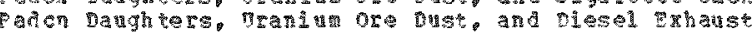

ader Decay produots

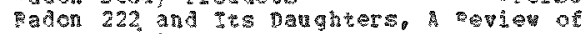

Faen 222 in

a dn

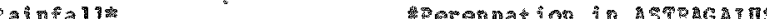

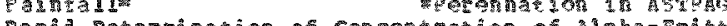

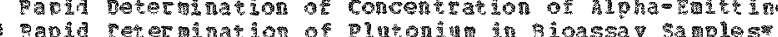

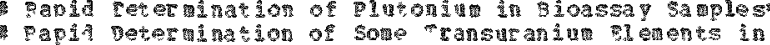

000662

000430

00053

90958

00949

000362

000165

000520

000275

00043

000 : 3

060 a 3

000135

000199

90009

00095

000432

00026

00027

000272

00026

00028

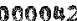

00049

00097

000297

00006

000070

000069

00053

000360

000085

000180

000490

$00055 \%$

00055

000573

00032

00032

005

0005

000142

00025

000383

00030

000352

000595

000517

000519

0001 6 S 5

0903

00004

00033

000303

00050

000

00051

00002

009528

0003

กnt 3

000235

000025

00033

0019

00015

nonos

00018

00006

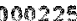

0010

000230

000231

000030

0004

700460

(1)

00039

(1)

000223

00022

00038

000 is 19

0004

000252

00902

0000

00005

$00050 \%$ 


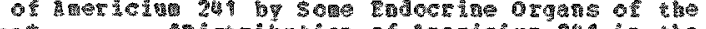

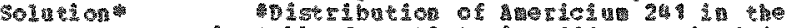

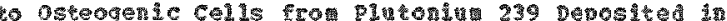

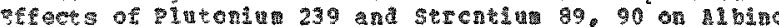

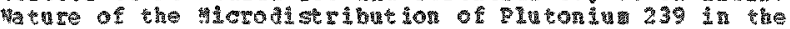
man

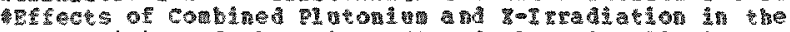

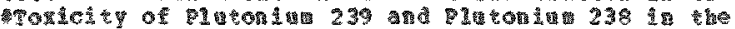
20.7 tcarcinogen

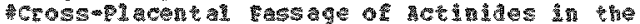
of ctrste

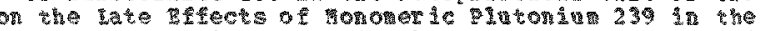

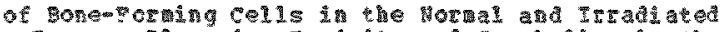

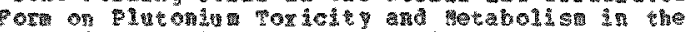

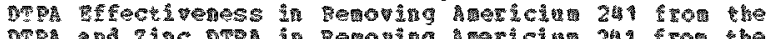

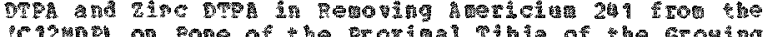

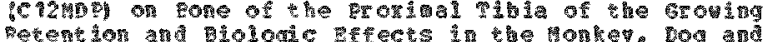

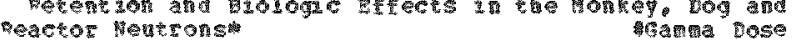

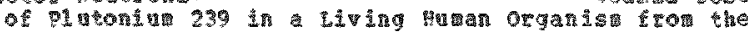

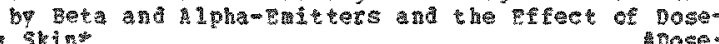
of $\sin ^{3} \sin ^{\circ}$

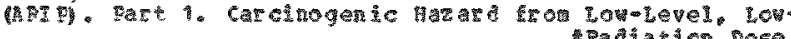

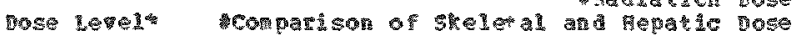

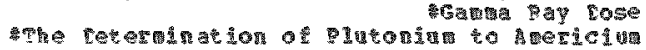

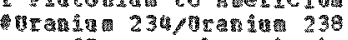

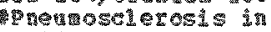

2010 and Di

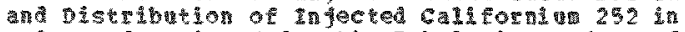

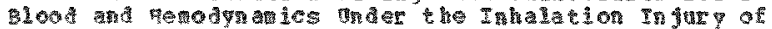

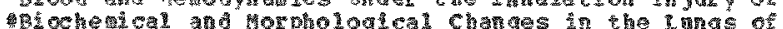

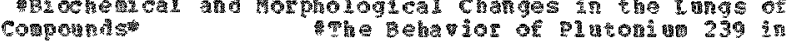

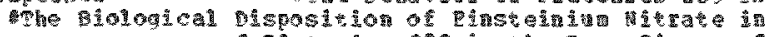
of oin

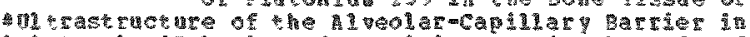
Sch

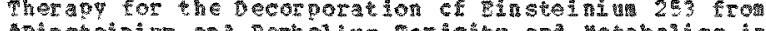

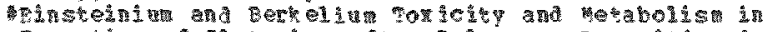

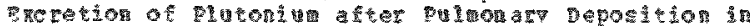

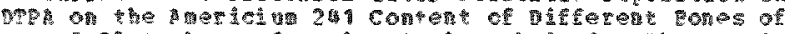

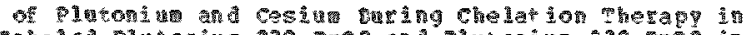

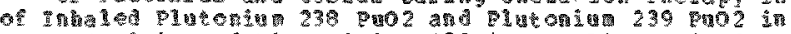

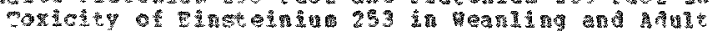

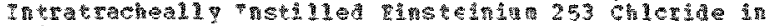

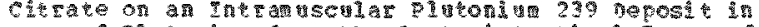

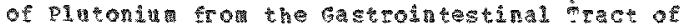

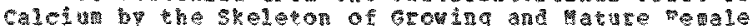

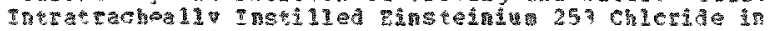

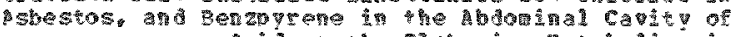

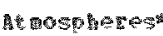

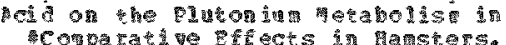

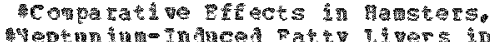

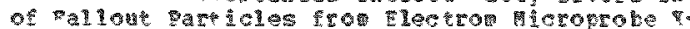
tgana *

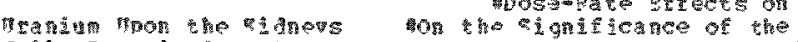

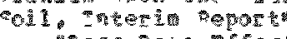

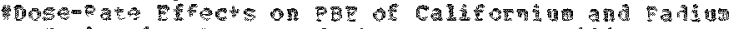

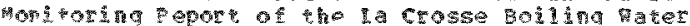
2.

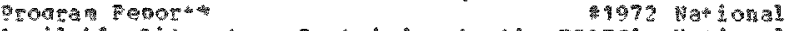

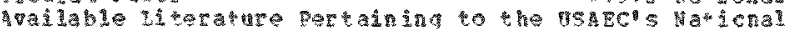

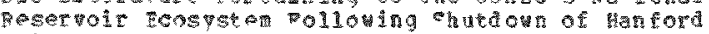

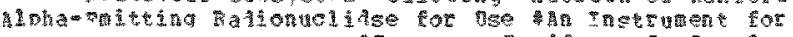

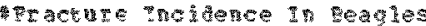

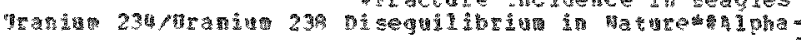

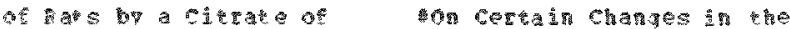

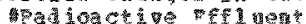
30

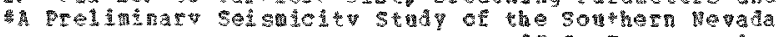
4.

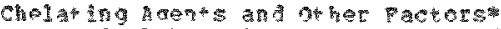

2etra a

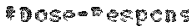

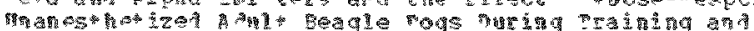

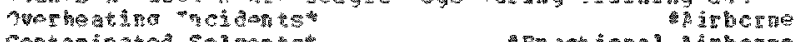
200

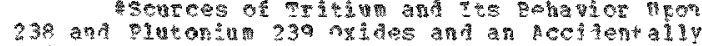
Hut

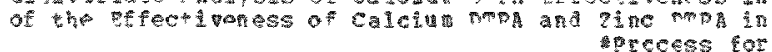

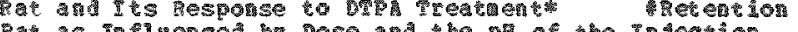
Bat as In I

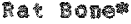

Q a

落 0 c

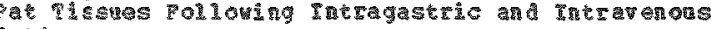

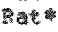

a

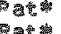

tats

(1)

(ats

Pats

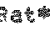

ats

Pats

Pate on Delayed Somat

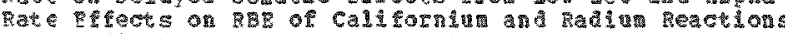

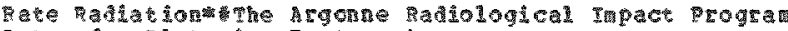

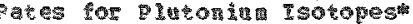

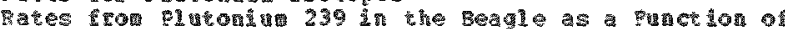
ot

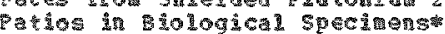

patios in sea

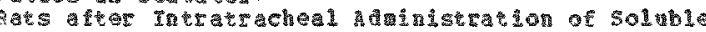

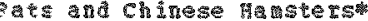

thet antion

ats and chinese

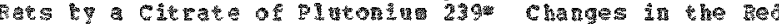

ate

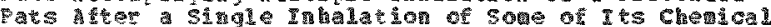

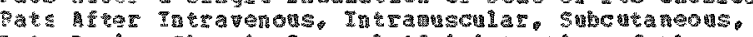

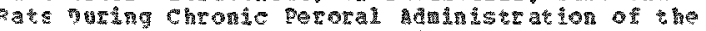

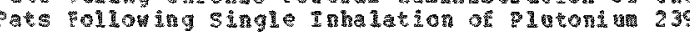

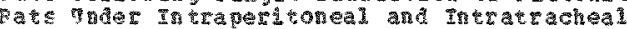

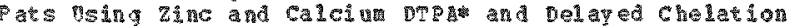

- a

ats

कo

Tat

Satcis

Pats

蕰

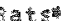

ate

Pa

Pa

at

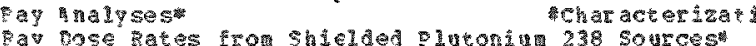

pay -

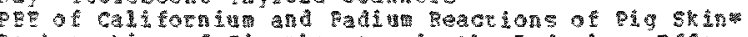

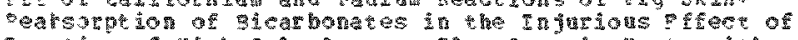

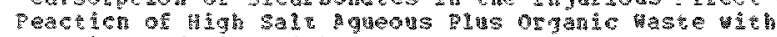

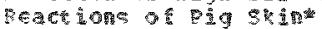

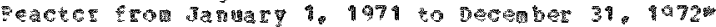

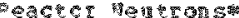

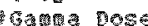

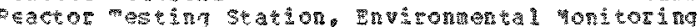

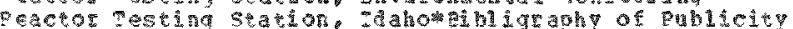

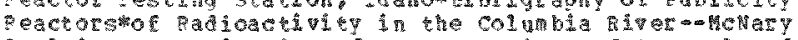

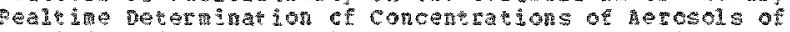

Tece

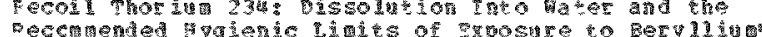

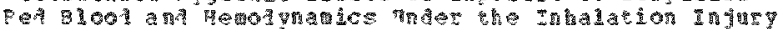

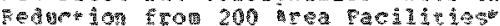

polon os Doposicion a

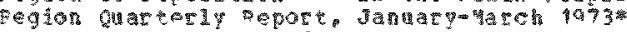

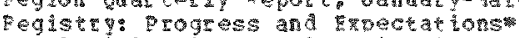

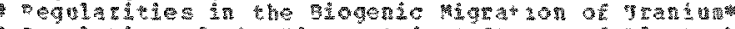

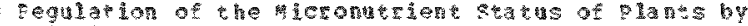

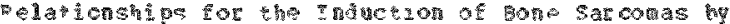

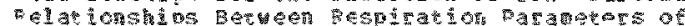

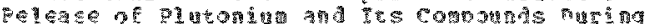

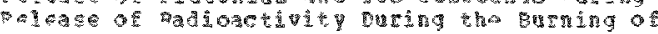

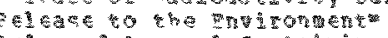

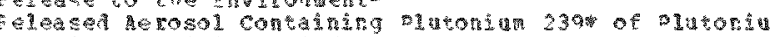

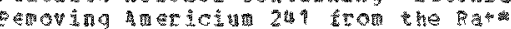

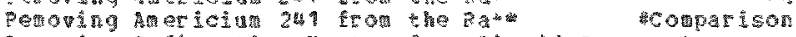

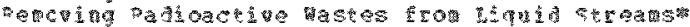

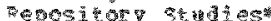

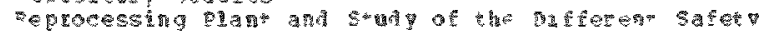

000197 600199

$0000 \mathrm{~s}$

000236

000124

000079

000013

009018

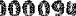

$00 \mathrm{~s}$ -

000202

000204

000132

000095

000203

500286

00019

000145

B50 11 16

00053

0038

000136

000006

00032

60045

$00021 \%$

909316

00009

000269

000102

000143

100144

00093

000189

090205

000161

00000

$00023 \%$

000207

000430

00013

000201

070206

090219

00013

009015

000280

00093

000131

00007

000015

60019

090426

0016

00002 \%

00025

070310

cegpos

00096

00057

000006

000492

000530

00059

585

000424

000348

00018

000525

00 ngas

000504
000390

00033

00047

000295

0002 t3

000134

900952

90970

000580

00953

60026

000290

000198

000576

000563 


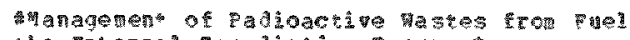

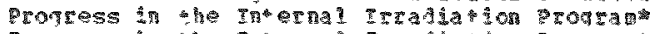
Progress 3 in the The ena

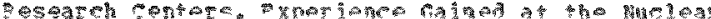
Jeseare 993

APF *aส 30100 ical \% 1973

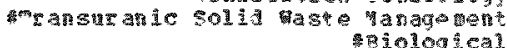
4t)

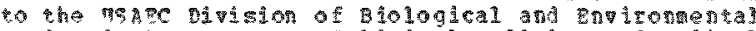

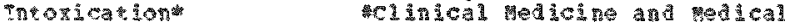

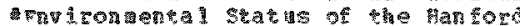

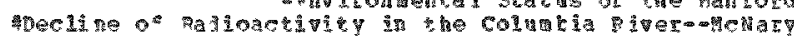

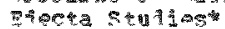

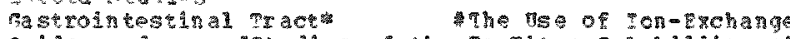
ox $\begin{aligned} & 1 \\ & \text { A }\end{aligned}$

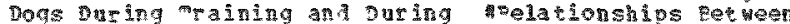

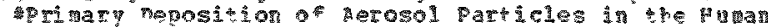
Deca product

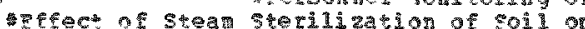

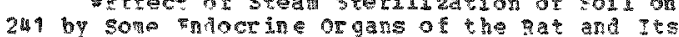

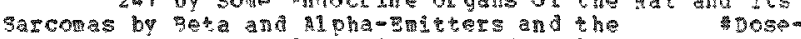

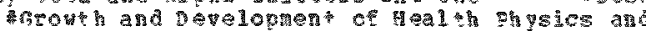

a Trivence of sot

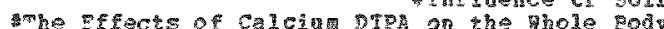

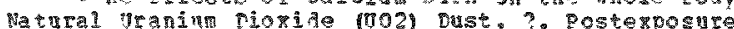
in ats and chinese thaserst in F

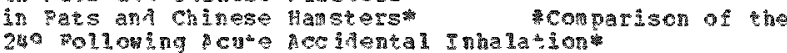

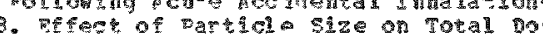

In ject ion

20

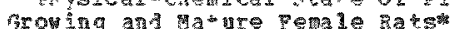

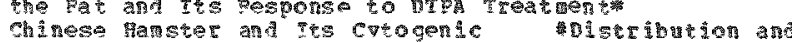
tung

Reag 10

Acter njecton

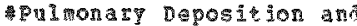

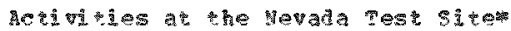

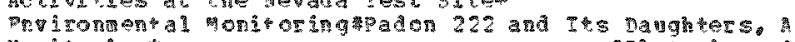
เดตร

กิ1

PI

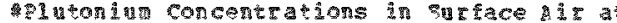
peport on ATransurat

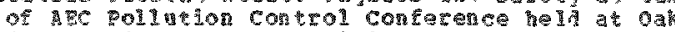

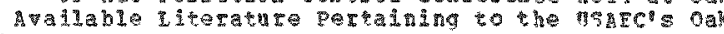
Dog ong

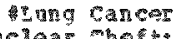

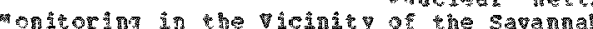

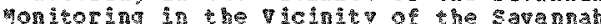

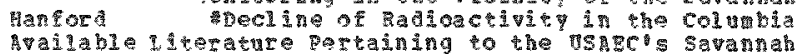

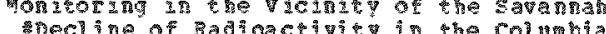
prosed ure?

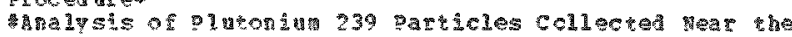

Pesingers

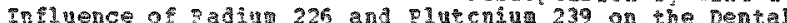

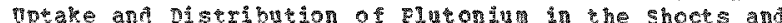
Ifor and 2 ine 3 Shecrs of

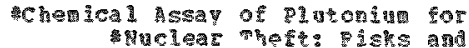

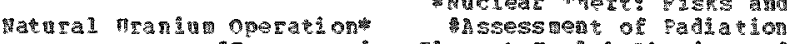

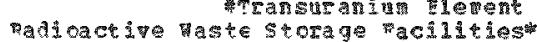

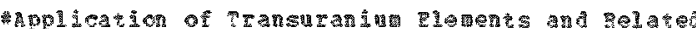

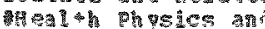

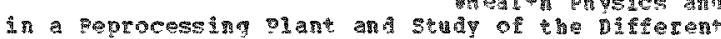

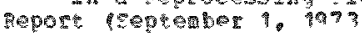
Qualicy of And

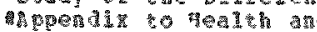
sealith an

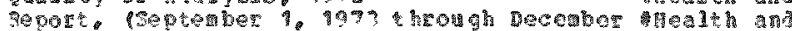

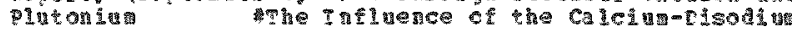

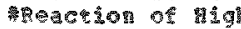

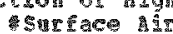

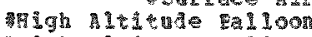
*

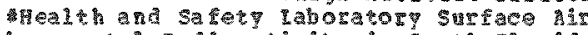
40.

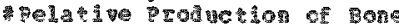

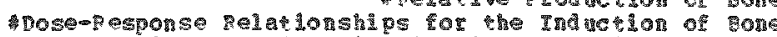

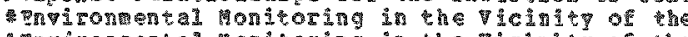

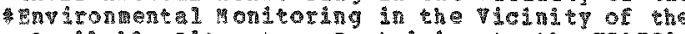

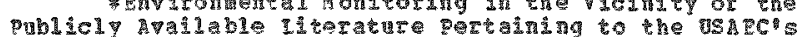

Peprocsing

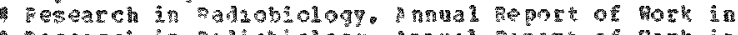

ceseach a

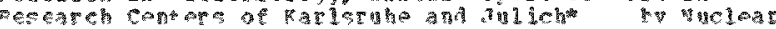

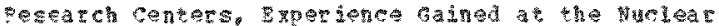

Desech 5it

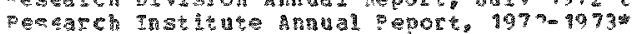

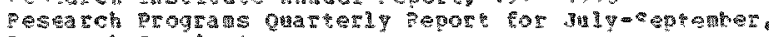
ecterarch seotion

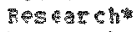

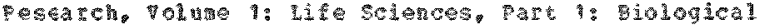

3

Res

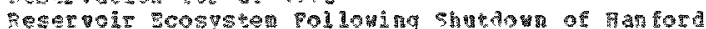

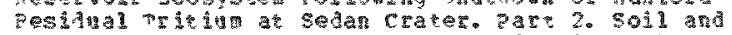

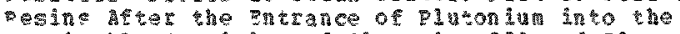

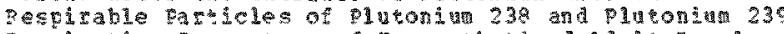

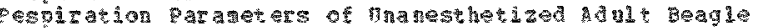

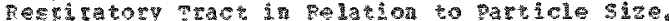

Bespiratory ract overirradiatan

pestonse of wo Desert plat spectes

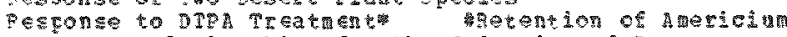

veronse pelationships for the Infuction of Bone

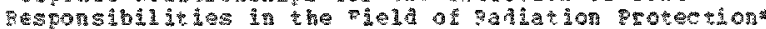

zesuspension by

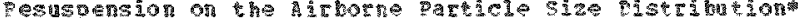

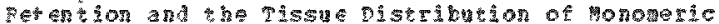

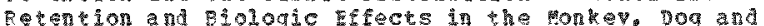

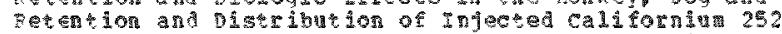

reten

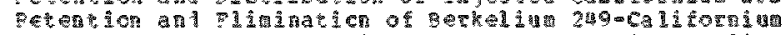

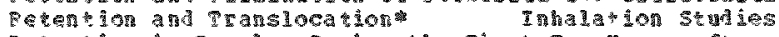

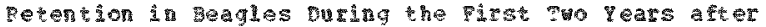

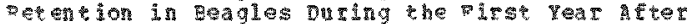

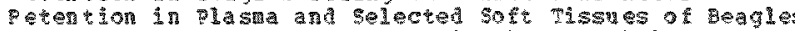

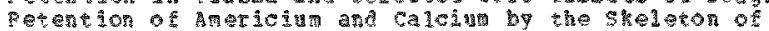

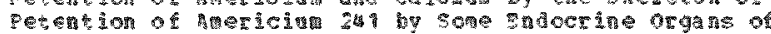

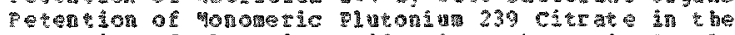

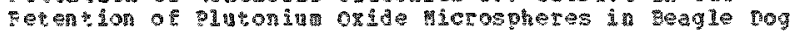

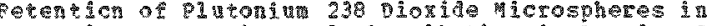

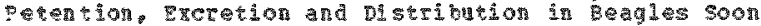

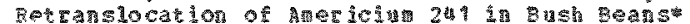

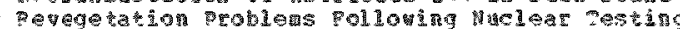

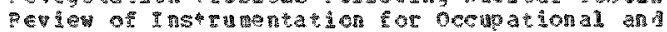

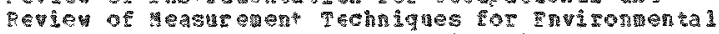

Tevien of Transuratic Tlements in solis, Plants and

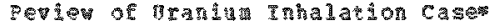

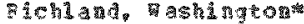

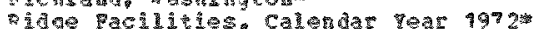

ตำเ

Pidge vationa

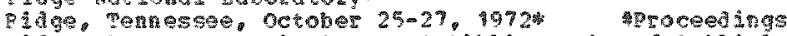
p.ju Tenn B.s.

to 1 k a

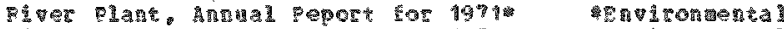

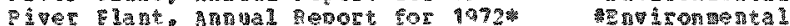

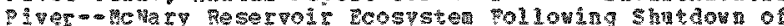

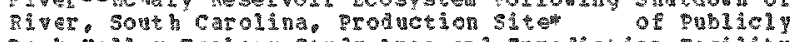

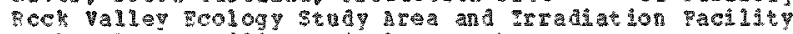

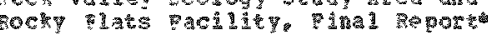

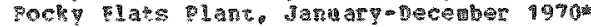

Peck rats

800\% canal 1 \%

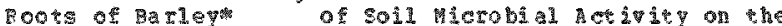

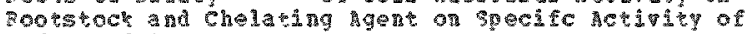
S.

aragerarat

Safer an

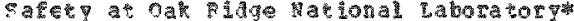

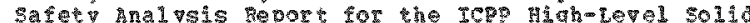

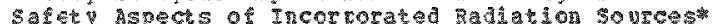

sate $\mathrm{Aspec}$

5. a

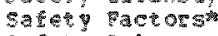

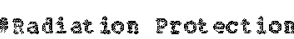

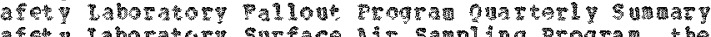

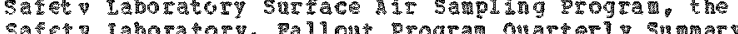

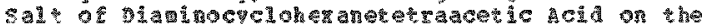

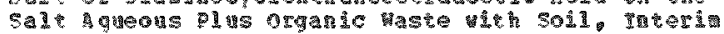

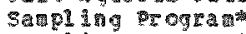

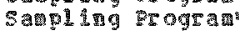

5avcling program

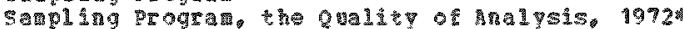

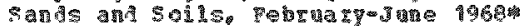

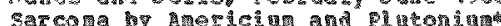

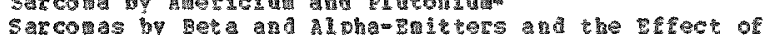

savas

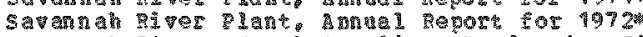

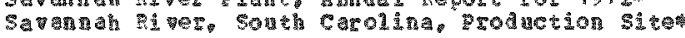

0095

00015

00055

100

0005

000ง 35

005592

00005

(40) 35

09023

00035

000 in

000424

000335

00002

00028 ?

00055

900390

0003

00022

0009197

000135

9005

000527

000526

000092

00014

000143

0001 14

00039

009009

000120

000121

00021

09007

001993

000032

00025

00012

90002 躬

mon 305

000 . 19

000418

6) 302

00037

0005

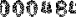

G065s

00058

$0005 \%$

$00039 \%$

0009

0004

000

000 烈 2

00059

00042

-001 68

0003

009527

- 000230

000248

0002 a

000265

009530

906

000545

00057

00054

0005 is

00023

00056

100472

000513

000 38

00002

000026

0005 角

000455

00045 ?

0005.9

0 1004

600 10

000456

00048

of 00059 
Les

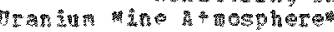
inguta

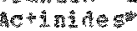

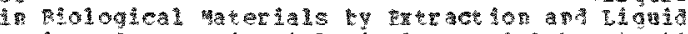

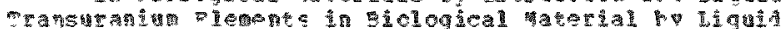

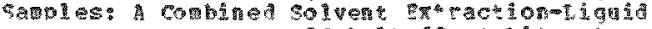

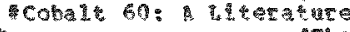

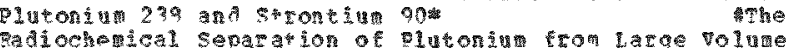

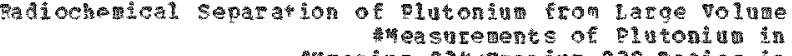

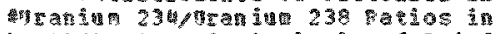

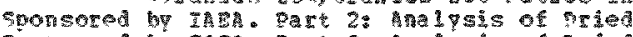

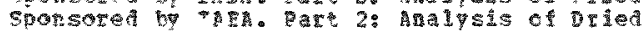

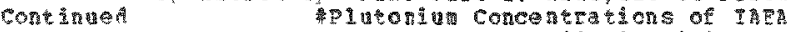

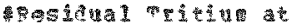

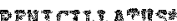
10690.

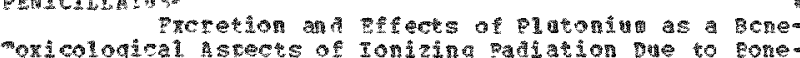

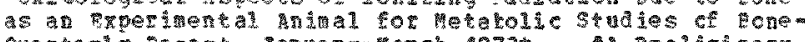

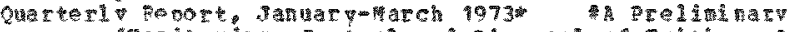
整os ffects associated st

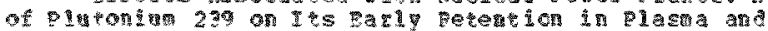
PE

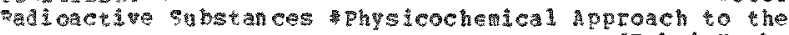
196.

Wiseion prodrets

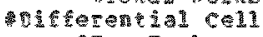

5.tô to to

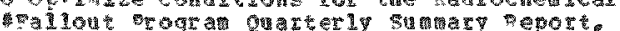
Frogra oum

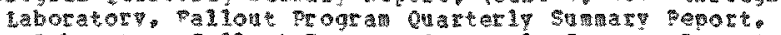

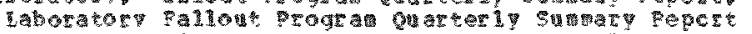

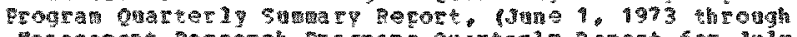

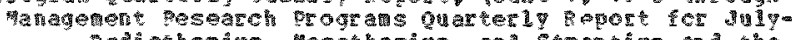

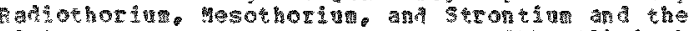

in Ani? the cinsal

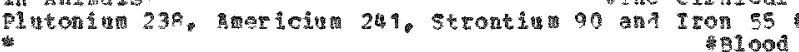
\%

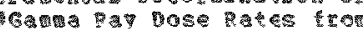
Transpor a

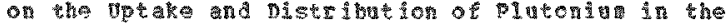
Che 23

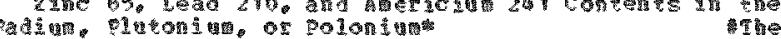
Coln

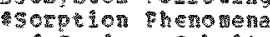
of hoth hols for analyses of cesin Cobalt

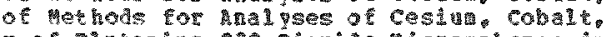

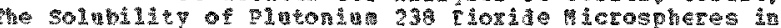

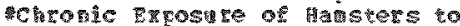

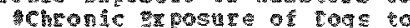
* lenen al chasactizarion of reharacterization of derval and

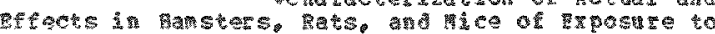

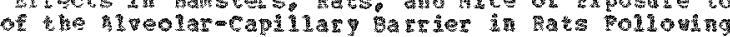

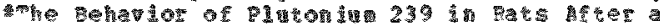

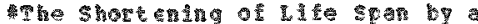

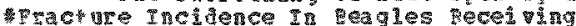

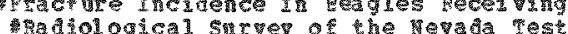
4

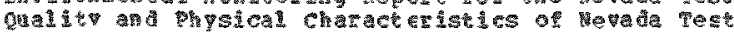

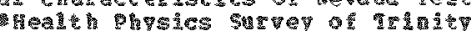

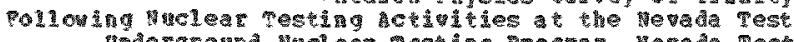

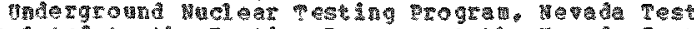

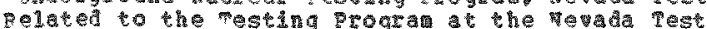

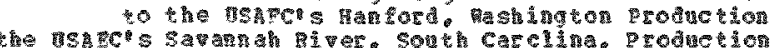
Pertain

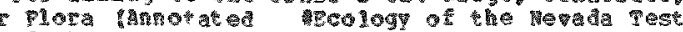

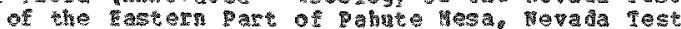

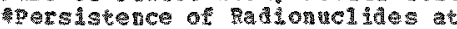

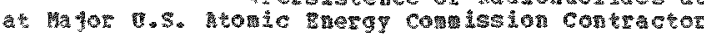

Pal

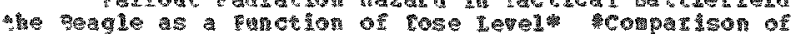

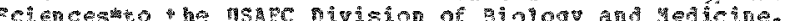

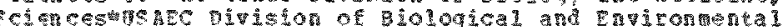

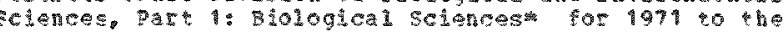

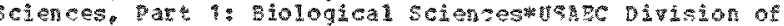

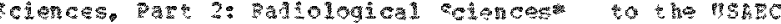

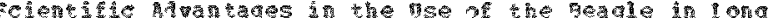
cicon

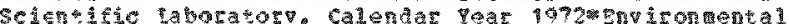

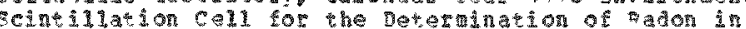

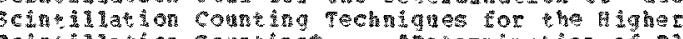

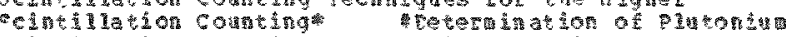

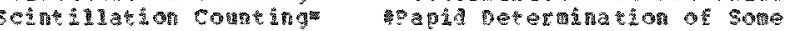

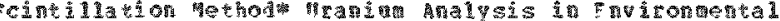
seatents

Seasonal Etratospheric Distribution of cadrin 109 .

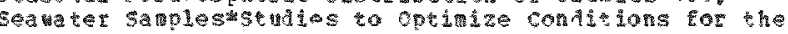

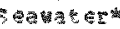

รeต พละ

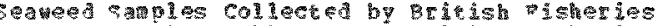

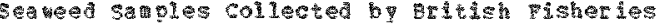

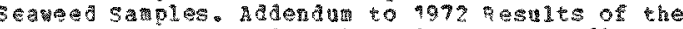

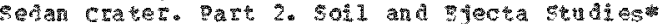

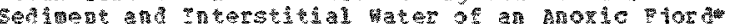

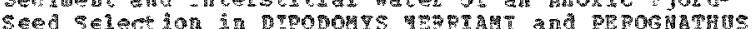
Gerkes

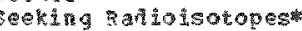

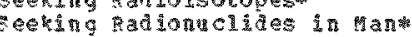

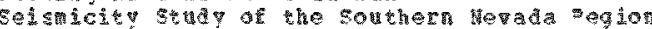

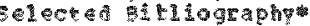

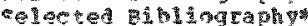

eleces os of

selection in DIPONOW

selection of organic compounts besigned to Elingate

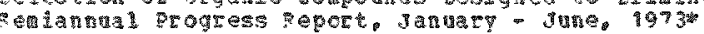

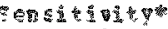

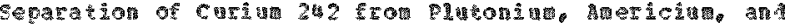

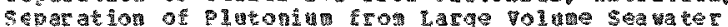

septerber \%. 1967 through Decenber 1. 1967)

sepremser 1. 1071)

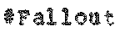

Septaker 1. 1973 through pecober 1. 1973) and Safery

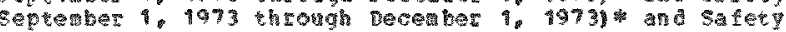
septerer tor

ortabior. 1973

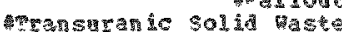

cogin

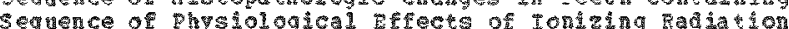

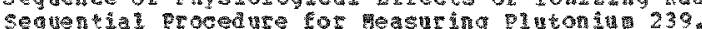

ser

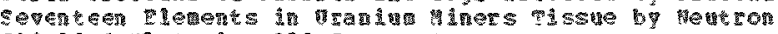

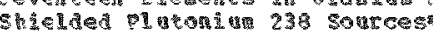

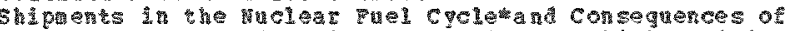

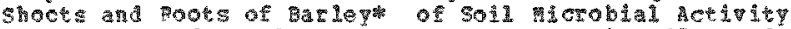

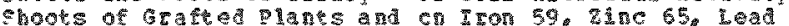

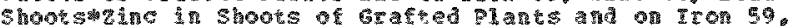

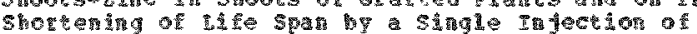

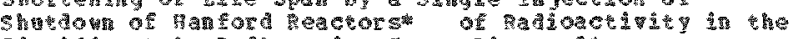

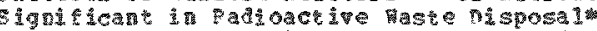

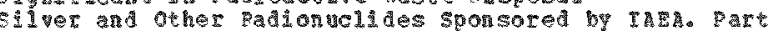

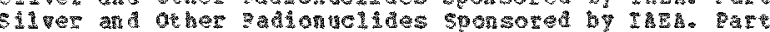
3.

8.

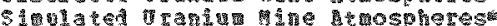

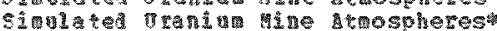

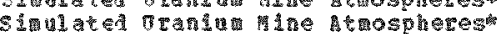

e in

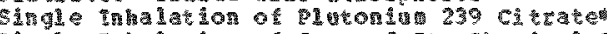

3.7.

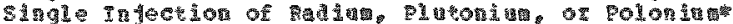

single In

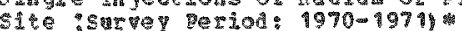

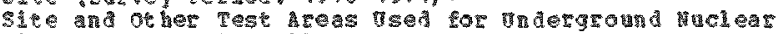
sis a

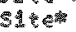

5 ince

S.

siter

Sitcow

\$is

Sidu

3.

Sit. Govgraphic and Ecol

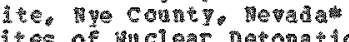

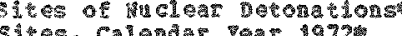

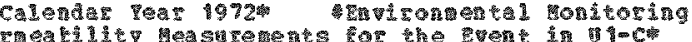

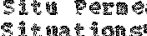

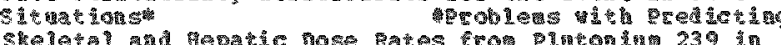

000397

00035

9056

100233

000470

000232

000233

00023

900 ही

000160

000465

0002

c00 506

090728

$0002 \%$

000510

$0002 \%$

90028

900265

0001036

90043

000434

000335

00032

000306

09023

000180

000049

000336

0605 5?

090331

000214

000306

cons 38

000363

000129

$0002 \%$

000년

000439

00043

$010 \mathrm{~A}$

000440

000592

000176

000299

00006

000073

900 390

000240

00028

00 .

00026

00042

00059

0003

0004 33

- 000209

900220

0073

00036

000523

001016

000 n日a.

1004 12

009030

00018

000425

00047

0013

0 ำ 32 .

00090

000327

00046 ?

00058

06050

$000 \mathrm{~S}^{2}$

0002

000335

00045

$0006 \%$

7003 3

000562

000215 
239 In Beagles: can Thep Be compared?

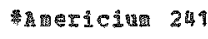
occurring osteosacconas in Felarive Effers of

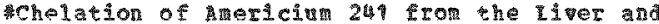

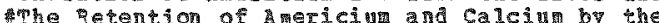
Foerinental study of Decontannaton of the Heructur al changes in 009 Fosorption of Plutong 239 Through the

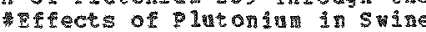
*he Desactivatich (Deconta

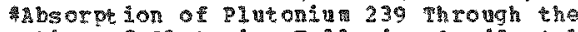

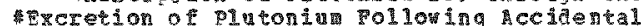
measurenent and ssessment of 5 in heasurenent and ssessient of

Hefects of ITradiating

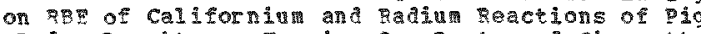
to Radon Danghters. Uran un Cre Dist, and Cigarecte

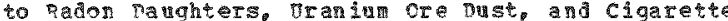
frabrication. Testing and Tyal mation of

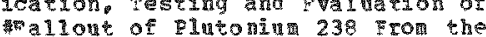
* Cinarron piutoniu production plant ileengo - In vitro Binding of PIutonin 239 by calcium or californin 249 and serkelsu 249 an the

239 on $\mathrm{xts}$ Friv Retention in olasa and selected -

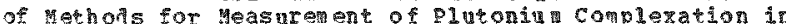

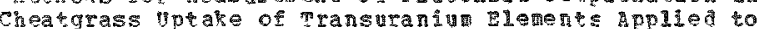
of 21 utoni un 230 , ungsten 195 and Lead 210 from Bffect of sta starilization of of Plutomin in the shoots and soots of Solitis Dotentel ole of the

Distritontion 4rifluence of Pliptong

the ogt range comolex in pevada

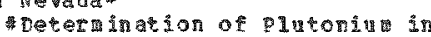

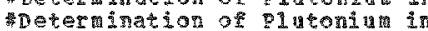

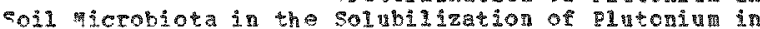

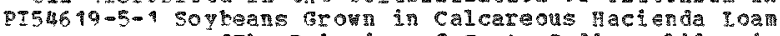
the pehavior of aste Panionaclides in

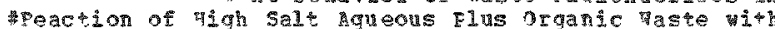
ith parioactive Fersistence of paisond ides in mpreparation and pesting of standar: ievels of alioactivity in iverwore palley

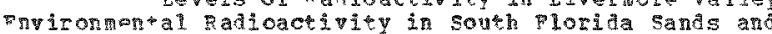
A pevier of Transilanic Elenents in

\#Safer Analysi geport for the PCD Problems

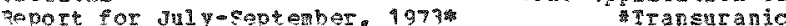

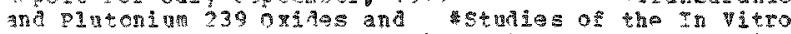
the Remowal of Inhaled lutonin 239 secosols of Varied 5i

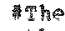

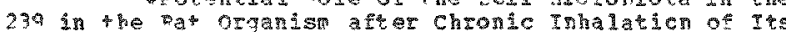

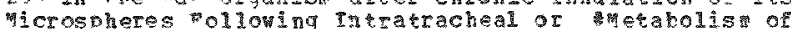
in ats a feer Intratracheal himin 1 istration of Pat as In Eluefcea by Dose as the pli of the Injection Ditrerent sethod of praparation or a cistate Injection

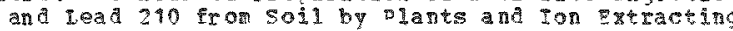
uraniug analysis in ny ironentral saples: a cembinea

of arioactivit During the curning of contaminated

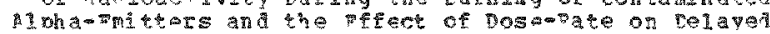
Disposat

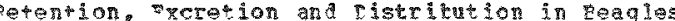

Trotentiat

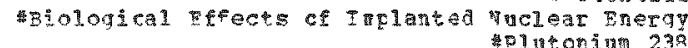

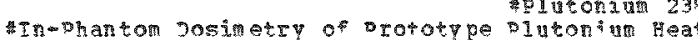

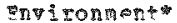

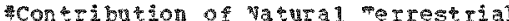

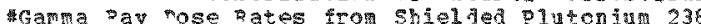
sarety snect of Incorcorated Radiation

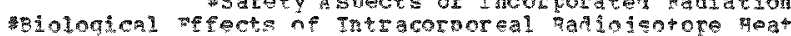

* Bologíc Effects of Intracorgoreal Radisotope neat

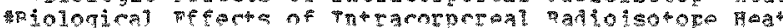

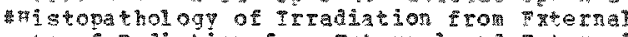

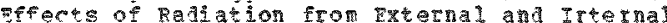

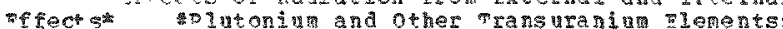

Investiga ion of Iung cancer Tnciaence in

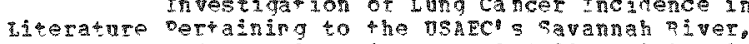

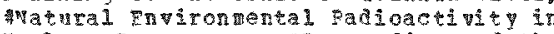
protection Fon Vuclear power sprocedings of the

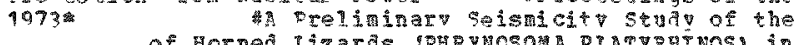
of Horned IIzards gPH yoson Dolng Danghters, Nraniun orm
Kreletal Distribution in Beaglest

Speletal Distribution of Americiug 241 and Rutoriu

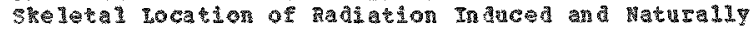

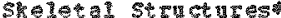

She leren of the Alut Baboom

skeleton of Growing and Mature perale Bats:

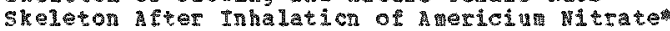

shelect containing Plutonita

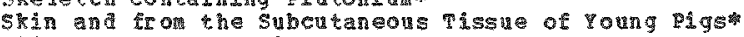

stin an It: Repoval

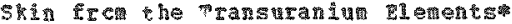

Skin of Anjwals and Its pistribution in the organis

Skin Contaminationt

sho contain ination

Skin Dcses from $5 k i n$ Contanin

skin Irradiation studies

Sking

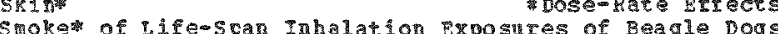

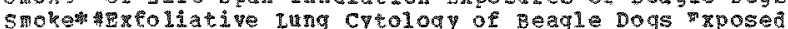

SHA-15A Ca DSn1es\%

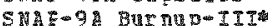

SM-1174, Section

Sotiun

Scft 1 issues of Beagles

Soft Tissues of Baglest

Soll and 7 fiecta stuafes*

Soil a

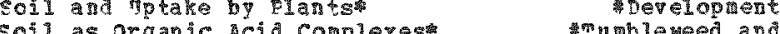

Chereal state of Pl of

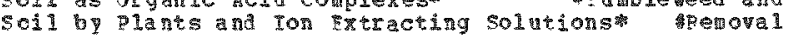

scil on pesponse of tho Desert Diant speciest

coli ith polvurechane coan

Sol 1 herobial activity on the pptake and Distribution

Sol1 picrobiot in the solvbilization of plutronin in

sell $\mathrm{g}$ icroflore

Sol1 Resuspension on the Airborne barticle size

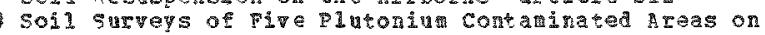
5०1

$30 \pm 1$

Sol1

Soil-giant systomes

Soj1. Interin aporth

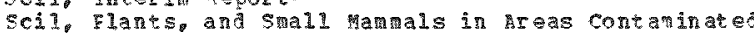
oils containing rinow puatities of padionuclides $\operatorname{sei} 15 \%$

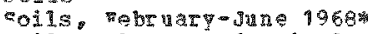

Scils, plants and aninal so

Solld padioactive waste storage acilities

Solid 5tate Detectors tc Environantal and Bjolonical

solid Wasce managenent pesearch Programs guarterit

solubilitip of pesplranle Particles of plutonin 238

colnbilit in seagle Doggtavage and DTPA reatrert for sclubitity of DI

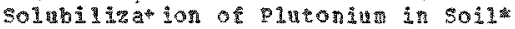

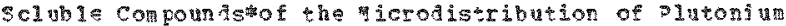

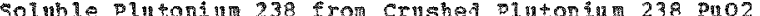

soluble Plutonin 239 compound Scluticnt Solution toistributom of plutoniu 239 palated

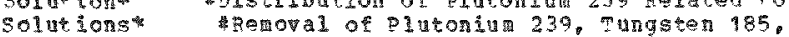

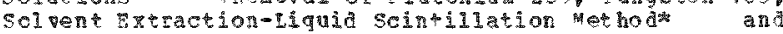
Solvents SOm atic Effects from Los Let and Alpha-Radiation

cccin feer Injection hallor

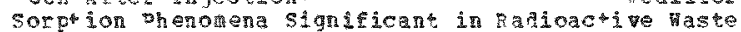

scurce weras and control heasures"

scurce for Attificial heart pevicas

sources for cardiac pace

ecurces for Cirtulation support systemst

Sources of Irit in and its Behavior pon polease to the

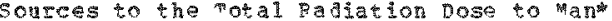

scurcesth

Sonsesth

sourcera

sourges

Scuters

Sourcesth

Conrces, Environent listribution and siomedical

South African 6014 oranjum couth Carolina. Eroduction sito of pubiclv Avilable

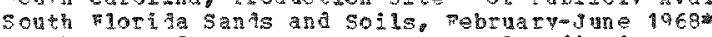
cuthern conference on Eviromental adjation

southern vevada Region cuartorly Report. Jaruary-march

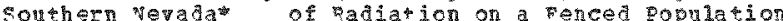

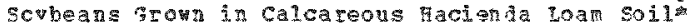

Sqan by a single In fect

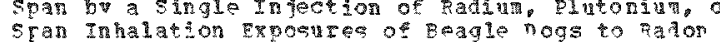

000198

000999

00023

000107

000048

000076

000158

000086

000039

000138

000097

000096

000380

000555

000555

000127

000126

000006

000223

000041

000316

000594

000561

000020

000229

000214

000247

000175

000252

000242

000240

000248

00000 ?

009526

000295

000255

000 แ1 14

000248

900246

000303

$00057 \%$

00n50?

000285

000462

0004 대

000302

000578

000422

000592

000283

000153

000200

00024

000124

000190

000102

000100

000195

000252

000278

000580

000136

00059

000560

000051

00030

090319

000535

000320

000310

000547

000058

000070

900060

000031

000450

00055

000356

000500

0004 is

$0007 \%$

090335

000298

009246

000030

900223 


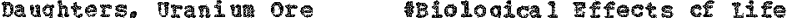

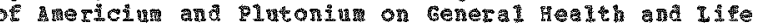

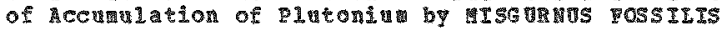

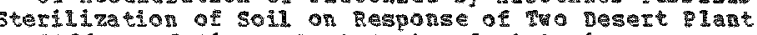

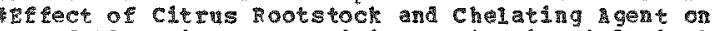

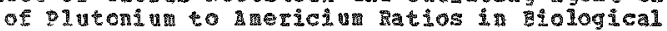

bv verton hetivation vitrahigh \# Benefit and Marn fron Exposure of Vertebrate

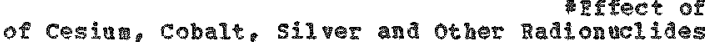
of cesiun. Cobalt, silver and other Radionulides Hadicactity of Hevada Hot

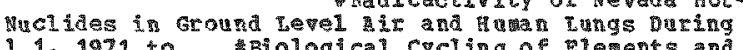

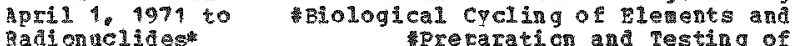

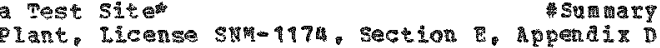

the revada Test sisto Test site

1972 pational Reactor Testing Dertaining to the ISAC's National Feactor Testing Envisonment al spets of velear Pever * rov romental

Tequlation of the ictor

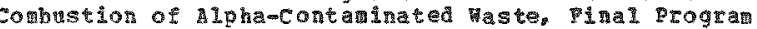
Blant spaciestie

speciest Lefect of 3epart for the ICPp migh-tevel sclid paloactive taste 238 and strontium ogs Q Eda 1 ing

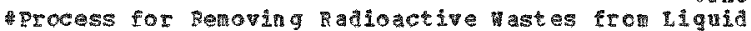

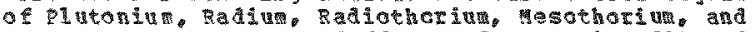
Effects of Elutoni 239 and

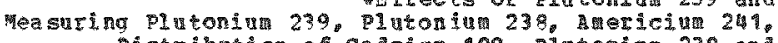
Diste ibution of cadrin 109 . Plutonin 23 and Swi ing of Pernissible Radiation Doses fron Todine 931,

Melative Effects of hmericin and plutenin cn skeletal * Ra a iological mergency operations.

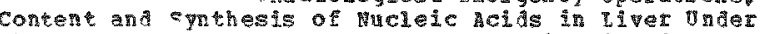

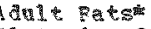

Pluterialin 239

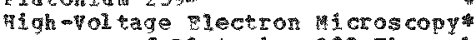
Wistribution and of Pluteni 239 Through the $5 k^{2}$ th and from the Witrate in Rats Afor Intravenons, Intragusen

Mrhalation of Tnsoluhle Iron oxide particies in the of organic Compounds Designed to Elininate Radioactive

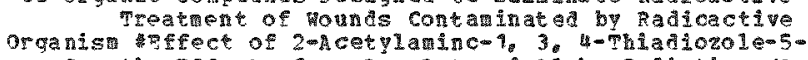

Sonatic Effects from ton let and lpha Radiation ta realeh ant Safery Laboratory Fallout Frogra cuarterly - 4allout pogran cuarteriy $9967 \%$ * Fallon Progra puateriy Hallow. Frogram Quarteri

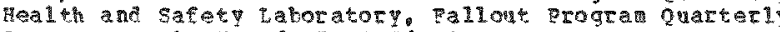
prograt at the revala est siter

and Physical character istics of vevad Test site ater

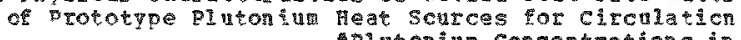

3972* * plutcriu concentrations it

Health an safety tabcratory *adionuclices in Fradonclides and Lea in trafiontides and lead in * Radonuclides and Lead in of Serosol Particles onto Foliage and other

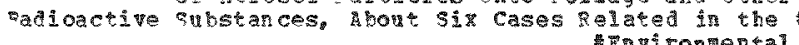

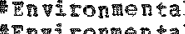
* avirongertal

19711 apadologicel

Decenber $31.9972^{\text {* }}$

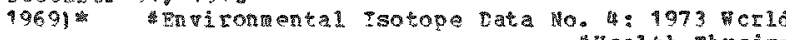
thealth physies *alological survey of the Hevada pest site pechniaues of persongel konitoring and padaticn

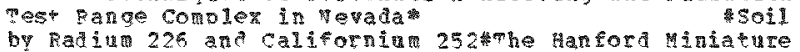

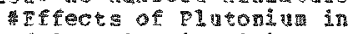
ap leter

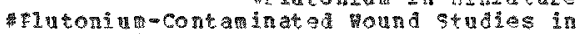

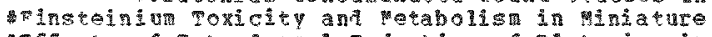
siffects of Intraneral injection of Pluteriun in

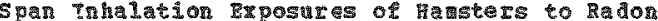

stats

Ppand stectic ACtivity of Iron and $z$ inc in shoots of Grafted speci 1 ins

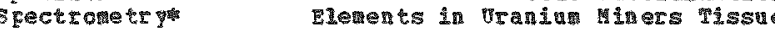
Speed Gross Alpha heradiography

Spera to Low Doses of Ioniting Radiation

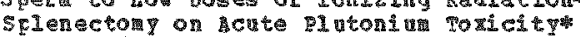

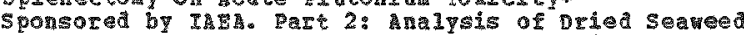
sconsered by IAE. Part 2 : malysis of Died seamed SFing systens

उpring 1962

4hlutoniug 239 and orther

satie Isotopes in varine prouronents. progress feport

standard Soils containg

Standard for the pransuranic Elewert

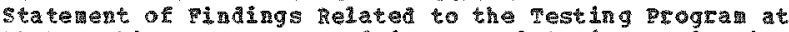
staterat * Statement, ondergrowa vielear tegting progra Hevada staticn. station. Iaho of publicity Apilable idterature stations

status of the Hatord Reser

status of Plants by Chelating gents and other Pactors

Statris Beport aressurized Steat sterilization of soll on Response of Tyo pesert Sterilization of Soli on Response of Two Desert plant

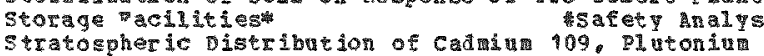
stratcscheric Inventories to harch $9972 \%$

Stratospheric Inventory of PIutonil 238

Strea

Strontitu and the sequence of mistopathologic chages

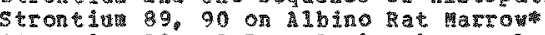

strontium $90^{\circ}$ and Iron 55 in Stron tis 90 The seasonal Stratospheric

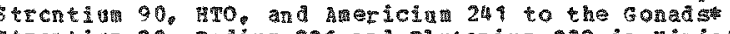

Structural changes in Dog skeleton coneaining plutoniu 000086 strecture $s^{\text {2t }}$

Student $\mathrm{g}$ औ

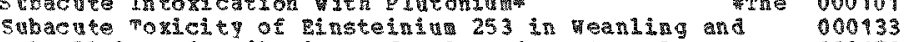
subcelluiar diseributions of polveric metravalent

Subcellugar Identification of trogenous particles Subcutaneous rissue of pout Figst Subcutareous, and Transcutaneous alnistraton

Sublezon Range*

Substances fror the organis aproach to the selection substances, About Six Cases pelated in the literature 5ulfonatide on the Elinination of vinin from the sumary prepared for the MAS-VRC Low Dosemstudy Group Sunary pertaining to plutonia Aerosols Sumary Report (September 1.1973 through December I.

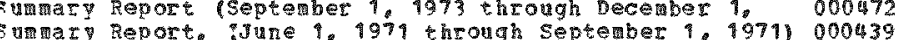
5 un suvar kepare (Jane

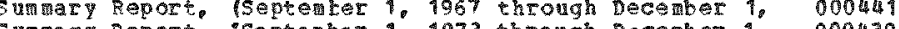

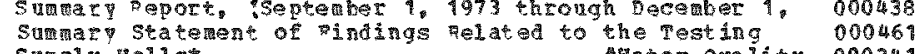
Sugply ells

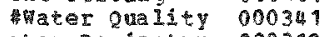
supcort systems an-Phantore Dosidety surface 15 at Richland, hashington

Surface Are Sampling Progeasto

surface Ar sapling Brogran, the quality of Analysis.

surface $\mathrm{Br}$.

corface Air

supface a

Serface Air

vif

Surgical preatuent or mounds contam in at ed by

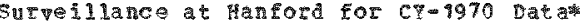

Surveiliance at Hand for Cor C 1979 (Addendur)

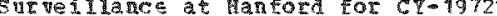

Survev of the Vevad Test Site fsurey period: 1970

survey of Applacations for Californiu 252 *

survev of sivironental Radiodctivity

Survey of tnvitornanta padoactivity. Januery 1.9072 3urver of I sotope Concentration in Precipitation :1968Surver of Tring site

Survev Eardod: 1970-1971)

surve ing

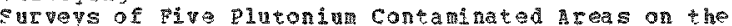

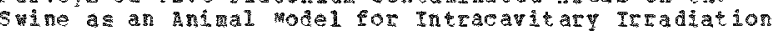
Swine skin and Its Removal

Sพ

5 wition

돈.

so
000221

000105

000242

000091

00078

00759

000015

000434

000521

000328

000285

000461

000561

000489

000589

000415

000243

000242

000242

000590

000459

00042

000085

000236

000289
000596

000590

000558

000133
000178

000002

000205

000391

000253

000373

100082

000136

0347

000341

000511

000515

000513

000596

00519

000517
000518

000098

000373

000423

000416

000425

000312

000520

000491

000323

000425

000553

000296

000225

000128

000137

000977 


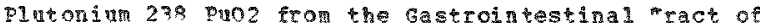
strontiun 90 , atin 225 and Plutoniub 239 in miniature

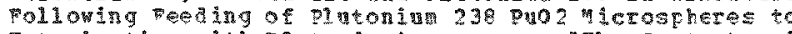

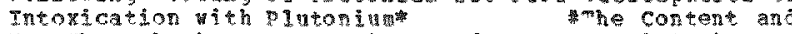
Hew hermol und nescent Doss Troation and the products on the tunctional state the central Nervous Aquatic Fol ution control New ire rotection araiation zefects on major organ

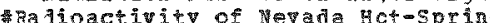
*he gehavior of taste Radicruclides in Soildelant pefocts on uncroorgan Plutonu Heat sources for circulation support intection \#poblems with Predicting Fallout padiation hazard in

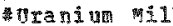
\#0รañ

9uton in oxide

* 1 pha Particle Incidence ir 5 maly * ssessment of low Energy phoson thiters in

in L Fel on

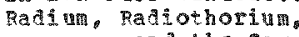

* Radiolsotcpes in the

moIDNN ma creosote Bush in

of ABC Poliution control conference held at oak idge. Literature per aining to the USAEC's oak Bidge. osteolast vingersto

Fisteinium 25 chloride in kats*

-

stect of Adaitional pathological pactors on the Iong *ung Cancer isk in Relation to long * Gama Dose Rate of americiun 241 A ter Iong Scientifle advantages in the vse of the 3eagle in ICno potential source zeoneribution of

in the chinese hamster and Its cytogenic 2 inect on the Introacto

Particles and Subcellular Distrabutons of Polymeric

Accidents in Iarge Muclear power Flatis. A Study of of Possible conseruences if cartain Assuma d ccidents. Rats $7 \mathrm{~s}$ ing zinc an * Interaction of plutonium and cesin buring chelation * Interaction of Platoniun an
Capsules on Dogs and prinatesto system at pic akai works\%

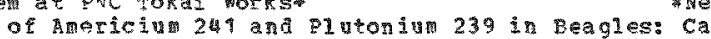

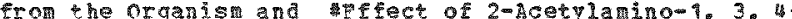

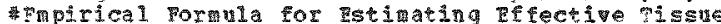
Hstimation of Ecective Tissu

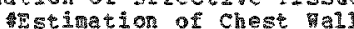

Nev Hor $201 \mathrm{~g}^{\text {the }}$

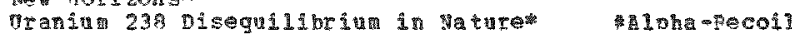
* Nevtron and Photon Flux from $x$ is ay Iurescem (C12mop) on Bone of the erozimal Inhation a instruent for contunous monitoring of Puos

Determination of seventen elenents in the 239 Through the skin and fror tho subcutaneous comparison os

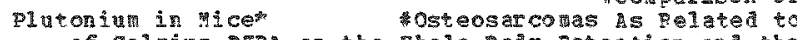

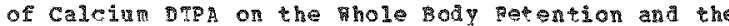
for the Meamurement of Dose ristritutions t Bone Inno 落stimation of tivective of californin 249 and Berkeling 249 in the sof 239 on Its rarly petention in lasma and Selected sof At

Histor and Ralytar pesults from Some postmorten

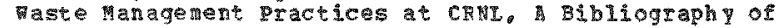
1973

Dosimetar for personnel Cosinempor

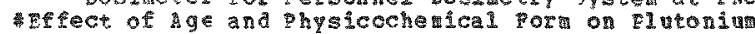

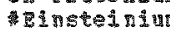
* is

ach Ancere

In 管 conparative

Other Tansuran wh

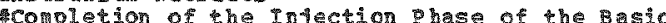

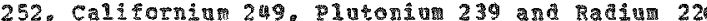

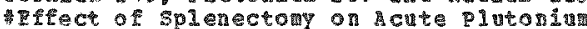

Sำำ

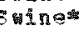

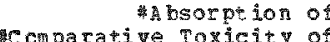
S. ascatitin and is of heleic Acids in Iiver Jnder subacute

systen at phe Toka

system for zxposure of Leagle Dogs to Fatioactive

$5 y \operatorname{sen}$

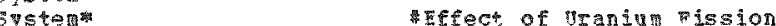

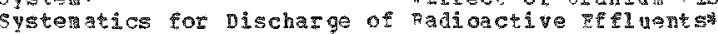

systems cor pilter plenumsth

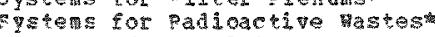

systems of mamals*

systens:

systems

systems

v

systers:

Tactical Battiefiela Si tuations

aflings poblems in Grand Junction, colorato

Talings studye Phase 1. progress poport

Tages

Taurine Excretion in peagle Dogs after whalation of

Technical s sects of Detection

Technical progress Re port on the metabolic studies of

iechnology. Part 2: Taiation Exposure Eron Plutoniu

Teeth cf Dogs. 1. The Distribution of plutoning.

teeth contsining plutonium Mesothorsu and strontin Terperature on the Distribution and Behavior of LAPEA

ennescee, october 25-27, 1972 ,

Trocerisigs

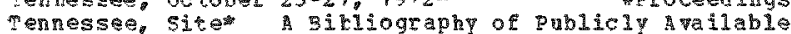

Tert Aloh irradiation on parathyroid decivity and

Ter Eiological Pifects of Intratracheally Tnstilled

er censequences of plutoniu 239 poisoning

Tero Exosure to padon caughters

Cern Irradiation ith Eactor veutronst

mer padobiological studies*

Term and conerol masuresto

er an and control Measures to the

* estesand Betention of pononeric plutoniun 239 citrate cestimony

Tetra valent Plutonim $239 \%$

Thert: Hishs and Sa feguards

군 1 SOSome

Fhecretical Possibilities and conseguences of major

Thecretically Possible but uaghly Inprobale,

Therap for the Decorporation of Einsteiniun 253 sron

Theracy in Rats*

Ther al and Padition effects of Plutoniur 238 Fuel

Therolutinescent Dosineter for gersonil Dosinetry

Then Be conpred.

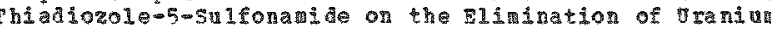

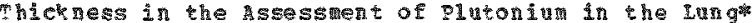

Fhickness in the tssessment of Plutoninm

mhichness in tung Connting for plutonium

Thit Anval Matonal conterence on qadation control.

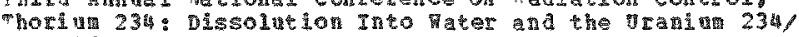
Thyrota scanners

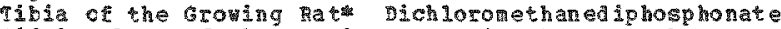
Tidal Vol ine of the Beagle Dog During typosure by

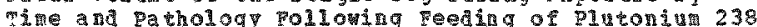

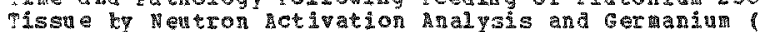

issue of 2 ats vuring Cbronic Peroral Administration of

ing of ye oung plgs

Tissue beposition of mericina and plutoniu

Tssue Distribution of hononeric and polyneric

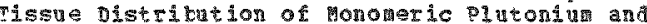

Tissue Tntertacest

Detector

Tiscue phickness in the Assassant of plutoniu in the

Tissue Thickness in the Assessment or Plutoniua

issues of Beagles;

Tissues of teaglestphysical-cherical state of plutoniu

Tisse Fol lowing Intragestic and Intravenovs

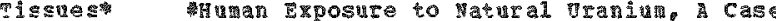

Tities, fot hors, and abstracts

需a dioact

Toka horks Seviannu 1 progress pevort. Manuary - June.

Tokai horks

cotscity an a tetabolis in the sat

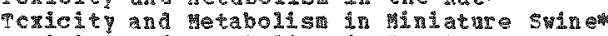

Tosicity an

cxicity of Anericin 241 vitrate and citrate

Fesicitr of pinsteini 2

mosicity of Inhaled DTrgas

Tordeith of Inhaled glutorin in Dogs

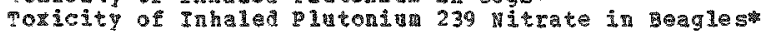

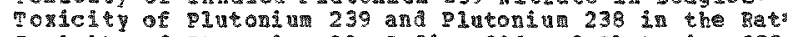

Tomicity of strontsu 90 . Fadiu 226 and P1 uton 239

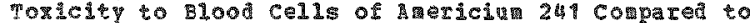

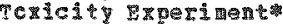

Tomiclty studies in lice

4caller na
009291

000140

000213

000101

000446

000351

000238

000195

000500

000542

000364

00052

000303

000362

000319

000060

000502

000507

000426

000084

000055

000463

000074

000565

000085

000085

000292

000585

000593

000056

000019

000397

000530

000135

000569

000320

000033

000330

000178

000314

000314

$00020 \%$

000208

000313

000446

000179

000082

000398

000399

000369

0055

000317

000145

000059

000213

000073

000161

000039

000113

00018

000092

000398

000399

000229

00021

000079

000372

00053

000538

000446

000177

000130

000160

00013

000210

000171

000167

000018

000140

000057

000219

00023 
and 1 utoni un

serking antiol sotopes

trelative

作

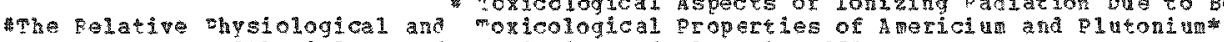

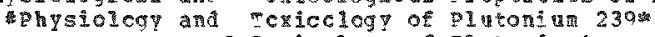

Poxicology of butoniun

Inhalation Gxicology Research Institute Annal Feport 1972-1973*

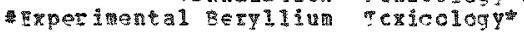

by ission Tret counting*

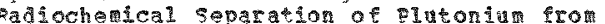

Deternination of Aleticint 241 in * Duton 242 plutoniar 236 as an Malytical of Aerosol particles in the Human pespirater

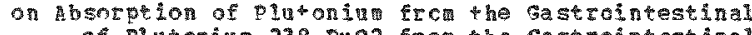
of D1utonin 238 Puo2 from the Gastrointestinal

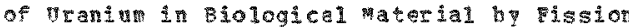
Dersonnel monitoring of pespiratory the Fntrance of PIutoriu into the Gastrcintestinal parameters of Bnanesthetized halt Beagle bogs suring

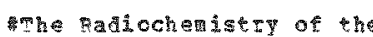

After Intravenous, Intramuscular, Subcutaneons, and barticle size or cotal Dose Deposition, Petention and 静 History of the - Health Physics considerati cns in Processing *nvironental qevels of plutomintion an the

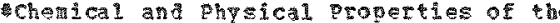

保1 Oassay of

Ghiparts in the Probability and conseguences of

a Pever of *avironaenteal tathwas of Standards tor the

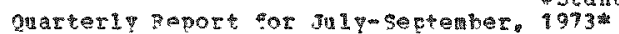

tage ratonal Laborator*

scintil1etion counting

* apid Deternination ce som whe pological fires of some sacts of the production of

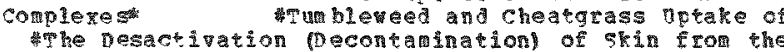
some Important Erobiens of Biological Action of pecer Anvances in the Hnited states of Aneriea on the Radiologica 1 Protection of Horkers Handing

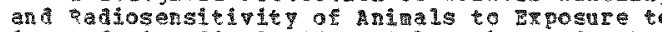

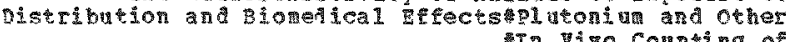
覀

to Bloor cells of Amertcin 241 conpared to othe

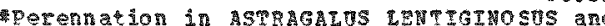

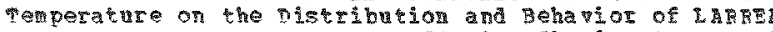
s. Fit ea ith Fhysics survey of Sources of

4B hevior

Wistribution of

\$llonitoring control and pispcsal of Eressure Mechanical properties of the helen. Hevad blements appired to Soll as organic heid complexess

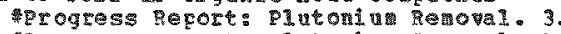

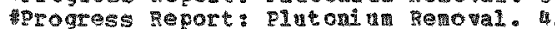

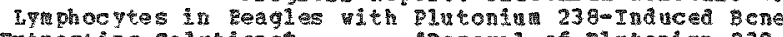

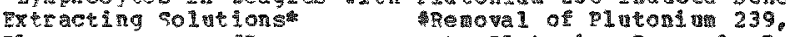

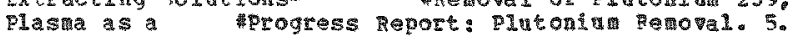

Fats Following Single Inhalaton of Plutonim 239

During lelationships Between Respiration araters of

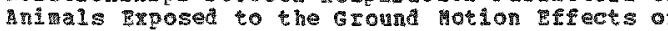

for the Hevad Test ste and ot her Test Areas sed fer

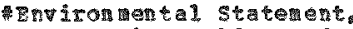
Mcientific Basis for Radiat ion protection Guilance for oistribution of zinstanu 253 in the petoplacental recent andinces in the

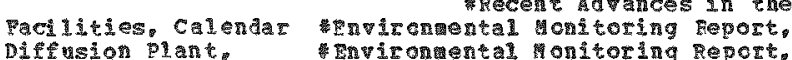

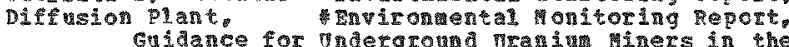
Guidance for underground vrania

Tear In halation study

Roots of FInI gents

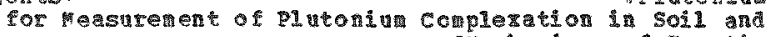

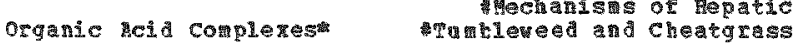
酸

1. 3. 4-Th่ ad of A Inoalky lphosphonic Mcids on the ristination of

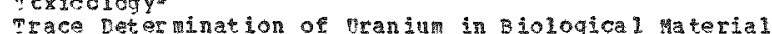

Tracer studies to optinize conditions for the

Tracer

Pracer

Tract in lation to Earticle size. Breathin

Tract of Rats

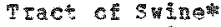

teffect of Age

Thact crartirnas ion

Tract
The plse of Ton-Exchange pesing hiter

Training and During lutoni un 239 puoz derosol

mrans-Eacific allout and protective countertineasurest

ransevis

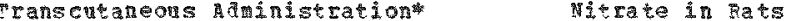

- rass location Inhalation stuaies. 3 . pect of

Trangloton ic :lement

Transpiutoniu pleatents

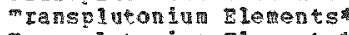

canspluton in

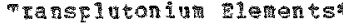

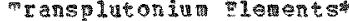

Transper of Plutonim 239 PuO2 in Dogst

Transportaton Accidents Involving adioactive laterial

Tranevande

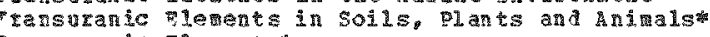

Tansuranie Fienencst

ransuranic Eletents

Transuranc solid

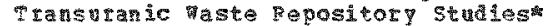

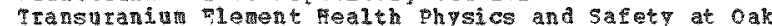

Transurani

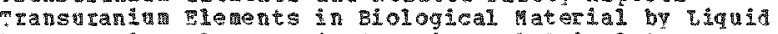

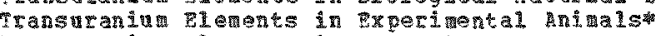

pransuranin Elements in Frances

Tagsurang

mansuraniu

Tansuraniu Elementste

Transutan in

Transuraniu El events*

Trasusuni

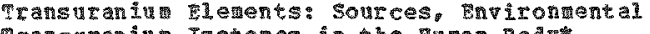

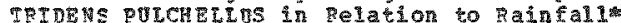

TRT

Tintey site

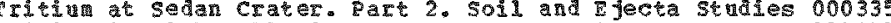

I

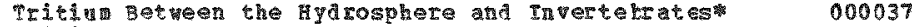

Trite

Tritiutition selected Bibliograph

Tit

4.

Tubleved and cheatgrass vptake of Transuranin

Tuar tricidence studies

Tumor Incidence studies

Tu的的

Destecton of crtotoric

Tugsten 185 and iea 290 from 5 a 1 by lants and Fon

1 trafil $x$.

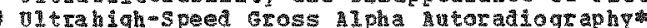

vitrastructure of he Aveolar-Capl11ary Barrier in

onanesthetized Adut seagle Dogs Derring praining and

ondergrouna velea Detonatons pilaife and Dowestic

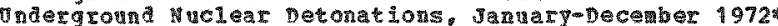

ทnd?

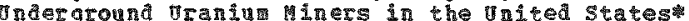

in $n$ it of the Ret

United states of merica on the Transtranin tanents

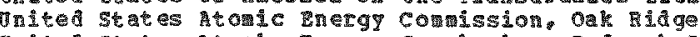

Inited states tonde Fnergy Con

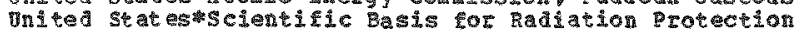

102) Dust. 2. postexposure Retention and BLOLogic

(07)

Tptake and Distribution of plutoniu in the shoots and

ifteke by cell cultures in presence sore chelating

gevel some chelating

uptake of mepatotropic Radionuclidest

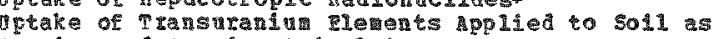

vrand4

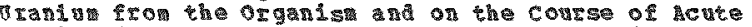

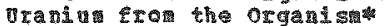

000111

000378

000008

00241

00258

000276

000270

00390

00219

000258

000025

000552

00264

000205

00009

00531

000311

000332

000274

000071

00568

000308

$00035 ?$

000508

000575

00545

000543

000007

000529

000097

00149

000539

00152

000370

000057

047

00024

000292

000335

000196

000581

000342

000175

000186

000485

000066

000252

000197

000078

000004

000052

000307

000473

000327

000419

000204

000539

00048

000494

300491

0015

00249

000174

000237
000235

000175

000067

000002

000011 
snorge ford

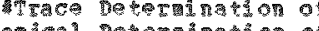

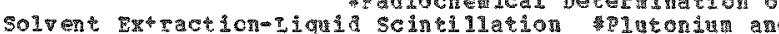
* and Bjologic Cencral Herrons spoter

象 $\cos 10 \mathrm{Ta}$

Scintill Characterizat ion of actual and 5 inulated

믈 Achronie Brosure of Dogs to sinulated Fehronic mosure of

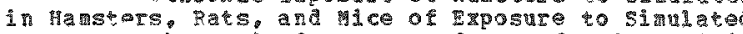
sposures to Short-Iived Decay Products of adon 222 in

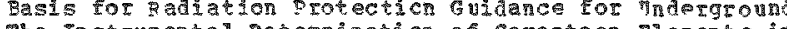

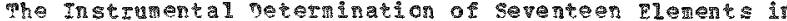
of Inag cancer Incidence in scuth firican Gold

a 7 a pey

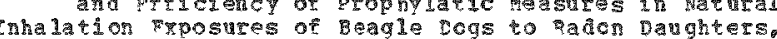

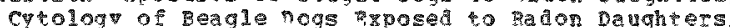

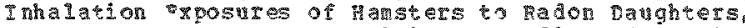

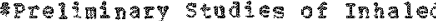

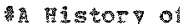
of yrand a

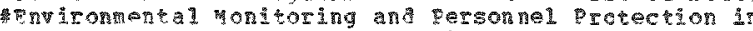
givinonental sudios fo

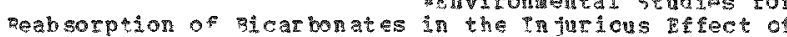

secos! horim 234: Tissolution Into

mordu 234: Dissolution into hater and the ynangm 234

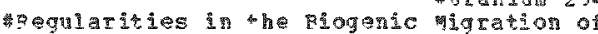
4physical and chemeat Prcperates of chelates as contrast mejias

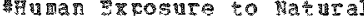

Sone postropten soharat Filtersin Betornination

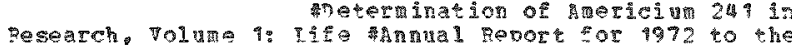
Physical Sciances. Pat thrual beport for 197 to the

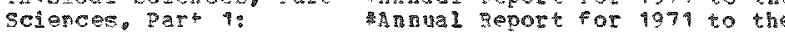
of Puhlicly Avajable Iterature sertaining to the

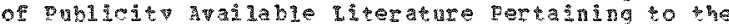

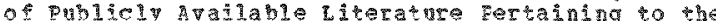

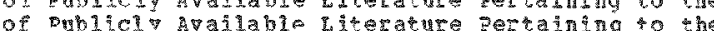
ma ioecological studies in

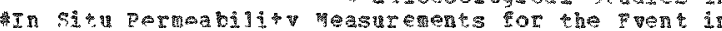

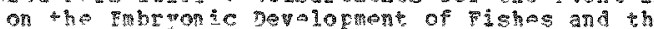
Iroced ute

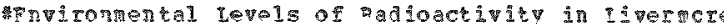

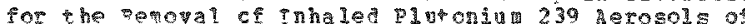

site. q. Geonraphis and cologic Distributions of the

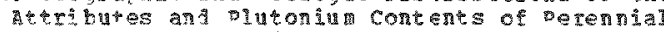

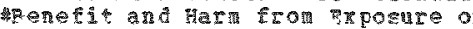

Inhaled Cerîn qu pusea clay particlas ot 巽?

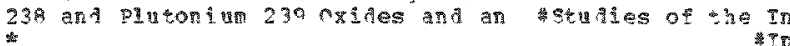

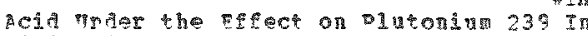

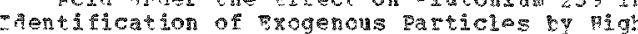

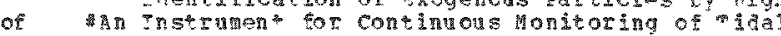

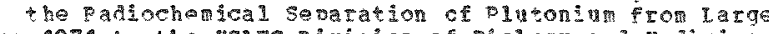

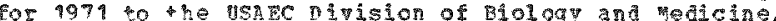

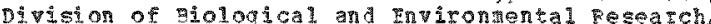
sostination of chest

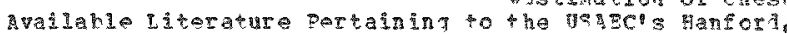

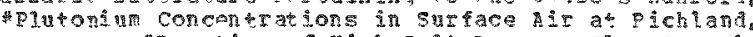

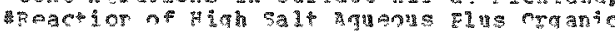

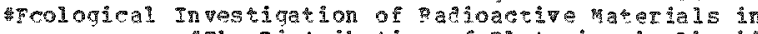

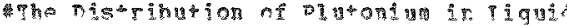

Horpton Tiblos, Authors and ahstracts

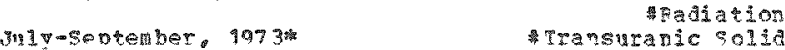

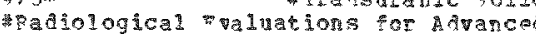

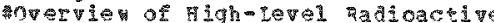

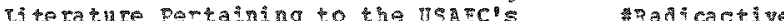

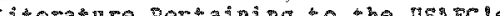

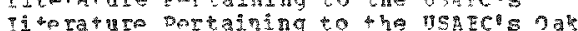
interatere pertaining to tho 药 4aleactiv andective atiactive the gehaviog of minsur and
Tring 0raniv

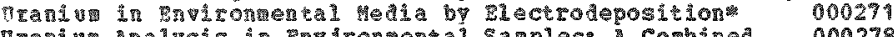
ๆran u पT Ta I

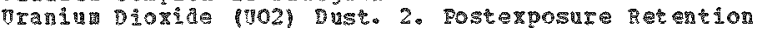
Uranin is Trani

voman

VTan

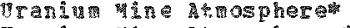

VIrand

7.

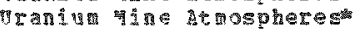

0rant

Traning inge stmospheres

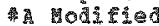

1ran

vrandus iners Tissue by neutron activation analysis

pranin Minerson

Draniu vining operations at Jadugua

tranith oneration\%

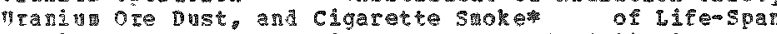

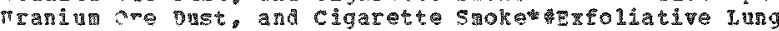

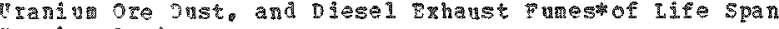
1)

Trang poígoning $(9824-1942)$

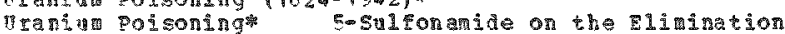
0rani un pocessing

vranin Provinces, A2

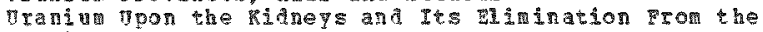

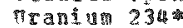

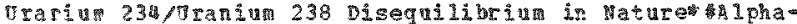

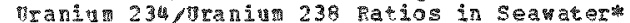

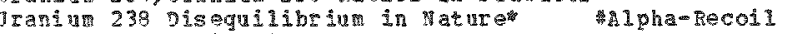

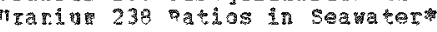

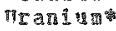

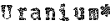

17.

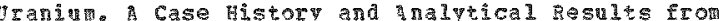

T1

Trine by cutiut 244 macer

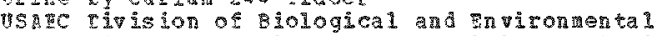

USAEC Livision of Biology and vedicine, Vol. 2 :

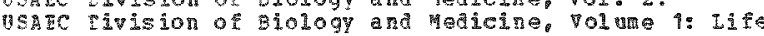

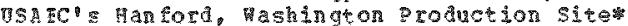

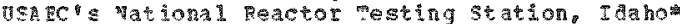

USA

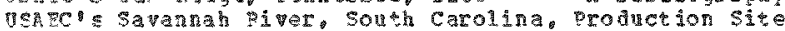
wah sutsequent to the Eanebery Event

$\eta \rightarrow=\mathrm{C}^{\infty}$

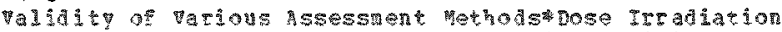

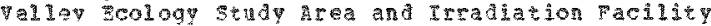

v11ev $5011 \mathrm{e}$

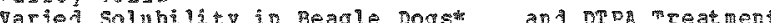
vascular lora (nnotated chechlistof the vevada Test Teqeta isn in the tetada Tese veretrate soar to ion Doses or ponzing adiation

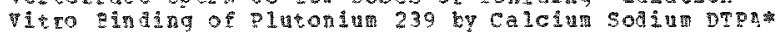
Vitro sigration of Alveolar acrophages Fron Dogs that

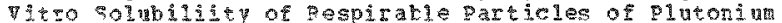

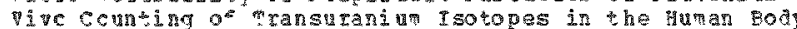
vive ceunting o

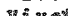
to h sicochom ice? changes in Doot voltage siectron ucroscopy

Tyribonucleic Yol

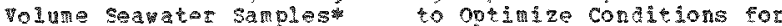

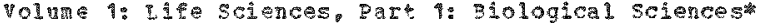

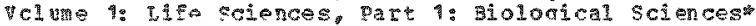

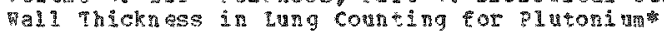

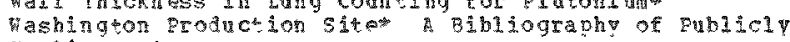
พือ

习ลद

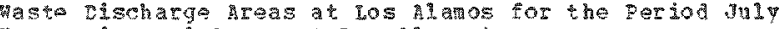

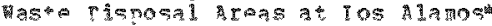

veste Tismosal

Waste Hanagenent Fractices at ofm A Bubiography of vasto Managemen Practices in

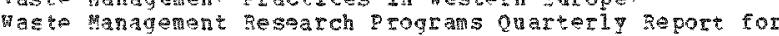
waste managenent studiess

waste

Taste mangement A Pibligraph of oublicity aylable yaste

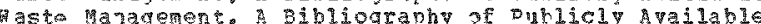

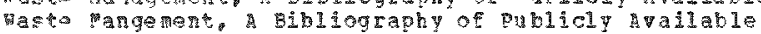
*asto Frocessing and Disposal

日aste Ratonuclifos in soli-Dlant systoms*

Haste pepsitor or studiest

Tiate ctorage
000450

000194

000114

00099

000507

000426

000460

000523

000368

000224

000220

000166

000401

000419

000073

000356

000395

009541
000223

000044

000221

000222

000075

000082

000503

000293

00034

000525

000269

000525

$00026 \%$

000295

000263

000212

000372

000260

000276

000232

000470

00058

00058

00059

$0005 \%$

000498

000343

000973

000495

000462

15

00029

000304

000020

000022

000283

000370

000346

000190

000002

000053

000233

000232

000360

000584

00059

000577

000436

000325

00058

090591

000592

000573

000582

$00058 \%$

000584

000503

000587

000303

000575

00057 


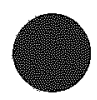

○ 


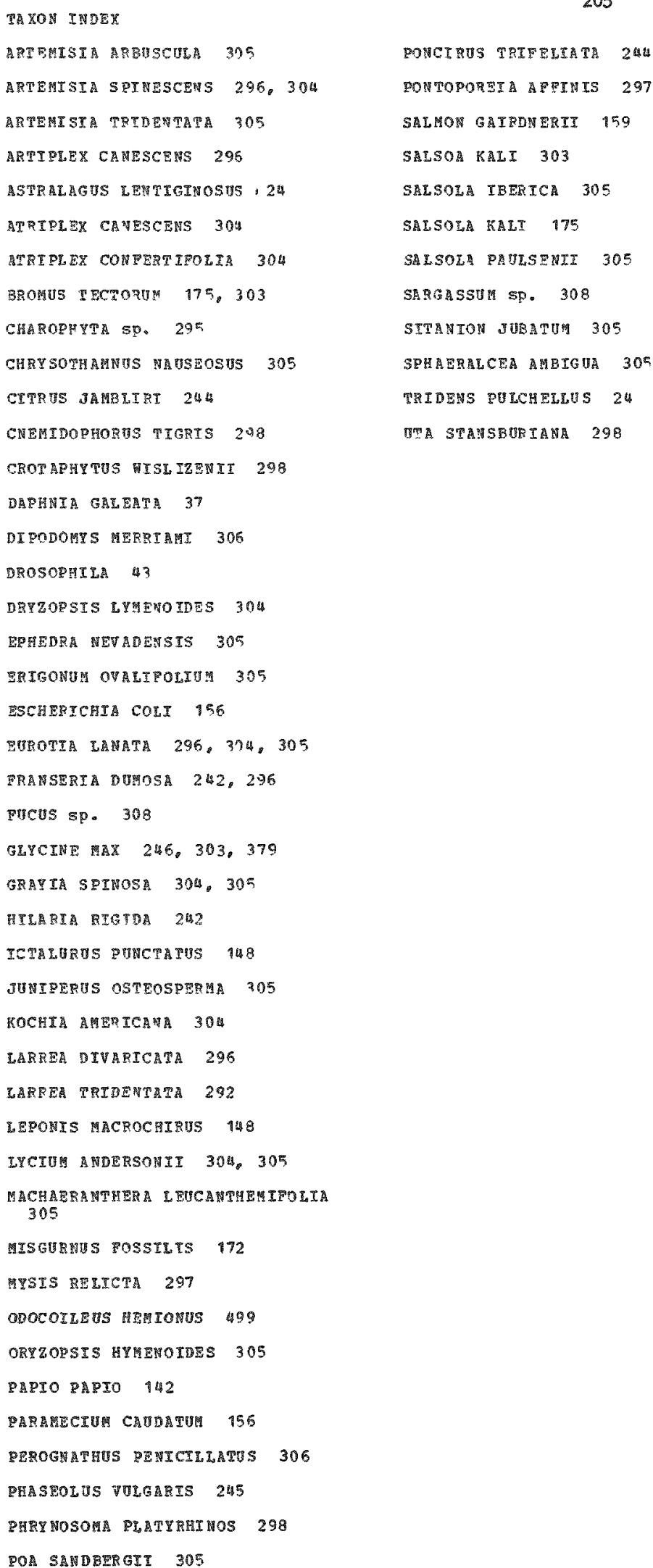


$$
\text { . }
$$ 
$\mathrm{A} / \mathrm{CONP}-15 / \mathrm{P}-765 \quad 385$

$A / C O N F-49 / P-395 \quad 451$

$A / C O N F-49 / P-451 \quad 430$

$A / C O N F-49 / P-637 \quad 535$

A/CONP $-49 / P-659 \quad 356$

$A / C O N F-49 / P-686 \quad 294$

$\mathrm{AAEC} / \mathrm{E}-272 \quad 293$

Academic Press, Neu York, Ney York 165,404

$A D-752049 \quad 89$

$A D-77013190$

AEC Symposium Series No. $17 \quad 402$

$A E C-t c-5433 \quad 6 L$

$A E C-\operatorname{tr}-5436 \quad 100$

$A E C-\operatorname{tr}-6408 \quad 27$

$\mathrm{AEC}-\mathrm{tr}_{\mathrm{I}}-6603 \quad 81$

AEC- $\operatorname{tr}-6886 \quad 63$

AEC-tr-6889 $39,125,182$

AEC-tr-6944 82, 96, 116

AEC-tr-6944 (Rev.) 253

$\mathrm{AEC}-\operatorname{tr}-7195 \quad 93,237$

AEC-tr-7306 172

$\mathrm{AEC}-\mathrm{tr}-7362 \quad 124$

$\mathrm{AEC}-\mathrm{tr}-7387 \quad 38,40,151,160,161$.

189,195

$A E C-\operatorname{tr}-7457 \quad 4,150$

AEC-tr $-7512 \quad 115,236$

$\mathrm{ABCU}-2332 \quad 554$

AECU $-3522 \quad 88$

AERE-R $-3783 \quad 445$

$A E R E-R-4054 \quad 380$

AHS B (RP) $-R-39 \quad 555$

A HSB (RP) $-R-41 \quad 371$

AHSB (5) $-R-10 \quad 413$

American Industrial Hygiene Association Journal, $34(11), 507-$ $\begin{array}{ll}511 & 2\end{array}$

American Journal of Roentgenology, Radium Therapy and Nuclear

Medicine, $117(3), 704-7105$

Analyst, $98,358-363262$

Anal ytical Chemistry, 42 (1), 121 $123 \quad 258$

Analytical Chemistry, 42(3), 419$421 \quad 268$

Analytical Chemistry, 46 (1), 113$118 \quad 285$

ANL $-5584 \quad 410$
ANL $-6723 \quad 117,186$

ANL $-6790 \quad 185,187$

ANL-7960 (Part 3) 297

ANL $-7970 \quad 179$

ANL-8007 505

ANL -8050 (Part 2) 393,394

ANL-8078 504

ANL/BS-26 (Part 1) 324

Annual Report for 197289

Archives of Dermatology, $86(4)$. $461-464 \quad 381$

Archives of oral Biology, 2, 215$238 \quad 85$

ARH-1972 574

ARH-2757 (Part 3) 570

Ballantine Books, New York, New York 567

Ballinger Publishing Company, Cambridge, Massachusetts 540

BNL-12919 353

BNL-17874 444

BNพL-B-278 415

BNHL-CC-313 577

BNWI-SA-4227 509

BNWL-tr-71 235

BNWL-1051 (Part 2) 528

BNWL-122 16,78

BNRL-1306 (Part 1) 220, 224

BNWL- 1650 (Part 1) 20, 22, 41, 52, $53,54,70,79,94,126,132$, 133, 141, 190, 191, 192, 204,

$205,207,208,221,223,225,233$

BNWL-1651 (Part 2) 470

BNWL-1669 (ADD) 423

BNหL-1683 (ADD) 416

BNWL-1727 (ADD) 417

BNWL-1750 (Part 1) 19,66, 69, 80, $127,128,130,166,177,193$;

$226 ; 232 ; 523$

BNWL-1750 (Part 2) 99, 247

BNHL-1751 (Part 1) 289, 511, 512, $526,527,579,580$

BNHL-1751 (Part 2) 289, 368, 384, 511,512

BNWL-1755 175

BNตL $-1758 \quad 582$

BNWI-1764 573

BNWL-1850 (Part 1) 17, 210

BNY्रL-1850 (Part 2) 1,98, 248,
BNFL-1850 (Part 2) 249, 284, 303, that begins with the digit two will be listed after everything that begins with the digit one. The machine reads and numbers material beginning at the left instead of the usual way of beginning at the right of a series of digits.

BNWL $-48028,55,131,137,168$,

$202,211,212,213,219,250$

BNGL $-714134,167,170,203,209$,

$251,352,533$

BNHL-715 (Part 2) 73,91, 422

BRH/ORO-72-2 556

British Journal of Industrial

Medicine, $29(81), 81-89372$

Calcified Tissue Research, 12(3), $239-24676$

Californium 252 Progress, 6, 1-52 164

Cancer Research, 33, 1604-1607 234

CBA-BIB-129 (ADD 1), 279 p. 333

$\mathrm{CEA}-\mathrm{BIB}-203 \quad 373$

$\mathrm{CN}-2786 \quad 50,74,163,188,355,469$

Comptes Rendus Acadeny of Science, Series D, 275(25), 3069-3071 142

CONF-448 371

CONP $-670938 \quad 183$

CONP $-680435 \quad 227$

CONF-680507 321

CONF-680607 276, 524

$\operatorname{CONP}-681032 \quad 312,353,431,534$

CONP $-690303 \quad 453$

CONF-690501 402

CONP-700101 334

CONP $-700810 \quad 315$

CONF-700816 (Vol. 2) 542

CONF $-700847 \quad 500$

CONP $-700930309,529,530,532$.

$543,545,546,562$

CONF-700931 157, 409

CONF-700965 329

CONP-701112 350

$\operatorname{CONF}-701138 \quad 450$

CONP-710501 305, 498, 501

CONF $-710562 \quad 556$

$\operatorname{CONP}-710809 \quad 37,146,148$

CONF $-710901294,356,430,451$,

535,539

$\operatorname{CONP} 710919 \quad 144$

CONF $791009 \quad 313$ 


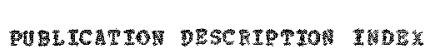

\begin{tabular}{|c|c|c|}
\hline coloto & 311 & \\
\hline $\operatorname{col} 2-7104$ & 391 & \\
\hline cons-71227 & 293 & \\
\hline $\cos \cos ^{2}-72041$ & 319 & \\
\hline 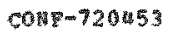 & 588 & \\
\hline $\begin{array}{r}\text { con-729503 } \\
370.376 \\
41.463\end{array}$ & $\begin{array}{l}123,149 \\
388.39 \\
541.548\end{array}$ & $\frac{346}{97}, 34 \%$ \\
\hline 60㻛-7205 & 316,57 & \\
\hline $\cos \%-7206103$ & 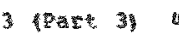 & 9 \\
\hline cone-72061 & 509 & \\
\hline 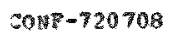 & 299 & \\
\hline con-7210109 & $9 \quad 272$ & \\
\hline$c 0 \mathrm{n}-721030$ & 576,595 & \\
\hline cont -721107 & 503 & \\
\hline cont -730603 & 428,462 & \\
\hline conto - 730907 & 325,375 & \\
\hline $\mathrm{CON}-731030$ & 65 & \\
\hline $\cos 2-731048$ & $30 \%$ & \\
\hline $\cos p-71101$ & 263 & \\
\hline $6040-73195$ & 564 & \\
\hline $\cos P-7-312$ & 410 & \\
\hline$c 00-119-234$ & 61 & \\
\hline $900-119-244$ & $58,122,22$ & 29 \\
\hline $\begin{array}{c}00-119-246 \\
19,721 \\
428,231\end{array}$ & 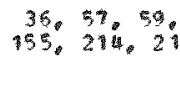 & 15.216 \\
\hline $\begin{array}{l}\cos -13-248 \\
382\end{array}$ & 120,135 & 136,15 \\
\hline $\cos -179-47$ & 71 & \\
\hline $000-218 \quad 86$ & 180 & \\
\hline $\tan ^{2} 23 \quad 210$ & & \\
\hline$-04=3167-28$ & 51 & \\
\hline $\cos \theta-35-12$ & 272 & \\
\hline$(1)=-3563-8$ & 256 & \\
\hline $600-65-68$ & 493 & \\
\hline 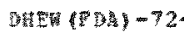 & $-8021 \quad 555$ & \\
\hline Docher & -1560 & \\
\hline Mecks & $3-2 \quad 56$ & \\
\hline$p p-19-71-52$ & 31 & \\
\hline $3 x+x-95=53$ & 492 & \\
\hline Despon-7/2-30- & $1 \quad 8 \$ 6$ & \\
\hline $105 y-13-30$ & $-1 \quad 482$ & \\
\hline 200004.55 & 2). $245-251$ & 297 \\
\hline Ecology 55 & $24.329=339$ & 306 \\
\hline
\end{tabular}

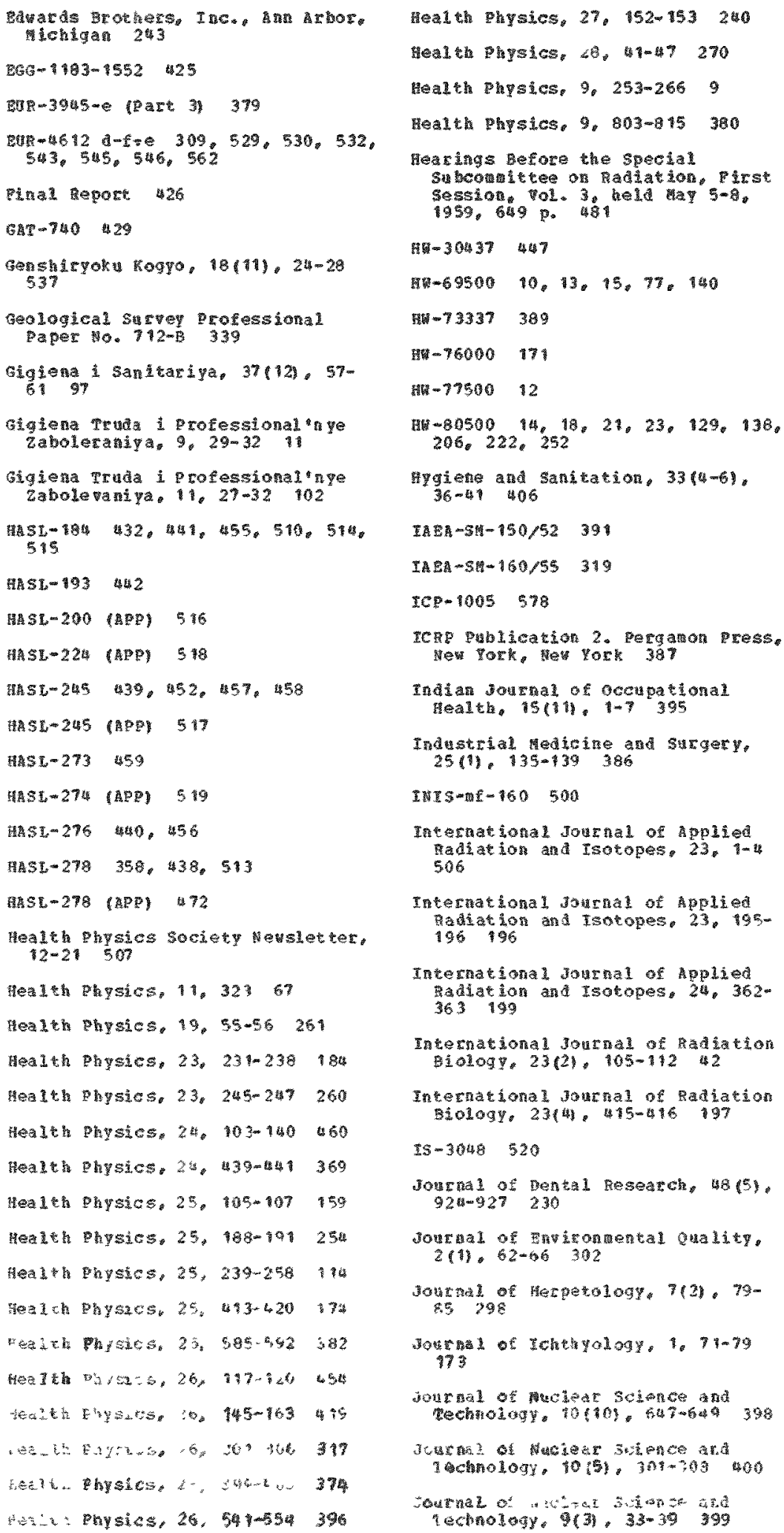

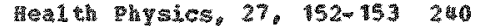

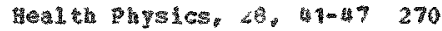

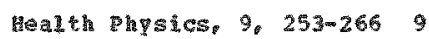

Heatch Physes,9.803-815 300

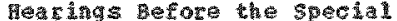
3ubcon

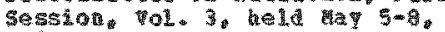
1959.699 .481

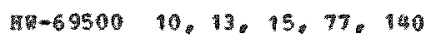

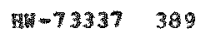

H觜-76000 17

$-79500 \quad 12$

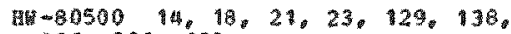
$206,222,252$

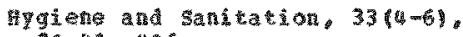
$36-4 \quad 506$

TA

IA $28-30-160 / 55319$

TCp-1005 578

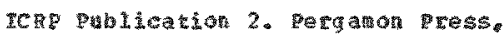
W Pork, Wes York 387

Ind a Jour Hea1

Industrit 25 (1) $135-39386$

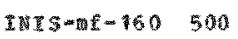

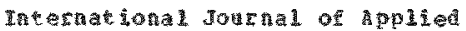
padiation and Isotopes, 23 , Io 506

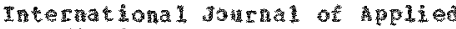
patation and isotopes. 23. 1950 $196 \quad 96$

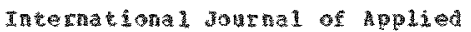
Saliation and Isotopes, $24.362=$ 363199

Internatonal 1 Jon

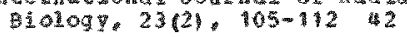

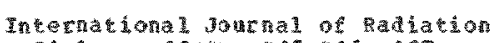
stology, $23(4), 45-41699$

$13-3648 \quad 520$

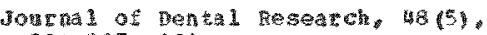
$924-427 \quad 250$

Jon 211) $62-66 \quad 302$

sour 5,298

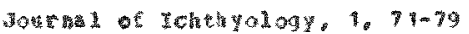
17.

Jour and of

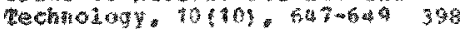

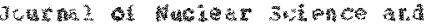

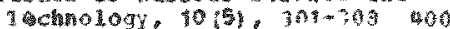

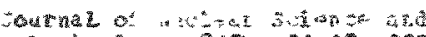

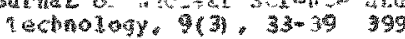


미를

\begin{tabular}{|c|c|}
\hline 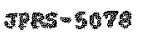 & 26 \\
\hline 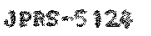 & 2 \\
\hline
\end{tabular}

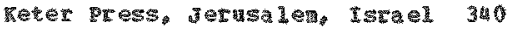

$4=-73-39 \quad 260$

IS-

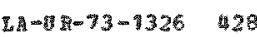

A $A=73-7=75=265$

$12-9-73-93735$

$4=-7+2=180 \quad 270$

, $=1309$ 100, 105, 106, 107, 108 109. 110. 11, 112, 13

$14-3719 \quad 323$

24-5127- (1) 575

$29=5184 \quad 43$

政-5282- 436

$43-5349-25 \quad 540$

$4 x-5425-345$

$4-5454 \quad 277$

c.

LEL-1799 解蛙

$\mathrm{ZBL}=2039$ औ4

L $84-213 \quad 53$

$9802452 \quad 521$

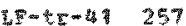

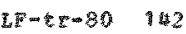

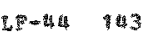

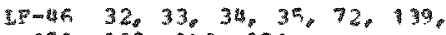

$153,283,33,351$

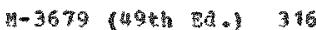

Madeano, $20(6), 326-332 \quad 2$ 保

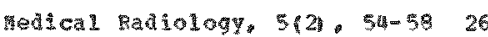

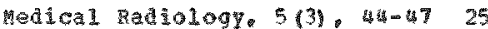

Nemoir No, 18 57, 594

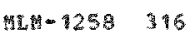

III)- $1267 \quad 310$

9.

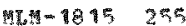

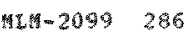

NAS $S=300 \% \quad 282$

MAS-

vation a

7.

Hith gook company Inc. Wet

vor', Hew yom 3 ?

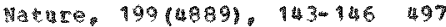

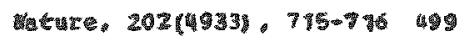

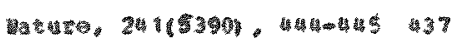

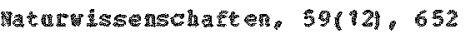
201

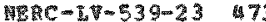

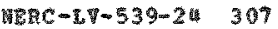

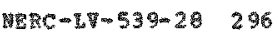

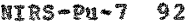

HLCO-1098 485

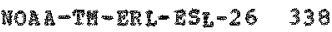

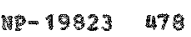

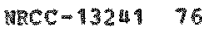

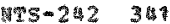

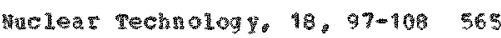

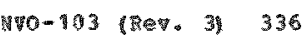

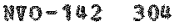

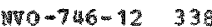

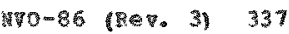

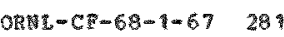

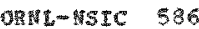

ORTL $-15 I C-39 \quad 536$

69:

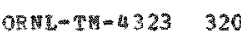

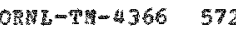

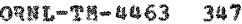

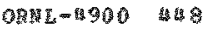

$0892-4930 \quad 27$

ORE

(E)

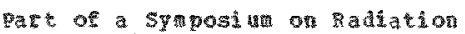
etatection roblens felating to

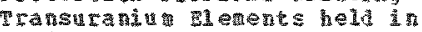

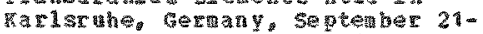
$25,1970,10.353-362 \%, 650$ p.

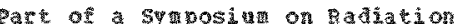
porection roblen me toting

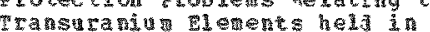

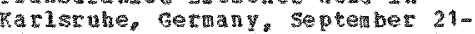
$25,1970,10.62-68), 450 \% 0529$

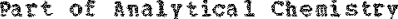
i)

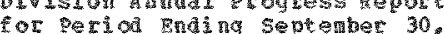

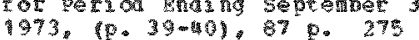

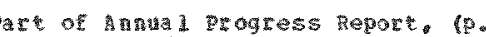
$86-1149.979 .96$

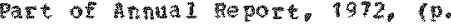
$125-1261,266$.

Pact ot Barker. J.J. (Bd.) grocedings of a $5 y$ agosiun on

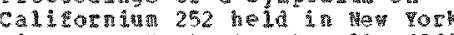

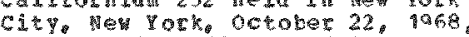
(p. $225-256), 376$ \%. 312

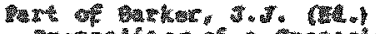

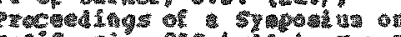

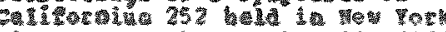

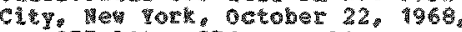

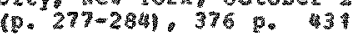

par of

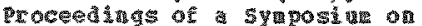
Calinorois 252 hela in

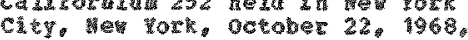

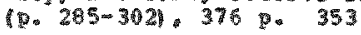

par of Bebrior or ceratn

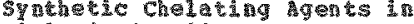

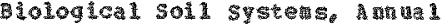
procress peport, (0, 27-30), 99 p. 2 的 2

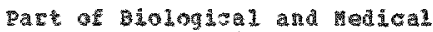

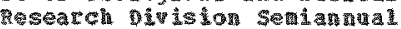

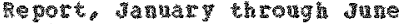
1962. 10. 18

Pat of Biological and felleat

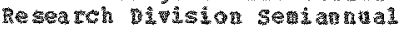
Report, Janary through

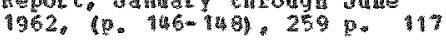

Part of siologicat and theal

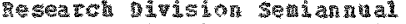

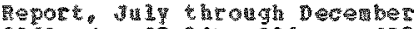
$4962,(1,97-9), 236 \%$

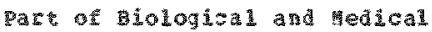

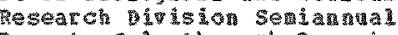
Report. 3ily through Decenher 1962. $1 \mathrm{p} .92-931.236 \mathrm{p}$. 19 ?

Pat of B Repore 1953 (9, 122-125) 163

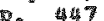

Pars of Bujuoso, (20, Health ensics problens of Internal Contaunation. poceedings of

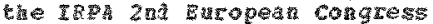

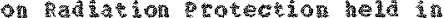

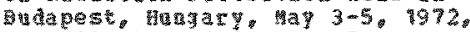

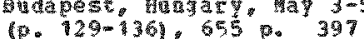

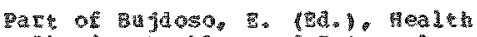

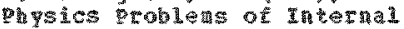

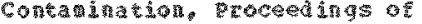

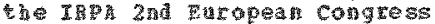
on Pad a gatapes? 15. $136-1431.655$ \%

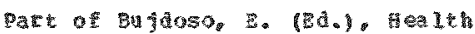
physus probleas of Internal Contanintion, proceedings of th IRp 2nd Puropea congress

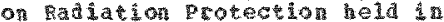

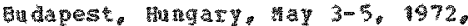

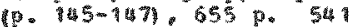

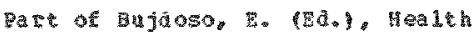

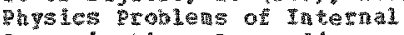

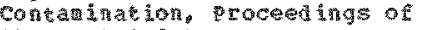

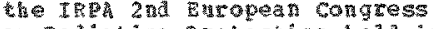
or madichion erotection fold in

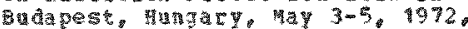
(p. $149-152) .655$ p. 349

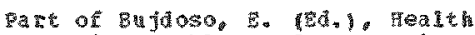

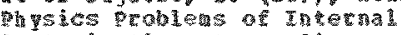
Contanation procedings of

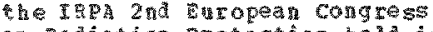
on Radition protecton held in

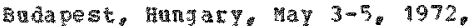
10. 101-1840 655 o. 123 
Part of Bujdoso, E. (Bd.), Health Physics Problems of Internal Contamination, Proceedings of the IRPA 2nd Buropean Congress on Radiation Protection held in Budapest, Hungary, May $3-5,1972$, (p. 187-195), 655 p. 149

Part of Bujdoso, B. (Bd.), Health Physics Problems of Internal Contamination, Proceedings of the IRPA 2nd European Congress on Radiation Protection hela in Budapest, Hungary, May 3-5, 1972 , (p. 239-243), 655 p. 390

Part of Bufdoso, E. (Ed.), Health Physics problems of Internal Contanination, Proceedings of the IRPA 2nd Buropean Congress on Radiation protection held in Budapest, Hungary, May 3-5, 1972 , (p. 287-289), 655 p. 548

Part of Bujdoso, B. (Ed.), Health Physics Problems of Internal Contamination, Proceedings of the IRPA 2nd Buropean Congress on Radiation Protection held in Budapest, Hungary, May 3-5, 1972 , (p. 459-463), 655 p. 463

Part of Bujdoso, E. (Bd.), Health Physics Problens of Internal Contamination, Proceedings of the IRPA 2nd Buropean Congress on Radiation Protection held in Budapest, Hungary, May $3-5,1972$, (p. 491-496), 655 p. 388

Part of Bujaoso, B. (Ed.), Health Physics Problems of Internal Contamination, Proceedings of the IRPA 2nd European Congress on Radiation protection held in Budapest, Hungary, May 3-5, 1972 , (p. 497-502), 655 p. 370

Part of Bujdoso, B. (Ed.), Health Physics Problems of Internal Contanination, Proceedings of the IRPA 2nd European Congress on Radiation protection held in Budapest, Hungary, May 3-5, 1972, (p. 503-507), 655 p. 346

Part of Bujdoso, B. (Ed.). Health Physics Problems of Internal Contamination, Proceedings of the IRPA 2nd European Congress on Radiation Protection held in Budapest, Hungary, May $3-5,1972$, Budapest, Hungary, May $3-5$,
(p. 593-599), 655 p. 407

Part of Bujdoso, E. (Ed.), Health Physics Problems of Internal Contamination, Proceedings of the IRPA 2nd Buropean Congress on Radiation protection held in Budapest, Hungary, May 3-5, 1972 , Budapest, Hungary, May 3-5.
(p. 601-603), 655 p. 376

Part of Buldakov, L.A., et al, Problems of Plutonium Toxicology, (p. 3-5), 225 p. 257

Part of Chemistry and Physics Progress Report, OctoberDecember 1970, (p. 17-19), 36 p. 414

Part of Ciaccio, L. L. (Bd.), Mater and Hater Poliution Handbook, volume 4, Chapter 25. Marcel Dekker, Inc., New York, New York, (p. $1357-1388$ ) 266
Part of Cook, T.D. (Ed.),

proceedings of a symcosium on Underground Waste Management and Environmental Implications held in Houston, Texas, December 6-9, 1971. The Collegiate Press,

George Banta Company, Inc..

Menasha, Wisconsin, (p. 341-354), 412 p. 571

Part of Cook, T.D. (Bd.) Proceedings of a symposiun on Underground Waste Karagement and Environmental Implications held in Houston, Texas, December 6-9, 1971. The Collegiate Press, George Banta Company, Inc. Menasha, Wisconsin, (p. 318-330), 412 p. 594

Part of Dougherty, T.F., et al (Eds.), Proceedings of a Symposium on Some Aspects of Internal Irradiation held at The Homestead, Heber, Utah, May $8-11$, 1961. Pergamon Press, New York, New York, (p. 207-232), 529 p.
147

Part of Dougherty, T.F., et al (Eds.), Proceedings of a Symposium on Some Aspects of Internal Irradiation held at The Homestead, Heber, Utah, May 8-11, 1961. Pergamon Press, Neu York, New York, (p. 397-407), 529 p. 103

Part of Dougherty, T.F., et al (Eds.), Proceedings of a Symposium on Some Aspects of Internal Irradiation held at The Homestead, Heber, Utah, May 8-11, 1961. Pergamon Press, oxford, England, (p. 131-143), 529 p. 181

Part of Dougherty, T.F.. et al (Eds.), Proceedings of a Symposium on Some Aspects of Internal Irradiation held at The Homestead, Heber, Utah, May $8-11$, 1961. Pergamon Press, oxford. England, (p. 179-186), 529 p.

Part of Dougherty, T.F., et al (Bds.). Proceedings of a Symposium on Some Aspects of Internal Irradiation held at The Homestead, Heber, Utah, May 8-11, 1961. Pergamon Press, oxford, England, (p. 27-45), 529 p. 87

Part of Dougherty, T.F., et al (Eds.). Proceedings of a Symposium on Some Aspects of Internal Irradiation held at The Homestead, Heber, Utah, May 8-11, 1961. Pergamon press, oxford, England, (p. $309-316), 529 \mathrm{p}$. 95

Part of Dougherty, T.F., Research in Radiobiology, Annual Report of Work in Progress in the Internal Irradiation Program, (p. $102-116) .424$ p. 122

Part of Dougherty, T.F., Research in Radiobiology, Annual Report of rork in progress in the Internal Irradiation Program, (p. 106-125) 380 p. 228
Part of Dougherty, T.F., Research in Radiobiology, Annual Report of Work in progress in the Internal Irradiation Program, (p. $110-140), 400$ p. 135

Part of Dougherty, T.F., Research in Radiobiology, Annual Report of Hork in Progress in the Internal Irradiation Program, (p. $(17-125), 424$ p. 58

Part of Dougherty, T.P., Research in Radiobiology, Annual Report of work in Progress in the Internal Irradiation program, (p. $126-146), 424$ p. 229

Part of Dougherty, T.P., Research in Radiobiology, Annuál Report of Work in progress in the Internal Irradiation program, (p. $137-147), 380$ p. 214

Part of Dougherty, T.F., Research in Radiobiology, Annual Report of Work in Progress in the Internal Irradiation Program, (p. $148-160), 380$ p. 36

Part of Dougherty, T.P., Research in Radiobiology, Annual Report of Mork in progress in the Internal Irradiation program, (p. $156-1621,400 \mathrm{p} .120$

Part of Dougherty, T.F., Research in Radiobiology, Annual Report of Work in Progress in the Internal Irradiation program, (p. $(61-166), 380$ p. 216

Part of Dougherty, T.F., Research in Radiobiology, Annual Report of Work in progress in the Internal Irradiation Progran, (p. $167-192), 380$ p. 215

Part of Dougherty, T.F., Research in Radiobiology, Annual Report of Hork in progress in the Internal Irradiation Program, (p. $249-2621,380$ p. 119

Part of Dougherty, T.F., Research in Radiobiology, Annual Report of Work in progress in the Internal Irradiation Program, (p. $263-265), 380$ p. 118

Part of Dougherty, T.P., Research in Radiobiology, Annual Report of Work in Progress in the Internal Irradiation Progran, (p. $272-281), 380 \mathrm{p} .57$

Part of Dougherty, T.F., Research in Radiobiology, Annual Report of Work in Progress in the Internal Irradiation program, (p. $274-287), 400$ p. 145

Part of Dougherty, T.F... Research in Radiobiology, Annual Report of Work in progress in the Internal Irradiation Program, (p. 284-286). 380 p. 231

Part of Dougherty, T.F., Research in Radiobiology, Annual Report of Work in progress in the Internal Irradiation program, (p. $289-298), 380$ p. 121 
Part of Dougherty, T.P., Research in Radiobiology, Annual Report of Work in Progress in the Internal Irradiation Program, (p. $358-364), 380$ p. 155

Part of Dougherty, T.F., Research in Radiobiology, Annual Report of work in progress in the Internal Irradiation Program, (p. $370-377), 400$ p. 136

Part of Dougherty, T.P., Research in Radiobiology, Annual Report of work in progress in the Internal Irradiation program, (p. $9-1051,380$ p. 60

Part of Dougherty, T.F., Research in Radiobiology, Annual RPORT OF Work in Progress in the Internal Irradiation Program, (p. 378$4001.400 \mathrm{p}$. 382

Part of Dougherty, T.F., Research in Radiobiology, Semiannual Report of Work in Progress on the Chronic Toxicity Program, (p. $(1-65), 185$ p. 218

Part of Dunaway, P. B, and White, M. G. (Bds.), The Dynamics of Plutonium in Desert Bnvironments, Proceedings of the NAEG Plutonium Environmental Studies Prograa Symposium held in Las Vegas, Nevada, October 2-3, 1973 , (p. 91-106), 369 p. 304

Part of Environmental Monitoring at Major U.S. Atomic Bnergy Commission Contractor Sites, Calendar Year 1972, (p. 10871113). 1217 p. 467

Part of Environmental Monitoring at Major U.S. Atomic Energy Commission Contractor Sites. Calendar Year 1972, (p. 11151129). 1217 p. 421

Part of Environmental Monitoring at Major U.S. Atomic Bnergy Commission Contractor Sites, Calendar Year 1972, (p. 1131$1176) .1217$ P. 435

Part of Environmental Monitoring at Major U.S. Atomic Bnergy Commission Contractor Sites,
Calendar Year 1972, (p. 1177Calendar Year 1972 ,
11881.1217 p. 420

Part of Environmental Monitoring at Major U.S. Atomic Bnergy Commission Contractor Sites. Calendar Year 1972, (p. 1189$1217), 1217$ p. 482

part of Environmental Monitoring at Major U.S. Atomic Energy Commission Contractor Sites, Calendar Year 1972, (p. 129-176), 1217 p. 476

Part of Environmental Monitoring at Major 0.S. Atomic Energy Commission Contractor Sites. Calendar Year 1972, (p. 177-195), 1217 p. 474

Part of Environmental Monitoring at Major $0 . S$. Atomic Energy Commission Contractor Sites. Calendar Year 1972, (p. 285-329), 1217 p. 520
Part of Environmental Monitoring at Major U.S. A tomic Energy Commission Contractor Sites, Calendar Year 1972, (p. 331-400). 1217 p. 505

Part of Environmental Monitoring at Major U.S. Atomic En Ergy Commission Contractor Sites, Calendar Year 1972, (P. 39-96), $1217 \mathrm{p} .443$

Part of Environmental Monitoring at Major U.S. A tomic Energy Commission Contractor Sites Calendar Year 1972, (p. 467-528), $1217 \mathrm{p} .493$

Part of Environmental Monitaring at Major U.S. Atomic Energy Commission Contractor Sites, Calendar Year 1972, (p. 529-552), 1217 p. 492

Part of Environmental Monitoring at Major V.S. Atomic Energy Commission Contractor Sites, Calendar Year 1972, (p. 553-596), $1217 \mathrm{p}$. 412

Part of Environmental Monitoring at Major U.S. Atomic Energy Commission Contractor Sites, Calendar Year 1972, (p. 597-627), 1217 p. 489

Part of Environmental Monitoring at Major U.S. A tomic Energy commission contractor Sites, Calendar Year 1972, (p. 629-654), 1217 p. 487

Part of Environmental Monitoring at Major U.S. Atomic Energy Commission Contractor Sites, Calendar Year 1972, (p. 655-698), 1217 p. 486

Part of Environmental Monitoring at Major U.S. A tomic Energy Commission Contractor sites, Calendar Year 1972, (p. 699-712), $1217 \mathrm{p} .488$

Part of Environmental Monitoring at Major U.S. A tomic Energy Commission Contractor Sites Calendar Year 1972, (p. 713-866), 1217 p. 473

Part of Environmental Monitoring at Major U.S. Atomic Energy Comission Contractor Sites Calendar Year 1972, (p. 867-887). 1217 p. 485

Part of Environmental Monitoring at Major U.S. Atomic Energy commission Contractor Sites. Calendar Year 1972, (p. 889-929). 1217 p. 484

Part of Environmental Monitoring at Major U.S. Atomic Energy Commission Contractor Sites Calendar Year 1972, (p. 931-955), $1217 \mathrm{p}$. 494

Part of Environmental Monitoring at Major U.S. A tomic Bnergy Comission Contractor sites, Calendar Year 1972, (p. 957-974), 1217 p. 429
Part of Environmental Monitoring at Major D.S. Atomic Energy Commission Contractor Sites, Calendar Year 1972, (p. 975$1086), 1217$ p. 417

Part of Environmental Monitoring at Major U.S. Atomic Energy Commission Contractor Sites, Calendar Year, (p. 401-412). 1217 p. 490

Part of Environmental Monitoring at Major U.S. Atomic Bnergy Commission Sites, Calendar Year 1972 , (p. 413-466), 1217 p. 444

Part of Fallout Program Quarterly Summary Report, December 1, 1967 through March 1, 1968, (p. II-2 II -25 ) 303 p. 442

Part of Pallout Program Quarterly Sumary Report, December 1, 1969 through March 1, 1970, (p. D-1 D-9). 399 p. 518

Part of Fallout Program Quarterly Summary Report, June 1, 1967 through September 1, 1968, (p. cth rough September 1,1
$1-(-66), 363$ p. 516

Part of Pallout Program Quarterly Sumary Report, June 1, 1971 through september 1, 1971, (p. C$1-(-102), 431$ p. 517

Part of Fallout Program Quarterly Summary Report, March 1, 1973 through June 1, 1973, (p. B-1 $B-114), 439$ p. 519

Part of Pirst, M.W. and Morgan, J. M., Jr.. (Eds.), Proceedings of the 11 th ABC Air Cleaning Symposium hela in Richland, Washington, August 31-Septembe 3, 1970 , (p. 791-806), 969 p. 542

Part of Goldsmith, E.I. (Bd.) Medical Primatology. Proceedings of the 3rd symposium on Bxperimental Medicine and Surgery in primates held in Lyon, Prance, June, 1972. Karger, Basel, New York, Ney York, (p. 226-236) 49

Part of Hardy, E.P., Fallout Program Quarterly Summary Report, June 1, 1973 through September 1 . 1973 , (p. I-27 - I-39), 176 p. 456

Part of Hardy, E.P., Jr. and Rivera, J., Pallout Program Quarterly Summary Report, September 1, 1967 through
December 1, 1967, (p. I-2 - I10), 406 p. 514

Part of Hardy, E.P., Jr. and Rivera, J.. Pallout Program Quarterly Summary Report. Quarterly Summary Report, September 1, 1967 through
December 1, 1967, (p. I-53 - I118), 406 p. 510

Part of Hardy, E.P., Jr. and Rivera, J., Fallout Program Quarterly Sumary Report, Quarterly Sumary Report,
September 1, 1967 through September 1, 1967 through
December 1, 1967, (p. II-26 - II$86), 406$ p. 455 


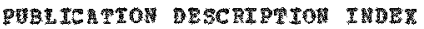

Part of fardy, E.P. 首, gnd Rilpea

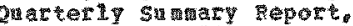
Septerber is 1967 theorit Decober 1. 1967. P. II-G - II251. 0606.515

Pat of

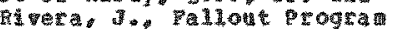

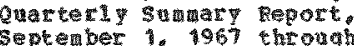

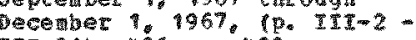
III-21) 406 ए" 32

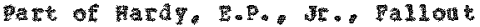

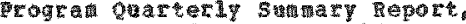
10. I-2- T-45), 163 o. 513

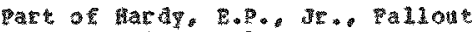

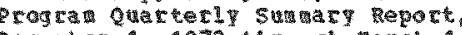

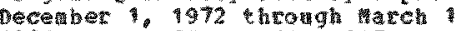
1973, (1. $5-37-1-63), 227$. 梦59

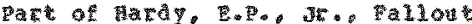

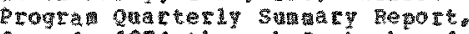
5une 1, 1971 through sebtemer 1971. (p. $\Sigma-84-I-1021,254$. 452

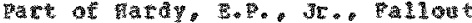

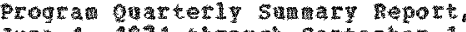

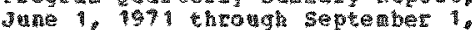

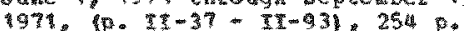
57

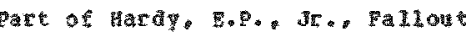

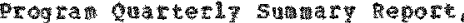

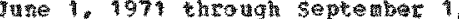

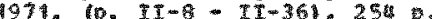
结 58

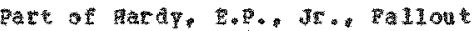
progra ouatery surary pepore

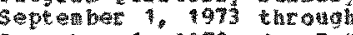

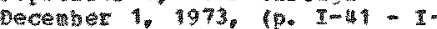
63.163 .358

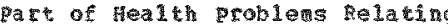
to Droduct for fonet of $1945 .(0.3-17) \cdot 35$ p. 459

pat of health problems relating to eroduct for wonth of narch 1945. (0, 18-29), 35 p. 190

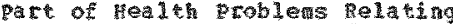
to product for month ô $1945,0.29-35,35 \% 74$

part of Health problexs leteing co product fat moth of hath 195. (0. $4-7), 35$. 35

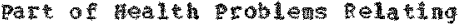

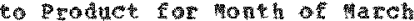
$1945 .(1.8-12) \cdot 350.50$

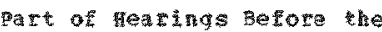
specia suborititee on radiation of the joint combitu

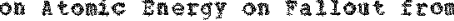
Maclear heapons pest hel Mat 5 8. 1959.

Pat of Hea ing Before the Special. \$ubcomintee on

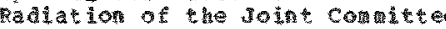

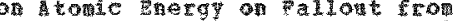

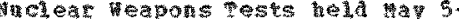
3. 1959, 101.3. (5.2191*2190) 480
Pa kandbook of troerionel

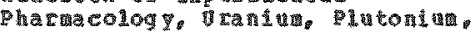

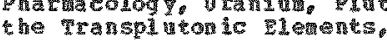

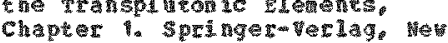

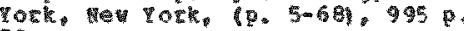
75

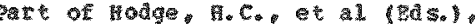

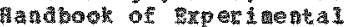

sharracolog

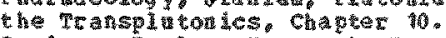

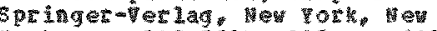

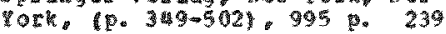

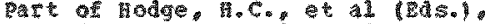

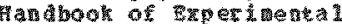

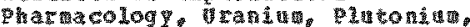
the pransplontos. Chaper 12 .

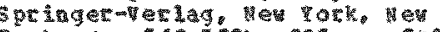
Tork (P. $569-592)$. $95 \%$ \% 549

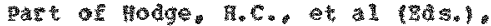

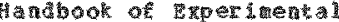
pharacolog

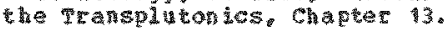

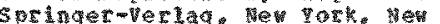

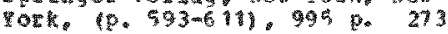

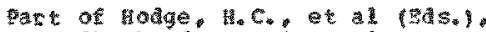

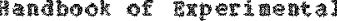

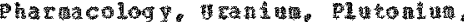

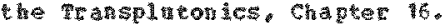

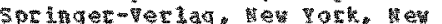
tork (10.69-7)

Pare of fodge. 埕.C. et al lads.

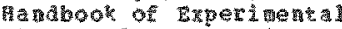

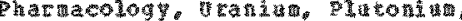
the Transpluton ics, Chater 17.

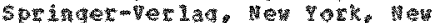

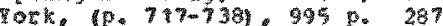

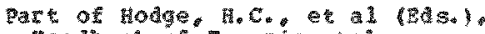

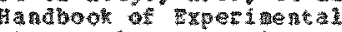

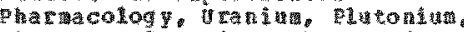
Che Tratsplatonies, chapte 2.

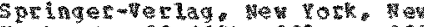
rork (5. 59-164), ggm p. 263

part of nodge H.C. et al $\left(20 s_{*}\right)$

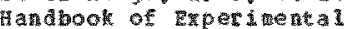

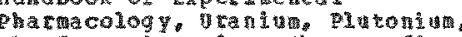

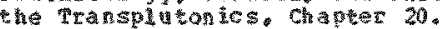

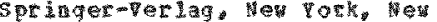
york. (p.999-9281,995 p. 27

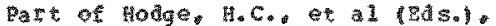

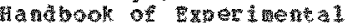

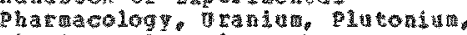

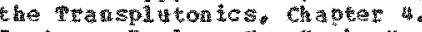

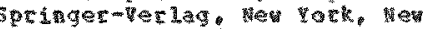
fork (p. 199-239). 995 p. 37

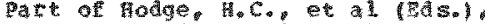

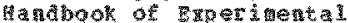

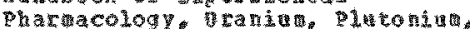
the Trasplaton $1 \mathrm{~s}$. Chaper 5 . the Trasplotonics chaper 5 .

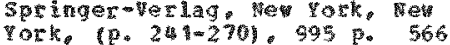

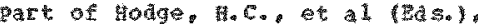

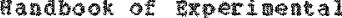

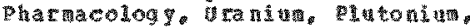
the pransplutonics, chaptes 6 the pranstutonics, chater 6.

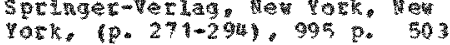

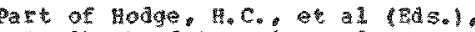

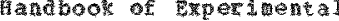

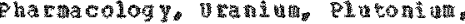
the Transplutontes, Chater 9.

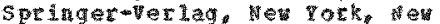
York (9. $323-347,995$ p. 283

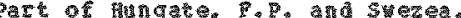

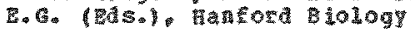

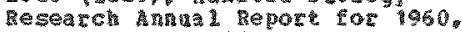

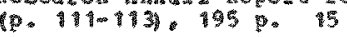

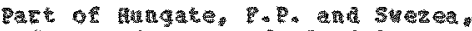

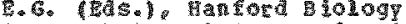

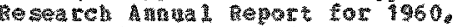
(9. 13-15), 195 \%

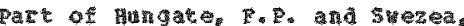

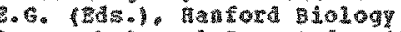

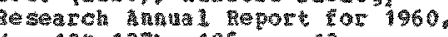
(10. $13(-137), 105 \mathrm{p} .13$

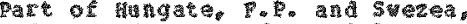

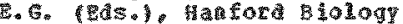

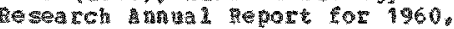

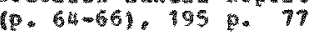

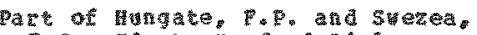

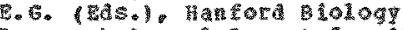

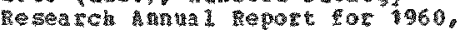
$(p \cdot 67-76), 195$ p. 10

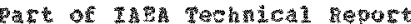

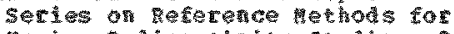
特 gechen

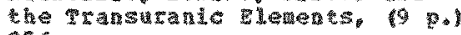
256

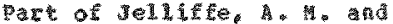

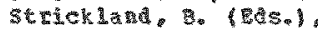
procesuld of the osstu

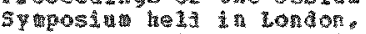

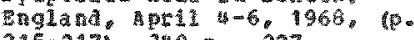
$215-2171,340$ p. 227

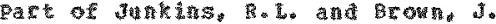

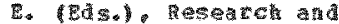
Dowelopaent fot

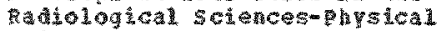

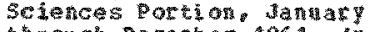
throgh Deceber 196 i, tp. 39 蝶. 309 p. 369

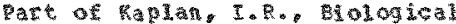
cycling of Elenents and 5 table

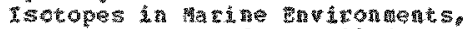

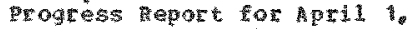
1971 to hay t. 19\%2. 205 . 329

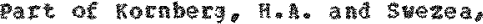

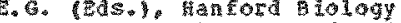

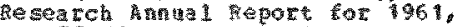
(0. $77-801.790 \%$. 12

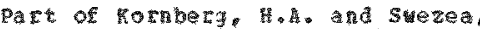

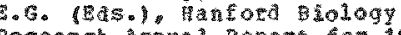

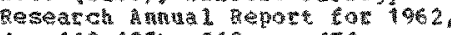
(p. $118-1251,259 \mathrm{p} \cdot 171$

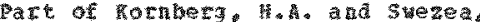

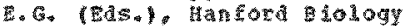

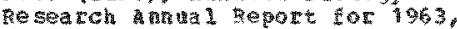

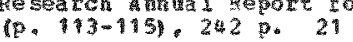

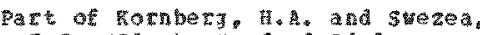

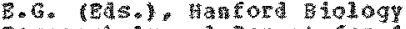

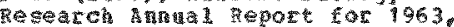
10. $16-199), 242$ p. 23

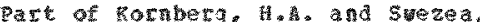

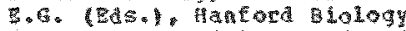

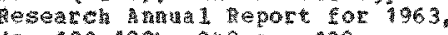

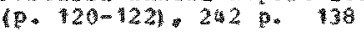

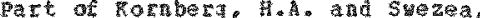
D. (Bas.). Hancor Blology Reserch and (4. 1231,242 . 129 


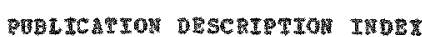

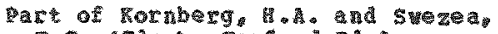

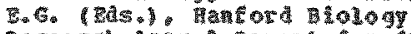

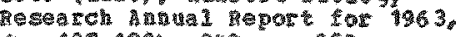

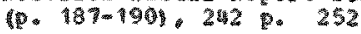

part of formber.

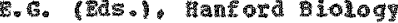
Tesearch a (p. $30-511,242$ p. 222

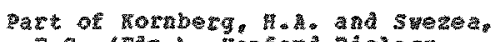

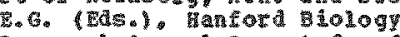

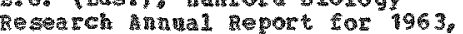
$(10.67-69) \cdot 242$ p. 18

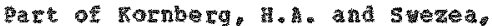

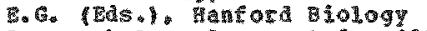
Research hual hepor for 1963. (p. $70-721,242$ ? 14

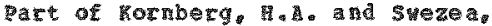

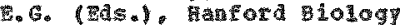

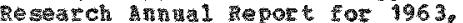
(0. $73-75) \cdot 242 \cdot 206$

part of Lebelinskin.

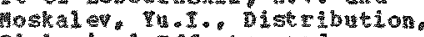

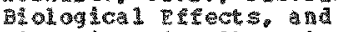

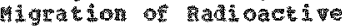
Isotopes, (p, $332-336), 400$ p. 236

garc of zetr.

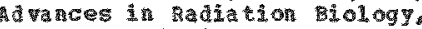

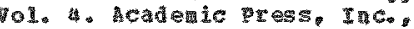

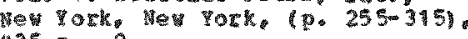
4. 35.9

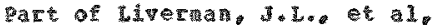
proceedistas of the to. Envi Tonenta 1 Prokection hency

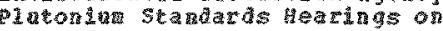
Q1 1 的on zenents: Sources, Bny bistributon and ionedical Effects held in wasingtor 5. Fecenber $10-11,1974$, (D. 311-

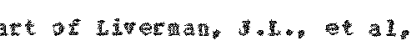
procesing of the 1.5

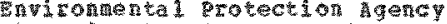

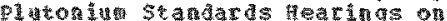

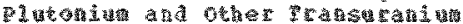

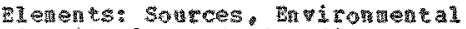
olstribution and isomedical 20 Decenber $10-11,1974,10,170$ 229,327 .

Pate of civervan procecalings of the th.

5.

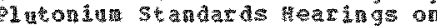

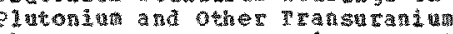

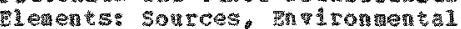
Distrabaton and Biomedical

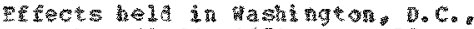
Oecar 168. 327 . 305

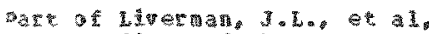
froceding of the in. 5

Envingonent protention gench

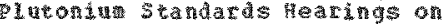

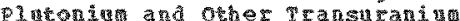

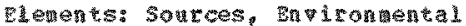
0 stribution and

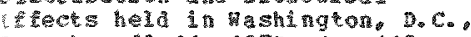
Decentor 19-11. 1974, (0. 19. $128,327,32$

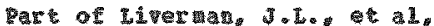
proceeding of he

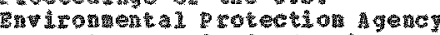
Q1 Q1 uton a

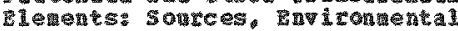

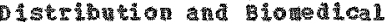
Fects hele in Decesber $10-11,1979,(\mathrm{~g}, \mathrm{~A}-10 \mathrm{f}$. $327 \%$

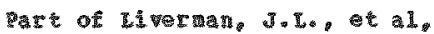
proceed ings of the vo

2u

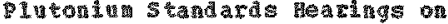

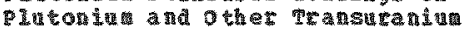

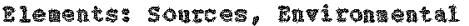

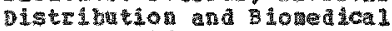
effects held in astington. D.c. Decedoer $10-11,1974,10,13 \%$ $1551,327 \mathrm{p}, 35$

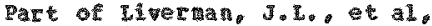
procked ings of the H.3.

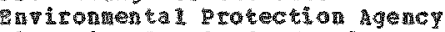
Q110 ton

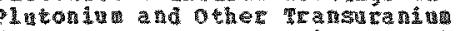

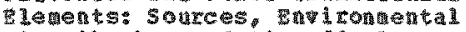
Distrobution and jometcal

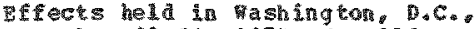
Decenter 10-11, 1974, $10,231=$ 23 然 327 ? 35

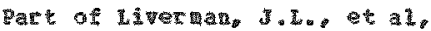
Proceedings of the t.3.

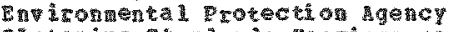

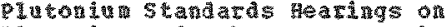

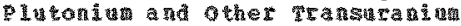
slements: soncces,

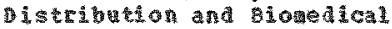

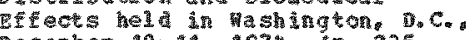

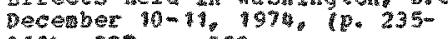
2691,327 p. 392

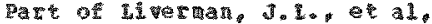
Erocedings of ane the

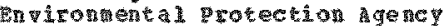

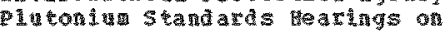

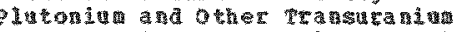

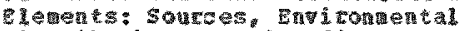

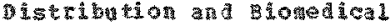

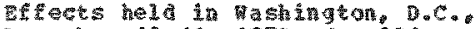
December 10m 19, 1974, (9.29\%$930.37 \%$. 50

Part of procedings of the th

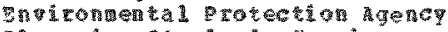

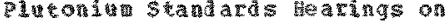

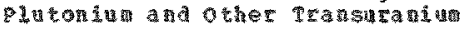
Tenents: Soures, Entronental

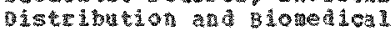

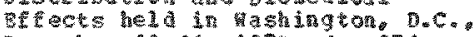
oecemer 10-11, 1974, 10.271$2891 \cdot 327$. 560

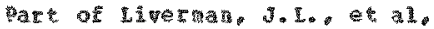

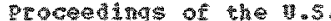

7. 1 1 1 tron

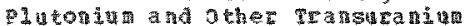

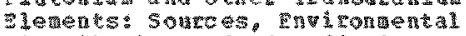
5i

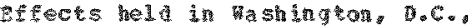

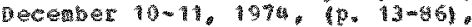
327 p. 569

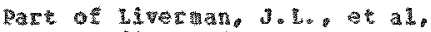
Proceedings of the 2ny romantal Proted tan Agencl c1 1 1 itcon 10 a 1emens: Sor Distriburion and iomedical

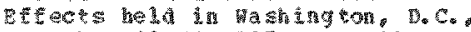
pecenber $10-11,197,10.99-$

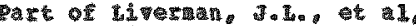
proceseditig of the 0 .

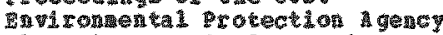

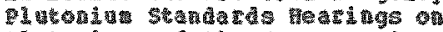
1 直 uto

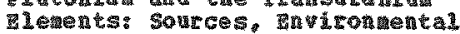
15tributon

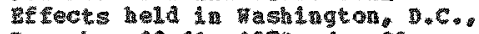

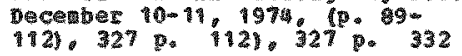

Eat of

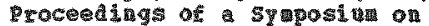

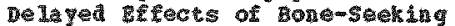

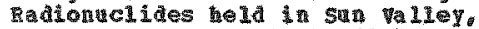
IAaho, setceber 12-14, 1967. ty

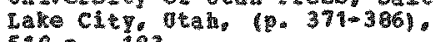
$51 \mathrm{pos}$

Pat of meciellan, 0 . and

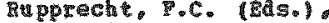

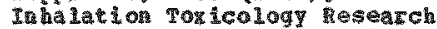

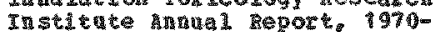
1971. 10.96-101, 973 . 143

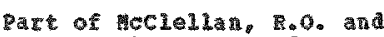

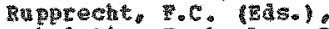

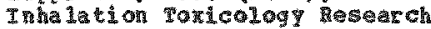
Thstitute anum hevort, 1971 1973, (10. $10-15), 342.351$

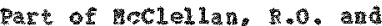

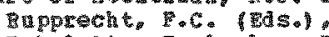
Inha la 1 on Toricology heseareh

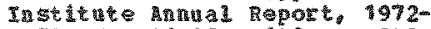
$1973,(10.21-23), 342$ p. 348

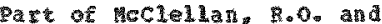

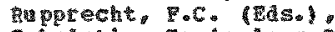
Inta Is stive Annal Report. $1972-$ 1973, 10. 219-2221.342 p. 72

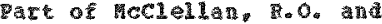

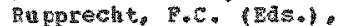
Inhe 10 tion pox colog the search

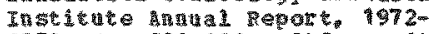
1973 (1). 230-232) $342 \cdot 34$

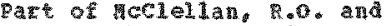

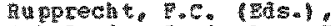

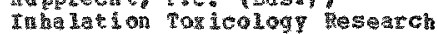
Instit $1973,10.24-301,342$ \%. 283

Pactic of

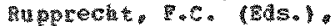

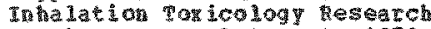

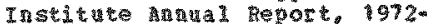
1973, (9. 240-243) 342 p. 33

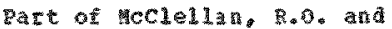

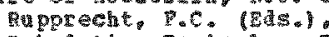
Inha lation Toxicology pescar Instictute Antraz Report 19721973. 20.255-2601, 342 ?. 153

Pat of meclellan, no0. and

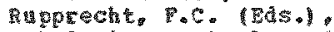

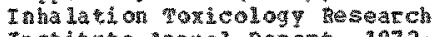

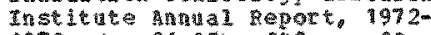
$1973,15,6-85,312,32$

Dart of Suporech

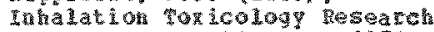

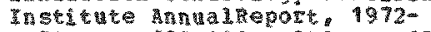
1973 (p. $233-239), 342$ p. 35

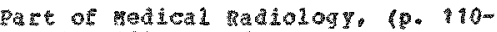
116), 253 p. 25

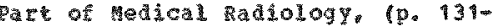
14), 260 p. 26 
Par of thoth

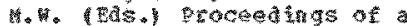

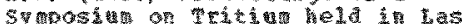

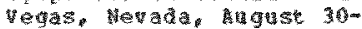

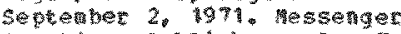

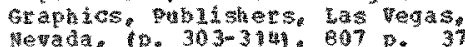

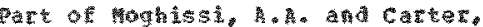

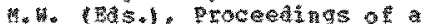

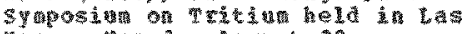

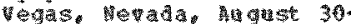

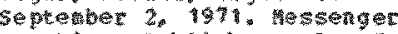
craphics, Publis

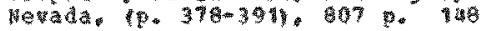

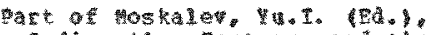

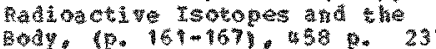

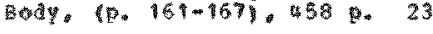

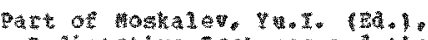

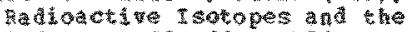

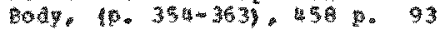

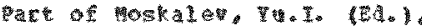

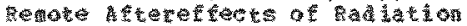
5a.

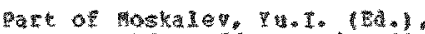

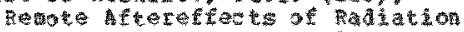

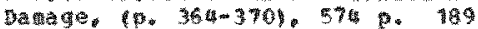

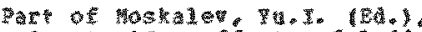

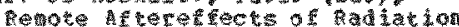

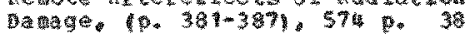

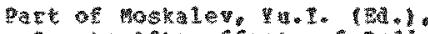

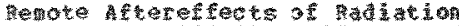

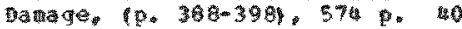

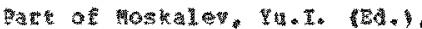

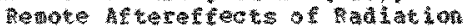

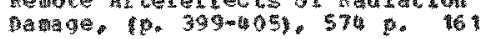

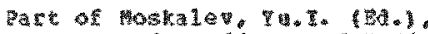

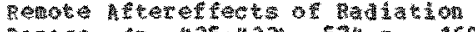

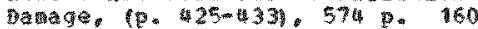

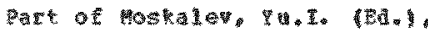

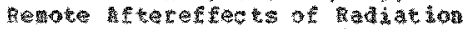

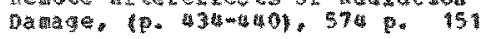

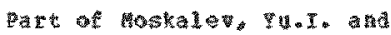

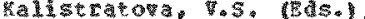

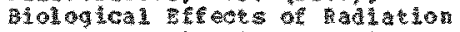

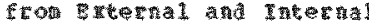

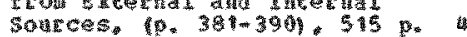

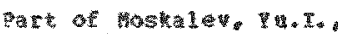

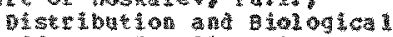

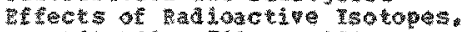

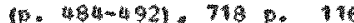

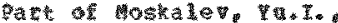

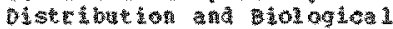

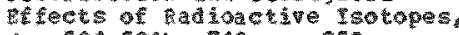
10. $54-5910.718$ o. 253

Pare of

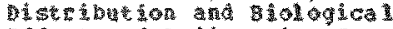

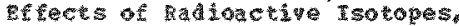
(5. $678-677 \cdot 718$ p. 22

7a

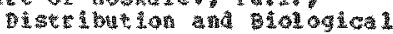

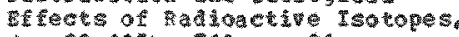
(P. $99-105) \cdot 718$ p. 96

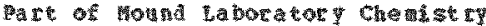

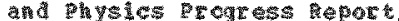

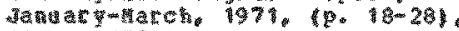
230.25

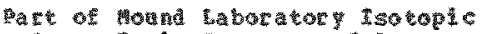
50

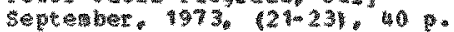

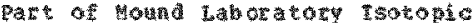

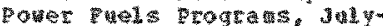

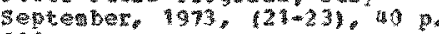
20

Pater of

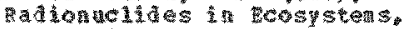

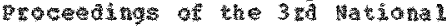

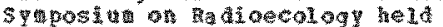

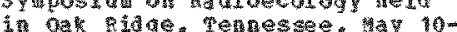

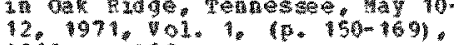
1269.97

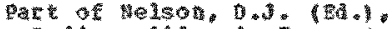

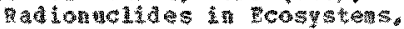
proceedings of the 3 red thana

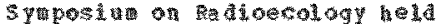
in

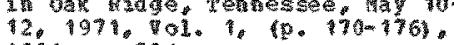
1268 क 501

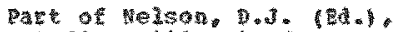

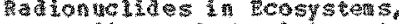

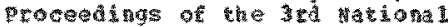

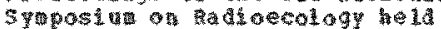

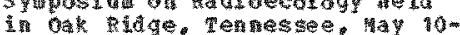

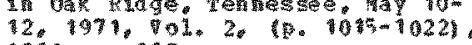
1260.305

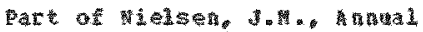

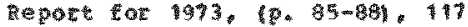
p. 69

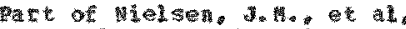

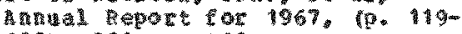
$(22), 230$ \% 422

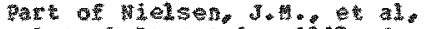

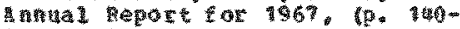
1) 210 p. 9

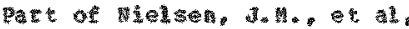

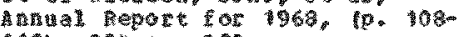

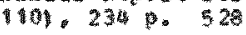

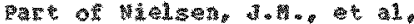

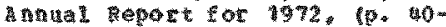

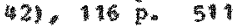

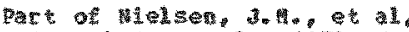

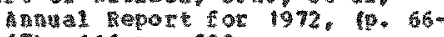
$671.16 \mathrm{p}$. 289

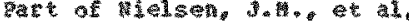

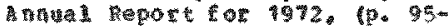
96. 116. 38

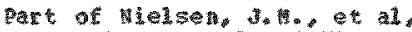

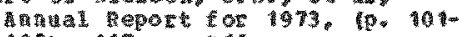
$103)$, 17 .

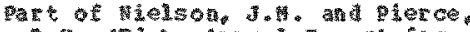

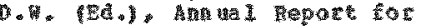
$196 \%(2,24-927), 230$ D. 73

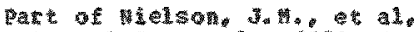

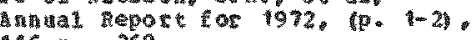
116 p. 365

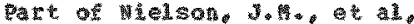
Ant $391,16.512$

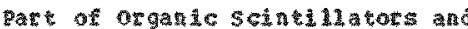
1.

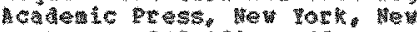
7or $10 \cdot 937-9591$ 465

Pat of procoedings of the

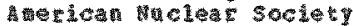
3)

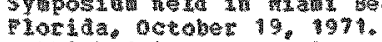

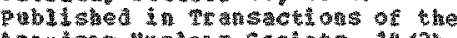

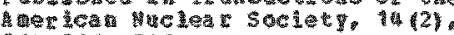
$510-5103$
3.

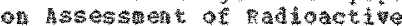
organ a

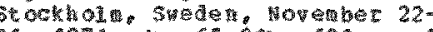

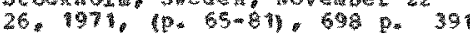

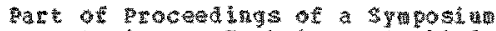

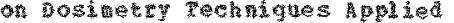

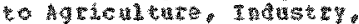

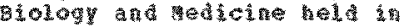

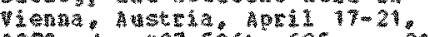

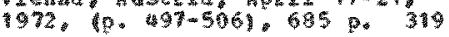

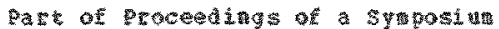
on Eng

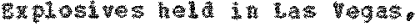

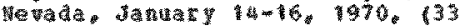
5.) 33

Dete of Proceed

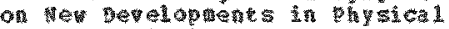

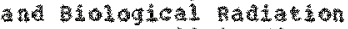

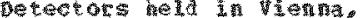

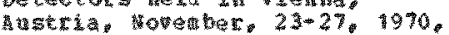

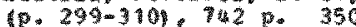

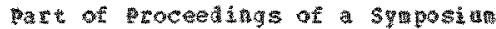

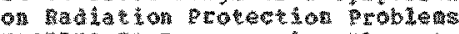

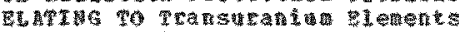

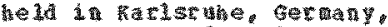

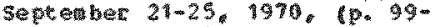

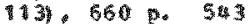

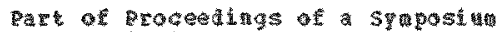

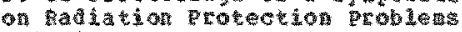

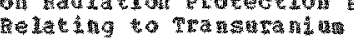

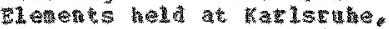

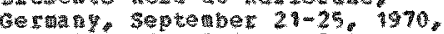
10. $29-325 \%, 660$, 5. 56

\$ar of troced

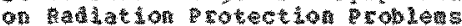

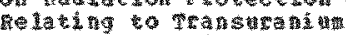

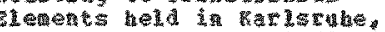

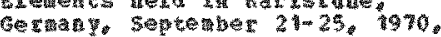

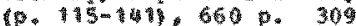

Pa

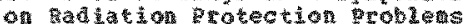
等 1 act

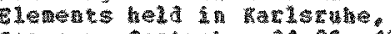
Gerara 3epteber 24.25 .1970$.

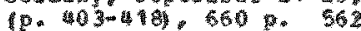

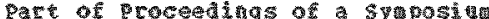
on radich

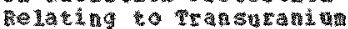
落e laring

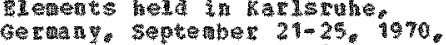

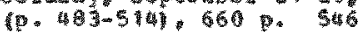

Par

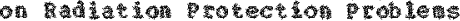

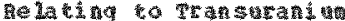

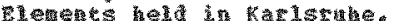
Geras. $(0+5-84) \cdot 6607252$

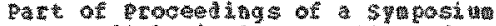
on tatiologice 1 rocection of

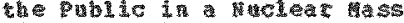

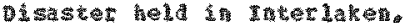

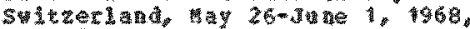
10. 5.531 .686 .321

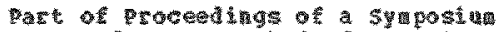

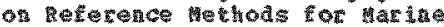

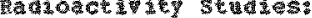

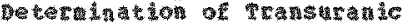

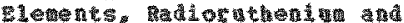

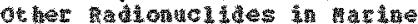
Envinomental saptes heda

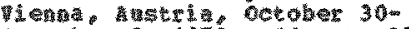

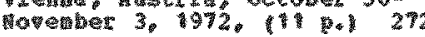




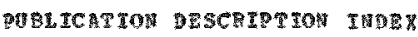

Dart areceatings of a suposit on the Assessment of Radioact it

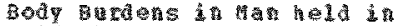

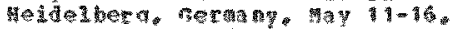

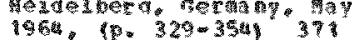

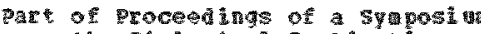
an the 319logical Inol betrons of the Mclear age held L3 ver 196. 6953

part of Proceed 1 ing of

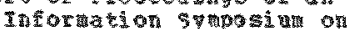
Disposal of Rationctive

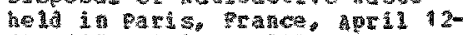
1. 972,290 po 58

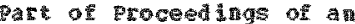
In ter 教y trageocher

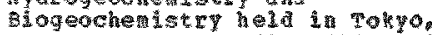

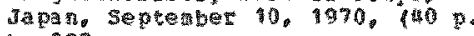
329

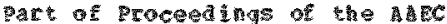

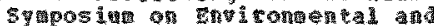

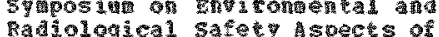
the ining and prowessing of

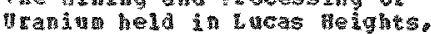

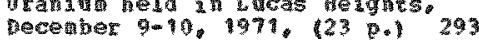

Date of procedings or the Ac Pol1u

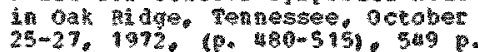
576

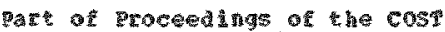
3.

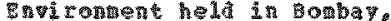
Inda

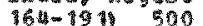

part ot prock

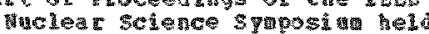

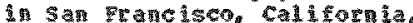

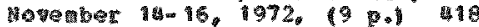

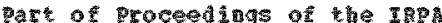

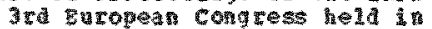

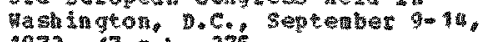
$1973,17 \%$

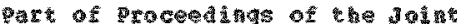
Teet socter a Indis

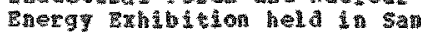

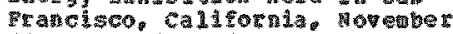
$15,197,19,19.1265$

Part of Procedtigs of the

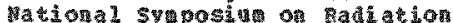

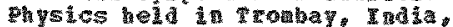

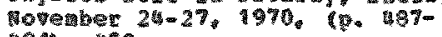
491150

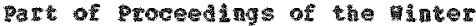

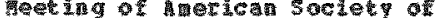

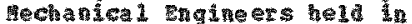

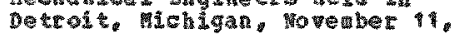

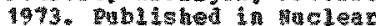

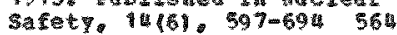

Part of Proced

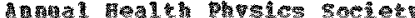

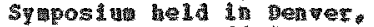

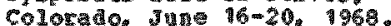

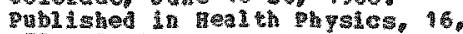

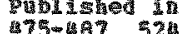

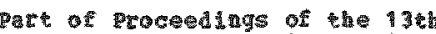
An 57y

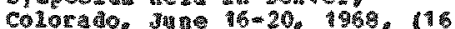

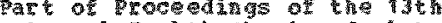

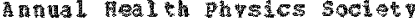
3)

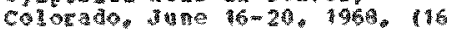
o. 2 .

Tas of procedings of the 17t In STrogs 10 a wevada Ju 12-1 1972. Fublis $599-693509$

Pat of procedings of the low An

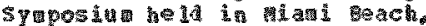
Forida, ane $17-21,1973,1169$ 1)

part of pocedings of the lat An

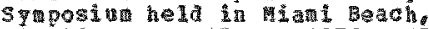

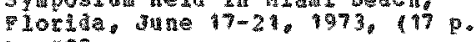
1. 29

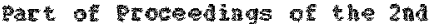
tn Peacer

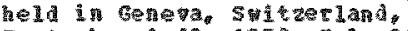
Septediber -13, 1958, Pol. 23 , (P. $34-35$ - 325

Part of Procedinas of the 2 nd I ntera

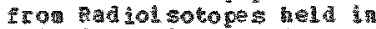

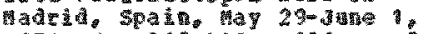

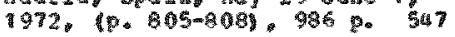

part of poopedings of the $2 \mathrm{nd}$ I

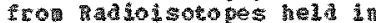

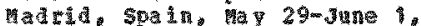

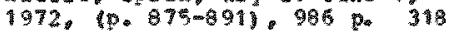

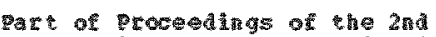

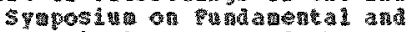

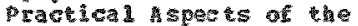
ApDL I I c11 th o

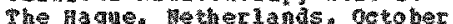
3. 1973. 10.

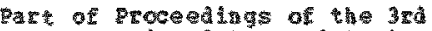
Triter a

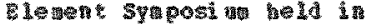

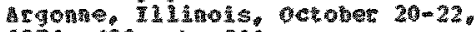

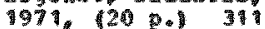

Eart of Procedings of cha 3 ra TRPA Tnceration 1 congtess hell

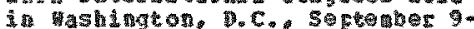
44.1973 (6) 325

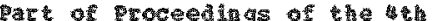

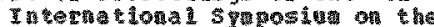

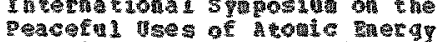

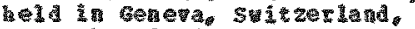

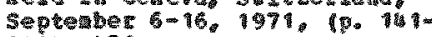
159 46

Dart of Procedings of the

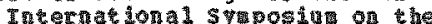

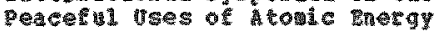

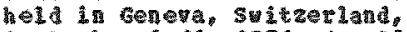

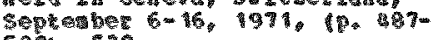
52 被 539

20. Inter Peacerri held in Geneva, 3 wh zeriand. septerber 6-16. $197 \%, 40.4 \%$ (c. $13-291356$
Par of proces ang of the the

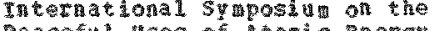

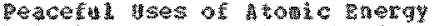

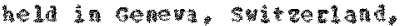
septerber $6-16,1971.001 .11$.

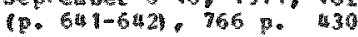

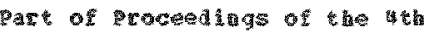

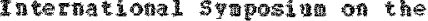

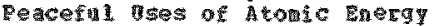

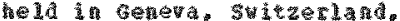
Sevtenter 6-16. 1971, 101.11 (1). $653-67$ t4 294

Part of proceerings of the

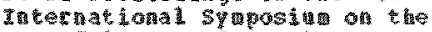
peacer

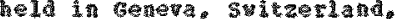
soptober 6-16, 1971. 701. 1\% $27.23-255 y^{535}$

Part of Procedings of the sth

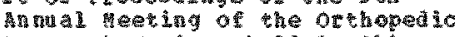
sesearch soctes hold it chicago

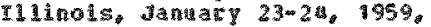
(2).

Par of proced at A

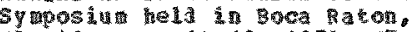

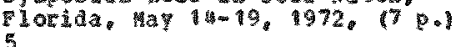

Fat of proged atus of the th

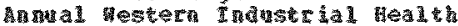
5y 1963. Publ 1shed w Journat of occupational hea icine, 5( 17905

part of Procentings of the 7 th wot

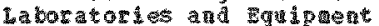
5\%

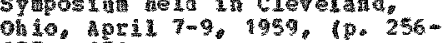
2759378

2ar of proutess in ocea wograp.

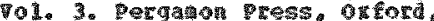

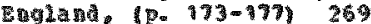

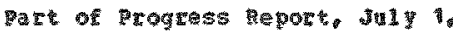

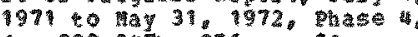
10. $223-2474,256$ p. 51

Par of

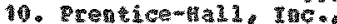

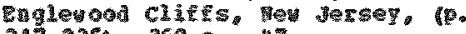
36 范

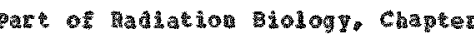
1.

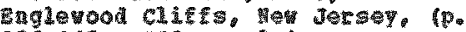
$236-2651$. 368 .

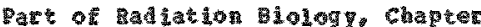
12. Tre

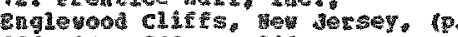
$26-2831,366$ ?. 365

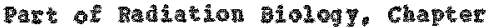

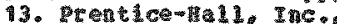

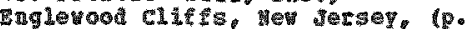

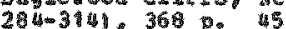

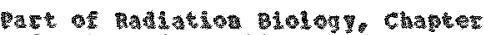

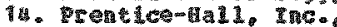

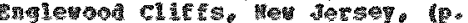
$315 \sin 31,360$ ? 365

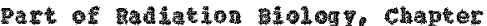

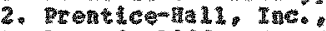
紫 $7-309.360 .52$ 


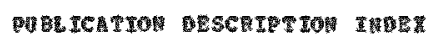

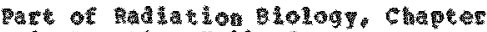

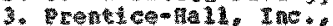

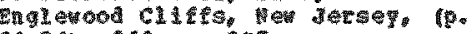
$31-561.368 .345$

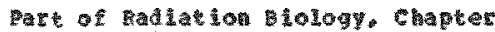

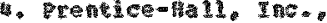

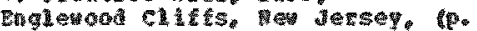
$5=891368.250$

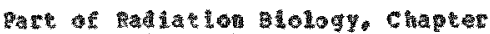
5, Prentece-

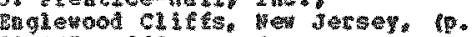
$90-177$. $35 \%$.

Dar of tad

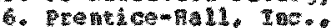

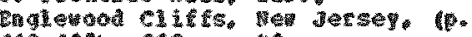
116-135). 369 p.

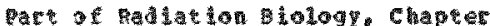

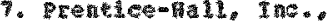

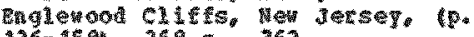

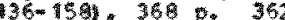

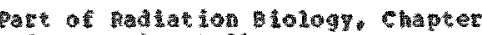

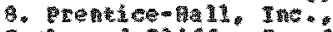

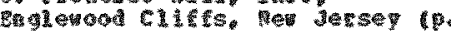
$159-1701,368 p_{*}$

Par tre 7. prentice-gall, no.

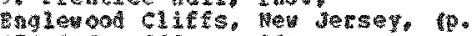
$17-216.3650 .56$

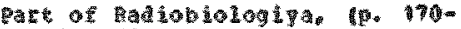
1005

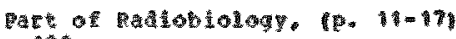
100

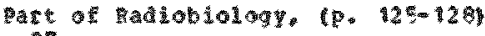

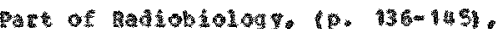
30.

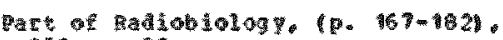
$253 \%$

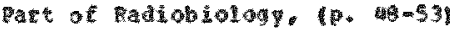
65

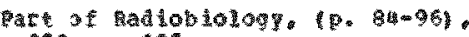
2535

Dare of Radobiolog $(0.63-72)$. 256 .

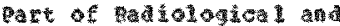

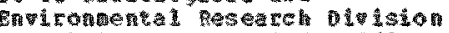

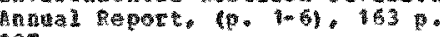
29

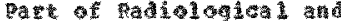

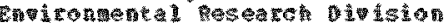
(5)

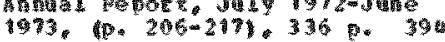

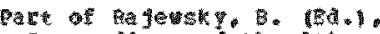

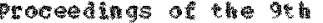

Internat 1 and 1 congress of

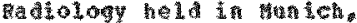

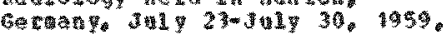

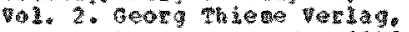

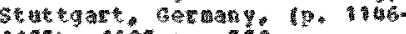
11551.625

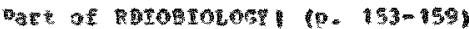
172

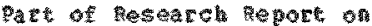

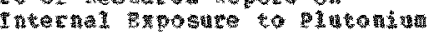

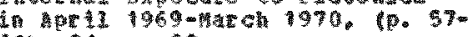
at. 9.9

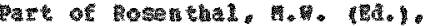

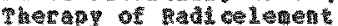

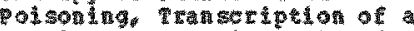

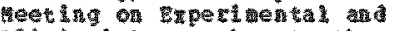

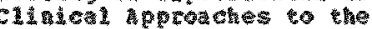

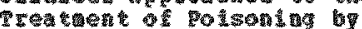

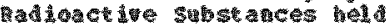

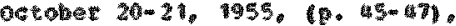
131 10. 10

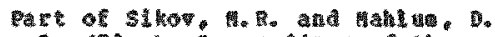

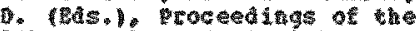

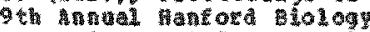
\$2

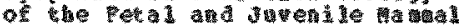

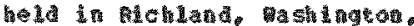

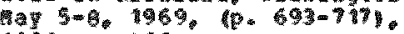
1026.002

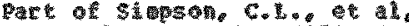

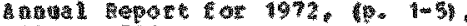
120.526

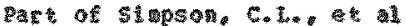

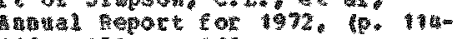
415. $152 \% .512$

Part of 3

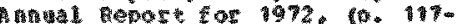
191.520.51

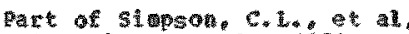
antal pegot

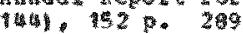

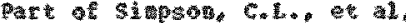
( 22.520 .527

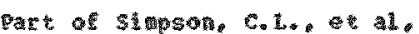

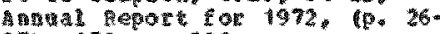
27.1520 .50

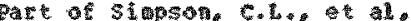

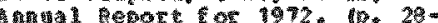
321.52 . 50

For of I A

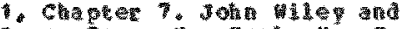

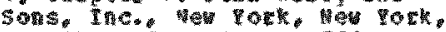

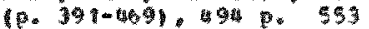

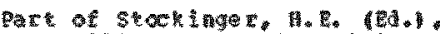
3.

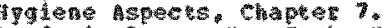

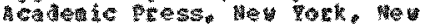

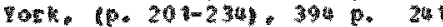

Pa

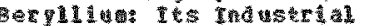

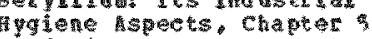

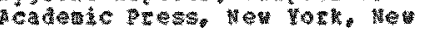

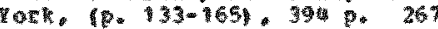

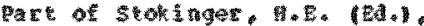

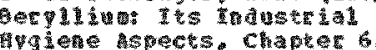

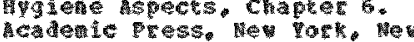
ork (0. 167-2001.394. 40

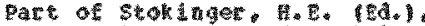

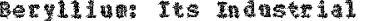

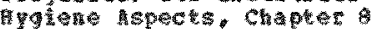

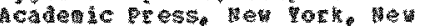

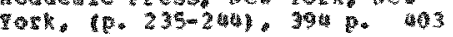

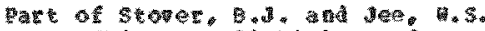

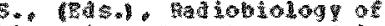

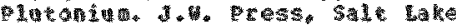

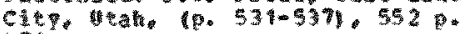
(4)

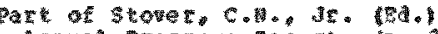

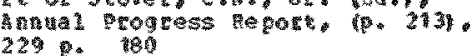

Pa

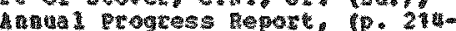
2151.229 . 66

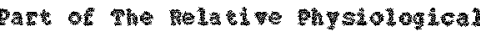
a

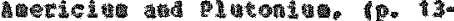
15. 6 . Don

Pat of and rot leatotical copertes of

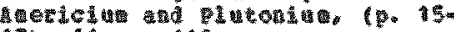
17.61\%. 113

Da a t a

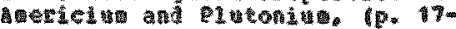
201.6. 612

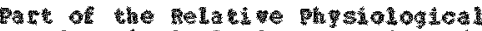

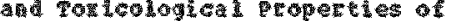

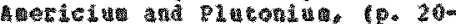
22). 61

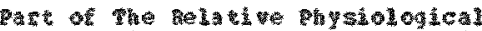

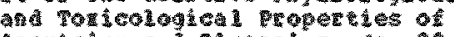

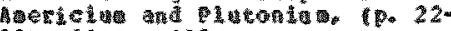
33)

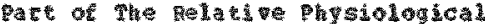
and Toricological 1 ceppertices of

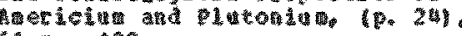
610.09

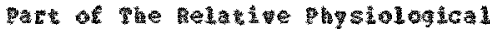

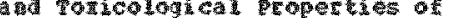
4. 25y. 6. 107

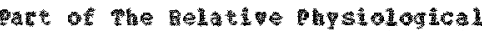

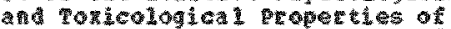

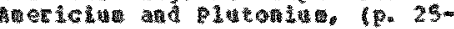
261.6. 0. 108

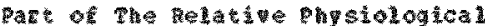

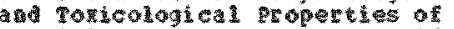
arected 27.61 .06

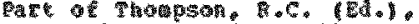

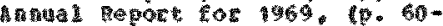
11. 90 10.22:

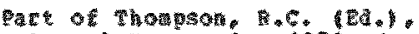

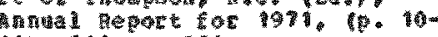
11. 31 1 126

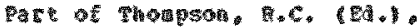

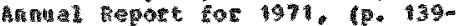
1851.313 .019

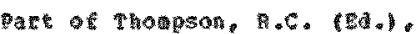

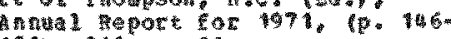
1524330.22

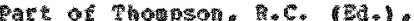

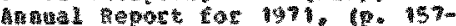
(6) 315 19

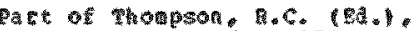
Ant 23) 33

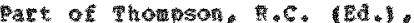

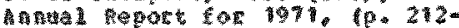
222) 31 34

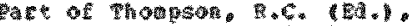
(1) $230) \cdot 313.53$

7. Manal Repore tor 1971 1p.232m $238.313 \cdot 22$ 
Par of Thompson,

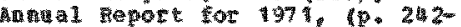
2450313.223

Pat of Thompon. T.C. La.

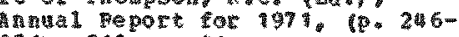
254 . 343 .

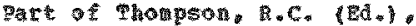

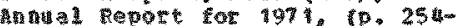
2621313.990

Part of thompon, Anal 1 port $2710.313 \mathrm{p}, 902$

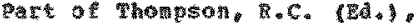
Anomal Report for $1971,10.27$. 2769.393 क. 208

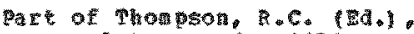

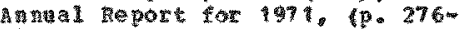
278.313720

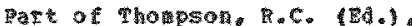

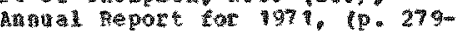
203, 31 3,205

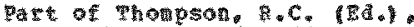

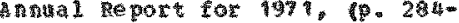
2861.313 .207

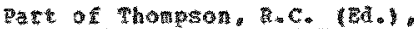
Antulat

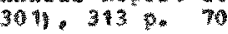

Pate of thomes.

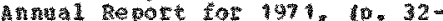
35. $313 \cdot 225$

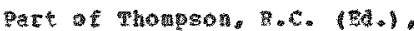

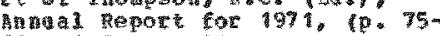
761,313 . 1. 13

Pat of Thonpson, R.C. 巽A.

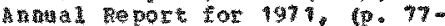
Q 1103130.3

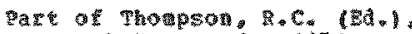

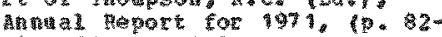
35. 313 . 33

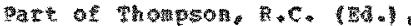

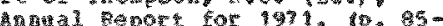
(4) 3130.204

Pare of whomon。

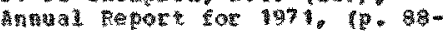
92). 313 . 73

Part of thompson. Annul peport tor 1972 . 10 . 11). 103.25

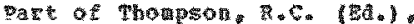

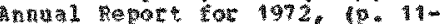
13. 1030.225

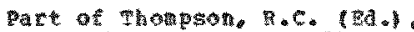

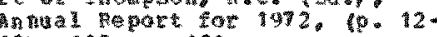
13. 430.130

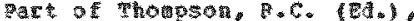

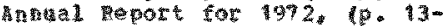
15103 103

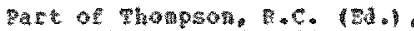

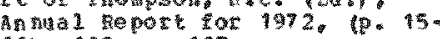
161. 103 . 12?

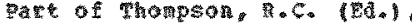
A 111. 1030.19

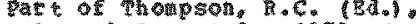

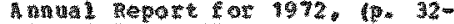
3) 1030.19

Dart of

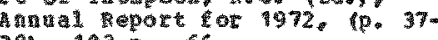
3 a). 103 ต 66

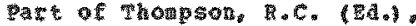
Anual tepot for $1972,(0.501$. 103.966

pate thopson. Antar 52). 103 . 523

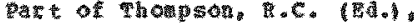

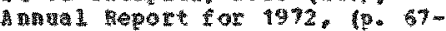
691.103 .69

pat of Thotpon.

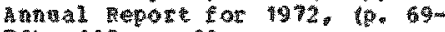
70). 103.30

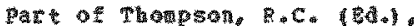

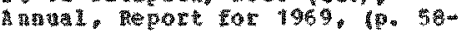
601.90 p. 220

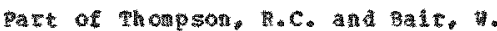

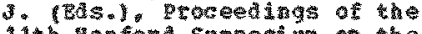

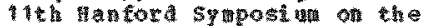

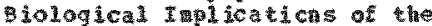
Transutant

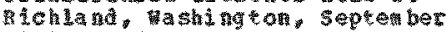
$27-29,1971$. Pubilshed in theal Physies, 22 \%

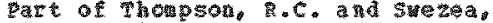

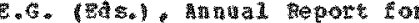

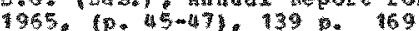

Qut of Thomson.

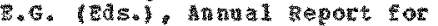

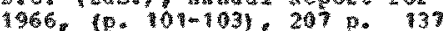

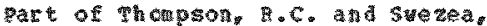
B.

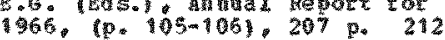

pa of Thomson. R.c. and serea.

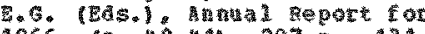
1966, $10.40-410,297$ p.

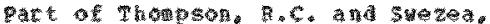

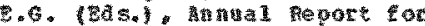

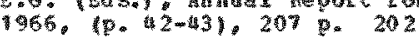

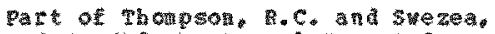

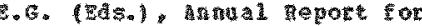

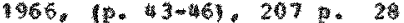

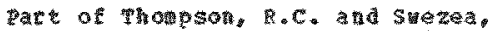

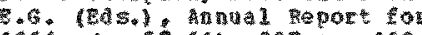
$1966.60 .57061\} .207$ \%. 169

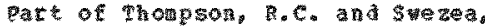

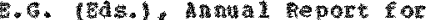
$496,(0.66), 207$ a. 219

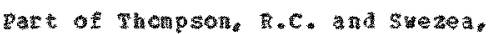

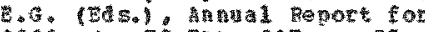
196. $(0.73-74) \cdot 207$ p. 55

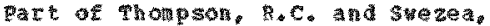

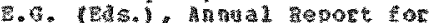

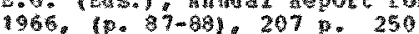

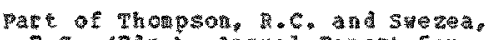

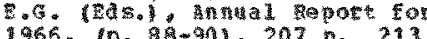

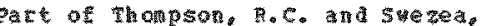

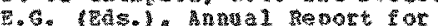

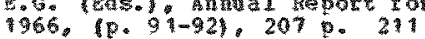

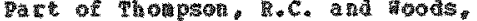

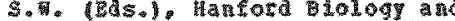
pesearch hom

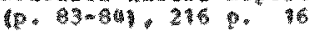

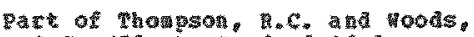

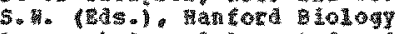

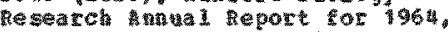
(p. $110-112) \cdot 116$ p. 76

Pat of Thuspon.

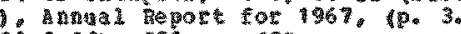
$20-3.221 * 25 \%$. 134

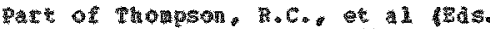

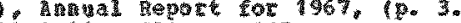
$22-3.261 .253$ \% 167

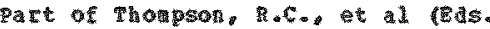

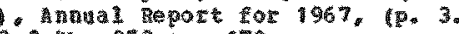
$3-3.4): 253$ \% 170

Parte or thoppon

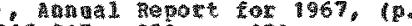
$35-317,253,352$

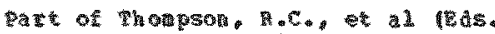

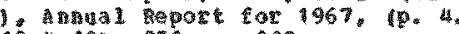
$18-4.191 .253$. 209

PaE O Phom

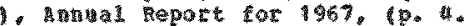
$3-4.653 .251$

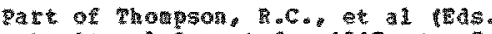
- Arul 1 hepot ar 1967. 1p. 5 . $24-5.251,253 \% 53$

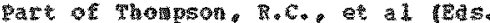

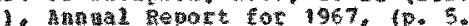
g.5. 141.253 . 203

Pat of thoppon.

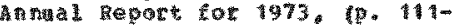
12162 \% 210

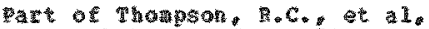

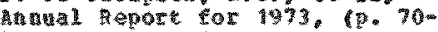
71,162 . 17

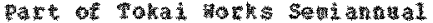
progtes

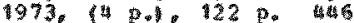

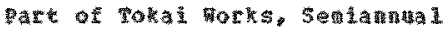

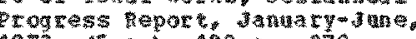
1973. (5.1. $122 \% 279$

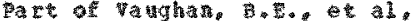

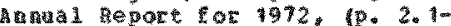
2.2. 105 . 99

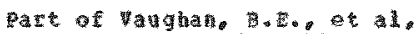

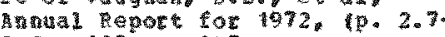
$2.8105 \% 27$

Pat of yughat B.

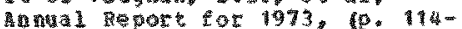
15,200 \%. 20.4

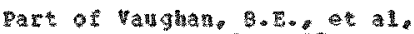

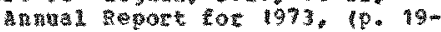
$21), 200$ p.

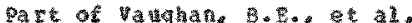
annua teport for 1973, fP. $21-$

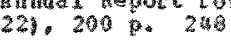

Dart of Wakghan, a. E. al,

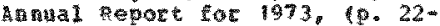
$24 y, 200$. 240

oa of Va A 4). 200 \%. 393 


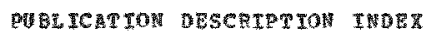

Pat of raughan B. E. et at

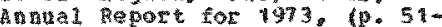
5. $200 \%$. 98

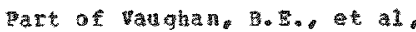
Ann a

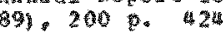

pare of allace A.s at a

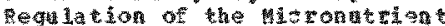
stacus of antes by cholating actents and other vertos.

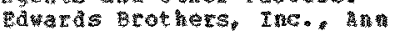

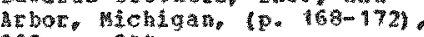
309.244

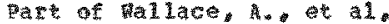

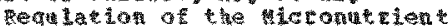
status of $p$ ants ov welating haten and other ractors. Ed

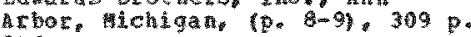
246

Pare of tallace.

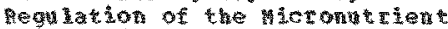
stratus of viants by chelde gert and other actos. that

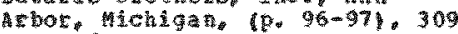
1. 2 年

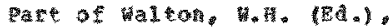
procecating of the is incernationat symposin on

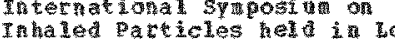

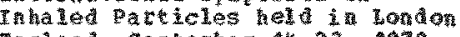
Ergland, segtember 1 is -23 , 1970 .

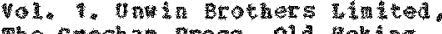
The treshat press. 01d hok

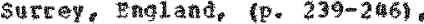
$1090 \%$. 159

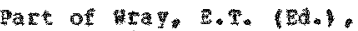
Prociedings of symosiut on Padiation and stin held in

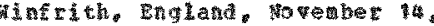

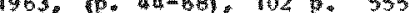

Ph.D. thesis. colotado the (niversit 7

Dh. D. Thesis. Georgia Instrtuce of Technology 320

p45 $-999-2 k-27$

atysics in sedsine and Balogy 15 th, $39-46$ 34

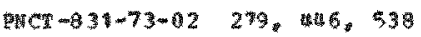

Praconi is 235

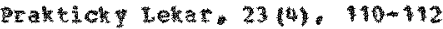
401

prentice-Hal1, Inc. Englendod

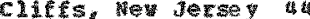

mesented at the 32 mand And Sy posiun of he nadiologica socity of torth merica held in chicago, tilinots, pecenber $1-6$. 194. (14) 9.175

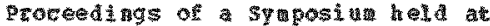

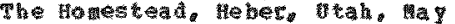
(2) 11, 1961.529.62

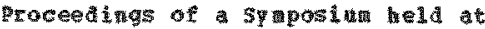

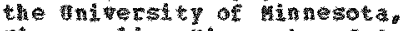

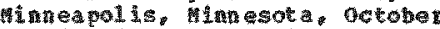

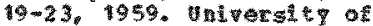

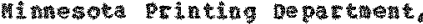

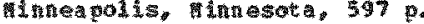

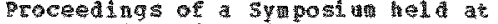

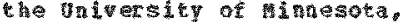

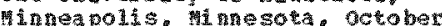

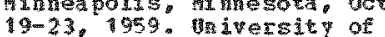

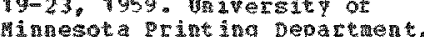
Hinesota peinting jepactuent. 360

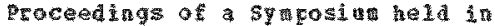
sas vegal,

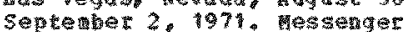
copucs. publshers, Las pegas。

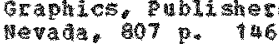

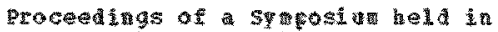

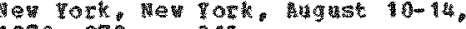
1970,970 . 315

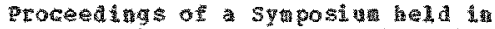

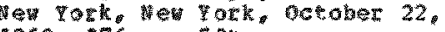
$1968,376 \%$ 534

Procedings of Sy posid held in

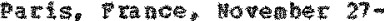
becentar 1972, 1266 p. 587

pcocedings of a syoposin held in

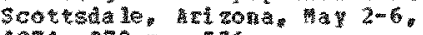
$197,378 * 556$

Proceedings of a sy posing of the Interact low or tadioactive

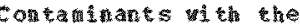

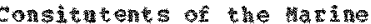
In tasington. Ju1 10-14, 1972. $7860.29 \%$

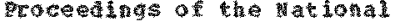

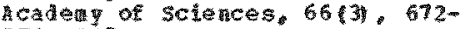
$676 \quad 27$

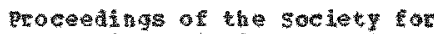

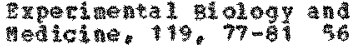

Drocedings of the 15 . 5 .

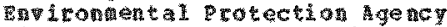

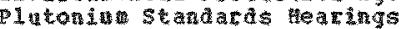
hela in shington. B. 6 .

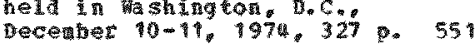

Procedings of the $3 \mathrm{Ed}$

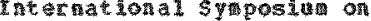

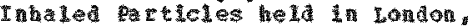

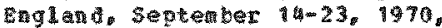
15. 102 . Then nothers

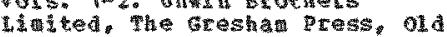
artho. Surrey. England. 1090 p. 09

2स0

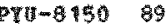

E-92-92 322

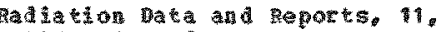

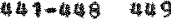

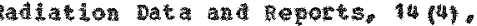
$267-27$ 1

padiation peseach, supplement, 5. $216-22730$

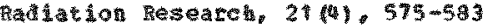
178

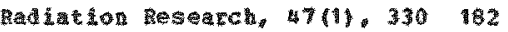

ad Itotor Research. $54(3) \cdot 654-673$ s.

fadicion 198
Radiation Research, $56(3), 540-553$ 194

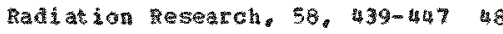

दad

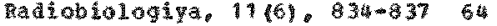

Eadioblologiva, 313, 11-17 100

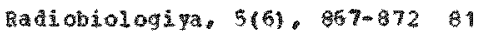

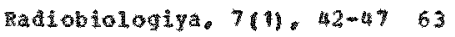

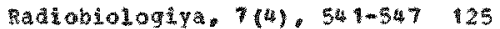

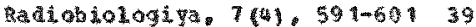

gadobology, 12(2), 272-278 124

tadocherical Ratoanalytea

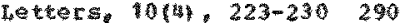

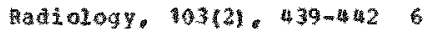

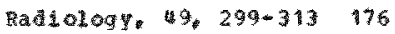

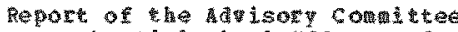
or the biological tefecs of

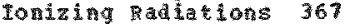

pepore of the steering fom inte tor nuelear Enetgy 591

AFP-Tras- 295

$27 P-196950$

Hoct Vale Miscellaneous

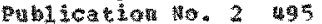

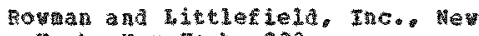
Youk wet 238

Safety series wo. 36599

Scierce, 117, 241-247 427

science, 167, 1370-1372 346

science.173 13911.47-48 525

Science. $183,715-722354$

selence, $180(4083), 300-302$

SL $\mathrm{AC}-159 \quad 420$

5T $2 / 00 c / 10-147 \quad 491$

STI/DOE/257 559

\$rT/Pat/261 315

$35 \pm / 24 / 269350$

STI/ $1000 / 290 \quad 39 ?$

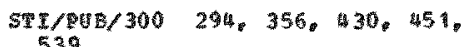

STI

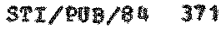

Ta

Tectrical Repots Series No. 147 491

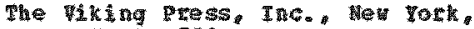

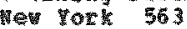

TTD-24635 536

T2D-245 55 


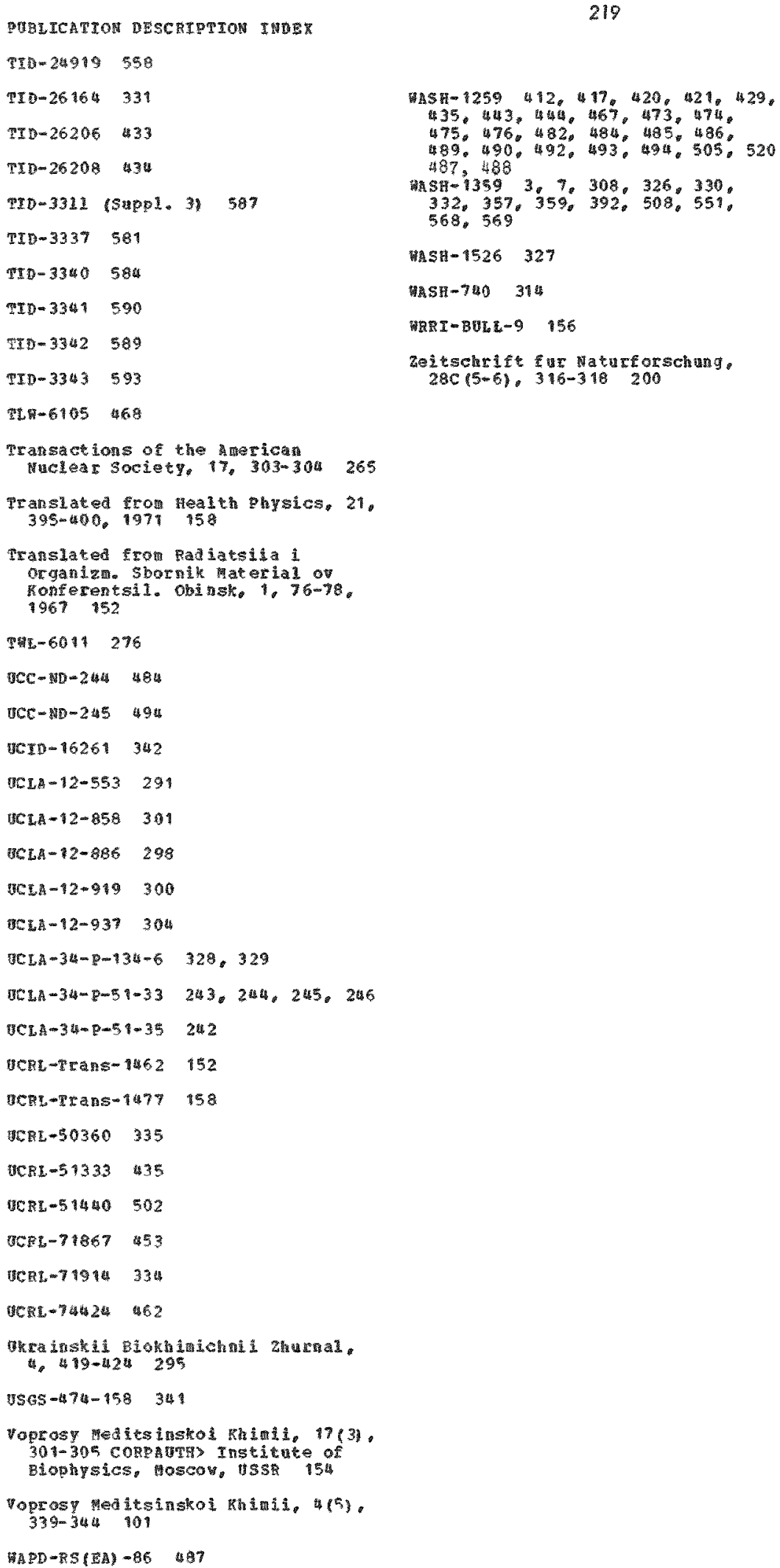


-

0 


\section{INTERNAL DISTRIBUTION}

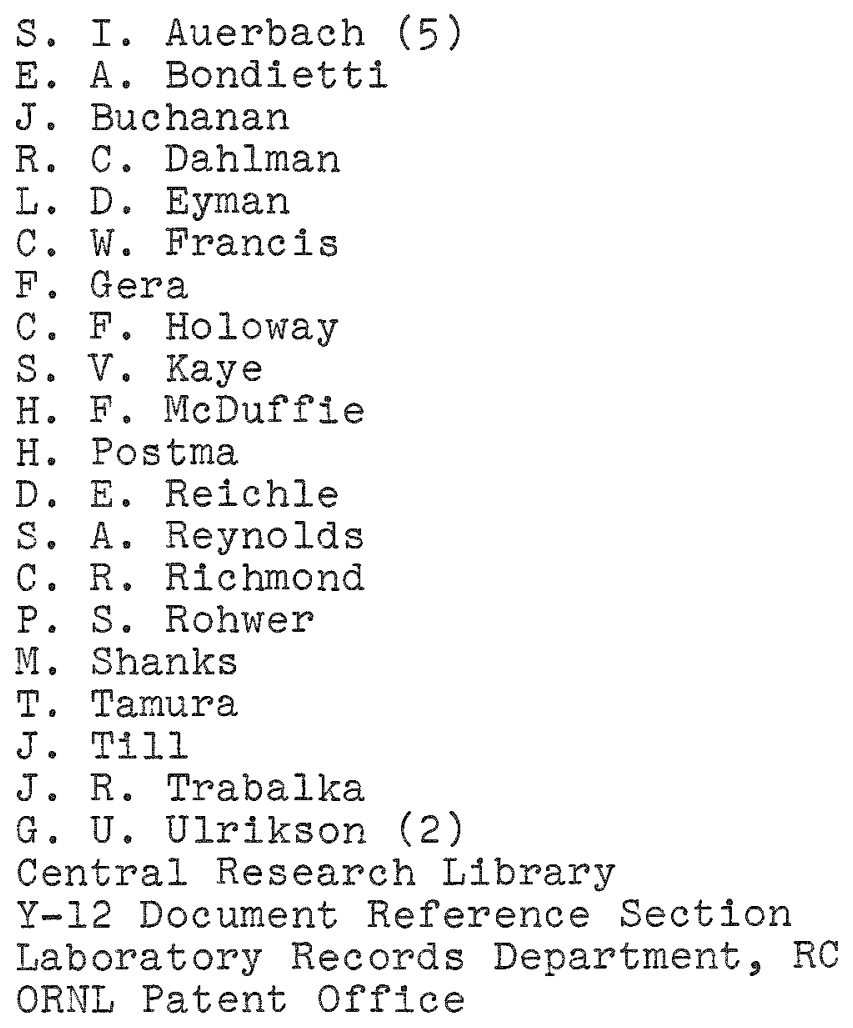


EXTERNAL DISTRIBUTION

J. P. Abbadessa, ERDA

C. S. Abrams, Argonne National Laboratory

R. E. Allen, ERDA

R. C. Amick, Nevada Operations Office

H. F. Anderson, Mound Laboratory

I. R. Anspaugh, Lawrence Livermore Laboratory

A. Antonelil, CNEN, Rome, Italy

D. R. Atherton, University of Utah

H. Atkinson, ERDA

F. Au, National Environmental Research Center

W. J. Bair, Battelle-Northwest Laboratories

F. P. Baranowski, ERDA

N. F. Barr, ERDA

D. S. Barth, National Environmental Research Center

J. Barth, National Environmental Research Center

E. W. Bean, Dow Chemical Company

M. B. Biles, ERDA

R. W. Bistline, Dow Chemical Company

W. Bliss, National Environmental Research Center

P. J. Bottino, Brookhaven National Laboratory

V. T. Bowen, Woods Hole Oceanographic Institution

$V$. Bowman, University of Nevada at Reno

W. G. Bradley, University of Nevada at Las Vegas

R. A. Brechbili, Nevada Operations Office

J. C. Burke, Woods Hole Oceanographic Institution

J. F. Burke, Albuquerque Operations Office

L. K. Bustad, Washington State University

E. D. Campbell, Nevada Operations Office

M. W. Carter, Georgia Institute of Technology

I. J. Casarett, University of Hawail

B. W. Church, Nevada Operations Office

F. Clark, ERDA

W. J. Clarke, Battelle-Northwest Laboratories

F. E. Coffman, ERDA

C. I. Comar, Electrical Power Research Institute, Palo Alto, CA

J. E. Connor, ERDA

C. F. Costa, National Environmental Research Center

F. T. Cross, Battelle-Northwest Laboratories

G. H. Daly, ERDA

R. S. Davidson, Battelle-Northwest Laboratories

J. J. Davis, U. S. Nuclear Regulatory Commission

L. J. Deal, ERDA

P. N. Dean, Los Alamos Scientific Laboratory

P. de Bortoli, Euratom Joint Nuclear Research Center, Italy

J. V. Dilley, Battelle-Northwest Laboratories

P. J. Dionne, Battelle-Northwest Laboratories

G.W. Dolphin, United Kingdom Atomic Energy Authority, England

J. H. Dougherty, University of Utah 
T. F. Dougherty, University of Utah

R. L. Douglas, National Environmental Research Center

E. N. Douthett, Nevada Operations Office

D. I. Dufek, Pantex Plant, Amarillo, Texas

J. E. Dummer, Los Alamos Scientific Laboratory

P. B. Dunaway, Nevada Operations Office (25)

P. W. Durbin, Lawrence Berkeley Laboratory

L. L. Eberhardt, Battelle-Northwest Laboratories

G. R. Eisele, Comparative Animal Research Laboratory

R. J. Engelman, ERDA

E. H. Essington, Los Alamos Scientific Laboratory

G. C. Facer, ERDA

P. Fenske, University of Nevada at Reno

E. B. Fowler, Los Alamos Scientific Laboratory

R. Franklin, ERDA

D. C. Fraser, United Kingdom Atomic Energy Authority

D. S. Gabriel, ERDA

P. Gaglione, Euratom Jolnt Nuclear Research Center, Italy

M. E. Gates, Nevada Operations office

E. Geiger, EIC, Santa Fe, liew Mexico

L. S. Germain, Lawrence Livermore Laboratory

R. O. Gilbert, Battelle-Northwest Laboratories

F. Girardi, Euratom, Italy

L. Gomez, Los Alamos Scientific Laboratory

A. Grauby, CEA, France

E. Graves, ERDA

T. E. Hakonson, Los Alamos Scientific Laboratory

V. Q. Hale, Battelle Columbus Laboratories

G. Hamada, U. S. Nuclear Regulatory Commission

R. Hanley, National Environmental Research Center

W. C. Fanson, Los Alamos Sclentific Laboratory

E. P. Hardy, Jr., Health and Safety Laboratory

J.H. Harley, Health and Safety Laboratory

J.A. Harris, ERDA

J.W. Healy, Los Alamos Scientific Laboratory

D. E. Hendricks, National Environmental Research Center

I. Hoffman, ERDA

E. B. Howard, Battelle-Northwest Laboratories

K. C. Humphreys, EG\&G, Inc.

D. G. Jacksor, Nevada Operations office

P. O. Jackson, Battelle-Northwest Laboratories

F. M. Jakubowski, National Environmental Research Center

A. C. James, Royal Free Hospital School of Medicine, England

W. S. S. Jee, University of Utah

G. W. Johnson, ERDA

J. Johnson, Colorado State UnIversity

I. J. Johnson, Los Alamos Scientific Laboratory

W. B. Johnstor, Albuquerque Operations office

H. S. Jordan, Los Alamos Scientific Laboratory

J.S. Yane, ERDA

IT. C. Rennedy, NOAA/AIr Resources Laboratory 
R. I. Kinnaman, Nevada Operations office

J. E. Kinnear, University of California at Los Angeles

R. Kinnlson, National Environmental Research Center

J. S. Kirby-Smith, ERDA

B. Klepper, Battelle-Northwest Laboratories

A. F. Kluk, ERDA

V. D. Leavitt, National Environmental Research Center

L. Leventhal, LFE/EAL

R. Lieberman, Southeastern Radiological Health Laboratory

J. I. Liverman, ERDA

R. R. Loux, Nevada Operations Office, OIS

R. Luna, Sandia Laboratories

J. McBride, National Environmental Research Center

R. O. McClelian, Lovelace Foundation

T. F. MCCraw, ERDA

J. H. McQueen, Los Alamos Scientific Laboratory

W. Majors, LFE/EAL

O. D. Markhan, Idaho Operations Office

J. S. Marshall, Argonne National Laboratory

W. Martin, Battelle Columbus Laboratories

G. B. Maxey, DRI, Reno, Nevada

R. D. Maxwell, ERDA

C. W. Mays, University of Utah

M. I. Mendelsohn, Lawrence Livermore Laboratory

M. I. Merritt, Sandia Laboratories

F. J. Miner, Dow Chemical Company

A. A. Moghissi, Georgia Institute of Technology

$K$. Moor, University of Nevada at Las Vegas

K. Z. Morgan, Georgia Institute of Technology

A. Morrow, UCLA/CETO

P. E. Morrow, University of Rochester

Yu. I. Moskalev, Institute of Biophysics, Moscow, USSR

W. D. Moss, Los Alamos Scientific Laboratory

A. A. Mullen, National Environmental Research Center

W. A. Myers, McClellan Air Force Base

I. C. Nelson, Battelle-Northwest Laboratories

T. A. Nemzek, ERDA

W. T. Nervik, Lawrence Livermore Laboratory

R. W. Newman, ERDA, Las Vegas, Nevada

Y. C. Ng, Lawrence Livermore Laboratory

C. E. Nichols, Allied Chemical Corporation

W. E. Niles, University of Nevada at Las Vegas

V. E. Noshkin, Lawrence Livermore Laboratory

J. Nyhan, Los Alamos Scientific Laboratory

T. P. O'Farrell, Battelle-Northwest Laboratories

J. I. Olsen, Lawrence Livermore Laboratory

J. Olson, ERDA.

D. P. Osanov, Institute of Biophysics, USSR

W. S. Osburn, Jr., ERDA

C. I. Osterberg, ERDA

H. J. Otway, International Atomic Energy Agency, Austria 
N. P. Page, ERDA

J. H. Patterson, Los Alamos Scientific Laboratory

R. G. Patzer, National Environmental Research Center

J. C. Payne, Jr., lJational Environmental Research Center

A. Perge, ERDA

P. I. Phelps, Lawrence Livermore Laboratory

S. R. Plotrowicz, National Research Council

F. I. Pittman, ERDA

G. G. Polikarpov, Institute of Biology of South Seas, USSR

W. I. Polzer, National Reactor Testing Station

G. D. Potter, National Environmental Research Center

K. Price, Atlantic-Richfield Hanford Company

W. D. Purtymun, Los Alamos Scientific Laboratory

W. M. Quam, EG\&G, Inc.

O. Raabe, Lovelace Foundation

D. Ramsder, Inited Kingdom Atomic Energy Authority

R. Ray, Nevada Operations office

W. A. Rhoads, EG\&G, Inc.

V. H. G. Rickover, ERDA

J. Rivera, Health and Sarety Laboratory

J.R. Roeder, AEC/NV, Albuquerque, New Mexico

D. Rohrer, Los Alamos Scientific Laboratory

E. M. Romney, Laboratory of IJuclear Medicine \& Rad. Biology

E. Ronne, American Nuclear Society, Hinsdale, Illinois

M. W. Rosenthal, Argonne National Laboratory

A. Rudolph, Battelle Columbus Laboratories

J. Rundo, United Kingdom Atomic Energy Authority

J.J. Russell, Public Fealth Service

C. I. Sanders, Battelle-Northwest Laboratories

W. R. Schell, University of Washington

W. W. Schroebel, ERDA

V. SchuItz, Washington state University

R. C. Seamans, Jr., ERDA

J. R. Seed, Dow Chemical Company

J. C. Sheppard, Battelle-Northwest Laboratories

B. Shleien, Northeastern Radiological Health Laboratory

B. W. Shore, Lawrence Livermore Laboratory

M. R. Sikov, Battelie-Northwest Laboratories

C. W. Sill, Idaho Operations office

R. Silverstrom, Nevada Operations office

D. Smith, National Environmental Research Center

H. Snith, United Kingdom Atomic Energy Authority

P. Smith, Environmental Protection Agency, Denver, Colorado

J. F. Sommers, ANC, Idaho Falls, Idaho

E. R. Sorom, Reynolds Electrical and Engineering Company

H. F. Soule, ERDA

A. H. Sparrow, Brookhaven Naticnal Laboratory

R. E. Stanley, National Environmental Research Center

J. N. Stannard, University of Rochester

J. D. Stewart, Nevada Operations office

B. J. Stover, University of North Carolina, Chapel Hill, NC 
B. O. Stuart, Battelle-Northwest Laboratories

P. Stuart, EG\&G, Inc .

T. P. Stuart, EG\&G, Inc.

W. W. Sutton, National Environmental Research Center

J. Swinebroad, ERDA

B. T. Taylor, United Kingdom Atomic Energy Authority

D. M. Taylor, Institute of Cancer Research

G. N. Taylor, University of Utah

J. M. Teem, ERDA

R. H. Thalgott, ERDA, Las Vegas, Nevada

R. G. Thomas, Los Alamos Scientific Iaboratory

G. Thompson, Woods Hole Oceanographic Institution

M. A. Thompson, Dow Chemical Company

R. C. Thompson, Battelle-Northwest Laboratories

R. D. Thorne, ERDA

D. D. W. Thornton, ERDA

J. T. Tinney, Lawrence Livermore Laboratory

G. Tompkins, University of California, Berkeley, California

J. Tower, Westinghouse Environmental Systems

P. T. Tueller, University of Nevada at Reno

W. S. Twenhofel, U. S. Geological Survey, Denver, Colorado

Al Valentine, Kerr-McGee Corporation

H. L. Volchok, Health and Safety Laboratory

A. Wallace, Laboratory of Nuclear Medicine and Rad. Biology

R. L. Watters, ERDA

G. J. Werkema, Dow Chemical Company

I. B. Werner, Palo Alto Laboratories

R. Wessman, IJFE/EAL

A. W. Western, Reynolds Electrical and Engineering Compary

W. Whicker, Colorado State University

M. G. White, Nevada Operations Office

D. Wickman, National Environmental Research Center

J. F. Willging, Dow Chemical Company

C. E. Williams, Nevada Operations Office

T. F. Winsor, Colorado State University

D. Wireman, Reynolds Electrical and Engineering Company

K. M. Wong, Woods Hole Oceanographic Institution

H. C. Woodson, Westinghouse Environmental Systems

D. T. Wruble, Western Environmental Research Laboratory

R. Yorde, Battelle Columbus Laboratories

Research and Technical Support Division, Oak Ridge

Technical Information Center, ERDA-Oak Ridge (2) 